\title{
EFEITO DA PRÉ-OXIDAÇÃO, COAGULAÇÃO, FILTRAÇÃO E PÓS-CLORAÇÃO NA FORMAÇÃO DE SUBPRODUTOS ORGÂNICOS HALOGENADOS EM ÁGUAS CONTENDO SUBSTÂNCIAS HÚMICAS
}

Cristina Filomêna Pereira Rosa Paschoalato

Tese apresentada à Escola de Engenharia de São Carlos da Universidade de São Paulo como parte dos requisitos para obtenção do título de doutor em Engenharia Civil área de concentração em Hidráulica e Saneamento.

ORIENTADOR: Prof. Dr. Luiz Di Bernardo

São Carlos

2005 
FOLHA DE JULGAMENTO

Candidata: Engenheira CRISTINA FILOMÊNA PEREIRA ROSA PASCHOALATO

Tese defendida e julgada em 29-04-2005 perante a Comissão Julgadora:

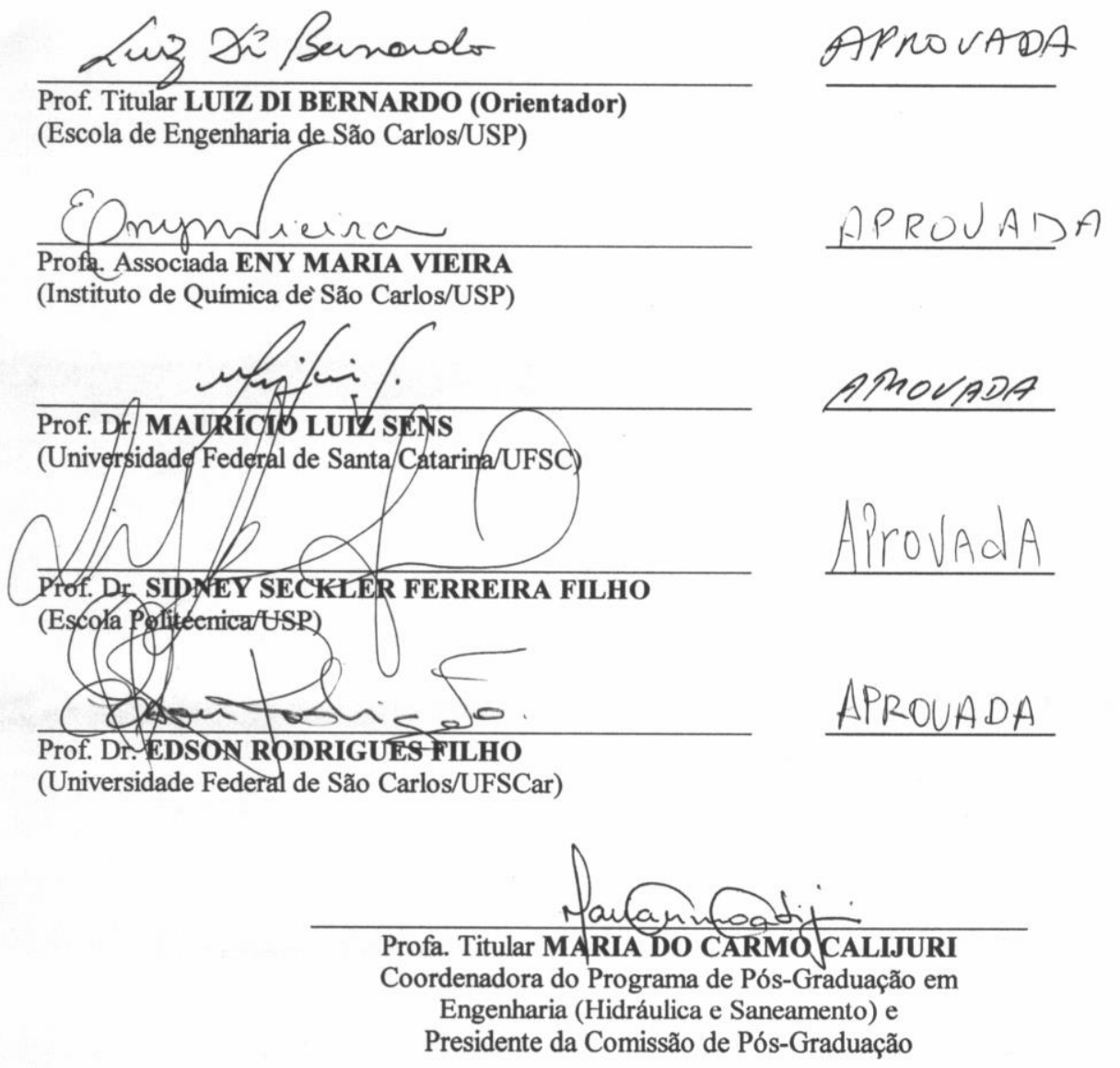


“Embora ninguém possa voltar atrás e fazer um novo começo, qualquer um pode começar agora e fazer um novo fim."

\section{Chico Xavier}

\section{DEDICATÓRIA}

A Deus por mais esta oportunidade em minha vida, ao meu marido e companheiro Celso e aos meus filhos Luma e Alexandre pelo amor e compreensão durante esses anos de dedicação aos estudos. Aos meus Pais Arnaldo e Terezinha (in memorian) pelo exemplo de vida. Ao Prof. Dr. Carlos Eduardo 
Blundi (in memorian) pelo apoio e incentivo. A eles eu dedico este trabalho.

\section{AGRADECIMENTOS}

Ao Prof. Dr. Luiz Di Bernardo pela brilhante orientação e amabilidade.

A amiga Giovana Katie Wiechetch pela preciosa colaboração sempre com muita amizade.

Ao Prof. Rodrigo Latanze da UNAERP pela dedicação aos ensinamentos de cromatografia.

Aos meus alunos de iniciação cientifica: Mauricio, Marcio, Patrícia, André e Aline e Taciana pelo carinho e dedicação ao trabalho.

Ao Prof. Jacob Fernando Ferreira da UNAERP pela contribuição especial.

A amiga Ângela Di Bernardo pelo apoio e auxilio imprescindível.

Aos amigos Paulo e Júlio do Laboratório de Saneamento pela ajuda indispensável.

A Prof. Vera Lúcia Soares pelo incentivo permanente.

Ao Prof. Sidinei Marques Roberto pela colaboração.

Ao Prof. Reinaldo Pisani Jr. pelo incentivo e colaboração.

Aos colegas professores do curso de Engenharia química da UNAERP pelo incentivo.

A UNAERP pelo apoio financeiro e utilização dos laboratórios.

A FAPESP pelo apoio financeiro.

"Ninguém é tão grande que não possa aprender, nem tão pequeno que não possa ensinar".

(Autor desconhecido) 


\section{SUMÁRIO}

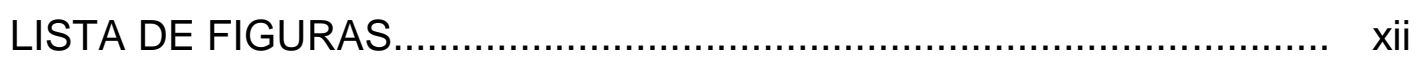

LISTA DE TABELAS.................................................................. xvii

LISTA DE ABREVIATURAS E SIGLAS............................................ $\mathrm{xx}$

LISTA DE SIMBOLOS....................................................................

RESUMO

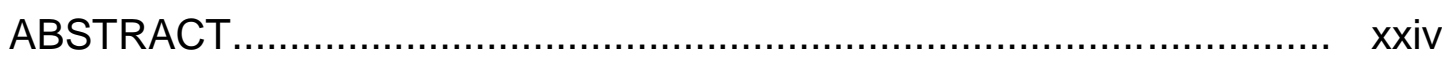

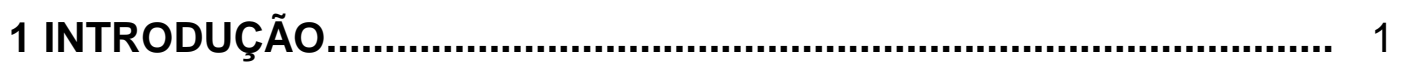

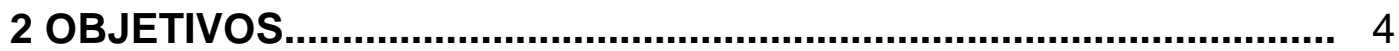

3 REVISÃO DA LITERATURA..................................................... 5

3.1 Aspectos toxicológicos ........................................................ 11

3.2 Formação de subprodutos..................................................... 17

3.2.1 Fatores de influência na formação de subprodutos........................ 17

3.2.1.1 Tempo de contato............................................................ 17

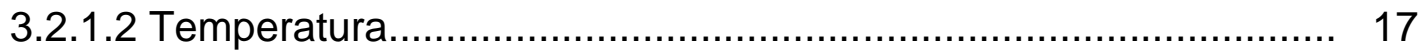

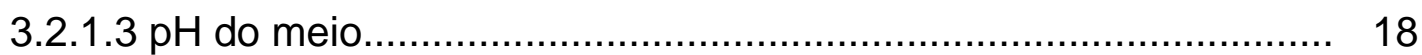

3.2.1.4 Característica dos precursores................................................ 19

3.2.1.5 Dosagem de cloro.......................................................... 20

3.3 Precursores de formação de trialometanos.................................. 20

3.4 Controle da formação de trialometanos........................................ 23

3.5 Características dos pré-oxidantes alternativos............................ 24

3.5.1 Dióxido de cloro............................................................ 25

3.5.2 Permanganato de potássio....................................................... 29 


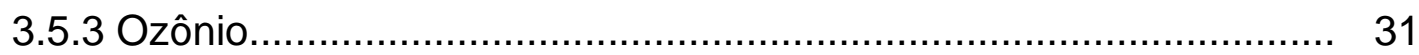

3.5.4 Peróxido de hidrogênio................................................................ 33

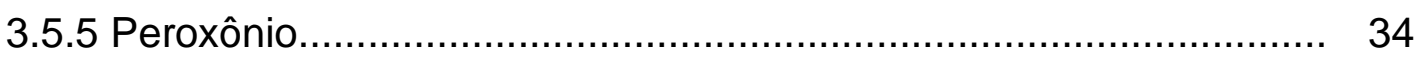

3.6 Considerações finais sobre a literatura......................................... 36

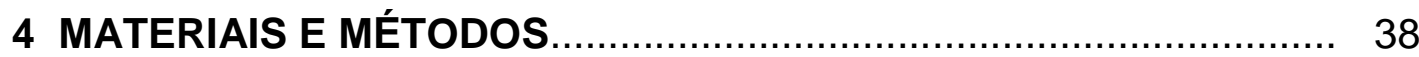

4.1 Extração de substâncias húmicas................................................. 42

4.1.1 Caracterização do extrato de substâncias húmicas........................ 43

4.2 Caracterização da água de estudo............................................... 44

4.3 Extrações e análises por cromatográfia em fase gasosa............. 46

4.3.1 Extração líquido-líquido........................................................... 46

4.3.2 Análises cromatográficas..................................................... 47

4.3.2.1 Determinação de trialometanos, cloro hidrato, cloripicrinas, haloacetonitrilas e haloacetonas.................................................... 47

4.3.3 Extração com derivatização...................................................... 51

4.3.3.1 Determinação de ácidos haloacéticos...................................... 51

4.4 Ensaios para definição de cor, temperatura e dosagem de cloro para determinação do potencial de formação de subprodutos.......... 53

4.5 Demanda de pré-oxidantes.......................................................... 54

4.5.1 Ensaios de demanda da pré-oxidação com cloro.......................... 56

4.5.2 Ensaios de demanda da pré-oxidação com dióxido de cloro........... 56

4.5.3 Ensaios de demanda da pré-oxidação com permanganato de

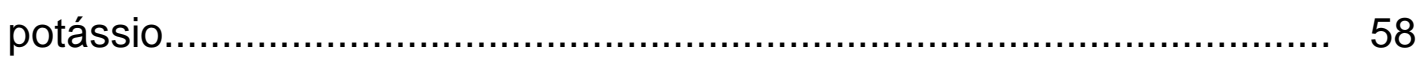

4.5.4 Ensaios de demanda da pré-oxidação com peróxido de

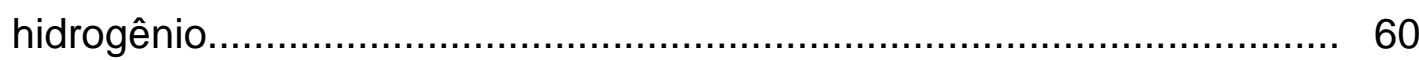

4.5.5 Ensaios de demanda da pré-oxidação com ozônio........................ 60

4.5.5.1 Determinação da produção de ozônio.......................................... 61

4.5.5.2 Ensaios de demanda com ozônio............................................... 64

4.5.6 Ensaios de demanda da pré-oxidação com

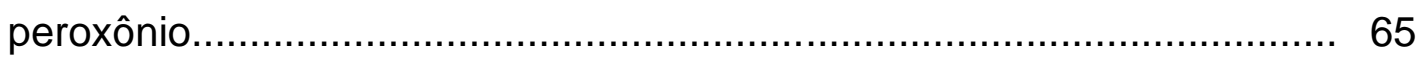

4.6 Ensaios para determinação da dosagem de coagulante.............. 66

4.7 Pós-cloração.............................................................................. 67 
4.8 Potencial de formação de subprodutos orgânicos halogenados 68

5 RESULTADOS E DISCUSSÃO.................................................. 72

5.1 Resultados de calibração para análises cromatográficas........... 72

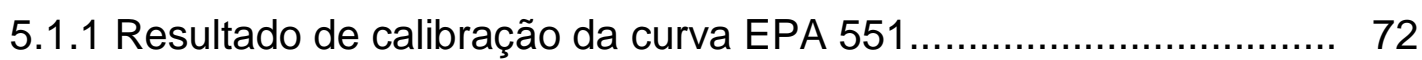

5.1.2 Resultado de calibração da curva EPA 552 ............................... 74

5.2 Características do extrato de substâncias húmicas...................... 75

5.2.1 Análises de Infravermelho............................................... 75

5.2 .2 Análises de Ultravioleta Visível .......................................... 76

5.2.3 Análises de metais no extrato de substâncias húmicas................. 77

5.3 Resultados dos ensaios para definição da cor aparente da água de estudo.

5.4 Caracterização da água de estudo............................................... 79

5.5 Resultados de ensaio para definição de temperatura................... 80

5.6 Resultados dos ensaios para definição da dosagem de cloro no potencial de formação de subprodutos em 7 dias.............................. 82

5.7 Resultados de ensaios de demanda de pré-oxidantes.................. 83

5.7.1 Ensaios de demanda com cloro.................................................. 83

5.7.2 Ensaios de demanda com dióxido de cloro................................... 84

5.7.3 Ensaios de demanda com permanganato de potássio.................... 85

5.7.4 Ensaios de demanda com peróxido de hidrogênio........................ 87

5.7.5 Ensaios de demanda com ozônio.................................................. 87

5.7.6 Ensaios de demanda com peróxido de hidrogênio e ozônio (peroxônio)............................................................................. 90

5.8 Resultados de ensaios de jarteste para determinação da dosagem de coagulante.................................................................... 91

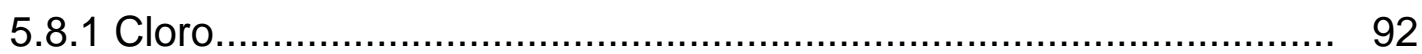

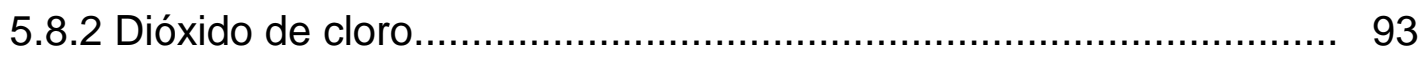

5.8.3 Permanganato de potássio........................................................ 94

5.8.4 Peróxido de hidrogênio................................................................ 95

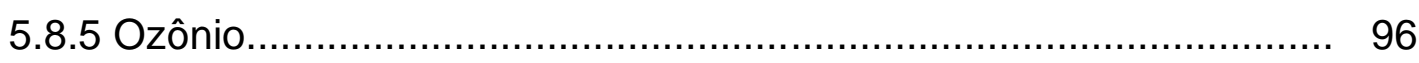

5.8.6 Peroxônio.................................................................................. 99 
5.9 Potencial de formação de subprodutos orgânicos halogenados 100

\subsection{Potencial de formação de subprodutos orgânicos} halogenados em 24 horas............................................................... 105

5.10.1 Subprodutos da pré-oxidação com cloro................................... 106

5.10.1.1 Subprodutos da pré-oxidação cloro, filtração e pós-cloração..... 106 5.10.1.2 Subprodutos da pré-oxidação com cloro, seguido de coagulação, filtração e pós-cloração.................................................. 108

5.10.2 Subprodutos da pré-oxidação com permanganato de potássio.... 112

5.10.2.1 Subprodutos da pré-oxidação com permanganato de potássio, filtração e pós-cloração

5.10.2.1 Subprodutos da pré-oxidação com permanganato de potássio, seguido de coagulação, filtração e pós-cloração.

5.10.3 Subprodutos da pré-oxidação com dióxido de cloro

5.10.3.1 Subprodutos da pré-oxidação com dióxido de cloro, filtração e pós-cloração.

5.10.3.2 Subprodutos da pré-oxidação com dióxido de cloro, seguido de coagulação, filtração e pós-cloração.

5.10.4 Subprodutos da pré-oxidação com peróxido de hidrogênio.

5.10.4.1 Subprodutos da pré-oxidação com peróxido de hidrogênio, filtração e pós-cloração

5.10.4.2 Subprodutos da pré-oxidação com peróxido de hidrogênio, seguido de coagulação, filtração e pós-cloração.

5.10.5 Subprodutos da pré-oxidação com ozônio

5.10.5.1 Subprodutos da pré-oxidação com ozônio, filtração e póscloração

5.10.5.2 Subprodutos da pré-oxidação com ozônio, seguido de coagulação, filtração e pós-cloração.

5.10.6 Subprodutos da pré-oxidação com peroxônio

5.10.6.1 Subprodutos da pré-oxidação com peroxônio, filtração e póscloração

5.10.6.2 Subprodutos da pré-oxidação com peroxônio, seguido de coagulação, filtração e pós-cloração. 
5.11 Avaliação dos subprodutos formados em função do préoxidante.

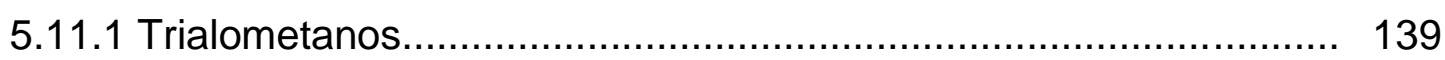

5.11.2 Cloro hidrato.................................................................. 140

5.11.3 Haloacetonitrilas............................................................ 141

5.11.4 Halocetonas .................................................................. 142

5.11.5 Ácidos haloacéticos........................................................... 143

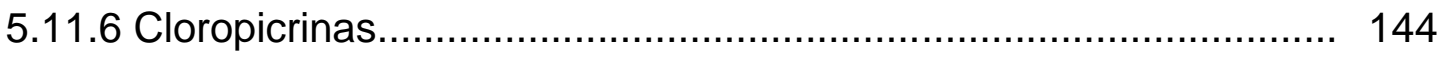

6 CONCLUSÕES E RECOMENDAÇÕES........................................ 145

7 REFERÊNCIAS BIBLIOGRÁFICAS.............................................. 148

\section{APÊNDICE A}

A - 01 Resumo da curva de calibração EPA 551 (551)

A - 02 Cromatograma ponto 1

A - 03 Cromatograma ponto 2

A - 04 Cromatograma ponto 3

A - 05 Cromatograma ponto 4

A - 06 Cromatograma ponto 5

A - 07 Cromatograma ponto 6

A - 08 Cromatograma de verificação - ponto 2

\section{APÊNDICE B}

B - 01 Resumo da curva de calibração EPA 552 (HAAO3)

B - 02 Cromatograma branco calibração

B - 03 Cromatograma ponto 1

B - 04 Cromatograma ponto 2

B - 05 Cromatograma ponto 3

B - 06 Cromatograma ponto 4

B - 07 Cromatograma ponto 6

B - 08 Cromatograma ponto 7

B - 09 Cromatograma de verificação - ponto 2 


\section{APÊNDICE C}

C - 01 Cromatograma PF 7 dias branco 30min 551

C - 02 Cromatograma PF 7 dias branco 168h 551

C - 03 Cromatograma PF 7 dias 30 min 551

C -04 Cromatograma PF 7 dias $168 \mathrm{~h} 551$

C - 05 Cromatograma PF 7 dias Branco 30 min 552

C - 06 Cromatograma PF 7 dias branco 168h 552

C - 07 Cromatograma PF 7 dias 30 min 552

C - 08 Cromatograma PF 7 dias 168h 552

\section{APÊNDICE D}

D - 01 Cromatograma do ensaio com pré-oxidação com cloro, filtração em papel, pós-cloração e incubação a $25^{\circ} \mathrm{C}$ com tempo de contato de $24 \mathrm{~h}-551$. $\mathrm{D}-02$ Cromatograma do ensaio com pré-oxidação com cloro, filtração em papel, pós-cloração e incubação a $25^{\circ} \mathrm{C}$ com tempo de contato de $24 \mathrm{~h}-552$. D - 03 Cromatograma do ensaio com pré-oxidação com cloro, coagulação filtração em papel, pós-cloração e incubação a $25^{\circ} \mathrm{C}$ com tempo de contato de $24 \mathrm{~h}-551$.

D - 04 Cromatograma do ensaio com pré-oxidação com cloro, coagulação filtração em papel, pós-cloração e incubação a $25^{\circ} \mathrm{C}$ com tempo de contato de $24 h-552$.

\section{APÊNDICE E}

E-01 - Cromatograma do ensaio com pré-oxidação com permanganato de potássio, filtração em papel, pós-cloração e incubação a $25^{\circ} \mathrm{C}$ com tempo de contato de $24 \mathrm{~h}-551$.

E-02 - Cromatograma do ensaio com pré-oxidação com permanganato de potássio, filtração em papel, pós-cloração e incubação a $25^{\circ} \mathrm{C}$ com tempo de contato de $24 \mathrm{~h}-552$.

E-03 - Cromatograma do ensaio com pré-oxidação com permanganato de potássio, coagulação filtração em papel, pós-cloração e incubação a $25^{\circ} \mathrm{C}$ com tempo de contato de $24 \mathrm{~h}-551$.

E-04- Cromatograma do ensaio com pré-oxidação com permanganato de potássio, coagulação filtração em papel, pós-cloração e incubação a $25^{\circ} \mathrm{C}$ com tempo de contato de $24 \mathrm{~h}-552$.

\section{APÊNDICE F}

F-01 Cromatograma do ensaio da pré-oxidação com dióxido de cloro, filtração em papel, pós-cloração, incubação a $25^{\circ} \mathrm{C}$ com tempo de contato de $12 \mathrm{~h}$, método 551.

F-02 Cromatograma do ensaio da pré-oxidação com dióxido de cloro, filtração em papel, pós-cloração, incubação a $25^{\circ} \mathrm{C}$ com tempo de contato de $12 \mathrm{~h}$, método 552. 
F-03 Cromatograma do ensaio da pré-oxidação com dióxido de cloro, coagulação, filtração em papel, pós-cloração, incubação a $25^{\circ} \mathrm{C}$ com tempo de contato de $12 \mathrm{~h}$, método 551

F-04 Cromatograma do ensaio da pré-oxidação com dióxido de cloro, coagulação, filtração em papel, pós-cloração, incubação a $25^{\circ} \mathrm{C}$ com tempo de contato de $12 \mathrm{~h}$, método 552.

\section{APÊNDICE G}

G-01 - Cromatograma do ensaio com pré-oxidação com peróxido de hidrogênio, filtração em papel, pós-cloração e incubação a $25^{\circ} \mathrm{C}$ com tempo de contato de $24 \mathrm{~h}-551$.

G-02 - Cromatograma do ensaio com pré-oxidação com peróxido de hidrogênio, filtração em papel, pós-cloração e incubação a $25^{\circ} \mathrm{C}$ com tempo de contato de $24 \mathrm{~h}-552$.

G-03 - Cromatograma do ensaio com pré-oxidação com peróxido de hidrogênio, coagulação filtração em papel, pós-cloração e incubação a $25^{\circ} \mathrm{C}$ com tempo de contato de $24 \mathrm{~h}-551$.

G-04- Cromatograma do ensaio com pré-oxidação com peróxido de hidrogênio, coagulação filtração em papel, pós-cloração e incubação a $25^{\circ} \mathrm{C}$ com tempo de contato de $24 \mathrm{~h}-552$.

\section{APÊNDICE H}

H-01 - Cromatograma do ensaio com pré-oxidação com ozônio, filtração em papel, pós-cloração e incubação a $25^{\circ} \mathrm{C}$ com tempo de contato de $24 \mathrm{~h}-551$. H-02 - Cromatograma do ensaio com pré-oxidação com ozônio, filtração em papel, pós-cloração e incubação a $25^{\circ} \mathrm{C}$ com tempo de contato de $24 \mathrm{~h}-552$. H-03 - Cromatograma do ensaio com pré-oxidação com ozônio, coagulação filtração em papel, pós-cloração e incubação a $25^{\circ} \mathrm{C}$ com tempo de contato de $24 \mathrm{~h}-551$.

H-04- Cromatograma do ensaio com pré-oxidação com ozônio, coagulação filtração em papel, pós-cloração e incubação a $25^{\circ} \mathrm{C}$ com tempo de contato de $24 \mathrm{~h}-552$.

\section{APÊNDICE I}

I-01 - Cromatograma do ensaio com pré-oxidação com peroxônio, filtração em papel, pós-cloração e incubação a $25^{\circ} \mathrm{C}$ com tempo de contato de $24 \mathrm{~h}-$ 551.

I-02 - Cromatograma do ensaio com pré-oxidação com peroxônio, filtração em papel, pós-cloração e incubação a $25^{\circ} \mathrm{C}$ com tempo de contato de $24 \mathrm{~h}-$ 552.

I-03 - Cromatograma do ensaio com pré-oxidação com peroxônio, coagulação filtração em papel, pós-cloração e incubação a $25^{\circ} \mathrm{C}$ com tempo de contato de $24 \mathrm{~h}-551$.

I-04- Cromatograma do ensaio com pré-oxidação com peroxônio, coagulação filtração em papel, pós-cloração e incubação a $25^{\circ} \mathrm{C}$ com tempo de contato de $24 \mathrm{~h}-552$. 


\section{LISTA DE FIGURAS}

Figura 3.1- Influência da temperatura e do tempo de contato na formação de clorofórmio.

Figura 3.2- Influência do pH na reação halofórmica.

Figura 3.3- Efeito da concentração molar de ácido húmico na produção de TAMs em $\mathrm{pH} 6,7$, a $25^{\circ} \mathrm{C}$ e dosagem de $10 \mathrm{mg} / \mathrm{L} \mathrm{Cl}_{2}$.

Figura 3.4 - Efeito da dosagem de cloro na formação de trialometanos totais. Fonte: TRUSSEL \& UMPHRES (1978).

Figura 3.5 - Modelo simplificado da estrutura molecular das

substâncias húmicas. Fonte: TRUSSEL \& UMPHERES (1978).

Figura 3.6 - Mecanismo de reação halofórmica. Fonte: TRUSSEL \& UMPHERES (1978).

Figura 4.1 - Fluxograma da preparação da água de estudo com extrato de substâncias húmicas e caracterizações.

Figura 4.2 - Fluxograma do desenvolvimento de duas metodologias analíticas por cromatografia em fase gasosa (CG-DCE).

Figura 4.3 - Fluxograma de ensaios com variação de cor, temperatura e dosagem de cloro.

Figura 4.4- Fluxograma dos ensaios de demanda com os préoxidantes alternativos para determinação de dosagem e tempo de contato a serem aplicados na etapa de pré-oxidação.

Figura 4.5- Fluxograma dos ensaios de jarteste para determinação da dosagem de coagulante estabelecendo condições de $\mathrm{pH}$, tempo de contato, gradiente de velocidade na mistura rápida e filtração em papel para obtenção de cor remanescente $<5 \mathrm{uH}$.

Figura 4.6- Fluxograma dos ensaios para avaliação do potencial de formação de subprodutos em 7 dias e taxas de formação

Figura 4.7- Fluxograma dos ensaios de pré-oxidação, coagulação, filtração, pós-cloração, incubação e analises CG-DCE.

Figura 4.8 - Cromatógrafo a gás com detetor de captura de elétrons, Varian, instalado na UNAERP.

Figura 4.9 - Fluxograma de sistema piloto para geração de ozônio.

Figura 4.10 - Sistema de geração de dióxido de cloro.

Figura 4.11 - Curva de calibração para determinação de residual de permanganato de potássio com absorbância em função da concentração, equação da reta e coeficiente de correlação obtido por regressão linear. 
Figura 4.12- Cilindro de oxigênio e aparelho utilizado para geração de ozônio.

Figura 4.13 - Fluxograma dos ensaios experimentais da segunda etapa.

Figura 5.1- Cromatograma de calibração do ponto 3 da curva EPA 551.

Figura 5.2 - Cromatograma de calibração do ponto 2 da curva EPA 552.

Figura 5.3 - Espectro da região do infravermelho das substâncias húmicas.

Figura 5.4 - Espectro de Visível na região de 465 a 665 nm para a amostra de substâncias húmicas.

Figura 5.5 - Valores de trialometanos em função do tempo de contato em diferentes temperaturas.

Figura 5.6 - Taxa ou velocidade de formação em função do tempo de contato para diferentes temperaturas.

Figura 5.7 - Demanda de cloro em função da dosagem aplicada para diferentes tempos de contato, a $25^{\circ} \mathrm{C}$.

Figura 5.8 - Demanda de dióxido de cloro em função da dosagem aplicada para diferentes tempos de contato a $25^{\circ} \mathrm{C}$.

Figura 5.9 - Demanda de permanganato de potássio em função da dosagem aplicada para diferentes tempos de contato a $25^{\circ} \mathrm{C}$.

Figura 5.10 - Dosagens obtidas de ozônio em $\mathrm{mg} / \mathrm{L}$ em função do tempo de contato.

Figura 5.11- Produção de ozônio em função do tempo de contato.

Figura 5.12- llustração da remoção de cor aparente antes e após

30 min de ozonização

Figura 5.13- Valores de demanda de ozônio em função do tempo de contato.

Figura 5.14 - Dosagem de sulfato de alumínio em função da cor remanescente utilizando-se cloro como pré-oxidante.

Figura 5.15 - Dosagem de sulfato de alumínio em função da cor aparente remanescente e pH de coagulação utilizando-se dióxido de cloro na pré-oxidação.

Figura 5.16- Dosagem de sulfato de alumínio em função da cor aparente remanescente e $\mathrm{pH}$ de coagulação utilizando-se $\mathrm{KMnO}_{4}$ como pré-oxidante.

Figura 5.17- Dosagem de sulfato de alumínio em função da cor aparente remanescente e $\mathrm{pH}$ de coagulação utilizando-se $\mathrm{H}_{2} \mathrm{O}_{2}$ como pré-oxidante.

Figura 5.18 - Valores de cor remanescente em função da dosagem de sulfato de alumínio para diversos tempos de contato, utilizando-se ozônio como pré-oxidante.

Figura 5.19 - Valores de cor remanescente em função da dosagem de sulfato de alumínio, utilizando-se ozônio como pré-oxidante no tempo de contato de 30 minutos.

Figura 5.20 - Valores de cor remanescente em função da dosagem de sulfato de alumínio para diferentes proporções de $\mathrm{H}_{2} \mathrm{O}_{2} / \mathrm{O}_{3}$. 
Figura 5.21- Valores de concentração de subprodutos agrupados por famílias em função do tempo de contato.

Figura 5.22 - Valores de potencial de formação em 7 dias com cloro expressos em concentração ( $\mu \mathrm{g} / \mathrm{L})$ e porcentagem (\%), com dosagem excessiva de cloro (15mg/L $\left.\mathrm{Cl}_{2}\right)$.

Figura 5.23 - Concentração de subprodutos ( $\mu \mathrm{g} / \mathrm{L})$, da pré-oxidação com cloro, filtração e pós-cloração em função do tempo de contato a $25^{\circ} \mathrm{C}$.

Figura 5.24 - Resultados expressos em porcentagem e concentração dos subprodutos da pré-oxidação com cloro, filtração em papel, póscloração, incubação a $25^{\circ} \mathrm{C}$.

Figura 5.25- Resultados de subprodutos com cloro na pré-oxidação, coagulação, filtração em papel, pós-cloração e incubação por $24 \mathrm{~h}$ a $25^{\circ} \mathrm{C}$.

Figura 5.26 - Resultados de potencial de formação de $24 \mathrm{~h}$ dos subprodutos da pré-oxidação com cloro, coagulação, filtração em papel, pós-cloração e incubação por $24 \mathrm{~h}$ a $25^{\circ} \mathrm{C}$ expressos em $\mu \mathrm{g} / \mathrm{L}$ e percentual.

Figura 5.27 - Comparação dos valores de potencial de formação de 7 dias com PF 24h sem coagulação e com coagulação, filtração e póscloração.

Figura 5.28 - Valores de concentração de subprodutos da préoxidação com permanganato de potássio, filtração e pós-cloração em função do tempo de contato a $25^{\circ} \mathrm{C}$.

Figura 5.29 - Resultados de potencial de formação de $24 \mathrm{~h}$ dos subprodutos da pré-oxidação com permanganato de potássio, filtração em papel, pós-cloração e incubação por $24 \mathrm{~h}$ a $25^{\circ} \mathrm{C}$ expressos em $\mu \mathrm{g} / \mathrm{L}$ e percentual.

Figura 5.30 - Concentração de subprodutos em função do tempo de contato com o uso da pré-oxidação com permanganato de potássio, coagulação, filtração, pós-cloração e incubação a $25^{\circ} \mathrm{C}$ em função do tempo de contato.

Figura 5.31 - Resultados de potencial de formação de $24 \mathrm{~h}$ dos subprodutos da pré-oxidação com permanganato de potássio, coagulação, filtração em papel, pós-cloração e incubação por $24 \mathrm{~h}$ a $25^{\circ} \mathrm{C}$ expressos em $\mu \mathrm{g} / \mathrm{L}$ e percentual.

Figura 5.32 - Resultados comparativos de potencial de formação de 7 dias com cloro e permanganato de potássio com presença e ausência de coagulação, filtração em papel, pós-cloração e incubação a $25^{\circ} \mathrm{C}$. Figura 5.33 - Valores de concentração de subprodutos formados com uso de dióxido de cloro filtração, pós-cloração e incubação a $25^{\circ} \mathrm{C}$ em função do tempo de contato.

Figura 5.34 - Resultados de potencial de formação de $24 \mathrm{~h}$ dos subprodutos da pré-oxidação com dióxido de cloro, filtração em papel, pós-cloração e incubação por $24 \mathrm{~h}$ a $25^{\circ} \mathrm{C}$ expressos em $\mu \mathrm{g} / \mathrm{L}$ e percentual. 
Figura 5.35 - Valores de concentração de subprodutos formados com uso de dióxido de cloro, coagulação, filtração em papel, pós-cloração e incubação a $25^{\circ} \mathrm{C}$ em função do tempo de contato.

Figura 5.36 - Valores de potencial de formação após 24h de tempo de contato para pré-oxidação com dióxido de cloro, coagulação, filtração em papel, pós-cloração e incubação a $25^{\circ} \mathrm{C}$, expressos em percentual e concentração.

Figura 5.37- Resultados de PF de 7 dias e $24 \mathrm{~h}$ com coagulação e $24 \mathrm{~h}$ sem coagulação, filtração em papel, pós-cloração, incubação a $25^{\circ} \mathrm{C}$, expressos em concentração.

Figura 5.38-Valores de concentração de subprodutos formados com uso de peróxido de hidrogênio, filtração em papel, pós-cloração e incubação a $25^{\circ} \mathrm{C}$ em função do tempo de contato.

Figura 5.39 - Valores de potencial de formação após 24h de tempo de contato para pré-oxidação com peróxido de hidrogênio, filtração em papel, pós-cloração e incubação a $25^{\circ} \mathrm{C}$, expressos em percentual e concentração.

Figura 5.40 - Valores de concentração de subprodutos formados com peróxido de hidrogênio, com coagulação, filtração em papel, póscloração, incubação a $25^{\circ} \mathrm{C}$ em função do tempo de contato.

Figura 5.41- Valores de potencial de formação após $24 \mathrm{~h}$ de tempo de contato para pré-oxidação com peróxido de hidrogênio, coagulação, filtração em papel, pós-cloração e incubação a $25^{\circ} \mathrm{C}$, expressos em percentual e concentração.

Figura 5.42 - Resultados de PF expressos em concentração de 7 dias, $24 \mathrm{~h}$ com coagulação e $24 \mathrm{~h}$ sem coagulação, filtração em papel, póscloração e incubação a $25^{\circ} \mathrm{C}$.

Figura 5.43 - Valores de concentração de subprodutos formados na pré-oxidação com ozônio, filtração em papel, pós-cloração, incubação a $25^{\circ} \mathrm{C}$ em função do tempo de contato.

Figura 5.44 - Valores de potencial de formação após 24h de tempo de contato para pré-oxidação com ozônio, filtração em papel, póscloração e incubação a $25^{\circ} \mathrm{C}$, expressos em percentual e concentração.

Figura 5.45 - Valores de concentração de subprodutos formados na pré-oxidação com ozônio, coagulação, filtração em papel, póscloração, incubação a $25^{\circ} \mathrm{C}$ em função do tempo de contato.

Figura 5.46 - Valores de potencial de formação após 24h de tempo de contato para pré-oxidação com ozônio, coagulação, filtração em papel, pós-cloração, incubação a $25^{\circ} \mathrm{C}$, expressos em percentual e concentração.

Figura 5.47 - Valores de PF de 7 dias e 24h, com o uso de ozônio na pré-oxidação, presença e ausência de coagulação, filtração, póscloração, incubação a $25^{\circ} \mathrm{C}$ expressos em concentração.

Figura 5.48 - Valores de concentração de subprodutos formados na pré-oxidação com peroxônio, filtração em papel, pós-cloração, incubação a $25^{\circ} \mathrm{C}$ em função do tempo de contato. 
Figura 5.49 - Valores de potencial de formação após 24h de tempo de contato para pré-oxidação com peroxônio, filtração em papel, póscloração, incubação a $25^{\circ} \mathrm{C}$, expressos em percentual e concentração. Figura 5.50 - Valores de concentração de subprodutos formados com peroxônio, coagulação, filtração em papel, pós-cloração, incubação a $25^{\circ} \mathrm{C}$ em função do tempo de contato.

Figura 5.51 - Valores de potencial de formação após $24 \mathrm{~h}$ de tempo de contato para pré-oxidação com peroxônio em presença de coagulação expressos em percentual e concentração.

Figura 5.52 - Resultados comparativos de PF 7dias, com PF de 24h para o peroxônio empregado na pré-oxidação, com coagulação e sem coagulação, filtração, pós-cloração e incubação a $25^{\circ} \mathrm{C}$.

Figura 5.53 - Resultados de PF de $24 \mathrm{~h}$ de trialometanos em presença e ausência de coagulação, filtração em papel, pós-cloração, incubação a $25^{\circ} \mathrm{C}$ em função dos pré-oxidantes aplicados.

Figura 5.54 - Resultados de PF 24h de cloro hidrato em presença e ausência de coagulação, filtração em papel, pós-cloração, incubação a $25^{\circ} \mathrm{C}$ em função dos pré-oxidantes aplicados.

Figura 5.55 - Resultados de PF 24h de haloacetonitrilas em presença e ausência de coagulação, filtração em papel, pós-cloração, incubação a $25^{\circ}$ em função dos pré-oxidantes aplicados.

Figura 5.56 - Resultados de PF 24h de halocetonas em presença e ausência de coagulação, filtração em papel, pós-cloração, incubação a $25^{\circ}$ em função dos pré-oxidantes aplicados.

Figura 5.57- Resultados de PF 24h de ácidos haloacéticos em presença e ausência de coagulação, filtração em papel, pós-cloração, incubação a $25^{\circ}$ em função dos pré-oxidantes aplicados. 


\section{LISTA DE TABELAS}

Tabela 3.1- Resultados obtidos por SANTOS (1988), de TAMs na água distribuída em várias localidades de São Paulo.

Tabela 3.2- Lista de informação de saúde para subprodutos da desinfecção (USEPA 1999).

Tabela 3.3- Risco relativo a ter câncer em função do volume de água clorada ingerida diariamente e do número de anos relativos à ingestão da água (CANTOR, 1992).

Tabela 3.4- Fórmulas químicas e denominações dos trialometanos.

Tabela 3.5 - Fórmulas estruturais de subprodutos orgânicos halogenados.

Tabela 3.6 - Principais subprodutos formados por uso de ozônio.

Tabela 3.7- Potencial padrão de oxi-redução para semi-reações em solução aquosa a $25^{\circ} \mathrm{C}$.

Tabela 4.1- Parâmetros, métodos analíticos, unidades e limites de detecção.

Tabela 4.2 - Resumo da curva de calibração para trialometanos, haloacetonitrilas, halocetonas, clorohidrato e cloropicrina em $\mu \mathrm{g} / \mathrm{L}$. Tabela 4.3- Resumo da curva analítica de calibração para ácidos haloacéticos.

Tabela 4.4- Curva de calibração de $\mathrm{KMnO}_{4}$ instalada no espectrofotômetro DR 2000-HACH.

Tabela 4.5 - Resumo das condições estabelecidas para os ensaios de determinação de dosagem de coagulante.

Tabela 4.6 - Resumo das condições dos ensaios de potencial de formação de subprodutos da oxidação.

Tabela 5.1- Resumo da validação do método EPA 551 obtido para o ponto 3.

Tabela 5.2- Resumo de validação do método 552 obtido no ponto 2 .

Tabela 5.3- Composição elementar das substâncias húmicas e as razões atômicas.

Tabela 5.4 - Resultados das análises de metais no extrato de substâncias húmicas.

Tabela 5.5 - Resultados obtidos de trialometanos ( $\mu \mathrm{g} / \mathrm{L})$, com tempo de contato de $24 \mathrm{~h}$ a $20^{\circ} \mathrm{C}$, com variação de cor aparente e dosagem de cloro (ácido tricloro isocianurico).

Tabela 5.6- Características físicas e químicas das águas utilizadas. 
Tabela 5.7 - Resultados obtidos de trialometanos $(\mu \mathrm{g} / \mathrm{L})$ e taxas

$(\mu \mathrm{g} / \mathrm{L}$.h) com variação de temperatura e tempo de contato.

Tabela 5.8 - Resultados de cloro residual livre com tempo de contato de 7 dias a $25^{\circ} \mathrm{C}$ para definir a dosagem de cloro e confirmação de residual livre persistente.

Tabela 5.9 - Resultados de residual de cloro e cálculo de demanda pré-oxidante para água de cor $200 \mathrm{uH}$ em função do tempo de contato a $25^{\circ} \mathrm{C}$

Tabela 5.10 - Resultados de residual de dióxido de cloro e cálculo de demanda de dióxido de cloro para água de cor $200 u H$ em função do tempo de contato a $25^{\circ} \mathrm{C}$.

Tabela 5.11- Resultados de residual de permanganato de potássio e cálculo da demanda pré-oxidante para água de cor $200 \mathrm{uH}$ a $25^{\circ} \mathrm{C}$.

Tabela 5.12 - Resultados dos ensaios para determinação da capacidade de produção de ozônio em função do tempo de contato.

Tabela 5.13- Resultados obtidos dos ensaios de demanda com ozônio em função do tempo de contato.

Tabela 5.14 - Resultados obtidos de ensaios com dosagens de diferentes proporções de peróxido de hidrogênio e ozônio durante 30 minutos com dosagem aplicada de $8,6 \mathrm{mg} / \mathrm{LO}_{3}$ em 11 litros água de estudo.

Tabela 5.15 - Resultados obtidos nos ensaios com o cloro na préoxidação.

Tabela 5.16- Resultados do ensaio com o pré-oxidante dióxido de cloro.

Tabela 5.17- Resultados obtidos no ensaio com permanganato de potássio.

Tabela 5.18- Resultados obtidos nos ensaios com peróxido de hidrogênio.

Tabela 5.19 Resultados de pH e cor remanescente em função da dosagem de sulfato de alumínio para diferentes tempos de contato. Tabela 5.20 - Resultados dos ensaios de dosagem de coagulante na água pré-oxidada com ozônio em pH após ozonização de 7,25 e cor remanescente $116 \mathrm{uH}$.

Tabela 5.21- Resultados de concentração residual de ozônio e cálculo da dosagem consumida para o tempo de contato de 30 minutos considerando a produção de $0,19 \mathrm{~g} \mathrm{O}_{3} / \mathrm{h}$.

Tabela 5.22- Valores obtidos de cor remanescente e pH de coagulação em função da variação da dosagem de sulfato de alumínio para proporções de $\mathrm{H}_{2} \mathrm{O}_{2} / \mathrm{O}_{3}: 0,5,1,0$ e 2,0.

Tabela 5.23- Resumo dos resultados obtidos nos ensaios em jarteste de dosagem de sulfato de alumínio e pH de coagulação para os diferentes pré-oxidantes em função da cor aparente remanescente. Tabela 5.24- Resultados de subprodutos orgânicos halogenados obtidos por análises cromatográficas expressos em $\mu \mathrm{g} / \mathrm{L}$ à $25^{\circ} \mathrm{C} \mathrm{com}$ dosagem de cloro de $15 \mathrm{mg} / \mathrm{LCl}_{2}$ em água com cor aparente $200 \mathrm{uH}$. 
Tabela 5.25- Valores de concentração utilizados no cálculo do potencial de formação em presença de excesso de cloro após 7 dias de tempo de contato à $25^{\circ} \mathrm{C}$.

Tabela 5.26 - Resultados de subprodutos da pré-oxidação com cloro, filtração em papel, pós-cloração, incubação a $25^{\circ} \mathrm{C}$ e o cálculo do PF $24 \mathrm{~h}$.

Tabela 5.27 - Subprodutos da pré-oxidação com cloro $\left(5 \mathrm{mgCl}_{2} / \mathrm{L}\right)$, coagulação (14mgSA/L), filtração em papel, pós-cloração $\left(5 \mathrm{mgCl}_{2} / \mathrm{L}\right)$ e incubação por $24 \mathrm{~h} \mathrm{a} 25^{\circ} \mathrm{C}$, em $\mu \mathrm{g} / \mathrm{L}$.

Tabela 5.28- Resultados de subprodutos da pré-oxidação com permanganato de potássio $\left(3,5 \mathrm{mg} \mathrm{KMnO}_{4} / \mathrm{L}\right)$, filtração em papel, póscloração $\left(5 \mathrm{mgCl}_{2} / \mathrm{L}\right)$ e incubação a $25^{\circ} \mathrm{C}$, em $\mu \mathrm{g} / \mathrm{L}$, em função do tempo de contato.

Tabela 5.29 - Subprodutos da pré-oxidação com permanganato de potássio, coagulação, filtração, pós-cloração e incubação por $24 \mathrm{~h}$ a $25^{\circ} \mathrm{C}$, em $\mu \mathrm{g} / \mathrm{L}$.

Tabela 5.30 - Resultados de subprodutos da pré-oxidação com dióxido de cloro, filtração em papel, pós-cloração e incubação por $24 \mathrm{~h}$ a $25^{\circ} \mathrm{C}$ e PF de 24h em $\mu \mathrm{g} / \mathrm{L}$.

Tabela 5.31- Resultados de subprodutos da pré-oxidação com dióxido de cloro, coagulação, filtração e incubação por $24 \mathrm{~h}$ a $25^{\circ} \mathrm{C} \mathrm{em} \mu \mathrm{g} / \mathrm{L}$. Tabela 5.32 - Resultados de subprodutos da pré-oxidação com peróxido de hidrogênio, filtração, incubação por $24 \mathrm{~h}$ a $25^{\circ} \mathrm{C}$ e PF de $24 \mathrm{~h} \mathrm{em} \mu \mathrm{g} / \mathrm{L}$.

Tabela 5.33- Subprodutos da pré-oxidação com peróxido de hidrogênio, com coagulação, filtração em papel, pós-cloração, incubação por $24 \mathrm{~h}$ a $25^{\circ} \mathrm{C}$ e PF de $24 \mathrm{~h}$, em $\mu \mathrm{g} / \mathrm{L}$.

Tabela 5.34 - Subprodutos da pré-oxidação com ozônio, filtração, incubação por $24 \mathrm{~h}$ a $25^{\circ} \mathrm{C}$ e PF de $24 \mathrm{~h}$, em $\mu \mathrm{g} / \mathrm{L}$.

Tabela 5.35- Subprodutos da pré-oxidação com ozônio, coagulação, filtração em papel, pós-cloração, incubação por $24 \mathrm{~h}$ a $25^{\circ} \mathrm{C}$ e PF de 24h, em $\mu \mathrm{g} / \mathrm{L}$.

Tabela 5.36 - Subprodutos da pré-oxidação com peroxônio, filtração, em papel, pós-cloração, incubação por $24 \mathrm{~h}$ a $25^{\circ} \mathrm{C}$ e PF $24 \mathrm{~h}$ em $\mu \mathrm{g} / \mathrm{L}$. Tabela 5.37- Subprodutos da pré-oxidação com peroxônio, coagulação, filtração em papel, pós-cloração e incubação por $24 \mathrm{~h}$ a $25^{\circ} \mathrm{C}, \mathrm{em} \mu \mathrm{g} / \mathrm{L}$. 


\section{LISTA DE ABREVIATURAS E SIGLAS}

$\begin{array}{ll}\text { ABS } & \text { Absortion Atomic Spectro } \\ \text { AHAs } & \text { Ácidos haloacéticos } \\ \text { BCAA } & \text { Ácido bromocloroacético } \\ \text { BCAN } & \text { Bromocloroacetonitrila } \\ \text { BDCAA } & \text { Ácido bromodicloroacético } \\ \text { CG-DCE } & \text { Cromatrografia Gasosa - Detetor Captura de Eletrons } \\ \text { CG-EM } & \text { Cromatografia Gasosa - Espectrômetro de Massa } \\ \text { CH } & \text { Cloro Hidrato } \\ \text { COT } & \text { Carbono Orgânico Total } \\ \text { CP } & \text { Cloropicrina } \\ \text { DBAA } & \text { Ácido dibromoacético } \\ \text { DBAN } & \text { Dibromoacetonitrila } \\ \text { DBCA } & \text { Ácido dibromocloroacético } \\ \text { DCAA } & \text { Ácido dicloroacético } \\ \text { DCAN } & \text { Dicloro acetonitrila } \\ \text { DCEL } & \text { Detetor de condutividade eletrica } \\ \text { DO3 } & \text { Demanda de ozônio } \\ \text { DQO } & \text { Demanda química de oxigênio } \\ \text { ETA } & \text { Estação de tratamento de Água } \\ \text { EUA } & \text { Estados Unidos da América } \\ \text { f } & \text { Fator de correção da solução padronizada de tiossulfato de sódio } \\ \text { FDA } & \text { Foof and Drug Administration } \\ \text { FL } & \text { Fase liquída } \\ \text { G } & \text { Gradiente de velocidade } \\ \text { GM } & \text { Gabinete do Ministro } \\ \text { HADs } & \text { Haloaldeídos } \\ \text { HANs } & \text { Haloacetonitrilas } \\ \text { HC } & \text { Haletos cianogênicos } \\ \text { HF } & \text { Halofenóis } \\ \text { HKs } & \text { Halocetonas } \\ \text { HPs } & \text { Halopicrinas } \\ \text { MBAA } & \text { Ácido monobromoacético } \\ \text { MCAA } & \text { Ácido monocloroacético } \\ \text { MON } & \text { Matéria Orgânica Natural } \\ \text { MTBE } & \text { Metil-terc butílico éter } \\ \text { N } & \text { Normalidade } \\ \text { PC } & \text { Produção Consumida } \\ & \end{array}$


PF 24h

PF 7 dias

$\mathrm{P}_{\mathrm{G}}$

$\mathrm{pH}$

PI

$\mathrm{PL}_{\mathrm{L}}$

$P_{T}$

SA

$\mathrm{SHS}$

SPD

TAMs

TBAA

TBAN

Tc

TCAA

TCAN

Tm

Tmr

UNAERP

USEPA

UV

$\mathrm{UV} / \mathrm{Vis}$

$\mathrm{Vc}$

$\mathrm{Vg}$
Potencial de Formação de 24horas

Potencial de Formação de 7 dias

Produção na fase gasosa

Potencial Hidrogeniônico

Padrão Interno

Produção na fase liquida

Produção total aplicada

Sulfato de alumínio

Substânias Húmicas

Subprodutos da desinfecção

Trialometranos

Ácido tribromoacético

Tribromoacetonitrila

Tempo de contato

Ácido tricloroacético

Tricloroacetonitrila

Tempo de mistura

Tempo de mistura rápida

Universidade da Associação de Ensino de Ribeirão Preto

United States Environment Protection Agency

Ultra Violeta

Ultravioleta Vísivel

Volume útil da câmara de contato

Volume gasto 


\section{LISTA DE SIMBOLOS}

\begin{tabular}{|c|c|}
\hline $\mathrm{HOCl}$ & Ácido Hipocloroso \\
\hline $\mathrm{NaHCO}_{3}$ & Bicarbonato de sódio \\
\hline $\mathrm{CHBrCl}_{2}$ & Bromodiclorometano \\
\hline $\mathrm{CHBr}_{3}$ & Bromofórmio \\
\hline $\mathrm{cm}$ & Centímetros \\
\hline $\mathrm{CHCl}_{3}$ & Clorofórmio \\
\hline $\mathrm{CHBr}_{2} \mathrm{Cl}$ & Dibromoclorometano \\
\hline $\mathrm{ClO}_{2}$ & Dióxido de Cloro \\
\hline $\mathrm{E}^{\circ}$ & Potencial de oxi-redução \\
\hline${ }^{\circ} \mathrm{C}$ & Grau Celsius \\
\hline $\mathrm{KOH}$ & Hidróxido de potássio \\
\hline $\mathrm{NaOH}$ & Hidróxido de sódio \\
\hline $\mathrm{Ca}(\mathrm{ClO})_{2}$ & Hipoclorito de Cálcio \\
\hline $\mathrm{h}$ & Hora \\
\hline $\mathrm{KI}$ & Iodeto de Potássio \\
\hline $\mathrm{KBr}$ & Brometo de potássio \\
\hline $\mathrm{L}$ & Litro \\
\hline$\mu \mathrm{m}$ & Micrometro \\
\hline$\mu \mathrm{g} / \mathrm{L}$ & Microgramas por litro \\
\hline $\mathrm{mg} / \mathrm{L}$ & Miligramas por litro \\
\hline $\mathrm{mL}$ & Mililitro \\
\hline $\min$ & Minutos \\
\hline M & Molaridade \\
\hline $\mathrm{N}$ & Normalidade \\
\hline $\mathrm{nm}$ & Nanômetro \\
\hline NTU & Unidade neftelometrica de turbidez \\
\hline $\mathrm{O}_{2}$ & Oxigênio \\
\hline $\mathrm{O}_{3}$ & Ozônio \\
\hline $\mathrm{KMnO}_{4}$ & Permanganato de potássio \\
\hline $\mathrm{H}_{2} \mathrm{O}_{2}$ & Peróxido de hidrogênio \\
\hline$\%$ & Porcentagem \\
\hline $\mathrm{Al}_{2}\left(\mathrm{SO}_{4}\right)_{3} \cdot 14,3 \mathrm{H}_{2} \mathrm{O}$ & Sulfato de alumínio \\
\hline $\mathrm{Tf}$ & Tempo final \\
\hline To & Tempo inicial \\
\hline $\mathrm{uH}$ & Unidade Hanzen de cor \\
\hline $\mathrm{V}$ & Volts \\
\hline
\end{tabular}




\section{RESUMO}

PASCHOALATO, C. F. P. R. (2005). Efeito da pré-oxidação, coagulação, filtração e pós-cloração na formação de subprodutos orgânicos halogenados em água contendo substâncias húmicas. São Carlos, 2005, 148 p. Tese (doutorado), Escola de Engenharia de São Carlos, Universidade de São Paulo.

A presença de substâncias húmicas em águas destinadas ao abastecimento tem ocasionado diversos problemas, decorrentes da formação de subprodutos orgânicos halogenados, principalmente quando se emprega a pré-oxidação com cloro. Os compostos orgânicos halogenados, reconhecidamente carcinogênicos e que podem ser encontrados nas águas tratadas e distribuída à população, são: trialometanos, ácidos haloacéticos, haloaldeidos, halocetonas, halofenóis e halopicrinas. Nas estações de tratamento de água para abastecimento (ETAs), a utilização da etapa de pré-oxidação da água bruta com cloro contribui para a formação desses subprodutos. A presente pesquisa teve como objetivo avaliar o potencial de formação de vinte e dois subprodutos com a utilização dos seguintes préoxidantes: cloro, dióxido de cloro, permanganato de potássio, peróxido de hidrogênio, ozônio e peroxônio. O potencial de formação de subprodutos foi simulado em uma água preparada com adição de substâncias húmicas extraídas de solo turfoso, por meio do uso da pré-oxidação, coagulação, filtração e pós-cloração. Os subprodutos foram quantificados por cromatografia gasosa com detetor de captura de eletrons. Os resultados obtidos mostraram que o uso de pré-oxidantes alternativos, tais como: permanganato de potássio; dióxido de cloro; peróxido de hidrogênio; ozônio e peroxônio, associados à coagulação, filtração e pós-cloração formam quantidades mínimas de subprodutos.

Palavras chaves: substâncias húmicas; pré-oxidação; formação de subprodutos; compostos halogenados. 


\begin{abstract}
PASCHOALATO, C. F. P. R. (2005). Effect of preoxidation, coagulation, filtration, and post-chlorination on the formation of halogenated organic byproducts in water prepared with humic substances. São Carlos, 2005, 148p. Thesis (Doctorate), Escola de Engenharia de São Carlos, Universidade de São Paulo.
\end{abstract}

The presence of humic substances in water destined for supply has brought many problems, resulting from the formation of halogenated organic subproducts, especially when preoxidation with chlorine is used. Halogenated organic compounds, which are admittedly carcinogenic and can be found in water treated and distriduted for the population, are: trihalometano, haloacetic acid, haloaldehyde, haloacetone, halophenol, and halopicrin. In water treatment stations for plants (WTPs), the use of preoxidation with chlorine of the raw water contributes for forming such byproducts. This research aims at evaluating the potential for the formation of twenty two byproducts using the following preoxidants: chlorine, chlorine dioxide, potassium permanganate, hydrogen peroxide, ozone, and peroxone. The potential of byproducts formation was simulated in water prepared with addition of humic substances extracted from peat soil by the use of different chemical products in pre-oxidation, coagulation, filtration, and postchlorination. Byproducts have quantified by gas chromatography with electron capture detector. The results obtained showed that the use of alternative preoxidant, such as: chlorine, chlorine dioxide, potassium permanganate, hydrogen peroxide, ozone, and peroxone, associated with coagulation, filtration, and post-chlorination form a minimum of byproducts.

Key-words: humic substances; preoxidation; byproduct formation; halogenated compound. 


\section{INTRODUÇÃO}

A partir da década de 70, diversos pesquisadores descobriram que a presença de matéria orgânica natural $(\mathrm{MON})$ em águas pode reagir com 0 cloro, causando a formação de compostos orgânicos halogenados, denominados subprodutos da desinfecção (SPD). Na década de 90, LYKINS (1994) observou que na desinfecção realizada com cloro livre, resulta a seguinte reação de formação de trialometanos (TAMs) e de outros subprodutos da desinfecção halogenados em presença de matéria orgânica natural e brometos:

$\mathrm{HOCl}+\mathrm{MON}$ ( precursores) $\rightarrow$ TAMs +outros SPD

Os principais SPD que podem ser formados são:

- Trialometanos (TAMs): clorofórmio $\left(\mathrm{CHCl}_{3}\right)$, bromodiclorometano $\left(\mathrm{CHBrCl}_{2}\right)$, dibromoclorometano $\left(\mathrm{CHBr}_{2} \mathrm{Cl}\right)$, bromofórmio $\left(\mathrm{CHBr}_{3}\right)$;

- Ácidos Haloacéticos (AHAs): ácido monocloroacético, ácido dicloroacético, ácido tricloroacético, ácido monobromoacético, ácido dibromocloroacético, ácido tribromoacético, ácido bromocloroacético, ácido bromodicloroacético, ácido dibromocloracético;

- Haloacetonitrilas (HANs): dicloroacetonitrila, tricloroacetonitrila, dibromoacetonitrila, tribromoacetonitrila, bromocloroacetonitrila.

- Haletos Cianogênicos (HCs): cloreto cianogênico, brometo cianogênico.

- Halopicrinas ( HPs): cloropicrina, bromopicrina

- Haloacetonas (HKs): 1,1-dicloropropanona, 1,1,1-tricloropropanona, 1,1-dicloro-2-butanona, 3,3-dicloro-2-butanona, 1,1,1-tricloro-2-butanona. 
- Haloaldeidos (HADs): dicloroacetaldeído, tricloroacetaldeído.

- Halofenóis (HFs): 2-clorofenol, 2,4-diclorofenol, 2,4,6-triclorofenol.

- MX [3-cloro-4-(diclorometil)-5-hidroxi-2(5H)-furanona].

Quando há necessidade da pré-oxidação com cloro e a água apresenta matéria orgânica natural originada de substâncias húmicas, existe a probabilidade de ocorrer a formação de compostos de cloro e bromo, que são os principais halogênios responsáveis pela formação de TAMs (STEVENS et al., 1976).

Em 1976, o Instituto Nacional de Câncer dos Estados Unidos identificou o clorofórmio como substância carcinogênica. De acordo com as normas e padrão de potabilidade de água para consumo humano atualmente em vigência no Brasil (Portaria 518 de 2004), o valor máximo permissível de trialometanos totais é de $100 \mu \mathrm{g} / \mathrm{L}$.

Algumas alternativas têm sido propostas para evitar a formação desses subprodutos, destacando-se o uso de oxidantes e desinfetantes alternativos tais como ácido peracético, permanganato de potássio, peróxido de hidrogênio, dióxido de cloro, ozônio, monocloramina e radiação ultravioleta.

Faz-se necessária a realização de pesquisas com aplicação desses oxidantes químicos alternativos, buscando o conhecimento do potencial de formação de subprodutos e fatores que o influencia, através da realização de análises químicas quantitativas.

Este trabalho de pesquisa vem colaborar para sistematizar os ensaios a serem aplicados na etapa de pré-oxidação nas estações de tratamento de água para avaliação do potencial de formação de subprodutos e técnicas analíticas para quantificar os compostos orgânicos formados.

A etapa final desta pesquisa foi a determinação dos subprodutos formados após terem sido estabelecidas as condições de concentração de substâncias húmicas presentes na água de estudo, demanda dos oxidantes, dosagem de coagulante, filtração e tempo de contato na pós-cloração. 
Os possíveis subprodutos formados foram identificados e quantificados através de uma prévia extração líquido-líquido e técnica analítica por cromatografia gasosa com detetor de captura de elétrons (CGDCE). Considerando a configuração do equipamento disponível no Laboratório de Recursos Hídricos da UNAERP e com a aquisição de colunas e dos padrões cromatográficos, foi possível quantificar 22 compostos orgânicos halogenados:

- Trialometanos (TAMs): clorofórmio $\left(\mathrm{CHCl}_{3}\right)$, bromodiclorometano $\left(\mathrm{CHBrCl}_{2}\right)$, dibromoclorometano $\left(\mathrm{CHBr}_{2} \mathrm{Cl}\right)$, bromofórmio $\left(\mathrm{CHBr}_{3}\right)$;

- Cloro hidrato $(\mathrm{CH})$;

- Ácidos Haloacéticos (AHAs): ácido monocloroacético (MCAA), ácido (DCAA)dicloroacético, ácido tricloroacético (TCAA), ácido monobromoacético (MCAA), ácido dibromoacético (DBAA), ácido tribromoacético (TBAA), ácido bromocloroacético (BCAA), ácido bromodicloroacético (BDCAA), ácido dibromocloroacético (DBCAA);

- Haloacetonitrilas (HANs)

dicloroacetonitrila

(DCAN), tricloroacetonitrila (TCAN), dibromoacetonitrila (DBAN), tribromoacetonitrila (TBAN), bromocloroacetonitrila (BCAN);

- Halopicrinas (HP): cloropicrina (CP);

- Haloacetonas (HKs): 1,1-dicloropropanona (DCP), 1,1,1tricloropropanona (TCP). 


\section{OBJETIVOS}

O objetivo geral do presente trabalho foi avaliar o potencial de formação de subprodutos orgânicos halogenados gerados em água contendo substâncias húmicas a partir da pré-oxidação com cloro, dióxido de cloro, permanganato de potássio, ozônio, peróxido de hidrogênio e ozônio combinado com peróxido de hidrogênio (peroxônio), coagulação, filtração e pós-cloração.

Baseado nesse objetivo geral, foram estipulados os objetivos específicos do estudo:

- Adaptar metodologias analíticas de cromatografia gasosa para quantificar os subprodutos orgânicos halogenados.

- Definir uma concentração de substância húmica padrão que, em presença de cloro, proporcionasse a formação de subprodutos;

- Determinar a demanda dos pré-oxidantes e dosagem de coagulante para estabelecer condições experimentais específicas e posterior avaliação do potencial de formação com repetitividade;

- Propor um procedimento experimental para avaliar o potencial de formação dos subprodutos gerados em função do tempo;

- Verificar a influência da coagulação e filtração no potencial de formação de subprodutos orgânicos halogenados. 


\section{REVISÃO DA LITERATURA}

Em 1974, pesquisadores americanos detectaram pela primeira vez a presença de trialometanos na água potável. Estudos realizados por ROOK (1974) na Holanda e por BELLAR, LICHTENBERG e KRONER (1974) nos Estados Unidos mostraram que os trialometanos não são contaminantes em níveis significativos na água bruta, mas são formados durante o processo de tratamento de água para o abastecimento público, através de uma reação química entre alguns compostos orgânicos e derivados de cloro, resultando valores entre 37 a $150 \mu \mathrm{g} / \mathrm{L}$.

Foi neste período que, em pesquisas realizadas em New Orleans (EUA), surgiram as primeiras correlações entre a água de abastecimento, os trialometanos e alguns tipos de câncer (BELLAR et al. 1974; BUN et al., STEVENS et al., 1976; BALSTER e BORZELLECA, 1982; MELNICK, 1987 e 1989).

Em 1975, BUN et al., publicaram um trabalho sobre a formação de trialometanos por cloração de água superficial do rio Missouri, tendo sido avaliado o efeito da adição de haletos de potássio na formação de TAMs. $O$ derivado de cloro utilizado foi hipoclorito de cálcio com dosagem de $7 \mathrm{mg} / \mathrm{L}$, resultando valores de $172 \mu \mathrm{g} / \mathrm{L}$ de $\mathrm{CHCl}_{3}, 20 \mu \mathrm{g} / \mathrm{L}$ de $\mathrm{CHBrCl}_{2}$ e $1 \mu \mathrm{g} / \mathrm{L}$ de $\mathrm{CHBr}_{2} \mathrm{Cl}$.

Em 1976, o National Institute of Ocupacional Safety and Health, dos Estados Unidos da América, recomendou que o valor máximo permitido, em água potável para clorofórmio fosse $2000 \mu \mathrm{g} / \mathrm{L}$ e a Food and Drug Administration (FDA) proibiu que esta substância fosse utilizada em drogas, cosméticos e embalagens alimentícias em função dos riscos serem maiores que os benefícios (ABDEL - RAHMAN, 1982). 
O National Academy's Safe Drinking Water Commitee (EUA) divulgou a hipótese de que a ingestão de água contendo clorofórmio (triclorometano) na concentração de $20 \mu \mathrm{g} / \mathrm{L}$, provocaria um caso a mais de câncer que o normal em cada 33.333 habitantes, com nível de confiança de 95\% (ABDEL-RAHMAN, 1982).

Em 1977, a United States Environmental Protection Agency (USEPA) publicou os resultados das pesquisas realizadas em 113 estações de tratamento de água para abastecimento público, listando 27 compostos orgânicos suspeitos de causarem problemas à saúde da população. Dentre eles, quatro eram trialometanos presentes em todas as águas que receberam o cloro na etapa de desinfecção e apresentavam concentrações superiores aos demais contaminantes citados por CANTOR et al., 1978; CANTOR, 1982; BOWMAN et al., 1978; SANTOS, 1988.

BOWMAN et al. (1978) estudaram a toxicidade dos halometanos em ratos e comprovaram a sua relação com o câncer. Os pesquisadores CANTOR et al. (1978) associaram a mortalidade por câncer com halometanos em água potável e determinaram uma correlação positiva dos níveis de TAMs com vários tipos de câncer, incluindo o de bexiga e de cérebro.

Em 1979, a USEPA estabeleceu que o valor máximo de contaminantes em concentração de trialometanos totais deveria ser de 100 $\mu \mathrm{g} / \mathrm{L}$ na água para consumo humano. Os pesquisadores ROOK e EVANS (1979) realizaram estudos para avaliação da remoção dos precursores de TAM utilizando resinas.

No Brasil, BATALHA (1979), publicou o primeiro trabalho sobre TAMs realizado nos sistemas públicos de abastecimento de água verificando a presença de clorofórmio e outros trialometanos na água de consumo humano.

Em São Paulo, RUOCO et al. (1981), publicaram um trabalho sobre a presença de trialometanos em águas para consumo humano, incidência e estudos sobre o potencial de formação, chegando às seguintes conclusões: i) não identificaram TAMs em amostras de água bruta de 8 mananciais que 
abastecem a cidade de São Paulo; ii) a cloração era responsável pela formação de TAMs; iii) os níveis encontrados para TAMs totais estavam acima do limite máximo (USEPA) de $100 \mu \mathrm{g} / \mathrm{L}$ em apenas uma das estações avaliadas; iiii) o clorofórmio foi o TAM que apresentou maior concentração e que a maioria dos níveis deste TAM estavam acima do valor máximo recomendado pela Organização Mundial de Saúde (OMS), que é $30 \mu \mathrm{g} / \mathrm{L}$.

Em 1982, CANTOR publicou a pesquisa "Evidência Epidemiológica da Carcinogenicidade dos Organoclorados em Água Potável", chegando à conclusão que existe uma correlação positiva e o risco aumenta com o número de anos de exposição do ser humano aos organoclorados e que deve haver controle dos níveis dos subprodutos da cloração e de outros contaminantes orgânicos na água potável.

BALSTER e BORZELLECA (1982) fizeram a avaliação da toxicidade dos trialometanos como contaminantes da água potável em ratos. Neste mesmo período, GHANBARI, WHEELER e KIRK (1982), estudaram a reação do cloro residual e do dióxido de cloro com lipídios e incorporação do cloro residual pelos lipídios, chegando à conclusão que o ácido hipocloroso $(\mathrm{HClO})$ incorporam muito mais as gorduras do que o dióxido de cloro $\left(\mathrm{ClO}_{2}\right)$.

No livro publicado por PERRY (1982), "Pollution: Causes, Effects and Control', no capítulo que trata dos aspectos químicos e analíticos das substâncias envolvidas no ciclo da água são estudados os TAMs, considerando-os como poluentes e apresentados os níveis permitidos de TAMs em águas potáveis na Alemanha $(25 \mu \mathrm{g} / \mathrm{L})$, Canadá (350 $\mu \mathrm{g} / \mathrm{L})$ e Holanda $(75 \mu \mathrm{g} / \mathrm{L})$.

MACÊDO et al. (1983), publicaram um trabalho intitulado "Estudos dos trialometanos", chegando à conclusão que a cloroamoniação seria o processo mais adequado do ponto de vista técnico e econômico para o controle de TAMs nas águas de abastecimento, pois utilizando a cloração com residual livre break point e aplicando amônia na água final a formação de TAMs é interrompida.

Em artigo publicado por McGUIRE (1989), a USEPA, juntamente com a Associação Metropolitana de Agências de Água dos Estados Unidos, 
desenvolveu um método analítico para uso nacional que foi aplicado inicialmente em 25 amostras de água. As análises foram realizadas pelo Laboraty Metropolitan Water District of Southern Califórnia (MWD). O método analítico desenvolvido para determinação de subprodutos da desinfecção é muito complexo, consome muito tempo e tem custo elevado. Neste experimento, foi utilizada uma coluna capilar de sílica fundida e cromatografia em fase gasosa com detetor de captura de elétrons. As amostras tiveram uma preparação substancial, que consistiu numa extração líquido-líquido com metilação em diazometano. Em geral o teor de trialometanos totais encontrado foi de $50 \%$ da concentração dos subprodutos totais de desinfecção (SPDT), uma fração considerável de ácidos haloacéticos com $25 \%$ do $S P D_{T}$, seguido dos aldeídos com $7 \%$ do $\mathrm{SPD}_{\mathrm{T}}$, outros subprodutos (18\%) foram encontrados em valores menores que o limite de detecção do método.

Assim, surgiu uma possível correlação entre o teor de trialometanos totais e de subprodutos totais. Este estudo foi muito significativo em termos econômicos e analíticos, porque surgiu a possibilidade de quantificação de trialometanos e de subprodutos totais por correlação matemática. SANTOS (1988) publicou os resultados obtidos de concentração de TAMs para várias localidades do litoral do Estado de São Paulo, apresentados na Tabela 3.1.

O Laboratory Metropolitan Water District of Southern California (MWD) e os pesquisadores KRASNER et al. (1989), publicaram um procedimento experimental utilizado em um projeto com 5 anos de controle efetuado em 35 locais de amostragem na Califórnia, EUA. Esta publicação foi de grande importância porque apresentou um procedimento que varia conforme o composto halogenado investigado e considerou outros fatores que influenciam no processo de formação de subprodutos.

Cada amostra analisada foi dividida em quatro partes: uma para determinação de Carbono Orgânico Total (COT) e de absorbância em UV 254nm; a segunda para determinação de formaldeido e acetaldeido (aldeídos); a terceira para determinação de haletos cianogênicos e cloro hidrato; a quarta parte para os outros compostos halogenados. 
Um produto químico desclorante específico foi aplicado em cada alíquota de amostra. Pela análise estatística dos resultados obtidos, os pesquisadores encontraram aproximadamente $23 \%$ de trialometanos, sendo $50 \%$ destes em clorofórmio, $12 \%$ de ácidos haloacéticos e $2 \%$ haloacetonitrilas e halocetonas. Uma porcentagem de $63 \%$ não definida permaneceu sem identificação analítica com o método utilizado. Apenas o composto cloreto cianogênico foi determinado por um sistema composto de cromatografia gasosa acoplada a espectrometria de massas (CG-EM).

Tabela 3.1- Resultados obtidos por SANTOS (1988), de TAMs na água distribuída em várias localidades de São Paulo.

\begin{tabular}{lccc}
\hline Cidade & $\begin{array}{c}\text { Valor máximo } \\
\text { TAMs }(\boldsymbol{\mu g} / \mathbf{L})\end{array}$ & $\begin{array}{c}\text { Valor médio } \\
\text { TAMs }(\boldsymbol{\mu g} / \mathbf{L})\end{array}$ & $\begin{array}{c}\text { Valor máximo } \\
\text { Clorofórmio } \\
\left(\boldsymbol{\mu g} \mathrm{CHCl}_{3} / \mathbf{L}\right)\end{array}$ \\
\hline Mongaguá & 77,00 & 33,00 & 70,00 \\
Peruíbe & 141,00 & 45,30 & 116,00 \\
Samaritá (S. Vicente) & 78,40 & 21,70 & 54,80 \\
Vicente de Carvalho & 129,00 & 57,94 & 105,00 \\
Guarujá & 146,00 & 67,90 & 139,20 \\
Bertioga & 133,00 & 54,60 & 128,00 \\
Itanhaém & 191,00 & 71,10 & 137,50 \\
Praia Grande & 432,00 & 69,61 & 158,00 \\
Cubatão & 437,00 & 87,10 & 118,40 \\
Santos & 587,00 & 113,61 & 160,00 \\
São Vicente & 641,00 & 96,50 & 109,00 \\
\hline
\end{tabular}

A Portaria $n^{\circ} 36 \mathrm{GM}$ do Ministério da Saúde passou a vigorar a partir de 1990, considerando entre os "componentes orgânicos que afetam a saúde", os trialometanos, limitando o valor máximo permissível a $100 \mu \mathrm{g} / \mathrm{L}$, com a seguinte observação: "sujeito a revisão em função de estudos toxicológicos em andamento; a remoção ou prevenção não deverá prejudicar a eficiência da desinfecção". Em 29 de dezembro de 2000, a publicação da portaria n¹469 GM do Ministério da Saúde estabeleceu padrões de 
qualidade para água de consumo humano, dos componentes orgânicos que afetam a saúde, cita como valor máximo permissível de concentração de trialometanos presentes na água em $100 \mu \mathrm{g} / \mathrm{L}$. Ressalta ainda que estes componentes tem análise obrigatória, seguindo um plano de amostragem em função da população a ser abastecida. Atualmente, a Portaria $n^{\circ} 518$, em vigor desde 25 de março de 2004, manteve como valor máximo $100 \mu \mathrm{g} / \mathrm{L}$.

Em 1990 apareceram os primeiros trabalhos de pesquisa envolvendo estudos sobre os precursores de TAMs, os ácidos húmicos e fúlvicos, ou seja, as substâncias responsáveis pela reação química indesejada.

AMY et al. (1990) utilizaram água de irrigação por drenagem e concluíram que, na agricultura da região avaliada, o uso da drenagem representa um potencial significativo na contribuição de precursores de TAMs.

Posteriormente, MILLER et al. (1990) publicaram um trabalho que avaliou o potencial de formação de TAMs em função da presença de carbono orgânico dos recursos hídricos do Kansas (EUA). A concentração média de TAMs resultou de $46,7 \mu \mathrm{g} / \mathrm{L}$, sendo que em somente $8 \%$ das amostras coletadas, foi ultrapassado o valor de $100 \mu \mathrm{g} / \mathrm{L}$.

RECKHOWM e SINGER (1990) publicaram um trabalho indicando que a cloração de águas brutas leva a uma maior formação de TAMs, tendo as concentrações de TAMs variado de 191 a $1280 \mu \mathrm{g} / \mathrm{L}$, e que o processo de tratamento convencional com uso de coagulante e sedimentação chega a reduzir $60 \%$ dos precursores de TAMs.

Em 1991, FAIR e BOLYARD (1991) publicaram os métodos analíticos aprovados pela USEPA para quantificação dos subprodutos da desinfecção (SPD). TARQUINI e RITTMANN (1992) escreveram sobre o uso do dióxido de cloro e carvão ativado, considerados como solução para o controle de TAMs. POURMOGHADAS (1992) publicou um trabalho no qual apresentou a determinação de nove (9) ácidos haloacéticos (AHAs) em água tratada. 
AMIRTHARAJAH, DENNET e STUDSTILL (1993) apresentaram o produto químico alternativo, cloreto férrico, como coagulante em substituição ao sulfato de alumínio para a remoção de matéria orgânica dissolvida e precursores de TAMs.

Em 1998, a USEPA propôs um estudo para definir a regulamentação de desinfetantes, desinfecção e subprodutos da desinfecção e propôs a redução dos níveis de trialometanos de 100 para 80 $\mu \mathrm{g} \cdot \mathrm{L}^{-1}$. Em 2000, a publicação "Drinking Water Standards and Health Advisories", recomendou o valor máximo de TAMs em $80 \mu \mathrm{g} / \mathrm{L}$.

Em São Paulo, TOMINAGA (1998) validou a correlação de dois métodos de análise por cromatografia em fase gasosa, com uso de detectores de captura de elétrons (DCE) e de condutividade elétrica (DCEL). Cita que tais métodos são precisos e exatos para quantificação de TAMs em água de abastecimento público, tendo o DCE resultado mais eficiente na quantificação de clorofórmio.

Os primeiros ensaios de bancada com enfoque na avaliação do potencial de formação de TAMs foram publicados por FIGUEIREDO et al. (1999), obtendo resultados a $20^{\circ} \mathrm{C}$, com taxas de produção de TAMs de 0,78 a 3,69 $\mu \mathrm{g} / \mathrm{h} . \mathrm{L}$, respectivamente para cloraminas e hipoclorito de sódio.

\subsection{Aspectos toxicológicos}

Em setembro de 1998, a revista Saúde publicou uma reportagem "Será que a água da sua casa pode provocar câncer?", que apresenta os níveis de concentração de TAMs obtidos em amostras de água das seguintes cidades: São Paulo (23 a $76 \mu \mathrm{g} / \mathrm{L})$; Belo Horizonte $(10 \mu \mathrm{g} / \mathrm{L})$; Porto Alegre $(50 \mu \mathrm{g} / \mathrm{L})$ e Rio de Janeiro $(25 \mu \mathrm{g} / \mathrm{L})$. No mesmo ano, a revista Ciência Hoje, publicou uma reportagem "A ameaça que vem das torneiras", ressaltando os trialometanos como um dos perigos da água tratada.

Os TAMs são rapidamente absorvidos pelo trato gastrintestinal. $O$ clorofórmio, após administração pela via oral, é rápida e quase completamente absorvido (tanto em animais de experimentação como no ser 
humano). A concentração sangüínea máxima de clorofórmio marcado $\left(C^{13}\right.$ ou $\mathrm{C}^{14}$ ) foi atingida dentro de 60 a 90 minutos após a ingestão.

$\mathrm{Na}$ exposição humana por inalação, 60 a $80 \%$ de toda quantidade de clorofórmio inalada é absorvida. A exposição a esse composto, em um ambiente contendo 13,2 a $31,8 \mathrm{~g}$ de $\mathrm{CHCl}_{3} / \mathrm{m}^{3}$ de ar, durante 3 a 10 minutos, resulta numa absorção de $73 \%$. Os Estudos experimentais realizados por BLOEMEN ${ }^{1}$ apud TOMINAGA (1999), indicam que a exposição ao clorofórmio, por inalação, durante um banho de ducha por 8 minutos, pode ser até 6 vezes maior do que pela ingestão da mesma água durante um período de 24h.

A água da piscina clorada é uma outra importante fonte de exposição aos TAMs (WHO², 1996 apud TOMINAGA 1999).

O clorofórmio na corrente sangüínea é transportado para os tecidos. Devido à sua predominante lipossolubilidade, acumula-se em tecidos com alto teor lipídico, como o tecido adiposo, fígado e rins. O clorofórmio parece ser capaz de atravessar a barreira placentária, uma vez que já foi detectado no cordão umbilical em concentrações maiores que no sangue materno. $O$ clorofórmio é biotransformado no fígado levando a formação de fosfogênio, o qual pode reagir rapidamente com a água levando a formação de $\mathrm{CO}_{2}$ e $\mathrm{HCl}$.

Uma outra via de biotransformação é a reação com a cisteína ou glutationa, gerando produtos secundários, ou com macromoléculas intracelulares induzindo ao dano celular. Os efeitos crônicos observados são caracteristicamente retardados, admitindo períodos de latência para a carcinogenicidade.

Segundo a USEPA (1999), os efeitos na saúde que os SPDs causam são avaliados através de estudos epidemiológicos e ou estudos toxicológicos em animais de laboratório. A Tabela 3.2 apresenta uma relação de vários subprodutos e sua classificação de câncer. $O$ esquema utilizado

\footnotetext{
${ }^{1}$ BLOEMEN, H.J.; Th, BURN J.(1993) Chemistry and analysis of volatile organic compoundas in the environment. Londos: Champman \& Hall.

${ }^{2}$ WORLD HEARTH ORGANIZATION. (1996) Guidelines for drinking water quality. 2. ed. Geneva; 1996. v.2, p.849-872.
} 
pela USEPA (1999) considerou estudos epidemiológicos e estudos realizados em animais que poderiam ter grandes evidências de carcinogenicidade no ser humano.

Para CANTOR et al. (1978), existe uma correlação positiva dos níveis de trialometanos com vários tipos de câncer incluindo o de bexiga e cérebro em ambos os sexos.

Tabela 3.2 - Lista de informação de saúde para subprodutos da desinfecção (USEPA, 1999).

\section{Subproduto}

Clorofórmio

Bromodiclorometano

Dibromoclorometano

Bromofórmio

Ácido Monocloroacético

Ácido Dicloroacético

Ácido Tricloroacético

Dicloroacetonitrila

Bromocloroacetonitrila

Dibromoacetonitrila

Tricloroacetonitrila

1,1-Dicloropropanona

1,1,1- Tricloropropanona

2-Clorofenol

2,4- Diclorofenol

2,4,6-Triclorofenol

Cloropicrina

Cloro Hidrato

Cloreto Cianogênico

Formaldeído
Câncer - Classificação

B2

B2

$\mathrm{C}$

B2

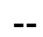

B2

C

C

$-$

C

$-$

D

D

B2

--

C

$--$

B1

Nota: Grupo B, provável carcinogenicidade humana: B1-Evidência limitada em estudos epidemiológicos e B2-Evidencia suficiente por estudos com animais. Grupo C, possível carcinogenicidade humana: Evidência limitada em estudos realizados em animais.

Grupo D, não classificado: inadequado para o ser humano e evidência de carcinogenidade em animal. 
Em 1992, os mesmos autores publicaram um trabalho no qual associam os subprodutos da cloração com o câncer, comparando o risco de adquirir a doença em função do número de anos ingerindo água clorada e do volume de água ingerido por dia. A Tabela 3.3 apresenta os resultados da pesquisa.

Tabela 3.3 - Risco relativo a ter câncer em função do volume de água clorada ingerida diariamente e do número de anos relativos à ingestão da água (CANTOR, 1992).

\begin{tabular}{cccccc}
\hline $\begin{array}{c}\text { Volume consumido } \\
\text { de água clorada por }\end{array}$ & \multicolumn{5}{c}{ Anos de utilização da água clorada } \\
\cline { 2 - 6 } dia (L/d) & 0 & $1-19$ & $20-39$ & $40-59$ & $>60$ \\
\hline \hline 0,80 & 1,0 & 1,0 & 1,0 & 1,0 & 1,0 \\
$0,81-1,12$ & 1,0 & 1,0 & 0,8 & 1,6 & 0,8 \\
$1,13-1,44$ & 1,2 & 1,2 & 0,8 & 1,3 & 1,1 \\
$1,45-1,95$ & 0,8 & 0,9 & 1,2 & 1,7 & 1,7 \\
1,96 & 1,2 & 1,0 & 1,2 & 1,7 & 2,0 \\
\hline
\end{tabular}

Risco máximo: 2,0.

Nota: O grau de risco, calculado pela National Blader Cancer Study leva em consideração fatores como o uso de cigarros, idade, sexo, ocupação, área geográfica, tamanho da população e tempo de residência numa determinada localidade.

\subsection{Formação de subprodutos}

Os trialometanos, considerados os principais subprodutos da cloração, são formados por compostos de carbono simples substituídos por halogênios e possuem a fórmula geral $\mathrm{CHX}_{3}$, onde $\mathrm{X}$ pode ser cloro, bromo, possivelmente iodo ou combinações dos mesmos. Na Tabela 3.4 são apresentadas suas fórmulas químicas e denominações. Aparecem principalmente na água potável, como subproduto resultante da reação entre substâncias químicas utilizadas no tratamento oxidativo (cloro livre) e 
matéria orgânica (ácidos húmicos e fúlvicos) naturalmente presente em mananciais de superfície utilizados para o abastecimento (água bruta). Portanto, a sua formação tem sido relacionada ao uso do cloro.

Os TAMs normalmente encontrados na água são espécies cloradas e bromadas. Com relação às espécies iodadas, ainda não foram encontradas referências da literatura sobre sua formação em água. Portanto, quando se faz referência aos TAMs, na realidade estão sendo mencionados apenas os quatro primeiros compostos da Tabela 3.4.

Tabela 3.4 - Fórmulas químicas e denominações dos trialometanos.

\begin{tabular}{ll}
\hline Fórmula química & Denominações \\
\hline $\mathrm{CHCl}_{3}$ & Triclorometano ou clorofórmio \\
$\mathrm{CHBrCl}_{2}$ & Bromodiclorometano \\
$\mathrm{CHBr}_{2} \mathrm{Cl}$ & Dibromoclorometano \\
$\mathrm{CHBr}_{3}$ & Tribromometano ou Bromofórmio \\
$\mathrm{CHCl}_{2} \mathrm{I}$ & Dicloroiodometano \\
$\mathrm{CHClBrl}$ & Bromocloroiodometano \\
$\mathrm{CHCl}_{2}$ & Clorodiiodometano \\
$\mathrm{CHBr}_{2} \mathrm{I}$ & Dibromoiodometano \\
$\mathrm{CHBr}_{2}$ & Bromodiodometano \\
$\mathrm{CHI}_{3}$ & Triiodometano ou lodofórmio
\end{tabular}

Fonte: SYMONS,1981.

$\mathrm{Na}$ Tabela 3.5 estão apresentadas as formulas estruturais de alguns subprodutos que tem sido detectado em água de abastecimento.

Tabela 3.5 - Fórmulas estruturais de alguns subprodutos orgânicos halogenados.

Trialometanos




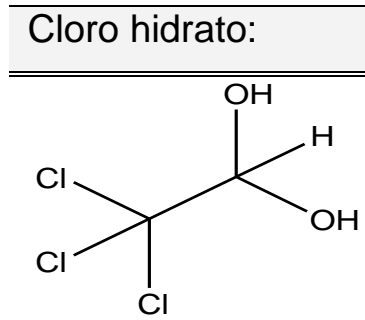

Cloral Hidrato
Halopicrinas:

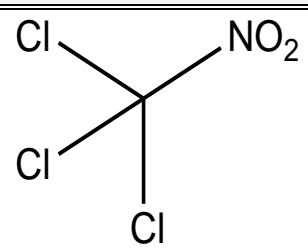

Cloropicrina

Haloacetonitrilas

dicloroacetonitrila tricloroacetonitrila dibromoacetonitrila bromocloroacetonitrila Halocetonas:<smiles>CC(=O)C(Cl)Cl</smiles>

1,1-dicloropropanona<smiles>CC(=O)C(Cl)(Cl)Cl</smiles>

1,1,1-tricloropropanona

\section{Ácidos haloacéticos:}<smiles>O=C(O)CCl</smiles>

ácido monocloroacético<smiles>O=C(O)CBr</smiles>

ácido monobromoacético<smiles>O=C(O)C(Cl)Br</smiles>

ácido bromocloroacético<smiles>O=C(O)C(Cl)Cl</smiles>

ácido dicloroacético<smiles>O=C(O)C(Br)Br</smiles>

ácido dibromoacético<smiles>O=C(O)C(Cl)(Cl)Br</smiles><smiles>O=C(O)C(Cl)(Cl)Cl</smiles>

ácido tricloroacético<smiles>O=C(O)C(Br)(Br)Br</smiles>

ácido tribromoacético<smiles>O=C(O)C(Cl)(Br)Br</smiles> 


\subsubsection{Fatores de influência na formação de subprodutos}

Vários fatores podem influenciar a reação de formação de subprodutos, destacando-se: tempo de contato, temperatura, $\mathrm{pH}$ do meio, característica e concentração de matéria orgânica natural, dosagem de cloro aplicada, residual de cloro livre e concentração de brometos (SINGER, 1994).

\subsubsection{Tempo de contato}

A velocidade da reação de formação de TAMs é lenta, podendo levar de uma hora a vários dias até atingir a produção máxima de subprodutos. Como a estrutura dos precursores é complexa e pouco conhecida, o tempo de contato entre o oxidante (cloro) e os precursores tem um aumento proporcional à formação de TAMs, ou seja, quanto maior o tempo de contato, maior a concentração de TAMs formados.

\subsubsection{Temperatura}

O aumento da temperatura influencia diretamente na reação do aumento da formação de TAMs. Em pesquisa realizada por STEVENS (1976), em Ohio (EUA), a temperatura da água variou de 2 a $28^{\circ} \mathrm{C}$ entre os períodos de inverno e do verão e, pelo monitoramento realizado na rede de distribuição, foram verificadas concentrações de clorofórmio de 30 a 200 $\mu \mathrm{g} / \mathrm{L}$ respectivamente, no aumento da temperatura e do tempo de contato em uma água clorada. Isto acarretou um aumento considerável da concentração de clorofórmio. Na Figura 3.1 está apresentado o resultado deste estudo. 


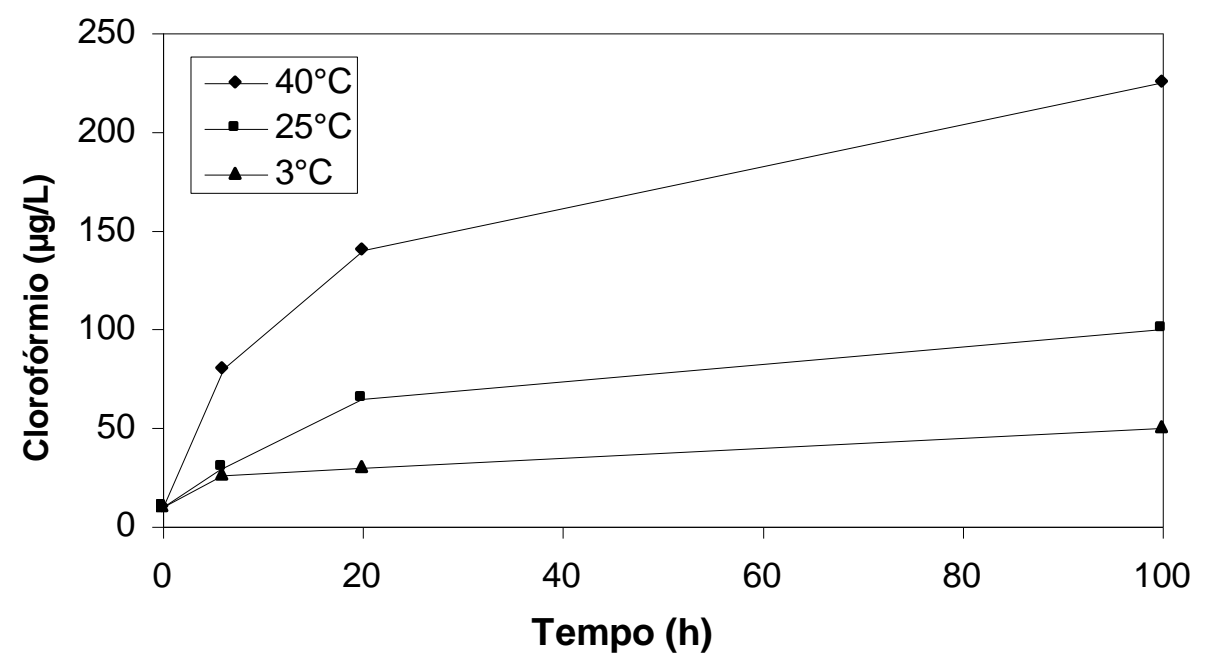

Figura 3.1- Influência da temperatura e do tempo de contato na formação de clorofórmio. Fonte: STEVENS et al. (1976).

\subsubsection{3 pH do meio}

Segundo ROOK (1979), a concentração de TAMs aumenta com o aumento do $\mathrm{pH}$. Em experimento realizado com ácidos fúlvicos em presença de cloro, com tempo de contato de $4 \mathrm{~h}$ e a $10^{\circ} \mathrm{C}$, os resultados obtidos e apresentados na Figura 3.2, mostram um aumento na concentração de clorofórmio em função do $\mathrm{pH}$.

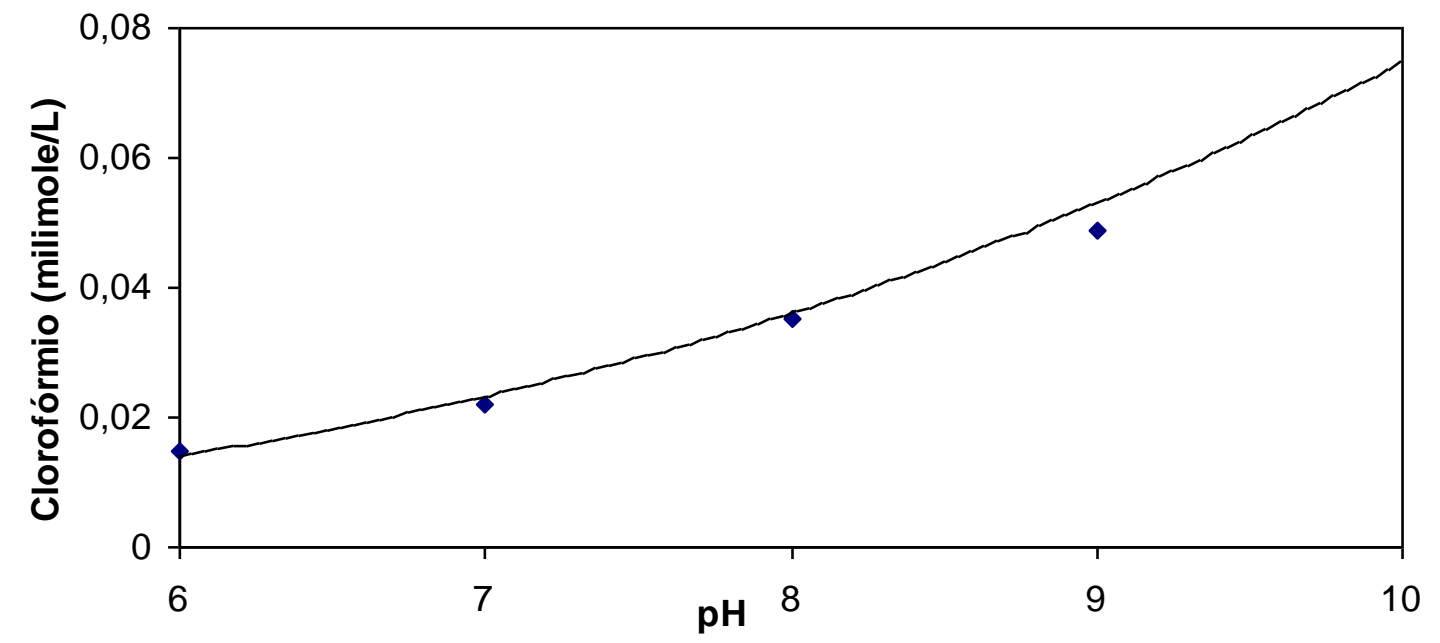

Figura 3.2 - Influência do pH na reação halofórmica para tempo de contato de $4 \mathrm{~h}$ a temperatura de $10^{\circ} \mathrm{C}$. Fonte: ROOK (1979). 


\subsubsection{Características dos precursores}

Os ácidos húmicos e fúlvicos têm sua origem resultante da decomposição da vegetação. A maioria destes ácidos contém radicais cetonas, que podem produzir halofórmios após reação com cloro livre (LAWRENCE, 1989).

Segundo SYMONS (1981), a reação de formação de TAMs pode ser esquematizada da seguinte forma:

Espécies halogenadas + Cloro livre + Precursores $\rightarrow$ TAMs + Subprodutos

Os estudos realizados por STEVENS (1976) mostraram que quanto maior a concentração de precursores, maior a concentração de TAMs. Porém a característica dos precursores tem uma relação direta com o potencial de formação de TAMs. Na Figura 3.3 está apresentado o efeito da variação da concentração de ácidos húmicos na formação de TAMs em um trabalho realizado sob as seguintes condições: água filtrada, $\mathrm{pH}$ igual a 6,7, temperatura mantida a $25^{\circ} \mathrm{C}$ e dosagem de cloro aplicada igual a $10 \mathrm{mg}$ $\mathrm{Cl}_{2} / \mathrm{L}$.

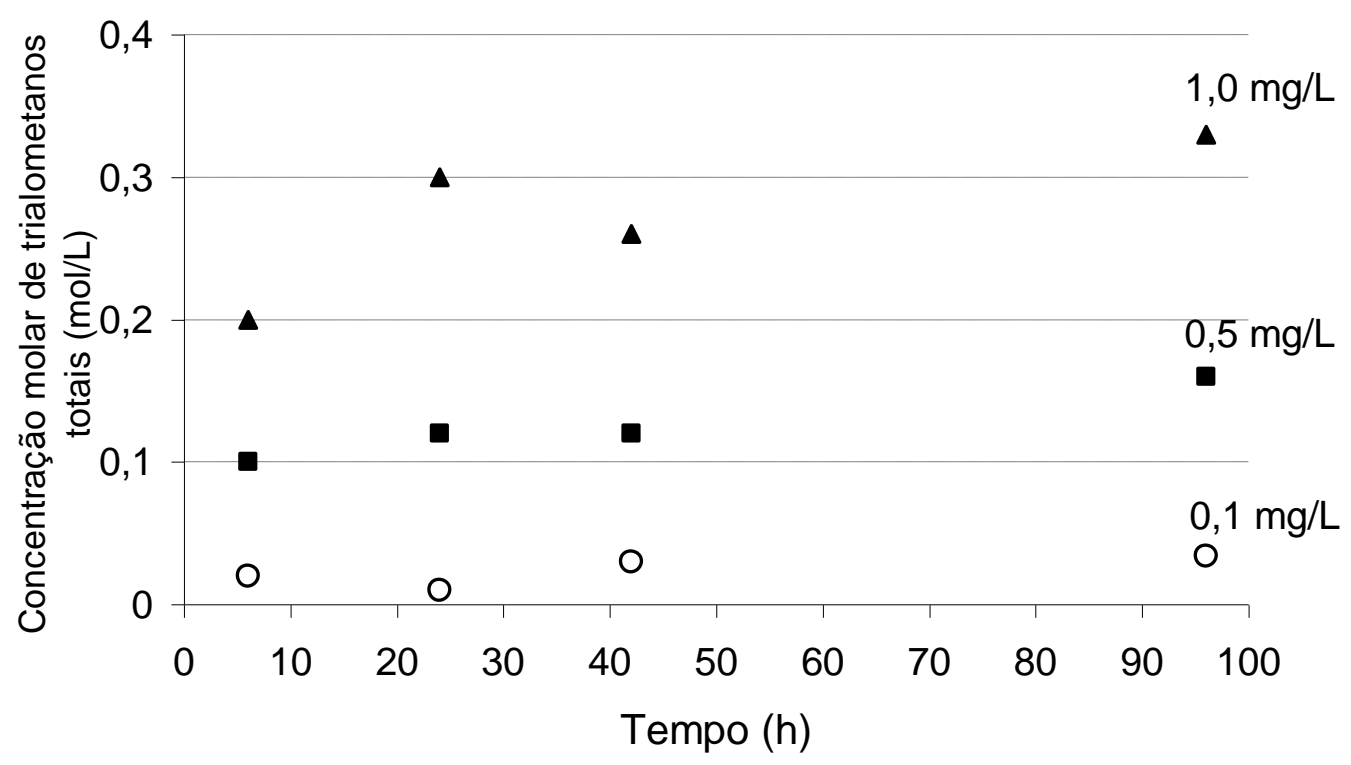

Figura 3.3- Efeito da concentração molar de ácido húmico na produção de TAMs em $\mathrm{pH} 6,7,25^{\circ} \mathrm{C}$ e dosagem de $10 \mathrm{mg} / \mathrm{L} \mathrm{Cl}_{2}$.

Fonte: STEVENS et al. (1976). 


\subsubsection{Dosagem de cloro}

Segundo TRUSSEL \& UMPHRES (1978) teoricamente a formação de TAMs pode ocorrer em três fases representadas no diagrama da Figura 3.4. A primeira região é a fase em que ocorre a demanda imediata de cloro aplicado devido à oxidação de compostos inorgânicos como, por exemplo, sulfeto, ferro (II) e amônia; esta reação vai consumir rapidamente uma determinada quantidade de cloro e os TAMs formados são apenas traços.

$\mathrm{Na}$ segunda região, depois de satisfeita a demanda imediata, o cloro adicional começa a reagir com a matéria orgânica presente numa reação que tende a linearidade entre a dosagem e a concentração de TAMs formado.

$\mathrm{Na}$ terceira região, depois de satisfeitas as duas primeiras demandas, se houver um residual de cloro livre, ocorrerá pequena formação adicional de TAMs.

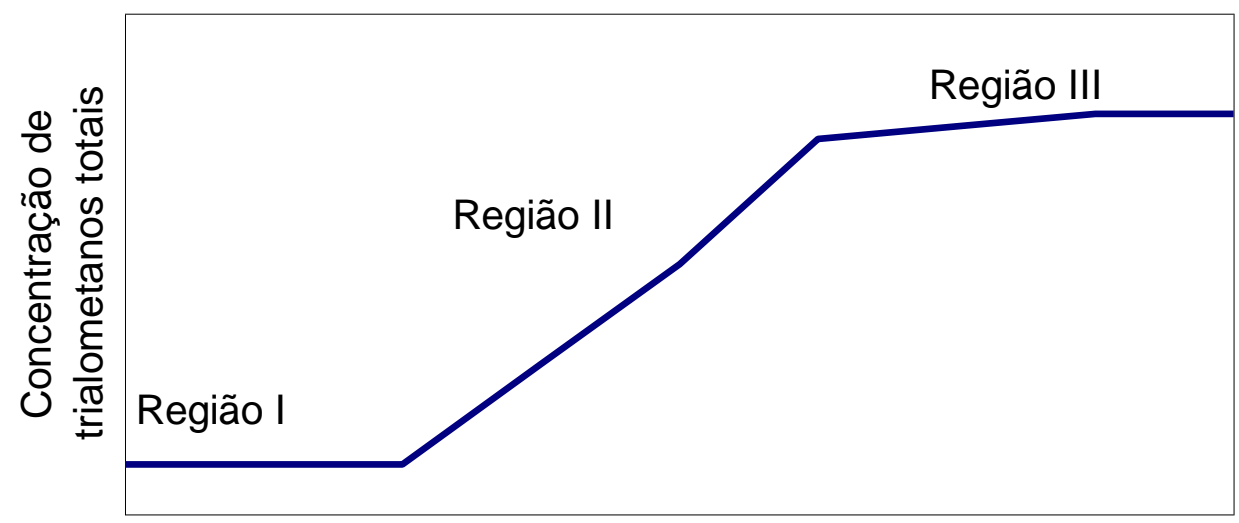

Dosagem de cloro

Figura 3.4 - Efeito da dosagem de cloro na formação de trialometanos totais Fonte: TRUSSEL \& UMPHRES (1978).

\subsection{Precursores de formação de trialometanos}

Os precursores de formação de TAMs nos corpos d'água que são utilizados como mananciais para 0 abastecimento podem variar 
sazonalmente e dependem do tipo de manancial (rios, lagos, reservatórios ou represas), tipo de solo, vegetação predominante, mata ciliar, ocupação urbana, industrial e agrícola (PARDO, 1996). Os ácidos húmicos e fúlvicos são as matérias orgânicas naturais encontradas em concentrações mais representativas, porém, outras formas de precursores podem eventualmente também estar presente nas águas superficiais.

Segundo TRUSSEL \& UMPHERES (1978) a estrutura das moléculas das substâncias húmicas pode ser representada de forma simplificada pelo modelo representado na Figura 3.5, ou seja, uma grande massa amorfa de poliheteros condensados com alguns grupos funcionais estendendo-se a partir de sua superfície que reagem com o cloro para formar os TAMs.

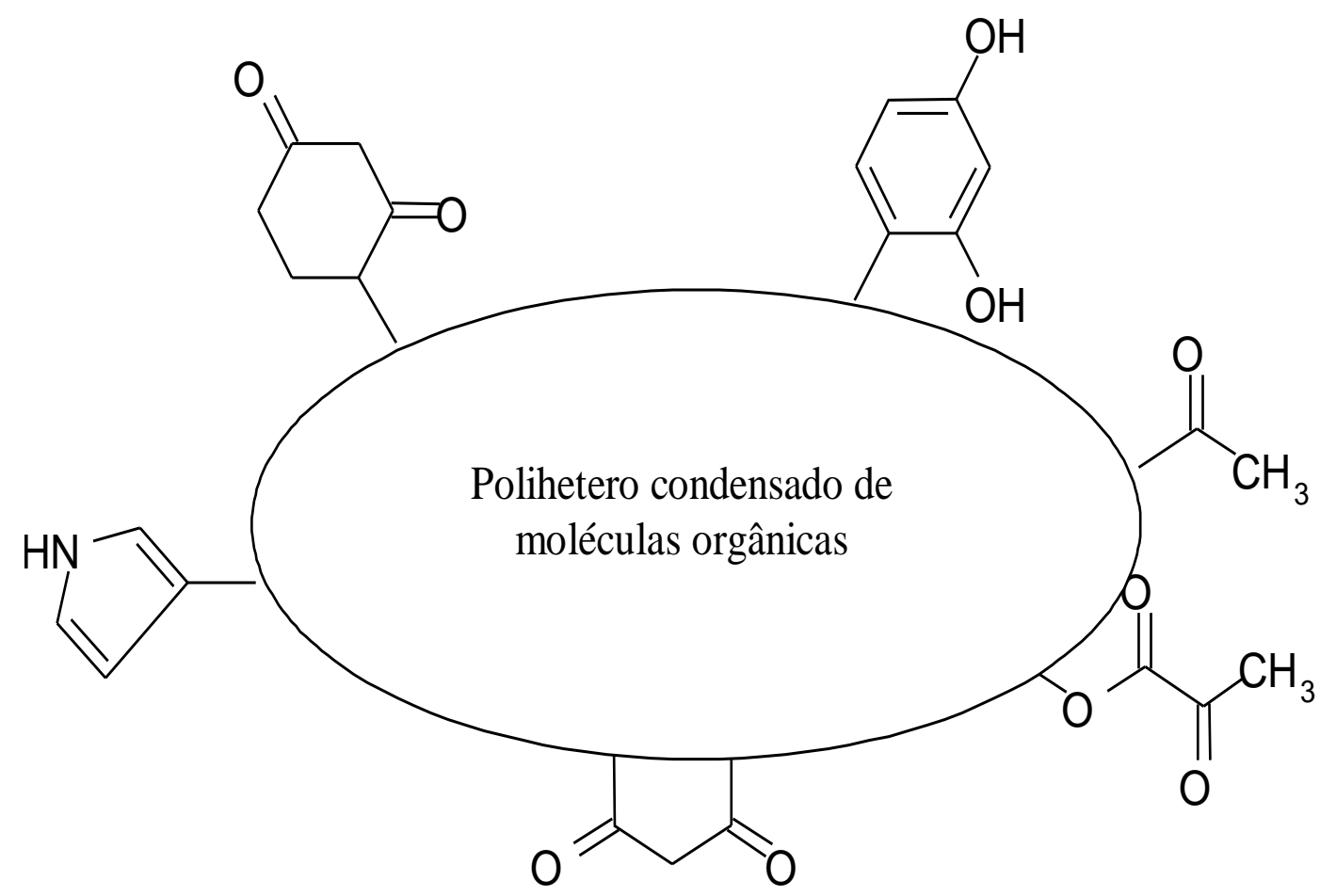

Figura 3.5 - Modelo simplificado da estrutura molecular das substâncias húmicas. Fonte: TRUSSEL \& UMPHERES (1978).

O mecanismo proposto por TRUSSEL \& UMPHERES (1978) para a reação de formação de trialometanos, apresentado na Figura 3.6, consiste em etapas alternadas de hidrólise e halogenação, sendo a primeira ionização a etapa determinante para a cinética da reação. Segundo os 
referidos pesquisadores, esta condição parece prevalecer também para a halogenação do humus aquático natural.

Segundo MUTTAMARA et al. (1995), o cloro pode formar TAMs quando em contato com substâncias húmicas, que incluem ácidos húmicos, ácidos fúlvicos e ácido himatomelânico, com materiais de algas, principalmente a clorofila, sua biomassa, produtos extracelulares e com uma variedade de substâncias aromáticas que ocorrem naturalmente em águas.

A matéria orgânica natural presente em águas superficiais é o principal precursor com o qual os compostos orgânicos halogenados totais reagem para formar estes subprodutos. Na ausência de brometos, ocorre apenas a formação de compostos clorados; no entanto, na presença de brometos, o ácido hipocloroso os oxida para formar o ácido hipobromoso ( $\mathrm{HBrO})$, que reage com o cloro residual, formando os compostos que possuem cloro e bromo.

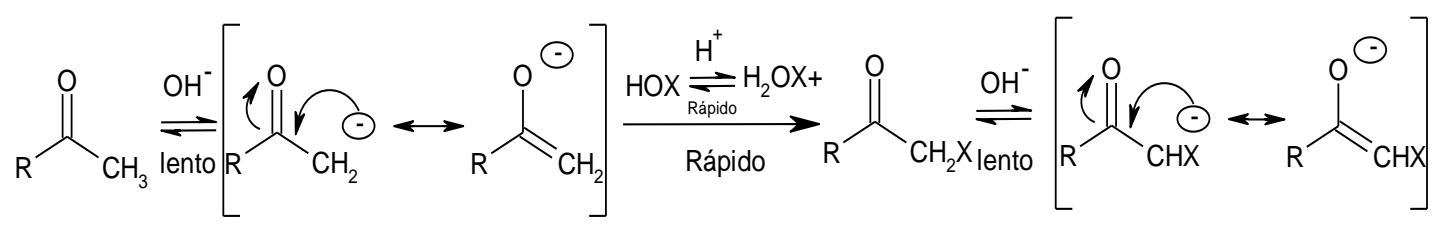
HOX $\underset{\text { Rápido }}{\stackrel{\mathrm{H}^{+}}{\rightleftharpoons}} \mathrm{H}_{2} \mathrm{OX}+\downarrow$ Rápido

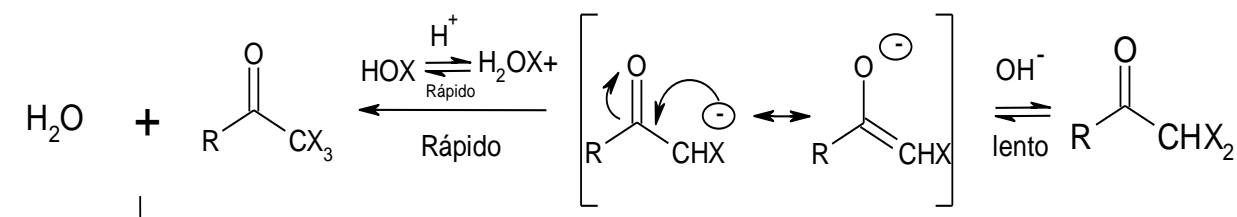
$\mathrm{OH}^{-}$<smiles>[Y]C[OH+]C([R])=O</smiles>

Figura 3.6 - Mecanismo de reação halofórmica.

Fonte: TRUSSEL \& UMPHERES (1978). 
Assim, surgiu uma possível correlação entre os trialometanos totais e os subprodutos totais. Este estudo foi muito significativo em termos econômicos e analíticos, porque mostrou a possibilidade de controle de trialometanos e de subprodutos totais por correlação matemática.

\subsection{Controle da formação de trialometanos}

Atualmente, as medidas que vêm sendo aplicadas e estudadas para o controle da formação de trialometanos nas estações de tratamento são as seguintes:

- Uso de oxidantes alternativos na pré-oxidação

- Uso de desinfetante alternativo final

- Remoção de precursores antes da aplicação de cloro

- Remoção de TAMs após a sua formação

O uso de oxidante alternativo proporciona a eliminação ou a diminuição do uso de cloro nas estações de tratamento de água (ETA). Vários oxidantes têm sido testados para redução da formação de subprodutos, dentre eles destacam-se: cloraminas, dióxido de cloro, ozônio, permanganato de potássio, peróxido de hidrogênio e radiação ultravioleta. Destes, os quatros primeiros são os mais utilizados no tratamento de água para o abastecimento público (MACEDO, 2001).

Em 2002, TITO BORGES et al. (2002) realizou um estudo para verificar a influência da amônia em águas quanto à redução no potencial de formação de trialometanos, o estudo foi realizado em bancada com água preparada por adição de solução de ácido húmico comercial e na presença de sulfato de amônio e de brometo de sódio. A dosagem aplicada na cloração foi de $3,0 \mathrm{mg} / \mathrm{LCl}_{2}$, o estudo comprovou que o aumento da concentração de amônia provocou uma redução significativa no potencial de formação de trialometanos nas amostras estudadas. 


\subsection{Características dos pré-oxidantes alternativos}

A oxidação química é uma alternativa que tem sido amplamente empregada para a remoção de matéria orgânica em processos de tratamento de água potável e águas residuárias industriais.

As ETAs utilizam a pré-cloração da água bruta, em função do poder oxidante dos derivados de cloro, como hipoclorito de sódio $(\mathrm{NaClO})$, hipoclorito de cálcio $\left[\mathrm{Ca}(\mathrm{ClO})_{2}\right]$ e o cloro $\left(\mathrm{Cl}_{2}\right)$, ser bastante eficiente visando a redução de sabor e odor. Esta técnica tem sido questionada quando utilizada em águas que apresentam substâncias húmicas e algas devido à possibilidade de formação de trialometanos.

A necessidade do controle de trialometanos incentivou 0 desenvolvimento de pesquisas envolvendo outros oxidantes, objetivando a substituição do cloro na oxidação das águas de abastecimento público.

Segundo SENS, et al. (2003) em uma pesquisa realizada para verificação da influência da pré-oxidação na tratabilidade das águas através da filtração direta descendente em mananciais com grandes concentrações de algas, com ensaios realizados em um sistema piloto de filtração direta descendente com a pré-oxidação por ozônio e o cloro, os resultados foram conclusivos no beneficio do uso de ozônio na pré-oxidação de águas contendo altas concentrações de algas, obtendo-se uma redução na formação de TAMs e produzindo água de melhor qualidade.

Porém, vale ressaltar que os mananciais podem sazonalmente apresentar cor elevada devido à presença de substâncias húmicas e a sua remoção por sistemas que operam com tratamento convencional ou por filtração direta, necessitam da utilização da pré-oxidação, que por facilidade e disponibilidade, empregam o cloro, conseguindo atender os padrões de potabilidade em vigor da água final a ser distribuída à população.

No Brasil, a desinfecção da água para consumo humano é usualmente realizada com adição de cloro na forma de gás. Quando usado, - cloro gasoso hidrolisa rapidamente em água para formar o ácido hipocloroso, conforme a Equação 3.1: 


$$
\mathrm{Cl}_{2}(\mathrm{~g})+\mathrm{H}_{2} \mathrm{O} \rightarrow \mathrm{HOCl}+\mathrm{H}^{+}+\mathrm{Cl}^{-}
$$

O ácido hipocloroso $(\mathrm{HOCl})$, se dissocia fracamente em hidrogênio e íons hipoclorito conforme a Equação 3.2:

$$
\mathrm{HOCl} \leftrightarrow \mathrm{H}^{+}+\mathrm{OCl}^{-}
$$

A quantidade deste compostos na água $\left(\mathrm{HOCl}\right.$ e $\left.\mathrm{OCl}^{-}\right)$é denominada cloro residual livre. Considerando que a desinfecção ocorre em água com total ausência de MON, a formação de subprodutos é menor.

Os pré-oxidantes alternativos a serem empregados no presente estudo são: dióxido de cloro, permanganato de potássio, ozônio, peróxido de hidrogênio e combinação de peróxido de hidrogênio e ozônio (peroxônio). $O$ cloro deverá ser empregado para obtenção do potencial máximo de formação de subprodutos orgânicos halogenados proporcionando uma referência para uma comparação com os pré-oxidantes alternativos.

\subsubsection{Dióxido de cloro}

O dióxido de cloro foi aplicado em água pela primeira vez como desinfetante e oxidante em 1944, nos Estados Unidos. Tem sido considerado um desinfetante eficiente mesmo com baixos valores de tempo de contato, é efetivo para o controle de sabor e odor, atua na oxidação de ferro e manganês e não é exercida demanda desse composto se a água a ser tratada contiver amônia.

O dióxido de cloro não produz quantidades significativas de SPDs, exceto a formação de íons clorito e clorato em determinadas condições de $\mathrm{pH}$, pois cerca de 50 a $70 \%$ do dióxido de cloro consumido é reduzido a clorito.

Segundo DI BERNARDO (1995), os SPDs formados com o dióxido de cloro, com a exceção do clorito e clorato, ainda não foram estudados 
convenientemente, não sendo conhecido o impacto dos mesmos no ser humano. Recentemente, CHANG et al. (2001) mostraram que, com dosagens de 1 e $10 \mathrm{mg} / \mathrm{L} \mathrm{ClO}_{2}$, ocorreu a formação de subprodutos (TAMs entre 13 e $11 \mu \mathrm{g} / \mathrm{L}$, AHAs entre 24,7 e $31 \mu \mathrm{g} / \mathrm{L}$, clorito entre 0,4 e $3,88 \mathrm{mg} / \mathrm{L}$ e clorato entre $<0,1$ e $0,28 \mathrm{mg} / \mathrm{L}$ ) em água superficial com presença de matéria orgânica.

Em uma pesquisa realizada por FERREIRA FILHO, et al. (2003), que teve como objetivos: avaliar o comportamento do dióxido de cloro como agente oxidante no tratamento de águas de abastecimento comparado ao cloro e a formação de subprodutos, concluiu-se que a aplicação do dióxido de cloro é viável em águas que apresentassem baixa demanda de agente oxidante proporcionando a redução na formação de clorito e a formação de TAMs ficou abaixo de $100 \mu \mathrm{g} / \mathrm{L}$.

O dióxido de cloro é um gás que possui alta solubilidade em água, quando esta possui pH entre 2 a 10. O dióxido de cloro pode ser gerado de várias formas, conforme métodos descritos a seguir:

- Utilizando clorato de sódio com peróxido de hidrogênio e ácido sulfúrico

$2 \mathrm{NaClO}_{3}+\mathrm{H}_{2} \mathrm{O}_{2}+\mathrm{H}_{2} \mathrm{SO}_{4} \rightarrow 2 \mathrm{ClO}_{2}+\mathrm{O}_{2}+2 \mathrm{H}_{2} \mathrm{O}$

- Utilizando clorito de sódio e ácido clorídrico

$5 \mathrm{NaClO}_{2}+4 \mathrm{HCl} \rightarrow 4 \mathrm{ClO}_{2}+5 \mathrm{NaCl}+2 \mathrm{H}_{2} \mathrm{O}$

- Utilizando clorito de sódio e cloro

$$
\begin{gathered}
\underline{\mathrm{Cl}}_{2}+\mathrm{H}_{2} \mathrm{O} \rightarrow \mathrm{HClO}+\mathrm{HCl} \\
2
\end{gathered} \frac{\mathrm{HCLO}+\mathrm{HCl} \rightarrow 2 \mathrm{ClO}_{2}}{2 \mathrm{NaClO}_{2}+\mathrm{Cl}_{2} \rightarrow 2 \mathrm{ClO}_{2}+2 \mathrm{NaCl}+\mathrm{H}_{2}} \underline{\mathrm{O}}
$$

- Utilizando clorito de sódio com ácido clorídrico e hipoclorito de sódio.

$$
\mathrm{NaClO}+\mathrm{HCl} \rightarrow \mathrm{HClO}+\mathrm{NaCl}
$$


$\frac{2 \mathrm{NaClO}_{2}+\mathrm{HClO}+\mathrm{HCl} \rightarrow 2 \mathrm{ClO}_{2}+2 \mathrm{NaCl}+\mathrm{H}_{2} \underline{\mathrm{O}}}{2 \mathrm{NaClO}_{2}+2 \mathrm{HCl}+\mathrm{NaClO} \rightarrow 2 \mathrm{ClO}_{2}+3 \mathrm{NaCl}+\mathrm{H}_{2} \mathrm{O}}$

- Utilizando clorito de sódio e ácido sulfúrico

$4 \mathrm{NaClO}_{2}+\mathrm{H}_{2} \mathrm{SO}_{4} \rightarrow 2 \mathrm{ClO}_{2}+\mathrm{HCl}+\mathrm{HClO}_{3}+2 \mathrm{Na}_{2} \mathrm{SO}_{4}+\mathrm{H}_{2} \mathrm{O}$

Quando há excesso de dióxido de cloro, pode ocorrer uma reação de competição proporcionando a formação do indesejável de íon clorato $\left(\mathrm{ClO}_{3}{ }^{-}\right)$através da seguinte reação química:

$$
\mathrm{NaClO}_{2}+\mathrm{Cl}_{2}+\mathrm{OH}^{-} \rightarrow \mathrm{Na}^{+}+\mathrm{ClO}_{3}^{-}+\mathrm{HCl}+\mathrm{Cl}^{-}
$$

A concentração da solução de dióxido de cloro gerada depende da concentração dos produtos utilizados na preparação e pode resultar de 1 a $30 \mathrm{~g} \mathrm{ClO}_{2} / \mathrm{L}$. Para uso em ensaios de bancada ou piloto, a solução gerada pode ser coletada e acondicionada sob refrigeração em frasco escuro mantendo por $24 \mathrm{~h}$ sua concentração original.

Segundo SINGER $^{3}$ (1992) apud USEPA (1999), a dosagem de 2mg/L de dióxido de cloro tem uma expectativa de produzir de 1,0 a 1,4mg/L de clorito. Nos EUA, a dosagem típica de dióxido de cloro para desinfecção de água para o abastecimento público varia de 0,07 a $2,0 \mathrm{mg} / \mathrm{L}$, resultando valores médio de concentração de clorito e clorato de 0,24 e $0,20 \mathrm{mg} / \mathrm{L}$, respectivamente. Sua ação como pré-oxidante e desinfetante constitui uma das alternativas de prevenção da formação de TAMs, atuando na oxidação dos precursores antes da desinfecção por adição de cloro.

A USEPA (1999) recomenda que a dosagem de dióxido de cloro não exceda a $1,4 \mathrm{mg} / \mathrm{L}$ e limita a concentração total combinada de dióxido de cloro, clorito e clorato em $1,0 \mathrm{mg} / \mathrm{L}$ de $\mathrm{Cl}_{2}$. Em proposta de regulamentação, recomenda um residual máximo de $0,8 \mathrm{mg} / \mathrm{L}$ de $\mathrm{ClO}_{2}$ e $1,0 \mathrm{mg} / \mathrm{L}$ para clorito.

Em 1986, numa pesquisa realizada com a água do rio Ohio (EUA) por AIETA \& BERG (1986), combinações de dosagens de dióxido de cloro e

\footnotetext{
${ }^{3}$ SINGER,P.C. (1992). Formation and characterizatin of disinfection byproducts. Presented at the first International Conference on the Safety of Water Disinfection: Balancing Chemical and Microbial Risks.
} 
cloro foram avaliadas para se determinar qual é a extensão da formação de TAMs nas condições da prática de uma ETA. A água bruta do rio Ohio foi coagulada, decantada, filtrada e tratada com várias combinações de dióxido de cloro e cloro. Constatou-se que mesmo pequenas dosagens de dióxido de cloro são suficientes para inibir a formação de TAMs em pelo menos $20 \%$.

A substituição do cloro pelo dióxido de cloro na pré-oxidação reduz a formação de subprodutos orgânicos. Alguns compostos orgânicos que podem ser formados, dependendo da dosagem e com presença de fenóis, são: clorofenóis, $\rho$-benzoquinona, ácidos oxálicos e maleicos.

Ainda segundo AIETA \& BERG (1986), a reação do dióxido de cloro com ácidos húmicos e fúlvicos não provoca a formação de TAMs, porém forma de 1 a $25 \%$ de compostos orgânicos não halogenados quando comparado a reação com cloro sob condições idênticas.

As vantagens do uso do dióxido de cloro são as seguintes:

- É mais efetivo que o cloro e cloraminas na inativação de vírus, Criptosporídio e Giardia;

- Oxida ferro, manganês e sulfetos;

- Pode melhorar a operação de clarificação;

- Não produz compostos halogenados, na ausência de excesso de cloro;

- Facilidade de produção;

- Sua atividade biocida não é afetada pelo pH;

- Fornece residual.

As desvantagens do uso do dióxido de cloro são as seguintes:

- Formação de subprodutos inorgânicos (clorito e clorato);

- Elevado custo de análises laboratoriais para quantificação de cloritos e cloratos;

- Elevado custo de clorito de sódio;

- É explosivo e, portanto deve ser gerado no local de aplicação; 
- Sofre decomposição sob ação da luz solar.

Os subprodutos inorgânicos do uso do dióxido de cloro são: cloreto, clorito e clorato. Os principais fatores que afetam as concentrações de dióxido de cloro, clorito e clorato na água final são:

- Dosagem aplicada por demanda de oxidante;

- A exposição à luz solar;

- A razão entre clorito de sódio e cloro durante a geração de dióxido de cloro;

- Reações entre cloro e o clorito com o cloro residual livre.

\subsubsection{Permanganato de potássio}

Nos EUA, o permanganato de potássio vem sendo utilizado para o tratamento de água desde 1913, onde é empregado em $16 \%$ do número total de ETAs, enquanto o cloro é empregado em $63,8 \%$ (USEPA, 1999). É um oxidante eficiente para o controle de sabor e odor e para a oxidação de ferro e manganês, especialmente quando esses metais encontram-se complexados com a matéria orgânica natural.

A aplicação de permanganato de potássio na pré-oxidação para controle de gosto e odor, cor ou algas pode levar a redução da formação de subprodutos da desinfecção.

O permanganato de potássio $\left(\mathrm{KMnO}_{4}\right)$ é um composto químico altamente reativo nas condições operacionais existentes nas estações de tratamento de água. Possui um poder oxidativo elevado e pode oxidar compostos orgânicos e inorgânicos.

O permanganato de potássio pode inativar várias bactérias e vírus, porém não é empregado como desinfetante porque seria necessário o uso de uma dosagem elevada, resultando em custo elevado. Mas esse agente químico tem sido utilizado com sucesso para oxidação de ferro e manganês, 
controle de algas em decantadores e diminuição do potencial de formação de trialometanos, DANIEL et al. (2001).

Comercialmente, o permanganato de potássio encontra-se disponível na forma sólida granulada de coloração violeta, apresenta solubilidade em água $\left(6,4 \mathrm{~g} / \mathrm{mL}\right.$ a $\left.20^{\circ} \mathrm{C}\right)$. Usualmente uma solução de 1 a 4 $\mathrm{g} / \mathrm{L}$ é preparada em batelada para uso nas ETAs.

O permanganato $\left(\mathrm{Mn}^{7+}\right)$ é reduzido a dióxido de manganês $\left(\mathrm{MnO}_{2}\right)$ $\left(\mathrm{Mn}^{4+}\right)$ que é precipitado na solução através de uma reação química exotérmica.

Em condições ácidas, suas reações principais são:

$$
\begin{array}{lll}
\mathrm{MnO}_{4}^{-}+4 \mathrm{H}^{+}+3 e^{-} \rightarrow \mathrm{MnO}_{2}+2 \mathrm{H}_{2} \mathrm{O} & \mathrm{E}^{0}=1,68 \\
\mathrm{MnO}_{4}^{-}+8 \mathrm{H}^{+}+5 e^{-} \rightarrow \mathrm{Mn}^{2+}+4 \mathrm{H}_{2} \mathrm{O} \quad \mathrm{E}^{0}=1,49
\end{array}
$$

Em condições alcalinas, a reação parcial é a seguinte:

$$
\mathrm{MnO}_{4}^{-}+2 \mathrm{H}_{2} \mathrm{O}+3 e^{-} \rightarrow \mathrm{MnO}_{2}+4 \mathrm{OH}^{-} \quad E^{0}=0,58
$$

As taxas de reação de oxidação dos constituintes encontrados em águas naturais são relativamente rápidas e dependem da temperatura, $\mathrm{pH}$ e dosagem de permanganato. Deve-se evitar um residual devido sua tendência de conferir coloração rósea à água.

A literatura ainda não traz referência sobre a formação de subprodutos com uso de permanganato de potássio. Existem vários estudos que relatam a substituição da pré-cloração pela pré-oxidação com $\mathrm{KMnO}_{4}$, e mantendo-se a pós-cloração final como único ponto de aplicação de cloro. Dentre eles, destaca-se um estudo realizado por OLIVEIRA (2002) sobre a minimização da formação de TAMs no tratamento de água de abastecimento. Foram realizados ensaios em reatores estáticos (Jar-teste) para simular a ETA, avaliou-se estrategicamente a mudança do ponto de aplicação do desinfetante após clarificação com a coagulação intensificada para aumentar a remoção de precursores de TAMs e utilizou o $\mathrm{KMnO}_{4}$ como pré-oxidante alternativo. Pelos resultados, OLIVEIRA concluiu que em geral, as concentrações de TAMs na água final foram menores nos ensaios 
realizados com o uso do $\mathrm{KMnO}_{4}$ na pré-oxidação. Porém, usando as dosagens comumente aplicadas em ETAs ( $<2,0 \mathrm{mg} / \mathrm{L} \mathrm{KMnO} 4)$, não pode ser considerada uma opção viável para minimizar a formação de TAMs, em vista da modesta diminuição. Contudo, pode-se considerar um pequeno efeito adicional na minimização da formação de tamis, nos casos em que a aplicação de permanganato de potássio na água bruta já for realizada na ETA para outros fins, como por exemplo, a oxidação de ferro e manganês, controle de gosto e odor.

O permanganato de potássio como pré-oxidante apresenta as seguintes vantagens (USEPA, 1999):

- Oxida ferro, manganês e compostos causadores de gosto e odor;

- Facilidade de transporte e armazenamento;

- Eficiente no controle da formação de TAMs e de outros subprodutos;

- Controla organismos indesejáveis e é efetivo contra certos vírus;

- Seu uso tem pequeno impacto no processo de tratamento.

O permanganato de potássio como pré-oxidante apresenta as seguintes desvantagens (USEPA, 1999):

- Necessita de longo tempo de contato;

- O residual pode causar coloração rósea na água;

- É tóxico e irritante à pele e mucosas;

- Pode ser fatal se ingerida a solução $1 \%$ utilizada na solução a ser dosada.

\subsubsection{Ozônio}

O ozônio não tem sido muito utilizado no Brasil, mas é comumente empregado na Europa e nos EUA desde o final do século XIX, para desinfecção e oxidação de água de abastecimento público.

O ozônio é o oxidante e o desinfetante mais efetivo usado em tratamento de água, necessita de menor tempo de contato, porém, sua ação desinfetante se dá por meio do residual de oxigênio molecular 
remanescente, o qual é instável e raramente encontrado na água após alguns minutos do ozônio ter sido aplicado.

O ozônio é uma forma alotrópica do oxigênio no qual três átomos de oxigênio combinam-se para formar a molécula de ozônio $\left(\mathrm{O}_{3}\right)$. É um gás incolor de odor facilmente identificado a partir de concentração de 0,02 a $0,05 \mathrm{mg} / \mathrm{L}$, é altamente corrosivo, tóxico e com baixa solubilidade em água. A sua aplicação nas estações de tratamento de água varia de 0,1 a 1,0 $\mathrm{mg} / \mathrm{L}$.

O ozônio decompõe-se espontaneamente na água, por meio de mecanismos complexos que envolvem a geração de radicais livres hidroxilas livres $\left({ }^{\star} \mathrm{OH}\right)$. Esses são muitos reativos, com taxas de reação na faixa de $10^{10}$ a $10^{13} \mathrm{M} / \mathrm{s}$. A meia vida dos radicais livres hidroxilas é de microsegundos, portanto as concentrações dos mesmos serão sempre menores que $10^{-12} \mathrm{~mol} / \mathrm{L}$.

Dois mecanismos de reação podem ocorrer na água:

- oxidação direta dos compostos pelo ozônio molecular $\left(\mathrm{O}_{3(\mathrm{aq})}\right)$;

- oxidação dos compostos pelos radicais livres hidroxilas produzidos durante a decomposição do ozônio.

Segundo GRASSI \& JARDIM (1993), a técnica comumente empregada na geração de ozônio, é a descarga em plasma frio ou descarga corona, onde o ozônio é formado pela decomposição do oxigênio molecular e posterior combinação de um átomo do radical oxigênio com uma molécula de oxigênio:

$$
\begin{aligned}
& \mathrm{O}_{2} \rightarrow \mathrm{O}^{*}+\mathrm{O}^{*} \\
& \mathrm{O}^{*}+\mathrm{O}_{2} \rightarrow \mathrm{O}_{3}
\end{aligned}
$$

O sistema é composto por uma fonte de oxigênio (ar de insumo), um gerador de ozônio, uma coluna (reator) de contato e um sistema de destruição do gás excedente produzido (off-gas).

O gás de insumo passa pelo gerador de ozônio onde é aplicada uma voltagem de 6000 a $20000 \mathrm{~V}$ a dois eletrodos e esta voltagem produz um arco elétrico. No arco uma parte do oxigênio se transforma em ozônio. 
Cerca de 1 a $10 \%$ do oxigênio que passam pelos eletrodos se transformam em ozônio.

Na coluna de contato, a água a ser oxidada tem contato com o gás de ozônio formado por dispersão através de uma placa de orifício ocorrendo a transferência do ozônio para a água. O gás excedente liberado da coluna de contato é destruído ou é reciclado ao inicio do processo.

Segundo USEPA (1999), o ozônio reage com a matéria orgânica natural contida em águas naturais e não forma subprodutos halogenados, mas forma uma variedade de subprodutos orgânicos e inorgânicos decorrentes da oxidação da matéria orgânica natural. Quando existe a presença de íons brometos na água a ser tratada, podem ser formados alguns TAMs. Na Tabela 3.6 estão apresentados os subprodutos possíveis de serem encontrados.

Tabela 3.6 - Principais subprodutos formados por uso de ozônio

\begin{tabular}{lc}
\hline Grupo Funcional & Subprodutos \\
\hline \hline Aldeídos & formaldeido, acetaldeido, glioxal, metil glioxal \\
Ácidos & acético, oxálico, fórmico e succínico \\
Subprodutos bromados & Íon bromato, ácido acético bromado \\
TAMs & bromofórmio, bromopicrina \\
Outros & peróxido de hidrogênio \\
\hline
\end{tabular}

Fonte: SINGER, 1992.

\subsubsection{Peróxido de hidrogênio}

O peróxido de hidrogênio é um forte oxidante e o seu potencial de oxidação, $E^{\circ}$, igual a $+1,76 \mathrm{~V}$. No mercado, pode ser encontrado em concentrações de 30 a $70 \%$ (v/v). A solução concentrada é altamente tóxica e irritante e deve ser armazenada em frasco plástico e escuro ao abrigo da luz. O peróxido de hidrogênio pode ser utilizado em combinação com outros produtos químicos como o $\mathrm{Fe}^{+2}, \mathrm{Cu}^{+1}$, com irradiação UV e, principalmente com o ozônio, para produzir radicais hidroxilas. 
O peróxido de hidrogênio quando em contato com a água, é parcialmente dissociados em íon hidroperóxido, como segue:

$$
\mathrm{H}_{2} \mathrm{O}_{2}+\mathrm{H}_{2} \mathrm{O} \rightarrow \mathrm{HO}_{2}^{-}+\mathrm{H}_{3} \mathrm{O}^{+}
$$

A molécula de peróxido de hidrogênio reage lentamente com o ozônio, no entanto, o íon hidroperóxido é altamente reativo (LANGLAIS et al.,1991).

O principal uso do peróxido de hidrogênio no tratamento de água destinada ao consumo humano é com o objetivo de controlar ou eliminar algas e/ou oxidar o ferro e o manganês presentes até os teores limitados pela Portaria 518 (2004), de 0,30 e 0,10 mg/L, respectivamente.

As indústrias que fabricam o peróxido de hidrogênio afirmam que sua decomposição gera subprodutos não prejudiciais à saúde.

\subsubsection{Peroxônio}

O uso do ozônio em conjunto com o peróxido de hidrogênio é denominado peroxônio. Nesse processo, há um acréscimo na concentração de *OH em relação ao processo de ozonização. Com a adição do peróxido, a produção do radical hidroxila é de 1:1 de ozônio, aumentando o potencial de oxidação e de desinfecção. A eficiência de oxidação é aumentada pela conversão de moléculas de ozônio em radical hidroxila e pelo aprimoramento da transferência do ozônio da fase gasosa para a fase líquida, aumentando as taxas de reação em geral.

As reações do ozônio e do peroxônio competem pelo substrato. A principal diferença é que a ozonização depende do alto grau da oxidação direta da matéria orgânica pelo ozônio, enquanto o peroxônio depende principalmente da oxidação do radical hidroxila. (DANIEL, 2001).

O mecanismo de reações entre o radical hidroxila e a matéria orgânica pode acontecer por três caminhos: a retirada do hidrogênio de um 
grupo $-\mathrm{CH}_{2}$, adição de radical e transferência de elétrons. Os radicais secundários, formados durante essas reações, podem reagir com ozônio adicional, com um outro radical, ou com outros compostos. Organoperóxidos podem ser formados pela reação do radical carbonil (C) com o oxigênio presente. Esses compostos podem entrar em uma cadeia de reações envolvendo ozônio e radical hidroxila, resultando na formação de novos radicais ou superóxidos (MASTEN \& DAVIES, 1997).

Segundo AIETA et al. (1988) ${ }^{4}$ apud COELHO (2002), o mecanismo da reação e a estequiometria resultante pode ser expressa pelos seguintes mecanismos:

$$
\begin{aligned}
& \mathrm{H}_{2} \mathrm{O}_{2} \quad \leftrightarrow \quad \mathrm{H}^{+}+\mathrm{HO}_{2}^{-} \\
& \mathrm{O}_{3}+\mathrm{HO}_{2}^{-} \rightarrow \mathrm{O}_{3}^{-}+{ }^{*} \mathrm{OH} \\
& \mathrm{O}_{3}^{-}+\mathrm{H}^{+} \leftrightarrow \mathrm{HO}_{3} \quad \mathrm{HO}_{2}^{-} \leftrightarrow \mathrm{H}^{+}+\mathrm{O}_{2} \\
& \mathrm{HO}_{3} \rightarrow{ }^{*} \mathrm{HO}+\mathrm{O}_{2} \quad \mathrm{O}_{2}^{-}+\mathrm{O}_{3} \rightarrow \mathrm{O}_{2}+\mathrm{O}_{3}^{-} \\
& \mathrm{O}_{3}{ }^{-}+\mathrm{H}^{+} \leftrightarrow \mathrm{HO}_{3} \\
& \mathrm{HO}_{3} \rightarrow{ }^{*} \mathrm{OH}+\mathrm{O}_{2} \\
& 1 \mathrm{H}_{2} \mathrm{O}_{2}+2 \mathrm{O}_{3} \rightarrow 2 \mathrm{OH}+3 \mathrm{O}_{2}
\end{aligned}
$$

A estequiometria da reação mostra uma relação molar de 0,5 de $\mathrm{H}_{2} \mathrm{O}_{2}$ para $\mathrm{O}_{3}$. Alguns fatores podem influenciar nesta relação. Primeiro, o $\mathrm{H}_{2} \mathrm{O}_{2}$ pode atuar como consumidor decrescendo a concentração de radicais ${ }^{*} \mathrm{OH}$. Segundo, $\mathrm{O} \mathrm{O}_{3}$ pode reagir diretamente com os radicais ${ }^{*} \mathrm{OH}$ e finalmente, $\mathrm{O}_{3} \mathrm{e}{ }^{*} \mathrm{OH}$ podem ser consumidos por constituintes na água.

$\mathrm{Na}$ prática, a relação ótima de $\mathrm{H}_{2} \mathrm{O}_{2}$ para $\mathrm{O}_{3}$ é dependente do sistema de geração de ozônio e da qualidade da água a ser tratada.

O ponto de adição do peróxido de hidrogênio ainda é controverso entre os autores consultados. Segundo LANGLAIS et al., (1991), o melhor ponto parece ser aquele no qual o ozônio sozinho já oxidou as moléculas

\footnotetext{
${ }^{4}$ AIETA, E. M. et al. (1988). Advanced Oxidation Processes for Treating Groundwater Contamined with TCE and PCE: Pilot Scale Evaluations. Journal AWWA, p.64-72.
} 
mais reativas, explorando a seletividade do ozônio, convertendo depois processo para a via radicalar oxidando as moléculas refratárias.

A titulo de comparação são apresentados, na Tabela 3.7 as semireações de alguns oxidantes e os potenciais padrão de oxi-redução $\left(\mathrm{E}^{0}{ }_{\text {red }}\right)$ em solução aquosa a $25^{\circ} \mathrm{C}$, que são mais comumente empregados no tratamento de água.

Tabela 3.7 - Potencial padrão de oxi-redução para semi-reações em solução aquosa a $25^{\circ} \mathrm{C}$.

\begin{tabular}{lcc}
\hline Oxidante & Semi-reação & $\begin{array}{c}\mathrm{E}_{\text {red }}^{0} \\
\text { (volts) }\end{array}$ \\
\hline Radical livre hidroxila & $\mathrm{OH}^{-}+\mathrm{H}^{+}+1 \mathrm{e}^{-} \rightarrow \mathrm{H}_{2} \mathrm{O}$ & 2,85 \\
Ozônio & $\mathrm{O}_{3}+2 \mathrm{H}^{+}+2 \mathrm{e}^{-} \rightarrow \mathrm{O}_{2}+\mathrm{H}_{2} \mathrm{O}$ & 2,07 \\
Peróxido de hidrogênio & $\mathrm{H}_{2} \mathrm{O}_{2}+2 \mathrm{H}+2 \mathrm{e}^{-} \rightarrow 2 \mathrm{H}_{2} \mathrm{O}$ & 1,78 \\
Permanganato & $\mathrm{MnO}_{4}^{-}+4 \mathrm{H}^{+}+3 \mathrm{e}^{-} \rightarrow \mathrm{MnO}_{2}+2 \mathrm{H}_{2} \mathrm{O}$ & 1,68 \\
Dióxido de cloro & $\mathrm{ClO}_{2}$ (aq) $+1 \mathrm{e}^{-} \rightarrow \mathrm{ClO}_{2}^{-}$ & 0,95 \\
Ácido hipocloroso & $1 / 2 \mathrm{HOCl}^{-} 1 / 2 \mathrm{H}^{+}+1 \mathrm{e}^{-} \rightarrow 1 / 2 \mathrm{Cl}^{-}+1 / 2 \mathrm{H}_{2} \mathrm{O}$ & 1,48 \\
Ín clorito & $1 / 2 \mathrm{OCl}^{-}+\mathrm{H}^{+}+1 \mathrm{e}^{-} \rightarrow 1 / 2 \mathrm{Cl}^{-}+1 / 2 \mathrm{H}_{2} \mathrm{O}$ & 1,64 \\
Monocloamina & $1 / 2 \mathrm{NH}_{2} \mathrm{Cl}^{+} \mathrm{H}^{+}+1 \mathrm{e}^{-} \rightarrow 1 / 2 \mathrm{Cl}^{-}+1 / 2 \mathrm{NH}_{4}$ & 1,40 \\
Dicloroamina & $1 / 4 \mathrm{NHCl}_{2}+3 / 4 \mathrm{H}^{+}+1 \mathrm{e}^{-} \rightarrow 1 / 2 \mathrm{Cl}^{-}+1 / 4 \mathrm{NH}_{4}$ & 1,34 \\
Oxigênio & $1 / 4 \mathrm{O}_{2}\left(\right.$ aq) $+\mathrm{H}^{+}+1 \mathrm{e}^{-} \rightarrow 1 / 2 \mathrm{H}_{2} \mathrm{O}$ & 1,23 \\
\hline Fonte:AWWA(1999) & &
\end{tabular}

Fonte: AWWA (1999).

\subsection{Considerações finais sobre a literatura}

Os resultados apresentados na literatura sobre a formação de subprodutos decorrentes da reação de matéria orgânica presente em mananciais de abastecimento de água com diferentes pré-oxidantes, principalmente com cloro, que é usualmente utilizado nas ETAs no Brasil, revelam a importância da realização de estudos sobre a toxicidade destes subprodutos que são compostos orgânicos halogenados prejudiciais à saúde humana. No Brasil, tem sido investigado principalmente a formação de 
trialometanos na água potável, sendo que os padrões de potabilidade prescritos na Portaria 518/2004, exige-se apenas o controle de trialometanos como subprodutos da desinfecção com limite máximo permissível de $100 \mu \mathrm{g} / \mathrm{L}$, não exigindo o controle da presença de outros compostos, tais como os ácidos haloacéticos, cloro hidrato e haloacetonitrilas, que podem afetar igualmente a saúde da população e devem ser considerados.

O uso do cloro na pré-oxidação, em águas contendo matéria orgânica natural, é responsável pela maior parcela dos subprodutos orgânicos halogenados formados e a utilização de oxidantes alternativos vem sendo estudada e aplicada em outros países. No Brasil, na literatura consultada, OLIVEIRA et al. (2002), realizaram ensaios em escala de bancada, para a verificação da minimização da formação de trialometanos, porém não foi encontrado uma referência sobre a padronização de ensaios com pré-oxidação que possibilitem a simulação da formação de subprodutos nas ETAs.

$O$ presente trabalho foi proposto para avaliar o efeito da préoxidação, coagulação, filtração e pós-cloração na formação de subprodutos orgânicos halogenados. Neste sentido, foi necessário o desenvolvimento de ensaios de demanda pré-oxidante, metodologias analíticas para quantificação de 22 compostos orgânicos halogenados e a adaptação de um procedimento experimental (APHA, 1998) para avaliar o potencial de formação de subprodutos quando se utilizam a pré-oxidação com cloro, dióxido de cloro, permanganato de potássio, peróxido de hidrogênio, ozônio e peroxônio no tratamento de água para abastecimento. 


\section{MATERIAIS E MÉTODOS}

O trabalho proposto foi desenvolvido em cinco etapas preliminares, que possibilitaram a definição dos parâmetros utilizados nos ensaios experimentais para avaliação da formação dos subprodutos orgânicos halogenados. Nas Figuras 4.1, 4.2, 4.3, 4.4, e 4.5 estão apresentados os fluxogramas dessas etapas.

As referidas etapas preliminares foram as seguintes:

- Extração de substâncias húmicas, preparação da água de estudo e caracterizações através de análises físico-químicas;

- Desenvolvimento de duas metodologias analíticas por cromatografia em fase gasosa com extração e calibração para determinação de 22 compostos orgânicos halogenados;

- Ensaios com variação de cor, temperatura e dosagem de cloro para o estabelecimento dos parâmetros adotados nos ensaios experimentais.

- Ensaios de demanda com os pré-oxidantes para determinação de dosagem e tempo de contato aplicados na pré-oxidação;

- Ensaios em reatores estáticos para determinação da dosagem de coagulante estabelecendo condições de $\mathrm{pH}$, tempo e gradiente de mistura rápida e filtração em filtro de papel Whatman 40 para obtenção de cor remanescente $<5 \mathrm{uH}$. 


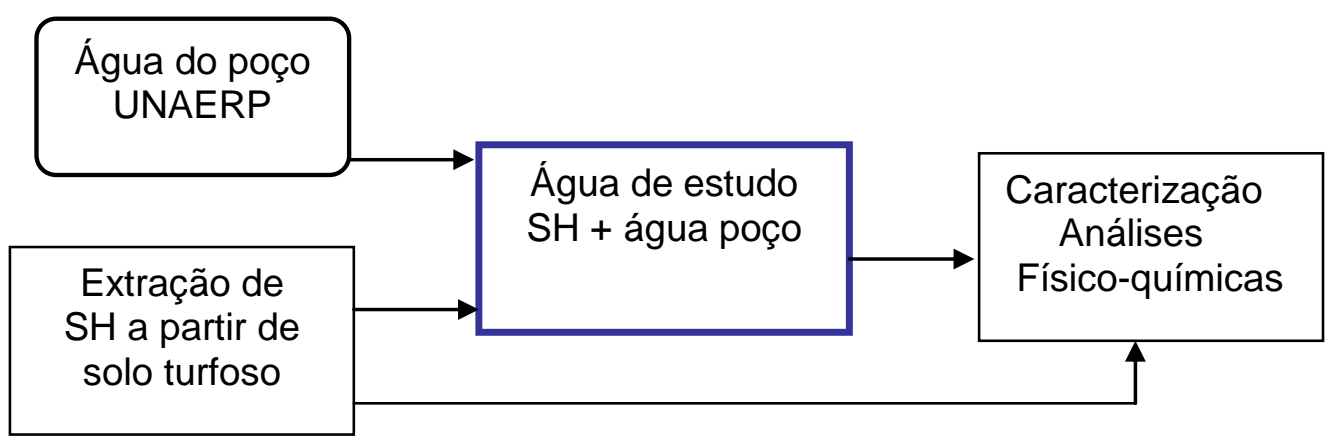

Figura 4.1 - Fluxograma da preparação da água de estudo com extrato de substâncias húmicas e caracterizações.

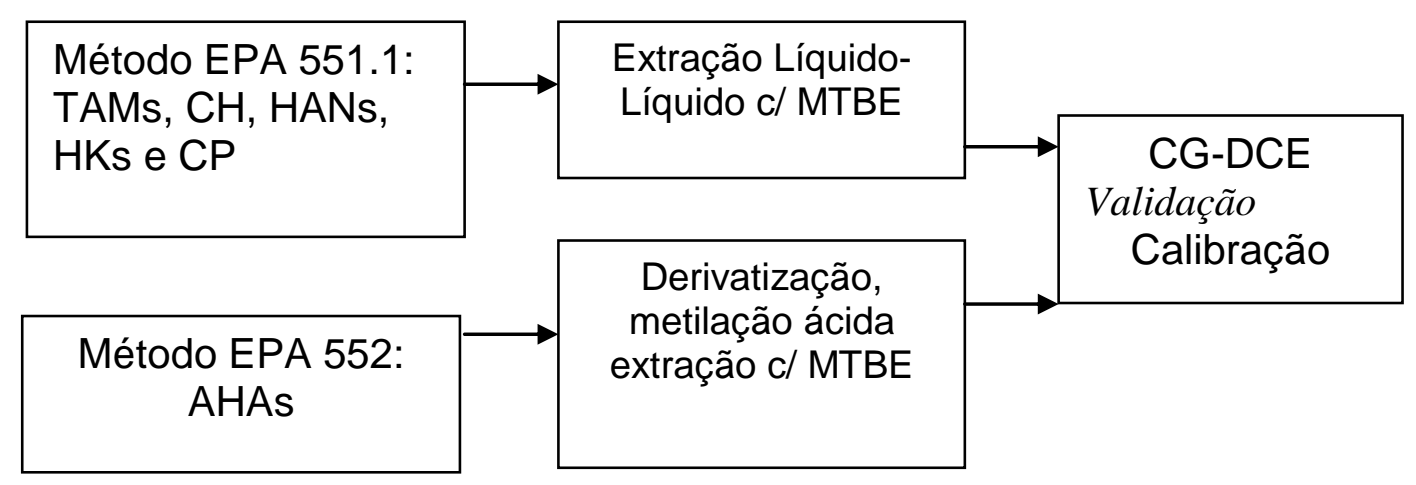

Figura 4.2 - Fluxograma do desenvolvimento de duas metodologias analíticas por cromatografia em fase gasosa (CG-DCE).

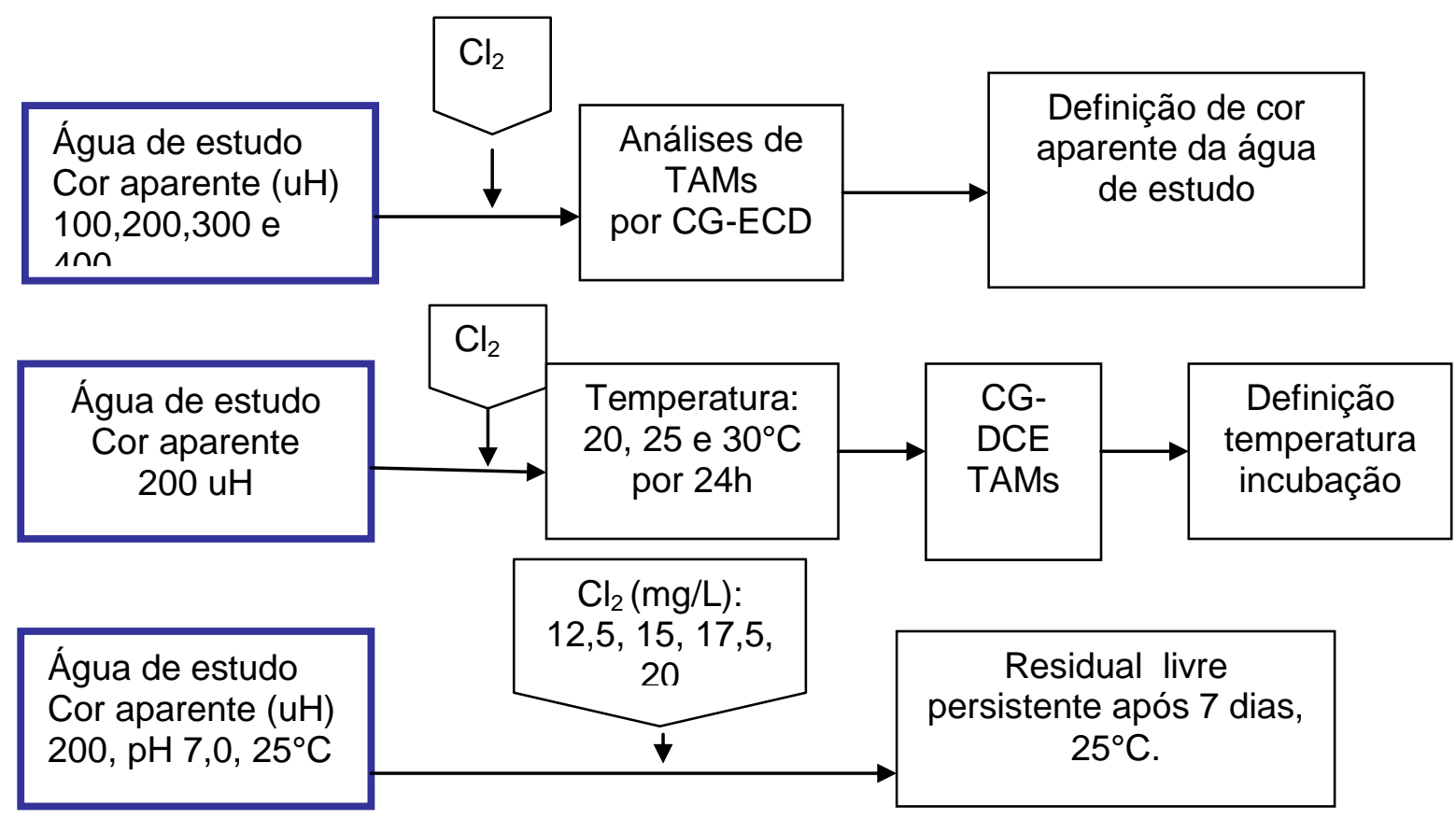

Figura 4.3 - Fluxograma de ensaios com variação de cor, temperatura e dosagem de cloro. 


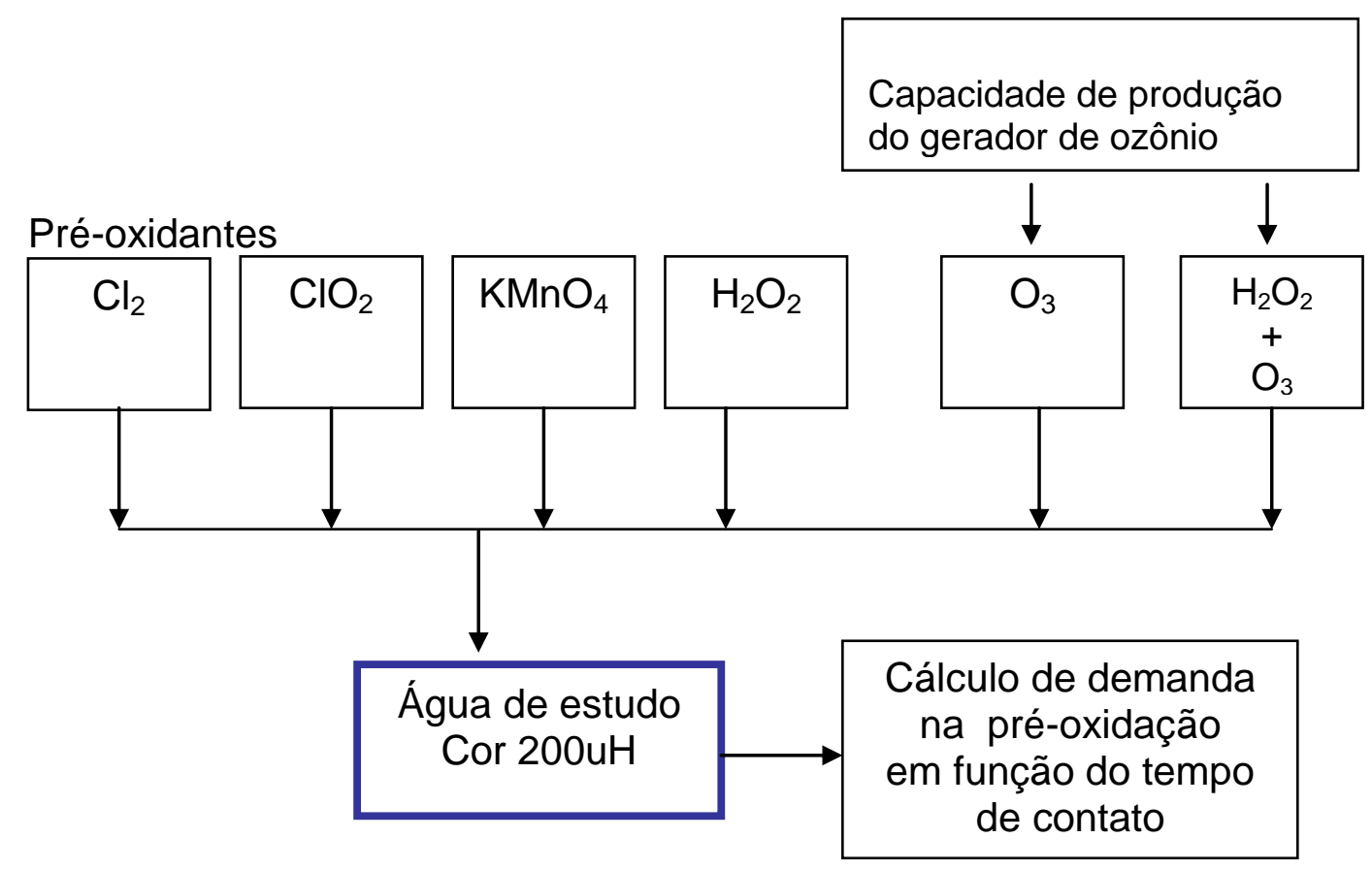

Figura 4.4- Fluxograma dos ensaios de demanda com os pré-oxidantes alternativos para determinação de dosagem e tempo de contato a serem aplicados na etapa de pré-oxidação.

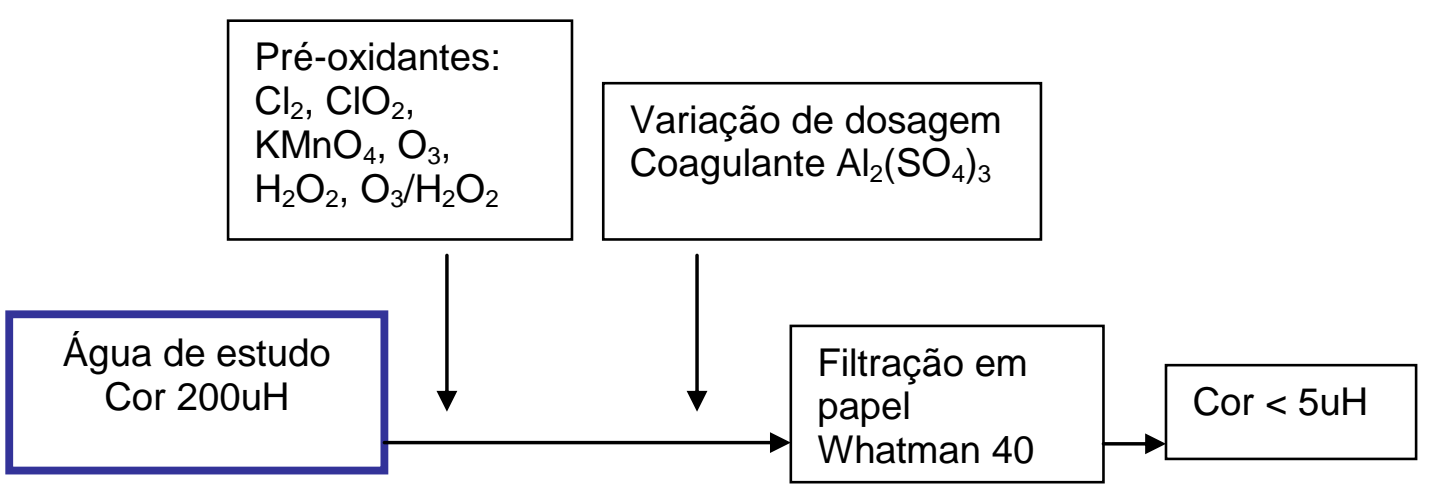

Figura 4.5- Fluxograma dos ensaios de jarteste para determinação da dosagem de coagulante estabelecendo condições de $\mathrm{pH}$, tempo de contato, gradiente de velocidade na mistura rápida e filtração em papel para obtenção de cor remanescente $<5 \mathrm{uH}$.

Os ensaios experimentais foram divididos em duas etapas: sendo a primeira etapa com uso de cloro para avaliação do potencial de formação de 7 dias $\left(\mathrm{PF}_{7}\right)$ dos subprodutos orgânicos halogenados e as respectivas taxas de formação, realizada com a água de estudo de cor $200 \mathrm{uH}$, submetida a 
uma dosagem elevada de cloro que foi determinada em ensaios preliminares, fornecendo um residual de cloro livre persistente acima de $3,5 \mathrm{mg} / \mathrm{L}$ após 7 dias de tempo de contato em $\mathrm{pH} 7,0$, a $25^{\circ} \mathrm{C}$. Alíquotas de $100 \mathrm{~mL}$ foram coletadas em diferentes tempos de contato que variaram de $2 \mathrm{~h}$ $\left(T_{0}\right)$ a 7 dias $\left(T_{f}\right)$, descloradas com adição de aproximadamente $2,0 \mathrm{~g} \pm 1,0$, de ácido ascórbico granulado, extraídas e analisadas por CG-DCE.

Os resultados obtidos nesse ensaio forneceram $0 \mathrm{PF}_{7}$ de 22 subprodutos em presença de excesso de cloro, ou seja, a capacidade máxima de formação dos subprodutos investigados em uma água contendo substâncias húmicas originada por turfa, assim como a taxa ou velocidade de formação dos mesmos. Esse $\mathrm{PF}_{7}$ foi 0 parâmetro de referência para avaliação da redução ou de não formação de subprodutos dos pré-oxidantes em estudo, inclusive para a situação pré-oxidação com cloro e pós-cloração.

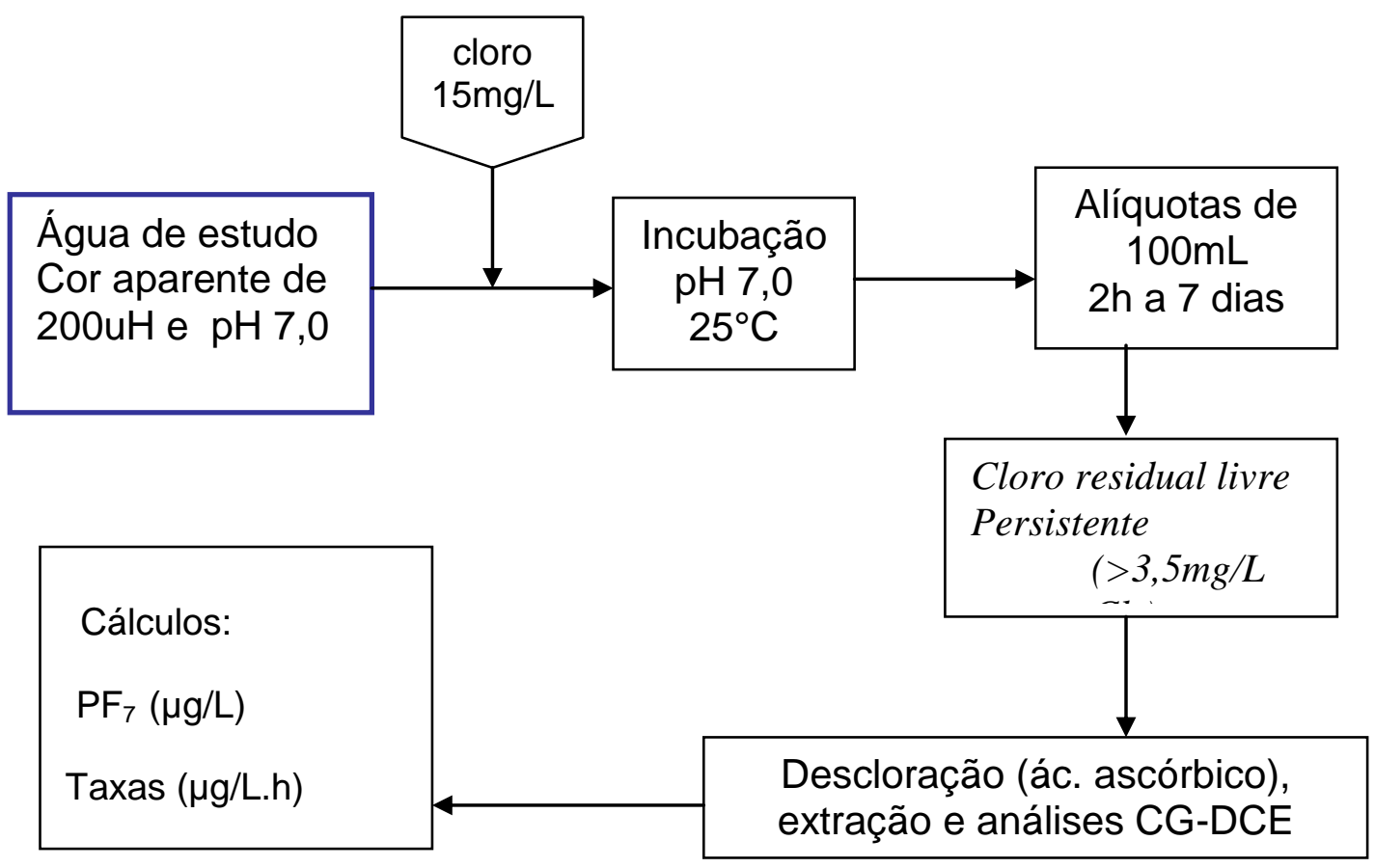

Figura 4.6 - Ensaios para avaliação do potencial de formação de subprodutos em 7 dias e taxas de formação.

Na segunda etapa simulou-se o sistema de tratamento de água com ensaios experimentais realizados para cada pré-oxidante em estudo com 
dosagens definidas por ensaios de demanda e mantendo-se fixas as seguintes condições: cor aparente da água em estudo, tempo de contato na pré-oxidação, dosagem de coagulante, tempo e gradiente de mistura rápida, pós-cloração, $\mathrm{pH}$ do meio, temperatura de incubação, tempo de contato na pós-cloração. Esta etapa está apresentada na Figura 4.7.

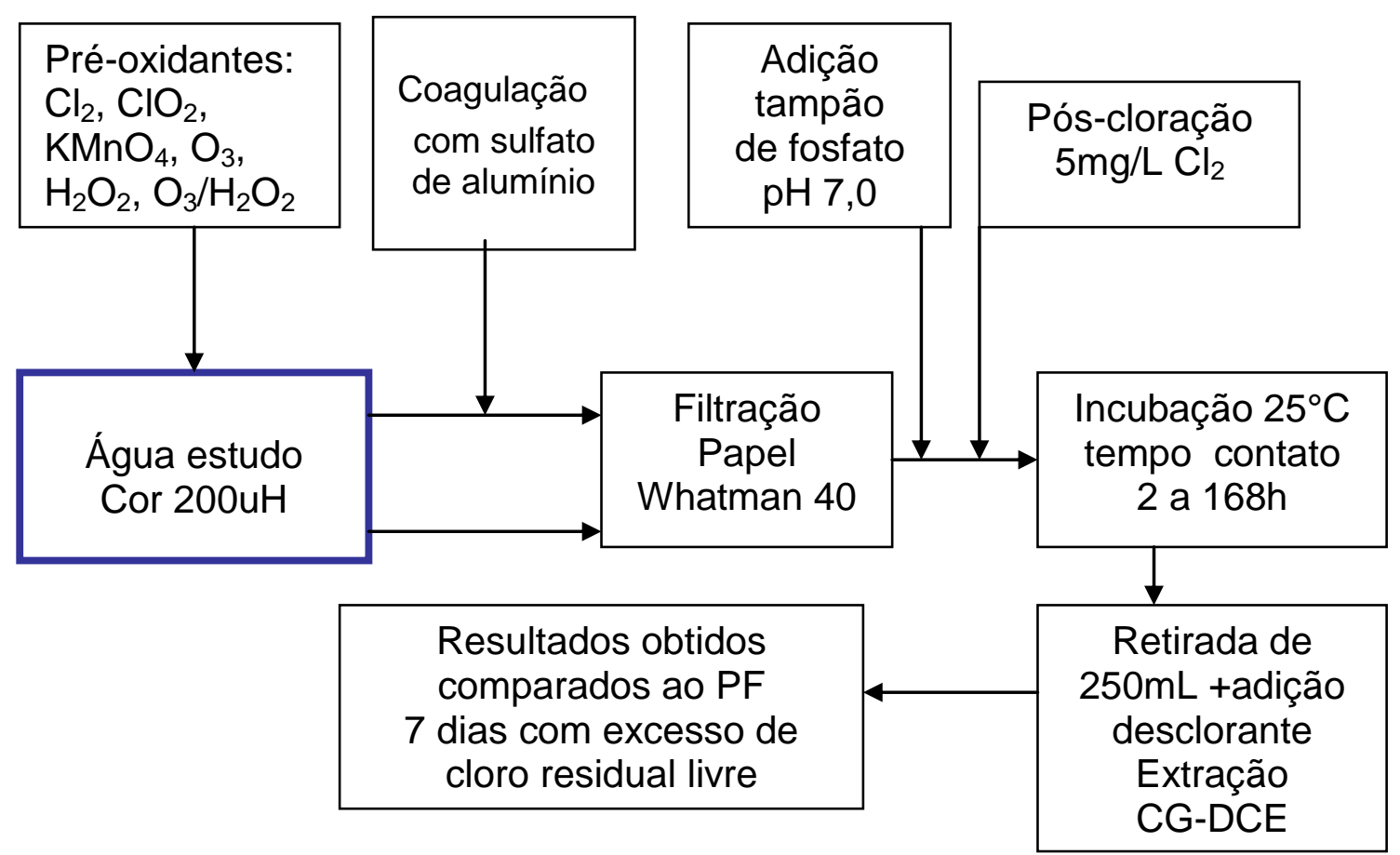

Figura 4.7 - Fluxograma dos ensaios de pré-oxidação, coagulação, filtração, pós-cloração, incubação e analises CG-DCE.

\subsection{Extração de substâncias húmicas}

As substâncias húmicas utilizadas para a preparação da água de estudo foram obtidas a partir de turfa conforme o procedimento de extração descrito a seguir.

A turfa foi coletada junto às margens do rio Moji-Guaçu, no $\mathrm{km} 40$ da rodovia SP-255, do município de Luís Antônio, SP. Em seguida, a turfa foi seca em temperatura ambiente, triturada e peneirada. 
Para a extração das substâncias húmicas (SHs) foi utilizado o método sugerido por ROCHA et al.(2000), que verificou os parâmetros adequados a serem utilizados na extração alcalina de SHs a partir de turfa. As etapas necessárias para esse processo de extração foram as seguintes:

- extração em solução $0,5 \mathrm{~mol} / \mathrm{L}$ de hidróxido de sódio $(\mathrm{NaOH})$;

- agitação de 4 horas;

- razão turfa/extrator 1:20 (m/v);

- temperatura ambiente (22 a $\left.27^{\circ} \mathrm{C}\right)$;

- decantação por 48 horas.

A solução sobrenadante produzida foi coletada e acondicionada em embalagens de papel celofani. Essas embalagens foram imersas em um banho com solução de $\mathrm{HCl} 1 \%$, para redução do $\mathrm{pH}$ até $<2$, posteriormente as embalagens foram lavadas com água do poço não clorada até teste de ausência de cloretos por titrimetria com auxílio de solução padronizada de nitrato de prata $\left(\mathrm{AgNO}_{3}\right)$. O volume total de extrato obtido foi armazenado em frasco plástico e estocado à temperatura de $4^{\circ} \mathrm{C}$.

O extrato obtido foi caracterizado por análises químicas.

\subsubsection{Caracterização do extrato de substâncias húmicas}

O extrato de substâncias húmicas obtido por extração em $\mathrm{NaOH}$, foi caracterizado pelo mesmo procedimento utilizado por CAMPOS (2004).

Para a realização das análises no extrato de substâncias húmicas foram necessários $200 \mathrm{~mL}$ de amostra que foram liofilizados em um liofilizador da marca Edwards, modelo F101-02-000.

As análises químicas elementares das frações das $\mathrm{SH}$ foram realizadas em um aparelho CHNS-O da marca Fisons, EA 1108. As porcentagens dos elementos carbono $(C)$, hidrogênio $(H)$, nitrogêno $(N)$ foram obtidas diretamente e o elemento oxigênio $(\mathrm{O})$ foi calculado por diferença. 
Para a realização das análises de Infra Vermelho (IV) foi empregado um espectrômetro da marca Bomem MB-102, utilizando a técnica de transformada de Fourier. Para essa análise foram confeccionadas pastilhas do material liofilizado, na proporção aproximada de 1:100 (1,0 mg de amostra e $100 \mathrm{mg}$ de $\mathrm{KBr}$ ), realizou-se 16 varreduras de espectro com $4 \mathrm{~cm}^{-1}$ de resolução.

Para as análises de UV/Vis das SHs foi utilizado um equipamento Hitachi modelo U3501. Dissolveu-se uma pequena quantidade de cada fração de SHs em $10 \mathrm{~mL}$ de solução de $\mathrm{NaHCO}_{3} 0,05 \mathrm{~mol} / \mathrm{L}$ e determinadas as razões entre as absorbâncias de $465 \mathrm{~nm}$ e $665 \mathrm{~nm}\left(\mathrm{E}_{4} / \mathrm{E}_{6}\right)$.

\subsection{Caracterização da água de estudo}

A água de estudo foi preparada utilizando-se a água de um poço artesiano localizado na Universidade de Ribeirão Preto (UNAERP) em Ribeirão Preto, SP, coletada em um ponto antes da adição do cloro. Uma determinada quantidade de extrato de substâncias húmicas foi adicionada a essa água para obtenção da água de estudo com cor aparente de $200 \pm 5$ $\mathrm{uH}$, definida por ensaios apresentados posteriormente.

As características da água do poço e da água de estudo foram avaliadas através de métodos analíticos (APHA, et al.,1998), discriminados na Tabela 4.1.

As técnicas analíticas utilizadas para determinação de metais foram de espectrofotometria por absorção atômica, tendo sido empregado o sistema de queimador com chama ar-acetileno, exceto para as determinações de mercúrio e arsênio em que foi utilizado o sistema de gerador de hidretos e forno de grafite para bário e chumbo. $O$ equipamento utilizado foi um espectrofotômetro de absorção atômica AA Analist 700 , marca Perkin Elmer. 
Tabela 4.1- Parâmetros, métodos analíticos, unidades e limites de detecção

\begin{tabular}{|c|c|c|c|}
\hline PARÂMETRO & UNIDADE & LDM & MÉTODO \\
\hline$\overline{\mathrm{pH}}$ & בadimensional & $0-14$ & Potenciométrico \\
\hline Cor aparente & $\mathrm{uH}$ (PtCo) & 1 & Espectrofotométrico \\
\hline Turbidez & NTU & 0,1 & Nefelométrico \\
\hline COT & $\mathrm{mg} / \mathrm{L}$ & 0,1 & Infravermelho \\
\hline UV 254nn & abs & 0,01 & Espectrofotométrico \\
\hline Alcalinidade bicarbonato & $\mathrm{mg} / \mathrm{L} \mathrm{CaCO}_{3}$ & 1 & Titrimétrico \\
\hline Oxig. Consumido & $\mathrm{mg} / \mathrm{L} \mathrm{O}_{2}$ & 0,1 & Titrimétrico \\
\hline DQO & $\mathrm{mg} / \mathrm{L} \mathrm{O}_{2}$ & 10 & Espectrofotométrico \\
\hline Nitrogênio amoniacal & $\mathrm{mg} / \mathrm{L} \mathrm{N}-\mathrm{NH}_{3}$ & 0,01 & Espectrofotométrico Nessler \\
\hline Dureza Total & $\mathrm{mg} / \mathrm{L} \mathrm{CaCO}_{3}$ & 1 & Titrimétrico EDTA \\
\hline Cloretos & $\mathrm{mg} / \mathrm{L} \mathrm{Cl}^{-}$ & 1 & Titrimétrico $-\mathrm{HgNO}_{3}$ \\
\hline Brometo & $\mathrm{mg} / \mathrm{L}$ & 0,1 & Espectrofotométrico \\
\hline Nitrato & $\mathrm{mg} / \mathrm{L} \mathrm{N}-\mathrm{NO}_{3}$ & 0,01 & Espectrofotométrico UV \\
\hline Nitrito & $\mathrm{mg} / \mathrm{L} \mathrm{N}-\mathrm{NO}_{2}$ & 0,01 & Espectrofotométrico \\
\hline Série de Sólidos & $\mathrm{mg} / \mathrm{L}$ & 1 & Gravimétrico \\
\hline Manganês & $\mathrm{mg} / \mathrm{L} \mathrm{Mn}$ & 0,001 & ABS Chama Ar-acetileno \\
\hline Ferro & $\mathrm{mg} / \mathrm{L} \mathrm{Fe}$ & 0,001 & ABS Chama Ar-acetileno \\
\hline Bário & $\mathrm{mg} / \mathrm{L} \mathrm{Ba}$ & 0,001 & ABS - Forno de Grafite \\
\hline Zinco & $\mathrm{mg} / \mathrm{L} \mathrm{Zn}$ & 0,001 & ABS Chama Ar-acetileno \\
\hline Níquel & $\mathrm{mg} / \mathrm{L} \mathrm{Ni}$ & 0,001 & ABS Chama Ar-acetileno \\
\hline Cobre & $\mathrm{mg} / \mathrm{L} \mathrm{Cu}$ & 0,001 & ABS Chama Ar-acetileno \\
\hline Arsênio & $\mu \mathrm{g} / \mathrm{L}$ As & 0,1 & ABS -Gerador Hidreto \\
\hline Cobalto & $\mathrm{mg} / \mathrm{L}$ Co & 0,001 & ABS Chama Ar-acetileno \\
\hline Mercúrio & $\mu \mathrm{g} / \mathrm{L} \mathrm{Hg}$ & 0,1 & ABS - Gerador Hidreto \\
\hline Cádmio & $\mathrm{mg} / \mathrm{L} \mathrm{Cd}$ & 0,001 & ABS Chama Ar-acetileno \\
\hline Chumbo & $\mu \mathrm{g} / \mathrm{L} \mathrm{Pb}$ & 0,1 & ABS Forno de grafite \\
\hline Cromo & $\mathrm{mg} / \mathrm{L} \mathrm{Cr}$ & 0,001 & ABS Chama Ar-acetileno \\
\hline Prata & $\mathrm{mg} / \mathrm{L} \mathrm{Ag}$ & 0,001 & ABS Chama Ar-acetileno \\
\hline
\end{tabular}

Um volume de $50 \mathrm{~mL}$ de amostra da água em estudo foi previamente digerido com a adição de porções iguais de ácido nítrico e ácido clorídrico. 0 extrato de $50 \mathrm{~mL}$ digerido, filtrado e reconstituído foi aspirado no equipamento de Absorção Atômica, para quantificação dos metais 
avaliados. Os resultados obtidos de leitura (em triplicata) de absorbância foram calculados através de uma curva analítica padrão de calibração de absorbância em função da concentração, obtendo-se resultados expressos em unidade de concentração.

Uma alíquota de $50 \mathrm{~mL}$ da água do poço sem cloração e um volume idêntico de água destilada, foram digeridas pelo mesmo procedimento e os extratos foram reconstituídos e analisados para verificação de constituintes naturais que poderiam estar presentes na água do poço e branco analítico para eliminação de interferentes dos ácidos adicionados para digestão.

\subsection{Extrações e análises por cromatografia em fase gasosa}

A utilização de procedimentos de extração são requisitos preliminares para as análises de compostos orgânicos através da técnica analítica de cromatografia gasosa.

Para atender a proposta de realização desse trabalho, foi necessária a utilização de duas extrações distintas, uma para a determinação de trialometanos, cloro hidrato, haloacetonitrilas, halocetonas e cloropicrina e a outra para determinação de ácidos haloacéticos. Os extratos obtidos foram analisados por métodos distintos.

\subsubsection{Extração líquido-líquido}

O método utilizado para extração de trialometanos, cloro hidrato, cloropicrinas, halocetonas e haloacetonitrilas, foram baseados no procedimento descrito pela USEPA 551.1 (1995).

Foram realizados diversos ensaios de extração para verificação da recuperação analítica e padronização do procedimento, pois a determinação do volume de amostra em função do volume de solvente utilizado é importante para completa extração.

Uma alíquota de $10 \mathrm{~mL}$ de amostra armazenada a $4^{\circ} \mathrm{C}$ foi rapidamente coletada e inserida em um frasco do tipo vial de $25 \mathrm{~mL}$, ao qual 
foi adicionado um volume de $10 \mu \mathrm{L}$ de diclorometano $1 \%$ (o diclorometano foi o padrão interno $(\mathrm{PI})$ do método e deverá ser introduzido em todas as amostras, padrões da curva de calibração e brancos).

A seguir, foram adicionados no vial $4 \mathrm{~mL}$ de Metil-Terc Butilico Éter (MTBE), mantido a $4^{\circ} \mathrm{C}$, e aproximadamente $1,0 \mathrm{~g}$ de sulfato de sódio puro, agente secante da fase orgânica.

O frasco vial foi agitado vigorosamente por 2 minutos e imediatamente acondicionado em freezer à $-4^{\circ} \mathrm{C}$.

Duas fases, bem definidas, separam-se dentro do frasco vial: a fase orgânica superior, chamada de extrato e a fase inferior, chamada de fase aquosa. A fase orgânica foi retirada e transferida para um frasco tipo vial de $4 \mathrm{~mL}$, acondicionada em freezer e conservada para análise em CG-DCE por um período máximo de 7 dias. A fase aquosa foi descartada.

\subsubsection{Análises cromatográficas}

As análises cromatográficas foram realizadas no laboratório de Recursos Hídricos da UNAERP, em Ribeirão Preto. O equipamento utilizado foi um cromatógrafo a gás (CG), da marca Varian, modelo $3600 \mathrm{CX}$, com detetor de captura de elétrons (DCE), o equipamento esta apresentado na Figura 4.8.

\subsubsection{Determinação de trialometanos, cloro hidrato, cloropicrinas haloacetonitrilas e haloacetonas}

O método utilizado para esta determinação cromatográfica, foi baseado nas recomendações da USEPA 551.1, porém as condições de operação do equipamento não são idênticas e podem apresentar variações de um equipamento para outro. Devido a este fato, houve a necessidade de se adequar diversas condições na metodologia referenciada. 


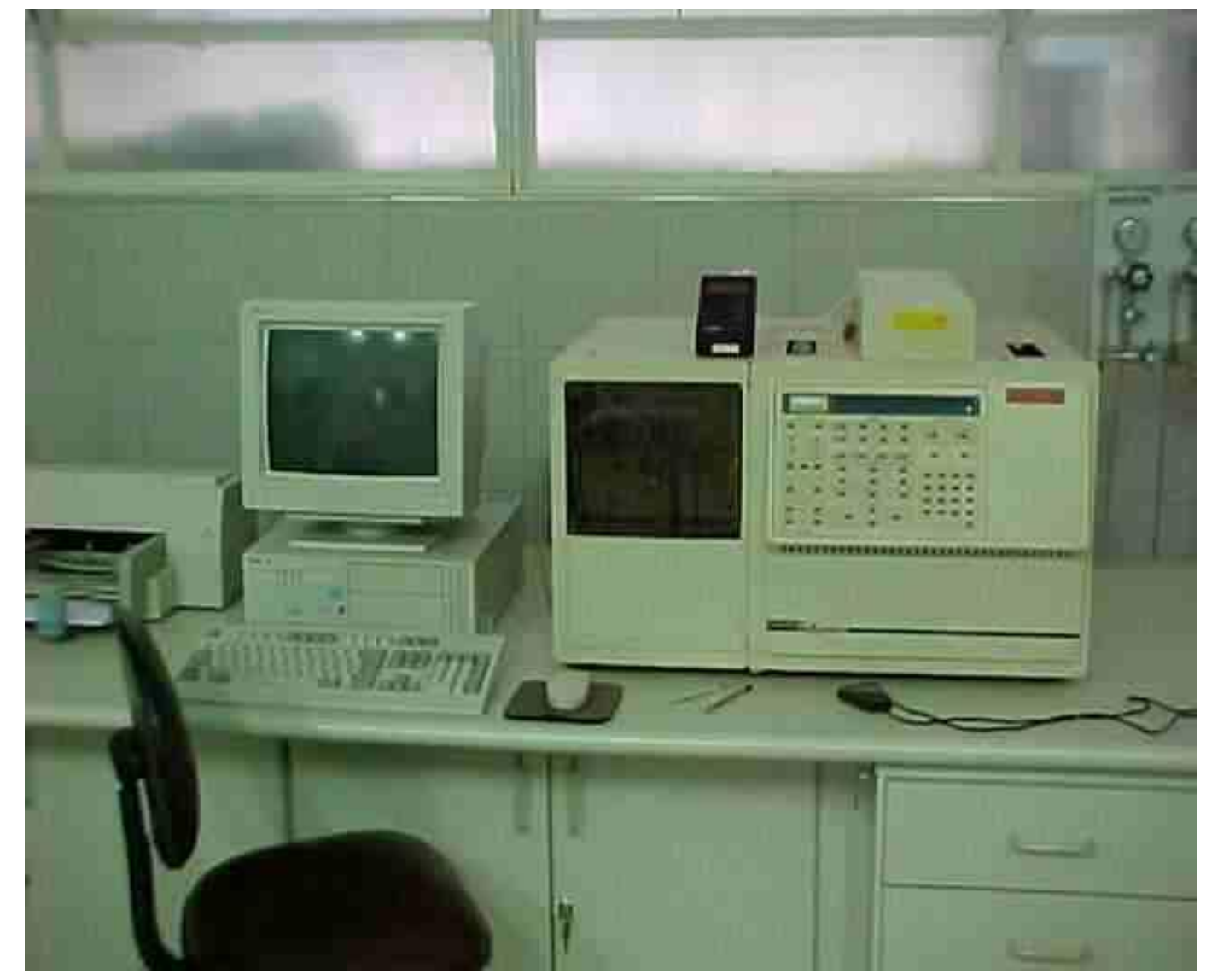

Figura 4.8- Cromatógrafo a gás com detetor de captura de elétrons, Varian, instalado na UNAERP.

As condições otimizadas para a operação do cromatógrafo foram as seguintes:

- Coluna J\&W-DB-1, 30m x 0,32mm ID e 5um filme;

- Gás de arraste nitrogênio 5.0 ECD com fluxo de $3,6 \mathrm{~mL} / \mathrm{min}, 74 \mathrm{~cm} / \mathrm{s}$ com pressão de 15 psi (1,071 atm);

- Temperatura do injetor a $160^{\circ} \mathrm{C}$ e temperatura do detetor a $290^{\circ} \mathrm{C}$;

- Temperatura inicial de $40^{\circ} \mathrm{C}$ por $1 \mathrm{~min}$, rampa de aquecimento até $125^{\circ} \mathrm{C}$ numa razão de $5^{\circ} \mathrm{C} / \mathrm{min} 2 \mathrm{~min}$, rampa de aquecimento até $150^{\circ} \mathrm{C}$ numa razão de $35^{\circ} \mathrm{C} / \mathrm{min}$ e permanece em $150^{\circ} \mathrm{C}$ por $10 \mathrm{~min}$;

- Com fluxo de divisão de amostra em $2 \mathrm{~mL} / \mathrm{min}$ e sensibilidade 10 ;

- Tempo total aproximado de 25 min para cada análise;

- Volume de extrato injetado $1 \mu \mathrm{L}$. 
Por este método foram determinados os seguintes compostos:

- Trialometanos (TAMs): clorofórmio, bromodiclorometano, dibromoclorometano, bromofórmio;

- Cloro hidrato $(\mathrm{CH})$;

- Haloacetonitrilas (HANs): dicloroacetonitrila, tricloroacetonitrila, dibromoacetonitrila, tribromoacetonitrila, bromocloroacetonitrila;

- Halopicrinas (HPs): cloropicrina;

- Haloacetonas (HKs): 1,1-dicloropropanona, 1,1,1-tricloropropanona.

O composto utilizado como padrão interno $(\mathrm{Pl})$ foi o diclorometano grau cromatográfico, marca J.T. Baker e foram utilizados os seguintes padrões para calibração:

- Padrão misto de trialometanos, marca Supelco (48140-U) para TAMs;

- Padrão puro de grau cromatográfico de bromofórmio, marca MERCK.

- Padrão misto de halogenados voláteis (EPA 551 B), marca Supelco (48046), para haloacetonitrilas, cloropicrina e haloacetonas;

- Padrão puro de cloro hidrato, marca Supelco (47335-U);

Como a concentração original dos padrões é elevada, uma diluição e mistura foi efetuada com acetona de pureza grau cromatográfica (J.T. Baker). A partir dessa diluição e mistura, foram preparadas as diluições para elaboração de uma curva analítica de calibração.

A curva analítica de calibração foi diluída em meio aquoso utilizandose balões volumétricos aferidos de $10 \mathrm{~mL}$. Á água utilizada para diluição dos padrões (meio aquoso), foi previamente purificada partindo de um volume de 5 litros de água ultrapura, obtida em um purificador Milli-Q. Para garantir a isenção de compostos voláteis, cloro e matéria orgânica a água ultrapura passou pelo seguinte procedimento:

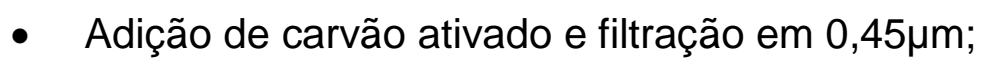

- Fervura por 10 minutos;

- Exposição à radiação UV por 1 minuto;

- Borbulhamento de nitrogênio por 5 min; 
- Resfriamento e acondicionamento em frasco de vidro escuro a $4^{\circ} \mathrm{C}$.

Em cada balão foram adicionados volumes excedentes de $10 \mu \mathrm{L}$ de padrão interno, diclorometano 1\%, inclusive em um branco, seguido de uma leve agitação. Posteriormente um volume de $4 \mathrm{~mL}$ de MTBE (a $4^{\circ} \mathrm{C}$ ) foi adicionado para extração líquído-líquido, seguido de forte agitação por 5 minutos e decantação a temperatura de $-4^{\circ} \mathrm{C}$.

Durante todo o procedimento de manipulação com padrões e solventes para diluição e preparo da curva de calibração, teve-se o cuidado de colocar gelo em uma bandeja plástica onde os reagentes e vidrarias em uso permanecerão apoiados para evitar perdas por evaporação.

Na Tabela 4.2 está apresentado um resumo da curva de calibração do método 551.1 USEPA para determinação de trialometanos, clorohidrato, haloacetonitrilas, halocetonas e cloropicrina.

Tabela 4.2 - Resumo da curva de calibração para trialometanos, haloacetonitrilas, halocetonas, clorohidrato e cloropicrina em $\mu \mathrm{g} / \mathrm{L}$.

\begin{tabular}{lcccccc}
\hline \multirow{2}{*}{ Compostos } & \multicolumn{6}{c}{ Pontos da curva de calibração } \\
\cline { 2 - 7 } & $\mathbf{1}$ & $\mathbf{2}$ & $\mathbf{3}$ & $\mathbf{4}$ & $\mathbf{5}$ & $\mathbf{6}$ \\
\hline Padrão Interno (PI) & $10 \mu \mathrm{L}$ & $10 \mu \mathrm{L}$ & $10 \mu \mathrm{L}$ & $10 \mu \mathrm{L}$ & $10 \mu \mathrm{L}$ & $10 \mu \mathrm{L}$ \\
Clorofórmio & 20 & 40 & 60 & 80 & 100 & 120 \\
Tricloroacetonitrila & 10 & 20 & 30 & 40 & 50 & 60 \\
Dicloroacetonitrila & 10 & 20 & 30 & 40 & 50 & 60 \\
Bromodiclorometano & 20 & 40 & 60 & 80 & 100 & 120 \\
Cloro hidrato & 20 & 50 & 80 & 100 & 120 & 150 \\
1,1-Dicloropropanona & 10 & 20 & 30 & 40 & 50 & 60 \\
Cloropicrina & 10 & 20 & 30 & 40 & 50 & 60 \\
Dibromoclorometano & 20 & 40 & 60 & 80 & 100 & 120 \\
1,1,1-Tricloropropanona & 10 & 20 & 30 & 40 & 50 & 60 \\
Bromocloroacetonitrila & 10 & 20 & 30 & 40 & 50 & 60 \\
Dibromoacetonitrila & 10 & 20 & 30 & 40 & 50 & 60 \\
Bromofórmio & 60 & 80 & 100 & 120 & 140 & 160 \\
\hline
\end{tabular}




\subsubsection{Extração com derivatização}

As extrações utilizadas para as determinações dos ácidos haloacéticos foram adaptadas do método USEPA 552.2; uma reação de derivatização foi necessária para transformar os ácidos em ésteres, e o procedimento foi efetuado por uma metilação ácida.

Uma alíquota de $50 \mathrm{~mL}$ foi retirada do frasco de $250 \mathrm{~mL}$ contendo a amostra desclorada e transferida para um balão volumétrico de $50 \mathrm{~mL}$, imediatamente foi adicionado um volume de $50 \mu \mathrm{L}$ de padrão Interno (2,3ácido dibrompropiônico, 10mg/L). Em seguida, a amostra foi acidificada com $1 \mathrm{~mL}$ de ácido sulfúrico concentrado e acrescentou-se $2 \mathrm{~g}$ de sulfato de cobre e $16 \mathrm{~g}$ de sulfato de sódio, o frasco foi tampado e agitado por $10 \mathrm{~min}$ em seguida, resfriado em geladeira até temperatura de $4^{\circ} \mathrm{C}$.

Como este procedimento gera uma reação exotérmica, o resfriamento é muito importante para evitar perdas dos compostos voláteis. Após completa dissolução e resfriamento da amostra, foram adicionados $5 \mathrm{~mL}$ de MTBE (gelado), manteve-se uma agitação por $10 \mathrm{~min}$ seguido de repouso para separação das fases, com auxílio de uma pipeta transferiu-se $3 \mathrm{~mL}$ da fase orgânica para um tubo de vidro com tampa rosqueável, no qual foi adicionado $1 \mathrm{~mL}$ de solução ácida de metanol 10\%. Após fechamento do frasco, o mesmo foi mantido sob aquecimento imerso em banho de água à $50^{\circ} \mathrm{C}$ por $2 \mathrm{~h}$.

Finalmente, o frasco foi resfriado e adicionaram-se $4 \mathrm{~mL}$ de solução saturada de bicarbonato de sódio em incrementos de $1 \mathrm{~mL}$.

O extrato obtido foi transferido para um frasco vial de $4 \mathrm{~mL}$ e armazenado em temperatura de $-4^{\circ} \mathrm{C}$; esse extrato tem validade analítica de 14 dias; um volume de $1 \mu \mathrm{L}$ foi injetado no cromatografo.

\subsubsection{Determinação de ácidos haloacéticos}

O método utilizado para esta determinação cromatográfica, foi baseado nas recomendações da USEPA 552.2, porém as condições de 
operação do equipamento não são idênticas e podem variar de um equipamento para outro equipamento. Devido a este fato, houve a necessidade de se adequar diversas condições que são variáveis na metodologia.

As condições cromatográficas otimizadas foram as seguintes:

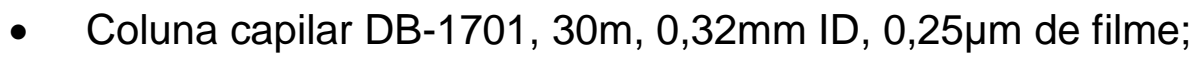

- Gás de arraste nitrogênio;

- Temperatura do injetor $250^{\circ} \mathrm{C}$, temperatura do detetor $300^{\circ} \mathrm{C}$;

- Fluxo de $1,4 \mathrm{~mL} / \mathrm{min}$, velocidade de $29 \mathrm{~cm} / \mathrm{s}$ em 6 psi (0,428 atm);

- Sem divisão de amostras, sensibilidade 10;

- Temperatura isoterma de $40^{\circ} \mathrm{C}$ por $3 \mathrm{~min}$, aquecimento a $130^{\circ} \mathrm{C}$ numa razão de $4^{\circ} \mathrm{C} / \mathrm{min}$ durante $5 \mathrm{~min}$, aquecimento a $180^{\circ} \mathrm{C}$ numa razão de $20^{\circ} \mathrm{C} /$ min durante $3 \mathrm{~min}$;

- Tempo total aproximado de corrida analítica 36,10 min.

Para elaboração da curva de calibração foi utilizada uma mistura de padrões da marca Supelco (4-7787), originalmente dissolvida em meio MTBE, com os seguintes compostos de ácidos haloacéticos (AHAs): ácido monocloroacético, ácido dicloroacético, ácido tricloroacético, ácido monobromoacético, ácido dibromoacético, ácido tribromoacético, ácido bromocloroacético, ácido bromodicloroacético, ácido dibromocloracético.

A concentração original de cada composto da mistura padrão e a variação de concentração obtida esta apresentada na Tabela 4.4

As soluções com concentrações variadas foram obtidas a partir de diluição da mistura original em meio MTBE. A seguir, seis balões volumétricos e aferidos foram utilizados para elaboração de 5 pontos de diferentes concentrações e 1 branco de calibração. A curva analítica foi diluída em meio aquoso com água isenta de compostos orgânicos voláteis, e cada ponto da curva foi derivatizado por metilação ácida conforme descrito no item 4.3.3.

Na Tabela 4.3 está apresentado um resumo da curva analítica 552 de calibração. 
Tabela 4.3- Resumo da curva analítica de calibração para ácidos haloacéticos.

\begin{tabular}{cccccccc}
\hline Compostos & $\begin{array}{c}\text { Conc. } \\
\text { original } \\
(\mathbf{m g} / \mathbf{L})\end{array}$ & \multicolumn{6}{c}{ Curva de Calibração $(\boldsymbol{\mu g} / \mathbf{L})$} \\
& & & & & & \\
& & & & & & & \\
& & & & & & & \\
\hline MCAA & 600 & 6 & 9 & 12 & 15 & 24 & 30 \\
MBAA & 400 & 4 & 6 & 8 & 10 & 16 & 20 \\
DCAA & 600 & 6 & 9 & 12 & 15 & 24 & 30 \\
TCAA & 200 & 2 & 3 & 4 & 5 & 8 & 10 \\
BCAA & 400 & 4 & 6 & 8 & 10 & 16 & 20 \\
BDCAA & 400 & 4 & 6 & 8 & 10 & 16 & 20 \\
DBAA & 200 & 2 & 3 & 4 & 5 & 8 & 10 \\
CDBAA & 1000 & 10 & 15 & 20 & 25 & 40 & 50 \\
TBAA & 2000 & 20 & 30 & 40 & 50 & 80 & 100 \\
PI & 10 & $50 \mu \mathrm{L}$ & $50 \mu \mathrm{L}$ & $50 \mu \mathrm{L}$ & $50 \mu \mathrm{L}$ & $50 \mu \mathrm{L}$ & $50 \mu \mathrm{L}$ \\
\hline
\end{tabular}

\subsection{Ensaios para definição de cor, temperatura e dosagem de cloro para determinação do potencial de formação de subprodutos.}

Os principais parâmetros que influem na formação de subprodutos são a concentração de substâncias húmicas, a temperatura e a dosagem de oxidante. Esses parâmetros foram fixados a partir de resultados preliminares obtidos por ensaios específicos.

Nesse estudo, a cor aparente foi o parâmetro de referência para avaliação da concentração de substâncias húmicas na água de estudo, cujo valor foi definido em um ensaio com 4 tipos de água preparadas com cor aparente de 100, 200, 300 e 400uH. Foram adicionados 10, 20 e 30mg/L de cloro (ácido tricloro isocianúrico, $90 \%$ ), em cada litro de amostra e foram incubadas por $24 \mathrm{~h}$ à temperatura de $20^{\circ} \mathrm{C}$. Em seguida, adicionou-se nas amostras um agente desclorante (ácido ascórbico) e efetuou-se a extração para determinação de TAMs por CG-ECD.

A temperatura de incubação foi definida após resultados obtidos de um ensaio realizado em uma água contendo substância húmica com cor aparente $100 \mathrm{uH}$, dosagem de $10 \mathrm{mg} / \mathrm{L}$ de cloro e incubação à temperatura de 20,25 e $30^{\circ} \mathrm{C}$. Foram coletadas alíquotas em tempos de contato de 2, 4, 12 
e $24 \mathrm{~h}$ e em seguida, foram realizadas as extrações e determinações de TAMs por CG-DCE.

Outro parâmetro previamente definido foi a dosagem de cloro aplicada na água de estudo. A dosagem deve fornecer um residual livre superior a 3,5 $\mathrm{mg} / \mathrm{L} \mathrm{Cl}_{2}$, após 7 dias de contato na temperatura de $25^{\circ} \mathrm{C}$ em $\mathrm{pH}$ do meio igual a 7,0, corrigido com adição de tampão de fosfato. Esse procedimento é recomendado pela APHA et al. (1998) para a determinação do potencial de formação de TAMs em presença de excesso de cloro em água bruta. Para determinação da dosagem de cloro excessiva, 4 litros de amostra de água de estudo foram divididas em 4 frascos de 1 litro, dosaram-se diferentes concentrações de cloro (hipoclorito de cálcio), de: 12,5, 15, 17 e 20 mg/L Cl$~_{2}$. Depois de 7 dias à temperatura de $25^{\circ} \mathrm{C}$ em $\mathrm{pH} 7,0$, foram determinados os residuais livres de cloro.

\subsection{Demanda de pré-oxidantes}

As dosagens dos pré-oxidantes (cloro, permanganato de potássio, dióxido de cloro e peróxido de hidrogênio) aplicadas na água de estudo foram determinadas em função dos resultados obtidos em ensaios de demanda de pré-oxidante em função do tempo de contato. As dosagens de ozônio e peroxônio foram determinadas em função da capacidade de geração de ozônio do sistema piloto instalado na UNAERP. Na Figura 4.9 é apresentado um fluxograma do sistema.

Os ensaios de demanda dos pré-oxidantes foram realizados em bancada com regime hidráulico descontinuo (batelada) por meio de reatores estáticos (jarteste), que é constituído de 6 jarros (recipientes) e fornece gradiente de velocidade entre 10 e $2.000 \mathrm{~s}^{-1}$, um espectrofotômetro visível DR 2000, cronômetro digital, potenciômetro digital para leitura de $\mathrm{pH}$, cubetas, pipetas e béqueres. O volume de amostra submetido a cada dosagem foi de 2 litros e o sistema permaneceu sob agitação branda em temperatura ambiente controlada à temperatura de $25^{\circ} \mathrm{C} \pm 1$. 
O procedimento foi realizado, segundo recomendações de Di BERNARDO et al. (2002), na seguinte seqüência:

- Colocar as porções de água em estudo (Cor $200 \mathrm{uH}$ ) em cada um dos seis jarros, enchendo-os simultaneamente de modo a assegurar a homogeneidade da água contida em cada jarro, até a obtenção de 2 litros;

- A agitação foi acionada e mantida em torno de $100 \mathrm{~s}^{-1}$ (90 rpm) e a temperatura ambiente do laboratório controlada por um aparelho de ar condicionado a $25^{\circ} \mathrm{C} \pm 1$;

- Em cada jarro foi adicionado um volume de solução de pré-oxidante para obtenção de dosagens variáveis e crescentes;

- Nos intervalos de tempo de contato de 15, 30, 60, 90 e 120 minutos, foram retiradas alíquotas para determinação do residual do oxidante aplicado.

Com a obtenção do teor residual de pré-oxidante empregado em função do tempo de contato foram determinadas as demandas de préoxidantes através da diferença entre a dosagem e o residual obtido.

O sistema piloto utilizado para geração de ozônio consiste em uma coluna de $1,5 \mathrm{~m}$ de altura e $11 \mathrm{~cm}$ de diâmetro, com aproximadamente 12 litros de capacidade, conforme esquema mostrado na Figura 4.9.

off-gas

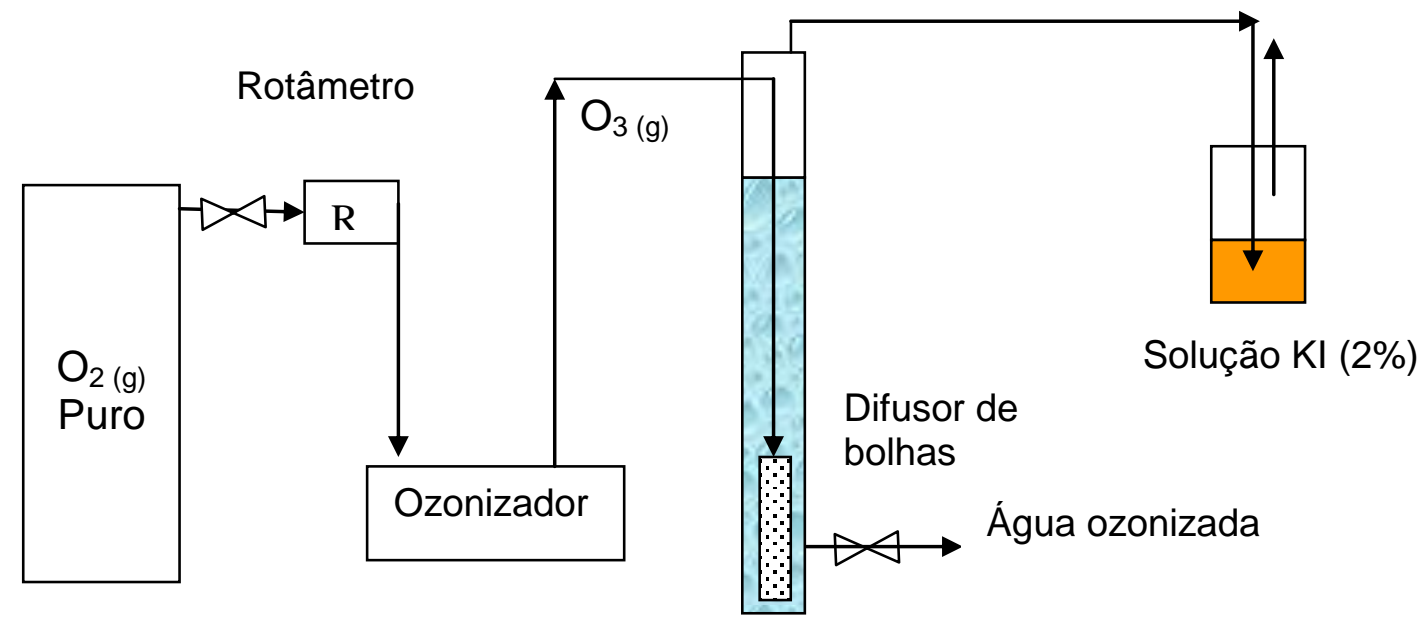

Figura 4.9 - Fluxograma do sistema piloto para geração de ozônio. 


\subsubsection{Ensaios de demanda da pré-oxidação com cloro}

A solução de cloro utilizada para realização do ensaio de préoxidação de água com SHs foi preparada utilizando-se o produto comercial hipoclorito de cálcio (70\%) granulado, em concentração de $1 \mathrm{~g} / \mathrm{L}$. O teor de cloro ativo do produto comercial utilizado foi confirmado através do método analítico titrimétrico com iodeto de potássio e tiossulfato de sódio.

A partir da solução recém-preparada foram calculados volumes que aplicados fornecessem dosagens que variaram de 2 a $25 \mathrm{mg} / \mathrm{L}$ de cloro.

O método utilizado para determinação de cloro residual livre foi colorimétrico com leituras em espectrofotômetro visível da marca $\mathrm{HACH}$, modelo DR 2000, programa n80 com uma curva de calibração de DPD variando de 0,1 a 2,2 $\mathrm{mg} / \mathrm{L} \mathrm{Cl} \mathrm{Cl}_{2}$ de concentração, em comprimento de onda de $530 \mathrm{~nm}$ em cubeta de $1 \mathrm{~cm}$.

Com os resultados obtidos de residual foram calculadas as demandas através da diferença entre dosagem aplicada e o residual em função do tempo de contato.

O critério utilizado para determinação da demanda de cloro necessária para completa oxidação de toda matéria orgânica presente na forma de extrato de $\mathrm{SH}$ da água em estudo foi o valor de dosagem que fornecesse uma demanda superior a aproximadamente duas vezes 0 residual. Este procedimento é recomendado para determinação de potencial de formação de subprodutos descrito pelo método 2350 B (APHA et al., 1998).

\subsubsection{Ensaios de demanda da pré-oxidação com dióxido de cloro}

Segundo USEPA (1999), a dosagem de dióxido de cloro não deve ultrapassar $1,4 \mathrm{mg} / \mathrm{L} \mathrm{ClO}_{2}$ e o residual não deve ser superior a 0,5 mg/L $\mathrm{ClO}_{2}$. Esses valores de dosagem foram recomendados para evitar a formação de subprodutos inorgânicos indesejáveis, como clorito e clorato. Porém, o ensaio de demanda teve como objetivo a avaliação da ação do 
pré-oxidante e verificação da permanência de residual livre. Os ensaios de demanda de pré-oxidação com dióxido de cloro foram realizados pelo método 2350D da APHA et al.,(1998).

A solução de dióxido de cloro foi gerada em um equipamento instalado na Escola de Engenharia de São Carlos - Universidade de São Paulo (EESC-USP), mostrado na Figura 4.10, o qual produz uma solução de dióxido de cloro a partir de uma solução diluída de ácido clorídrico e clorito de sódio. A concentração de $\mathrm{ClO}_{2}$ obtida na solução foi de $95,8 \mathrm{mg} / \mathrm{L} \mathrm{Cl}_{2}$ ou $182 \mathrm{mg} / \mathrm{L} \mathrm{ClO}_{2}$.

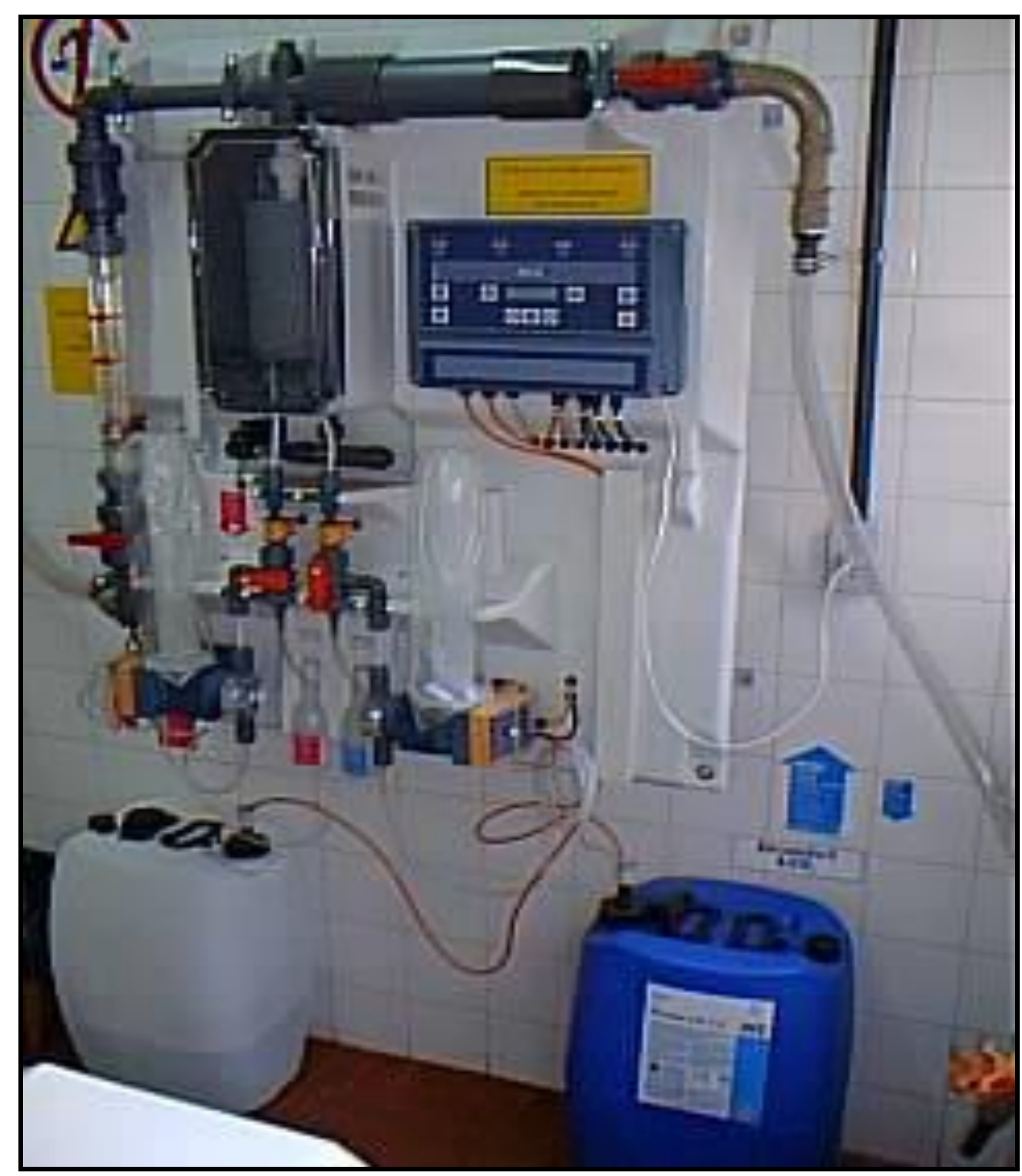

Figura 4.10 - Sistema de geração de dióxido de cloro instalado EESC-USP. 
As leituras de concentração e residual de dióxido de cloro foram efetuadas por método colorimétrico com adição de DPD em $530 \mathrm{~nm}$ num equipamento espectrofotômetro modelo DR 2000, HACH. Os valores obtidos em concentração de cloro livre foram multiplicados por 1,9 (correção estequiométrica) para obtenção de concentração residual em dióxido de cloro $\left(\mathrm{mg} / \mathrm{L} \mathrm{ClO}_{2}\right)$. Devido à falta de equipamento especifico, não foram possíveis as determinações das concentrações de clorito e clorato após dosagem de dióxido de cloro.

Foi utilizado como "branco" a própria água de estudo para eliminação da interferência de absorbância em função da cor existente na água de estudo.

\subsubsection{Ensaio de demanda de pré-oxidação com permanganato de potássio}

As dosagens foram efetuadas a partir de uma solução preparada com uma massa de permanganato de potássio, $\mathrm{KMnO}_{4}$, dissolvida em água deionizada e fervida, $1000 \mathrm{~g} / \mathrm{L}$. A seguir, foi preparada a solução de $10 \mathrm{mg} / \mathrm{L}$.

As leituras de residual de permanganato foram efetuadas em um espectrofotômetro DR 2000, $\mathrm{HACH}$, em comprimento de onda de $530 \mathrm{~nm}$, através de uma curva analítica de calibração com leituras de absorbância em função de diferentes concentrações de solução de permanganato de potássio em meio ácido sulfúrico $(\mathrm{pH}<2)$. Utilizou-se a água de estudo com cor como branco para eliminação da interferência nas leituras de absorbância. Na Tabela 4.4 e na Figura 4.11 têm-se as concentrações, leituras de absorbância e a curva de calibração obtida para determinação do residual de $\mathrm{KMnO}_{4}$ respectivamente.

Os procedimentos utilizados nos ensaios foram idênticos aos demais, porém, a alíquota retirada para leitura de residual foi acidificada com ácido sulfúrico $6 \mathrm{~N}$ até $\mathrm{pH}<2$. As dosagens de permanganato de potássio utilizadas nos ensaios variaram de 1,0 a $12 \mathrm{mg} \mathrm{KMnO}_{4} / \mathrm{L}$, com tempos de contato de: $10,20,30,60,90$ e 120 minutos. 
As leituras obtidas de residual de permanganato após á pré-oxidação foram duvidosas. Como ocorreu a oxidação da matéria orgânica, a água de estudo perdeu a coloração amarelada inicial e passou a apresentar uma coloração rósea. Este fato causou uma interferência nas leituras de absorbância.

Portanto, o critério adotado para determinação da dosagem de permanganato foi à obtenção do primeiro tom róseo persistente.

Tabela 4.4 - Curva de calibração de $\mathrm{KMnO}_{4}$ instalada no espectrofotômetro DR 2000-HACH.

\begin{tabular}{ccc}
\hline $\begin{array}{c}\text { Volume de solução } \\
10 \mathrm{mg} / \mathrm{L} \text { de } \mathrm{KMnO}_{4} \text { em 100mL }\end{array}$ & $\begin{array}{c}\text { Concentração } \\
\mathrm{mg} / \mathrm{LMnO}_{4}\end{array}$ & $\begin{array}{c}\text { Absorbância } \lambda: 530 \mathrm{~nm} \\
\left(\mathrm{~cm}^{-1}\right)\end{array}$ \\
\hline 10 & 1,0 & 0,006 \\
15 & 1,5 & 0,019 \\
20 & 2,0 & 0,035 \\
25 & 2,5 & 0,050 \\
30 & 3,0 & 0,067 \\
35 & 3,5 & 0,083 \\
\hline
\end{tabular}

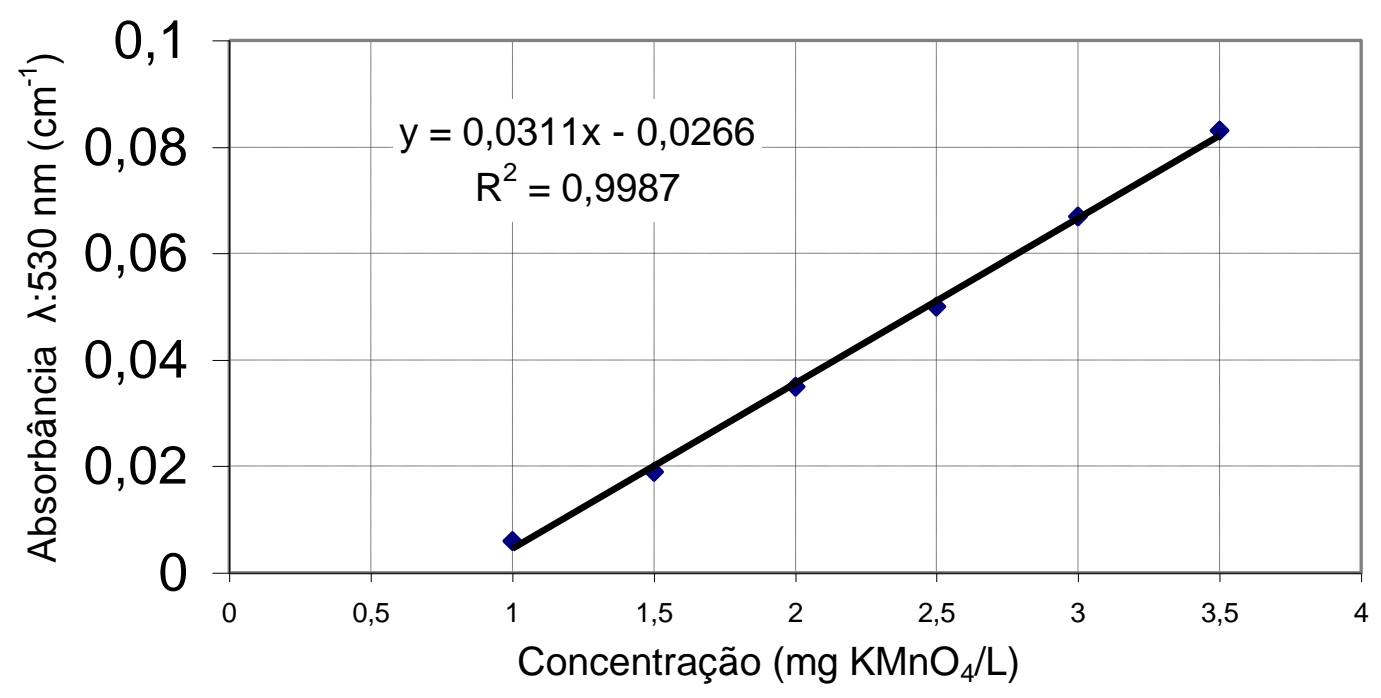

Figura 4.11 - Curva de calibração para determinação de residual de permanganato de potássio com absorbância em função da concentração, equação da reta e coeficiente de correlação obtido por regressão linear. 


\subsubsection{Ensaios de demanda de pré-oxidante com peróxido de hidrogênio}

Foi utilizada uma solução comercial pura com $35 \% \mathrm{v} / \mathrm{v}$ de concentração, marca Clamarim 503 da Degussa-Hüls. A confirmação da concentração foi determinada pelo método recomendado por MASSCHELEN (1977), que consiste na adição de $5 \mathrm{~mL}$ de $\mathrm{H}_{2} \mathrm{SO}_{4} 20 \%$ em $10 \mathrm{~mL}$ da solução de $\mathrm{H}_{2} \mathrm{O}_{2}$ e titulometria com $\mathrm{KMnO}_{4}(0,1 \mathrm{~N})$ até obtenção de uma coloração rosa. $O$ cálculo foi feito utilizando-se a equação (4.1):

$\mathrm{mg} / \mathrm{L} \mathrm{H}_{2} \mathrm{O}_{2}=\left(\mathrm{mL}\right.$ gastos de $\left.\mathrm{KMnO}_{4} 0,1 \mathrm{~N}\right){ }^{*} 170,1$ ou

$\% \mathrm{H}_{2} \mathrm{O}_{2}=\left(\mathrm{mL}\right.$ gastos de $\left.\mathrm{KMnO}_{4} 0,1 \mathrm{~N}\right){ }^{*} 0,017$

As medidas de residual de peróxido de hidrogênio foram realizadas pelo método espectrofotométrico UV $(\lambda=260 \mathrm{~nm})$ com cobalto e bicarbonato para a faixa de leitura de 0,02 a $0,2 \mathrm{mg} / \mathrm{L}$. A curva analítica de calibração foi preparada por uma solução de 10.000 mg/L obtida a partir da solução comercial.

O método consiste na adição sucessiva de $1 \mathrm{~mL}$ de solução de hexametafosfato e $1 \mathrm{~mL}$ de solução de cobalto em $80 \mathrm{~mL}$ de amostra em balão volumétrico de $100 \mathrm{~mL}$. Completava-se o volume com solução de bicarbonato de sódio saturada para realizar as leituras do residual de $\mathrm{H}_{2} \mathrm{O}_{2}$ das amostras.

\subsubsection{Ensaios de demanda da pré-oxidação com ozônio}

Os ensaios de pré-oxidação com ozônio e peroxônio foram realizados em um sistema piloto instalado no laboratório da UNAERP. O sistema foi constituído de um cilindro de oxigênio puro, um aparelho gerador de ozônio, uma coluna de acrílico, cilíndrica medindo $1,5 \mathrm{~m}$ de altura e $11 \mathrm{~cm}$ de 
diâmetro, um rotâmetro para controle de vazão de gás, uma pedra porosa para difusão das bolhas, mangueiras, pinças e um erlenmeyer com tampa perfurada para adsorção de ozônio não dissolvido off gas. A Figura 4.12 mostra o cilindro, o aparelho gerador de ozônio e a coluna.

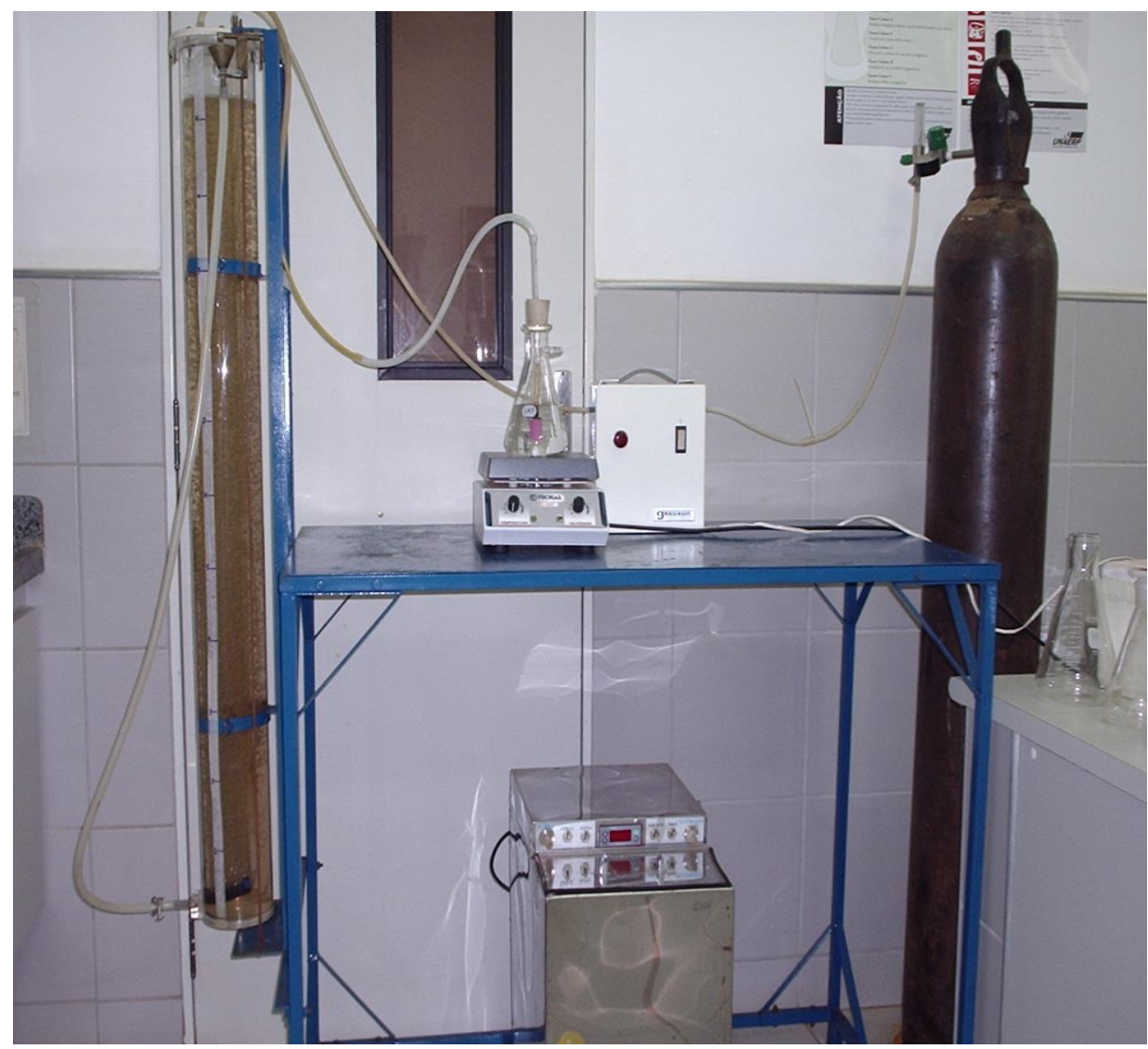

Figura 4.12 - Cilindro de oxigênio e aparelho utilizado para geração de ozônio.

\subsubsection{Determinação da produção de ozônio}

A capacidade de produção (geração) de ozônio na câmara de contato foi determinada pela seguinte metodologia:

- Um volume de 11 litros de água de poço (sem SHs) foi introduzido na coluna;

- Adicionou-se uma massa de iodeto de potássio para resultar concentração de $2 \%$;

- A alimentação de oxigênio foi mantida com uma vazão de $2 \mathrm{~mL} / \mathrm{min}$ e o ozônio gerado foi conduzido e dissolvido na massa líquida de água da 
coluna por meio de uma mangueira com uma pedra porosa na extremidade da coluna;

- O excesso de gás de ozônio, denominado off gas, produzido e não dissolvido na câmara de contato foi adsorvido em um recipiente (erlenmeyer de $800 \mathrm{~mL}$ ) contendo um volume de $400 \mathrm{~mL}$ de uma solução de $\mathrm{KI} 2 \%$;

- Após a estabilidade do fluxo de oxigênio, foi ligado o aparelho para dar início à geração e introdução do ozônio na coluna e depois de um tempo de contato, interrompeu-se a geração de ozônio e imediatamente retirou-se o frasco do off gas e coletaram-se 3 alíquotas de $200 \mathrm{~mL}$ da fase líquida para determinação da concentração residual de ozônio. Esse procedimento foi repetido para os seguintes tempos de contato: 5, 10, 15, 20, 25 e 30 min.

As concentrações de residual de ozônio na fase líquida e na fase gasosa (off gas), foram determinadas por titrimetria pelo método iodométrico (APHA et al., 1998), diferenciando-se apenas nos volumes de amostra empregados na titulação.

As alíquotas coletadas foram fixadas com adição de $20 \mathrm{~mL}$ de solução de $\mathrm{H}_{2} \mathrm{SO}_{4}(1 \mathrm{~N})$ e protegendo-a contra a incidência de luz ambiente.

Depois, as alíquotas foram tituladas com uma solução de tiossulfato de sódio $(0,025 \mathrm{~N})$ até a mesma adquirir uma coloração amarelo palha. Em seguida, foram adicionados 5 gotas de indicador de amido, tornando o meio com uma coloração azulada e a titulação foi completada até a amostra tornar-se incolor. O volume de solução de tiossulfato de sódio foi anotado.

Para o cálculo da produção de ozônio em $\mathrm{g} / \mathrm{h}$, foram consideradas a soma da quantidade de ozônio dissolvido na fase líquida e a quantidade de ozônio adsorvida na fase gasosa (off gas) em função do tempo de contato, conforme a equação (4.2):

$\mathrm{P}_{\mathrm{T}}=\mathrm{P}_{\mathrm{L}}+\mathrm{P}_{\mathrm{G}}$

onde:

$\mathrm{P}_{\mathrm{T}}$ : Produção total de ozônio $\left(\mathrm{gO}_{3} / \mathrm{h}\right)$

$\mathrm{P}_{\mathrm{L}}$ : Produção de ozônio na fase líquida $\left(\mathrm{g} \mathrm{O}_{3} / \mathrm{h}\right)$

$P_{G}$ : Produção de ozônio adsorvido na fase gasosa off gas $\left(\mathrm{g} \mathrm{O}_{3} / \mathrm{h}\right)$ 
A produção de ozônio na fase liquida foi calculada pela seguinte equação (4.3):

$\mathrm{P}_{\mathrm{L}}=\left(\mathrm{D}_{\mathrm{L}} \cdot \mathrm{V}_{\mathrm{c}} \cdot / \mathrm{T}_{\mathrm{C}}\right)^{*} 0,06$

onde:

$\mathrm{D}_{\mathrm{L}}$ : dosagem de ozônio na fase líquida $\left(\mathrm{mg} \mathrm{O}_{3} / \mathrm{L}\right)$

Vc: volume de liquido introduzido na câmara de contato (11L)

Tc: tempo de contato ( $\mathrm{min}$ )

A dosagem ou concentração de ozônio dissolvida na fase líquida, foi calculada pela seguinte equação (4.4):

$D_{L}=V g$. N. $f .24000 / \mathrm{Va}$

onde:

Vg: volume gasto de tiossulfato de sódio na titulação $(\mathrm{mL})$

$\mathrm{N}$ : normalidade do tiossulfato de sódio $(0,025 \mathrm{~N})$

Va: volume da alíquota de amostra retirada para titulação $(200 \mathrm{~mL})$

A produção de ozônio da fase gasosa (off gas) foi calculada pela equação (4.5):

$P_{G}=\left(D_{G} \cdot V_{G} \cdot / T_{c}\right)^{*} 0,06$

onde:

$\mathrm{D}_{\mathrm{G}}$ : Dosagem de ozônio na fase gasosa ( $\mathrm{mg} \mathrm{O}_{3} / \mathrm{L}$ )

$V_{G}$ : volume da solução de $\mathrm{Kl} 2 \%$ no off gas $(400 \mathrm{~mL})$

O cálculo da concentração de ozônio na fase gasosa (off gas) foi obtido pela equação (4.6):

$D_{G}=V g \cdot N . f .24000 / V a$

onde:

Vg: volume gasto de tiossulfato de sódio $(\mathrm{mL})$

$\mathrm{N}$ : normalidade do tiossulfato de sódio $(0,025 \mathrm{~N})$

Va: Volume de alíquota de amostra retirada para titulação $(400 \mathrm{~mL})$ 


\subsubsection{Ensaios de demanda com ozônio}

Após terem sido realizados os ensaios que permitiram o cálculo para a determinação da capacidade de geração de ozônio, foram realizados os ensaios de demanda utilizando-se um volume de $11 \mathrm{~L}$ de água de estudo introduzidos na coluna de ozonização.

Os ensaios de demanda foram realizados para diferentes tempos de contato de aplicação de ozônio, sendo: 5, 10, 15, 20, 25, 30 e 40 min.

Para cada tempo de contato foram determinadas as concentrações de residual de ozônio na fase líquida e na fase gasosa (off gas).

Para a determinação da demanda de ozônio, foi necessário o cálculo da produção consumida considerando-se a capacidade de produção de ozônio subtraída do residual obtido na fase líquida e do residual da fase gasosa (off gas), conforme a equação (4.7):

$P_{C}=P_{T}-P_{L}-P_{G}$

onde:

$\mathrm{P}_{\mathrm{C}}$ : produção consumida $\left(\mathrm{g} \mathrm{O}_{3} / \mathrm{h}\right)$

$\mathrm{P}_{\mathrm{T}}$ : produção total aplicada $\left(\mathrm{g} \mathrm{O}_{3} / \mathrm{h}\right)$

$\mathrm{P}_{\mathrm{L}}$ : produção na fase líquida $\left(\mathrm{g} \mathrm{O}_{3} / \mathrm{h}\right)$

$\mathrm{P}_{\mathrm{G}}$ : produção na fase gasosa $\left(\mathrm{g} \mathrm{O}_{3} / \mathrm{h}\right)$

A produção de ozônio na fase líquida foi calculada pela equação (4.3) e a produção na fase gasosa pela equação (4.5). Para a determinação das concentrações nas fases líquida e gasosa, foram recolhidas alíquotas de $200 \mathrm{~mL}$ e $400 \mathrm{~mL}$ respectivamente. As concentrações foram calculadas utilizando-se as equações (4.4) e (4.6).

A demanda de ozônio foi calculada a partir da seguinte equação (4.8):

$\mathrm{DO}_{3}=\mathrm{PC}_{\mathrm{C}} \cdot \mathrm{Tc} \cdot 1000 / \mathrm{Vc}{ }^{*} 60$

onde: 
$\mathrm{DO}_{3}$ : demanda consumida de ozônio $\left(\mathrm{mg} \mathrm{O}_{3} / \mathrm{L}\right)$

$\mathrm{P}_{\mathrm{C}}$ : Produção consumida $\left(\mathrm{g} \mathrm{O}_{3} / \mathrm{h}\right)$

Tc: tempo de contato ( $\mathrm{min}$ )

Vc: volume útil da câmara de contato (11L)

\subsubsection{Ensaios de demanda de pré-oxidante com peroxônio}

A demanda de peróxido de hidrogênio combinado com ozônio foi definida pelos resultados obtidos em ensaios realizados com uso de diferentes proporções de peróxido de hidrogênio e ozônio.

Considerando que o peróxido de hidrogênio reage com o ozônio conforme a seguinte reação química (4.9):

$$
1 \mathrm{H}_{2} \mathrm{O}_{2}+2 \mathrm{O}_{3} \rightarrow 2 \mathrm{OH}+3 \mathrm{O}_{2}
$$

Pela relação estequiométrica da reação, tem-se a seguinte relação de proporcionalidade:

$$
\frac{\mathrm{C} \mathrm{H} \underline{H}_{2} \underline{O}_{2}}{1}=\frac{\mathrm{C}_{\underline{O}}}{2}
$$

$2 \mathrm{H}_{2} \mathrm{O}_{2}=\mathrm{C} \mathrm{O}_{3}$ ou $\quad \mathrm{CH}_{2} \mathrm{O}_{2}=0,5 \cdot \mathrm{C} \mathrm{O}_{3}$

A proporção de aplicação de peróxido de hidrogênio/ozônio deve ser estudada para cada água de estudo. Foram efetuados os ensaios variandose as proporções de $\mathrm{H}_{2} \mathrm{O}_{2} / \mathrm{O}_{3}$, sendo utilizados $0,5,1,0$ e 2,0. A obtenção do menor valor de cor remanescente foi o parâmetro utilizado para a escolha da proporção $\mathrm{H}_{2} \mathrm{O}_{2} / \mathrm{O}_{3}$ adotada.

Foi utilizada uma solução de peróxido de hidrogênio $(30 \% \mathrm{v} / \mathrm{v})$ para a preparação de uma solução de concentração $1 \%$ v/v. Com base nos valores obtidos, foram calculados os volumes de solução de peróxido de hidrogênio a $1 \% \mathrm{v} / \mathrm{v}$, a serem adicionados para obtenção das proporções desejadas. 


\subsection{Ensaios para determinação da dosagem de coagulante}

Após terem sido determinadas as dosagens a serem aplicadas na etapa de pré-oxidação, foram necessárias à realização de ensaios de jarteste para determinação da dosagem de coagulante a ser empregada. Estes ensaios foram realizados separadamente para cada pré-oxidante em estudo sendo: cloro, dióxido de cloro, permanganato de potássio, peróxido de hidrogênio, ozônio e peroxônio.

Para obtenção de reprodutibidade dos resultados nos ensaios com os diversos coagulantes, algumas condições foram fixadas. A Tabela 4.5 apresenta essas condições.

Devido a sua larga aplicação em estações de tratamento de água no Brasil, o coagulante escolhido foi o sulfato de alumínio Uma solução de $5.000 \mathrm{mg} / \mathrm{L}$ foi preparada a partir de uma solução comercial com massa específica de 1,330 $\mathrm{g} / \mathrm{L}$ e $675,6 \mathrm{~g} / \mathrm{L}$.

Quando necessário, o pH de coagulação foi corrigido com auxílio de uma solução de ácido clorídrico $(0,01 \mathrm{~N})$.

Os procedimentos utilizados para a realização dos ensaios de jarteste foram os seguintes:

- Preencher os 6 jarros com a água de estudo de cor $200 u H$ de forma alternada até completar 2 litros;

- Acionar a agitação e controlar em $100 \mathrm{~s}^{-1}$;

- Adicionar simultaneamente a dosagem idêntica de pré-oxidante que foi determinada anteriormente;

- Aguardar exatamente $30 \mathrm{~min}$;

- Medir o pH e se necessário adicionar alíquota de $\mathrm{HCl}$ 0,1N para manter o pH da solução em 6,0;

- Alterar a agitação de 100 para a agitação em $1000 \mathrm{~s}^{-1}$;

- Adicionar volumes crescentes de solução coagulante de sulfato de alumínio;

- Aguardar exatamente $1 \mathrm{~min}$;

- Filtrar em filtro de papel Whatman 40. 
Com o filtrado obtido, foram efetuadas leituras de $\mathrm{pH}$ e de cor remanescente em espectrofotômetro através de uma curva de calibração de absorbância em função da concentração de cor $(\mathrm{uH})$. O parâmetro utilizado para determinação da dosagem ótima foi o ensaio que fornecesse uma cor remanescente menor que $5 \mathrm{uH}$.

Tabela 4.5 - Resumo das condições estabelecidas para os ensaios de determinação de dosagem de coagulante.

\begin{tabular}{lc}
\hline Parâmetros & Condições \\
\hline Água de estudo & $2 \mathrm{~L}$ \\
Temperatura ambiente & $25^{\circ} \mathrm{C}$ \\
$\mathrm{pH}$ & 7,60 \\
Pré-oxidação: & $30 \mathrm{~min}$ \\
Tempo de contato & Resultados dos ensaios de \\
Dosagem & $\begin{array}{c}\text { demanda } \\
\text { pré-oxidação }\end{array}$ \\
& $100 \mathrm{~s}^{-1}$ \\
Gradiente de velocidade de mistura & 5,5 \\
Coagulação: & 1 min $^{-1}$ \\
pH & $1000 \mathrm{~s}^{-1}$ \\
Tempo de contato & \\
Gradiente de velocidade de mistura & Whatman 40 \\
rápida & \\
Filtração: & Filtro de papel
\end{tabular}

\subsection{Pós-cloração}

A etapa de pós-cloração foi efetuada sob condições idênticas para todos os pré-oxidantes em estudo.

O cloro é um oxidante que reconhecidamente causa a formação de subprodutos; assim, neste trabalho, os ensaios com o cloro foram importantes para se comparar os oxidantes alternativos em estudo. Logo, o estabelecimento de uma condição favorável à formação dos subprodutos em presença de cloro foi imposta para os outros oxidantes.

Ao longo deste trabalho foi observado que a formação dos subprodutos pode variar com o tipo de cloro aplicado. 
Inicialmente foi utilizado o produto ácido tricloro isocianúrico, comercialmente conhecido como "cloro orgânico ou tricloro", comercializado em pastilhas para uso em piscinas, com teor de cloro ativo de $90 \%$. Os resultados obtidos sobre a formação de trialometanos foram relativamente baixos e sua aplicação aumenta o teor de carbono orgânico total.

Efetuaram-se também alguns ensaios de oxidação seguidos de análises de TAMs com o uso de hipoclorito de cálcio e com hipoclorito de sódio. As maiores concentrações de TAMs e a persistência de residual foi o critério adotado para escolha do tipo de oxidante.

A solução de hipoclorito de cálcio utilizada foi preparada com uma concentração de aproximadamente $700 \mathrm{mg} / \mathrm{L}$.

A dosagem aplicada nesta etapa foi definida em $5 \mathrm{mg} / \mathrm{L}$; usualmente esta dosagem, aplicada em água filtrada, pode ser elevada, porém, devido ao objetivo principal desse trabalho ter sido o de avaliar o efeito da préoxidação, coagulação, filtração e pós-cloração no potencial de formação de subprodutos orgânicos halogenados, uma dosagem pouco superior à estabelecida.

Uma condição importante para esta avaliação é a presença de residual de cloro livre após o período de contato de 24h. Portanto, a dosagem em excesso foi importante para propiciar a formação dos subprodutos identificados na etapa posterior e os ensaios com os préoxidantes alternativos, submetidos às mesmas condições de pós-cloração deverão ter ou não a redução da formação de subprodutos.

\subsection{Potencial de formação de subprodutos orgânicos halogenados}

Os ensaios para a determinação do potencial de formação de subprodutos orgânicos halogenados (PF) da oxidação de água com presença de substâncias húmicas extraídas de solo turfoso constitui a etapa determinante do trabalho. Os ensaios experimentais foram efetuados segundo adaptação da metodologia 5710 A e B (APHA et al., 1998). A Tabela 4.6 apresenta um resumo das condições do ensaio. 
Considerando que os principais fatores que influenciam na formação dos subprodutos são tipo de oxidante, temperatura, concentração de matéria orgânica, $\mathrm{pH}$ e tempo de contato, alguns ensaios preliminares foram necessários e foram descritos no item 4.4. Os resultados desses ensaios estabeleceram as condições de cor aparente da água de estudo, temperatura de incubação e dosagem de cloro do PF de 7 dias. Estas condições foram utilizadas nos ensaios experimentais de potencial de formação de subprodutos para cada pré-oxidante em estudo.

Em relação ao $\mathrm{pH}$ e tempo de contato, o referido método recomenda a adição de um tampão de fosfato para fixar o valor do $\mathrm{pH}$ da água de estudo em 7,0 e o tempo de contato final para avaliação do PF recomendado foi de $24 \mathrm{~h}$.

No procedimento adaptado para realização do ensaio experimental de potencial de formação (PF 24h), foi utilizado um volume de $8 \mathrm{~L}$ de amostra de água de estudo divididos em quatro jarros (jarteste) de $2 \mathrm{~L}$ e um volume de $4 \mathrm{~L}$ de água de poço sem adição de substâncias húmicas, divididos e dois jarros de $2 \mathrm{~L}$.

Em seguida aplicou-se uma dosagem de pré-oxidante em estudo em todos os jarros, definidas pela demanda, descrita no item 4.5. Após 30 minutos de tempo de contato com um gradiente de velocidade de mistura em $100 \mathrm{~s}^{-1}$, foi aplicado uma dosagem de coagulante (sulfato de alumínio), 2 jarros de água com cor não receberam a adição de coagulante (a dosagem de coagulante foi definida no item 4.6).

Depois de decorrido 1 minuto de tempo de mistura rápida com gradiente de velocidade de mistura rápida de $1000 \mathrm{~s}^{-1}$, iniciou-se a filtração em papel Whatman 40. Os volumes filtrados foram recolhidos em três frascos distintos, sendo:

- frasco de água de estudo com cor e com coagulação (4L);

- frasco de água de estudo com cor e sem coagulaçãp (4L);

- frasco de água do poço sem cor e com coagulação (4L).

$\mathrm{O} \mathrm{pH}$ das amostras filtradas e recolhidas nos diferentes frascos foi fixado em 7,0, com adição de uma solução tampão de fosfato. 
Uma solução de cloro, recém-preparada, foi adicionada em cada frasco para obtenção de uma dosagem de $5 \mathrm{mg} / \mathrm{L}$ de cloro (pós-cloração). Imediatamente, os frascos foram fechados e lacrados com papel parafinado para evitar perdas de compostos voláteis por evaporação.

A seguir, os frascos foram submetidos á temperatura de $25 \pm 1^{\circ} \mathrm{C}$, em um equipamento de banho-maria termostatizado.

Nos tempos de contato de: 0,5, 2, 6,12 e 24h, os frascos foram abertos e rapidamente coletados $100 \mathrm{~mL}$ de amostra em um frasco contendo aproximadamente $1 \mathrm{~g}$ de agente desclorante (ácido ascórbico).

Os frascos identificados foram imediatamente lacrados $e$ acondicionados em geladeira à temperatura de $4^{\circ} \mathrm{C}$. Em seguida cada frasco foi utilizado para extrações líquido-líquido e posterior análises por cromatografia gasosa (CG-DCE).

O tempo máximo recomendado entre a coleta e a extração não deve ser superior a 7dias e o tempo máximo entre extração e análise cromatográfica não deve ser superior a 14 dias quando acondicionando à temperatura de $-4^{\circ} \mathrm{C}$ (freezer).

A Tabela 4.6 apresenta um resumo das condições do ensaio e a Figura 4.13 apresenta um fluxograma da etapa determinante.

Tabela 4.6 - Resumo das condições dos ensaios de potencial de formação de subprodutos da oxidação.

\begin{tabular}{lc}
\hline VARIAVÉIS & CONDIÇÕES \\
\hline Temperatura & $25^{\circ} \mathrm{C}$ em banho termostatizado \\
$\mathrm{pH}$ & $7,0 \mathrm{com}$ adição de tampão de fosfato \\
\multicolumn{1}{c}{ Cor remanescente } & $<5 \mathrm{uH}$ \\
Dosagem na pós-cloração & $5 \mathrm{mg} / \mathrm{L} \mathrm{Cl} 2$ \\
Volume de amostra & $250 \mathrm{~mL}$ em frasco escuro de vidro e fechado. \\
Tempo de contato & 0,$5 ; 2 ; 6 ; 12$ e $24 \mathrm{~h}$ \\
Inibidor (desclorante) & Ácido ascórbico
\end{tabular}



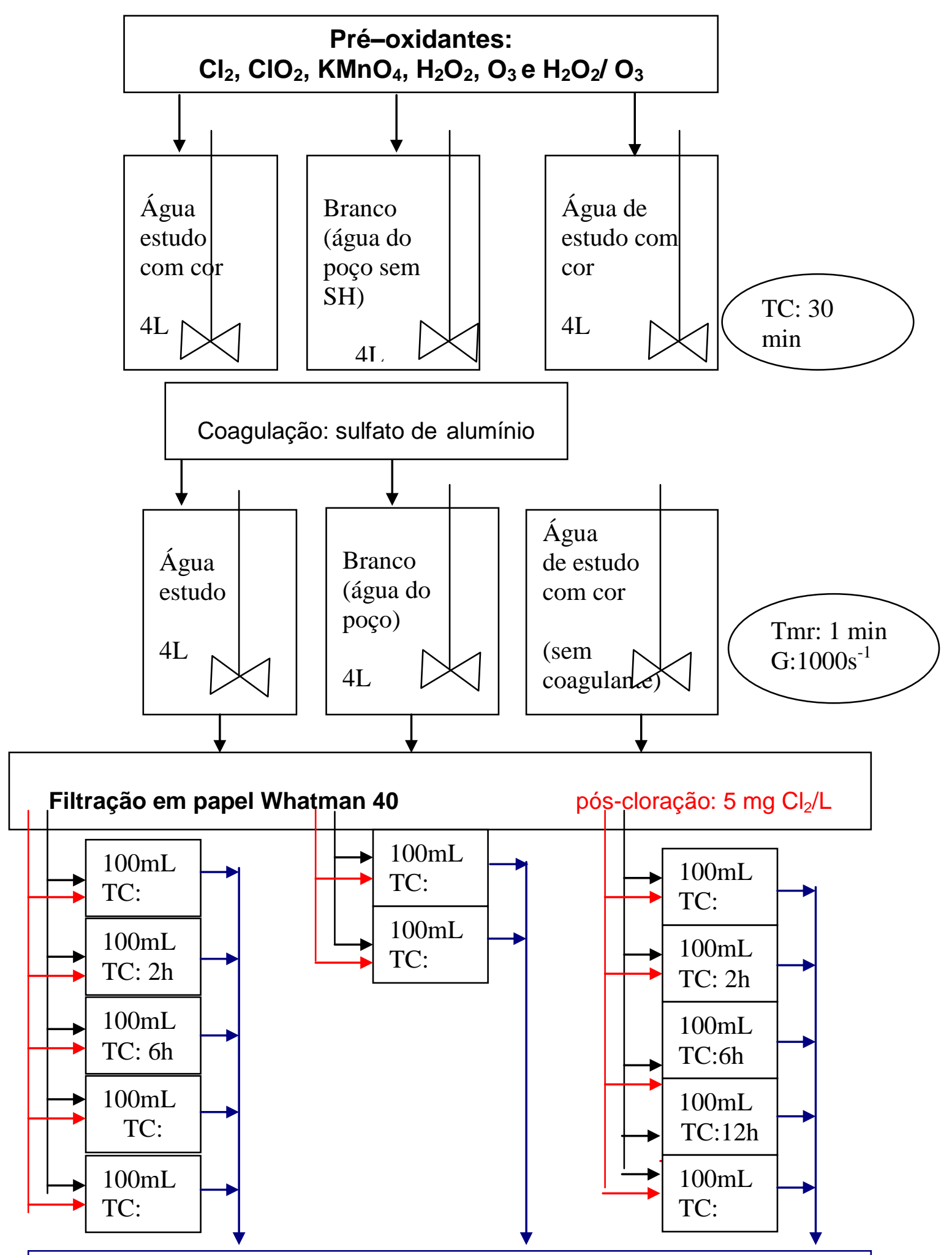

Adição de inibidor desclorante, extração líquido-líquido, análises cromatográficas e cálculos de potencial de formação de subprodutos

Figura 4.13 - Fluxograma dos ensaios experimentais da segunda etapa. 


\section{RESULTADOS E DISCUSSÃO}

\subsection{Resultados de calibração para análises cromatográficas}

As análises por cromatografia (CG-DCE) foram utilizadas para identificação e quantificação de 22 compostos orgânicos halogenados.

Os resultados analíticos obtidos de concentração por cromatografia foram expressos em $\mu \mathrm{g} / \mathrm{L}$; essa sensibilidade elevada requer padronizações dos procedimentos de extração e calibrações analíticas com soluções validadas. Para uma confiabilidade analítica é aceitável um desvio padrão de até $20 \%$.

Foi necessária a elaboração de duas curvas analíticas de calibração para identificação de 22 compostos orgânicos halogenados. As curvas foram denominadas de curva EPA 551 para TAMs, $\mathrm{CH}, \mathrm{CP}, \mathrm{HANs}$ e HKs e curva EPA 552 para determinações de AHAs.

\subsubsection{Resultado de calibração da curva EPA 551}

$\mathrm{Na}$ Tabela 5.1 e na Figura 5.1 estão apresentados os resultados obtidos da validação, desvio padrão e o cromatograma referente a um ponto da curva que foi analisado como verificação. Nos Apêndices A estão todos os resultados e cromatogramas obtidos para calibração da curva EPA 551 e um resumo com as equações lineares obtidas para cada composto. 
Tabela 5.1 - Resumo da validação do método EPA 551 obtido para o ponto 3.

\begin{tabular}{|c|c|c|c|c|}
\hline Compostos EPA 551 & $\begin{array}{c}\text { Tempo } \\
\text { Retenção } \\
\text { (min) }\end{array}$ & $\begin{array}{c}\text { Expectativa } \\
(\mu \mathrm{g} / \mathrm{L})\end{array}$ & $\begin{array}{c}\text { Resultados } \\
(\mu \mathrm{g} / \mathrm{L})\end{array}$ & $\begin{array}{c}\text { Desvio } \\
\text { Padrão } \\
\text { (\%) }\end{array}$ \\
\hline IIP - Padrão interno & 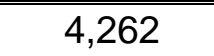 & 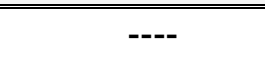 & ב--- & 0 \\
\hline Clorofórmio & 6,748 & 60 & 69,99 & 16,7 \\
\hline Tricloroacetonitrila & 8,901 & 30 & 31,92 & 6,4 \\
\hline Dicloroacetonitrila & 9,374 & 30 & 32,63 & 8,8 \\
\hline Bromodiclorometano & 9,895 & 60 & 64,45 & 7,4 \\
\hline Cloro hidrato & 10,257 & 80 & 91,61 & 14,5 \\
\hline 1,1-Dicloropropanona & 10,839 & 30 & 30,55 & 1,8 \\
\hline Cloropicrina & 13,101 & 30 & 30,88 & 2,9 \\
\hline Dibromoclorometano & 13,467 & 60 & 62,42 & 4,0 \\
\hline Bromocloroacetonitrila & 14,453 & 30 & 29,19 & 2,7 \\
\hline 1,1,1-tricloropropanona & 15,516 & 30 & 32,57 & 8,6 \\
\hline Dibromoacetonitrila & 17,003 & 30 & 31,45 & 4,8 \\
\hline Bromofórmio & 17,164 & 100 & 108,89 & 8,9 \\
\hline
\end{tabular}

Nota: Método 551.MTH - cromatograma reppf005.run - ponto 3

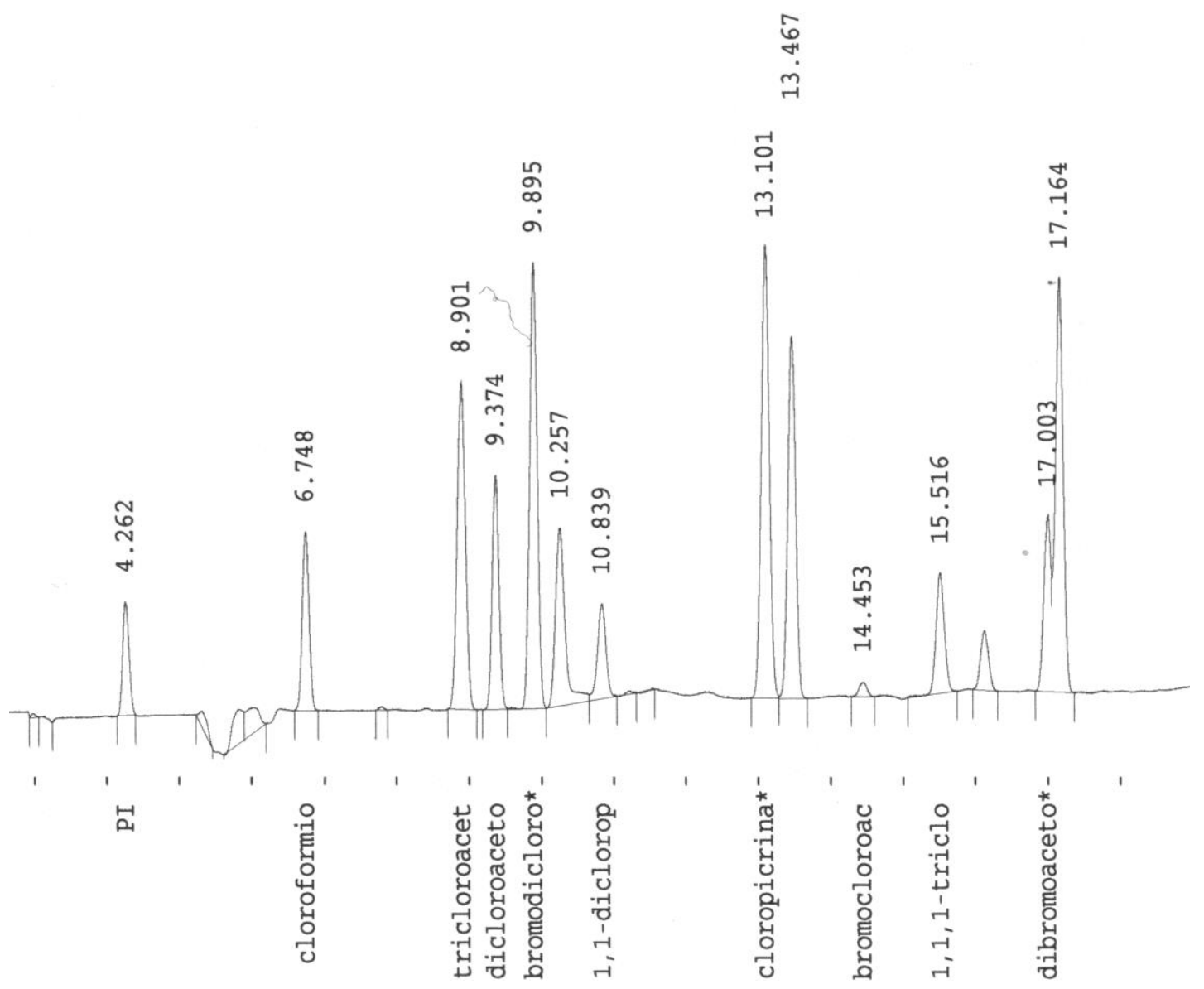

Figura 5.1 - Cromatograma de calibração do ponto 3 da curva EPA 551 


\subsubsection{Resultado de calibração da curva EPA 552}

Na Tabela 5.2 e na Figura 5.2 estão apresentados os resultados obtidos da calibração, desvio padrão e o cromatograma referente a um ponto da curva que foi analisado como verificação. Nos Apêndices B estão apresentados todos os resultados e cromatogramas obtidos para calibração da curva EPA 552 e um resumo com as equações lineares obtidas para cada composto.

Tabela 5.2- Resumo de validação do método 552 obtido no ponto 2.

Curva EPA 552

Ácidos

Haloaceticos

$\begin{array}{llccc} & \text { Tempo de } & & & \\ \text { Sigla } & \begin{array}{l}\text { Eetenção } \\ (\min )\end{array} & (\mu \mathrm{g} / \mathrm{L}) & (\mu \mathrm{g} / \mathrm{L}) & \begin{array}{c}\text { Desvio } \\ \text { Padrão }\end{array} \\ & & & \end{array}$

Ac. Monocloroacético

MCAA 8,652

MBAA

10,561

DCAA

10,986

Ac. Dicloracético

TCAA

12,961

Ac. Bricloroacéico

BCAA

14,291

BDCAA $\quad 16,845$

Ac. Bromodicloroacético

DBAA

17,506

Ac. Clorodibromoacético

CDBAA

17,947

TBAA

20,695

2,3-Dibromopropiônico

PI 21,157

21,157

9,00
6,00
9,00
3,00
6,00
6,00
3,00
15,00
30,00
----

Cromatograma: Método HAAO3.mth, HAAOZ016.run.

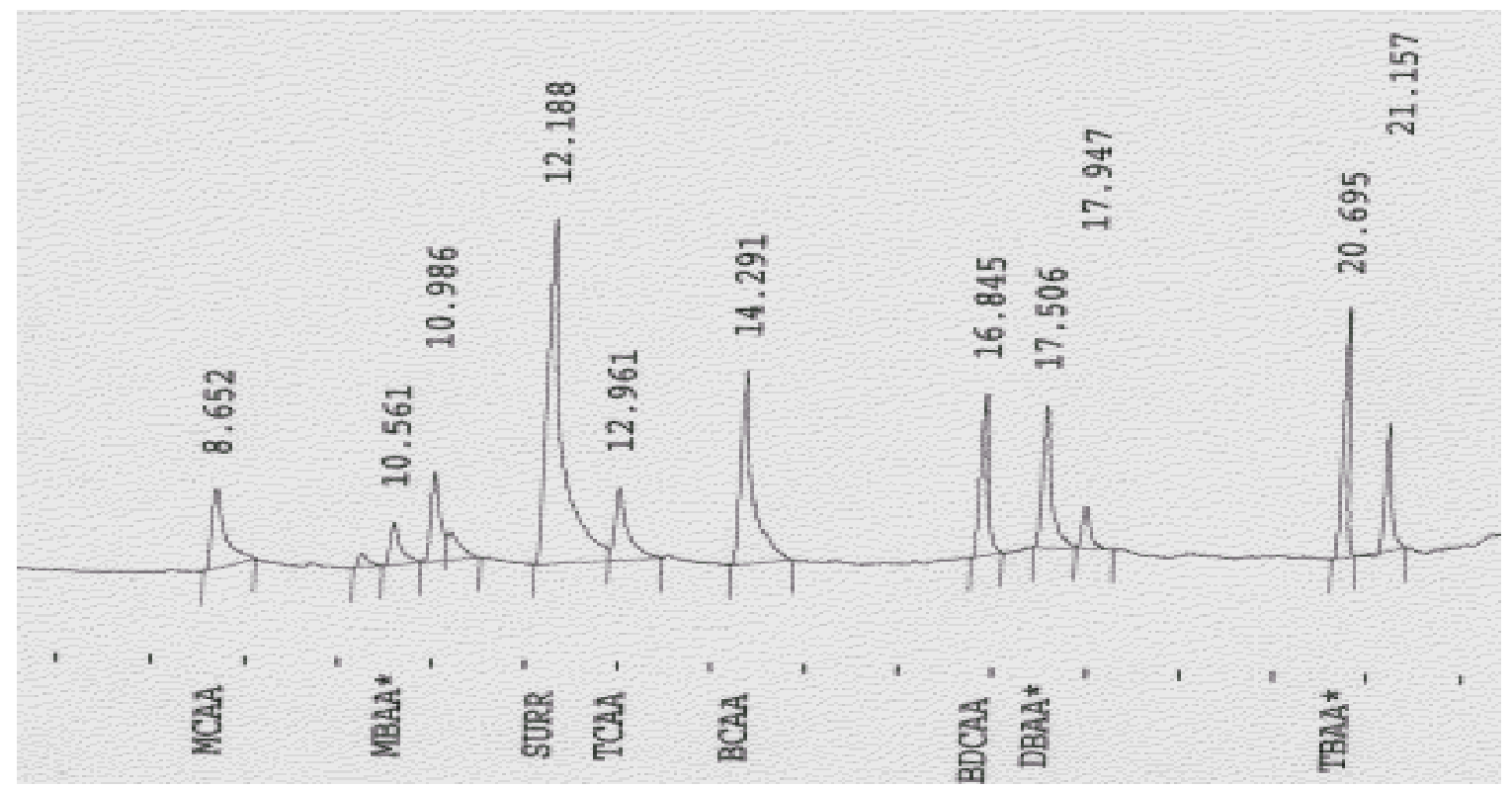

Figura 5.2- Cromatograma de calibração do ponto 2 da curva EPA 552. 


\subsection{Características do extrato de substâncias húmicas}

A composição química do extrato de SHs foi obtida através da análise elementar e razões atômicas, na Tabela 5.3 estão apresentados os resultados. O valor obtido de $53,31 \%$ de oxigênio indica a presença de compostos carboxílicos e carboidratos.

Tabela 5.3- Composição elementar das substâncias húmicas e as razões atômicas.

\begin{tabular}{cccc|ccc}
\hline \multicolumn{4}{c|}{ Massa \% } & \multicolumn{3}{c}{ Razões atômicas } \\
\hline \hline $\mathrm{C}$ & $\mathrm{H}$ & $\mathrm{N}$ & $\mathrm{O}$ & $\mathrm{H} / \mathrm{C}$ & $\mathrm{O} / \mathrm{C}$ & $\mathrm{C} / \mathrm{N}$ \\
40,30 & 4,37 & 1,82 & 53,31 & 1,30 & 0,99 & 25,77 \\
\hline
\end{tabular}

De acordo com ROCHA \& ROSA (2003), as razões molares H/C e $\mathrm{C} / \mathrm{N}$ geralmente têm sido utilizadas para estimar o grau de aromaticidade e de humificação das substâncias húmicas, respectivamente. A razão molar $\mathrm{H} / \mathrm{C}=1,30$ indica elevada aromaticidade e a razão molar $\mathrm{C} / \mathrm{N}$ indica alto grau de humificação.

\subsubsection{Análises de Infravermelho}

Os resultados obtidos por espectros na região de infravermelho (IV), realizados com as substâncias húmicas, estão apresentados na Figura 5.3, os quais exibiram bandas típicas de absorção. Segundo ROCHA \& ROSA (2003), os espectros na região do IV das substâncias húmicas mostram bandas largas provavelmente por causa da sobreposição das bandas de absorção dos constituintes individuais da mistura heterogênea de grupos os quais constituem as substâncias húmicas.

$\mathrm{Na}$ região de $3390 \mathrm{~cm}^{-1}$, observa-se uma banda larga caracterizada pela ligação de $\mathrm{H}$ a grupos $\mathrm{OH}$ provenientes de grupos alcoólicos e carboxílicos. Em $2900 \mathrm{~cm}^{-1}$ aparece uma banda característica de vibrações de grupos $\mathrm{CH}_{3}$ e $\mathrm{CH}_{2}$, próxima a moléculas de oxigênio de cadeias alifáticas. Uma banda forte aparece na região próxima a $1600 \mathrm{~cm}^{-1}$, podendo ser 
atribuída às vibrações $\mathrm{COO}^{-}$e $\mathrm{C}=\mathrm{C}$ de aromáticos, junto com as bandas de olefinas C-C.

Próximo de $1400 \mathrm{~cm}^{-1}$ aparece uma banda característica de deformação $\mathrm{O}-\mathrm{H}$, deformação angular $\mathrm{CH}_{3}, \mathrm{C}-\mathrm{O}$ característico de estiramento de grupamentos fenólicos $\mathrm{OH}$ e estiramento anti-simétrico de COO- Ainda nessa região pode-se atribuir em $1450 \mathrm{~cm}^{-1}$ um estiramento característico de grupos $\mathrm{CH}$ de alifáticos (ROCHA \& ROSA, 2003).

$\mathrm{Na}$ região entre $100-1100 \mathrm{~cm}^{-1}$ aparecem bandas que podem ser atribuídas a estiramentos $\mathrm{C}-\mathrm{O}$ de polissacarídeos e ainda a vibrações de ligações $\mathrm{C}-\mathrm{C}$ de alifáticos ou $\mathrm{CH}$ de anéis aromáticos.

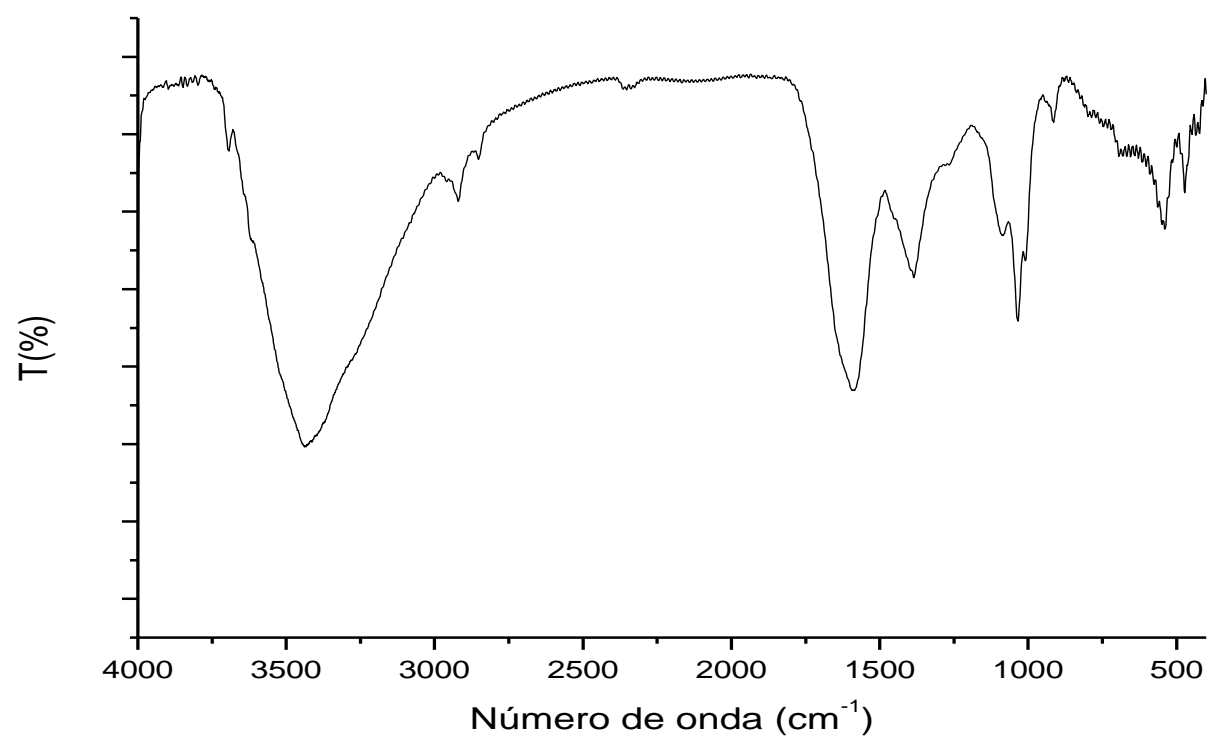

Figura 5.3 - Espectro da região do infravermelho das substâncias húmicas.

\subsubsection{Análises de Ultravioleta Vísivel}

Na Figura 5.4 está apresentado o espectro vísivel na região de 400 a $800 \mathrm{~nm}$ para a amostra de substâncias húmicas, de onde foi possível calcular a razão de absorção no comprimento de onda de $465 \mathrm{~nm}$ e $665 \mathrm{~nm}$ (razão $E_{4} / E_{6}$ ). $O$ valor da razão $E_{4} / E_{6}$ encontrado foi de 3,20, indicando que as substâncias húmicas se apresentavam em um estágio de humificação 
avançado. Segundo TRAINA et al. $(1990)^{5}$ apud ROCHA \& ROSA (2003) a aromaticidade das substâncias húmicas pode ser estimada quantitativamente por espectroscopia na região visível. O tamanho molecular das substâncias húmicas influi na quantidade de unidades aromáticas. As frações de maior tamanho molecular contêm maior número de estruturas aromáticas, ocorrendo uma gradual diminuição das estruturas aromáticas nas frações de menor tamanho molecular.

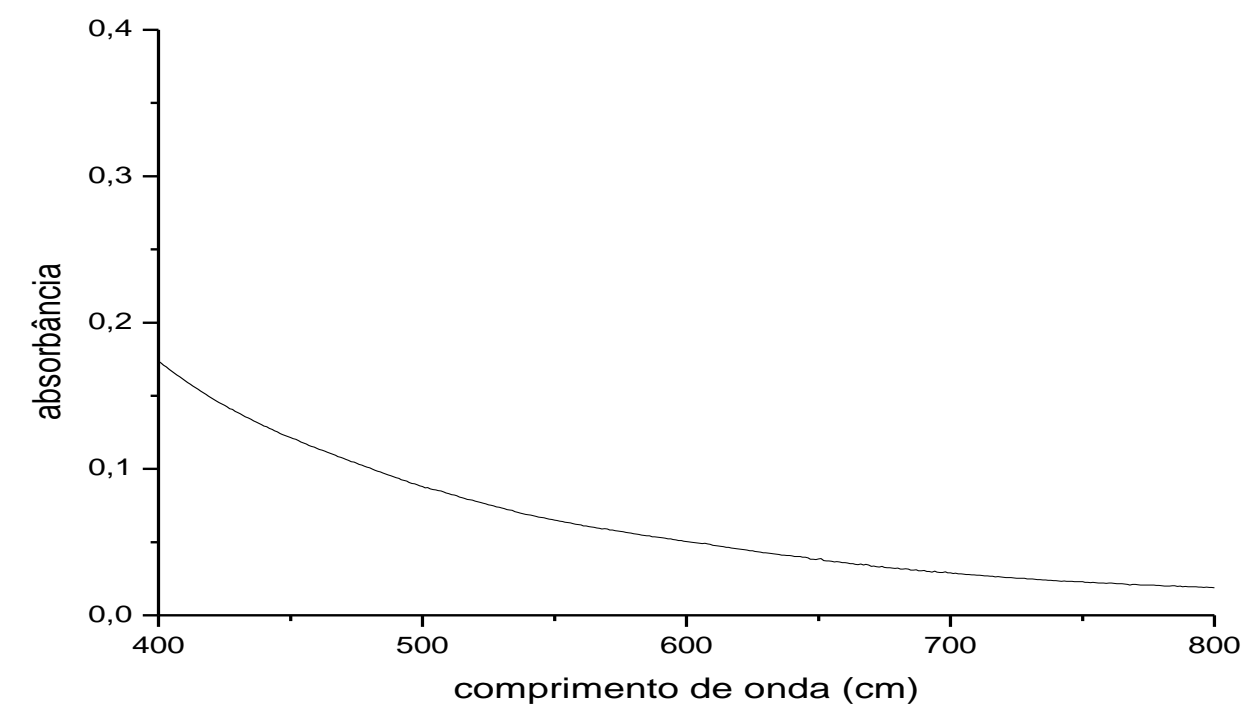

Figura 5.4- Espectro de visível na região de 465 a 665 nm para a amostra de substâncias húmicas.

\subsubsection{Análises de metais no extrato de substâncias húmicas}

O método utilizado foi de espectrofotometria por absorção atômica com queimador de chama ar-acetileno (APHA et al., 1998). Um volume de $50 \mathrm{~mL}$ de amostra do extrato de substâncias húmicas foi previamente digerida com a adição de porções iguais de ácido nítrico e ácido clorídrico com aquecimento seguido de filtração e reconstituição volumétrica com água deionizada isenta de metais.

\footnotetext{
${ }^{5}$ TRAINA, S. J.; NOVAK, J.; SMECK, N.E (1990) An Ultraviolet Absorbance Method of Estimating the Percent Aromatic Carbon Content of Humic Acids. J. Environmental Quality, v. 19, p. 151-3.
} 
Na Tabela 5.4 estão apresentados os resultados obtidos, bem como a concentração e leitura dos padrões utilizados. O extrato apresentou uma concentração elevada de ferro.

Tabela 5.4 - Resultados das análises de metais no extrato de substâncias húmicas.

\begin{tabular}{lccc}
\hline Metais & Resultados & $\begin{array}{c}\text { Padrão de } \\
\text { Calibração }\end{array}$ & $\begin{array}{c}\text { Leitura do } \\
\text { Padrão }\end{array}$ \\
\hline Manganês & $0,113 \mathrm{mgMn} / \mathrm{L}$ & 0,100 & 0,108 \\
Ferro & $18,690 \mathrm{mgFe} / \mathrm{L}$ & 1,000 & 1,012 \\
Zinco & $0,405 \mathrm{mgZn} / \mathrm{L}$ & 1,000 & 1,116 \\
Níquel & $0,119 \mathrm{mgNi} / \mathrm{L}$ & 1,000 & 1,080 \\
Cobre & $1,542 \mathrm{mgCu} / \mathrm{L}$ & 1,000 & 1,093 \\
Chumbo & $0,478 \mathrm{mgPb} / \mathrm{L}$ & 1,000 & 1,025 \\
Cromo & $0,353 \mathrm{mgCr} / \mathrm{L}$ & 1,000 & 1,042 \\
\hline
\end{tabular}

\subsection{Resultados dos ensaios para definição da cor aparente da água de estudo}

Os resultados dos ensaios realizados em amostras de água de estudo preparada com diferentes concentrações de substâncias húmicas em função de diferentes dosagens de cloro (ácido tricloro isocianúrico) estão apresentados na Tabela 5.5 .

Tabela 5.5 - Resultados obtidos de trialometanos ( $\mu \mathrm{g} / \mathrm{L}$ ), com tempo de contato de $24 \mathrm{~h}$ a $20^{\circ} \mathrm{C}$, com variação de cor aparente e dosagem de cloro (ácido tricloro isocianurico).

\begin{tabular}{ccccc}
\hline $\begin{array}{c}\text { Dosagem de cloro } \\
\mathrm{mg} / \mathrm{L} \mathrm{Cl}_{2}\end{array}$ & \multicolumn{4}{c}{ Cor aparente aproximada (uH) } \\
\cline { 2 - 5 } & $100 \mathrm{uH}$ & $200 \mathrm{uH}$ & $300 \mathrm{uH}$ & $400 \mathrm{uH}$ \\
\hline \hline 10 & 46,12 & 93,38 & 82,91 & 76,46 \\
20 & 46,64 & 80,02 & 123,64 & 164,78 \\
30 & 36,74 & 81,65 & 95,88 & 127,95 \\
\hline
\end{tabular}

Pela avaliação dos resultados obtidos nos ensaios, definiu-se por realizar o presente trabalho com uma água de estudos com cor $200 \mathrm{uH}$ devido ao fato de terem sido obtidos valores de TAMs próximos a $100 \mu \mathrm{g} / \mathrm{L}$ e cor aparente de $200 \mathrm{uH}$ pode ocorrer em corpos d'água naturais. 


\subsection{Caracterização da água de estudo}

Na tabela 5.6 estão apresentados os resultados obtidos por análises físico-químicas da água do poço e da água de estudo.

Tabela 5.6- Características físicas e químicas das águas utilizadas.

\begin{tabular}{|c|c|c|c|}
\hline Parâmetro & Unidade & Água poço & Água de estudo \\
\hline$\overline{\mathrm{pH}}$ & adimensional & 6,22 & 7,60 \\
\hline Cor aparente & $\mathrm{uH}$ (PtCo) & 2 & 202 \\
\hline Turbidez & NTU & 0,21 & 2,5 \\
\hline Carbono orgânico total & $\mathrm{mg} / \mathrm{L}$ & $<1$ & 6,078 \\
\hline UV 254nm & abs & 0,013 & 0,264 \\
\hline Alcalinidade bicarbonato & $\mathrm{mg} / \mathrm{L} \mathrm{CaCO}_{3}$ & 12,5 & 13 \\
\hline Oxigênio consumido & $\mathrm{mg} / \mathrm{L} \mathrm{O}_{2}$ & $<0,1$ & 5,3 \\
\hline DQO & $\mathrm{mg} / \mathrm{L} \mathrm{O}_{2}$ & $<5$ & 17 \\
\hline Nitrogênio amoniacal & $\mathrm{mg} / \mathrm{L} \mathrm{N}-\mathrm{NH}_{3}$ & $<0,01$ & $<0,01$ \\
\hline Dureza Total & $\mathrm{mg} / \mathrm{L} \mathrm{CaCO}_{3}$ & 5 & 10 \\
\hline Cloretos & $\mathrm{mg} / \mathrm{L} \mathrm{Cl}^{-}$ & 1 & 10,1 \\
\hline Brometo & $\mathrm{mg} / \mathrm{L}$ & $<0,1$ & $<0,1$ \\
\hline Nitrato & $\mathrm{mg} / \mathrm{L} \mathrm{N}-\mathrm{NO}_{3}$ & 0,686 & 1,668 \\
\hline Nitriro & $\mathrm{mg} / \mathrm{L} \mathrm{N}-\mathrm{NO}_{2}$ & $<0,001$ & 0,003 \\
\hline Sólidos totais & $\mathrm{mg} / \mathrm{L}$ & 17 & 65 \\
\hline Manganês & $\mathrm{mg} / \mathrm{L} \mathrm{Mn}$ & 0,002 & 0,020 \\
\hline Ferro & $\mathrm{mg} / \mathrm{L} \mathrm{Fe}$ & $<0,001$ & 0,590 \\
\hline Bário & $\mathrm{mg} / \mathrm{L} \mathrm{Ba}$ & $<0,01$ & 0,050 \\
\hline Zinco & $\mathrm{mg} / \mathrm{L} \mathrm{Zn}$ & 0,102 & 0,257 \\
\hline Níquel & $\mathrm{mg} / \mathrm{L} \mathrm{Ni}$ & $<0,001$ & $<0,001$ \\
\hline Cobre & $\mathrm{mg} / \mathrm{L} \mathrm{Cu}$ & 0,012 & 0,154 \\
\hline Arsênio & $\mu \mathrm{g} / \mathrm{L}$ As & $<0,01$ & 0,05 \\
\hline Mercúrio & $\mu \mathrm{g} / \mathrm{L} \mathrm{Hg}$ & $<0,1$ & 2,45 \\
\hline Cádmio & $\mathrm{mg} / \mathrm{L} \mathrm{Cd}$ & 0,001 & 0,005 \\
\hline Chumbo & $\mu \mathrm{g} / \mathrm{L} \mathrm{Pb}$ & 0,108 & 0,625 \\
\hline Cromo & $\mathrm{mg} / \mathrm{L} \mathrm{Cr}$ & 0,002 & 0,027 \\
\hline Prata & $\mathrm{mg} / \mathrm{L} \mathrm{Ag}$ & $<0,01$ & $<0,01$ \\
\hline
\end{tabular}




\subsection{Resultados de ensaios para definição de temperatura}

Os ensaios para definição de temperatura foram realizados em uma água de estudo preparada com cor aparente de $100 \mathrm{uH}$ e a dosagem de cloro foi de $10 \mathrm{mg} / \mathrm{L}$ (ácido tricloro isocianúrico). As amostras foram incubadas em diferentes temperaturas e, para diferentes tempos de contato, coletou-se uma alíquota para extração e análise de TAMs por CG-DCE. Na Tabela 5.7 estão apresentados os resultados obtidos, dentre os TAMs investigados, apenas o clorofórmio foi detectado.

Tabela 5.7 - Resultados obtidos de trialometanos ( $\mu \mathrm{g} / \mathrm{L}$ ) e taxas ( $\mu \mathrm{g} / \mathrm{L} . \mathrm{h}) \mathrm{com}$ variação de temperatura e tempo de contato.

\begin{tabular}{|c|c|c|c|c|c|c|}
\hline \multirow{3}{*}{$\begin{array}{c}\text { Tempo } \\
\text { (h) }\end{array}$} & \multicolumn{6}{|c|}{ Temperatura } \\
\hline & \multicolumn{2}{|c|}{$20^{\circ} \mathrm{C}$} & \multicolumn{2}{|c|}{$25^{\circ} \mathrm{C}$} & \multicolumn{2}{|c|}{$30^{\circ} \mathrm{C}$} \\
\hline & $\begin{array}{l}\text { TAMs } \\
(\mu \mathrm{g} / \mathrm{L})\end{array}$ & $\begin{array}{c}\text { Taxa } \\
\text { ( } \mu \mathrm{g} / \mathrm{L} . \mathrm{h})\end{array}$ & $\begin{array}{l}\text { TAMs } \\
(\mu \mathrm{g} / \mathrm{L})\end{array}$ & $\begin{array}{c}\text { Taxa } \\
(\mu \mathrm{g} / \mathrm{L} . \mathrm{h})\end{array}$ & $\begin{array}{l}\text { TAMs } \\
(\mu \mathrm{g} / \mathrm{L})\end{array}$ & $\begin{array}{c}\text { Taxa } \\
(\mu \mathrm{g} / \mathrm{L} . \mathrm{h})\end{array}$ \\
\hline 2 & 26,28 & 13,14 & 27,15 & 13,57 & 38,36 & 19,18 \\
\hline 4 & 26,15 & 6,54 & 41,96 & 10,49 & 43,56 & 10,89 \\
\hline 12 & 43,52 & 3,63 & 56,08 & 4,67 & 66,36 & 5,53 \\
\hline 24 & 62,35 & 2,60 & 63,43 & 2,64 & 52,23 & 2,18 \\
\hline
\end{tabular}

Nas Figuras 5.5 estão apresentados os resultados obtidos de formação de TAMs em função do tempo de contato para as diferentes temperaturas. Observou-se que até $12 \mathrm{~h}$ de tempo de contato a formação de TAMs foi maior com o aumento da temperatura, após 24h, no ensaio com $30^{\circ} \mathrm{C}$, houve uma diminuição no valor de TAMs, esse fato pode ser devido a uma perda por volatilização de TAMs no momento de abertura do frasco para coleta. O maior valor obtido de TAMs foi de $60 \mu \mathrm{g} / \mathrm{L}$ em $25^{\circ} \mathrm{C}$ após $24 \mathrm{~h}$. Portanto, para realização do presente trabalho adotou-se a temperatura de $25^{\circ} \mathrm{C}$, por ser uma temperatura com ocorrência natural em certos corpos d'água no Brasil. 


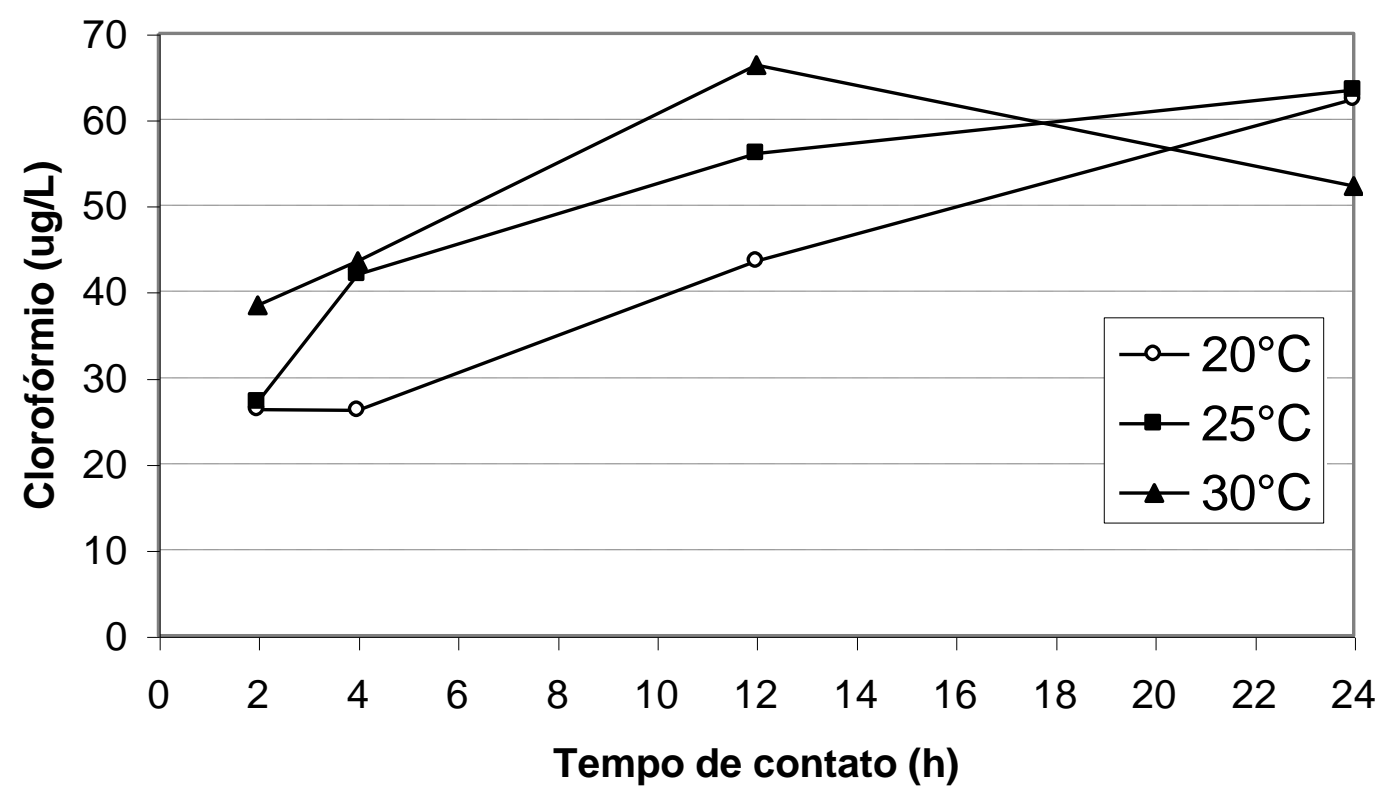

Figura 5.5 - Valores de trialometanos (clorofórmio) em função do tempo de contato em diferentes temperaturas.

$\mathrm{Na}$ Figura 5.6 estão apresentados os resultados de taxa ou velocidade de formação em função do tempo de contato para diferentes temperaturas.

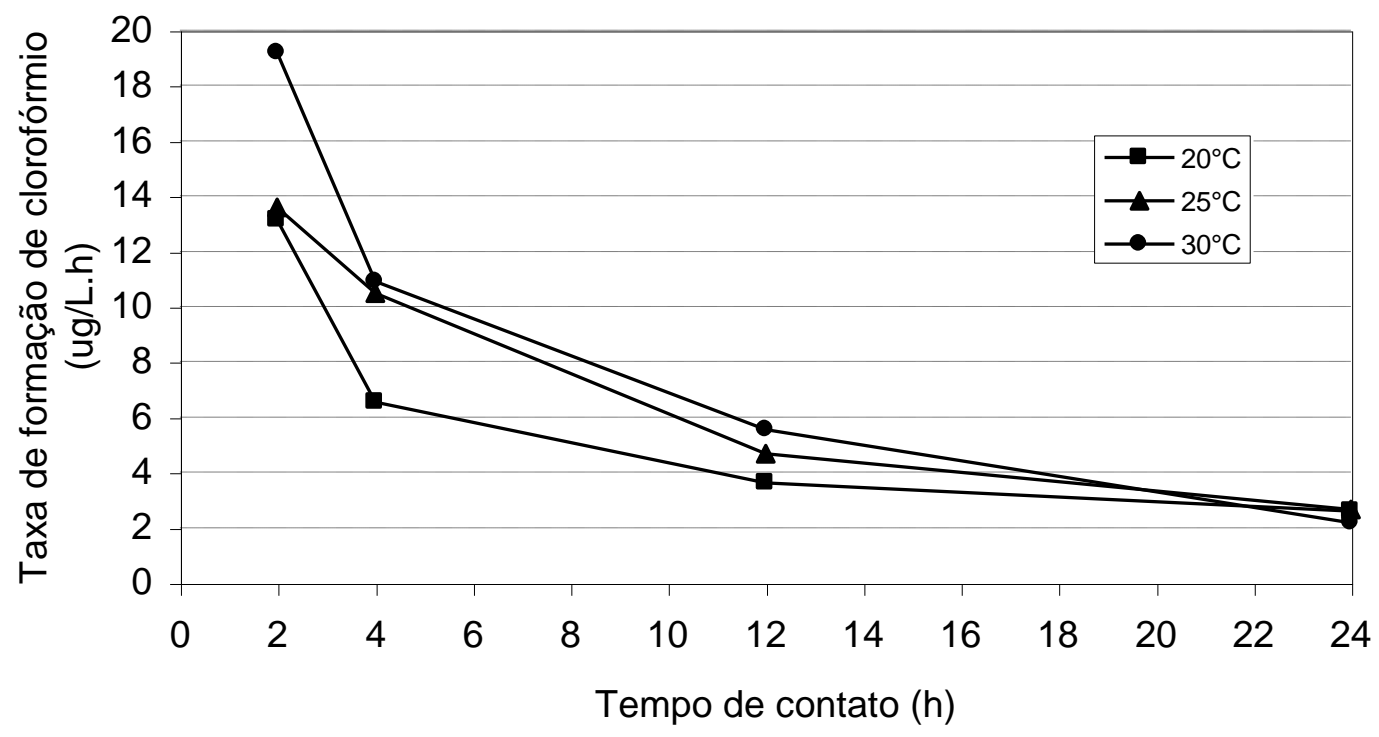

Figura 5.6 - Taxa de formação de clorofórmio em função do tempo de contato para diferentes temperaturas. 
Pelos resultados obtidos verificou-se que após 12 horas de tempo de contato a influência da temperatura apresentou-se com variação de taxas desprezíveis.

\subsection{Resultados dos ensaios para definição da dosagem de cloro no potencial de formação de subprodutos em 7 dias}

O potencial de formação de subprodutos orgânicos em 7 dias da água de estudo com cor $200 \mathrm{uH}$ foi determinado através de um ensaio com variação de dosagens que garantissem um excesso de residual de cloro livre após 7 dias de tempo de contato a $25^{\circ} \mathrm{C}$ em pH 7,0. Os resultados obtidos estão apresentados na Tabela 5.8.

As dosagens de 15, 17,5 e $20 \mathrm{mg} / \mathrm{L}$ de cloro, forneceram um residual de 3,5, 3,9 e 4,4 mg/L $\mathrm{Cl}_{2}$ respectivamente. Segundo a metodologia referenciada, após 7 dias o residual livre deve estar entre 3,5 e 5,0 mg/L. Portanto, adotou-se a dosagem de $15 \mathrm{mg} / \mathrm{L}$ para ser aplicada nos ensaios de potencial de formação de 7 dias.

Tabela 5.8 - Resultados de cloro residual livre com tempo de contato de 7 dias a $25^{\circ} \mathrm{C}$ para definir a dosagem de cloro e confirmação de residual livre persistente.

\begin{tabular}{ccc}
\hline Tipo de cloro & $\begin{array}{c}\text { Dosagem } \\
(\mathbf{m g ~ C l} / \mathbf{L})\end{array}$ & $\begin{array}{c}\text { Cloro residual livre } \\
\text { após } \mathbf{~} \text { dias } \\
\left(\mathbf{m g ~ C l}_{\mathbf{2}} / \mathbf{L}\right)\end{array}$ \\
\hline \hline Hipoclorito de cálcio granulado com & 15,0 & 0,48 \\
(70\% p/p) de cloro disponível & 17,5 & 3,50 \\
& 20,0 & 3,90 \\
\hline
\end{tabular}




\subsection{Resultados dos ensaios de demanda de pré-oxidantes}

Todos os ensaios para determinação de demanda de pré-oxidantes foram realizados em uma sala com temperatura controlada a $25^{\circ} \mathrm{C} \pm 1$. Utilizou-se água de estudo com cor aparente de $200 \mathrm{uH}$, o gradiente de velocidade para a mistura foi estabelecido em $100 \mathrm{~s}^{-1}$ e o tempo de contato igual a 30 minutos.

A seguir são apresentadas por tabelas e gráficos contendo resultados obtidos nos ensaios de demanda dos pré-oxidantes: cloro; dióxido de cloro; permanganato de potássio; peróxido de hidrogênio; ozônio e peroxônio.

\subsubsection{Ensaios de demanda com cloro}

A Tabela 5.9 apresenta os resultados obtidos de cloro residual livre para diferentes dosagens de cloro em função do tempo de contato. Os valores de demanda foram obtidos através do cálculo da diferença entre a dosagem de cloro aplicada e cloro residual livre obtido. Na Figura 5.7 esta apresentada à demanda de cloro em função da dosagem para cada tempo de contato.

Tabela 5.9 - Resultados de residual de cloro e cálculo de demanda préoxidante para água de cor $200 \mathrm{uH}$ em função do tempo de contato a $25^{\circ} \mathrm{C}$.

\begin{tabular}{lccccccc}
\hline & $\begin{array}{c}\text { Tempo de } \\
\text { contato } \\
\text { (min) }\end{array}$ & $\mathbf{3 , 0}$ & $\mathbf{5 , 0}$ & $\mathbf{1 0 , 0}$ & $\mathbf{1 2 , 0}$ & $\mathbf{1 5 , 0}$ & $\mathbf{2 0 , 0}$ \\
\cline { 3 - 8 } & 10 & 1,12 & 3,18 & 7,85 & 9,7 & 11,5 & 16 \\
\hline Residual & 10 & 1,880 & 1,820 & 2,150 & 2,300 & 3,500 & 4,000 \\
\hline Demanda & & 1,11 & 2,78 & 7,25 & 8,55 & 11,4 & 14,4 \\
\hline Residual & 30 & 1,890 & 2,220 & 2,750 & 3,450 & 3,600 & 5,600 \\
Demanda & & 0,92 & 2,56 & 6,85 & 8,05 & 11,1 & 14,2 \\
\hline Residual & 60 & 2,080 & 2,440 & 3,150 & 3,950 & 3,900 & 5,800 \\
Demanda & & 0,6 & 2,03 & 6,6 & 7,75 & 10,7 & 14,1 \\
\hline Residual & 90 & 2,400 & 2,970 & 3,400 & 4,250 & 4,300 & 5,900 \\
Demanda & & 0,43 & 1,74 & 6,05 & 7,65 & 10 & 13,9 \\
\hline Residual & 120 & 0,570 & 3,260 & 3,950 & 4,350 & 5,000 & 6,100 \\
\hline Demanda & & 2,550 & & & & \\
\hline
\end{tabular}




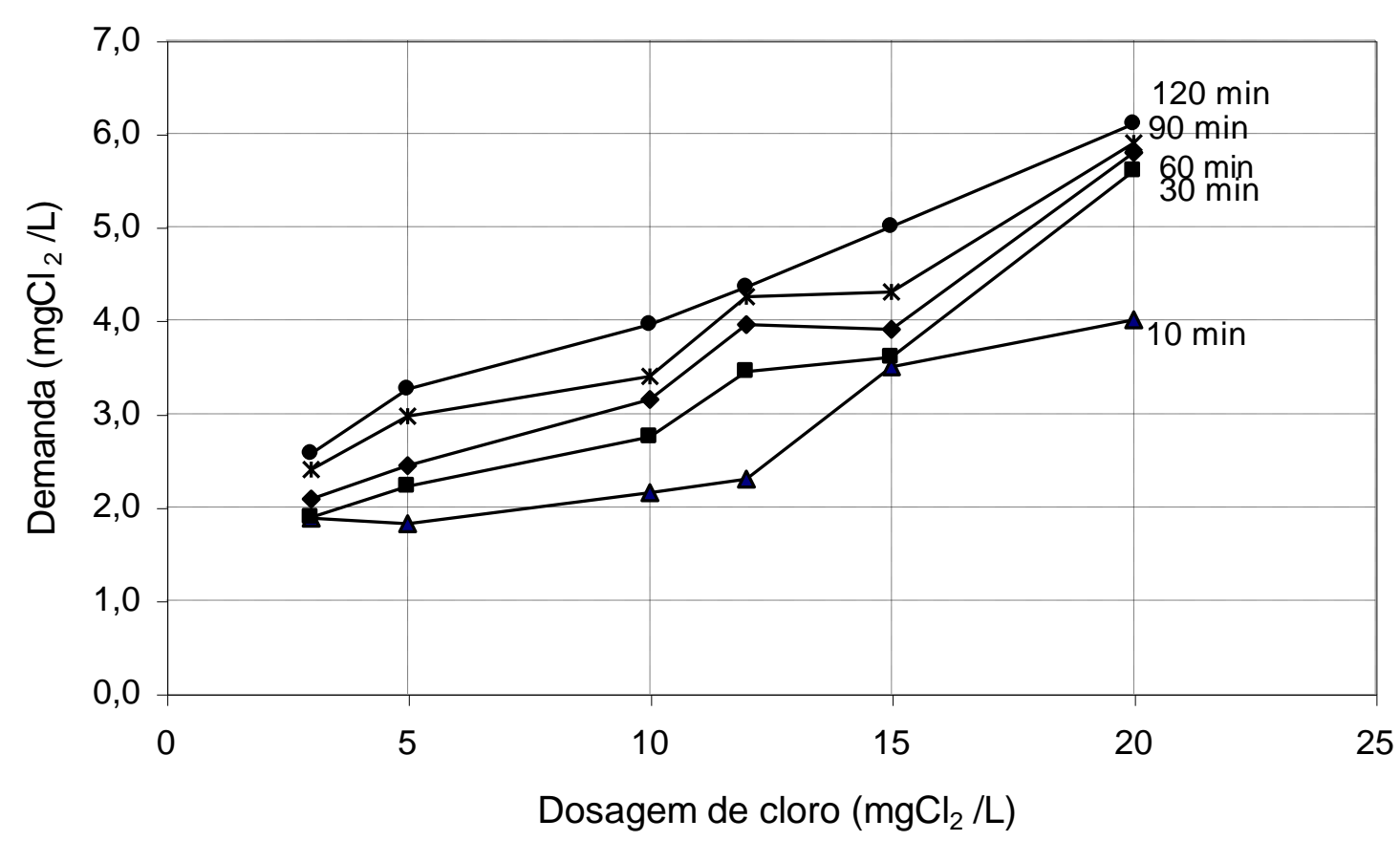

Figura 5.7 - Demanda de cloro em função da dosagem aplicada para diferentes tempos de contato, a $25^{\circ} \mathrm{C}$.

Pelos resultados obtidos, observou-se que após $30 \mathrm{~min}$ de tempo de contato, a dosagem de $5 \mathrm{mgCl}_{2} / \mathrm{L}$ forneceu um residual de $2,78 \mathrm{mg} \mathrm{Cl}_{2} / \mathrm{L}$, obtendo-se uma demanda de cloro na pré-oxidação de aproximadamente $50 \%$ da dosagem. Considerando que a Portaria 518 cita como valor máximo permissível de cloro total a concentração de $5 \mathrm{mgCl}_{2} / \mathrm{L}$, adotou-se a dosagem de $5 \mathrm{mgCl}_{2} / \mathrm{L}$, que satisfaz as duas condições.

\subsubsection{Ensaios de demanda com dióxido de cloro}

$\mathrm{Na}$ Tabela 5.10 e na Figura 5.8 estão apresentados os resultados obtidos de residual de dióxido de cloro os valores calculados de demanda em função do tempo.

Pelos resultados obtidos, após 30 minutos a dosagem de 1,2 $\mathrm{mg}$ $\mathrm{ClO}_{2} / \mathrm{L}$ satisfez a demanda e forneceu um residual de $0,114 \mathrm{mg} \mathrm{ClO} / / \mathrm{L}$, atendendo as recomendações da USEPA (1990). Na Figura 5.6 estão apresentados os valores de demanda em função da dosagem de dióxido de cloro aplicada para cada tempo de contato. 
Tabela 5.10 - Resultados de residual de dióxido de cloro e cálculo de demanda de dióxido de cloro para água de cor $200 u H$ em função do tempo de contato a $25^{\circ} \mathrm{C}$.

\begin{tabular}{|c|c|c|c|c|c|c|c|}
\hline & \multirow{2}{*}{$\begin{array}{c}\text { Tempo de } \\
\text { contato (min) }\end{array}$} & \multicolumn{6}{|c|}{ Dosagem $\mathrm{mgClO}_{2} / \mathrm{L}$} \\
\hline & & 0,6 & 1,2 & 1,8 & 2,4 & 3,0 & 3,2 \\
\hline$\overline{R e s}$ & 15 & 0,095 & 0,152 & 0,323 & 0,700 & 1,159 & 1,330 \\
\hline Dem & & 5 & 1,048 & 77 & 0 & 1,841 & 870 \\
\hline Res & 30 & & 0,114 & & & & 0,950 \\
\hline Dem & & & 1,086 & 0 & 1 & 2,183 & 2,250 \\
\hline & 60 & & 0,057 & & & 0,38 & 0,532 \\
\hline Dem & & & 1,143 & & 2, & 2,620 & 2,668 \\
\hline & 90 & &, 057 & & & 0,209 & 0,304 \\
\hline Dem & &, 562 & 1,143 & & 2,324 & 2,791 & 2,896 \\
\hline & 120 & & 0,057 & & 0,057 & 0,057 & 0,152 \\
\hline Demanda & & 0,562 & 1,143 & 1,743 & 2,343 & 2,943 & 3,048 \\
\hline
\end{tabular}

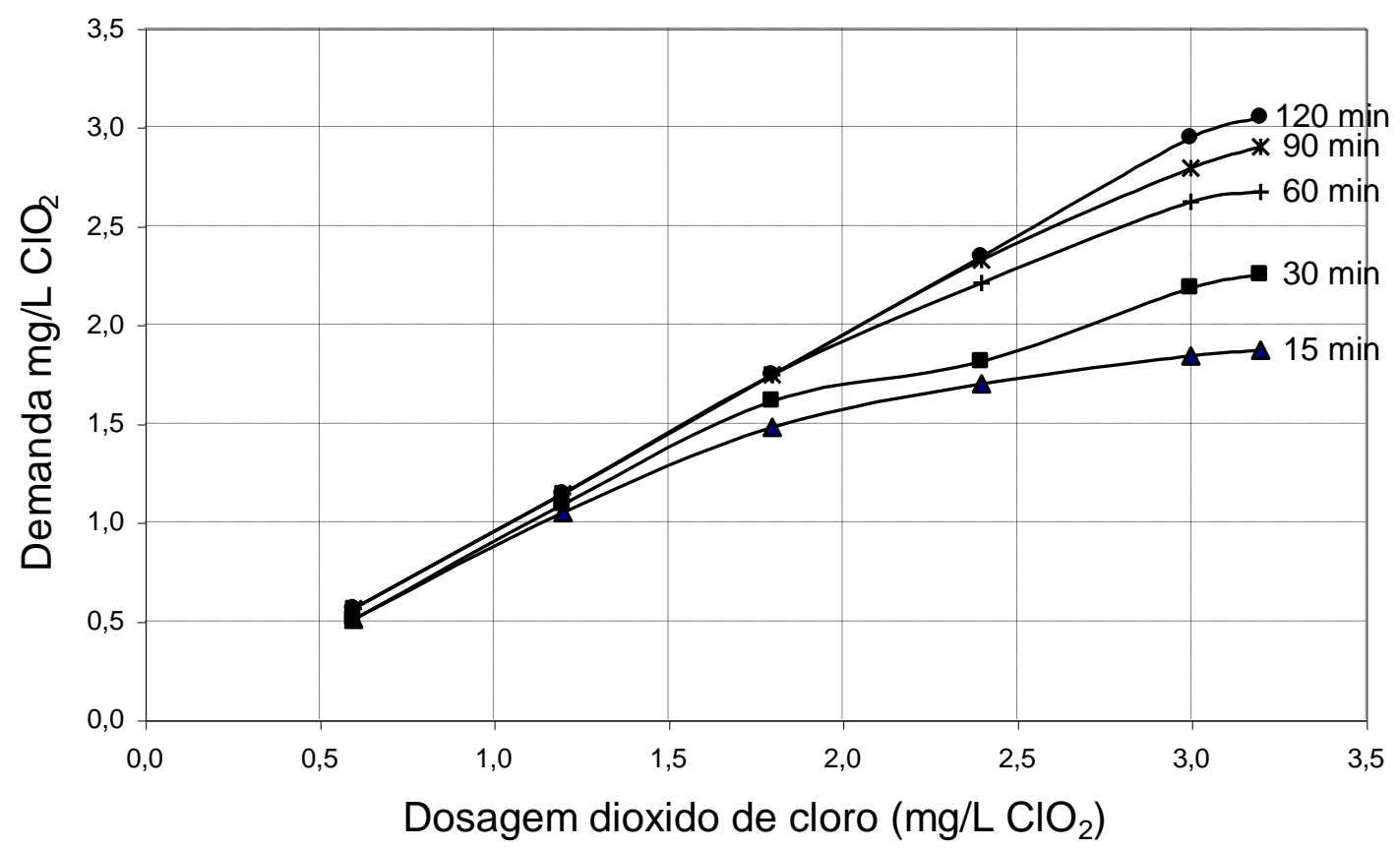

Figura 5.8 - Demanda de dióxido de cloro em função da dosagem aplicada para diferentes tempos de contato a $25^{\circ} \mathrm{C}$.

\subsubsection{Ensaios de demanda com permanganato de potássio}

$\mathrm{Na}$ Tabela 5.11 podem ser vistos os resultados obtidos de residual $\mathrm{KMnO}_{4}$ em função do tempo de contato e os valores de demanda obtidos por cálculo da diferença entre dosagem aplicada e residual de $\mathrm{KMnO}_{4}$. 
Tabela 5.11- Resultados de residual de permanganato de potássio e cálculo da demanda pré-oxidante para água de cor $200 \mathrm{uH}$ a $25^{\circ} \mathrm{C}$.

\begin{tabular}{|c|c|c|c|c|c|c|c|}
\hline & \multirow{2}{*}{$\begin{array}{c}\text { Tempo } \\
\text { contato (min) }\end{array}$} & \multicolumn{6}{|c|}{$\begin{array}{c}\text { Dosagem } \\
\left(\mathrm{mgKMnO}_{4} / \mathrm{L}\right)\end{array}$} \\
\hline & & 1,0 & 2,0 & 2,5 & 3,0 & 3,5 & 4,0 \\
\hline Residual & $10 \mathrm{~min}$ & 0,739 & 1,789 & 2,112 & 2,512 & 2,801 & 3,495 \\
\hline Demanda & & 0,261 & 0,211 & 0,388 & 0,488 & 0,699 & 0,505 \\
\hline Residual & $30 \mathrm{~min}$ & 0 & 1,199 & 1,57 & 1,936 & 2,273 & 2,826 \\
\hline Demanda & & 1,000 & 0,801 & 0,930 & 1,064 & 1,227 & 1,174 \\
\hline Residual & $60 \mathrm{~min}$ & 0 & 0,872 & 1,311 & 1,76 & 2,051 & 2,587 \\
\hline Demanda & & 1,000 & 1,128 & 1,189 & 1,240 & 1,449 & 1,413 \\
\hline Residual & $90 \mathrm{~min}$ & 0 & 0,516 & 1,263 & 1,592 & 1,88 & 2,397 \\
\hline Demanda & & 1,000 & 1,484 & 1,237 & 1,408 & 1,620 & 1,603 \\
\hline Residual & $120 \mathrm{~min}$ & 0 & 0 & 1,213 & 1,582 & 1,874 & 2,345 \\
\hline Demanda & & 1,000 & 2,000 & 1,287 & 1,418 & 1,626 & 1,655 \\
\hline
\end{tabular}

Na Figura 5.9 são mostrados os resultados de demanda em função da dosagem de permanganato de potássio aplicada.

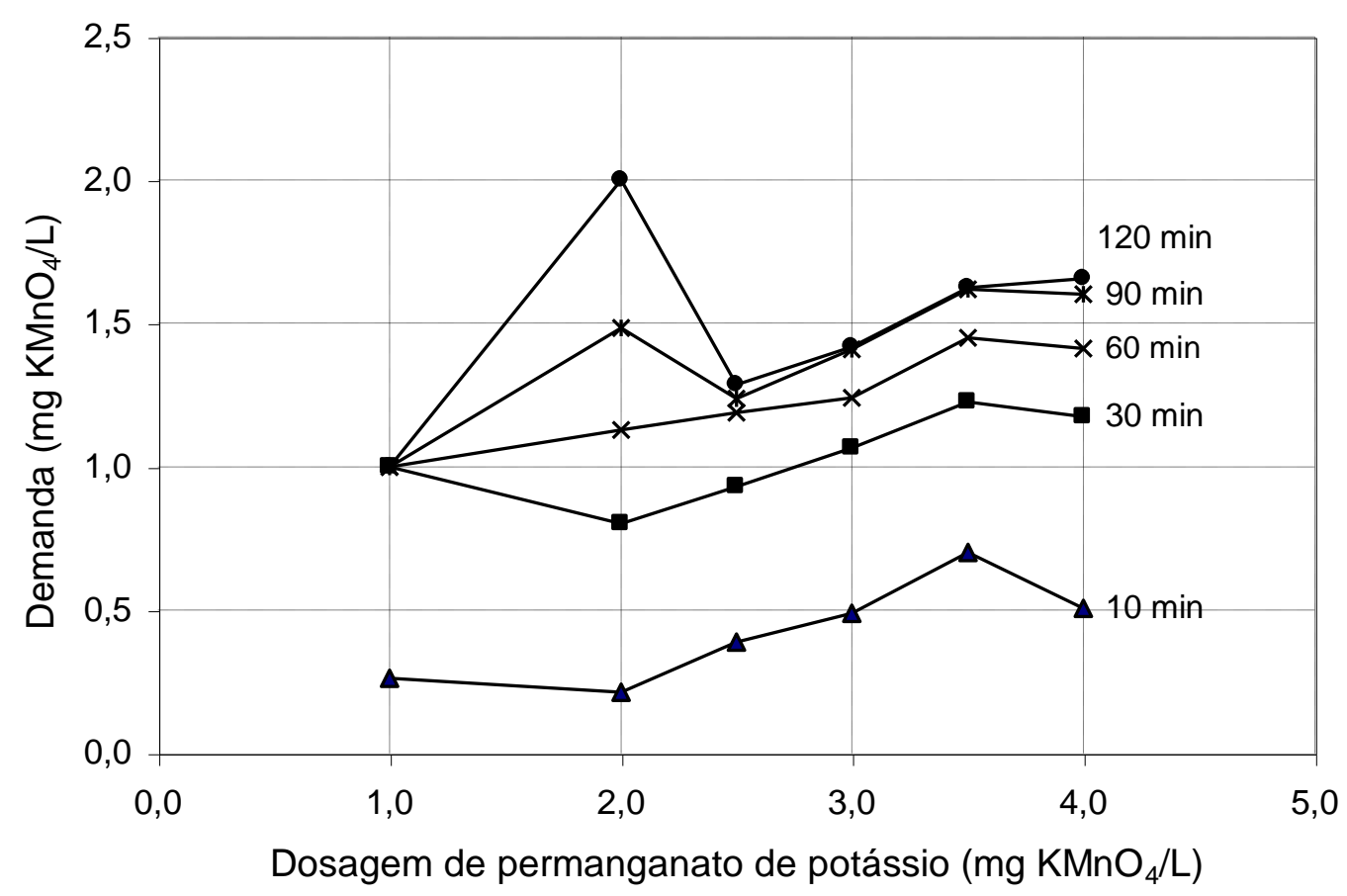

Figura 5.9 - Demanda de permanganato de potássio em função da dosagem aplicada para diferentes tempos de contato a $25^{\circ} \mathrm{C}$.

Observou-se que após 30 minutos de tempo de contato ocorreu uma demanda de aproximadamente de 1,227 mg/L para a dosagem de 3,5 mg/L 
de $\mathrm{KMnO}_{4}$. Considerando-se a obtenção de uma tonalidade levemente rosa na amostra, adotou-se a dosagem de $\mathrm{KMnO}_{4}$ igual a $3,5 \mathrm{mg} / \mathrm{L}$ com tempo de contato de 30 minutos para ser utilizada nos ensaios experimentais de formação de subprodutos.

\subsubsection{Ensaios de demanda com peróxido de hidrogênio}

Os ensaios de demanda de peróxido de hidrogênio foram realizados nas mesmas condições dos demais pré-oxidantes. Os resultados obtidos de residual em $\mathrm{mg} / \mathrm{L}$ de $\mathrm{H}_{2} \mathrm{O}_{2}$ em função do tempo ficaram abaixo do limite de detecção do método $\left(0,1 \quad \mathrm{mgH}_{2} \mathrm{O}_{2} / \mathrm{L}\right)$ até a dosagem de $35 \mathrm{mg} / \mathrm{L}$. Considerando que acima deste valor, o uso do peróxido de hidrogênio como pré-oxidante poderia ser economicamente inviável, foi adotada a dosagem de $35 \mathrm{mg} / \mathrm{L}$ para os ensaios de formação de subprodutos.

\subsubsection{Ensaios de demanda com ozônio}

Para determinação da demanda de ozônio foi necessário à realização de ensaios preliminares que fornecessem dados para o calculo da capacidade de produção da coluna instalada. Esses resultados estão apresentados na Tabela 5.12. Observa-se que a capacidade de produção de ozônio obtida foi em média de $0,19 \mathrm{~g}$ de $\mathrm{O}_{3} / \mathrm{h}$.

Tabela 5.12 - Resultados dos ensaios para determinação da capacidade de produção de ozônio em função do tempo de contato.

\begin{tabular}{|c|c|c|c|c|c|c|c|}
\hline \multirow{2}{*}{$\begin{array}{c}\text { Tempo } \\
\text { contato } \\
(\min )\end{array}$} & \multicolumn{3}{|c|}{ Fase Líquida } & \multicolumn{3}{|c|}{ Fase gasosa (off gas) } & \multirow[b]{2}{*}{$\begin{array}{c}\mathrm{PT} \\
\mathrm{g} / \mathrm{h} \mathrm{O}_{3}\end{array}$} \\
\hline & $\begin{array}{c}\mathrm{Vg} \\
(\mathrm{mL})\end{array}$ & $\begin{array}{c}\mathrm{D}_{\mathrm{L}} \\
\mathrm{mg} / \mathrm{L} \mathrm{O}_{3}\end{array}$ & $\begin{array}{c}\mathrm{P}_{\mathrm{L}} \\
\left(\mathrm{g} / \mathrm{h} \mathrm{O}_{3}\right)\end{array}$ & $\begin{array}{c}\mathrm{Vg} \\
(\mathrm{mL})\end{array}$ & $\begin{array}{c}D_{G} \\
(\mathrm{mg} / \mathrm{L})\end{array}$ & $\begin{array}{c}\mathrm{PG}_{(\mathrm{G}} \\
\left(\mathrm{g} / \mathrm{h} \mathrm{O}_{3}\right)\end{array}$ & \\
\hline$\overline{5}$ & 0,50 & $\overline{1,5}$ & $\overline{0,19}$ & $\overline{11,19}$ & $\overline{1,76}$ & 0,0084 & 0,20 \\
\hline 10 & 0,9 & 2, & 0,19 & $1, i$ & 1, & 0,004 & 0,19 \\
\hline 15 & 1,33 & 3,9 & 0,17 & 1,25 & 1,85 & 0,0030 & 0,18 \\
\hline 20 & 1,85 & 5,5 & 0,18 & 1,3 & 2,04 & 0,0024 & 0,18 \\
\hline 25 & 2,40 & 7,1 & 0,19 & 1,24 & 1,83 & 0,0018 & 0,19 \\
\hline 30 & 3,15 & 9,3 & 0,20 & 1,53 & 2,26 & 0,0018 & 0,21 \\
\hline & & & & & & média & 0,19 \\
\hline
\end{tabular}


Nas Figuras 5.10 e 5.11, são mostrados os resultados de dosagem e a produção para as fases líquida e gasosa em função do tempo de contato.

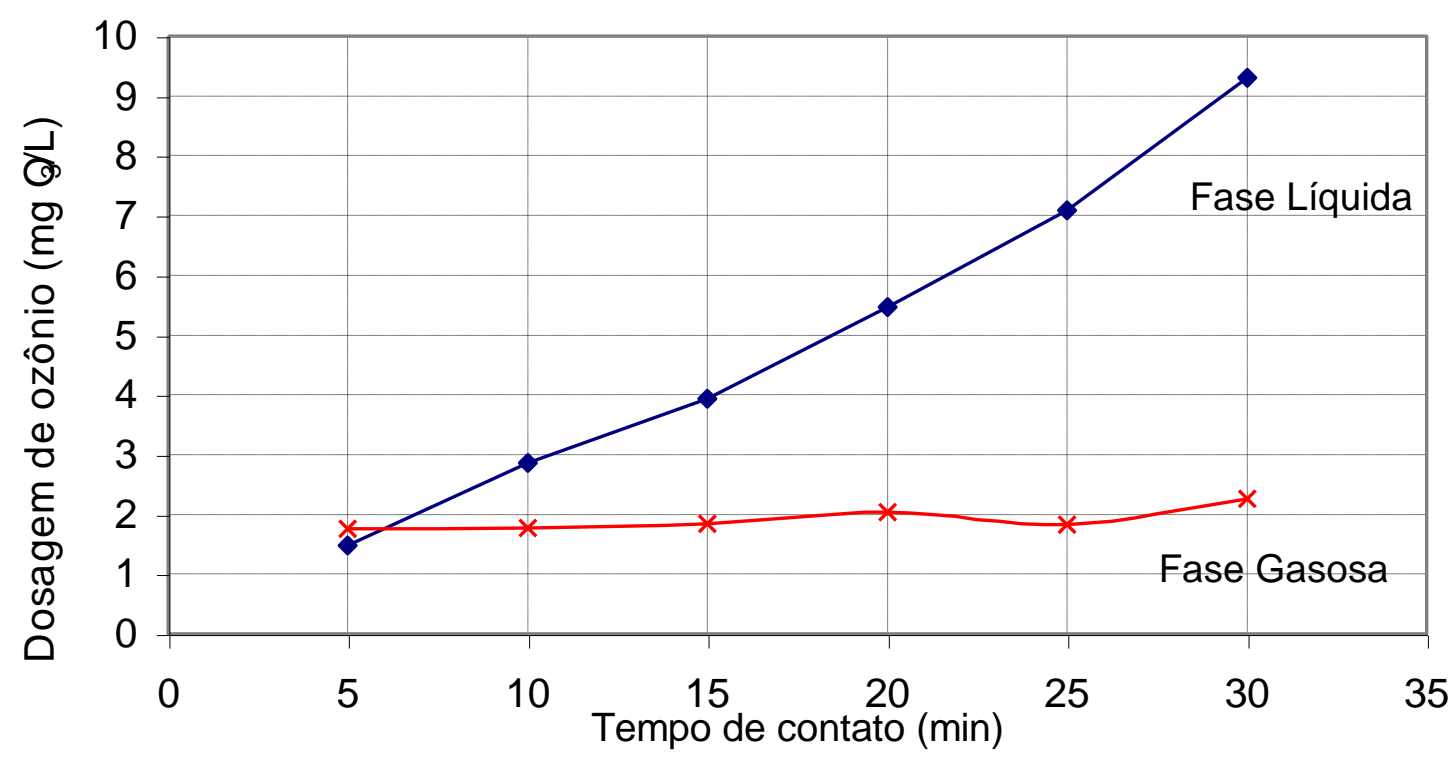

Figura 5.10 - Dosagens obtidas de ozônio em mg/L em função do tempo de contato.

Os ensaios de demanda com ozônio foram realizados em um sistema piloto. Para cada tempo de contato utilizou-se uma batelada de 11 litros de água de estudo com cor $200 \mathrm{uH}$, a aplicação de ozônio foi estabelecida pelos cálculos de capacidade de produção do sistema em $0,19 \mathrm{~g} / \mathrm{h}$ de $\mathrm{O}_{3}$. Os resultados estão apresentados na Tabela 5.13 e na Figura 5.13.

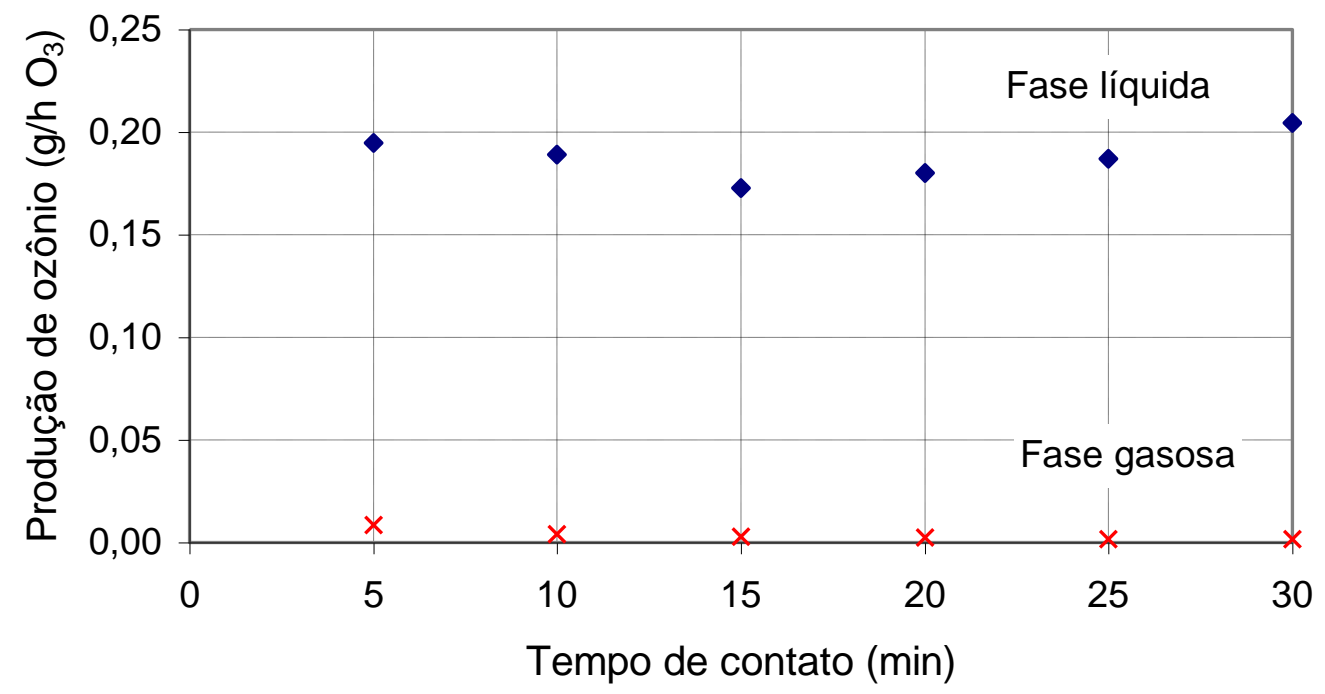

Figura 5.11- Produção de ozônio em função do tempo de contato. 
Após tempo de contato de $30 \mathrm{~min}$, a demanda de ozônio permaneceu em aproximadamente $4,0 \mathrm{mgO}_{3} / \mathrm{L}$ e, com residual na fase líquida de aproximadamente $0,6 \mathrm{mgO}_{3} / \mathrm{L}$, a cor remanescente obtida foi de $116 \mathrm{uH}$. Adotou-se o tempo de contato de 30 minutos de ozonização para ser utilizado nos ensaios de formação de subprodutos. Na Figura 5.12 é mostrada a remoção de cor de $200 \mathrm{uH}$ para $116 \mathrm{uH}$ após 30 minutos de ozonização.

Tabela 5.13- Resultados obtidos dos ensaios de demanda com ozônio em função do tempo de contato.

\begin{tabular}{|c|c|c|c|c|c|c|c|c|}
\hline \multirow{2}{*}{ Parâmetro } & \multirow{2}{*}{ Unidade } & \multicolumn{7}{|c|}{ Tempo de contato (min) } \\
\hline & & 5 & 10 & 15 & 20 & 25 & 30 & 40 \\
\hline $\begin{array}{l}\text { Volume gasto } \\
\text { Fase liquida }\end{array}$ & $\mathrm{mL}$ & 0,05 & 0,26 & 0,19 & 0,26 & 0,21 & 0,2 & 0,23 \\
\hline $\begin{array}{l}\text { Concentração } \\
\text { Residual FL }\end{array}$ & $\mathrm{mg} / \mathrm{L}$ & 0,15 & 0,77 & 0,56 & 0,77 & 0,62 & 0,59 & 0,68 \\
\hline Produção FL & $\mathrm{g} \mathrm{O}_{3} / \mathrm{h}$ & 0,02 & 0,05 & 0,02 & 0,03 & 0,02 & 0,01 & 0,01 \\
\hline
\end{tabular}

\begin{tabular}{lcccccccc}
$\begin{array}{l}\text { Volume gasto } \\
\text { off gas }\end{array}$ & $\mathrm{mL}$ & 1,50 & 13,69 & 40,16 & 47,25 & 53,69 & 76,88 & 127 \\
$\begin{array}{l}\text { Concentração } \\
\text { off gas }\end{array}$ & $\mathrm{mg} \mathrm{O}_{3} / \mathrm{L}$ & 2,21 & 20,21 & 59,28 & 69,74 & 79,25 & 113,47 & 187,45 \\
$\begin{array}{l}\text { Produção } \\
\text { off gas }\end{array}$ & $\mathrm{g} \mathrm{O}_{3} / \mathrm{h}$ & 0,01 & 0,05 & 0,09 & 0,08 & 0,08 & 0,09 & 0,11 \\
\hline
\end{tabular}

\begin{tabular}{|c|c|c|c|c|c|c|c|c|}
\hline $\begin{array}{l}\text { Aplicação de } \\
\mathrm{O}_{3}\end{array}$ & $\mathrm{~g} / \mathrm{h}$ & 0,19 & 0,19 & 0,19 & 0,19 & 0,19 & 0,19 & 0,19 \\
\hline $\begin{array}{l}\text { Produção } \\
\text { remanescente }\end{array}$ & $\mathrm{g} \mathrm{O}_{3} / \mathrm{h}$ & 0,16 & 0,09 & 0,07 & 0,08 & 0,10 & 0,09 & 0,07 \\
\hline $\begin{array}{l}\text { Demanda de } \\
\text { ozônio }\end{array}$ & $\mathrm{mg} \mathrm{O}_{3} / \mathrm{L}$ & 1,21 & 1,38 & 1,60 & 2,45 & 3,70 & 3,92 & 4,02 \\
\hline $\begin{array}{l}\text { Cor } \\
\text { remanescente }\end{array}$ & $\mathrm{uH}$ & 180 & 157 & 136 & 127,4 & 116,7 & 116 & 115 \\
\hline
\end{tabular}




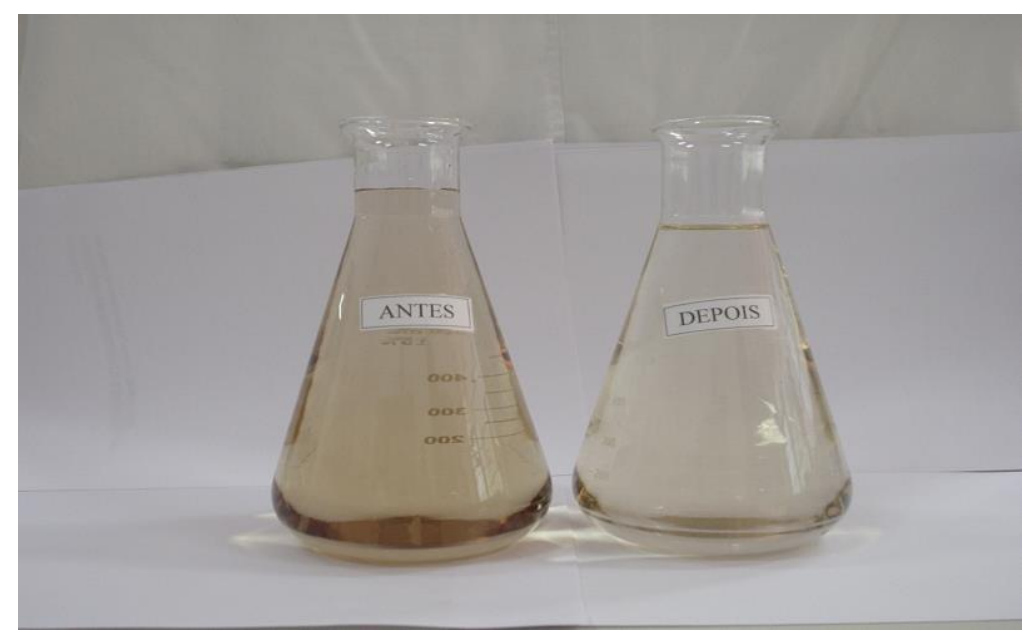

Figura 5.12 - llustração da remoção de cor aparente antes e após 30 minutos de ozonização.

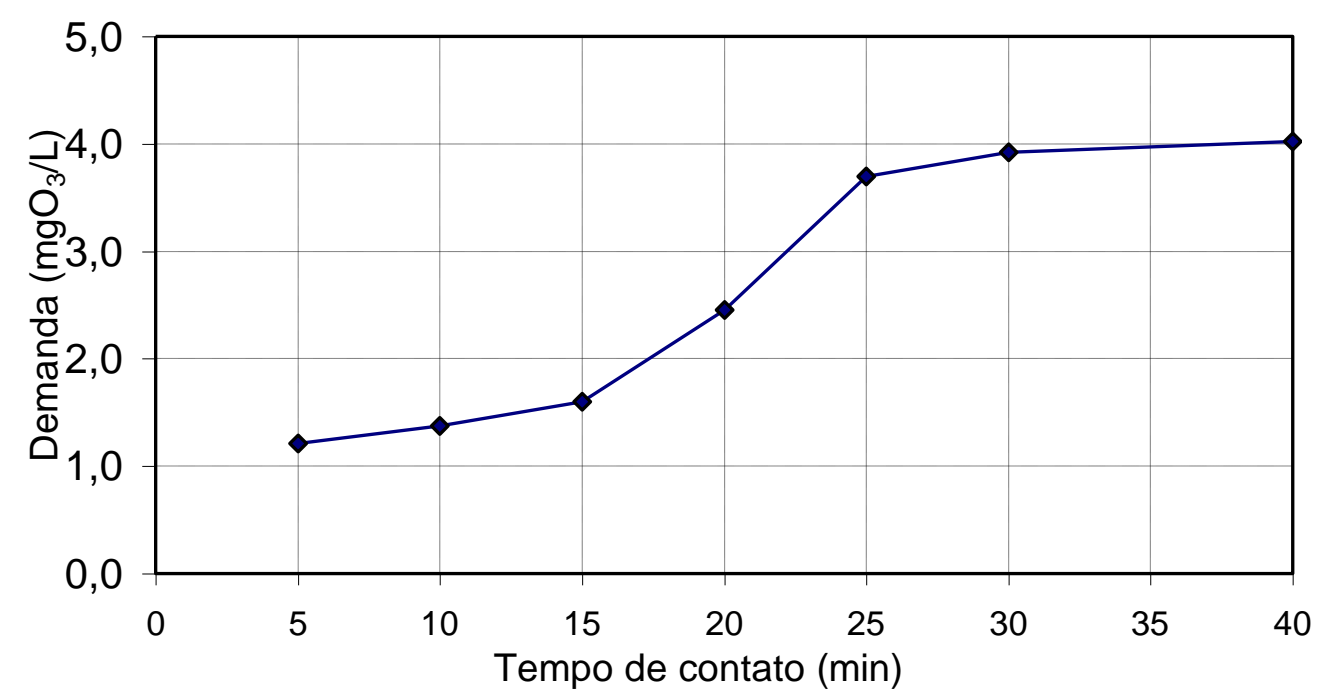

Figura 5.13 - Valores de demanda de ozônio em função do tempo de contato.

\subsubsection{Ensaios de demanda com peróxido de hidrogênio e ozônio (peroxônio)}

A demanda de peroxônio foi definida em função dos resultados obtidos nos ensaios realizados com diferentes dosagens e proporções de peróxido de hidrogênio e ozônio, sendo utilizados, $\mathrm{H}_{2} \mathrm{O}_{2} / \mathrm{O}_{3}: 0,5,1,0$, e 2,0., conforme apresentado na Tabela 5.14. 
Tabela 5.14 - Resultados obtidos de ensaios com dosagens de diferentes proporções de peróxido de hidrogênio e ozônio durante 30 minutos com dosagem aplicada de $8,6 \mathrm{mg} / \mathrm{LO}_{3}$ em 11 litros água de estudo.

\begin{tabular}{lcccc}
\hline \multirow{2}{*}{ Parâmetro } & \multirow{2}{*}{ Unidade } & \multicolumn{3}{c}{ Proporção: $\mathbf{H}_{\mathbf{2}} \mathbf{O}_{\mathbf{2}} / \mathbf{O}_{\mathbf{3}}$} \\
& & $\mathbf{0 , 5}$ & $\mathbf{1 , 0}$ & $\mathbf{2 , 0}$ \\
\hline Volume de $\mathrm{H}_{2} \mathrm{O}_{2}$ adicionado & $\mathrm{mL}$ & 5 & 10 & 20 \\
Dosagem $\mathrm{H}_{2} \mathrm{O}_{2}$ & $\mathrm{mg} / \mathrm{L}$ & 4,3 & 8,6 & 17,2 \\
Tempo contato & $\mathrm{min}$ & 30 & 30 & 30 \\
Volume gasto tiossulfato $\mathrm{FL}$ & $\mathrm{mL}$ & 0,82 & 0,62 & 0,56 \\
Concentração residual $\mathrm{FL}$ & $\mathrm{mgO}_{3} / \mathrm{L}$ & 2,42 & 1,83 & 1,65 \\
Produção FL & $\mathrm{gO}_{3} / \mathrm{h}$ & 0,05 & 0,04 & 0,04 \\
Volume gasto tiossulfato off gas & $\mathrm{mL}$ & 89,8 & 85,00 & 90,59 \\
Concentração off gas & $\mathrm{mgO}_{3} / \mathrm{L}$ & 132,54 & 125,46 & 133,71 \\
Produção off gas & $\mathrm{gO}_{3} / \mathrm{h}$ & 0,11 & 0,10 & 0,11 \\
Aplicação de O & $\mathrm{gO}_{3} / \mathrm{h}$ & 0,19 & 0,19 & 0,19 \\
Produção remanescente & $\mathrm{gO}_{3} / \mathrm{h}$ & 0,03 & 0,05 & 0,05 \\
Dosagem consumida & $\mathrm{mgO}_{3} / \mathrm{L}$ & 1,40 & 2,24 & 2,12 \\
Cor remanescente & $\mathrm{uH}$ & 105 & 106 & 113 \\
\hline
\end{tabular}

Avaliando os resultados do ensaio, a proporção $\mathrm{H}_{2} \mathrm{O}_{2} / \mathrm{O}_{3}$ igual a 2,0 apresentou menor remoção de cor remanescente; as demais proporções estudadas apresentaram valores próximos de remoção de cor. Considerando o custo-benefício do uso de peróxido de hidrogênio para aplicação em ETAs, adotou-se a proporção $\mathrm{H}_{2} \mathrm{O}_{2} / \mathrm{O}_{3}$ igual a 0,5 conforme relação estequiométrica apresentada pela reação química (4.8), sendo a dosagem estabelecida em 4,3mg $\mathrm{H}_{2} \mathrm{O}_{2} / \mathrm{L} \mathrm{e} 8,6 \mathrm{mg} \mathrm{O}_{3} / \mathrm{L}$.

$1 \mathrm{H}_{2} \mathrm{O}_{2}+2 \mathrm{O}_{3} \rightarrow 2 \mathrm{OH}+3 \mathrm{O}_{3}$

\subsection{Resultados dos ensaios de jarteste para determinação da dosagem de coagulante}

Após terem sido determinadas as dosagens de pré-oxidantes, foram realizados ensaios em jarteste para determinação da dosagem de coagulante. Estes ensaios foram realizados separadamente para cada préoxidante em estudo.

As condições de pré-oxidação foram estabelecidas pelos resultados dos ensaios de demanda, o coagulante utilizado em todos os ensaios foi o sulfato de alumínio, $\mathrm{Al}_{2}(\mathrm{SO} 4)_{3} \cdot 14,3 \mathrm{H}_{2} \mathrm{O}$, tendo sido utilizada uma solução com concentração de $5000 \mathrm{mg} / \mathrm{L}$. As condições de mistura rápida foram 
mantidas com um gradiente de velocidade em $1000 \mathrm{~s}^{-1}$ e com tempo de mistura rápida de 1 minuto, seguido de filtração em filtro de papel Whatman 40 e leitura de cor remanescente. Os resultados obtidos para cada préoxidante são colocados a seguir.

\subsubsection{Cloro}

As condições estabelecidas para os ensaios com cloro foram: dosagem de cloro na pré-oxidação de $5 \mathrm{mg} / \mathrm{L} \mathrm{Cl}_{2} ; \mathrm{pH}$ da água de estudo igual a 7,60; adição de $100 \mu \mathrm{L} \mathrm{HCl}(1 \mathrm{~N})$ para obtenção de $\mathrm{pH}$ igual a 6,0 na coagulação, otimizado por WIECHETECH (2005). Pelos resultados obtidos, a dosagem de sulfato de alumínio (SA) que proporcionou a obtenção de água com cor remanescente $<5 \mathrm{uH}$ foi $14 \mathrm{mg} / \mathrm{L}$ de $\mathrm{Al}_{2}(\mathrm{SO} 4)_{3} \cdot 14,3 \mathrm{H}_{2} \mathrm{O}$. Na Tabela 5.15 e a Figura 5.14 estão apresentados os resultados obtidos.

Tabela 5.15 - Resultados obtidos nos ensaios com o cloro na pré-oxidação.

\begin{tabular}{cccc}
\hline Jarro & $\begin{array}{c}\text { Dosagem de sulfato de } \\
\text { alumínio }(\mathrm{mg} / \mathrm{L})\end{array}$ & $\begin{array}{c}\mathrm{pH} \text { de } \\
\text { coagulação }\end{array}$ & $\begin{array}{c}\text { Cor aparente } \\
\text { remanescente }(\mathrm{uH})\end{array}$ \\
\hline \hline $\mathbf{1}$ & 10 & 6,37 & 138 \\
2 & 12 & 6,03 & 6 \\
3 & 14 & 5,70 & 4 \\
4 & 16 & 5,44 & 11 \\
5 & 18 & 5,09 & 15 \\
$\mathbf{6}$ & 20 & 5,00 & 59 \\
\hline
\end{tabular}

Nota: sulfato de alumínio como $\mathrm{Al}_{2}\left(\mathrm{SO}_{4}\right)_{3} \cdot 14,3 \mathrm{H}_{2} \mathrm{O}$

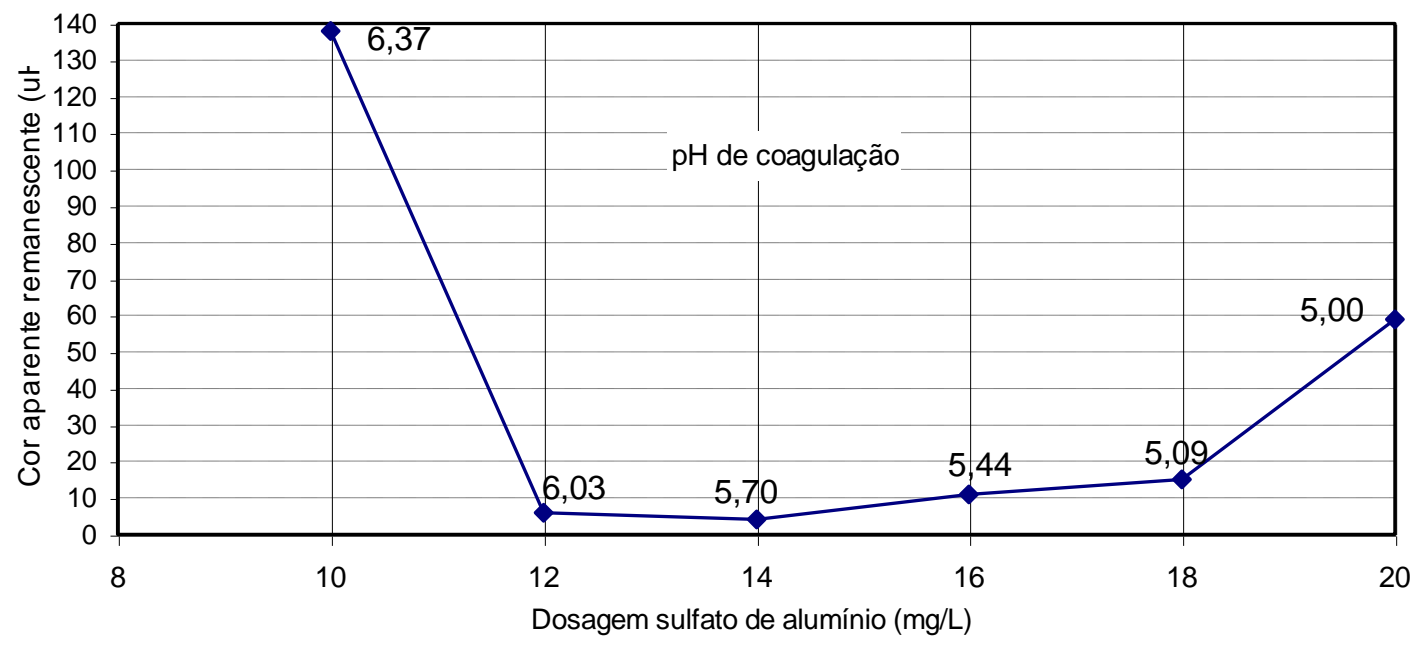

Figura 5.14 - Dosagem de sulfato de alumínio em função da cor remanescente utilizando-se cloro como pré-oxidante. 


\subsubsection{Dióxido de cloro}

As condições dos ensaios foram: dosagens de 1,2 mg/L $\mathrm{ClO}_{2}$ de dióxido de cloro na pré-oxidação; $\mathrm{pH}$ da água pré-oxidada igual a 6,41 sem adição de ácido clorídrico. Pelos resultados obtidos, a dosagem obtida de sulfato de alumínio que proporcionou a obtenção de água com cor remanescente $<5 \mathrm{uH}$ foi $10 \mathrm{mg} / \mathrm{L}$ AS e o residual obtido de dióxido de cloro foi de $0,057 \mathrm{mg} / \mathrm{L} \mathrm{ClO}_{2}$. A Tabela 5.16 e a Figura 5.15 apresentam os resultados obtidos.

Tabela 5.16 - Resultados do ensaio com o pré-oxidante dióxido de cloro

\begin{tabular}{cccc}
\hline Jarro & $\begin{array}{c}\text { Dosagem de Sulfato de } \\
\text { alumínio }(\mathrm{mg} / \mathrm{L})\end{array}$ & $\begin{array}{c}\mathrm{pH} \text { de } \\
\text { coagulação }\end{array}$ & $\begin{array}{c}\text { Cor aparente } \\
\text { Remanescente }(\mathrm{uH})\end{array}$ \\
\hline \hline 1 & 4 & 6,46 & 169 \\
2 & 6 & 6,25 & 174 \\
3 & 8 & 6,11 & 170 \\
$\mathbf{4}$ & 10 & $\mathbf{5 , 8 2}$ & $\mathbf{3}$ \\
5 & 12 & 5,43 & 5 \\
6 & 14 & 5,18 & 7 \\
\hline
\end{tabular}

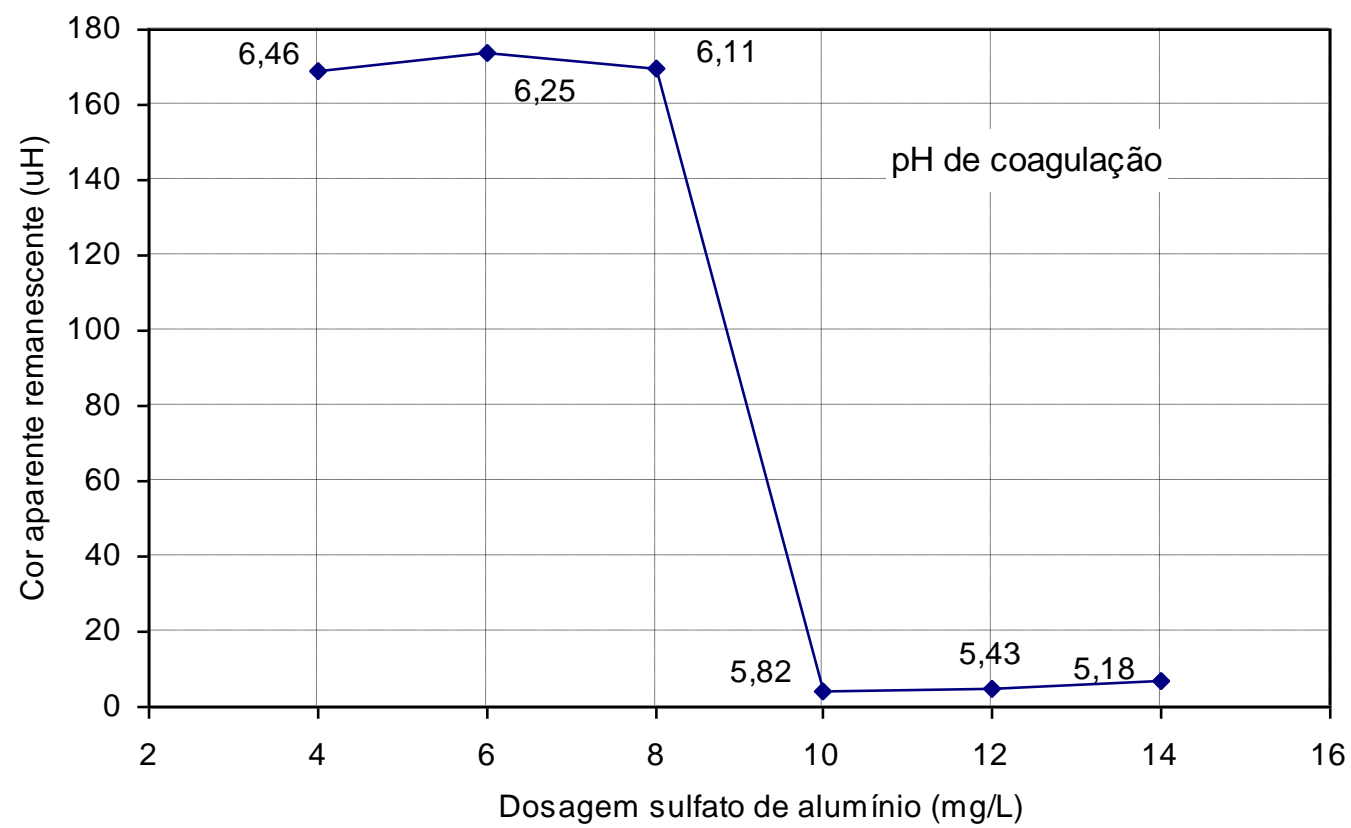

Figura 5.15 - Dosagem de sulfato de alumínio em função da cor aparente remanescente e $\mathrm{pH}$ de coagulação utilizando-se dióxido de cloro na préoxidação. 


\subsubsection{Permanganato de potássio}

As condições dos ensaios de pré-oxidação com permanganato de potássio foram: dosagem de $2 \mathrm{mg} / \mathrm{L}$ de $\mathrm{KMnO}_{4} ; \mathrm{pH}$ da água de estudo foi de 7,60 e pH da água pré-oxidada foi de 7,34; o volume adicionado de $\mathrm{HCl}$ $(0,1 \mathrm{~N})$ foi de $0,5 \mathrm{~mL}$. A dosagem de alumínio que forneceu cor remanescente igual a $3 \mathrm{uH}(<5 \mathrm{uH})$ foi $12 \mathrm{mg} / \mathrm{L} \mathrm{SA}$. Na Tabela 5.17 e na Figura 5.16 estão apresentados os resultados obtidos.

Tabela 5.17- Resultados obtidos no ensaio com permanganato de potássio.

\begin{tabular}{cccc}
\hline Jarro & $\begin{array}{c}\text { Dosagem de sulfato de } \\
\text { alumínio }(\mathrm{mg} / \mathrm{L})\end{array}$ & $\begin{array}{c}\mathrm{pH} \text { de } \\
\text { coagulação }\end{array}$ & $\begin{array}{c}\text { Cor aparente } \\
\text { remanescente(uH) }\end{array}$ \\
\hline 1 & 10 & 6,18 & 80 \\
2 & 12 & 6,12 & 3 \\
3 & 14 & 5,86 & 4 \\
4 & 16 & 5,58 & 10 \\
5 & 18 & 5,25 & 26 \\
6 & 20 & 5,08 & 25 \\
\hline
\end{tabular}

Nota: sulfato de alumínio como $\mathrm{Al}_{2}(\mathrm{SO} 4)_{3} .14,3 \mathrm{H}_{2} \mathrm{O}$

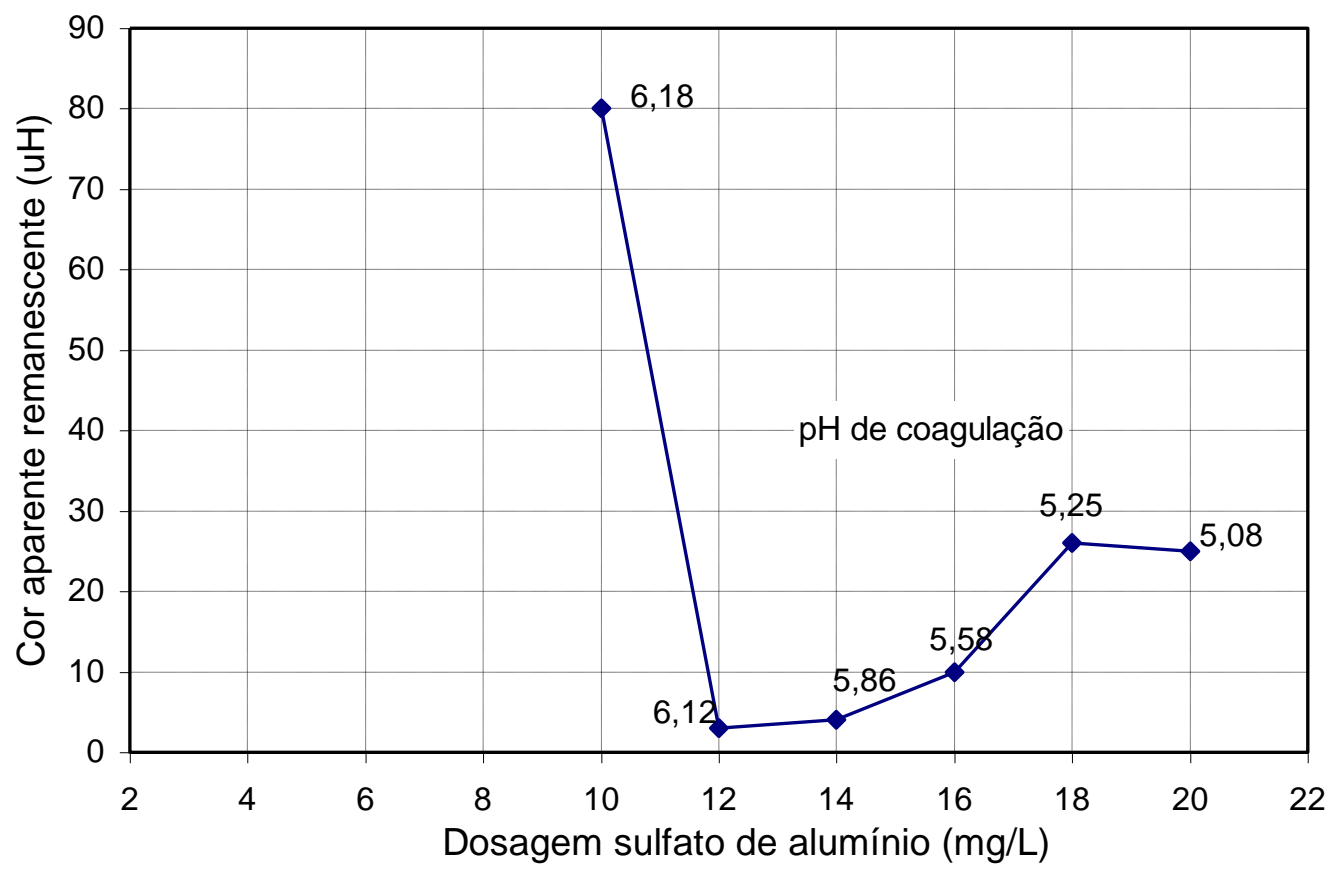

Figura 5.16 - Dosagem de sulfato de alumínio em função da cor aparente remanescente e $\mathrm{pH}$ de coagulação utilizando-se $\mathrm{KMnO}_{4}$ como pré-oxidante. 


\subsubsection{Peróxido de hidrogênio}

As condições dos ensaios foram: dosagem de peróxido de hidrogênio $35 \mathrm{mg} / \mathrm{L} \mathrm{H}_{2} \mathrm{O}_{2}$; $\mathrm{pH}$ da água de estudo 7,03 e pH da água pré-oxidada 7,10; volume de $0,2 \mathrm{~mL}$ de $\mathrm{HCl}(0,01 \mathrm{~N})$. A dosagem de sulfato de alumínio que forneceu cor remanescente $<1 \mathrm{uH}$ foi de $12 \mathrm{mg} / \mathrm{L}$. A Tabela 5.18 e a Figura 5.17 apresentam os resultados obtidos.

Tabela 5.18 - Resultados obtidos nos ensaios com peróxido de hidrogênio.

\begin{tabular}{cccc}
\hline Jarro & $\begin{array}{c}\text { Dosagem de sulfato } \\
\text { de alumínio }(\mathrm{mg} / \mathrm{L})\end{array}$ & $\begin{array}{c}\mathrm{pH} \text { de } \\
\text { coagulação }\end{array}$ & $\begin{array}{c}\text { Cor aparente } \\
\text { remanescente }(\mathrm{uH})\end{array}$ \\
\hline \hline 1 & 10 & 6,64 & 50 \\
2 & 12 & 6,43 & $<1$ \\
3 & 14 & 6,24 & $<1$ \\
4 & 16 & 6,00 & 5 \\
5 & 18 & 5,65 & 48 \\
6 & 20 & 5,35 & 74 \\
\hline
\end{tabular}

Nota: sulfato de alumínio como $\mathrm{Al}_{2}(\mathrm{SO} 4)_{3} \cdot 14,3 \mathrm{H}_{2} \mathrm{O}$

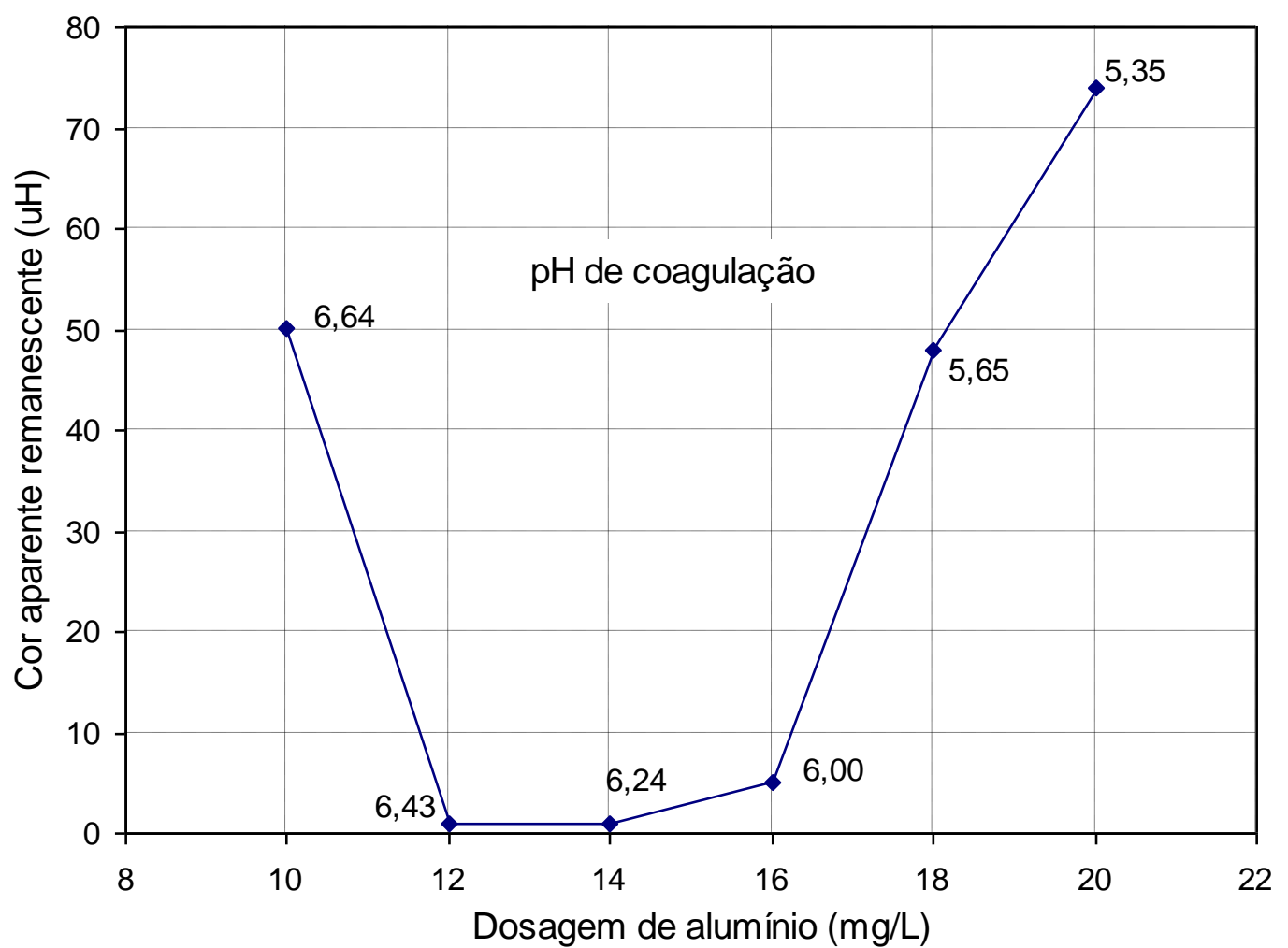

Figura 5.17 - Dosagem de sulfato de alumínio em função da cor aparente remanescente e $\mathrm{pH}$ de coagulação utilizando-se peróxido de hidrogênio como pré-oxidante. 


\subsubsection{Ozônio}

Os resultados dos ensaios para determinação da dosagem de coagulante com a utilização de ozônio na pré-oxidação estão apresentados na Tabela 5.19. A água de estudo inicialmente apresentou cor $203 \mathrm{uH} \mathrm{e} \mathrm{pH}$ 5,77 .

Tabela 5.19 Resultados de pH e cor remanescente em função da dosagem de sulfato de alumínio para diferentes tempos de contato.

\begin{tabular}{|c|c|c|c|c|c|c|c|}
\hline \multirow{4}{*}{\multicolumn{2}{|c|}{$\begin{array}{c}\text { Tempo de } \\
\text { contato na } \\
\text { pré-oxidação }\end{array}$}} & \multirow{4}{*}{$\begin{array}{c}\text { Após } \\
\text { pré-oxidação }\end{array}$} & \multicolumn{5}{|c|}{$\mathrm{N}^{\circ}$ jarros } \\
\hline & & & 1 & 2 & 3 & 4 & 5 \\
\hline & & & \multicolumn{5}{|c|}{ Dosagem sulfato alumínio (mg/L) } \\
\hline & & & 12 & 16 & 20 & 24 & 28 \\
\hline \multirow{2}{*}{$10 \mathrm{~min}$} & $\mathrm{pH}$ & 7,25 & 6,74 & 6,10 & 5,68 & 5,20 & $4,9,92$ \\
\hline & Cor & 157 & 151 & 3 & 18 & 56 & 51 \\
\hline \multirow{2}{*}{$15 \min$} & $\mathrm{pH}$ & 7,25 & 6,44 & 6,19 & 6,05 & 5,65 & 5,20 \\
\hline & Cor & 136 & 131 & 25 & 2 & 4 & 32 \\
\hline \multirow{2}{*}{$20 \min$} & $\mathrm{pH}$ & 7,53 & 6,38 & 6,11 & 5,72 & 5,33 & 5,00 \\
\hline & Cor & 127,4 & 121 & 4 & 7 & 57 & 75 \\
\hline \multirow{2}{*}{$25 \mathrm{~min}$} & $\mathrm{pH}$ & 7,50 & 6,42 & 6,06 & 5,61 & 5,20 & 4,92 \\
\hline & Cor & 120 & 109 & 4 & 2 & 22 & 38 \\
\hline \multirow{2}{*}{$30 \mathrm{~min}$} & $\mathrm{pH}$ & 7,05 & 6,24 & 6,01 & 5,63 & 5,22 & 5,00 \\
\hline & Cor & 116 & 97 & 11 & 4 & 22 & 43 \\
\hline
\end{tabular}

Pelos resultados obtidos, o tempo de contato de 30 minutos na préoxidação com ozônio foi mais eficiente na remoção de cor (43\%), a dosagem ótima de sulfato de alumínio foi de $20 \mathrm{mg} / \mathrm{L} \mathrm{com} \mathrm{pH}$ igual a 5,63. Na Figura 5.18 estão os resultados obtidos para todos os tempos de contato e na Tabela 5.20 e na Figura 5.19 estão apresentados os resultados do ensaio para o tempo de contato de 30 minutos com os valores obtidos de $\mathrm{pH}$ de coagulação. 
Tabela 5.20 - Resultados dos ensaios de dosagem de coagulante na água pré-oxidada com ozônio em pH após ozonização de 7,25 e cor remanescente $116 \mathrm{uH}$.

\begin{tabular}{cccc}
\hline jarro & $\begin{array}{c}\text { Dosagem } \\
\text { Sulfato de alumínio } \\
\mathbf{m g / L}\end{array}$ & $\mathbf{p H}$ & $\begin{array}{c}\text { Cor remanescente } \\
\text { (uH) }\end{array}$ \\
\hline \hline 1 & 12 & 6,24 & 97 \\
2 & 16 & 6,01 & 11 \\
3 & 20 & 5,63 & 4 \\
4 & 24 & 5,22 & 22 \\
5 & 28 & 5,00 & 43 \\
\hline
\end{tabular}

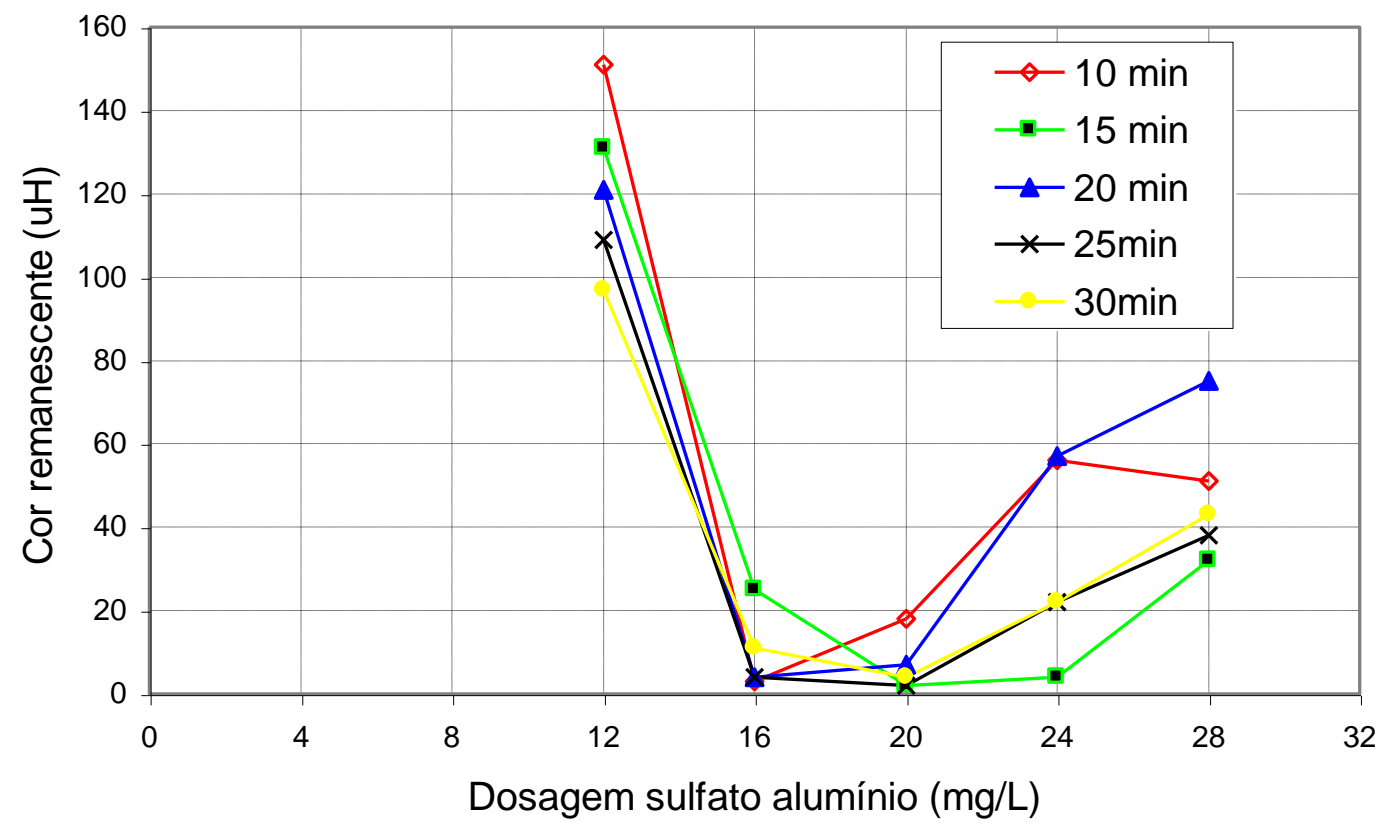

Figura 5.18 - Valores de cor remanescente em função da dosagem de sulfato de alumínio para diversos tempos de contato, utilizando-se ozônio como pré-oxidante.

Após a determinação do tempo de contato na pré-oxidação com ozônio e a dosagem de coagulante a ser empregada, foram calculados os valores da dosagem consumida de ozônio com medidas de concentração de residual na fase líquida e na fase gasosa. Na Tabela 5.21 estão apresentados os resultados obtidos. 


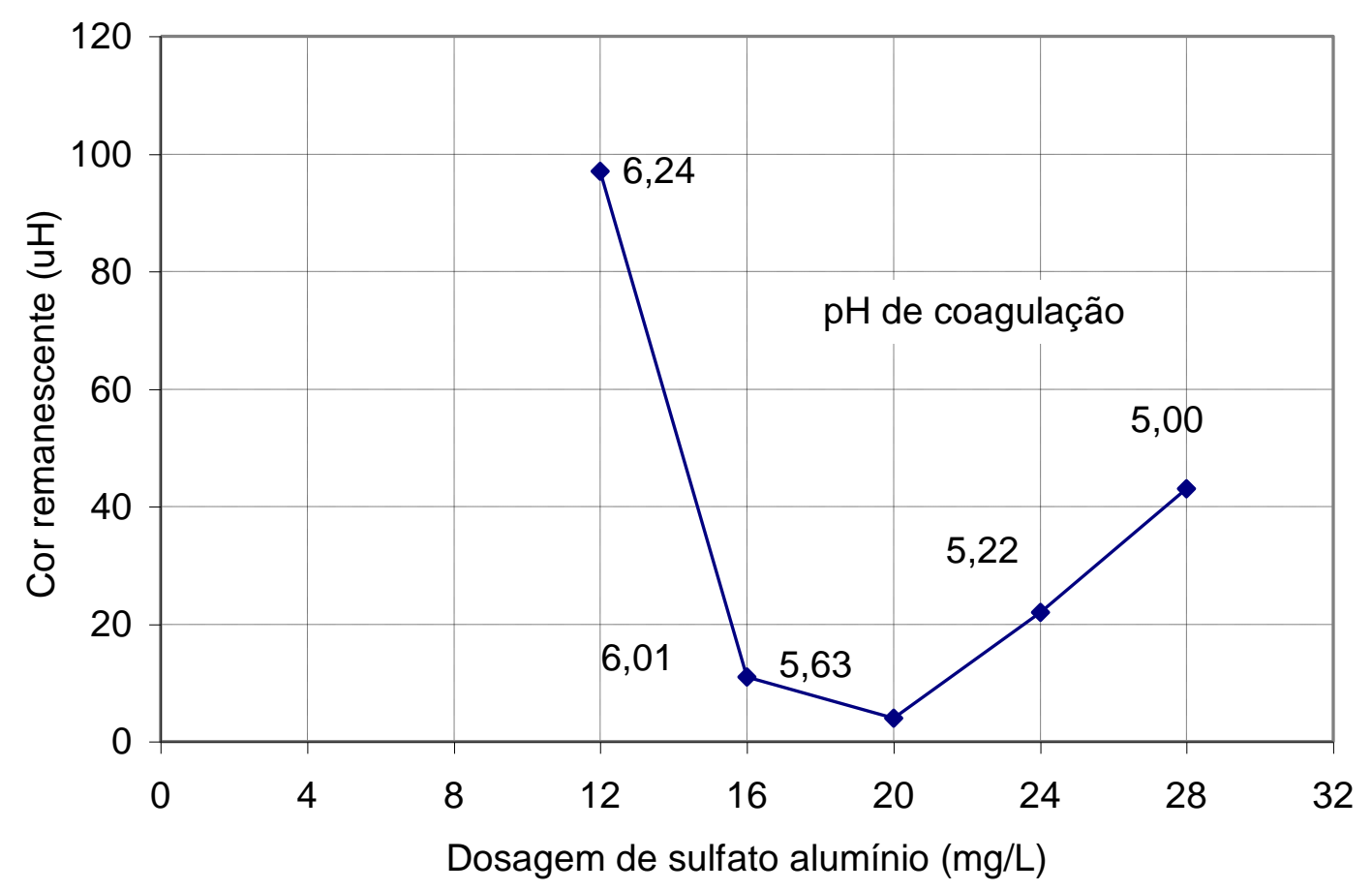

Figura 5.19 - Valores de cor remanescente em função da dosagem de sulfato de alumínio, utilizando-se ozônio como pré-oxidante no tempo de contato de 30 minutos.

Tabela 5.21- Resultados de concentração residual de ozônio e cálculo da dosagem consumida para o tempo de contato de 30 minutos considerando a produção de $0,19 \mathrm{~g} \mathrm{O}_{3} / \mathrm{h}$.

\begin{tabular}{lccc}
\hline & $\begin{array}{c}\text { Volume gasto de } \\
\text { tiossulfato }(\mathrm{mL})\end{array}$ & $\begin{array}{c}\text { Concentração } \\
\text { residual } \\
\left(\mathrm{mg} \mathrm{O}_{3} / \mathrm{L}\right)\end{array}$ & $\begin{array}{c}\text { Dosagem } \\
\text { consumida } \\
\left(\mathrm{g} \mathrm{O}_{3} / \mathrm{h}\right)\end{array}$ \\
\hline \hline Residual fase gasosa (off gás) & 76,88 & 113,475 & 0,091 \\
Residual fase liquida & 0,2 & 0,590 & 0,013 \\
$\mathrm{D}_{\mathrm{A}}-\mathrm{D}_{\mathrm{FL}}-\mathrm{D}_{\mathrm{G}}$ & & & 0,086 \\
\hline
\end{tabular}

Pela equação, calculou-se a dosagem consumida de ozônio.

$\mathrm{D}_{\text {Consumida }} \mathrm{O}_{3}=\left(\mathrm{D}_{\mathrm{A}}-\mathrm{D}_{\mathrm{FL}}-\mathrm{D}_{\mathrm{G}}\right){ }^{*} \mathrm{TC}^{*} 1000 / \mathrm{VC}{ }^{*} 60$

$D_{\text {Consumida }} \mathrm{O}_{3}=0,086 * 30 * 1000 / 11 * 60$

$\mathrm{D}$ Consumida $\mathrm{O}_{3}=3,920 \mathrm{mg} \mathrm{O} / \mathrm{L}$ 


\subsubsection{Peroxônio}

Os resultados dos ensaios para determinação da dosagem de coagulante com a utilização de peroxônio na pré-oxidação estão apresentados na Tabela 5.22 e na Figura 5.20. Para a dosagem aplicada de $18 \mathrm{mg} / \mathrm{L}$ de $\mathrm{SA}$, cor remanescente ficou abaixo de $5 \mathrm{uH}$ para as proporções $\mathrm{H}_{2} \mathrm{O}_{2} / \mathrm{O}_{3}: 0,5,1,0$ e 2,0 .

Tabela 5.22- Valores obtidos de cor remanescente e pH de coagulação em função da variação da dosagem de sulfato de alumínio para proporções de $\mathrm{H}_{2} \mathrm{O}_{2} / \mathrm{O}_{3}: 0,5,1,0$ e 2,0 .

\begin{tabular}{cccccc}
\hline Jarro & $\begin{array}{c}\text { Dosagem de } \\
\text { sulfato de alumínio } \\
(\mathrm{mg} / \mathrm{L})\end{array}$ & $\begin{array}{c}\text { pH de } \\
\text { coagulação }\end{array}$ & 0,5 & 1,0 & 2,0 \\
\hline \hline 1 & 12 & 6,10 & 103 & 85 & 83 \\
2 & 14 & 6,04 & 71 & 21 & 17 \\
3 & 16 & 5,90 & 8 & 11 & 6 \\
4 & 18 & 5,61 & 3 & 2 & 1 \\
5 & 20 & 5,43 & 10 & 1 & 1 \\
\hline
\end{tabular}

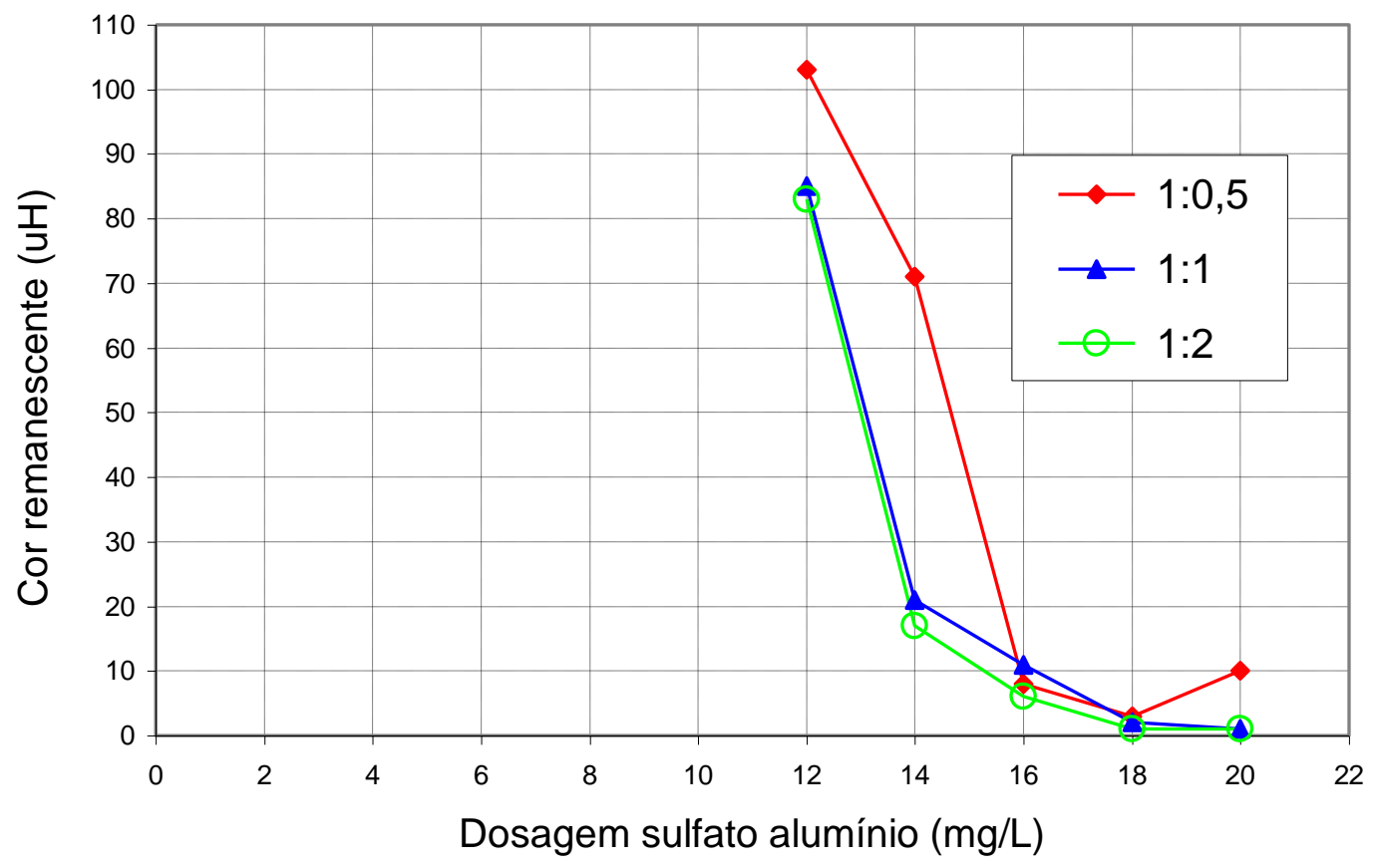

Figura 5.20 - Valores de cor remanescente em função da dosagem de sulfato de alumínio para diferentes proporções de $\mathrm{H}_{2} \mathrm{O}_{2} / \mathrm{O}_{3}$. 
Na Tabela 5.23 estão apresentados os resultados obtidos nos ensaios preliminares que determinaram a demanda de pré-oxidante e a dosagem de coagulante em função da cor remanescente. Esses resultados foram utilizados nos ensaios experimentais para avaliação da formação de subprodutos.

Tabela 5.23- Resumo dos resultados obtidos nos ensaios em jarteste de dosagem de sulfato de alumínio e pH de coagulação para os diferentes préoxidantes em função da cor aparente remanescente.

\begin{tabular}{|c|c|c|c|c|c|}
\hline $\begin{array}{c}\text { Tipo } \\
\text { pré-oxidante }\end{array}$ & $\begin{array}{c}\text { Dosagem } \\
\text { pré-oxidante } \\
(\mathrm{mg} / \mathrm{L})\end{array}$ & $\begin{array}{c}\text { Dosagem } \\
\text { coagulante } \\
\text { (mg/L) }\end{array}$ & $\begin{array}{c}\mathrm{pH} \\
\text { de } \\
\text { coagulação }\end{array}$ & $\begin{array}{c}\text { Cor após } \\
\text { filtração } \\
\text { (uH) }\end{array}$ & $\begin{array}{c}\text { Pós-cloração } \\
\left.(\mathrm{mg} / \mathrm{L} \mathrm{Cl})_{2}\right)\end{array}$ \\
\hline Cloro & 5,0 & 14 & 5,70 & 4 & 5 \\
\hline Dióxido de cloro & 1,2 & 10 & 5,82 & 4 & 5 \\
\hline Permanganato & 3,5 & 12 & 6,12 & 3 & 5 \\
\hline Peróxido & 35,0 & 12 & 6,43 & $<1$ & 5 \\
\hline Ozônio & 3,92 & 20 & 5,63 & 4 & 5 \\
\hline Peroxônio & $4,3: 8,6$ & 18 & 5,61 & 3 & 5 \\
\hline
\end{tabular}

\subsection{Potencial de formação de subprodutos orgânicos halogenados}

Os resultados dos ensaios experimentais de formação de subprodutos orgânicos halogenados, em presença de excesso de cloro por 7 dias estão apresentados na Tabela 5.24. Alguns cromatogramas típicos estão apresentados nos Apêndices C.

As condições estabelecidas para a realização dos ensaios foram: volume de $4 \mathrm{~L}$ de água de estudo com cor $200 \mathrm{uH}$, a dosagem excessiva de cloro (hipoclorito de cálcio) foi de $15 \mathrm{mg} / \mathrm{L}$ expresso como cloro; adição de tampão para ajuste de $\mathrm{pH}$ igual a 7,0; a temperatura de incubação foi mantida à $25^{\circ} \mathrm{C}$; o tempo de contato variou de: $0,5,2,6,12,24,48,120 \mathrm{e}$ $168 \mathrm{~h}$. 
Um frasco contendo 4 litros de água do poço sem a presença de substância húmica foi submetido às mesmas condições, e foram retiradas alíquotas após os tempos de contato de 0,5h e 168h (branco).

Tabela 5.24- Resultados de subprodutos orgânicos halogenados obtidos por análises cromatográficas expressos em $\mu \mathrm{g} / \mathrm{L}$ à $25^{\circ} \mathrm{C}$ com dosagem de cloro de $15 \mathrm{mg} / \mathrm{LCl}_{2}$ em água com cor aparente $200 \mathrm{uH}$.

\begin{tabular}{|c|c|c|c|c|c|c|c|c|}
\hline \multirow{2}{*}{ Subprodutos } & \multicolumn{8}{|c|}{ Tempo de contato $(\mathrm{h})$} \\
\hline & 0,5 & 2 & 6 & 12 & 24 & 48 & 120 & 168 \\
\hline \multicolumn{9}{|l|}{ Trialometanos } \\
\hline Clorofórmio & 32,74 & 50,58 & 57,54 & 79,32 & 84,47 & 79,47 & 112,17 & 117,82 \\
\hline Bromodiclorometano & 0,80 & 1,02 & 1,55 & 1,21 & 1,16 & 3,98 & 1,37 & 1,38 \\
\hline Dibromoclorometano & 0,73 & 0,61 & 1,14 & $<0,1$ & $<0,2$ & 0,69 & 0,90 & 0,60 \\
\hline Bromofórmio & $<0,1$ & $<0,1$ & $<0,1$ & $<0,1$ & $<0,1$ & $<0,1$ & $<0,1$ & $<0,1$ \\
\hline Total TAMs $(\mu \mathrm{g} / \mathrm{L})$ & 34,27 & 52,21 & 60,23 & 80,53 & 85,63 & 84,14 & 114,44 & 119,80 \\
\hline \multicolumn{9}{|l|}{ Clorohidrato } \\
\hline Total CH $(\mu \mathrm{g} / \mathrm{L})$ & 2,48 & 4,62 & 5,56 & 7,26 & 8,47 & 13,95 & 24,81 & 28,82 \\
\hline \multicolumn{9}{|l|}{ Haloacetonitrilas: } \\
\hline Tricloroacetonitrila & $<0,1$ & $<0,1$ & $<0,1$ & $<0,1$ & $<0,1$ & $<0,1$ & $<0,1$ & $<0,1$ \\
\hline Dicloroacetonitrila & 2,68 & 4,62 & 6,48 & 8,66 & 8,01 & 7,93 & 6,25 & 5,68 \\
\hline Dibromoacetonitrila & $<0,1$ & $<0,1$ & 1,52 & $<0,1$ & 2,59 & 2,09 & $<0,1$ & $<0,1$ \\
\hline Bromocloroacetonitrila & $<0,1$ & $<0,1$ & $<0,1$ & $<0,1$ & $<0,1$ & $<0,1$ & $<0,1$ & $<0,1$ \\
\hline Total HANs $(\mu \mathrm{g} / \mathrm{L})$ & 2,68 & 4,62 & 8,00 & 8,66 & 10,60 & 10,02 & 6,25 & 5,68 \\
\hline \multicolumn{9}{|l|}{ Halocetonas } \\
\hline 1,1,1 Tricloropropanona & 2,72 & 3,23 & 3,35 & 4,32 & 3,39 & 3,35 & 1,40 & 1,01 \\
\hline 1,1-Dicloropropanona & $<0,1$ & $<0,1$ & $<0,1$ & $<0,1$ & $<0,1$ & $<0,1$ & $<0,1$ & $<0,1$ \\
\hline Total Hk & 2,72 & 3,23 & 3,35 & 4,32 & 3,39 & 3,35 & 1,40 & 1,01 \\
\hline \multicolumn{9}{|l|}{ Halopicrinas } \\
\hline Cloropicrina ( & $<0,1$ & $<0,1$ & $<0,1$ & $<0,1$ & $<0,1$ & $<0,1$ & $<0,1$ & $<0,1$ \\
\hline \multicolumn{9}{|l|}{ Ácidos haloacéticos } \\
\hline MCAA & 3,37 & 1,71 & 1,35 & 2,87 & 14,27 & 3,57 & $<0,1$ & 8,17 \\
\hline MBAA & $<0,1$ & $<0,1$ & $<0,1$ & $<0,1$ & $<0,1$ & 0,84 & $<0,1$ & $<0,1$ \\
\hline DCAA & 15,36 & 13,05 & 13,09 & 14,54 & 20,37 & 22,23 & 50,38 & 87,40 \\
\hline TCAA & 14,57 & 33,55 & 34,06 & 45,40 & 63,73 & 71,81 & 61,31 & 101,48 \\
\hline BCAA & 0,66 & $<0,1$ & $<0,1$ & $<0,1$ & $<0,1$ & 0,11 & $<0,1$ & $<0,1$ \\
\hline BDCAA & $<0,1$ & $<0,1$ & $<0,1$ & $<0,1$ & $<0,1$ & $<0,1$ & $<0,1$ & $<0,1$ \\
\hline DBAA & $<0,1$ & $<0,1$ & $<0,1$ & $<0,1$ & $<0,1$ & $<0,1$ & $<0,1$ & $<0,1$ \\
\hline CDBAA & 4,63 & 0,91 & 0,85 & 0,42 & $<0,1$ & $<0,1$ & $<0,1$ & $<0,1$ \\
\hline TBAA & $<0,1$ & $<0,1$ & $<0,1$ & $<0,1$ & $<0,1$ & $<0,1$ & $<0,1$ & $<0,1$ \\
\hline Total AHAs $(\mu \mathrm{g} / \mathrm{L})$ & 38,59 & 49,22 & 49,35 & 63,23 & 98,37 & 98,56 & 111,69 & 197,32 \\
\hline
\end{tabular}

Os resultados do potencial de formação de subprodutos foram calculados a partir da diferença entre a variação da concentração de 
subprodutos orgânicos halogenados formados entre $0,5 \mathrm{~h}$ e $168 \mathrm{~h}$ (7 dias) e da variação da concentração em uma amostra sem a presença de substâncias húmicas, conforme mostra a equação (5.1).

$P F_{7 d i a s}=\left[\left(C_{F}-C_{0}\right)-\left(C_{F B}-C_{0 B}\right)\right]$

onde:

$\mathrm{C}_{\mathrm{F}}$ : Concentração obtida após 168h $(\mu \mathrm{g} / \mathrm{L})$

$\mathrm{C}_{0}$ : Concentração inicial obtida após $0,5 \mathrm{~h} \quad(\mu \mathrm{g} / \mathrm{L})$

$\mathrm{C}_{\mathrm{FB}}$ : Concentração final do branco após 168h $(\mu \mathrm{g} / \mathrm{L})$

$\mathrm{C}_{\mathrm{F} 0}$ : Concentração inicial do branco obtida após $0,5 \mathrm{~h}(\mu \mathrm{g} / \mathrm{L})$

$\mathrm{Na}$ Tabela 5.25 estão apresentados os valores utilizados para cálculo do PF 7 dias à $25^{\circ} \mathrm{C}$. Todos os cromatogramas obtidos para e estão apresentados nos Apêndices C.

Dentro do limite de detecção da metodologia analítica empregada, os subprodutos que apresentaram valores mais significativos foram

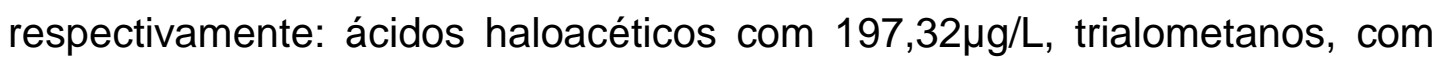
$119,80 \mu \mathrm{g} / \mathrm{L}$, cloro hidrato com $28,82 \mu \mathrm{g} / \mathrm{L}$, haloacetonitrila com $10,60 \mu \mathrm{g} / \mathrm{L}$ e halocetonas com 4,32 $\mu \mathrm{g} / \mathrm{L}$. A cloropicrina não foi detectada após $168 \mathrm{~h}$, nos demais tempos de contatos, os valores de cloropicrina apresentaram-se abaixo do limite de detecção do método. Após 168h, o total das concentrações dos subprodutos formados foi de $352,63 \mu \mathrm{g} / \mathrm{L}$.

$\mathrm{Na}$ Figura 5.21 estão apresentados os valores de concentração de TAMs, AHAs, $\mathrm{CH}, \mathrm{HK}$ e HANs em função do tempo de contato. Pode-se observar uma tendência crescente e proporcional na formação dos subprodutos investigados.

$\mathrm{Na}$ avaliação do PF 7 dias, 91\% dos subprodutos formados são TAMs e AHAs, sendo $55 \%$ de AHAs e $36 \%$ de TAMs. Nos $9 \%$ restantes estão o clorohidrato com 7\%, as HANs com $2 \%$. Não ocorreu a formação de halopicrinas e halocetonas. Na Figura 5.22 estão apresentados os resultados de subprodutos formados em concentração e porcentual. 
Tabela 5.25- Valores de concentração utilizados no cálculo do potencial de formação em presença de excesso de cloro após 7 dias de tempo de contato à $25^{\circ} \mathrm{C}$.

\begin{tabular}{|c|c|c|c|c|c|}
\hline \multirow{2}{*}{ Subprodutos } & \multicolumn{2}{|c|}{ branco } & \multicolumn{2}{|c|}{ amostras } & \multirow{2}{*}{$\mathrm{PF}_{7 \text { dias }}$} \\
\hline & 0,5 & 168 & 0,5 & 168 & \\
\hline \multicolumn{6}{|l|}{ Trialometanos } \\
\hline Clorofórmio & 17,77 & 20,6 & 32,74 & 117,82 & 82,25 \\
\hline Bromodiclorometano & 0,71 & 0,70 & 0,80 & 1,38 & 0,46 \\
\hline Dibromoclorometano & $<0,1$ & 1,06 & 0,73 & 0,60 & $<0,1$ \\
\hline Bromofórmio & $<0,1$ & $<0,1$ & $<0,1$ & $<0,1$ & $<0,1$ \\
\hline Total TAMs $(\mu \mathrm{g} / \mathrm{L})$ & 18,48 & 22,36 & 34,27 & 119,80 & 81,65 \\
\hline \multicolumn{6}{|l|}{ Clorohidrato } \\
\hline Total CH $(\mu \mathrm{g} / \mathrm{L})$ & $<0,1$ & 9,45 & 2,48 & 28,82 & 16,89 \\
\hline \multicolumn{6}{|l|}{ Haloacetonitrilas } \\
\hline Tricloroacetonitrila & $<0,1$ & $<0,1$ & $<0,1$ & $<0,1$ & $<0,1$ \\
\hline Dicloroacetonitrila & 0,35 & $<0,1$ & 2,18 & 5,68 & 3,85 \\
\hline Dibromoacetonitrila & $<0,1$ & $<0,1$ & $<0,1$ & $<0,1$ & $<0,1$ \\
\hline Bromocloroacetonitrila & $<0,1$ & $<0,1$ & $<0,1$ & $<0,1$ & $<0,1$ \\
\hline Total HANs ( $\mu \mathrm{g} / \mathrm{L})$ & 0,35 & $<0,1$ & 2,18 & 5,68 & 3,85 \\
\hline \multicolumn{6}{|l|}{ Halocetonas } \\
\hline 1,1,1-Tricloropropanona & $<0,1$ & $<0,1$ & 2,72 & 1,01 & $<0,1$ \\
\hline 1,1-Dicloropropanona & $<0,1$ & $<0,1$ & $<0,1$ & $<0,1$ & $<0,1$ \\
\hline Total HKs $(\mu \mathrm{g} / \mathrm{L})$ & $<0,1$ & $<0,1$ & 2,72 & 1,01 & $<0,1$ \\
\hline \multicolumn{6}{|l|}{ Halopicrinas: } \\
\hline Cloropicrina $(\mu \mathrm{g} / \mathrm{L})$ & $<0,1$ & $<0,1$ & $<0,1$ & $<0,1$ & $<0,1$ \\
\hline \multicolumn{6}{|l|}{ Ácidos haloacéticos } \\
\hline MCAA & 0,26 & 0,92 & 3,37 & 8,17 & 4,14 \\
\hline MBAA & $<0,1$ & $<0,1$ & $<0,1$ & $<0,1$ & $<0,1$ \\
\hline DCAA & 0,32 & 27,91 & 15,86 & 87,4 & 44,45 \\
\hline TCAA & 0,22 & 4,05 & 14,57 & 101,48 & 83,08 \\
\hline BCAA & $<0,1$ & 0,49 & 0,66 & $<0,1$ & $<0,1$ \\
\hline BDCAA & 0,23 & 0,91 & $<0,1$ & $<0,1$ & $<0,1$ \\
\hline DBAA & 0,39 & 0,41 & $<0,1$ & 0,27 & $<0,1$ \\
\hline CDBAA & $<0,1$ & $<0,1$ & 4,63 & $<0,1$ & $<0,1$ \\
\hline TBAA & $<0,1$ & $<0,1$ & $<0,1$ & $<0,1$ & $<0,1$ \\
\hline Total AHAs ( $\mu \mathrm{g} / \mathrm{L})$ & 1,42 & 34,69 & 38,59 & 197,32 & 125,46 \\
\hline
\end{tabular}




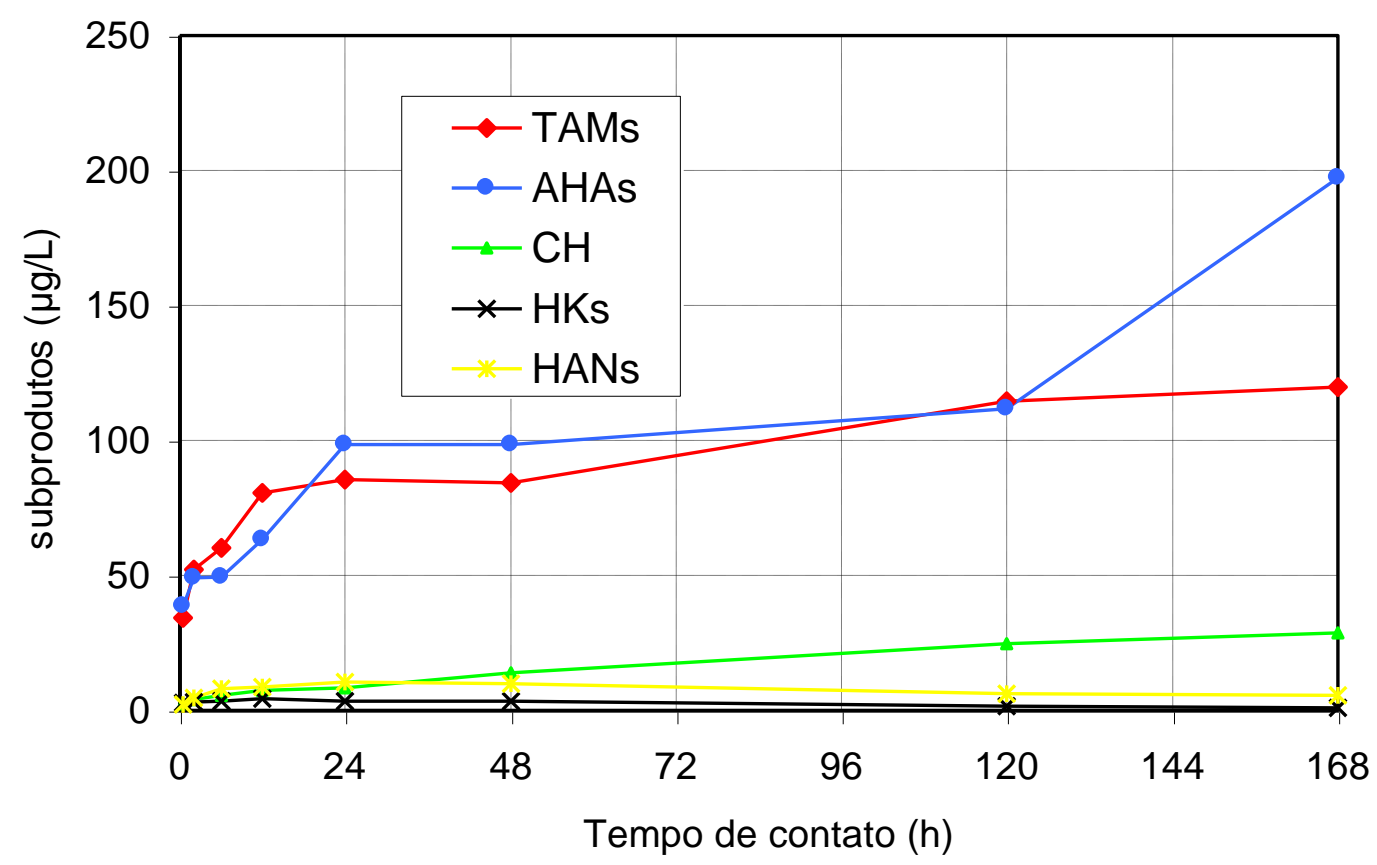

Figura 5.21 - Valores de concentração de subprodutos agrupados por famílias em função do tempo de contato a $25^{\circ} \mathrm{C}$.

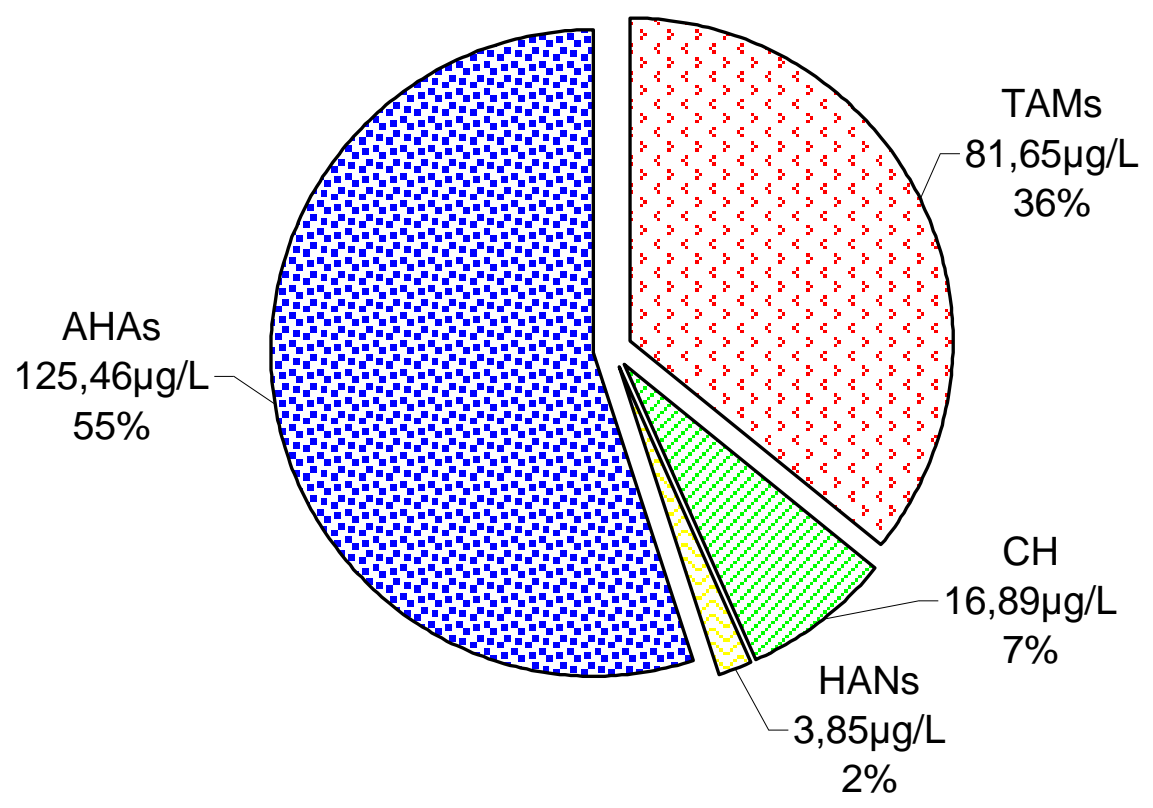

Figura 5.22 - Valores de potencial de formação em 7 dias com cloro expressos em concentração $(\mu \mathrm{g} / \mathrm{L})$ e porcentagem $(\%)$, com dosagem excessiva de cloro $\left(15 \mathrm{mg} / \mathrm{L} \mathrm{Cl}_{2}\right)$. 


\subsection{Potencial de formação de subprodutos orgânicos halogenados em 24 horas.}

Os subprodutos orgânicos halogenados foram formados através de ensaios experimentais realizados com diferentes pré-oxidantes, sendo: cloro, dióxido de cloro, permanganato de potássio, peróxido de hidrogênio, ozônio e peróxido de hidrogênio combinado com ozônio (peroxônio).

Esses ensaios foram realizados com a ausência e a presença de coagulação, seguidos de filtração, pós-cloração, incubação por $24 \mathrm{~h}$ a $25^{\circ} \mathrm{C}$, descloração, extrações líquido-líquido e análises cromatográficas.

Para cada pré-oxidante empregado, uma amostra da água de poço sem a presença de substâncias húmicas foi submetida às mesmas condições e foi denominada como "branco". Pelos resultados de subprodutos formados no tempo inicial $(0,5 \mathrm{~h})$ e final $(24 \mathrm{~h})$, foi possível efetuar o cálculo do potencial de formação após 24horas (PF 24h), equação (5.2). No cálculo do PF 24h, as quantidades de subprodutos que se formaram no "branco" foram descontadas, permanecendo apenas os subprodutos formados pela presença dos precursores em estudo, as substâncias húmicas.

PF 24h $=\left[\left(C_{F}-C_{0}\right)-\left(C_{F B}-C_{0 B}\right)\right]$

onde:

$\mathrm{C}_{\mathrm{F}}$ : Concentração obtida após 24h $(\mu \mathrm{g} / \mathrm{L})$

$\mathrm{C}_{0}$ : Concentração inicial obtida após $0,5 \mathrm{~h}(\mu \mathrm{g} / \mathrm{L})$

$\mathrm{C}_{\mathrm{FB}}$ : Concentração final do branco após 24h ( $\left.\mu \mathrm{g} / \mathrm{L}\right)$

$\mathrm{C}_{\mathrm{F} 0}$ : Concentração inicial do branco obtida após $0,5 \mathrm{~h}(\mu \mathrm{g} / \mathrm{L})$

A seguir estão apresentados os resultados obtidos e discussões para cada pré-oxidante em estudo e subdivididos por presença e ausência de coagulação. 


\subsubsection{Subprodutos da pré-oxidação com cloro}

As condições estabelecidas para a pré-oxidação com cloro e coagulação com sulfato de alumínio $\left(5 \mathrm{mgCl}_{2} / \mathrm{L}\right)$ foram determinadas em etapas anteriores, essas condições foram mantidas em todos os ensaios, variando apenas a presença e ausência de coagulação, a dosagem na póscloração foi estabelecida em $5 \mathrm{mgCl}_{2} / \mathrm{L}$ para todos os ensaios.

\subsubsection{Subprodutos da pré-oxidação com cloro, filtração e pós- cloração}

$\mathrm{Na}$ Tabela 5.26 estão apresentados os valores obtidos de subprodutos formados na pré-oxidação com cloro, filtração e pós-cloração para diferentes tempos de contato, os valores de branco e os resultados do cálculo do potencial de formação de $24 \mathrm{~h}$.

Na Figura 5.23 estão apresentados todos os resultados em função do tempo de contato e pode-se observar que até $12 \mathrm{~h}$, ocorreu uma tendência crescente de formação de todos os subprodutos. Após esse período, ocorreu uma tendência de estabilização na formação. Alguns cromatogramas típicos estão apresentados nos Apêndices D-01 e D-02.

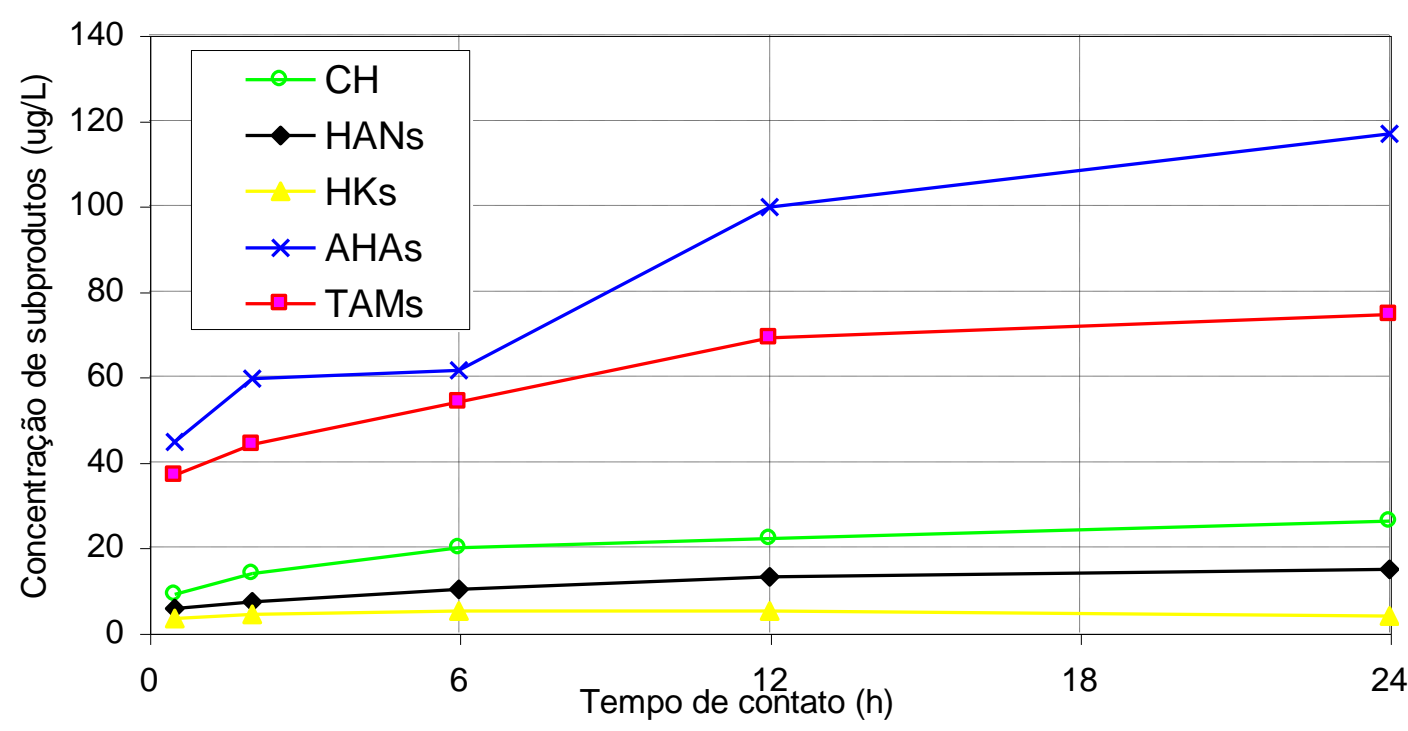

Figura 5.23 - Concentração de subprodutos ( $\mu \mathrm{g} / \mathrm{L})$, da pré-oxidação com cloro, filtração e pós-cloração em função do tempo de contato a $25^{\circ} \mathrm{C}$. 
Tabela 5.26 - Resultados de subprodutos da pré-oxidação com cloro, filtração em papel, pós-cloração, incubação a $25^{\circ} \mathrm{C}$ e o cálculo do PF $24 \mathrm{~h}$.

\begin{tabular}{|c|c|c|c|c|c|c|c|c|}
\hline \multirow{3}{*}{ Subprodutos } & \multicolumn{7}{|c|}{ Tempos de contato $(\mathrm{h})$} & \multirow{3}{*}{$\begin{array}{l}\text { PF } \\
24 h\end{array}$} \\
\hline & \multicolumn{2}{|c|}{ Branco } & \multicolumn{4}{|c|}{ Amostras } & \multirow[b]{2}{*}{24} & \\
\hline & 0,5 & 24 & 0,5 & 2 & 6 & 12 & & \\
\hline \multicolumn{9}{|l|}{ Trialometanos: } \\
\hline Clorofórmio & 15,87 & 23,25 & 35,78 & 42,69 & 52,16 & 67,39 & 72,06 & 28,90 \\
\hline Bromodiclorometano & 0,87 & 1,41 & 1,12 & 1,37 & 1,91 & 1,55 & 2,40 & 0,74 \\
\hline Dibromoclorometano & $<0,1$ & $<0,1$ & $<0,1$ & $<0,1$ & $<0,1$ & $<0,1$ & $<0,1$ & $<0,1$ \\
\hline Bromofórmio & $<0,1$ & $<0,1$ & $<0,1$ & $<0,1$ & $<0,1$ & $<0,1$ & $<0,1$ & $<0,1$ \\
\hline Total TAMs $(\mu \mathrm{g} / \mathrm{L})$ & 16,74 & 24,66 & 36,90 & 44,06 & 54,07 & 68,94 & 74,46 & 29,64 \\
\hline Cloro hidrato $(\mu \mathrm{g} / \mathrm{L})$ & 40 & 18,91 &, 06 & 13,88 & 19,94 & 22,03 & 26,13 & 6,56 \\
\hline Cloropicrina $(\mu \mathrm{g} / \mathrm{L})$ & $=0,1$ & 0,1 & $<0,1$ & 0,1 & $<0,1$ & $<0,1$ & $<0,1$ & 0,1 \\
\hline \multicolumn{9}{|l|}{ Haloacetonitrilas: } \\
\hline Tricloroacetonitrila & $<0,1$ & $<0,1$ & $<0,1$ & $<0,1$ & $<0,1$ & $<0,1$ & $<0,1$ & $<0,1$ \\
\hline Dicloroacetonitrila & 1,70 & 4,40 & 5,71 & 7,17 & 10,07 & 13,12 & 14,73 & 6,32 \\
\hline acetonitrila & $<0,1$ & $<0,1$ & $<0,1$ & $<0,1$ & $<0,1$ & $<0,1$ & $<0,1$ & $<0,1$ \\
\hline Bromocloroacetonitrila & $<0,1$ & $<0,1$ & $<0,1$ & $<0,1$ & $<0,1$ & $<0,1$ & $<0,1$ & $<0,1$ \\
\hline Total HANs $(\mu \mathrm{g} / \mathrm{L})$ & 1,70 & $\mathbf{4 , 4 0}$ & 5,71 & 7,17 & 10,07 & 13,12 & 14,73 & 6,32 \\
\hline \multicolumn{9}{|l|}{ Halocetonas: } \\
\hline 1,1,1-Tricloropropanona & 0,89 & 1,31 & 3,31 & 4,37 & 5,04 & 5,03 & 3,98 & 0,25 \\
\hline 1,1-Diclor & $<0,1$ & $<0,1$ & $<0,1$ & $<0,1$ & $<0,1$ & $<0,1$ & $<0,1$ & $<0,1$ \\
\hline Total HKs & 0,89 & 1,31 & 3,31 & 4,37 & 5,04 & 5,03 & 3,98 & 0,25 \\
\hline \multicolumn{9}{|l|}{ Ácidos haloacéticos: } \\
\hline & 0,18 & 2,65 & 1,01 & 1,56 & 3,60 & 2,86 & 4,64 & 1,16 \\
\hline $\mathrm{ME}$ & 0,17 & 2,46 & 0,29 & 0,44 & 3,15 & 0,41 & 4,50 & 1,92 \\
\hline DCAA & 1,34 & 8,43 & 39,14 & 51,75 & 43,72 & 89,72 & 92,60 & 46,37 \\
\hline TCAA & 0,30 & 1,78 & 4,25 & 5,74 & 10,90 & 6,65 & 14,96 & 9,23 \\
\hline BCAA & 0,11 & 0,10 & $<0,1$ & $<0,1$ & $<0,1$ & $<0,1$ & $<0,1$ & $<0,1$ \\
\hline BDCAA & 0,01 & $<0,1$ & $<0,1$ & $<0,1$ & $<0,1$ & $<0,1$ & $<0,1$ & $<0,1$ \\
\hline DBAA & $<0,1$ & $<0,1$ & $<0,1$ & $<0,1$ & $<0,1$ & $<0,1$ & $<0,1$ & $<0,1$ \\
\hline CDBAA & $<0,1$ & $<0,1$ & $<0,1$ & $<0,1$ & $<0,1$ & $<0,1$ & $<0,1$ & $<0,1$ \\
\hline TBAA & $<0,1$ & $<0,1$ & $<0,1$ & $<0,1$ & $<0,1$ & $<0,1$ & $<0,1$ & $<0,1$ \\
\hline Total AHAs $(\mu \mathrm{g} / \mathrm{L})$ & 2,09 & 15,42 & 44,69 & 59,49 & 61,37 & 99,64 & 116,70 & 58,68 \\
\hline
\end{tabular}

Após 24h, o composto cloropicrina não foi detectado dentro do limite de quantificação do método. Os valores de TAMs apresentaram-se abaixo de $100 \mu \mathrm{g} / \mathrm{L}$. A formação de ácidos haloacéticos foi superior a formação de TAMs. Após 24h, o composto clorohidrato apresentou uma concentração de $26,13 \mu \mathrm{g} / \mathrm{L}$.

Os resultados calculados do potencial de formação de $24 \mathrm{~h}$, dentre os subprodutos formados, foram: os AHAs com $59 \%$ do total, os TAMs com 
$38 \%$ e o $\mathrm{CH}$ e HANs com 6\% cada. A Figura 5.22 apresenta esses resultados.

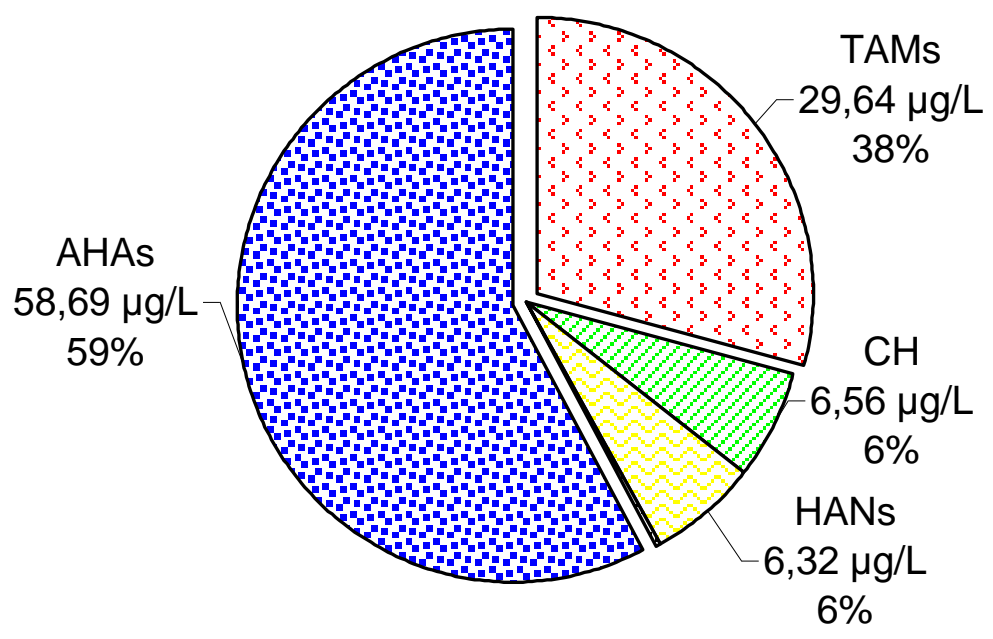

Figura 5.24 - Resultados expressos em porcentagem e concentração dos subprodutos da pré-oxidação com cloro, filtração em papel, pós-cloração, incubação a $25^{\circ} \mathrm{C}$.

\subsubsection{Subprodutos da pré-oxidação com cloro seguido de coagulação, filtração e pós-cloração}

Na Tabela 5.27 estão apresentados os resultados dos subprodutos obtidos com o emprego de cloro na pré-oxidação ( $5 \mathrm{mgCl}_{2} / \mathrm{L}$ ), seguido de coagulação (14 mgSA/L), filtração, pós-cloração $\left(5 \mathrm{mgCl}_{2} / \mathrm{L}\right)$ e incubação por 24h.

Os resultados obtidos foram crescentes em função do tempo de contato. Dentre os valores de AHAs, o DCAA e o TCAA apresentaram valores mais significativos, seguidos de MCAA e MBAA, os demais não apresentaram valores dectados pelo método, o maior valor obtido de AHAs foi de $86,59 \mu \mathrm{g} / \mathrm{L}$ após $24 \mathrm{~h}$.

Os valores de TAMs apresentaram-se abaixo do recomendado pela legislação, o maior valor obtido após $24 \mathrm{~h}$ foi de $48,32 \mu \mathrm{g} / \mathrm{L}$, sendo $45,97 \mu \mathrm{g} / \mathrm{L}$ de clorofórmio e $2,35 \mu \mathrm{g} / \mathrm{L}$ de bromodiclorometano. O clorohidrato apresentou concentração de $27,32 \mu \mathrm{g} / \mathrm{L}$, dentre os compostos de haloacetonitrilas, ocorreu a formação apenas do dicloroacetonitrila com valor 


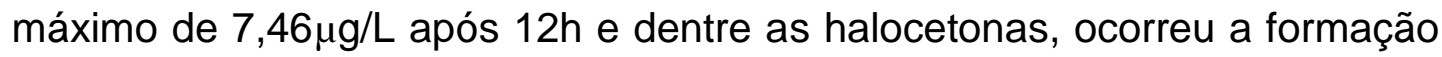
apenas do composto 1,1,1-tricloropropanona com valores variando de 2,42 a $3,83 \mu \mathrm{g} / \mathrm{L}$. A cloropicrina não foi detectada dentro do limite de quantificação do método. Alguns cromatogramas típicos estão apresentados nos Apêncices D-03 e D-04.

Tabela 5.27 - Subprodutos da pré-oxidação com cloro $\left(5 \mathrm{mgCl}_{2} / \mathrm{L}\right)$, coagulação (14mgSA/L), filtração em papel, pós-cloração $\left(5 \mathrm{mgCl}_{2} / \mathrm{L}\right)$ e incubação por $24 \mathrm{~h}$ a $25^{\circ} \mathrm{C}$, em $\mu \mathrm{g} / \mathrm{L}$.

\begin{tabular}{|c|c|c|c|c|c|c|c|c|}
\hline \multirow{2}{*}{ Subprodutos } & \multicolumn{7}{|c|}{ Tempo de contato (h) } & \multirow[b]{2}{*}{ PF 24h } \\
\hline & \multicolumn{2}{|c|}{ Branco } & \multicolumn{4}{|c|}{ amostras } & 24 & \\
\hline \multicolumn{9}{|l|}{ Trialometanos } \\
\hline Clorofórmio & 15,87 & 23,25 & 29,93 & 33,56 & 34,59 & 43,49 & 45,97 & 8,66 \\
\hline Bromodiclorometano & 0,87 & 1,41 & 1,24 & 1,64 & 1,71 & 2,16 & 2,35 & 0,57 \\
\hline Dibromoclorometano & $<0,1$ & $<0,1$ & $<0,1$ & $<0,1$ & 1,26 & $<0,1$ & $<0,1$ & $<0,1$ \\
\hline Bromofórmio & $<0,1$ & $<0,1$ & $<0,1$ & $<0,1$ & $<0,1$ & $<0,1$ & $<0,1$ & $<0,1$ \\
\hline TotalTAMs $(\mu \mathrm{g} / \mathrm{L})$ & 16,74 & 24,66 & 31,17 & 35,20 & 37,56 & 45,65 & 48,32 & 9,23 \\
\hline Cloro Hidrato & 8,40 & 18,91 & 14,77 & 14,94 & 17,57 & 23,30 & 27,32 & 2,04 \\
\hline \multicolumn{9}{|l|}{ Halopicrina } \\
\hline Cloropicrina $(\mu \mathrm{g} / \mathrm{L})$ & $<0,1$ & $<0,1$ & $<0,1$ & $<0,1$ & $<0,1$ & $<0,1$ & $<0,1$ & $<0,1$ \\
\hline \multicolumn{9}{|l|}{ Haloacetonitrilas } \\
\hline Tricloroacetonitrila & $<0,1$ & $<0,1$ & $<0,1$ & $<0,1$ & $<0,1$ & $<0,1$ & $<0,1$ & $<0,1$ \\
\hline Dicloroacetonitrila & 1.70 & 4,40 & 3.60 & 4.31 & 5.31 & 7,46 & 7.21 & 0.91 \\
\hline Dibromoacetonitrila & $<0,1$ & $<0,1$ & $<0,1$ & $<0,1$ & $<0,1$ & $<0,1$ & $<0,1$ & $<0,1$ \\
\hline Bromocloroacetonitrila & $<0,1$ & $<0,1$ & $<0,1$ & $<0,1$ & $<0,1$ & $<0.1$ & $<0,1$ & $<0,1$ \\
\hline Total HANs $(\mu \mathrm{g} / \mathrm{L})$ & 1,70 & 4,40 & 3,60 & 4,31 & 5,31 & 7,46 & 7,21 & 0,91 \\
\hline \multicolumn{9}{|l|}{ Halocetonas } \\
\hline 1,1,1-Tricloropropanona & 0,89 & 1,31 & 2,42 & 3,83 & 3,00 & 3,61 & 3,38 & 0,54 \\
\hline 1,1-Dicloroprope & $<0,1$ & $<0,1$ & $<0,1$ & $<0,1$ & $<0,1$ & $<0,1$ & $<0,1$ & $<0,1$ \\
\hline Total HKs $(\mu \mathrm{g} / \mathrm{L})$ & 0,89 & 1,31 & 2,42 & 3,83 & 3,00 & 3,61 & 3,38 & 0,54 \\
\hline \multicolumn{9}{|l|}{ Ác.Haloacéticos } \\
\hline MCAA & 0,18 & 2,65 & 1,67 & 1,39 & 1,89 & 1,74 & 4,12 & $<0,1$ \\
\hline MBAA & 0,17 & 2,46 & 0,35 & 0,31 & 4,01 & 0,39 & 1,86 & $<0,1$ \\
\hline DCAA & 1,34 & 8,43 & 28,99 & 38,81 & 41,92 & 49,01 & 63,71 & 27,63 \\
\hline TCAA & 0,30 & 1,78 & 7,63 & 8,89 & 7,19 & 14,24 & 16,90 & 7,79 \\
\hline BCAA & 0,11 & 0,17 & $<0,1$ & $<0,1$ & $<0,1$ & $<0,1$ & $<0,1$ & $<0,1$ \\
\hline BDCAA & $<0,1$ & 0,09 & $<0,1$ & $<0,1$ & $<0,1$ & $<0,1$ & $<0,1$ & $<0,1$ \\
\hline DBAA & 0,05 & 0,04 & $<0,1$ & $<0,1$ & $<0,1$ & $<0,1$ & $<0,1$ & $<0,1$ \\
\hline CDBAA & $<0,1$ & $<0,1$ & $<0,1$ & $<0,1$ & $<0,1$ & $<0,1$ & $<0,1$ & $<0,1$ \\
\hline TBAA & $<0,1$ & $<0,1$ & $<0,1$ & $<0,1$ & $<0,1$ & $<0,1$ & $<0,1$ & $<0,1$ \\
\hline Total AHAs $(\mu \mathrm{g} / \mathrm{L})$ & 2,15 & 15,62 & 38,64 & 49,40 & 55,01 & 55,38 & 86,59 & 34,62 \\
\hline
\end{tabular}


Na Figura 5.25 estão apresentados os valores totais de subprodutos formados em presença de cloro na pré-oxidação, com o emprego da coagulação, filtração em papel, pós-cloração e incubação a $25^{\circ} \mathrm{C}$ em função do tempo de contato.

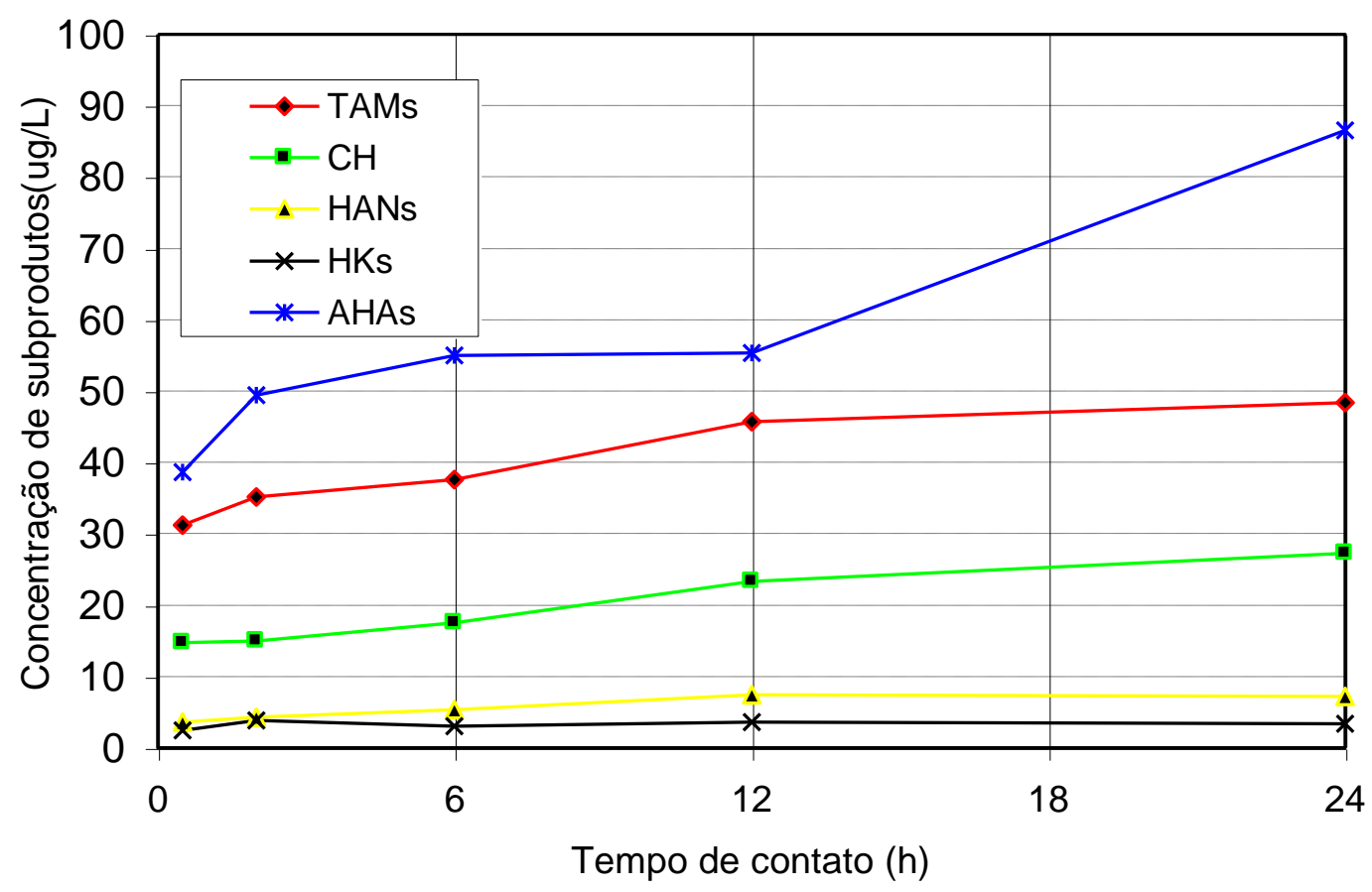

Figura 5.25- Resultados de subprodutos com cloro na pré-oxidação, coagulação, filtração em papel, pós-cloração e incubação por $24 \mathrm{~h}$ a $25^{\circ} \mathrm{C}$.

Pelos valores calculados de potencial de formação de 24h, os ácidos haloacéticos apresentaram-se com $74 \%$ do total, os TAMs com $19 \%$, o clorohidrato com $4 \%$, as haloacetonitrilas com $2 \%$ e as halocetonas com $1 \%$. Na Figura 5.26 estão apresentados os resultados obtidos.

Na Figura 5.27 estão apresentados os resultados de potencial de formação de 7 dias comparados ao potencial de formação de $24 \mathrm{~h}$ com presença e ausência de coagulação. Pode-se observar que após 7 dias a formação de TAMs é maior, porém após 24h a maior formação foi de AHAs.

Os valores de PF 24h com o uso de coagulação apresentaram-se inferiores aos ensaios realizados com ausência de coagulação. Essa diferença mostrou-se acentuada para TAMs, tendo sido obtidos os seguintes PF 24h: 29,64 $\mu \mathrm{g} / \mathrm{L}$ sem coagulação e 9,23 $\mu \mathrm{g} / \mathrm{L}$ com coagulação. O cloro 
hidrato apresentou-se com PF de $24 \mathrm{~h}$ de $6,56 \mu \mathrm{g} / \mathrm{L}$ sem coagulação e reduziu para 2,04 $\mu \mathrm{g} / \mathrm{L}$ com coagulação.

Os valores de PF de 24h para HANs apresentaram-se com 6,32 $\mu \mathrm{g} / \mathrm{L}$ sem coagulação e reduziu para $0,91 \mu \mathrm{g} / \mathrm{L}$ com coagulação. Em relação aos AHAs a redução devido a presença de coagulação não foi muito significativa, $58,68 \mu \mathrm{g} / \mathrm{L}$ sem coagulação e $34,62 \mu \mathrm{g} / \mathrm{L}$ com coagulação.

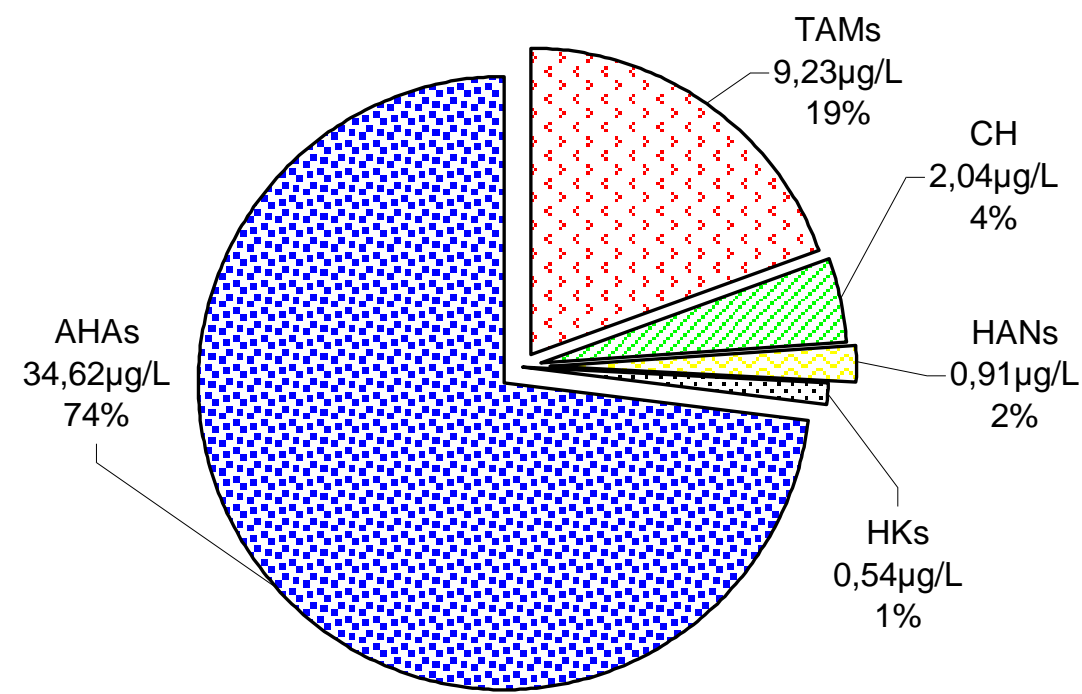

Figura 5.26 - Resultados de potencial de formação de $24 \mathrm{~h}$ dos subprodutos da pré-oxidação com cloro, coagulação, filtração em papel, pós-cloração e incubação por $24 \mathrm{~h}$ a $25^{\circ} \mathrm{C}$ expressos em $\mu \mathrm{g} / \mathrm{L}$ e percentual.

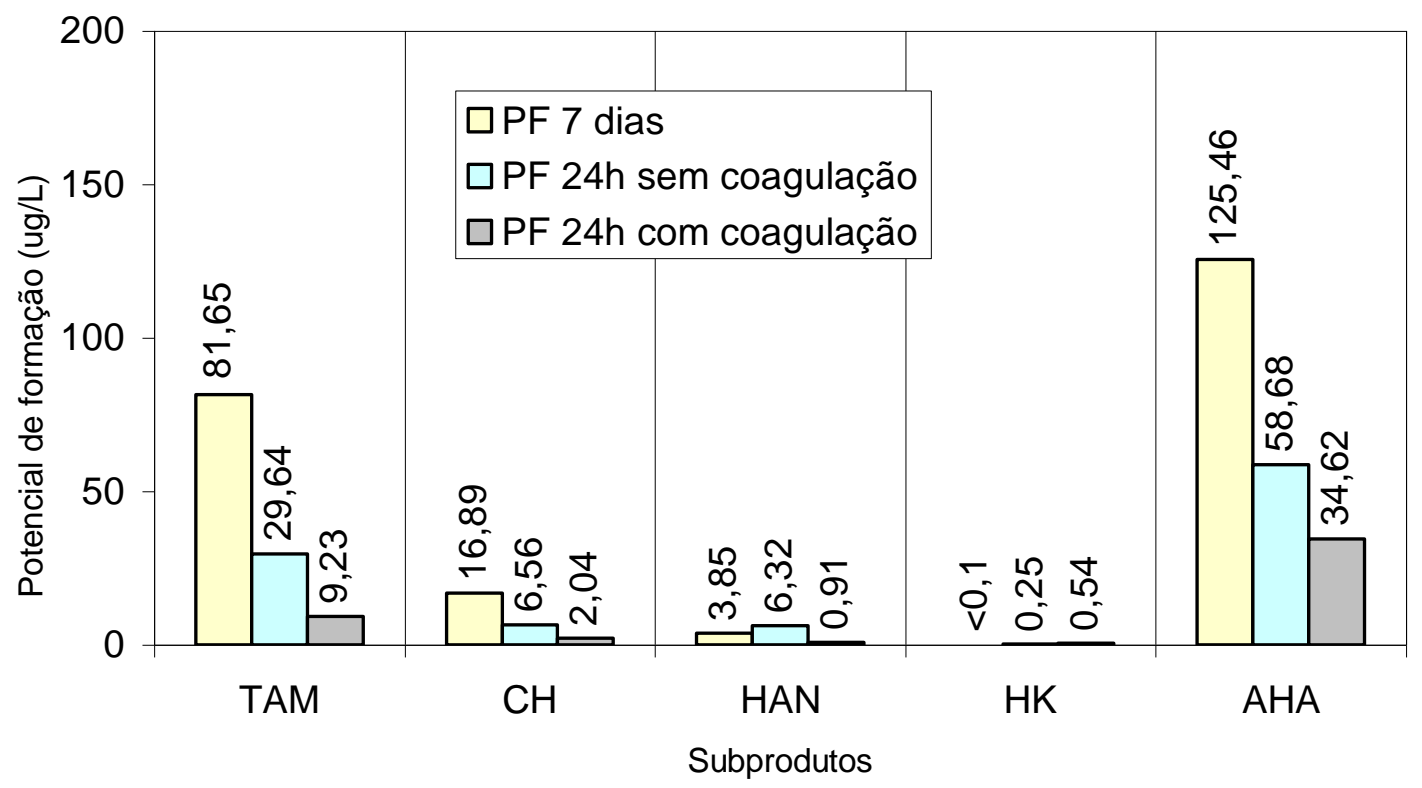

Figura 5.27 - Comparação dos valores de potencial de formação de 7 dias com PF 24h sem coagulação e com coagulação, filtração e pós-cloração. 


\subsubsection{Subprodutos da pré-oxidação com permanganato de potássio}

As condições estabelecidas para a pré-oxidação com permanganato de potássio $\left(3,5 \mathrm{mg} \mathrm{KMnO}_{4} / \mathrm{L}\right.$ ) e coagulação com sulfato de alumínio (12 $\mathrm{mgSA} / \mathrm{L}$ ) foram determinadas em etapas anteriores, essas condições foram mantidas em todos os ensaios, variando apenas a ausência e a presença da etapa de coagulação, a dosagem na pós-cloração foi estabelecida em $5 \mathrm{mgCl}_{2} / \mathrm{L}$ para todos os ensaios.

\subsubsection{Subprodutos da pré-oxidação com permanganato de potássio, filtração e pós-cloração}

$\mathrm{Na}$ Tabela 5.28 estão apresentados os resultados obtidos de subprodutos formados com o uso do permanganato de potássio na préoxidação $\left(3,5 \mathrm{mg} \mathrm{KMnO}_{4} / \mathrm{L}\right)$, filtração em papel, pós-cloração $\left(5 \mathrm{mgCl}_{2} / \mathrm{L}\right)$ e incubação a $25^{\circ} \mathrm{C}$.

A formação de subprodutos foi crescente em função do tempo de contato; após 6h houve uma tendência de estabilização. Esse comportamento não foi observado para os AHAs.

A cloropicrina não foi detectada após $24 \mathrm{~h}$ de tempo de contato. Os demais subprodutos aparecem em todos os tempos avaliados.

O maior subproduto obtido foi os AHAs com a formação de 143,61 $\mu \mathrm{g} / \mathrm{L}$ após $24 \mathrm{~h}$, em seguida os TAMs com 55,50 $\mu \mathrm{g} / \mathrm{L}$ e o $\mathrm{CH}$ com 17,21 $\mu \mathrm{g} / \mathrm{L}$.

Os valores de TAMs obtidos no branco podem estar associados ao uso do cloro na etapa de pós-cloração.

Com o uso de permanganato de potássio na pré-oxidação, na ausência de coagulação com e pós-cloração, a maior fração dos subprodutos formados foi de AHAs, com $84 \%$ do total, seguido de TAMs com $14 \%$ e clorohidrato com $2 \%$. As frações de haloacetoniltrila e halocetonas ficaram abaixo de $1 \%$.

$\mathrm{Na}$ Figura 5.28 estão apresentados os valores de concentração de subprodutos da pré-oxidação com permanganato de potássio, filtração em 
papel, pós-cloração em função do tempo de contato. Alguns cromatogramas típicos estão apresentados nos Apêndices E-01 e E-02.

Tabela 5.28- Resultados de subprodutos da pré-oxidação com permanganato de potássio $\left(3,5 \mathrm{mg} \mathrm{KMnO}_{4} / \mathrm{L}\right)$, filtração em papel, póscloração $\left(5 \mathrm{mgCl}_{2} / \mathrm{L}\right)$ e incubação a $25^{\circ} \mathrm{C}$, em $\mu \mathrm{g} / \mathrm{L}$, em função do tempo de contato.

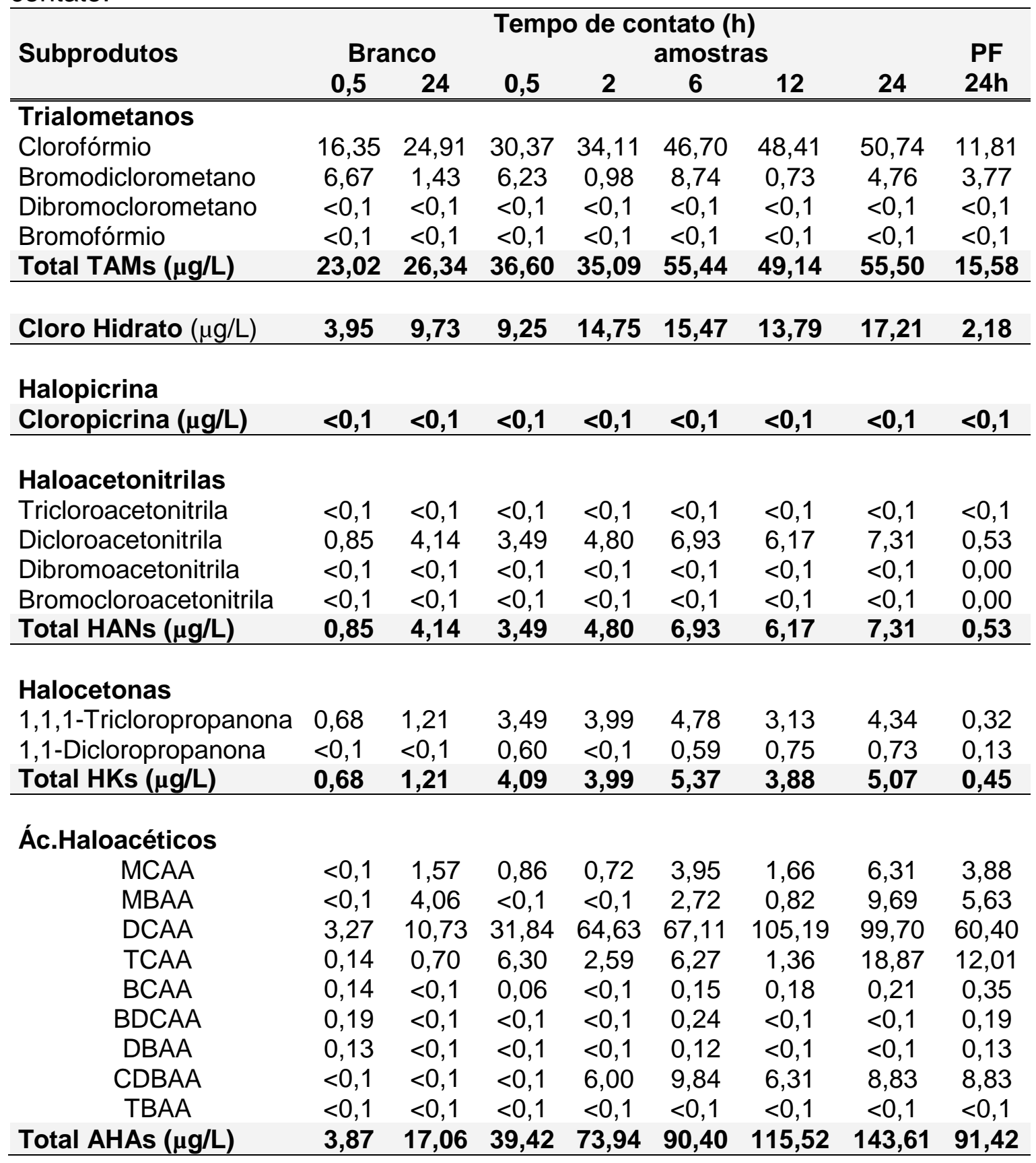

Na Figura 5.29 estão apresentados os resultados obtidos do cálculo do PF 24h em percentual e em concentração. Após $6 \mathrm{~h}$ de tempo de contato, 
observou-se um comportamento similar e uma tendência de estabilização na formação de TAMs, $\mathrm{CH}$, HANs, HKs, exceto para AHAs, que apresentou uma formação crescente até $24 \mathrm{~h}$.

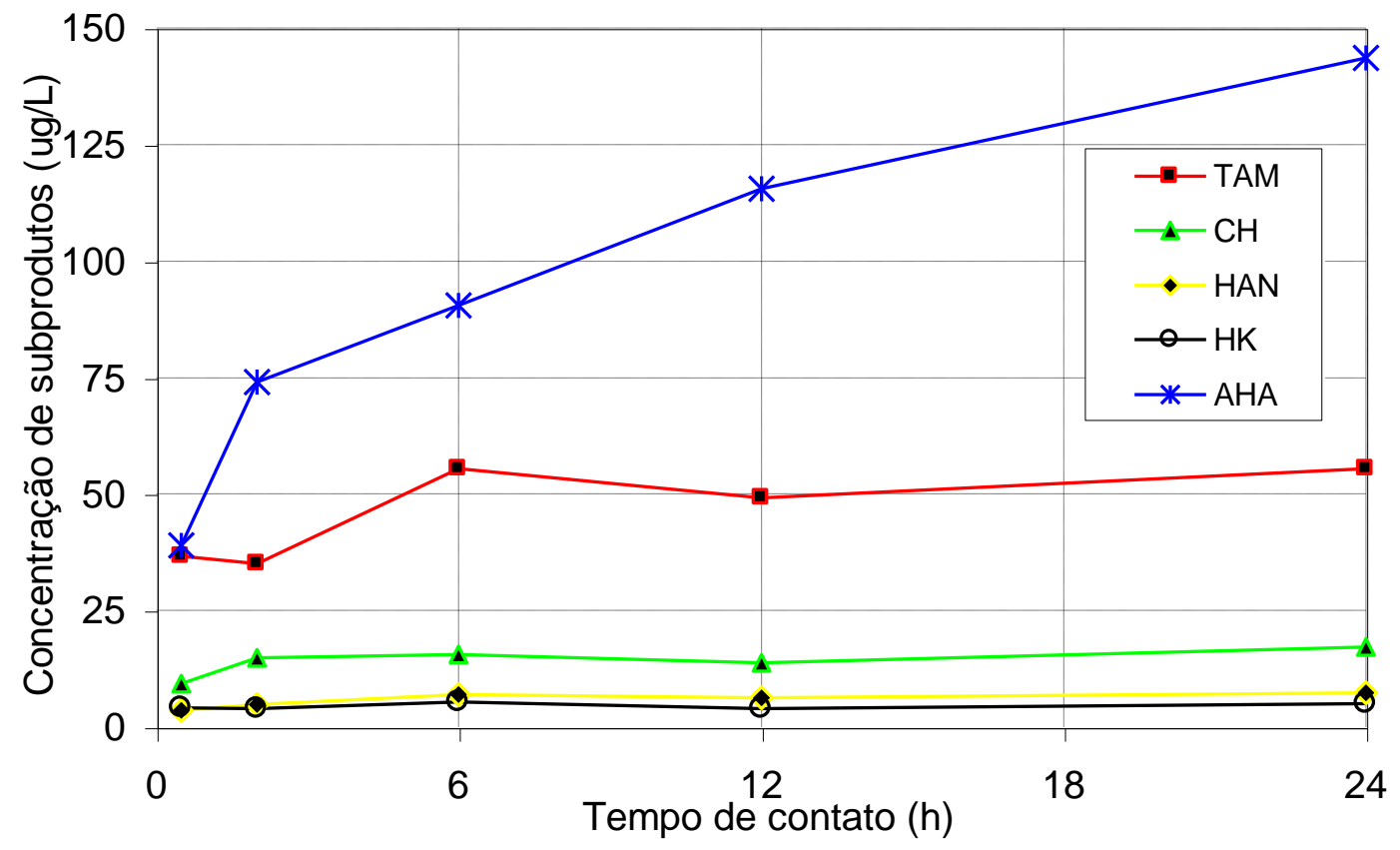

Figura 5.28- Valores de concentração de subprodutos da pré-oxidação com permanganato de potássio, filtração e pós-cloração em função do tempo de contato a $25^{\circ} \mathrm{C}$.

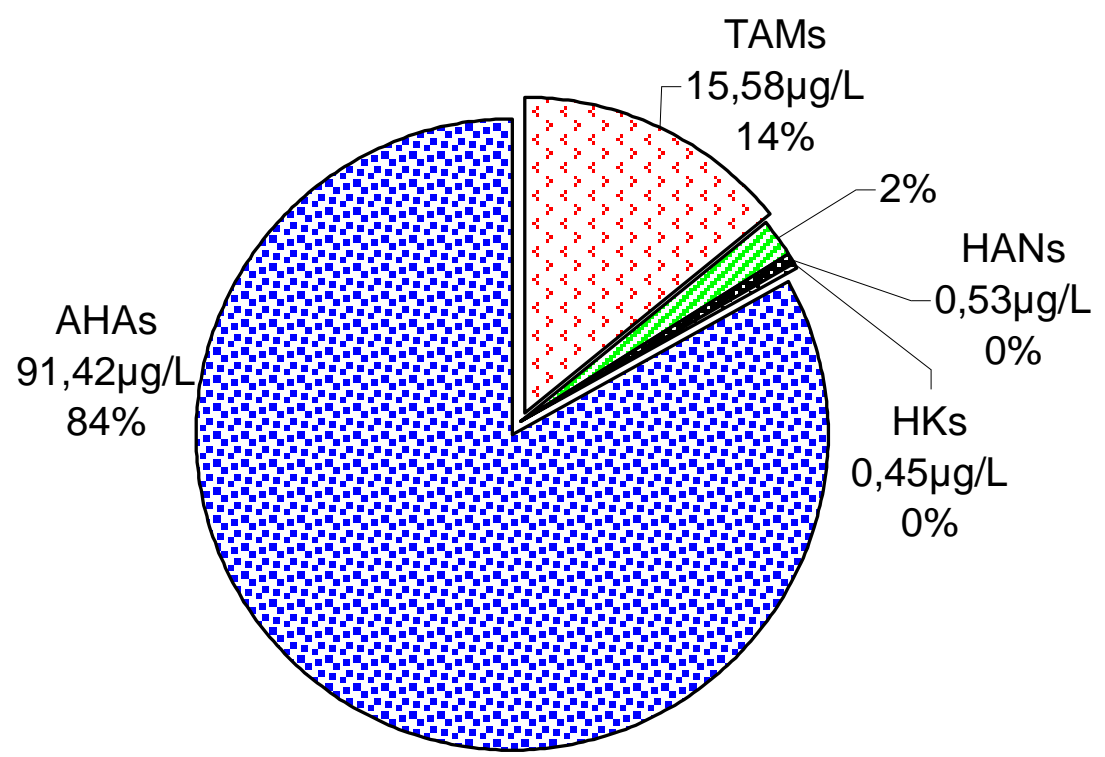

Figura 5.29- Resultados de potencial de formação de $24 \mathrm{~h}$ dos subprodutos da pré-oxidação com permanganato de potássio, filtração em papel, póscloração e incubação por $24 \mathrm{~h}$ a $25^{\circ} \mathrm{C}$ expressos em $\mu \mathrm{g} / \mathrm{L}$ e percentual. 
5.10.2.1 Subprodutos da pré-oxidação com permanganato de potássio, seguido de coagulação, filtração e pós-cloração

$\mathrm{Na}$ Tabela 5.29 estão apresentados os resultados de subprodutos obtidos e o PF24h para o uso de permanganato de potássio $\left(3,5 \mathrm{mgKMnO}_{4} / \mathrm{L}\right)$ na pré-oxidação em presença de coagulação (12mg AS/L), filtração em papel, pós-cloração $\left(5 \mathrm{mgCl}_{2} / \mathrm{L}\right)$ e incubação a $25^{\circ} \mathrm{C}$.

Tabela 5.29 - Subprodutos da pré-oxidação com permanganato de potássio, coagulação, filtração, pós-cloração e incubação por $24 \mathrm{~h}$ a $25^{\circ} \mathrm{C}$, em $\mu \mathrm{g} / \mathrm{L}$.

\begin{tabular}{|c|c|c|c|c|c|c|c|c|}
\hline \multirow[b]{2}{*}{ SUBPRODUTOS } & \multicolumn{7}{|c|}{ Tempo de contato $(\mathrm{h})$} & \multirow[b]{2}{*}{ PF 24h } \\
\hline & $\begin{array}{l}\text { Bra } \\
0,5\end{array}$ & $\begin{array}{c}\text { nco } \\
24 \\
\end{array}$ & 0,5 & \multicolumn{2}{|c|}{ amostras } & s 12 & 24 & \\
\hline \multicolumn{9}{|l|}{ Trialometanos } \\
\hline Clorofórmio & 16,35 & 24,91 & 21,31 & 21,12 & 23,04 & 25,41 & 25,18 & $<0,1$ \\
\hline Bromodiclorometano & 6,67 & 1,43 & 0,61 & 1,65 & 1,67 & 4,98 & 5,60 & 10,23 \\
\hline Dibromoclorometano & $<0,1$ & $<0,1$ & $<0,1$ & $<0,1$ & 2,74 & $<0,1$ & $<0,1$ & $<0,1$ \\
\hline Bromofórmio & $<0,1$ & $<0,1$ & $<0,1$ & $<0,1$ & $<0,1$ & $<0,1$ & $<0,1$ & $<0,1$ \\
\hline Total TAMs $(\mu \mathrm{g} / \mathrm{L})$ & 23,02 & 26,34 & 21,92 & 22,77 & 27,45 & 30,39 & 30,78 & 5,54 \\
\hline Cloro Hidrato $(\mu \mathrm{g} / \mathrm{L})$ & 3,95 & 9,73 & 13,38 & 13,55 & 18,46 & 19,88 & 20,99 & 1,83 \\
\hline \multicolumn{9}{|l|}{ Halopicrina } \\
\hline \multicolumn{9}{|l|}{ Haloacetonitrilas } \\
\hline Tricloroacetonitrila & $<0,1$ & $<0,1$ & $<0,1$ & $<0,1$ & $<0,1$ & $<0,1$ & $<0,1$ & $<0,1$ \\
\hline Dicloroacetonitrila & 0,85 & 4,14 & 1,94 & 2,33 & 2,45 & 3,12 & 3,26 & $<0,1$ \\
\hline Dibromoacetonitrila & $<0,1$ & $<0,1$ & $<0,1$ & $<0,1$ & $<0,1$ & $<0,1$ & $<0,1$ & $<0,1$ \\
\hline Bromocloroacetonitrila & $<0,1$ & $<0,1$ & $<0,1$ & $<0,1$ & $<0,1$ & $<0,1$ & $<0,1$ & $<0,1$ \\
\hline Total HANs $(\mu \mathrm{g} / \mathrm{L})$ & 0,85 & 4,14 & 1,94 & 2,33 & 2,45 & 3,12 & 3,26 & $<0,1$ \\
\hline \multicolumn{9}{|l|}{ Halocetonas } \\
\hline 1,1,1-Tricloropropanona & 0,68 & 1,21 & 1,50 & 1,67 & 1,63 & 1,88 & 1,50 & $<0,1$ \\
\hline 1,1-Dicloropropanona & $<0,1$ & $<0,1$ & $<0,1$ & $<0,1$ & $<0,1$ & $<0,1$ & 0,50 & 0,50 \\
\hline Total HKs $(\mu \mathrm{g} / \mathrm{L})$ & 0,68 & 1,21 & 1,50 & 1,67 & 1,63 & 1,88 & 2,00 & $<0,1$ \\
\hline \multicolumn{9}{|l|}{ Ác.Haloacéticos } \\
\hline MCAA & $<0,1$ & 1,57 & 0,34 & 0,79 & 0,14 & 0,42 & 0,76 & $<0,1$ \\
\hline MBAA & $<0,1$ & 4,06 & 0,34 & 0,67 & 0,35 & $<0,1$ & 3,37 & $<0,1$ \\
\hline DCAA & 3,27 & 10,73 & 3,82 & 6,08 & 5,60 & 11,01 & 10,14 & $<0,1$ \\
\hline TCAA & 0,14 & 0,70 & 0,82 & 1,07 & 0,26 & 0,51 & 0,78 & $<0,1$ \\
\hline BCAA & 0,14 & $<0,1$ & 0,07 & 0,10 & 0,10 & 0,57 & $<0,1$ & 0,14 \\
\hline BDCAA & 0,19 & $<0,1$ & $<0,1$ & $<0,1$ & $<0,1$ & $<0,1$ & 0,31 & 0,50 \\
\hline DBAA & 0,13 & $<0,1$ & $<0,1$ & $<0,1$ & $<0,1$ & $<0,1$ & $<0,1$ & 0,13 \\
\hline CDBAA & $<0,1$ & $<0,1$ & $<0,1$ & $<0,1$ & $<0,1$ & $<0,1$ & 3,99 & 3,99 \\
\hline TBAA & $<0,1$ & $<0,1$ & $<0,1$ & $<0,1$ & $<0,1$ & $<0,1$ & $<0,1$ & $<0,1$ \\
\hline Total AHAs $(\mu \mathrm{g} / \mathrm{L})$ & 3,87 & 17,06 & 5,32 & 14,71 & 6,45 & 24,78 & 19,35 & 0,84 \\
\hline
\end{tabular}


Alguns cromatogramas típicos estão apresentados nos Anexos E-03 e E-04. Na presença de coagulação não ocorreu à formação de cloropicrina, os AHAs foram os subprodutos que apresentaram maior formação após 24h, seguido de TAMs, $\mathrm{CH}$, HANs e HKs. Após 12h ocorreu uma tendência de estabilização para TAMs, $\mathrm{CH}$, HANs e HKs. Os AHAs não apresentaram a tendência de estabilização até 24h. Na Figura 5.30 estão apresentados os valores de concentração dos subprodutos em função do tempo de contato.

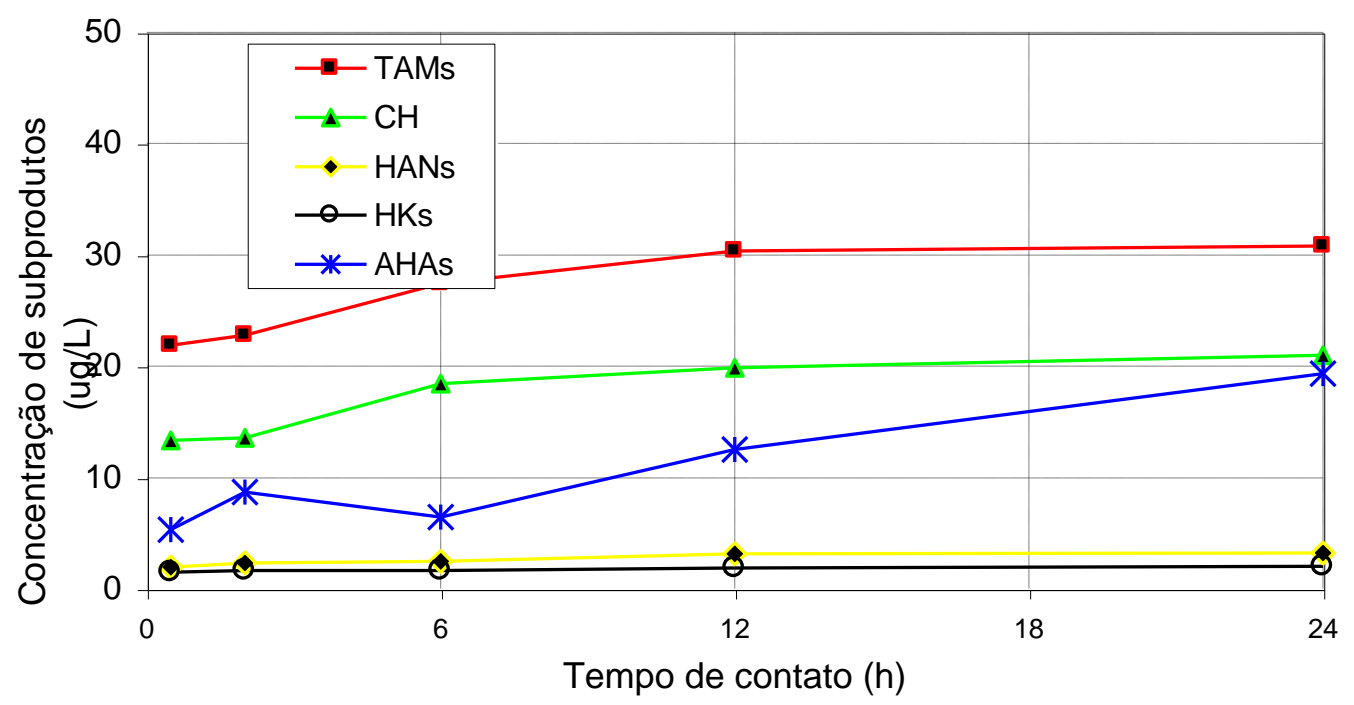

Figura 5.30 - Concentração de subprodutos em função do tempo de contato com o uso da pré-oxidação com permanganato de potássio, coagulação, filtração, pós-cloração e incubação a $25^{\circ} \mathrm{C}$ em função do tempo de contato.

Os valores em percentuais obtidos do PF de 24h, apresentaram-se mais significativos para TAMs, representados por uma fração de $68 \%$, seguidos de $\mathrm{CH}$ com 22\% e AHAs com 10\%. Na Figura 5.31 estão apresentados os resultados.

A Figura 5.32 apresenta a comparação dos valores de PF de 7dias e de PF de 24h com presença e ausência de coagulação, filtração em papel, pós-cloração e incubação a $25^{\circ} \mathrm{C}$. Observou-se que a presença de coagulação reduziu a formação em todos os subprodutos, principalmente para TAMs e AHAs. Os PF de 24h para os AHAs na ausência de coagulação ficaram próximos ao PF de 7 dias. Para o $\mathrm{CH}$ a redução na formação devido

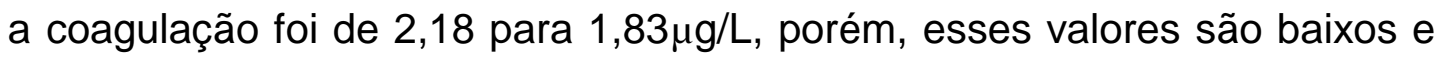
podem não ser representativos. 


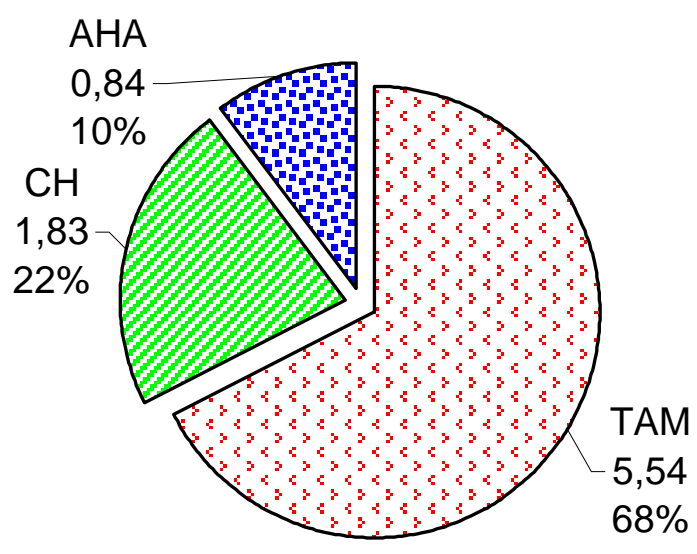

Figura 5.31 - Resultados de potencial de formação de 24h dos subprodutos da pré-oxidação com permanganato de potássio, coagulação, filtração em papel, pós-cloração e incubação por $24 \mathrm{~h}$ a $25^{\circ} \mathrm{C}$ expressos em $\mu \mathrm{g} / \mathrm{L}$ e percentual.

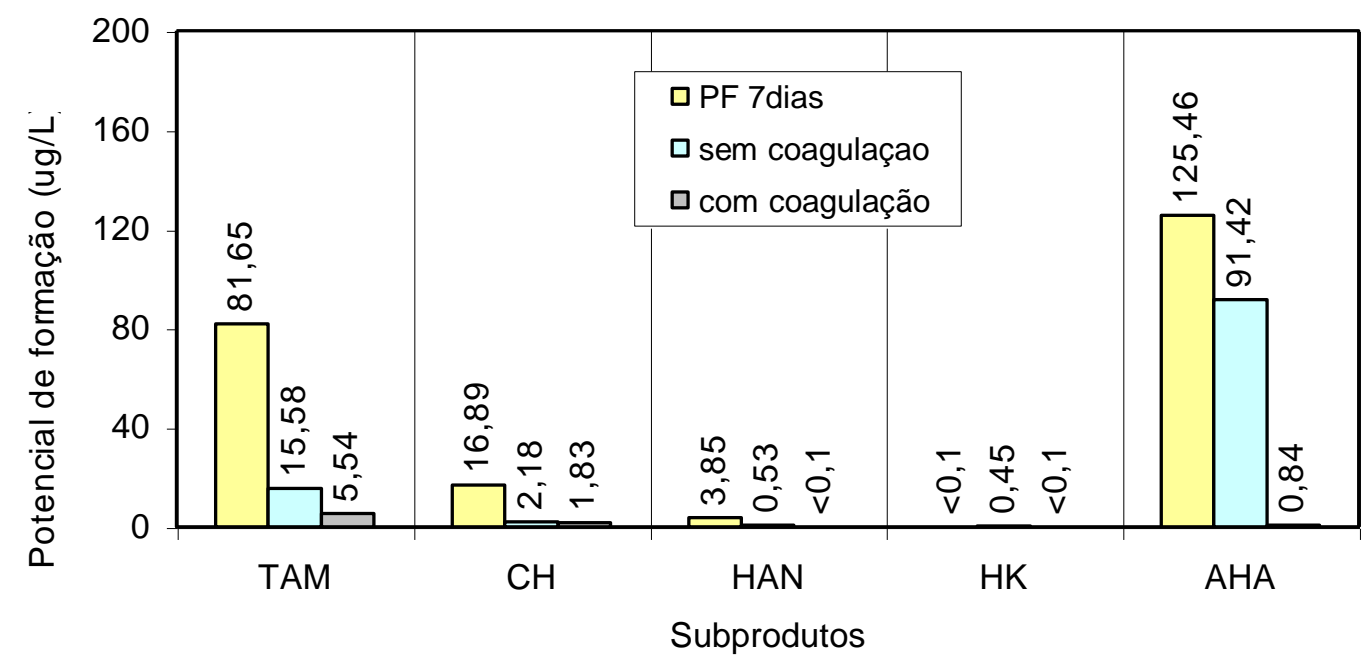

Figura 5.32 - Resultados comparativos de potencial de formação de 7 dias com cloro e permanganato de potássio com presença e ausência de coagulação, filtração em papel, pós-cloração e incubação a $25^{\circ} \mathrm{C}$.

\subsubsection{Subprodutos da pré-oxidação com dióxido de cloro}

As condições estabelecidas para a pré-oxidação com dióxido de cloro foram determinadas em etapas anteriores, variando-se apenas a ausência e a presença da etapa de coagulação, seguido de filtração em papel, póscloração e incubação a $25^{\circ} \mathrm{C}$. 


\subsubsection{Subprodutos da pré-oxidação com dióxido de cloro, filtração e pós-cloração}

$\mathrm{Na}$ Tabela 5.30 estão apresentados os resultados de subprodutos obtidos e do PF $24 \mathrm{~h}$ para o uso de dióxido de cloro $\left(1,2 \mathrm{mgClO}_{2} / \mathrm{L}\right)$ na préoxidação, filtração em papel, pós-cloração $\left(5 \mathrm{mgCl}_{2} / \mathrm{L}\right)$ e incubação a $25^{\circ} \mathrm{C}$.

Tabela 5.30 - Resultados de subprodutos da pré-oxidação com dióxido de cloro, filtração em papel, pós-cloração e incubação por $24 \mathrm{~h}$ a $25^{\circ} \mathrm{C}$ e $\mathrm{PF}$ de $24 \mathrm{~h} \mathrm{em} \mu \mathrm{g} / \mathrm{L}$.

\begin{tabular}{|c|c|c|c|c|c|c|c|c|}
\hline \multirow{3}{*}{ SUBPRODUTOS } & \multicolumn{7}{|c|}{ Tempo de contato (h) } & \multirow{3}{*}{$\begin{array}{l}\text { PF } \\
24 \mathrm{~h}\end{array}$} \\
\hline & \multicolumn{2}{|c|}{ Branco } & \multicolumn{4}{|c|}{ amostras } & \multirow[b]{2}{*}{24} & \\
\hline & 0,5 & 24 & 0,5 & 2 & 6 & 12 & & \\
\hline \multicolumn{9}{|l|}{ Trialometanos } \\
\hline Clorofórmio & 16,76 & 18,70 & 32,34 & 39,53 & 65,96 & 74,72 & 95,16 & 60,88 \\
\hline Bromodiclorometano & 0,64 & 3,99 & 0,73 & 1,30 & 1,78 & 2,15 & 2,93 & $<0,1$ \\
\hline Dibromoclorometano & $<0,1$ & $<0,1$ & 0,88 & $<0,1$ & $<0,1$ & $<0,1$ & 0,84 & $<0,1$ \\
\hline Bromofórmio & $<0,1$ & $<0,1$ & $<0,1$ & $<0,1$ & $<0,1$ & $<0,1$ & $<0,1$ & $<0,1$ \\
\hline Total TAMs $(\mu \mathrm{g} / \mathrm{L})$ & 17,40 & 22,69 & 33,95 & 40,83 & 67,74 & 76,87 & 98,93 & 59,69 \\
\hline Cloro Hidrato $(\mu \mathrm{g} / \mathrm{L})$ & $<0,1$ & 2,83 & 7,59 & 8,61 & 12,28 & 19,83 & 27,85 & 17,43 \\
\hline \multicolumn{9}{|l|}{ Halopicrina } \\
\hline Cloropicrina ( $\mu \mathrm{g} / \mathrm{L})$ & $<0,1$ & 0,21 & $<0,1$ & $<0,1$ & $<0,1$ & 0,22 & $<0,1$ & $<0,1$ \\
\hline \multicolumn{9}{|l|}{ Haloacetonitrilas } \\
\hline Tricloroacetonitrila & $<0,1$ & $<0,1$ & $<0,1$ & $<0,1$ & $<0,1$ & $<0,1$ & $<0,1$ & $<0,1$ \\
\hline Dicloroacetonitrila & 0,00 & 1,44 & 1,53 & 2,48 & 4,65 & 5,96 & 7,17 & 4,20 \\
\hline Dibromoacetonitrila & $<0,1$ & $<0,1$ & $<0,1$ & $<0,1$ & $<0,1$ & $<0,1$ & $<0,1$ & $<0,1$ \\
\hline Bromocloroacetonitrila & $<0,1$ & $<0,1$ & $<0,1$ & $<0,1$ & $<0,1$ & $<0,1$ & $<0,1$ & $<0,1$ \\
\hline Total HANs $(\mu \mathrm{g} / \mathrm{L})$ & $<0,1$ & 1,44 & 1,53 & 2,48 & 4,65 & 5,96 & 7,17 & 4,20 \\
\hline \multicolumn{9}{|l|}{ Halocetonas } \\
\hline 1,1,1Tricloropropanona & $<0,1$ & 2,48 & 2,19 & 2,62 & 3,31 & 3,60 & 7,00 & 2,33 \\
\hline 1,1-Dicloropropanona & $<0,1$ & $<0,1$ & $<0,1$ & $<0,1$ & $<0,1$ & $<0,1$ & 7,30 & 7,30 \\
\hline Total HKs $(\mu \mathrm{g} / \mathrm{L})$ & $<0,1$ & 2,48 & 2,19 & 2,62 & 3,31 & 3,60 & 14,30 & 9,63 \\
\hline \multicolumn{9}{|l|}{ Ác.Haloacéticos } \\
\hline MCAA & $<0,1$ & 0,42 & 0,75 & 1,33 & 1,23 & 2,42 & 3,11 & 1,94 \\
\hline MBAA & $<0,1$ & $<0,1$ & $<0,1$ & 0,59 & 0,49 & 0,54 & 0,96 & 0,96 \\
\hline DCAA & 0,52 & 2,98 & 15,80 & 25,65 & 30,36 & 65,20 & 74,26 & 56,00 \\
\hline TCAA & $<0,1$ & 1,20 & 13,78 & 24,09 & 25,33 & 49,47 & 53,57 & 38,59 \\
\hline BCAA & $<0,1$ & $<0,1$ & $<0,1$ & $<0,1$ & $<0,1$ & $<0,1$ & $<0,1$ & $<0,1$ \\
\hline BDCAA & $<0,1$ & $<0,1$ & $<0,1$ & $<0,1$ & $<0,1$ & $<0,1$ & $<0,1$ & $<0,1$ \\
\hline DBAA & $<0,1$ & $<0,1$ & $<0,1$ & $<0,1$ & $<0,1$ & $<0,1$ & $<0,1$ & $<0,1$ \\
\hline CDBAA & $<0,1$ & $<0,1$ & $<0,1$ & $<0,1$ & $<0,1$ & $<0,1$ & $<0,1$ & $<0,1$ \\
\hline TBAA & $<0,1$ & $<0,1$ & $<0,1$ & $<0,1$ & $<0,1$ & $<0,1$ & $<0,1$ & $<0,1$ \\
\hline Total AHAs $(\mu \mathrm{g} / \mathrm{L})$ & 0,52 & 4,60 & 30,33 & 51,66 & 57,41 & 117,63 & 131,90 & 97,49 \\
\hline
\end{tabular}


Alguns cromatogramas típicos estão apresentados nos Apêndices F-01 e F02. Os valores de AHAs apresentaram-se maiores e com uma formação crescente em função do tempo de contato, o maior valor obtido foi de 131,90 $\mu \mathrm{g} / \mathrm{L}$, os demais subprodutos apresentaram uma tendência de estabilização após 6h. Este comportamento pode ser observado na Figura 5.33.

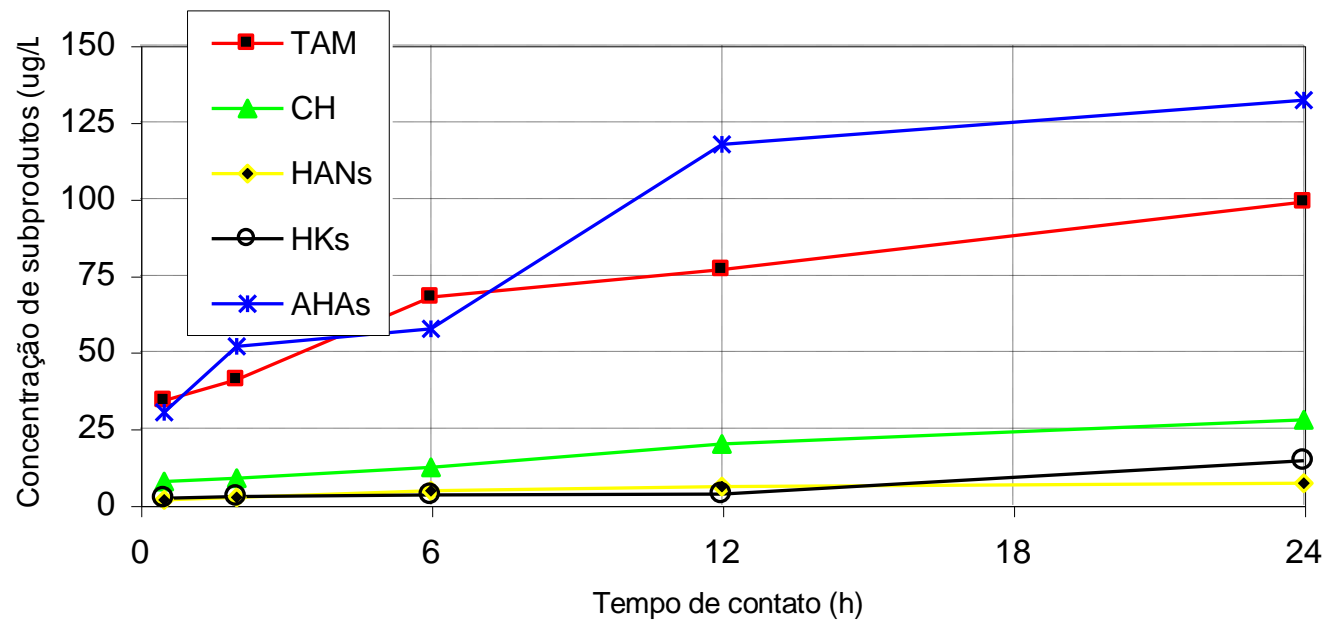

Figura 5.33 - Valores de concentração de subprodutos formados com uso de dióxido de cloro filtração, pós-cloração e incubação a $25^{\circ} \mathrm{C}$ em função do tempo de contato.

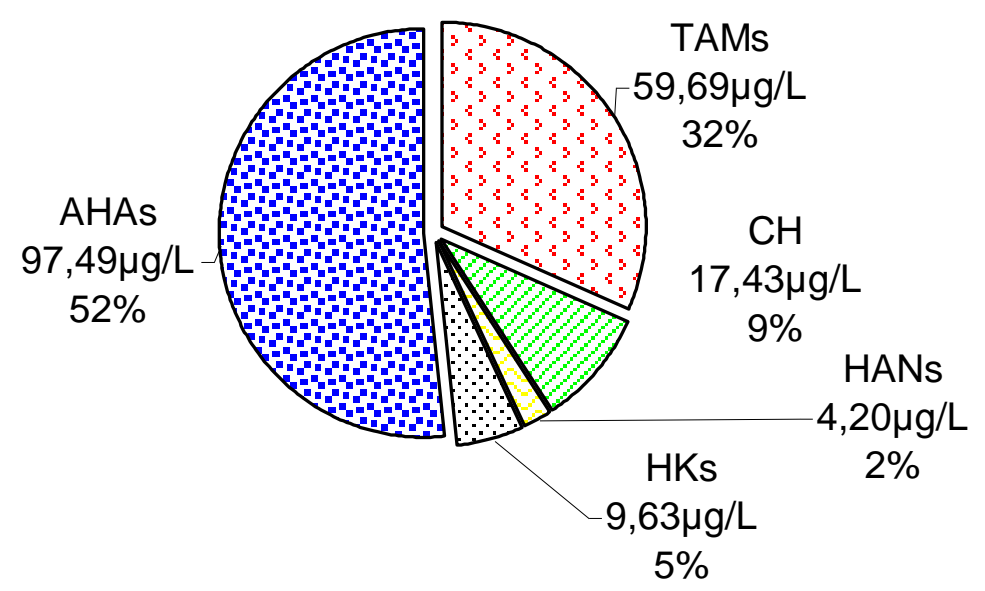

Figura 5.34 - Resultados de potencial de formação de $24 \mathrm{~h}$ dos subprodutos da pré-oxidação com dióxido de cloro, filtração em papel, pós-cloração e incubação por $24 \mathrm{~h}$ a $25^{\circ} \mathrm{C}$ expressos em $\mu \mathrm{g} / \mathrm{L}$ e percentual.

Uma fração de $84 \%$ dos subprodutos foi formada por AHAs e TAMs, com $52 \%$ e $32 \%$ respectivamente, o $\mathrm{CH}$ contribui com $9 \%$ do total, e os $7 \%$ restantes ficaram divididos entre HKs, 5\% e HANs com 2\%. Na Figura 5.34 estão apresentados os resultados obtidos. 
5.10.3.2 Subprodutos da pré-oxidação com dióxido de cloro, seguido de coagulação, filtração e pós-cloração

$\mathrm{Na}$ Tabela 5.31 estão apresentados os resultados de subprodutos obtidos e do PF 24h para o uso de dióxido de cloro na pré-oxidação, coagulação $(10 \mathrm{mgSA} / \mathrm{L})$, filtração em papel, pós-cloração $\left(5 \mathrm{mgCl}_{2} / \mathrm{L}\right)$ e incubação a $25^{\circ} \mathrm{C}$ em função do tempo de contato.

Tabela 5.31- Resultados de subprodutos da pré-oxidação com dióxido de cloro, coagulação, filtração e incubação por $24 \mathrm{~h}$ a $25^{\circ} \mathrm{C} \mathrm{em} \mu \mathrm{g} / \mathrm{L}$.

\begin{tabular}{|c|c|c|c|c|c|c|c|c|}
\hline \multirow{3}{*}{ Subprodutos } & \multirow{2}{*}{\multicolumn{2}{|c|}{ Branco }} & \multicolumn{5}{|c|}{ Tempo de contato $(\mathrm{h})$} & \multirow{3}{*}{$\begin{array}{c}\text { PF } \\
24 h\end{array}$} \\
\hline & & & & & amostr & & & \\
\hline & 0,5 & 24 & 0,5 & 2 & 6 & 12 & 24 & \\
\hline \multicolumn{9}{|l|}{ Trialometanos } \\
\hline Clorofórmio & 16,76 & 18,70 & 22,94 & 25,28 & 28,84 & 30,18 & 31,25 & 6,37 \\
\hline Bromodiclorometano & 0,64 & 3,99 & 1,08 & 1,98 & 2,39 & 2,91 & 2,97 & $<0,1$ \\
\hline Dibromoclorometano & $<0,1$ & $<0,1$ & $<0,1$ & $<0,1$ & $<0,1$ & $<0,1$ & $<0,1$ & $<0,1$ \\
\hline Bromofórmio & $<0,1$ & $<0,1$ & $<0,1$ & $<0,1$ & $<0,1$ & $<0,1$ & $<0,1$ & $<0,1$ \\
\hline Total TAMs ( $\mu \mathrm{g} / \mathrm{L}$ ) & 17,40 & 22,69 & 24,02 & 27,26 & 31,23 & 33,09 & 34,22 & 4,91 \\
\hline Cloro Hidrato $(\mu \mathrm{g} / \mathrm{L})$ & $<0,1$ & 2,83 & 6,81 & 9,97 & 9,91 & 12,83 & 14,15 & 4,51 \\
\hline
\end{tabular}

Halopicrina

$\begin{array}{llllllllll}\text { Cloropicrina }(\mu \mathrm{g} / \mathrm{L}) & <0,1 & <0,1 & <0,1 & <0,1 & <0,1 & <0,1 & <0,1 & <0,1\end{array}$

\begin{tabular}{|c|c|c|c|c|c|c|c|c|}
\hline Haloacetonitrilas & & & & & & & & \\
\hline Tricloroacetonitrila & 0,1 & $=0,1$ & $<0,1$ & $<0,1$ & $<0,1$ & $<0,1$ & $<0,1$ & $<0,1$ \\
\hline Dicloroacetonitrila & 0,1 & 44 & 0,83 & 1,45 & 2,43 & 3,08 & 0 & 1,73 \\
\hline Dibromoacetonitrila & 0,1 & $<0,1$ & $<0,1$ & $<0,1$ & $<0,1$ & $<0,1$ & $<0,1$ & $<0,1$ \\
\hline Bromocloroacetonitrila & 0,1 & $<0,1$ & $<0,1$ & $<0,1$ & $<0,1$ & $<0,1$ & $<0,1$ & $<0,1$ \\
\hline Tot & $=01$ & 1,44 & $0 ?$ & 1,45 & 243 & 3,08 & 4,00 & 1,73 \\
\hline Halo & & & & & & & & \\
\hline ona & 0,1 & 2,48 & 1,11 & 2,09 & 2,22 & 2,18 & 2,14 & $<0,1$ \\
\hline nona & 0,1 & $<0,1$ & $<0,1$ & $<0,1$ & $<0,1$ & $<0,1$ & $<0,1$ & $<0,1$ \\
\hline Tota & 0,1 & 2,48 & 1,11 & 2,09 & 2,22 & 2,18 & 2,14 & $<0,1$ \\
\hline Ác.r & & & & & & & & \\
\hline MCA & $<0,1$ & 0,42 & 0,23 & 0,37 & 0,64 & 2,13 & 4,81 & 4,16 \\
\hline MBAA & $<0,1$ & $<0,1$ & $<0,1$ & 0,80 & $<0,1$ & $<0,1$ & $<0,1$ & $<0,1$ \\
\hline DCAA & 0,52 & 2,98 & 5,59 & 13,53 & 19,98 & 40,10 & $<0,1$ & $<0,1$ \\
\hline TCAA & $<0,1$ & 1,20 & 1,75 & 7,81 & 5,45 & 9,96 & 14,35 & 11,40 \\
\hline BCAA & $<0,1$ & $<0,1$ & $<0,1$ & 0,24 & $<0,1$ & $<0,1$ & 49,02 & 49,02 \\
\hline BDCAA & $<0,1$ & $<0,1$ & 1,27 & 0,67 & $<0,1$ & $<0,1$ & 6,98 & 5,71 \\
\hline DBAA & $<0,1$ & $<0,1$ & 0,89 & 0,51 & $<0,1$ & $<0,1$ & 1,45 & 0,56 \\
\hline CDBAA & $<0,1$ & $<0,1$ & $<0,1$ & $<0,1$ & 2,99 & $<0,1$ & $<0,1$ & $<0,1$ \\
\hline TBAA & $<0,1$ & $<0,1$ & $<0,1$ & $<0,1$ & $<0,1$ & $<0,1$ & $<0,1$ & $<0,1$ \\
\hline Total AHAs ( & 0,52 & 4,60 & 9,73 & 23,93 & 29,06 & 52,19 & 76,61 & 62,80 \\
\hline
\end{tabular}


Alguns cromatogramas típicos estão apresentados nos Apêndices F-03 e F-04. Na Figura 5.35 estão apresentados os resultados obtidos de subprodutos em função do tempo de contato. Os TAMs, CH, HANs e HKs apresentaram um comportamento similar com uma tendência de estabilização na formação após $6 \mathrm{~h}$ de tempo de contato. Dentro do período avaliado, os AHAs apresentaram uma tendência de crescimento acentuada.

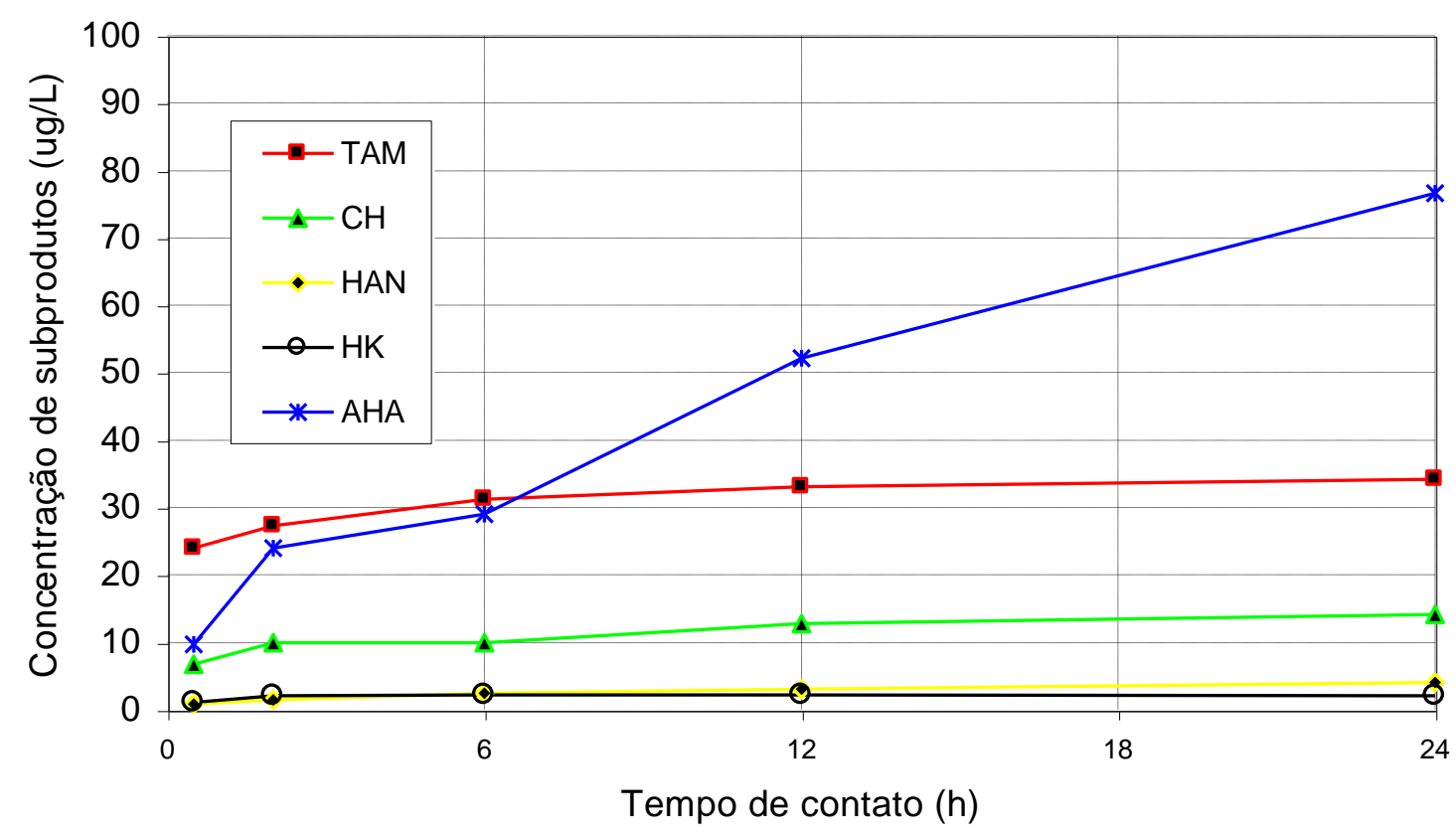

Figura 5.35 - Valores de concentração de subprodutos formados com uso de dióxido de cloro, coagulação, filtração em papel, pós-cloração e incubação a $25^{\circ} \mathrm{C}$ em função do tempo de contato.

Na Figura 5.36 estão apresentados os resultados em porcentagem agrupados por compostos formados, sendo $85 \%$ do total de subprodutos compostos por AHAs, os $15 \%$ restantes estão subdivididos em $7 \%$ para TAMs, $6 \%$ de $\mathrm{CH}, 2 \%$ de HANs e $1 \%$ de HKs.

Comparando-se os valores de PF de 7dias e de PF de 24h com presença e ausência de coagulação, observou-se que o emprego da coagulação reduziu a formação em todos os subprodutos, principalmente para os TAMs. Na ausência de coagulação, a o PF de $24 \mathrm{~h}$ de $\mathrm{CH}$, HANs e HKs foi superior ao PF de 7 dias A remoção menos significativa foi para AHAs. Na Figura 5.37 estão apresentadas as comparações dos resultados obtidos. 


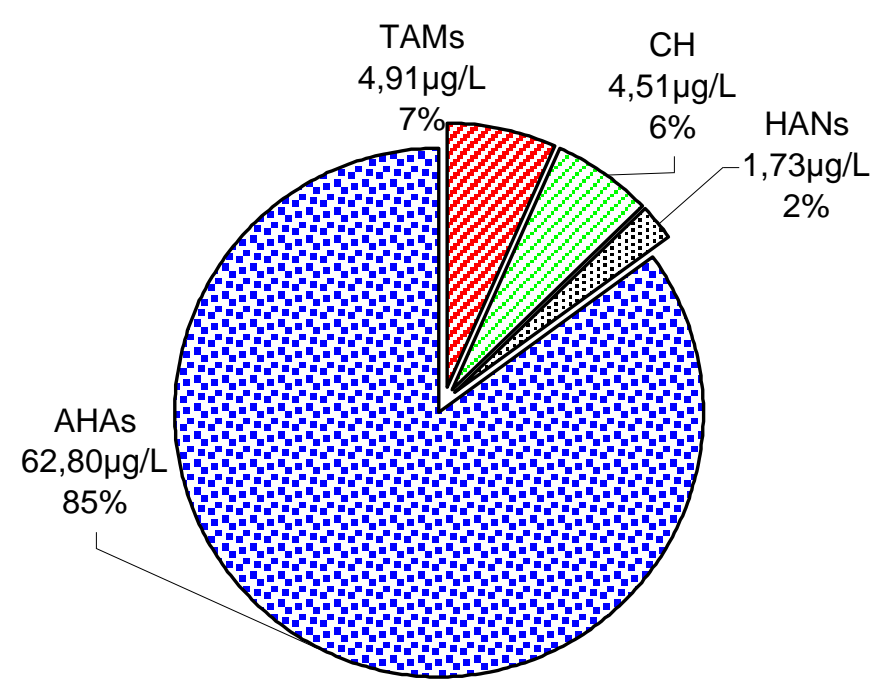

Figura 5.36 - Valores de potencial de formação após $24 \mathrm{~h}$ de tempo de contato para pré-oxidação com dióxido de cloro, coagulação, filtração em papel, pós-cloração e incubação a $25^{\circ} \mathrm{C}$, expressos em percentual e concentração.

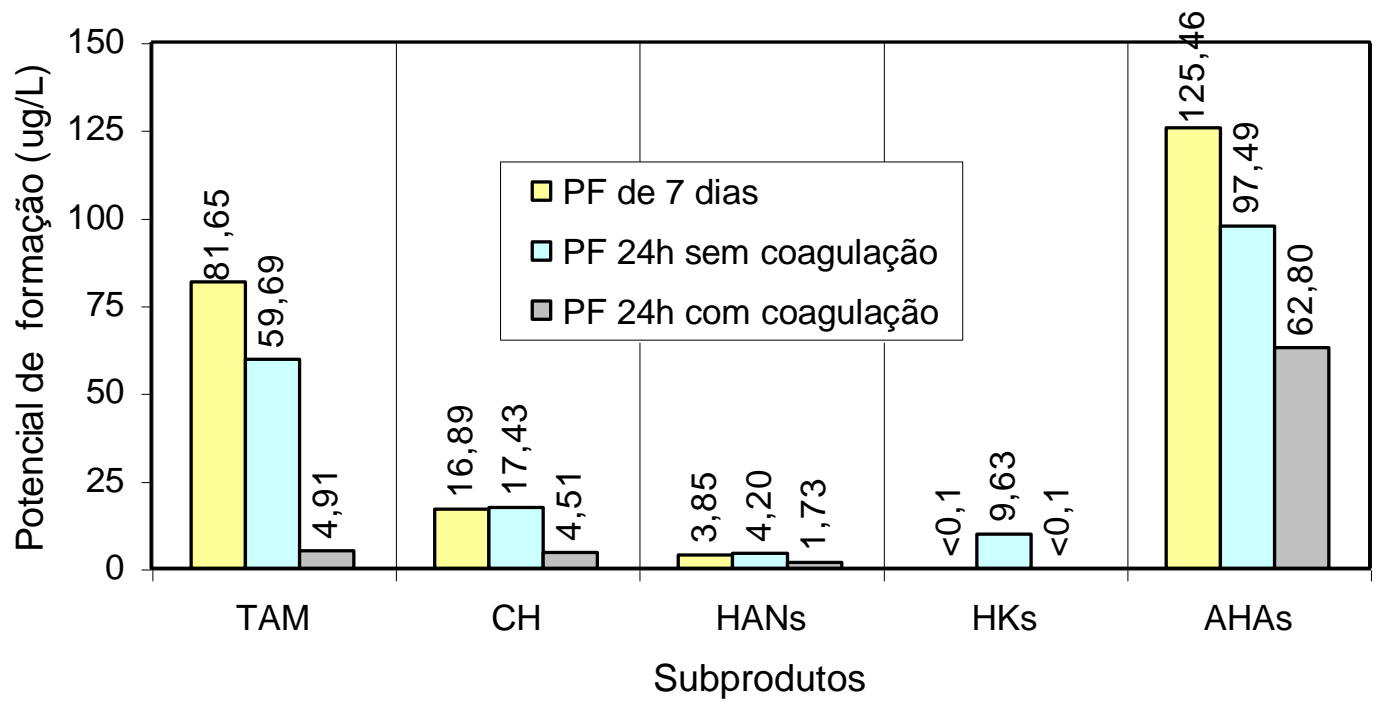

Figura 5.37- Resultados de PF de 7 dias e 24h com coagulação e $24 \mathrm{~h}$ sem coagulação, filtração em papel, pós-cloração, incubação a $25^{\circ} \mathrm{C}$, expressos em concentração.

\subsubsection{Subprodutos da pré-oxidação com peróxido de hidrogênio}

As condições estabelecidas para a pré-oxidação com peróxido de hidrogênio foram determinadas em etapas anteriores, variando-se apenas a ausência e a presença da etapa de coagulação. 
5.10.4.1 Subprodutos da pré-oxidação com peróxido de hidrogênio, filtração e pós-cloração

$\mathrm{Na}$ Tabela 5.32 estão apresentados os resultados de subprodutos obtidos e do PF 24h para o uso de peróxido de hidrogênio ( $35 \mathrm{mg} \mathrm{H}_{2} \mathrm{O}_{2} / \mathrm{L}$ ) na pré-oxidação, filtração em papel, pós-cloração $\left(5 \mathrm{mgCl}_{2} / \mathrm{L}\right)$ e incubação a $25^{\circ} \mathrm{C}$.

Tabela 5.32 - Resultados de subprodutos da pré-oxidação com peróxido de hidrogênio, filtração, incubação por $24 \mathrm{~h}$ a $25^{\circ} \mathrm{C}$ e PF de $24 \mathrm{~h}$ em $\mu \mathrm{g} / \mathrm{L}$.

\begin{tabular}{|c|c|c|c|c|c|c|c|c|}
\hline \multirow{3}{*}{ Subprodutos } & \multirow{2}{*}{\multicolumn{2}{|c|}{ Branco }} & \multicolumn{5}{|c|}{ Tempo de contato $(\mathrm{h})$} & \multirow{3}{*}{$\begin{array}{c}\text { PF } \\
24 h\end{array}$} \\
\hline & & & & & amostra & & & \\
\hline & 0,5 & 24 & 0,5 & 2 & 6 & 12 & 24 & \\
\hline \multicolumn{9}{|l|}{ Trialometanos } \\
\hline Clorofórmio & 18,02 & 17,29 & 16,37 & 16,49 & 17,17 & 17,62 & 19,27 & 3,63 \\
\hline Bromodiclorometano & 0,36 & 0,47 & $<0,1$ & $<0,1$ & 0,42 & $<0,1$ & $<0,1$ & $<0,1$ \\
\hline Dibromoclorometano & $<0,1$ & 0,89 & $<0,1$ & $<0,1$ & $<0,1$ & 1,97 & 1,58 & 0,69 \\
\hline Bromofórmio & $<0,1$ & $<0,1$ & $<0,1$ & $<0,1$ & $<0,1$ & $<0,1$ & $<0,1$ & 0,00 \\
\hline Total TAMs ( $\mu \mathrm{g} / \mathrm{L})$ & 18,38 & 18,65 & 16,37 & 16,49 & 17,59 & 19,59 & 20,85 & 4,21 \\
\hline Cloro Hidrato $(\mu \mathrm{g} / \mathrm{L})$ & $<0,1$ & $<0,1$ & $<0,1$ & 2,30 & $<0,1$ & $<0,1$ & 5,56 & 5,56 \\
\hline
\end{tabular}

Halopicrina

$\begin{array}{lllllllll}\text { Cloropicrina }(\boldsymbol{\mu g} / \mathrm{L}) & <0,1 & <0,1 & <0,1 & <0,1 & <0,1 & <0,1 & <0,1 & <0,1\end{array}$

Haloacetonitrilas

Tricloroacetonitrila

Dicloroacetonitrila

Dibromoacetonitrila

Bromocloroacetonitrila

Total HANs $(\mu \mathrm{g} / \mathrm{L})$

$\begin{array}{llllllll}<0,1 & <0,1 & <0,1 & <0,1 & <0,1 & <0,1 & <0,1 & <0,1 \\ <0,1 & <0,1 & <0,1 & <0,1 & <0,1 & <0,1 & <0,1 & <0,1 \\ <0,1 & <0,1 & <0,1 & <0,1 & <0,1 & <0,1 & <0,1 & <0,1 \\ <0,1 & <0,1 & <0,1 & <0,1 & <0,1 & <0,1 & <0,1 & <0,1 \\ <0,1 & <0,1 & <0,1 & <0,1 & <0,1 & <0,1 & <0,1 & <0,1\end{array}$

Halocetonas

\begin{tabular}{lllllllll} 
1,1,1Tricloropropanona & $<0,1$ & $<0,1$ & $<0,1$ & $<0,1$ & $<0,1$ & $<0,1$ & $<0,1$ & $<0,1$ \\
1,1-Dicloropropanona & $<0,1$ & $<0,1$ & $<0,1$ & $<0,1$ & $<0,1$ & $<0,1$ & $<0,1$ & $<0,1$ \\
Total HKs $(\mu \mathrm{g} / \mathrm{L})$ & $<0,1$ & $<0,1$ & $<0,1$ & $<0,1$ & $<0,1$ & $<0,1$ & $<0,1$ & $<0,1$ \\
\hline
\end{tabular}

Ác.Haloacéticos

\begin{tabular}{lllllllll} 
MCAA & $<0,1$ & $<0,1$ & $<0,1$ & $<0,1$ & $<0,1$ & $<0,1$ & $<0,1$ & $<0,1$ \\
MBAA & $<0,1$ & $<0,1$ & $<0,1$ & $<0,1$ & $<0,1$ & $<0,1$ & $<0,1$ & $<0,1$ \\
DCAA & 2,23 & 1,43 & 1,94 & 1,09 & 2,24 & 1,24 & $<0,1$ & $<0,1$ \\
TCAA & $<0,1$ & 0,59 & $<0,1$ & 0,58 & $<0,1$ & 0,72 & $<0,1$ & $<0,1$ \\
BCAA & 1,84 & $<0,1$ & $<0,1$ & $<0,1$ & 0,88 & $<0,1$ & 0,94 & 2,78 \\
BDCAA & $<0,1$ & $<0,1$ & $<0,1$ & $<0,1$ & $<0,1$ & 0,89 & 2,30 & 2,30 \\
DBAA & $<0,1$ & $<0,1$ & 0,45 & 0,73 & $<0,1$ & $<0,1$ & 0,76 & 0,31 \\
CDBAA & $<0,1$ & $<0,1$ & $<0,1$ & $<0,1$ & $<0,1$ & $<0,1$ & $<0,1$ & $<0,1$ \\
TBAA & $<0,1$ & $<0,1$ & $<0,1$ & $<0,1$ & $<0,1$ & $<0,1$ & $<0,1$ & $<0,1$ \\
Total AHAs $(\boldsymbol{\mu g} / \mathbf{L})$ & $\mathbf{4 , 0 7}$ & $\mathbf{2 , 0 2}$ & $\mathbf{2 , 3 9}$ & $\mathbf{2 , 4 0}$ & $\mathbf{3 , 1 2}$ & $\mathbf{2 , 8 5}$ & $\mathbf{4 , 0 0}$ & $\mathbf{3 , 6 6}$ \\
\hline
\end{tabular}


Alguns cromatogramas típicos estão apresentados nos Apêndices G-01 e G-02. Os subprodutos de maior formação foram os TAMs com

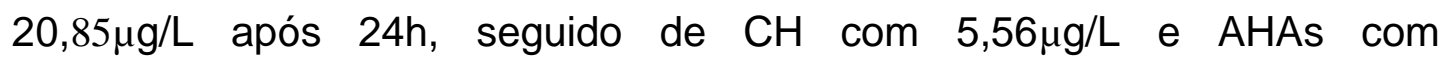
$4,00 \mu \mathrm{g} / \mathrm{L}$,todos os compostos apresentaram uma tendência de estabilização na formação após $12 \mathrm{~h}$ de tempo de contato. Na Figura 5.38 estão apresentados os resultados.

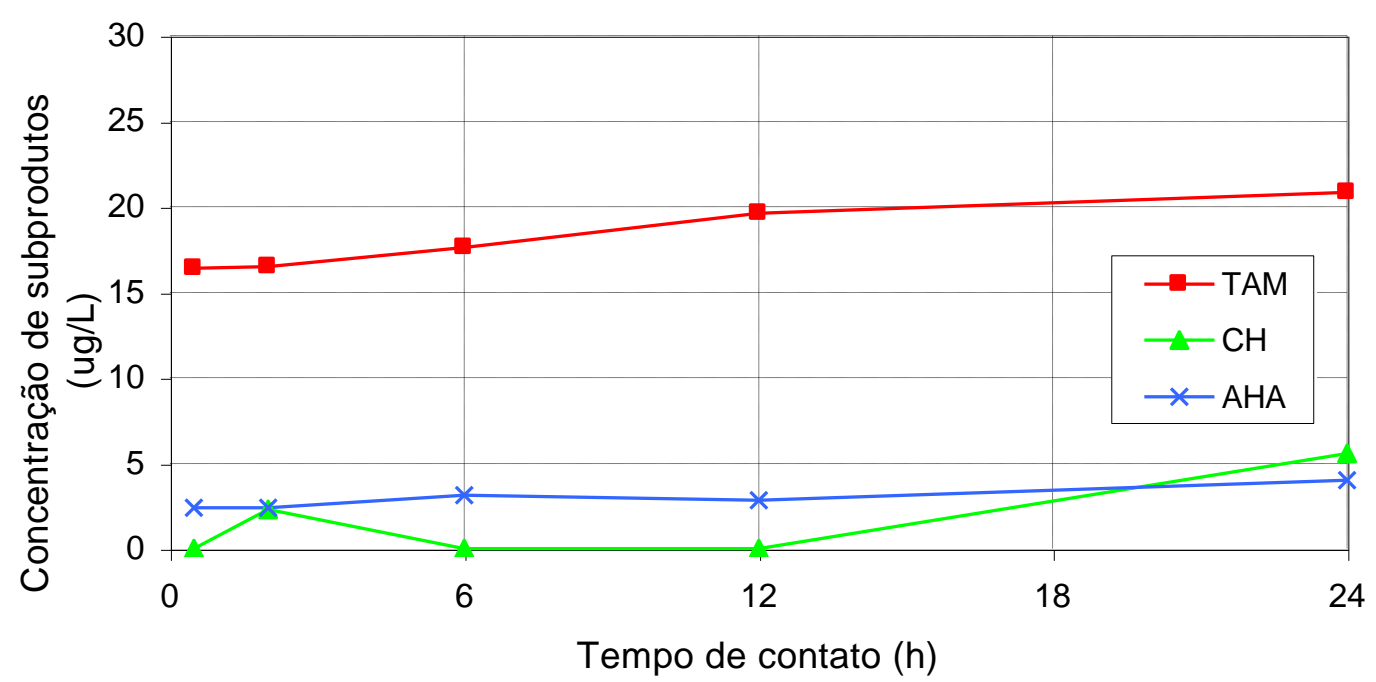

Figura 5.38- Valores de concentração de subprodutos formados com uso de peróxido de hidrogênio, filtração em papel, pós-cloração e incubação a $25^{\circ} \mathrm{C}$ em função do tempo de contato.

Na Figura 5.39 está apresentada a composição obtida, sendo: 31\% de TAMs, $42 \%$ para $\mathrm{CH}$, e $27 \%$ para AHAs.

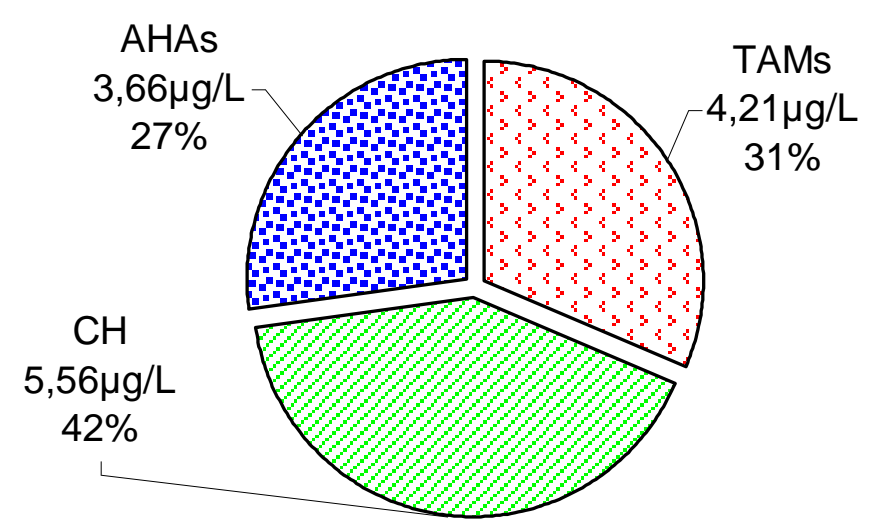

Figura 5.39 - Valores de potencial de formação após 24h de tempo de contato para pré-oxidação com peróxido de hidrogênio, filtração em papel, pós-cloração e incubação a $25^{\circ} \mathrm{C}$, expressos em percentual e concentração. 


\subsubsection{Subprodutos da pré-oxidação com peróxido de hidrogênio, seguido de coagulação, filtração e pós-cloração}

$\mathrm{Na}$ Tabela 5.33 estão apresentados os resultados de subprodutos formados com o uso de peróxido de hidrogênio (35mg $\mathrm{H}_{2} \mathrm{O}_{2} / \mathrm{L}$ ) na préoxidação, coagulação (12mgSA/L), filtração em papel, pós-cloração $\left(5 \mathrm{mgCl}_{2} / \mathrm{L}\right)$, incubação a $25^{\circ} \mathrm{C}$ e o cálculo do potencial de formação de $24 \mathrm{~h}$.

Tabela 5.33- Subprodutos da pré-oxidação com peróxido de hidrogênio, com coagulação, filtração em papel, pós-cloração, incubação por $24 \mathrm{~h}$ a $25^{\circ} \mathrm{C}$ e PF de $24 \mathrm{~h}$, em $\mu \mathrm{g} / \mathrm{L}$.

\begin{tabular}{|c|c|c|c|c|c|c|c|c|}
\hline \multirow{3}{*}{ Subprodutos } & \multicolumn{7}{|c|}{ Tempo de contato (h) } & \multirow{3}{*}{$\begin{array}{c}\text { PF } \\
24 h\end{array}$} \\
\hline & \multicolumn{2}{|c|}{ Branco } & \multicolumn{4}{|c|}{ Amostras } & \multirow[b]{2}{*}{24} & \\
\hline & 0,5 & 24 & 0,5 & 2 & 6 & 12 & & \\
\hline \multicolumn{9}{|l|}{ Trialometanos } \\
\hline Clorofórmio & 3,02 & 7,29 & 16,03 & 18,18 & 18,28 & 20,31 & 20,52 & 5,22 \\
\hline Bromodiclorometano & 36 & 0,47 & $<0$ & 0,66 & 1,25 & $<0,1$ & & $<0,1$ \\
\hline rometano & $<0,1$ & 0,89 & $<0,1$ & $<0,1$ & 0,83 & $<0,1$ & 6,05 & 5,16 \\
\hline Bron & $<0,1$ & $<0,1$ & $<0,1$ & $<0,1$ & $<0,1$ & $<0,1$ & $<0,1$ & $<0,1$ \\
\hline$(\mu \mathrm{g} / \mathrm{L})$ & 18,38 & 18,65 & 16,03 & 18,84 & 20,36 & 20,31 & 26,57 & 10,27 \\
\hline Cloro H & 0,1 & 0,1 & $=0,1$ & $=01$ & 01 & $<01$ & & 0,69 \\
\hline \multicolumn{9}{|l|}{ Halopicrinas } \\
\hline Cloropicrina $(\mu \mathrm{g} / \mathrm{L})$ & 0.1 & -01 & -01 & -01 & $<0,1$ & -01 & 1 & $<0,1$ \\
\hline \multicolumn{9}{|l|}{ Haloacetonitrilas } \\
\hline Tricloroacetonitrila & $<0,1$ & $<0,1$ & $<0,1$ & $<0,1$ & $<0,1$ & $<0,1$ & $<0,1$ & $<0,1$ \\
\hline &, 1 & $<$ & $<$ & $<0,1$ & $<0,1$ & $<0,1$ & & $<0,1$ \\
\hline & 0,1 & $<$ & $<0,1$ & $<0,1$ & $<0,1$ & $<0,1$ & 1 & $<0,1$ \\
\hline $\mathrm{Brc}$ & $<0,1$ & $<$ & $<0,1$ & $<0,1$ & $<0,1$ & $<0,1$ & & $<0,1$ \\
\hline Tota & & & & & 0,1 & & & $<0,1$ \\
\hline \multicolumn{9}{|l|}{ Halocetonas } \\
\hline & $<0,1$ & $<0,1$ & $<0,1$ & -01 & $<0,1$ & $<0,1$ & & $<0,1$ \\
\hline & $<0,1$ & $<0$ & $<0,1$ & $<0,1$ & $<0,1$ & $<0,1$ & & $<0,1$ \\
\hline Total HKs $(\mu \mathrm{g} / \mathrm{L})$ & -01 & -0 & -01 & $<0,1$ & $<0,1$ & $<0,1$ & & $<0,1$ \\
\hline \multicolumn{9}{|l|}{ Ác. Haloacéticos } \\
\hline MCAA & $<0,1$ & $<0,1$ & $<0,1$ & $<0,1$ & $<0,1$ & $<0$, & 1 & $<0,1$ \\
\hline M & $<0,1$ & $<0,1$ & $<0,1$ & $<0,1$ & $<0,1$ & $<0,1$ & & $<0,1$ \\
\hline DCAA & 2,23 & 1,43 & 0,26 & 1,04 & $<0,1$ & $<0,1$ & 0,83 & 1,37 \\
\hline TCAA & $<0,1$ & 0,59 & 0,16 & $<0,1$ & $<0,1$ & 0,83 & $<0,1$ & $<0,1$ \\
\hline BCAA & 1,84 & $<0,1$ & 0,21 & 0,43 & $<0,1$ & $<0,1$ & $<0,1$ & 1,63 \\
\hline BDCAA & $<0,1$ & $<0,1$ & $<0,1$ & $<0,1$ & 2,47 & $<0,1$ & $<0,1$ & $<0,1$ \\
\hline DBAA & $<0,1$ & $<0,1$ & $<0,1$ & 0,57 & 2,67 & 1,15 & 0,46 & 0,46 \\
\hline CDBAA & $<0,1$ & $<0,1$ & $<0,1$ & $<0,1$ & $<0,1$ & $<0,1$ & $<0,1$ & $<0,1$ \\
\hline TBAA & $<0,1$ & $<0,1$ & $<0,1$ & $<0,1$ & $<0,1$ & $<0,1$ & $<0,1$ & $<0,1$ \\
\hline Total AHAs & 4,07 & 2,02 & 0,63 & 2,04 & 5,14 & 1,98 & 1,29 & 2,71 \\
\hline
\end{tabular}


Alguns cromatogramas típicos estão apresentados nos Apêndices G03 e G-04. Na Figura 5.40 estão apresentados os resultados de subprodutos em função do tempo de contato, os TAMs foram os compostos com maior formação, tendo sido obtido $26,57 \mu \mathrm{g} / \mathrm{L}$, seguido de clorohidrato com 10,69 $\mu \mathrm{g} / \mathrm{L}$ e os AHAs se formaram em menor quantidade, com $1,29 \mu \mathrm{g} / \mathrm{L}$. Pelo limite de detecção do presente método não foi possível a identificação da formação de HANs, CP e HKs.

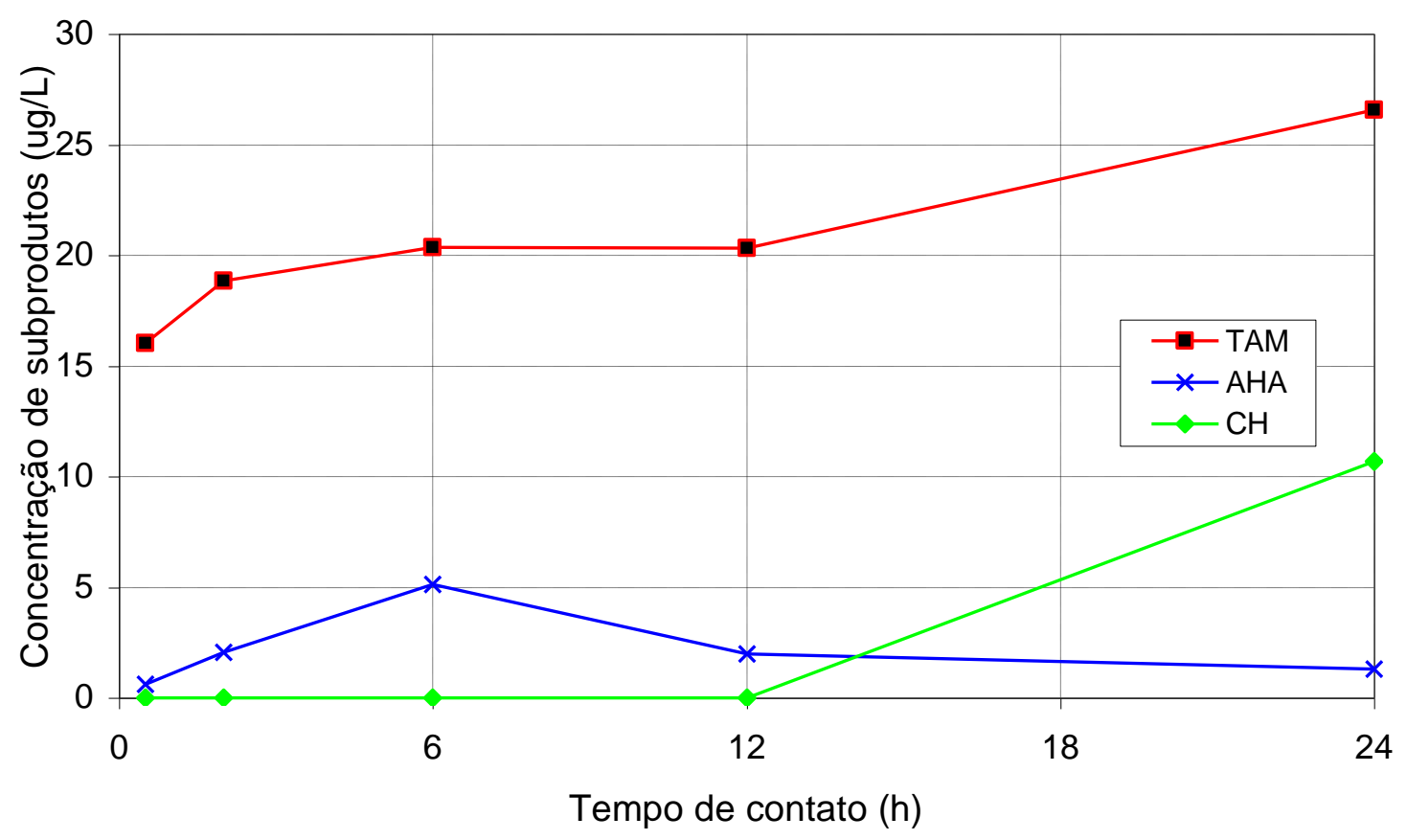

Figura 5.40- Valores de concentração de subprodutos formados com peróxido de hidrogênio, com coagulação, filtração em papel, pós-cloração, incubação a $25^{\circ} \mathrm{C}$ em função do tempo de contato.

Na Figura 5.41 estão apresentados os resultados dos subprodutos em percentagem e concentração, com uma fração de $43 \%$ para TAMs, $11 \%$ para AHAs e $46 \%$ para $\mathrm{CH}$.

$\mathrm{Na}$ Figura 5.42 estão apresentados os resultados comparativos de potencial de formação. Comparando os resultados, o uso da coagulação não apresentou de redução na formação de TAMs e AHAs. Todos os ensaios com peróxido de hidrogênio apresentaram PF de 24h inferior ao PF de 7 dias. 


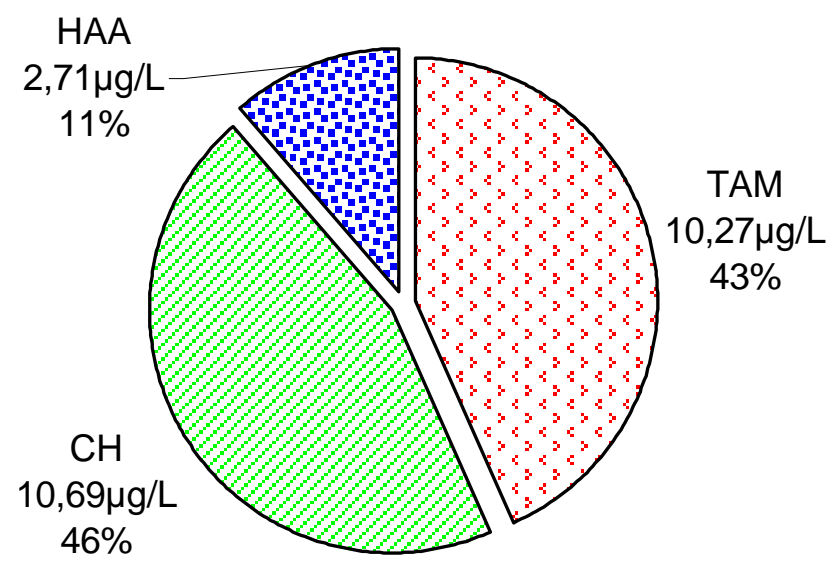

Figura 5.41- Valores de potencial de formação após 24h de tempo de contato para pré-oxidação com peróxido de hidrogênio, coagulação, filtração em papel, pós-cloração e incubação a $25^{\circ} \mathrm{C}$, expressos em percentual e concentração.

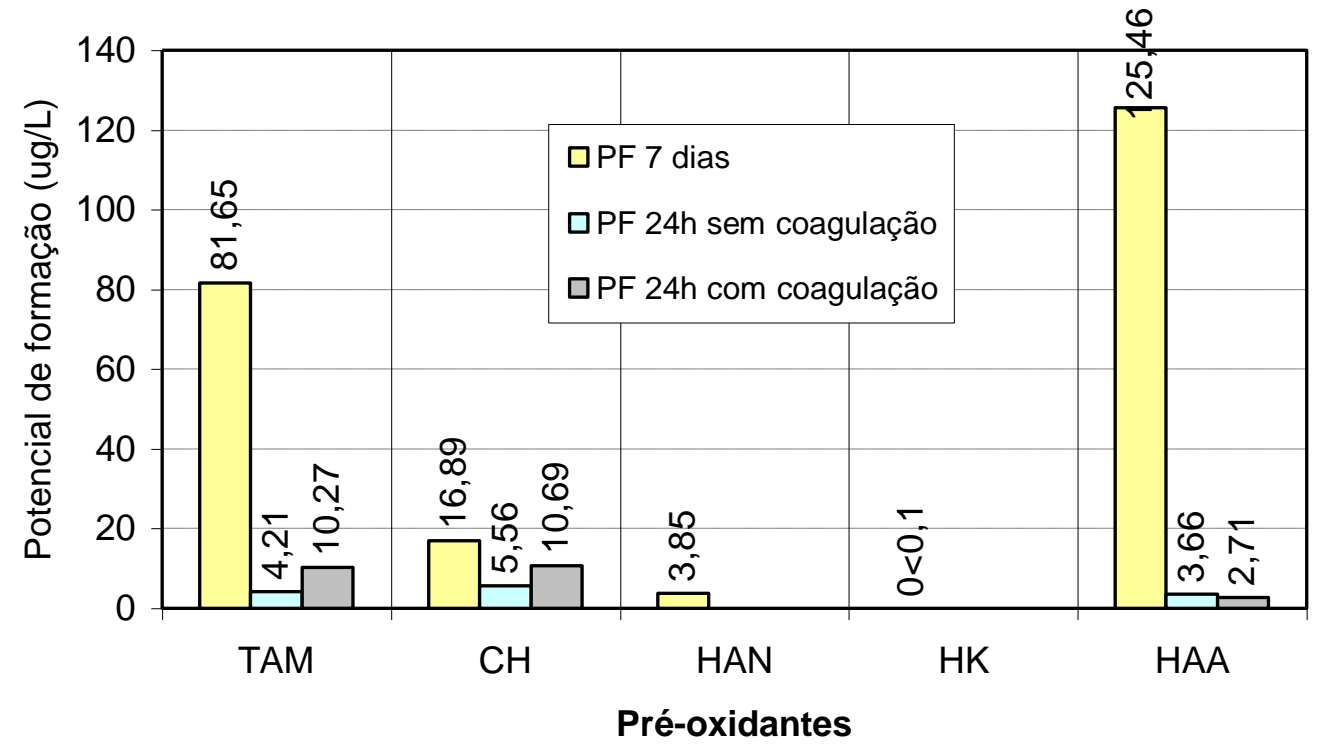

Figura 5.42 - Resultados de PF expressos em concentração de 7 dias, 24h com coagulação e $24 \mathrm{~h}$ sem coagulação, filtração em papel, pós-cloração e incubação a $25^{\circ} \mathrm{C}$.

\subsubsection{Subprodutos da pré-oxidação com ozônio}

As condições estabelecidas para a pré-oxidação com ozônio foram determinadas em etapas anteriores, variando-se apenas a ausência e a presença da etapa de coagulação, filtração em papel, pós-cloração e incubação a $25^{\circ} \mathrm{C}$. 


\subsubsection{Subprodutos da pré-oxidação com ozônio, filtração e pós- cloração}

$\mathrm{Na}$ Tabela 5.34 estão apresentados os resultados de subprodutos formados com o uso de ozônio $\left(3,92 \mathrm{mgO}_{3} / \mathrm{L}\right)$, filtração em papel, póscloração $\left(5 \mathrm{mgCl}_{2} / \mathrm{L}\right)$, incubação a $25^{\circ} \mathrm{C}$ e o cálculo do potencial de formação de 24h. Alguns cromatogramas típicos estão apresentados nos Apêndices $\mathrm{H}-01$ e $\mathrm{H}-02$.

$\mathrm{Na}$ figura 5.43 estão apresentados os valores de concentração de subprodutos formados com o uso de ozônio na pré-oxidação e na ausência da etapa de coagulação. Durante o período avaliado, os AHAs foram os subprodutos que mais se formaram, obtendo-se após $24 \mathrm{~h} 127,29 \mu \mathrm{g} / \mathrm{L}$, seguido dos TAMs com 59,79 $\mu \mathrm{g} / \mathrm{L}, \mathrm{CH}$ com $30,42 \mu \mathrm{g} / \mathrm{L}$, HANs com $11,64 \mu \mathrm{g} / \mathrm{L}$ e HKs com $6,43 \mu \mathrm{g} / \mathrm{L}$. A cloropicrina foi identificada com valores próximos ao limite de detecção nas amostras de $6 \mathrm{~h}$ e $24 \mathrm{~h}$, sendo $0,15 \mu \mathrm{g} / \mathrm{L}$ e $0,25 \mu \mathrm{g} / \mathrm{L}$ respectivamente.

Observou-se uma tendência crescente na formação de AHAs, os demais, após $6 \mathrm{~h}$ apresentaram uma tendência de estabilização na formação.

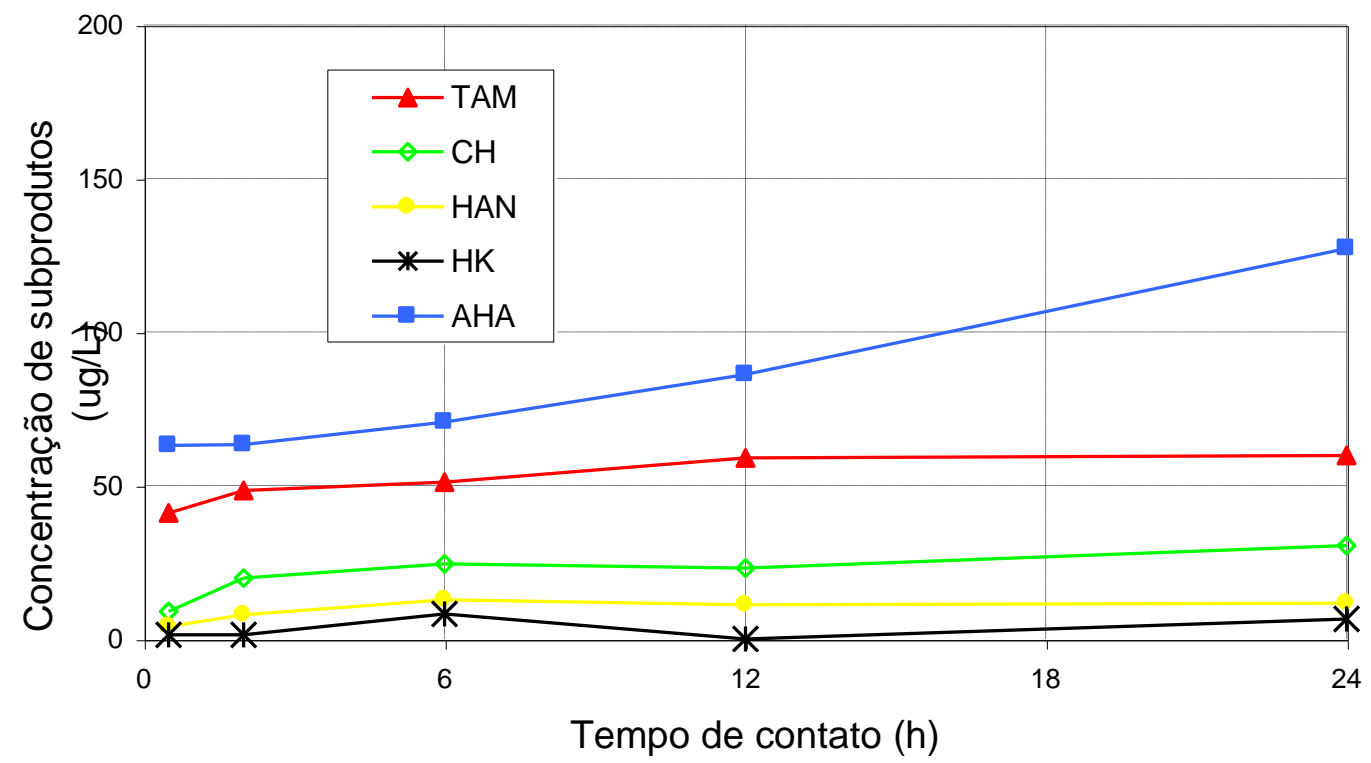

Figura 5.43- Valores de concentração de subprodutos formados na préoxidação com ozônio, filtração em papel, pós-cloração, incubação a $25^{\circ} \mathrm{C}$ em função do tempo de contato. 
Tabela 5.34 - Subprodutos da pré-oxidação com ozônio, filtração, incubação por $24 \mathrm{~h}$ a $25^{\circ} \mathrm{C}$ e PF de $24 \mathrm{~h}$, em $\mu \mathrm{g} / \mathrm{L}$.

\begin{tabular}{|c|c|c|c|c|c|c|c|c|}
\hline \multirow{3}{*}{ Subprodutos } & \multicolumn{7}{|c|}{ Tempo de contato (h) } & \multirow{3}{*}{$\begin{array}{c}\text { PF } \\
24 h\end{array}$} \\
\hline & \multicolumn{2}{|c|}{ Branco } & \multicolumn{5}{|c|}{ Amostra } & \\
\hline & 0,5 & 24 & 0,5 & 2 & 6 & 12 & 24 & \\
\hline \multicolumn{9}{|l|}{ Trialometanos } \\
\hline Clorofórmio & 25,24 & 26,49 & 36,13 & 40,66 & 45,62 & 51,76 & 55,10 & 20,22 \\
\hline Bromodiclorometano & 4,29 & 3,95 & 4,25 & 6,94 & 5,07 & 7,20 & 4,69 & 0,10 \\
\hline Dibromoclorometano & $<0,1$ & $<0,1$ & 0,54 & 0,82 & 0,46 & $<0,1$ & $<0,1$ & $<0,1$ \\
\hline Bromofórmio & $<0,1$ & $<0,1$ & $<0,1$ & $<0,1$ & $<0,1$ & $<0,1$ & $<0,1$ & $<0,1$ \\
\hline Total TAMs $(\mu \mathrm{g} / \mathrm{L})$ & 29,53 & 30,44 & 40,92 & 48,42 & 51,15 & 58,96 & 59,79 & 19,78 \\
\hline Cloro Hidrato ( $\mu \mathrm{g} / \mathrm{L})$ & 3,59 & 1,81 & 9,07 & 19,88 & 24,58 & 23,01 & 30,42 & 23,13 \\
\hline \multicolumn{9}{|l|}{ Halopicrina } \\
\hline Cloropicrina ( $\mu \mathrm{g} / \mathrm{L})$ & 0,83 & 0,37 & $<0,1$ & $<0,1$ & 0,15 & $<0,1$ & 0,25 & $<0,1$ \\
\hline \multicolumn{9}{|l|}{ Haloacetonitrilas } \\
\hline Tricloroacetonitrila & $<0,1$ & $<0,1$ & $<0,1$ & $<0,1$ & $<0,1$ & $<0,1$ & $<0,1$ & $<0,1$ \\
\hline Dicloroacetonitrila & 1,46 & 0,57 & 1,35 & 2,80 & 4,69 & 4,60 & 5,90 & 5,44 \\
\hline Dibromoacetonitrila & $<0,1$ & $<0,1$ & $<0,1$ & $<0,1$ & $<0,1$ & $<0,1$ & $<0,1$ & $<0,1$ \\
\hline Bromocloroacetonitrila & 1,06 & 1,14 & 2,86 & 5,16 & 8,17 & 6,58 & 5,74 & 2,80 \\
\hline Total HANs $(\mu \mathrm{g} / \mathrm{L})$ & 2,52 & 1,71 & 4,21 & 7,96 & 12,86 & 11,18 & 11,64 & 8,24 \\
\hline \multicolumn{9}{|l|}{ Halocetonas } \\
\hline 1,1,1-Tricloropropanona & $<0,1$ & $<0,1$ & $<0,1$ & $<0,1$ & 6,86 & $<0,1$ & 5,43 & 5,43 \\
\hline 1,1-Dicloropropanona & 3,09 & 1,54 & 1,39 & 1,40 & 1,37 & $<0,1$ & 1,00 & $<0,1$ \\
\hline Total HKs $(\mu \mathrm{g} / \mathrm{L})$ & 3,09 & 1,54 & 1,39 & 1,40 & 8,23 & 0,00 & 6,43 & 6,59 \\
\hline \multicolumn{9}{|l|}{ Ác. Haloacéticos } \\
\hline MCAA & $<0,1$ & 14,85 & 9,89 & 13,30 & 14,67 & 22,52 & 33,93 & 9,19 \\
\hline MBAA & $<0,1$ & 2,21 & 1,66 & $<0,1$ & 3,52 & 6,00 & 2,13 & $<0,1$ \\
\hline DCAA & $<0,1$ & 6,44 & 44,23 & 42,96 & 45,99 & 50,21 & 71,77 & 21,10 \\
\hline TCAA & 4,42 & 1,75 & 5,95 & 3,09 & 4,00 & 5,92 & 17,43 & 14,15 \\
\hline BCAA & 1,55 & 2,98 & 1,32 & 3,85 & 2,55 & 1,50 & 2,03 & $<0,1$ \\
\hline BDCAA & 1,11 & $<0,1$ & $<0,1$ & $<0,1$ & $<0,1$ & $<0,1$ & $<0,1$ & 1,11 \\
\hline DBAA & $<0,1$ & 0,47 & $<0,1$ & $<0,1$ & $<0,1$ & $<0,1$ & $<0,1$ & $<0,1$ \\
\hline CDBAA & $<0,1$ & $<0,1$ & $<0,1$ & $<0,1$ & $<0,1$ & $<0,1$ & $<0,1$ & $<0,1$ \\
\hline TBAA & $<0,1$ & $<0,1$ & $<0,1$ & $<0,1$ & $<0,1$ & $<0,1$ & $<0,1$ & $<0,1$ \\
\hline Total AHAs $(\mu \mathrm{g} / \mathrm{L})$ & 7,08 & 28,70 & 63,05 & 63,20 & 70,73 & 86,15 & 127,29 & 42,62 \\
\hline
\end{tabular}

Na Figura 5.44 estão apresentadas as composições de subprodutos formados. As frações de AHAs compõe $42 \%$ do total de subprodutos formados, seguidos de $\mathrm{CH}$ com $23 \%$, TAMs com $21 \%$, HANs com $8 \%$ e HKs com $6 \%$. 


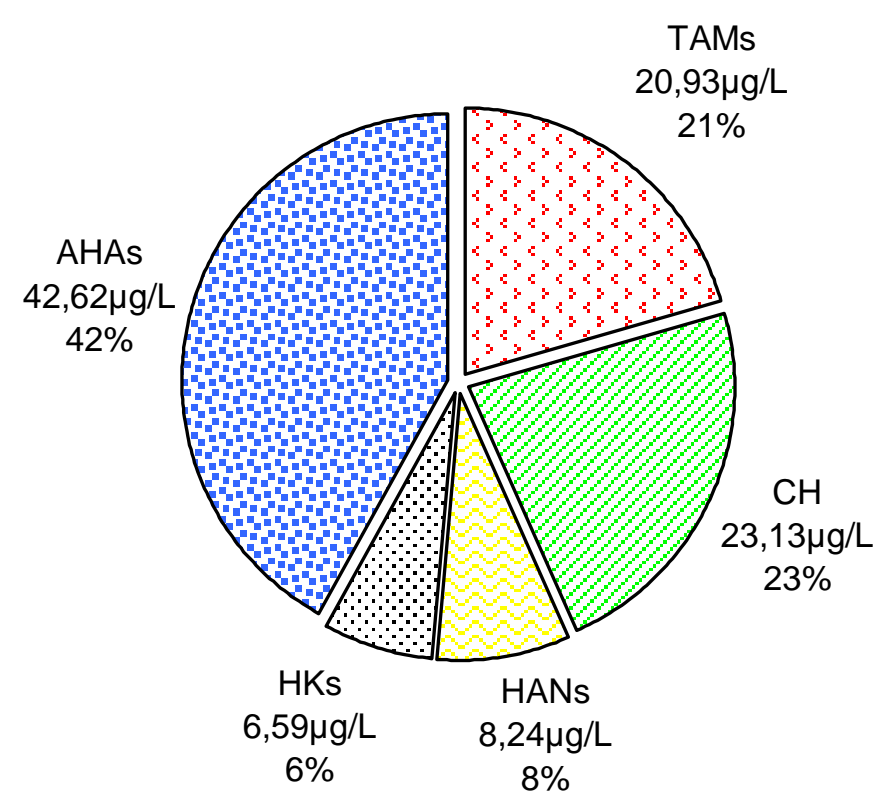

Figura 5.44- Valores de potencial de formação após 24h de tempo de contato para pré-oxidação com ozônio, filtração em papel, pós-cloração e incubação a $25^{\circ} \mathrm{C}$, expressos em percentual e concentração.

5.10.5.2 Subprodutos da pré-oxidação com ozônio, seguido de coagulação, filtração e pós-cloração

$\mathrm{Na}$ Tabela 5.35 estão apresentados os resultados de subprodutos formados com o uso de ozônio na pré-oxidação $\left(3,92 \mathrm{mgO}_{3} / \mathrm{L}\right)$, coagulação (20mgSA/L) filtração, pós-cloração $\left(5 \mathrm{mg} \mathrm{Cl} / 2\right.$ ), incubação a $25^{\circ} \mathrm{C}$ e o cálculo do potencial de formação de $24 \mathrm{~h}$. Alguns cromatogramas típicos estão apresentados nos Apêndices $\mathrm{H}-03$ e H-04.

Após $12 \mathrm{~h}$, os valores de AHAs aumentaram significativamente, atingindo valores próximos a $200 \mu \mathrm{g} / \mathrm{L}$, os demais subprodutos apresentaram uma tendência de estabilização após $6 \mathrm{~h}$. A Figura 5.45 ilustra esse comportamento.

Os valores obtidos de TAMs variaram de $36,87 \mu \mathrm{g} / \mathrm{L}$ a $54,76 \mu \mathrm{g} / \mathrm{L}$, para o $\mathrm{CH}$ os valores variaram de $10,99 \mu \mathrm{g} / \mathrm{L}$ e $25,82 \mu \mathrm{g} / \mathrm{L}$, para HANs os valores obtidos variaram de $5,11 \mu \mathrm{g} / \mathrm{L}$ a $15,33 \mu \mathrm{g} / \mathrm{L}$ e para $\mathrm{HKs}$ variaram de $1,45 \mu \mathrm{g} / \mathrm{L}$ a $13,13 \mu \mathrm{g} / \mathrm{L}$. 
Nas amostras coletadas nos tempos de contato de 2 e 6h foram identificados traços de cloropicrina.

Tabela 5.35- Subprodutos da pré-oxidação com ozônio, coagulação, filtração em papel, pós-cloração, incubação por $24 \mathrm{~h}$ a $25^{\circ} \mathrm{C}$ e PF de $24 \mathrm{~h}$, em $\mu \mathrm{g} / \mathrm{L}$.

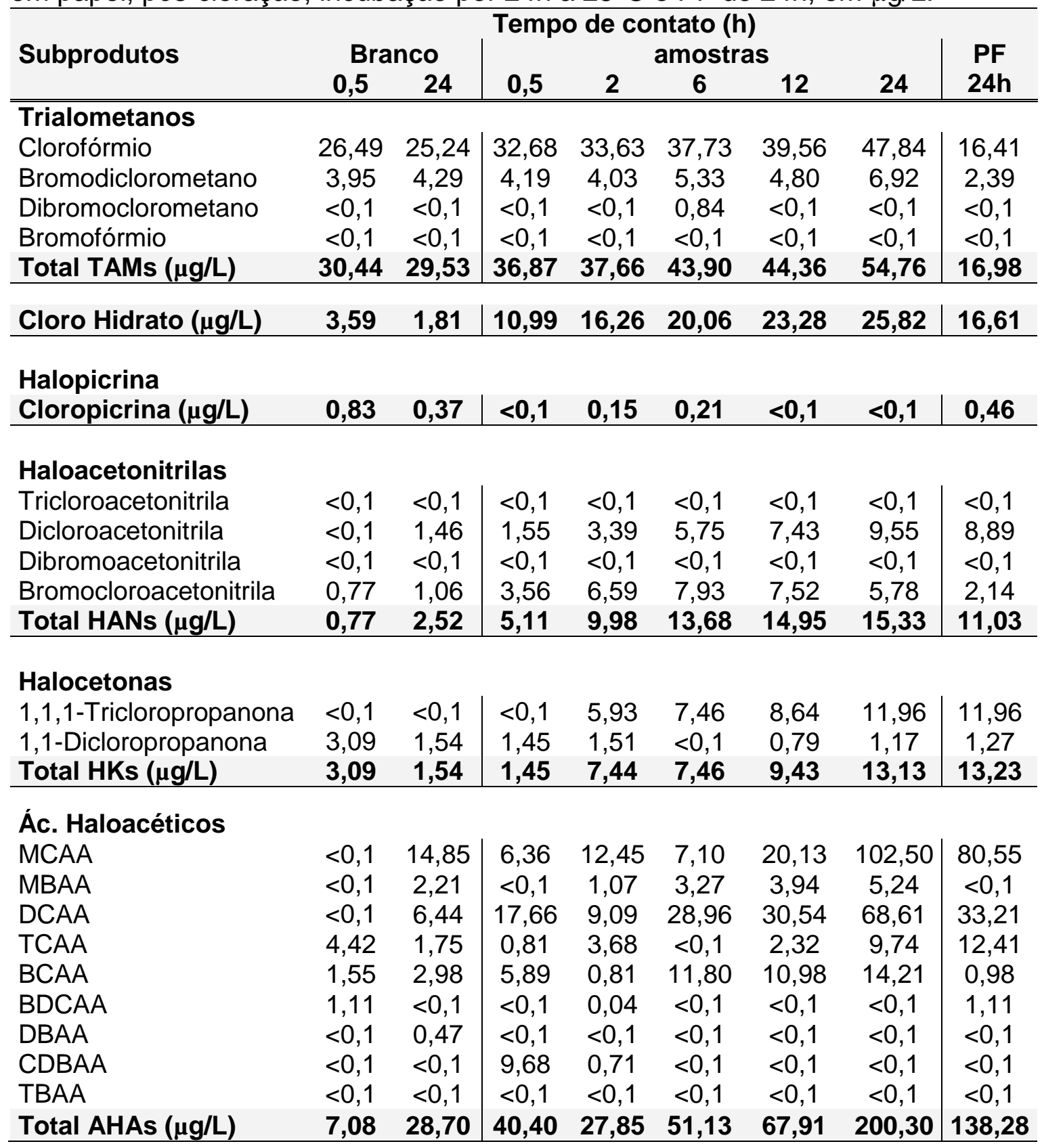




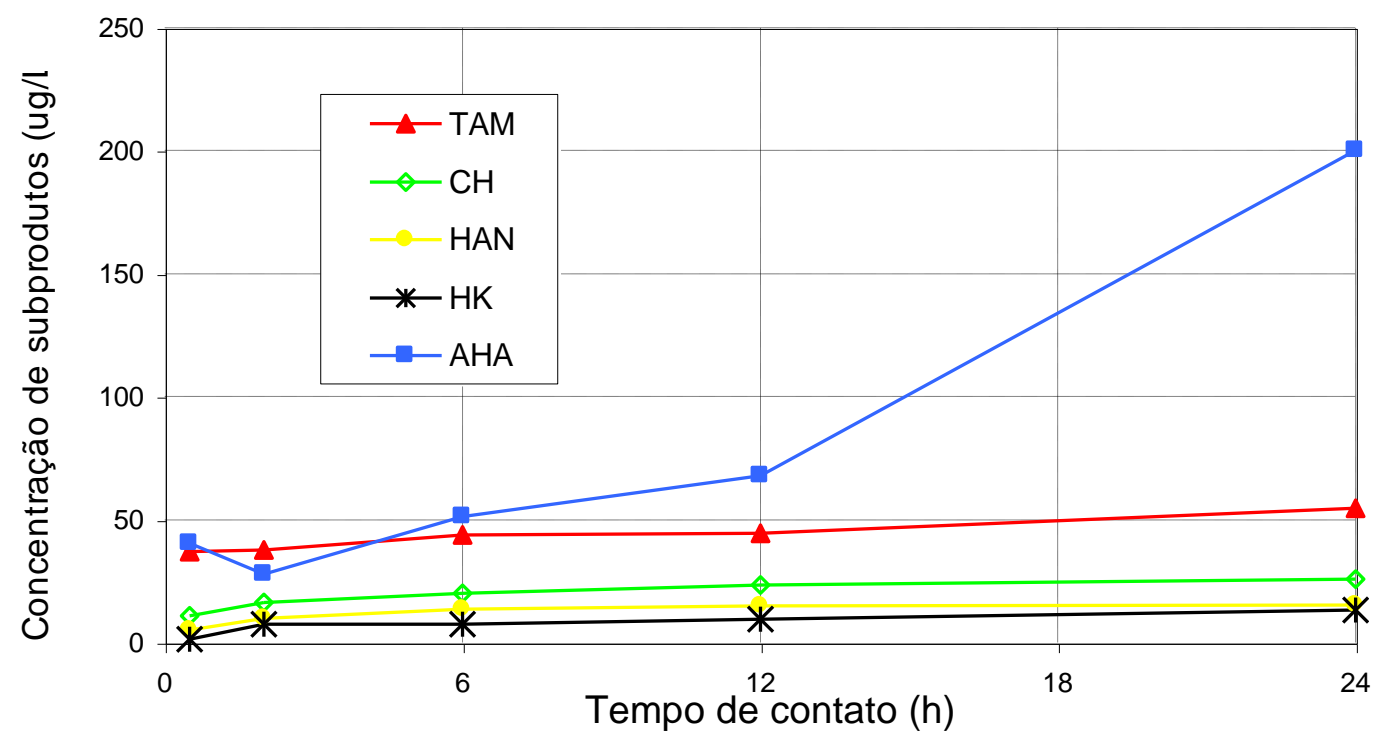

Figura 5.45- Valores de concentração de subprodutos formados na préoxidação com ozônio, coagulação, filtração em papel, pós-cloração, incubação a $25^{\circ} \mathrm{C}$ em função do tempo de contato.

$\mathrm{Na}$ avaliação do potencial de formação de $24 \mathrm{~h}$, representado na Figura 5.46, uma fração de $70 \%$ é de AHAs, o restante subdivide-se em $8 \%$ para TAMs, $9 \%$ para $\mathrm{CH}, 6 \%$ para HANs e $7 \%$ para $\mathrm{HKs}$.

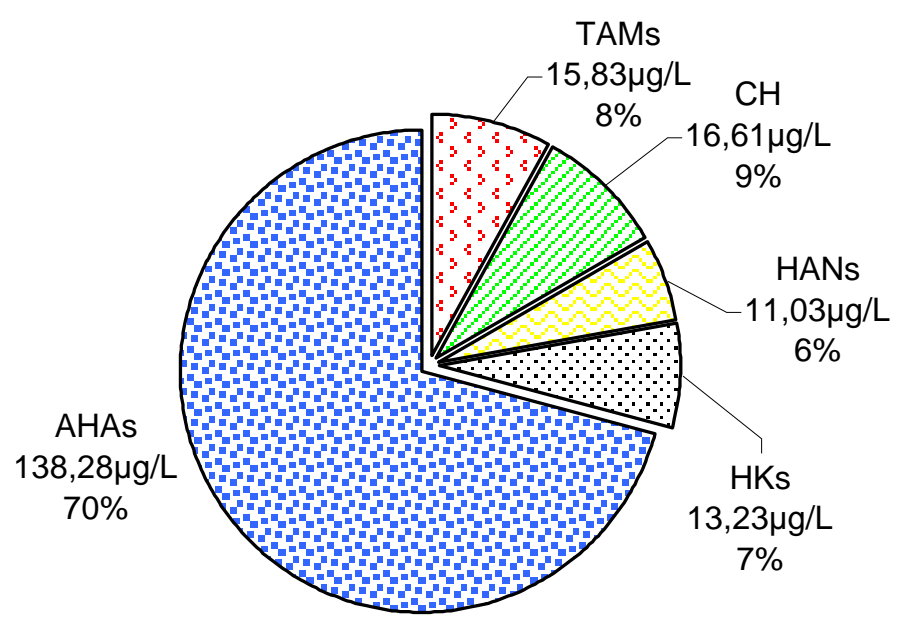

Figura 5.46- Valores de potencial de formação após 24h de tempo de contato para pré-oxidação com ozônio, coagulação, filtração em papel, póscloração, incubação a $25^{\circ} \mathrm{C}$, expressos em percentual e concentração.

Comparando-se o potencial de formação de 7 dias em presença de cloro com os PF de 24h com ausência e presença de coagulação, observou- 
se a maior formação para os AHAs. Na Figura 5.47 estão apresentados os resultados comparativos. Observou-se que o uso da coagulação não reduziu o potencial de formação quando comparado aos ensaios com ausência de coagulação.Com o uso do ozônio na pré-oxidação o PF de 24h dos AHAs foi superior ao PF de 7 dias.

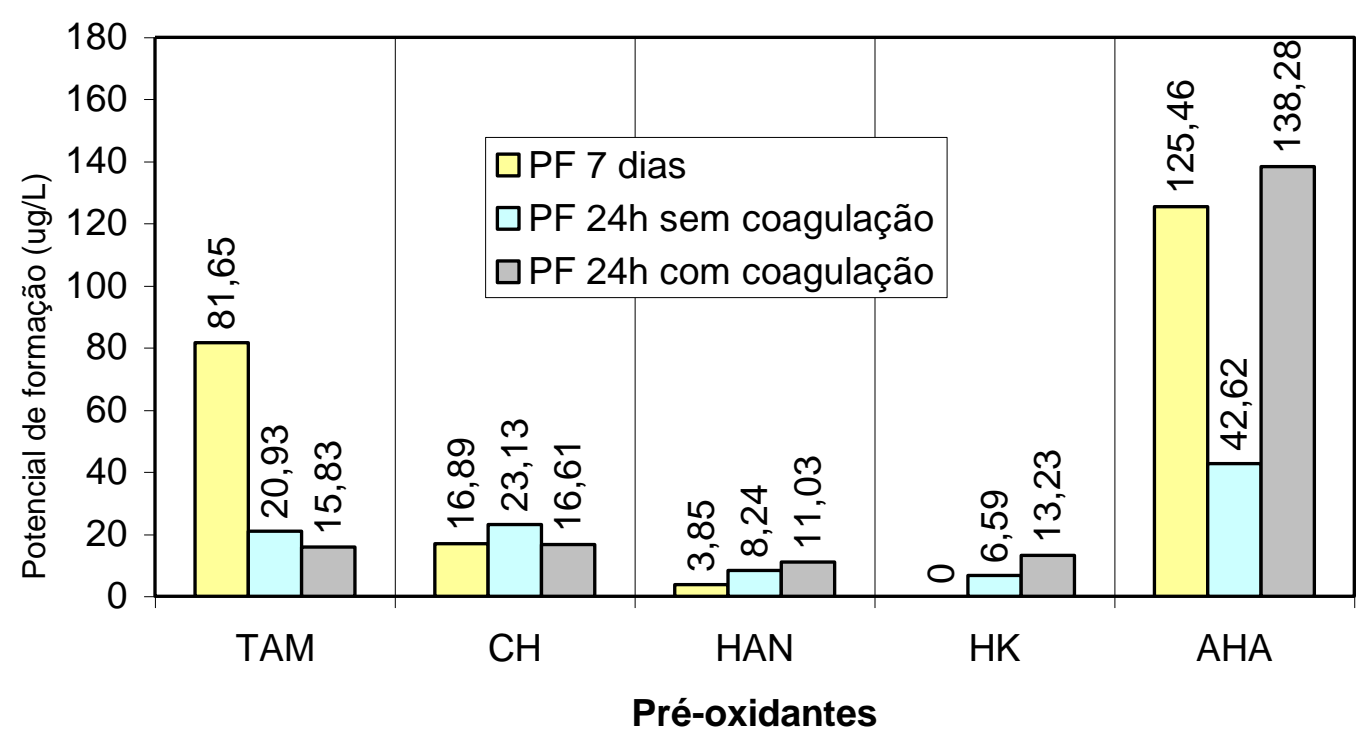

Figura 5.47 - Valores de PF de 7 dias e 24h, com o uso de ozônio na préoxidação, presença e ausência de coagulação, filtração, pós-cloração, incubação a $25^{\circ} \mathrm{C}$ expressos em concentração.

\subsubsection{Subprodutos da pré-oxidação com peroxônio}

As condições estabelecidas para a pré-oxidação com peroxônio foram determinadas em etapas anteriores, variando-se apenas a ausência e a presença da etapa de coagulação, filtração em papel, pós-cloração $\left(5 \mathrm{mgCl}_{2} / \mathrm{L}\right)$ e incubação a $25^{\circ} \mathrm{C}$.

\subsubsection{Subprodutos da pré-oxidação com peroxônio, filtração e pós- cloração}

$\mathrm{Na}$ Tabela 5.36 estão apresentados os resultados de subprodutos formados com o uso de peroxônio $\left(4,3 \mathrm{mg} / \mathrm{LH}_{2} \mathrm{O}_{2}\right.$ e $\left.8,6 \mathrm{mg} / \mathrm{LO}_{3}\right)$ na préoxidação, filtração em papel, pós-cloração $\left(5 \mathrm{mgCl}_{2} / \mathrm{L}\right)$, incubação a $25^{\circ} \mathrm{C}$ e 0 
cálculo do potencial de formação de 24h. Alguns cromatogramas típicos estão apresentados nos Apêndices I-01 e I-02.

Tabela 5.36 - Subprodutos da pré-oxidação com peroxônio, filtração, em papel, pós-cloração, incubação por $24 \mathrm{~h}$ a $25^{\circ} \mathrm{C}$ e PF $24 \mathrm{~h}$ em $\mu \mathrm{g} / \mathrm{L}$.

\begin{tabular}{|c|c|c|c|c|c|c|c|c|}
\hline \multirow{3}{*}{ Subprodutos } & \multirow{2}{*}{\multicolumn{2}{|c|}{ Branco }} & \multicolumn{6}{|c|}{ Tempo de contato (h) } \\
\hline & & & & & Amostr & & & PF \\
\hline & 0,5 & 24 & 0,5 & 2 & 6 & 12 & 24 & $24 \mathrm{~h}$ \\
\hline \multicolumn{9}{|l|}{ Trialometanos } \\
\hline Clorofórmio & 20,89 & 23,80 & 24,44 & 32,60 & 39,67 & 47,68 & 53,83 & 26,48 \\
\hline Bromodiclorometano & $<0,1$ & 2,23 & 2,11 & 2,53 & 3,15 & 3,66 & 3,01 & $<0,1$ \\
\hline Dibromoclorometano & $<0,1$ & $<0,1$ & $<0,1$ & $<0,1$ & $<0,1$ & $<0,1$ & $<0,1$ & $<0,1$ \\
\hline Bromofórmio & $<0,1$ & $<0,1$ & $<0,1$ & $<0,1$ & $<0,1$ & $<0,1$ & $<0,1$ & $<0,1$ \\
\hline Total TAMs $(\mu \mathrm{g} / \mathrm{L})$ & 20,89 & 26,03 & 26,55 & 35,13 & 42,82 & 51,34 & 56,84 & 25,15 \\
\hline Cloro Hidrato ( $\mu \mathrm{g} / \mathrm{L})$ & 0,1 & 7,26 & 6,09 & 9,55 & 20,62 & 16,40 & 29,04 & 15,69 \\
\hline
\end{tabular}

Halopicrina

\begin{tabular}{lllllllll} 
Cloropicrina $(\mu \mathrm{g} / \mathrm{L})$ & $<0,1$ & 1,06 & 0,44 & 0,75 & 0,94 & 1,07 & $<0,1$ & 0,44 \\
\hline
\end{tabular}

Haloacetonitrilas

Tricloroacetonitrila

Dicloroacetonitrila

Dibromoacetonitrila

Bromocloroacetonitrila

Total HANs $(\mu \mathrm{g} / \mathrm{L})$

$\begin{array}{cccccccc}<0,1 & <0,1 & <0,1 & <0,1 & <0,1 & <0,1 & <0,1 & <0,1 \\ <0,1 & 2,69 & 1,44 & 3,35 & 4,67 & 5,21 & 5,54 & 1,41 \\ <0,1 & <0,1 & <0,1 & <0,1 & <0,1 & <0,1 & <0,1 & <0,1 \\ <0,1 & 1,54 & 2,63 & 4,19 & 7,13 & 5,33 & 6,88 & 2,71 \\ <0,1 & \mathbf{4 , 2 3} & \mathbf{4 , 0 7} & \mathbf{7 , 5 4} & \mathbf{1 1 , 8 0} & \mathbf{1 0 , 5 4} & \mathbf{1 2 , 4 2} & \mathbf{4 , 1 2}\end{array}$

Halocetonas

\begin{tabular}{llllllllc} 
1,1,1-Tricloropropanona & $<0,1$ & $<0,1$ & $<0,1$ & $<0,1$ & $<0,1$ & $<0,1$ & 11,32 & 11,32 \\
1,1-Dicloropropanona & $<0,1$ & $<0,1$ & $<0,1$ & $<0,1$ & $<0,1$ & $<0,1$ & $<0,1$ & $<0,1$ \\
Total HKs $(\boldsymbol{\mu} \mathbf{g} / \mathrm{L})$ & $<\mathbf{0 , 1}$ & $<\mathbf{0 , 1}$ & $<\mathbf{0 , 1}$ & $<\mathbf{0 , 1}$ & $<\mathbf{0 , 1}$ & $<\mathbf{0 , 1}$ & $\mathbf{1 1 , 3 2}$ & $\mathbf{1 1 , 3 2}$ \\
\hline
\end{tabular}

\begin{tabular}{lcccccccc} 
Ác. Haloacéticos & & & & & & & & \\
MCAA & 4,46 & 21,06 & 6,43 & 8,02 & 10,02 & 15,70 & 21,65 & $<0,1$ \\
MBAA & $<0,1$ & 1,04 & 0,80 & 0,42 & 1,88 & 2,04 & 3,35 & 1,51 \\
DCAA & 1,48 & 4,16 & 7,69 & 17,23 & 11,90 & 11,77 & 21,12 & 10,75 \\
TCAA & 0,60 & 1,51 & 2,64 & 5,16 & 7,30 & 9,47 & 9,39 & 5,84 \\
BCAA & $<0,1$ & $<0,1$ & $<0,1$ & $<0,1$ & $<0,1$ & $<0,1$ & $<0,1$ & $<0,1$ \\
BDCAA & 0,58 & $<0,1$ & $<0,1$ & $<0,1$ & $<0,1$ & $<0,1$ & $<0,1$ & 0,58 \\
DBAA & $<0,1$ & 0,19 & 0,13 & 0,67 & 0,68 & 0,62 & 0,90 & 0,58 \\
CDBAA & $<0,1$ & $<0,1$ & $<0,1$ & $<0,1$ & $<0,1$ & $<0,1$ & $<0,1$ & $<0,1$ \\
TBAA & $<0,1$ & $<0,1$ & $<0,1$ & $<0,1$ & $<0,1$ & $<0,1$ & $<0,1$ & $<0,1$ \\
Total AHAs $(\boldsymbol{\mu g} / \mathbf{L})$ & $\mathbf{7 , 1 2}$ & $\mathbf{2 7 , 9 6}$ & $\mathbf{1 7 , 6 9}$ & $\mathbf{3 1 , 5 0}$ & $\mathbf{3 1 , 7 8}$ & $\mathbf{3 9 , 6 0}$ & $\mathbf{5 6 , 4 1}$ & $\mathbf{1 7 , 8 8}$ \\
\hline
\end{tabular}

Na Figura 5.48 estão apresentados os resultados de subprodutos formados com uso de peroxônio na pré-oxidação, e ausência de coagulação, após $24 \mathrm{~h}$, os valores de TAMs e AHAs ficaram próximos a $60 \mu \mathrm{g} / \mathrm{L}$, os 
demais ficaram entre 10 e $30 \mu \mathrm{g} / \mathrm{L}$ com uma tendência de estabilização após $6 \mathrm{~h}$ de tempo de contato.

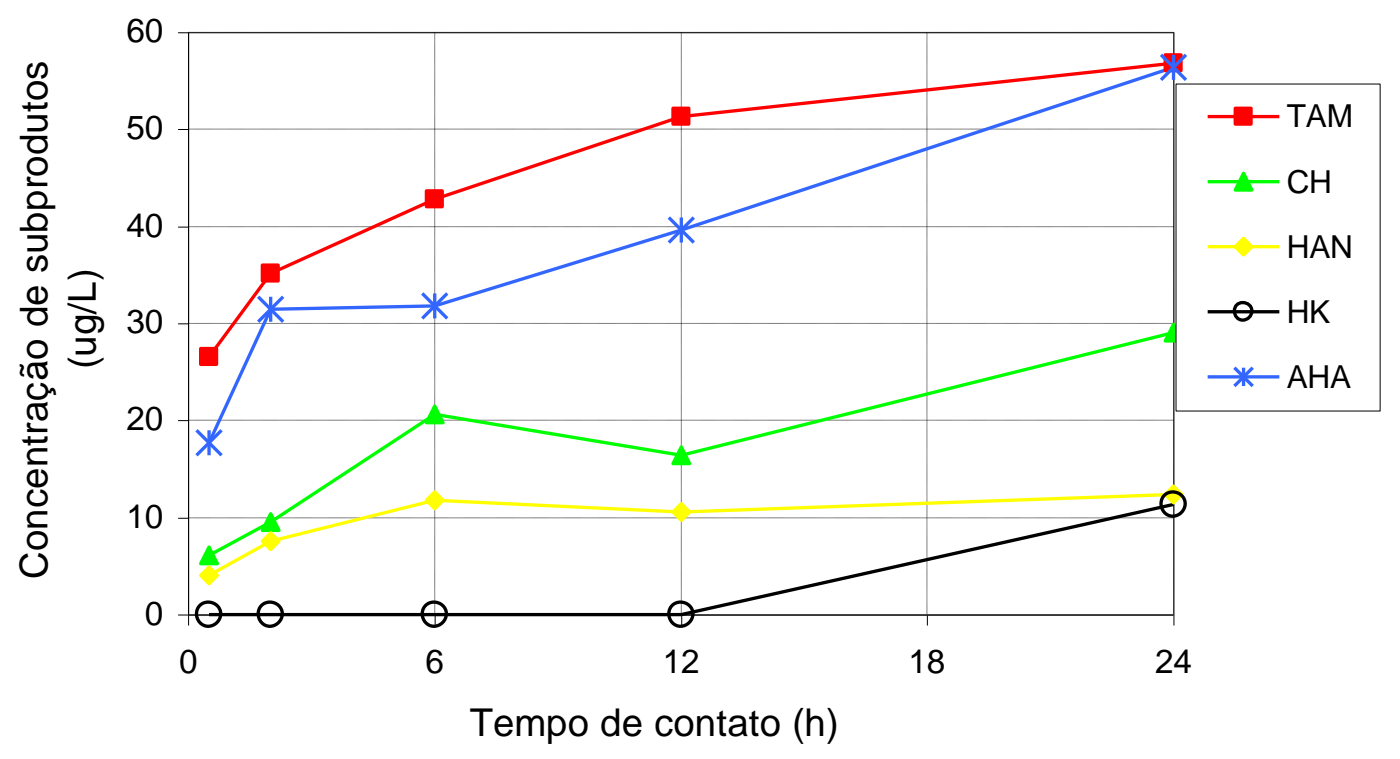

Figura 5.48 - Valores de concentração de subprodutos formados na préoxidação com peroxônio, filtração em papel, pós-cloração, incubação a $25^{\circ} \mathrm{C}$ em função do tempo de contato.

A Figura 5.49 apresenta o PF de $24 \mathrm{~h}$ com a seguinte composição: uma fração maior de $34 \%$ para TAMs, $24 \%$ para AHAs, $21 \%$ para $\mathrm{CH}, 15 \%$ para HKs e $6 \%$ para HANs.

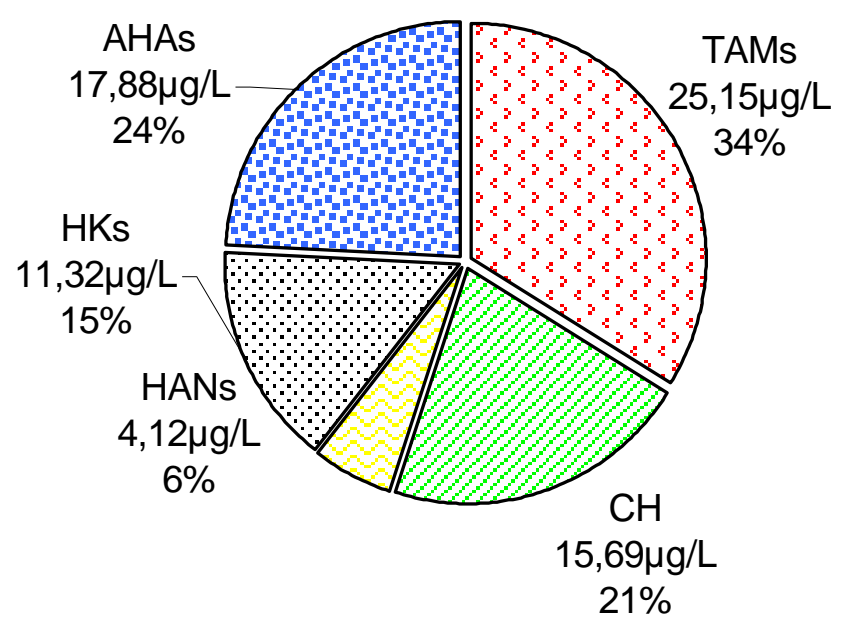

Figura 5.49 - Valores de potencial de formação após 24h de tempo de contato para pré-oxidação com peroxônio, filtração em papel, pós-cloração, incubação a $25^{\circ} \mathrm{C}$, expressos em percentual e concentração. 
5.10.6.2 Subprodutos da pré-oxidação com peroxônio, seguido de coagulação, filtração e pós-cloração

$\mathrm{Na}$ Tabela 5.37 estão apresentados os resultados de subprodutos formados com o uso de peroxônio, coagulação (18mgSA/L), filtração em papel, pós-cloração $\left(5 \mathrm{mgCl}_{2} / \mathrm{L}\right)$, incubação a $25^{\circ} \mathrm{C}$ e o calculo do potencial de formação de $24 \mathrm{~h}$.

Tabela 5.37- Subprodutos da pré-oxidação com peroxônio, coagulação, filtração em papel, pós-cloração e incubação por $24 \mathrm{~h}$ a $25^{\circ} \mathrm{C}$, em $\mu \mathrm{g} / \mathrm{L}$.

\begin{tabular}{|c|c|c|c|c|c|c|c|c|}
\hline \multirow{3}{*}{ Subprodutos } & \multicolumn{7}{|c|}{ Tempo de contato (h) } & \multirow{3}{*}{$\begin{array}{c}\text { PF } \\
24 h\end{array}$} \\
\hline & \multicolumn{2}{|c|}{ Branco } & \multicolumn{4}{|c|}{ Amostras } & \multirow[b]{2}{*}{24} & \\
\hline & 0,5 & 24 & 0,5 & 2 & 6 & 12 & & \\
\hline \multicolumn{9}{|l|}{ Trialometanos } \\
\hline Clorofórmio & 20,89 & 23,80 & 25,85 & 28,26 & 31,38 & 40,18 & 39,45 & 10,69 \\
\hline Bromodiclorometano & $<0,1$ & 2,23 & 2,35 & 2,55 & 3,14 & 3,57 & 3,30 & $<0,1$ \\
\hline Dibromoclorometano & $<0,1$ & $<0,1$ & $<0,1$ & $<0,1$ & $<0,1$ & $<0,1$ & $<0,1$ & 0,00 \\
\hline Bromofórmio & $<0,1$ & $<0,1$ & $<0,1$ & $<0,1$ & $<0,1$ & $<0,1$ & $<0,1$ & 0,00 \\
\hline Total TAMs $(\mu \mathrm{g} / \mathrm{L})$ & 20,89 & 26,03 & 28,20 & 30,81 & 34,52 & 43,75 & 42,75 & 9,41 \\
\hline Cloro Hidrato & $<0,1$ & 7,26 & 10,73 & 13,34 & 22,43 & 30,83 & 31,00 & 13,01 \\
\hline \multicolumn{9}{|l|}{ Halopicrina } \\
\hline Cloropicrina $(\mu \mathrm{g} / \mathrm{L})$ & $<0,1$ & 1,06 & $<0,1$ & $<0,1$ & 0,62 & 0,89 & 1,22 & 0,16 \\
\hline \multicolumn{9}{|l|}{ Haloacetonitrilas } \\
\hline Tricloroacetonitrila & $<0,1$ & $<0,1$ & $<0,1$ & $<0,1$ & $<0,1$ & $<0,1$ & $<0,1$ & $<0,1$ \\
\hline Dicloroacetonitrila & $<0,1$ & 2,69 & 1,88 & 3,07 & 3,92 & 4,63 & 4,39 & $<0,1$ \\
\hline Dibromoacetonitrila & $<0,1$ & $<0,1$ & $<0,1$ & $<0,1$ & $<0,1$ & $<0,1$ & $<0,1$ & $<0,1$ \\
\hline Bromocloroacetonitrila & $<0,1$ & 1,54 & 3,46 & 4,02 & 6,88 & 8,55 & 6,73 & 1,73 \\
\hline Total HANs $(\mu \mathrm{g} / \mathrm{L})$ & $<0,1$ & 4,23 & 5,34 & 7,09 & 10,80 & 13,18 & 11,12 & 1,55 \\
\hline \multicolumn{9}{|l|}{ Halocetonas } \\
\hline 1,1,1-Tricloropropanona & $<0,1$ & $<0,1$ & $<0,1$ & $<0,1$ & $<0,1$ & 12,08 & 14,77 & 14,77 \\
\hline 1,1-Dicloropropanona & $<0,1$ & $<0,1$ & $<0,1$ & $<0,1$ & $<0,1$ & $<0,1$ & $<0,1$ & $<0,1$ \\
\hline Total HKs $(\mu \mathrm{g} / \mathrm{L})$ & $<0,1$ & $<0,1$ & $<0,1$ & $<0,1$ & $<0,1$ & 12,08 & 14,77 & 14,77 \\
\hline \multicolumn{9}{|l|}{ Ác. Haloacéticos } \\
\hline MCAA & 4,46 & 21,06 & 4,48 & 9,06 & 3,89 & 13,66 & 24,76 & 3,68 \\
\hline MBAA & $<0,1$ & 1,04 & 0,40 & $<0,1$ & 2,99 & 1,42 & 1,53 & $<0,1$ \\
\hline DCAA & 1,48 & 4,16 & 2,70 & 6,04 & 14,35 & 11,31 & 13,16 & 7,78 \\
\hline TCAA & 0,60 & 1,51 & 3,47 & 14,68 & 13,08 & 4,42 & 9,56 & 5,18 \\
\hline BCAA & $<0,1$ & $<0,1$ & $<0,1$ & $<0,1$ & $<0,1$ & $<0,1$ & $<0,1$ & $<0,1$ \\
\hline BDCAA & 0,58 & $<0,1$ & $<0,1$ & $<0,1$ & $<0,1$ & $<0,1$ & $<0,1$ & 0,58 \\
\hline DBAA & $<0,1$ & 0,19 & 0,29 & 0,18 & 0,46 & 1,77 & 0,48 & $<0,1$ \\
\hline CDBAA & $<0,1$ & $<0,1$ & $<0,1$ & $<0,1$ & $<0,1$ & $<0,1$ & $<0,1$ & $<0,1$ \\
\hline TBAA & $<0,1$ & $<0,1$ & $<0,1$ & $<0,1$ & $<0,1$ & $<0,1$ & $<0,1$ & $<0,1$ \\
\hline Total AHAs $(\mu \mathrm{g} / \mathrm{L})$ & 7,12 & 27,96 & 11,34 & 29,96 & 34,77 & 32,58 & 49,49 & 17,31 \\
\hline
\end{tabular}


Alguns cromatogramas típicos estão apresentados nos Apêndices I02 e I-03.

Na Figura 5.43 estão apresentados os resultados de subprodutos formados com o uso de peroxônio na pré-oxidação e presença de coagulação, filtração, pós-cloração e incubação a $25^{\circ} \mathrm{C}$. Após $24 \mathrm{~h}$ de tempo de contato, os valores de TAMs e AHAs ficaram próximos a $50 \mu \mathrm{g} / \mathrm{L}$, os demais subprodutos ficaram entre 10 e $30 \mu \mathrm{g} / \mathrm{L}$ com uma tendência de estabilização após 6h de tempo de contato.

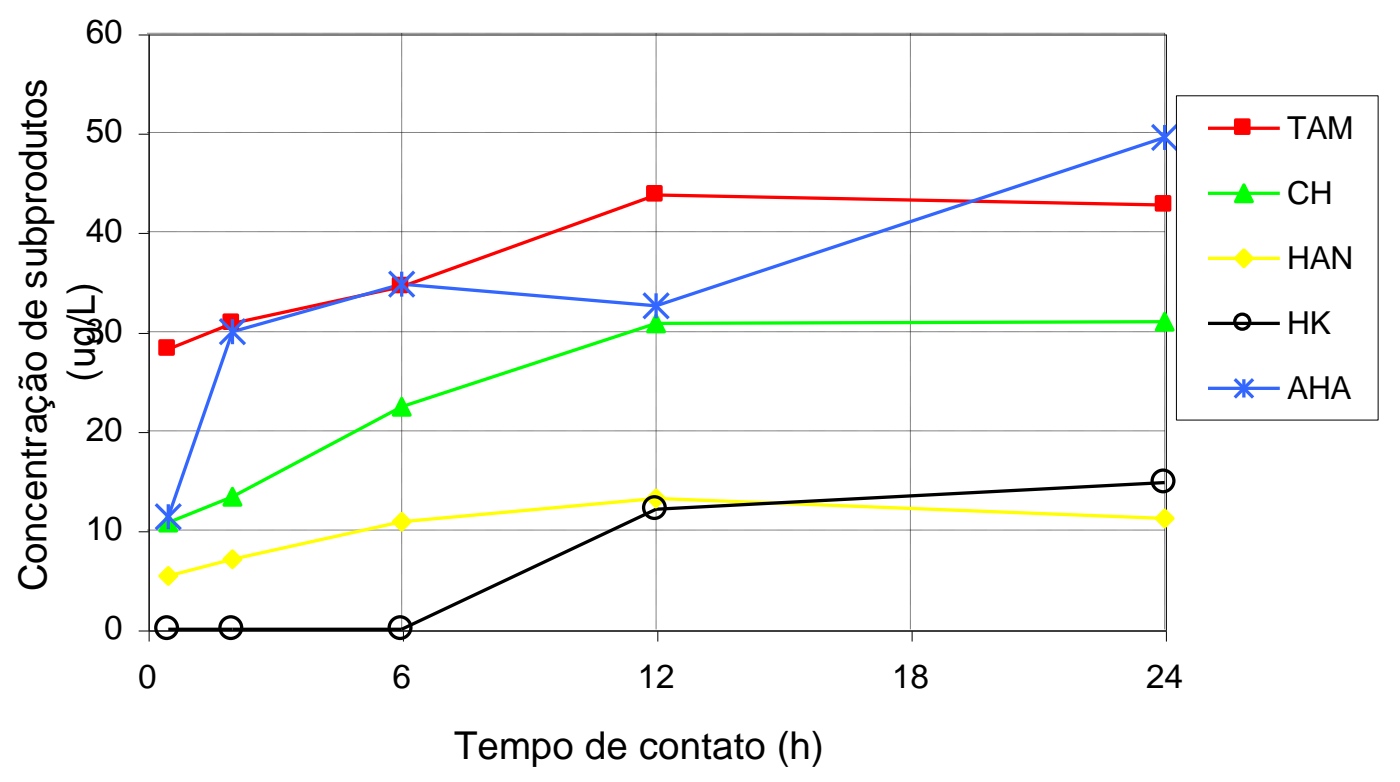

Figura 5.50 - Valores de concentração de subprodutos formados com peroxônio, coagulação, filtração em papel, pós-cloração, incubação a $25^{\circ} \mathrm{C}$ em função do tempo de contato.

Na Figura 5.51 estão apresentados os valores obtidospara o PF de 24h em porcentagem, a composição obtida foi a seguinte: uma fração de $31 \%$ para $\mathrm{AHAs}, 26 \%$ para $\mathrm{HKs}, 23 \%$ para $\mathrm{CH}, 17 \%$ para TAMs e $3 \%$ para HANs.

A fração de $23 \%$ para $\mathrm{CH}$ foi devido ao cálculo do PF de $24 \mathrm{~h}$ que utilizou valores menores que 1 obtidos no branco. 


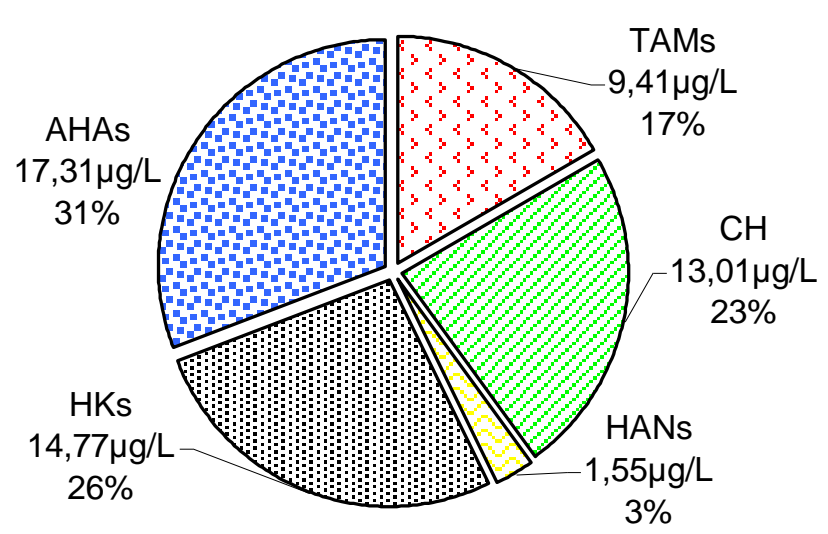

Figura 5.51- Valores de potencial de formação após 24h de tempo de contato para pré-oxidação com peroxônio, coagulação, filtração em papel, pós-cloração, incubação a $25^{\circ} \mathrm{C}$, expressos em percentual e concentração.

$\mathrm{Na}$ Figura 5.52 estão apresentados os resultados calculados de potencial de formação de 7 dias com cloro comparados ao PF de $24 \mathrm{~h}$ com presença e ausência de coagulação, filtração em papel, pós-cloração e incubação a $25^{\circ} \mathrm{C}$. Nos ensaios onde foi empregada a coagulação, observou-se uma redução PF de 24h para os seguintes subprodutos: TAMs, $\mathrm{CH}$ e HANs. Essa redução não foi significativa para os valores de potencial de formação de AHAs e HKs.

Os valores obtidos no PF de 24h para $\mathrm{CH}$ e HANs, comparados ao PF de 7 dias apresentaram-se muito próximos.

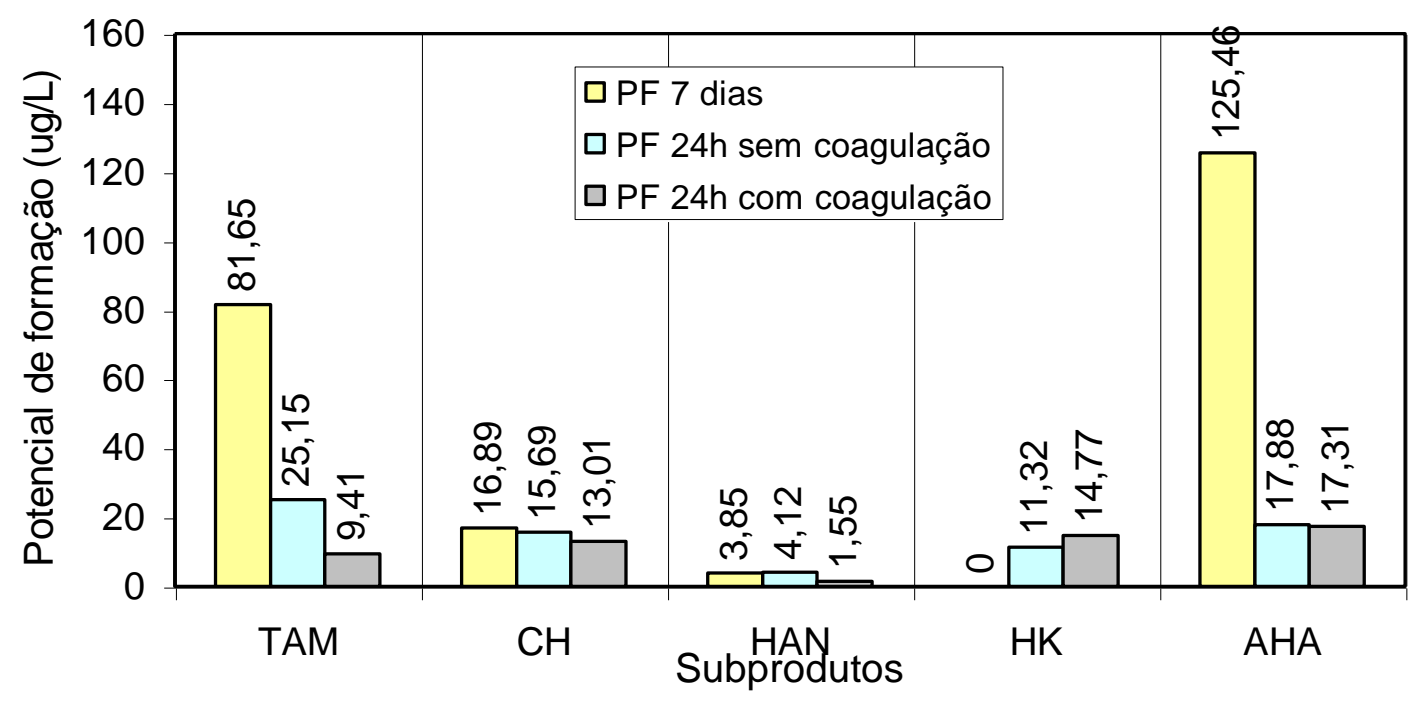

Figura 5.52 - Resultados comparativos de PF 7dias, com PF de 24h para o peroxônio empregado na pré-oxidação, com coagulação e sem coagulação, filtração, pós-cloração e incubação a $25^{\circ} \mathrm{C}$. 


\subsection{Avaliação dos subprodutos formados em função do pré-oxidante}

Os pré-oxidantes utilizados no presente trabalho foram: cloro, dióxido de cloro, permanganato de potássio, peróxido de hidrogênio, ozônio e peroxônio. Para uma melhor avaliação do potencial de formação dos subprodutos após $24 \mathrm{~h}$, estão apresentados os resultados de subprodutos em função dos pré-oxidantes aplicados.

\subsubsection{Trialometanos}

Na Figura 5.53 estão apresentados os resultados de PF de $24 \mathrm{~h}$ de trialometanos em função dos pré-oxidantes aplicados na presença e ausência de coagulação. Em todos os ensaios os valores de TAMs ficaram abaixo de $100 \mu \mathrm{g} / \mathrm{L}$. Os ensaios com ausência de coagulação formaram maior quantidade de TAMs, exceto para o uso de $\mathrm{H}_{2} \mathrm{O}_{2}$, porém os valores foram relativamente baixos considerando a unidade em $\mu \mathrm{g} / \mathrm{L}$.

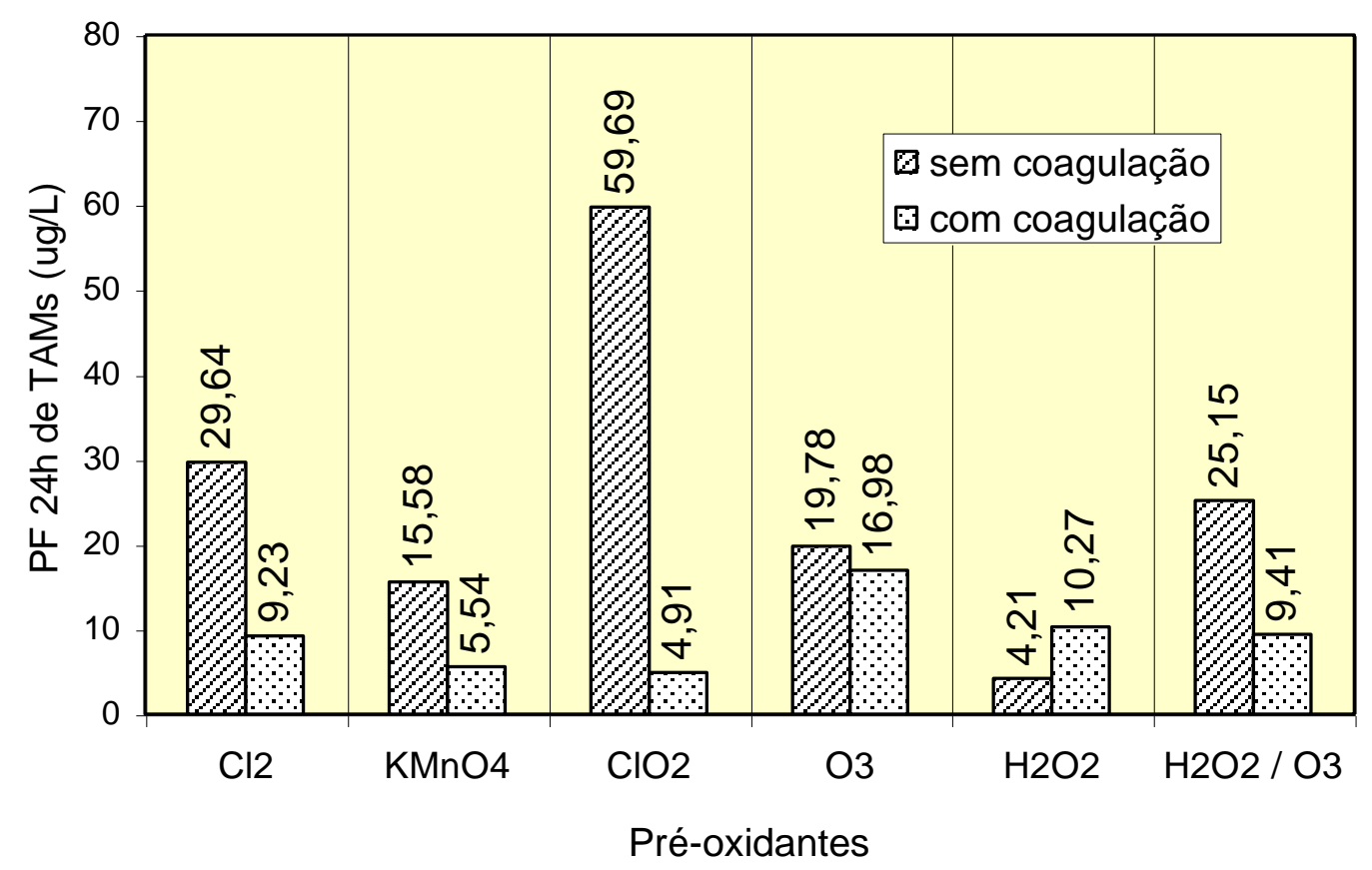

Figura 5.53 - Resultados de PF de $24 \mathrm{~h}$ de trialometanos em presença e ausência de coagulação, filtração em papel, pós-cloração, incubação a $25^{\circ} \mathrm{C}$ em função dos pré-oxidantes aplicados. 
O maior PF 24h de TAMs ocorreu com o uso de dióxido de cloro na pré-oxidação e com a ausência de coagulação, obtendo-se 59,69 $\mu \mathrm{g} / \mathrm{L}$ de TAMs, em seguida o cloro com $29,64 \mu \mathrm{g} / \mathrm{L}$, o ozônio com $19,78 \mu \mathrm{g} / \mathrm{L}$ e o peroxônio com $25,15 \mu \mathrm{g} / \mathrm{L}$. O ensaio que forneceu a menor formação de TAMs foi com a pré-oxidação com dióxido de cloro, coagulação, filtração em papel e pós-cloração.

\subsubsection{Cloro hidrato}

Na Figura 5.54 estão apresentados os resultados de PF de $24 \mathrm{~h}$ de cloro hidrato em função dos pré-oxidantes aplicados na presença e ausência de coagulação. No ensaio realizado com o uso do ozônio na pré-oxidação e na ausência de coagulação obteve-se o maior potencial formação de cloro hidrato, $23,13 \mu \mathrm{g} / \mathrm{L}$, seguido de $17,43 \mu \mathrm{g} / \mathrm{L}, 15,69 \mu \mathrm{g} / \mathrm{L}$ para o uso de dióxido

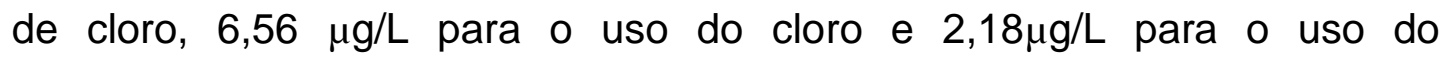
permanganato de potássio. $\mathrm{O} \mathrm{PF} 24 \mathrm{~h}$ de $\mathrm{CH}$ com uso de peróxido de hidrogênio obtido foi $<0,1 \mu \mathrm{g} / \mathrm{L}$.

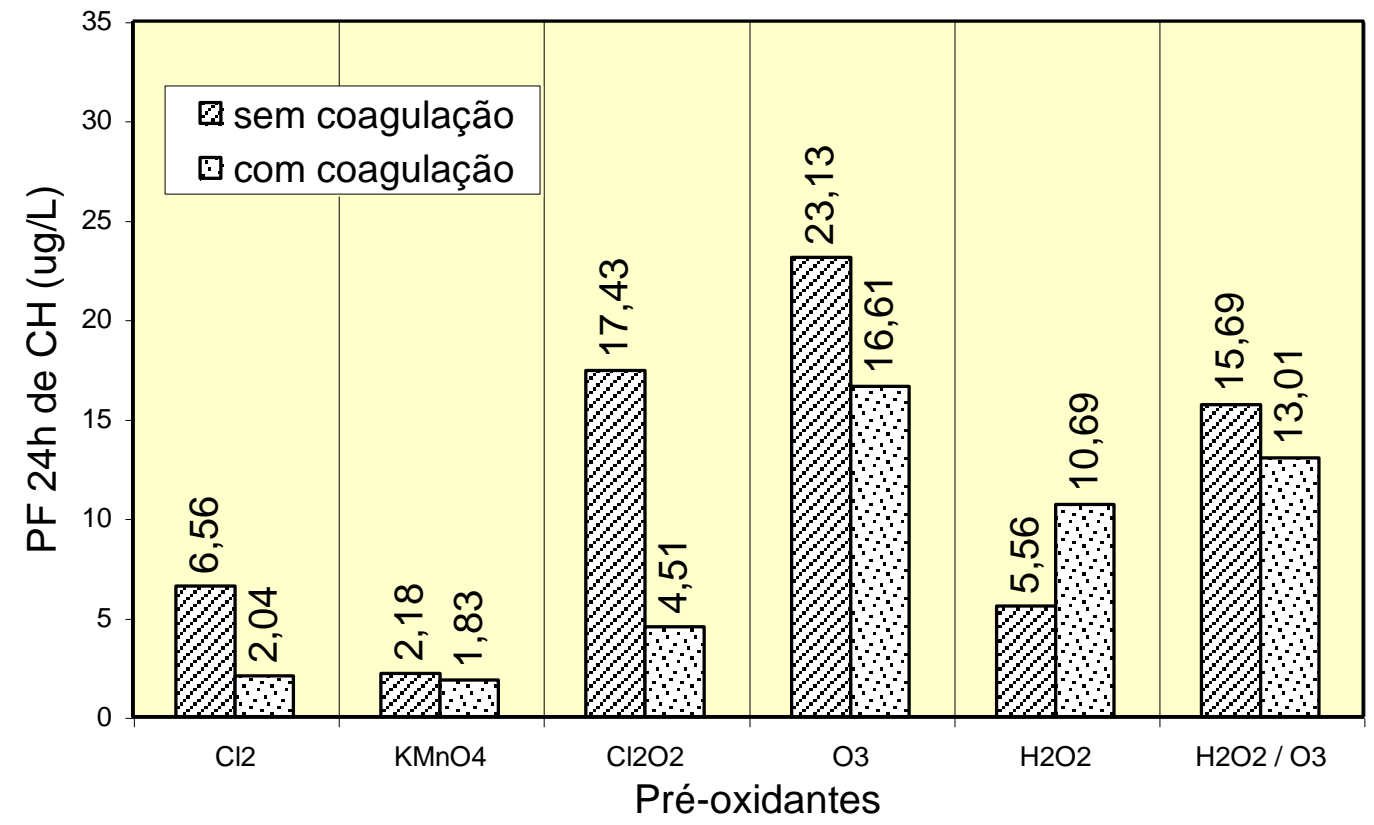

Figura 5.54 - Resultados de PF 24h de cloro hidrato em presença e ausência de coagulação, filtração em papel, pós-cloração, incubação a $25^{\circ} \mathrm{C}$ em função dos pré-oxidantes aplicados. 
O menor PF 24h de $\mathrm{CH}$ ocorreu nos ensaios com o uso da

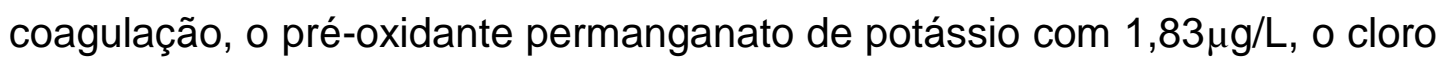

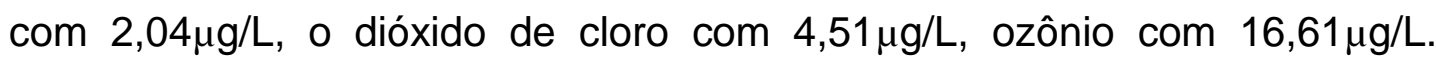
Observou-se que para o pré-oxidante peroxônio, a presença ou ausência de coagulação resultou valores próximos de PF $24 \mathrm{~h}$ de $\mathrm{CH}$.

\subsubsection{Haloacetonitrilas}

Na Figura 5.55 estão apresentados os resultados de PF de $24 \mathrm{~h}$ de haloacetonitrilas em função dos pré-oxidantes aplicados na presença e ausência de coagulação.

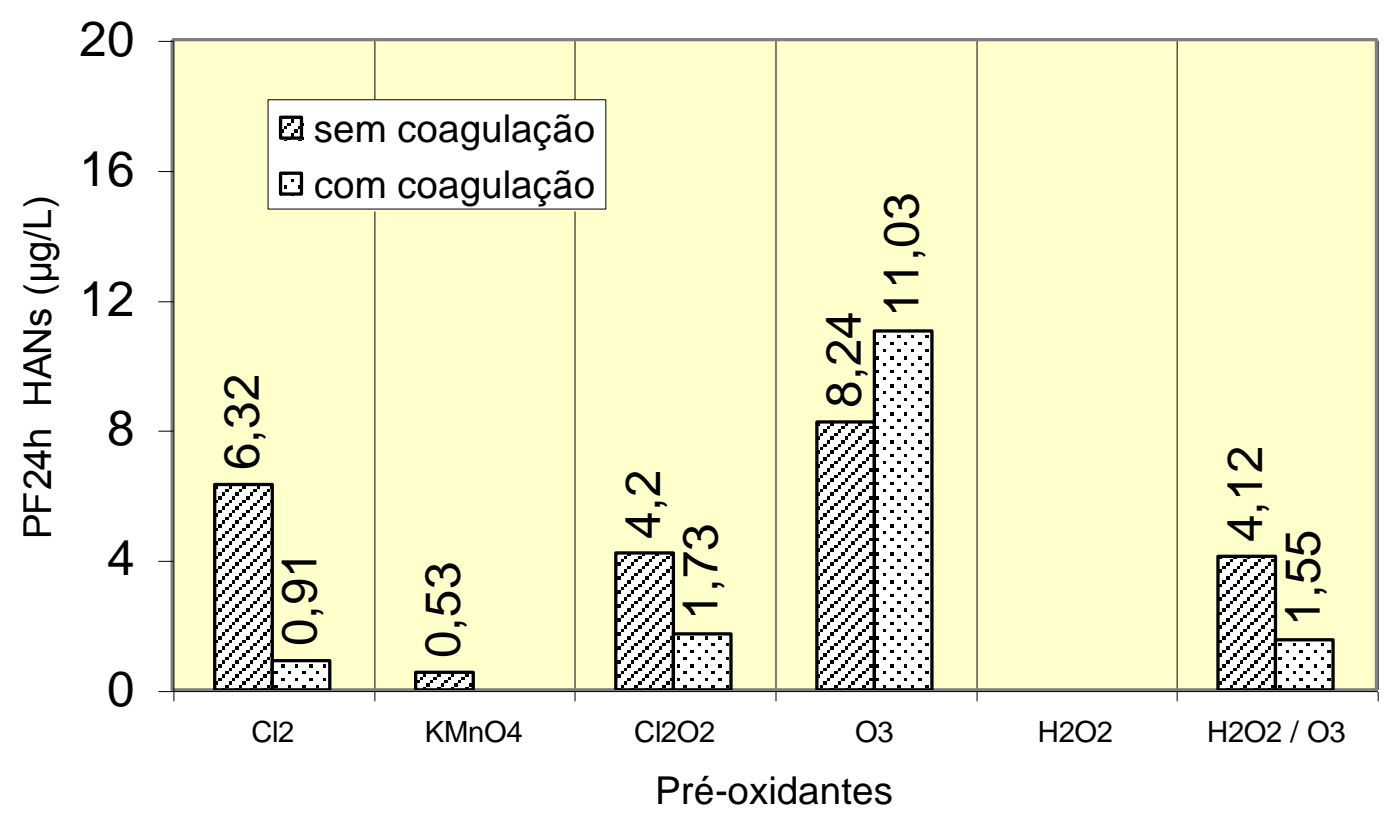

Figura 5.55 - Resultados de PF 24h de haloacetonitrilas em presença e ausência de coagulação, filtração em papel, pós-cloração, incubação a $25^{\circ}$ em função dos pré-oxidantes aplicados.

Todos os resultados de haloacetonitrilas ficaram abaixo de $11,5 \mu \mathrm{g} / \mathrm{L}$. O maior valor obtido foi de $11,03 \mu \mathrm{g} / \mathrm{L}$ para o uso de ozônio na pré-oxidação e na presença de coagulação. 
As haloacetonitrilas não foram detectadas quando foi aplicado o préoxidante peróxido de hidrogênio. $\mathrm{O}$ uso de coagulante resultou na menor formação para o cloro, permanganato, dióxido de cloro e peroxônio.

\subsubsection{Halocetonas}

$\mathrm{Na}$ Figura 5.56 estão apresentados os resultados de PF de 24h de halocetonas em função dos pré-oxidantes aplicados na presença e ausência de coagulação.

O maior valor de PF 24h de HKs foi obtido no ensaio com uso de préoxidação com peroxônio em presença de coagulação, seguido do ozônio com 13,23 $\mu \mathrm{g} / \mathrm{L}$ e cloro com $0,54 \mu \mathrm{g} / \mathrm{L}$. Nos ensaios realizados em ausência de coagulação, o maior PF 24h de HKs foi de peroxônio, com 11,32 $\mu \mathrm{g} / \mathrm{L}$,

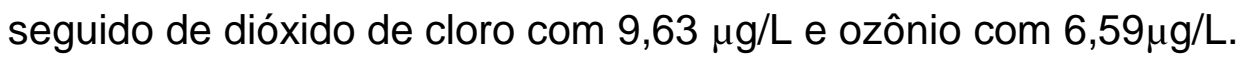

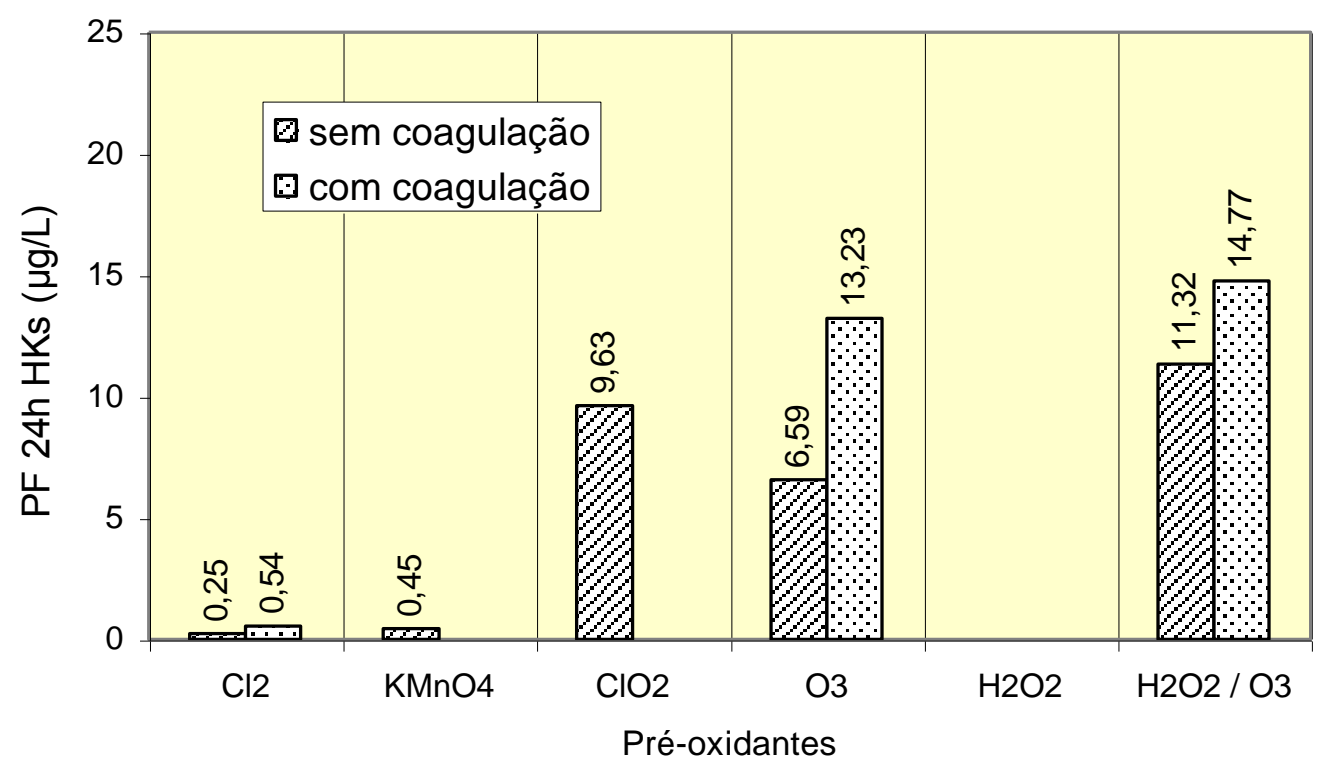

Figura 5.56- Resultados de PF 24h de halocetonas em presença e ausência de coagulação, filtração em papel, pós-cloração, incubação a $25^{\circ}$ em função dos pré-oxidantes aplicados.

Os valores de PF 24h de $\mathrm{KHs}$ obtidos nos ensaios com cloro e permanganato de potássio podem ser considerados desprezíveis. Não 
houve a formação de HKs quando o peróxido de hidrogênio foi utilizado como pré-oxidante.

\subsection{5 Ácidos haloacéticos}

Na Figura 5.57 estão apresentados os resultados de PF de 24h de ácidos haloacéticos em função dos pré-oxidantes aplicados na presença e ausência de coagulação.

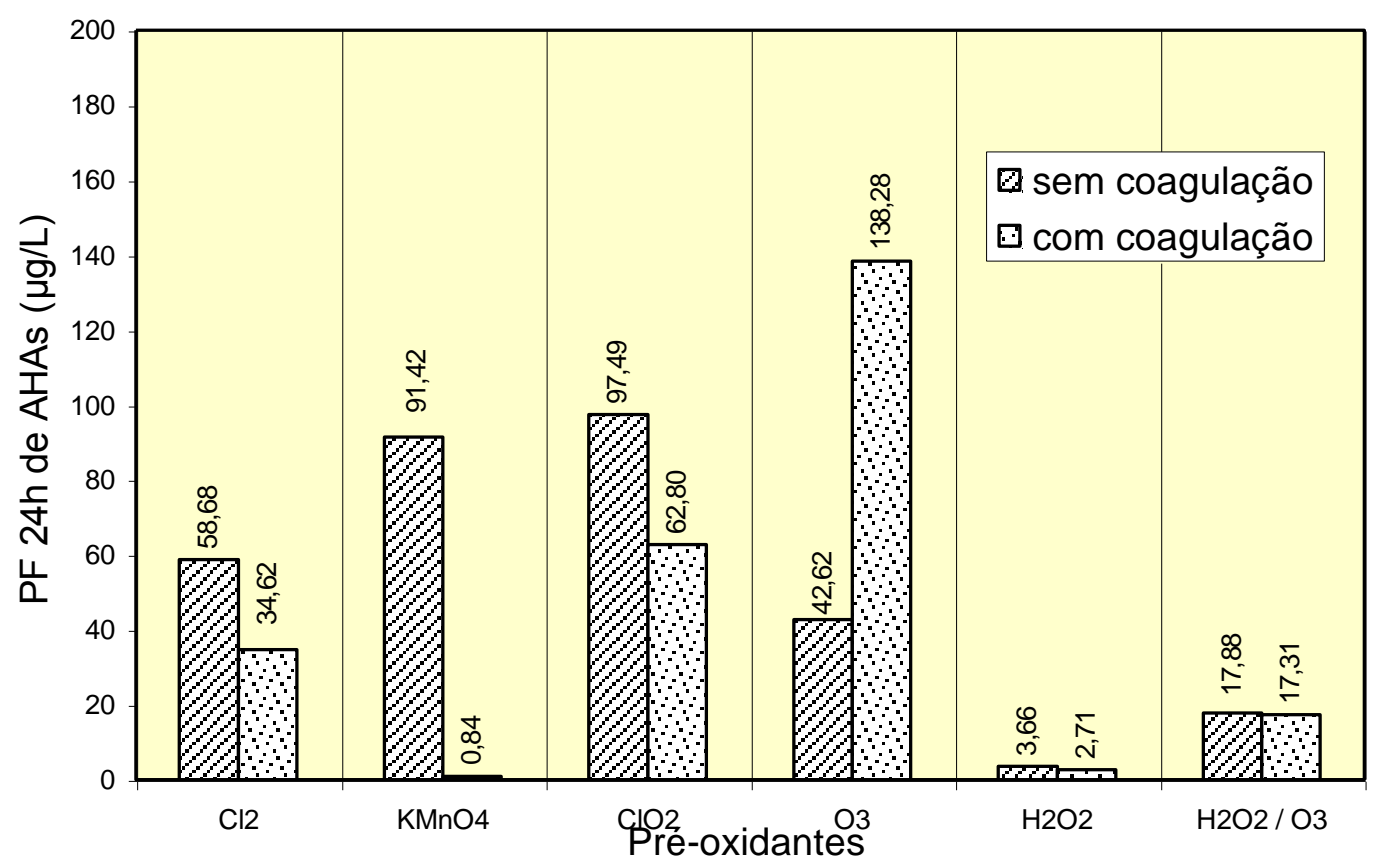

Figura 5.57- Resultados de PF 24h de ácidos haloacéticos em presença e ausência de coagulação, filtração em papel, pós-cloração, incubação a $25^{\circ}$ em função dos pré-oxidantes aplicados.

O maior valor obtido de PF $24 \mathrm{~h}$ de AHAs foi de $138,28 \mu \mathrm{g} / \mathrm{L}$ no ensaio com o uso de ozônio na pré-oxidação e na presença de coagulação. $\mathrm{Na}$ ausência de coagulação, o maior valor obtido foi de dióxido de cloro com $97,49 \mu \mathrm{g} / \mathrm{L}$, permanganato de potássio com $91,42 \mu \mathrm{g} / \mathrm{L}$ e cloro com $58,68 \mu \mathrm{g} / \mathrm{L}$. 
A presença e a ausência de coagulação não resultaram alterações significativas quando os pré-oxidantes utilizados foram: cloro, peróxido de hidrogênio e peroxônio.

\subsubsection{Cloropicrinas}

Nas condições em que os ensaios experimentais foram realizados, as cloropicrinas não foram formadas ou ficaram abaixo do limite de quantificação do método analítico empregado $(<0,1 \mu \mathrm{g} / \mathrm{L})$. 


\section{CONCLUSÕES E RECOMENDAÇÕES}

Com base no trabalho realizado, concluiu-se que:

a. O método recomendado pela USEPA 551.1, para a identificação e quantificação de compostos orgânicos halogenados: trialometanos, cloro hidrato, haloacetonitrilas, halocetonas e halopicrinas, apresentou ótima sensibilidade para a identificação destes subprodutos. O método 552 empregado para a quantificação de ácidos haloacéticos apresentou sensilbilidade quando se aplicou na metodologia a ausência de divisão de amostras para injeção no cromatografo.

b. Os fatores que influenciaram no aumento da formação de trialometanos foram: maior concentração de substâncias húmicas, tempo de contato e temperatura da água de estudo.

c. O uso do ensaio de potencial de formação de 7 dias deve ser empregado na água bruta para avaliação a capacidade da formação de subprodutos orgânicos halogenados. Porém a realização de um branco é importante, observou-se que uma quantidade de subprodutos pode ser formada independente do precursor existente. Esta reação pode ser devido à presença de carbono associado a outros constituintes, tais como: alcalinidade, dureza e dióxido de carbono livre.

d. As taxas de formação de subprodutos são menores no inicio dos ensaios, fato que pode estar associado a uma competição pelo oxidante exercida pela presença outros compostos. Após o tempo de contato de aproximadamente $6 \mathrm{~h}$, a formação tende a estabilidade. 
e. A formação de ácidos haloacéticos é superior à formação de trialometanos, cloro hidrato, haleacetonitrilas e halocetonas.

f. Nos ensaios que foram empregados a coagulação com sulfato de alumínio proporcionaram uma redução na formação de trialometanos, cloro hidrato, haloacetonitrilas e ácidos haloacéticos.

g. A pré-oxidação com ozônio reduz a formação de subprodutos exceto para AHAs, porém o ozônio foi o pré-oxidante que apresentou maior 7 potencial de formação de trialometanos em 24 horas.

h. A pré-oxidação com permanganato de potássio, coagulação, filtração em papel, pós-cloração pode ser uma alternativa muito interessante em ETAs, tendo-se o cuidado de se efetuar ensaios de demanda para evitar tonalidade rósea na água distribuída.

i. O dióxido de cloro é um pré-oxidante eficiente na presença de coagulação, filtração em papel e pós-cloração, porém ocorreu uma formação considerável de ácidos haloacéticos.

j. O peróxido de hidrogênio formou valores baixos de trialometanos, cloro hidrato e traços de ácidos haloacéticos e não houve a formação de haloacetonitrilas e halocetonas.

k. O uso do peroxônio mostrou-se uma alternativa interessante, tendo sido obtido o potencial de formação de $25,15 \mu \mathrm{g} / \mathrm{L}$ de trialometanos.

I. O peróxido de hidrogênio e o peroxônio foram os pré-oxidantes que apresentaram um menor potencial de formação de ácidos haloacéticos. 
m. Houve a formação de cloro hidrato em todos os ensaios realizados com os pré-oxidantes estudados.

Em função dos resultados obtidos nesta investigação, recomenda-se:

a. A realização de ensaios com pré-oxidantes alternativos para água contendo substancias húmicas de origem aquática.

b. Sugere-se que o Ministério da saúde estabeleça uma regulamentação incluindo ácidos haloacéticos e cloro hidrato nos padrões de qualidade de água para consumo humano. 


\section{REFERÊNCIAS BIBLIOGRAFICAS}

ABDEL-RAHMAN, M. S. (1982). The presence of trihalometanes in soft drinks. Journal of Applied Toxicology, v.2, n.3, p. 165-166.

AIETA, E. M.; BERG, J.D. (1986). A review of chlorine dioxide in drinking water treatment. Journal of the American Water Works Association - AWWA, v.78, n.6, p.62, jun.

AMIRTHARAJAH, A., DENNETT, K. E., STUDSTILL, A. (1993). Feric Chloride coagulation for removal of dissolved organic matter and trihalomethane precursors. Water Science Tecnology, v.27, n.11, p.113-121.

AMY, G. L., THOMPSON, J. M. TAN, L., DAVIS, M. K., KRASNER, S. W. (1990). Evaluation de THM precursor contribuitions from agricultural drains. Journal American Water Works Association. P.57-64, Jan.

APHA, AWWA, WPCF (1998). Standard Methods for the Examination of Water and Wastewater. 19th edition, Washington, USA.

AWWA (1999). Water Quality \& Treatment Handbook of Comnunity Wats Suplies, Fifth edition, Cap.12, p.12,3.

BATALHA, B. L. A.(1979). A presença do clorofórmio e outros trihalometanos na água de consumo humano. Congresso Brasileiro de Engenharia Sanitária e Ambiental, 10, Anais Manaus, Associação Brasileira de Engenharia Sanitária e Ambiental - ABES, p. 1-45.

BALSTER, R. L., BORZELLECA, J. F. (1982). Behavioral toxicity of trihalomethane contaminants of drinking water in mice. Environmental Health Perspectives, v.46, p.127-136.

BELLAR, T.A., LICHTENBERG, J. J., KRONER, R. C. (1974). The occurrence of organohalides in chlorinated drinking waters. Journal American Water Environment Research, v.66, n.12; p.703-706.

BOWMAN, F. J., BORZELLECA, J. F., MUNSON, A. E. (1978). The toxicity of some halomethanes in mice. Toxicology and Applied Pharmacology, v.44, n.1, p.213-215. 
BRASIL, Leis Decretos, etc. Ministério da Saúde. Portaria 36/GM. 19 de janeiro de 1990, Brasília, Brasil.

BRASIL, Leis Decretos, etc. Ministério da Saúde. Portaria 1469/GM. 29 de dezembro de 2000, Brasília, Brasil.

BRASIL, Leis Decretos, etc. Ministério da Saúde. Portaria 518/GM. 25 de março de 2004, Brasília, Brasil.

BUN, W. W., HAAS, B. B., DEANE, E. R. et al. (1975). Formation of trihalometanes by chlorination of surface water. Environment Letters, v.10, n.3, p.205-213.

CAMPOS, S. X. (2004). Influência das Substâncias Húmicas de Diferentes Massas Molares na Coagulação, Floculação e Sedimentação no Tratamento de Água. São Carlos. Tese (Doutorado) - Instituto de Química de São Carlos, Universidade de São Paulo.

CANTOR, K. P., HOOVER, R., MASON, T. J. et al. (1978). Associations of cancer mortality with halomethanes in drinking water. Journal National Cancer Institute, v. 61, n.4, p. 979-985, Oct.

CANTOR, K. P. (1982). Epidemiological evidence of carcinogenicity of chlorinated organics in drinking water. Environmental Health Perspectives, v.46, n.12, p.187-195.

COELHO, E. R.C. (2002). Influência da pré-oxidação com ozônio e peróxido de hidrogênio nop desempenho de uma instalação FiME - Para tratamento de águas de abastecimento. Tese de doutorado, Escola de Engenharia de São Carlos-Universidade de São Paulo, 255p, São Carlos SP.

CHANG, C., HSIEH, Y., LIN, Y., HU, P., LIU,C., WANG, K. (2001). The effect of the molecular mass of the organic matter in raw water on the formation of disinfection by-products. Jounar of Water Supply. Aqua n. 50.1 pg.39-45.

DI BERNARDO,L. (1995). Algas e suas influências na qualidade das águas e nas tecnologias de tratamento. ABES, Rio de Janeiro, Brasil.

DANIEL, L.A. et al. (2001). Processos de desinfecção e desinfetantes alternativos na produção de água potável. cap. 2. ABES-PROSAB. Rio de Janeiro, RJ.

FAIR, P. S.; BOLYARD, M. (1991). Status of disinfectant/disinfection byproduct methods in relation to the disinfection by-products rule. In: AWWAWater Quality Technology Conference, Orlando: American Water Works Association - AWWA, p.399-407. 
FERREIRA FILHO, S. S.; HESPANHOL, I.; PIVELI, R.P. Aplicabilidade do dióxido de cloro no tratamento de águas de abastecimento. $22^{\circ}$ Congresso Brasileiro de Engenharia Sanitária e Ambiental. Set. 03. Joinville, Santa Catarina.

FIGUEIREDO, R. F.; PARDO, S. D. A.; CORAUCCI FILHO, B. (1999). Fatores que influenciam a formação de trihalometanos em águas de abastecimento. 20ำ Congresso Brasileiro de Engenharia Sanitária e Ambiental, Rio de Janeiro, anais Associação Brasileira de Engenharias Sanitária e Ambiental - ABES, p.1362-1362.

GASI, T. M. T.; SAMAPIO, A O.; PACHECO, C. E. M.; CAMACHO, P.R.R.; ANDRADE, E. M. (1995). Aplicação de ácido peracético para desinfecção de efluentes de lodos ativados. In: 18 ${ }^{\circ}$ Congresso Brasileiro de Engenharia Sanitária e Ambiental, ABES. Salvador, BA.

GHANBARI, H. A.; WHEELER, W. B.; KIRK, J.R. (1982). Reactions of aqueous chlorine and chlorine dioxide with lipids: chlorine incorporation. Journal of Food Science, v.47, p.483-485.

GRASSI, M. T.; JARDIM, W.F.(1993). Ozonização de águas: Aspectos químicos e toxicológicos. São Paulo Revista DAE - SABESP n.173, set/out.

GUTHRIE, R. K. (1988). Food sanitation, 3 ed. New York: AVI, 327p.

JEFFERY, G. H.; BASSET, J.; MENDHAM, J.; DENNEY, R. C. (1992). Analise Química Quantitativa. VOGEL, p. 287-288, 5ª edição LTC Editora, Rio de Janeiro, RJ.

KRASNER, S. W.; McGUIRE M. J.; JACANGELO, J. G.; PATANIA, N. L., REAGAN; K. M., AIETA M.E. (1989). The occurrence of disinfection byproducts in US drinking water. Journal American Water Works Association AWWA Research \& Technology, USA, p:41-53, Aug.

$\mathrm{KOCH}$, B. et al. (1988). Analyses of halogenated disinfection by-products by capillary chromatografhy. American Water Works Association AWWA WWTC, St. Louis, Mo.

LANGLAIS, B.; RECKHOW, D. A.; BRINK, D. R. Eds (1991). Ozone in water treatment: Aplications and Engineering. Lewis Publishers, Inc., Chelsea. Micg.

LAWRENCE, J..(1989). Humic acid and related substances in the environment. In: Afghan BK, editor. Analysis of trace organicas in the aquatic environment. Boca Ratton: CRC Press; p.313-337. 
LYKINS, Jr. B.W.; KOFFSKEY,W.E. \& PATTERSON, K. S. (1994). Alternative disinfectntes for drinking water. USA JEE-ASCE, vol.120, n.4, p.745-758, Aug.

MACÊDO, L. H. H.; NOGUTI, M.; ABE, H. Y. (1983). Estudos dos trihalometanos. Congresso Brasileiro de Engenharia Sanitária e Ambiental, 12, Balneário Camburiú, Anais. Balneário Camburiú-SC. Associação Brasileira de Engenharia Sanitária e Ambiental, p.1-20.

MACÊDO, J. A B. (2001). Subprodutos do processo de desinfeção de água pelos derivados clorados - disinfection bysubproducts. Juiz de Fora-MG, p67.

MASSCHELEN, W. (1977). Spectrophotometric Determination of Residual Hydrogen Peroxide. Water and Sewerage Works, p.69.

MANUAL of Practice FD-10 - Wastewater Disinfection. (1996). Alexandria (VA), Water Environmental Federation.

MASTEN, S. J.; DAVIES, S. H. R. (1997). Chemical oxidation and Reduction. In: FREMAMN, H. M. Ed..

MELNICK, R. L. (1987). Toxicology and carcinogenesis studies or bromodichloromethane. Washington, D.C.: U.S. Departament of health and human services, p182.

MELNICK, R. L. (1989). Toxicology and carcinogenesis studies or tribromomethane (bromofórmio). Washington, D.C.: U.S. Departament of health and human services, p194.

McGUIRE,M. J. (1989). Preparing for the Disinfection by-products Rule: A Water Industry Status Report. Journal American Water Works Association AWWA. p. 35-40. Aug.

MILLER, R. E.; RANDTKE, S. J.; HATHAWAY, L. R.; DENNE, J. E. (1990). Organic carbon and THM formation potencial in Kansas Groundwaters. Jounal American Water Works Association-AWWA, p.49-62, March.

MUTTAMARA, S.; SALES, C. I.; GAZALI, Z.. (1995) The formation of thihalomethanos from chemical disinfectantes and humic substances in drinking water. Water Supply, v.13, n.2. p 105-17.

MOZETO, A. A., GARZURI, M. P., FERREIRA, S. S. F, Remoção de compostos orgânicos naturais no processo convencional de tratamento de água: monitoramento da estação de tratamento de água do Alto da Boa Vista (ETA-ABV). 20ํㅡㄹ Congresso Brasileiro ABES, Rio de Janeiro, 1999. 
OLIVEIRA, C. A.. (2002). Minimização da formação de trihalometanos no tratamento de água de abastecimento. São Paulo. 120p. Dissertação de mestrado, Escola Politecnica da Universidade de São Paulo.

PERRY, R. (1982). Aspects of the chemistry and analysis of substances of concern in the water cycle. Poluition: causes, effects and control. London: Roy M. Harrison. p33-50.

PARDO, S.D.A. (1996). Avaliação do potencial de formação de trihalometanos em sistemas de abastecimento de água. Dissertação de mestrado, 119p. Faculdade de Engenharia Civil, Universidade Estadual de Campinas.

POURMOGHADAS, H.(1992). Determination of nine haloacetc acids in finished drinking water. In: Water Quality Technology Conference, Toronto: American Water Works Association, p. 447-464.

RECKHOWM, D. A.; SINGER, P. C. (1990). Chlorination by-products in drinking waters: from formation potentials to finished water concentrations. Journal American Water Works Association -AWWA, p.173-180, April.

REVISTA SAÚDE (1998). Será que a água da sua casa pode provocar cancer? Alguns estudos sugerem que sim. n.180, set.1998, p.61-64.

REVISTA CIENCIA HOJE (1998). Ameaça na água potável. Dez 1998, p.2934.

ROOK, J.; EVANS, S. (1974). Renoval of trihalometanos precursors from surface waters using weak resins. Journal American Water Works Association -AWWA, v.9, n. p520-524.

ROCHA, J. C. \& ROSA, A. H. (2003). Substâncias Húmicas Aquáticas: Interação com Espécies Metálicas. São Paulo, Editora UNESP, 120 p.

ROCHA, J. C.; ROSA, A. H.; FURLAN, M. (2000). Substâncias Húmicas de turfa: Estudo dos parâmetros que influenciam no processo de extração alcalina. Química Nova, SBQ, v.23, n.4, p.471.

RUOCCO JÚNIOR, J.; SUZIKI, M.; AIBA, C. J. (1981). Trihalometanos em águas para consumo humano, incidência e estudos de potencial de formação. Congresso Brasileiro de Engenharia Sanitária e Ambiental, 11, Fortaleza. Associação de Engenharia Sanitária e Ambiental - ABES, p.2-29.

SANTOS, C. L. (1988). O Controle de trihalometanos (THM) nas águas de abastecimento público. São Paulo: USP, 217p. Dissertação de mestrado em Saúde Pública. Universidade de São Paulo, SP. 
SENS, L. M. et al. (2003). Influência da pré-oxidação na tratabilidade das águas através da filtração direta descendente em mananciais com grandes concentrações de algas. $22^{\circ}$ Congresso Brasileiro de Engenharia sanitária e Ambiental. ABES - CD-ROON, I-094, Set. 2003. Joinville, Santa Catarina.

SINGER, P. C.; ASCE, M.(1994). Control of disinfection by-products in drinking water. JEE-ASCE, v. 120, n. 4., p.727-741. July/August, USA.

STEVENS, A. A.; SLOCUM, C. J.; SEEGER, D. R.; ROBECK, G. G. (1976). Clorination of organics in drinking water. Journal American Water Works Association, n.68, p. 615-620.

SYMONS J.M.; STEVENS, A.A.; CLARK R. M.; GELDREICH E.E.; LOVE O.T. (1981). Treatment techniques for controlling trihalomethanes in drinking water. Ohio, USA, EPA, 289p.

TARQUINI, A.; RITTMANN, D. D. (1992). Can chlorine dioxide and activated carbon control THM? Water Engineering \& Management, v.6, p. 16-17. June.

TITO BORGES, J.; GUIMARÃES, J. R.; SPARRAPAN, R.; EBERLIN, M.N. (2002). A influência da amônia no potencial de formação de trialometanos. XXVIII Congresso Interamericano de Ingenieria Sanitária y Ambiental. Oct. 2002, Cancún, México.

TRUSSEL, R. R.; UMPHRES, M. D. (1978). The formation of trihalomethanes. Journal the American Water Works Association, v.70. n.11, p.604, nov.

TOMINAGA, M, Y. (1998). Trialometanos em água de abastecimento validação e correlação de dois métodos de análises por cromatografia gasosa. São Paulo; Dissertação de mestrado, Faculdade de Ciências Farmacêuticas da USP.

TOMINAGA, M. Y.; MIDIO, A. F. (1999). Exposição humana a trialometanos presentes em água tratada. São Paulo, Rev. Saúde Pública, 33(4), p. 413421.

UNITED STATES ENVIRONMENTAL PROTECTION AGENCY-USEPA (2002). Trihalometanes in drinking water: Sampling, Analysis, Monitoring, and Compilance. EPA 570/9-83-002, august.

UNITED STATES ENVIRONMENTAL PROTECTION AGENCY-USEPA (1999). Alternative Disinfectants and Oxidants Guindance Manual. Washington, EPA 5-1april.

UNITED STATES ENVIRONMENTAL PROTECTION AGENCY-USEPA (1995). Method 551.1. Determination of chlorination disinfection byproducts, chlorinated solvents, and halogenated pesticides/herbicides in drinking water 
by liquid-liquid extracion and gas chromatografhy with electron-capture detection. CD-ROM Revisão 1. Set.1995, Ohio, USA.

UNITED STATES ENVIRONMENTAL PROTECTION AGENCY-USEPA (1995). Method 552..2 Determination of haloacetic acids and dalapon in, in drinking water by liquid-liquid extracion, derivatization and gas chromatografhy with electron-capture detection. CD-ROM Revisão 1. Set.1995, Ohio, USA.

WIECHETECH, G. K. (2005). Remoção de substâncias húmicas em tratamento de água por meio de pré-oxidação e dupla filtração. Tese de doutorado. Escola de Engenharia de São Carlos-USP. São Carlos SP 


\section{APÊNDICE A}

A-01 Resumo da curva de calibração EPA 551 (551)

A-02 Cromatograma ponto 1

A-03 Eromatograma ponto 2

A-04 Cromatograma ponto 3

A-05 Cromatograma ponto 4

A-06 Cromatograma ponto 5

A-06 Cromatograma ponto 6

A-07 Cromatograma de verificação - ponto 3 
Calibration Curves Report - Page 1

File: c:Istarlmodule16lthmacet2.mth

Detector: ADC Board, Address: 16, Channel ID: B

PI

Standard for Internal Standard Analysis cloroformio

Internal Standard Analysis

Resp. Fact. RSD: $25.32 \%$

Curve Type: Linear

Origin: Ignore (Edited)

Corr. Coef. $\left(R^{2}\right): 0.970825$

$y=+1.5008 e-002 x+5.2060 e-001$

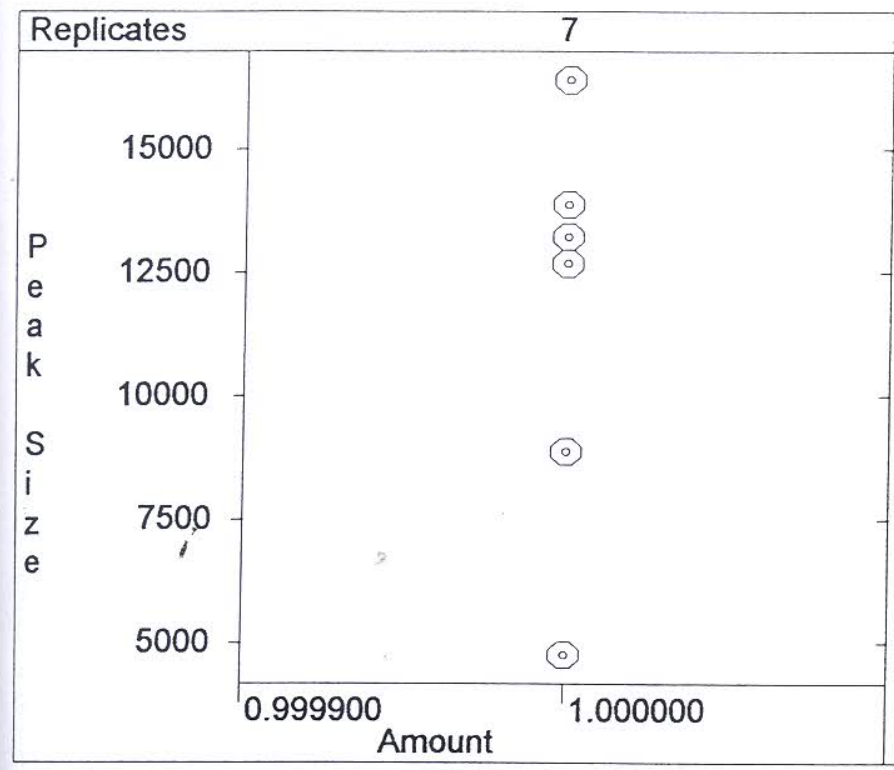

tricloroacetonitrila

Internal Standard Analysis

Resp. Fact. RSD: $12.75 \%$

Curve Type: Linear

Origin: Ignore (Edited)

Corr. Coef.( $\left(R^{2}\right): 0.988485$

$y=+1.6128 e-001 x+8.0513 e-001$

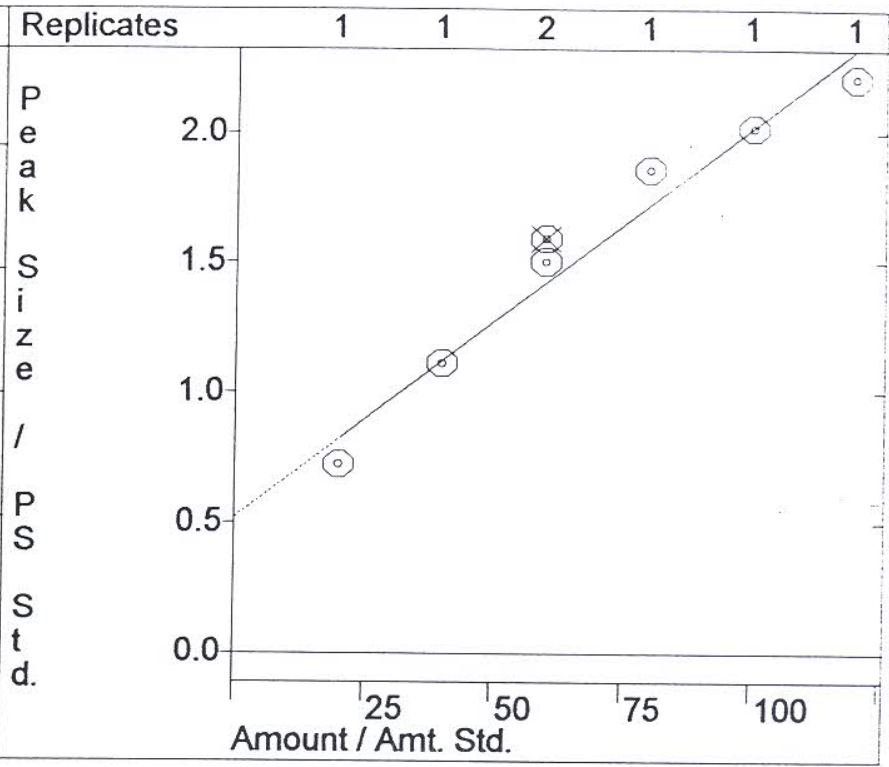

dicloroacetonitrila

Internal Standard Analysis

Resp. Fact. RSD: $13.49 \%$

Curve Type: Linear

Origin: Ignore (Edited)

Corr. Coef.(R $\left.{ }^{2}\right)$ : 0.981731

$y=+9.0038 e-002 x+5.2503 e-001$

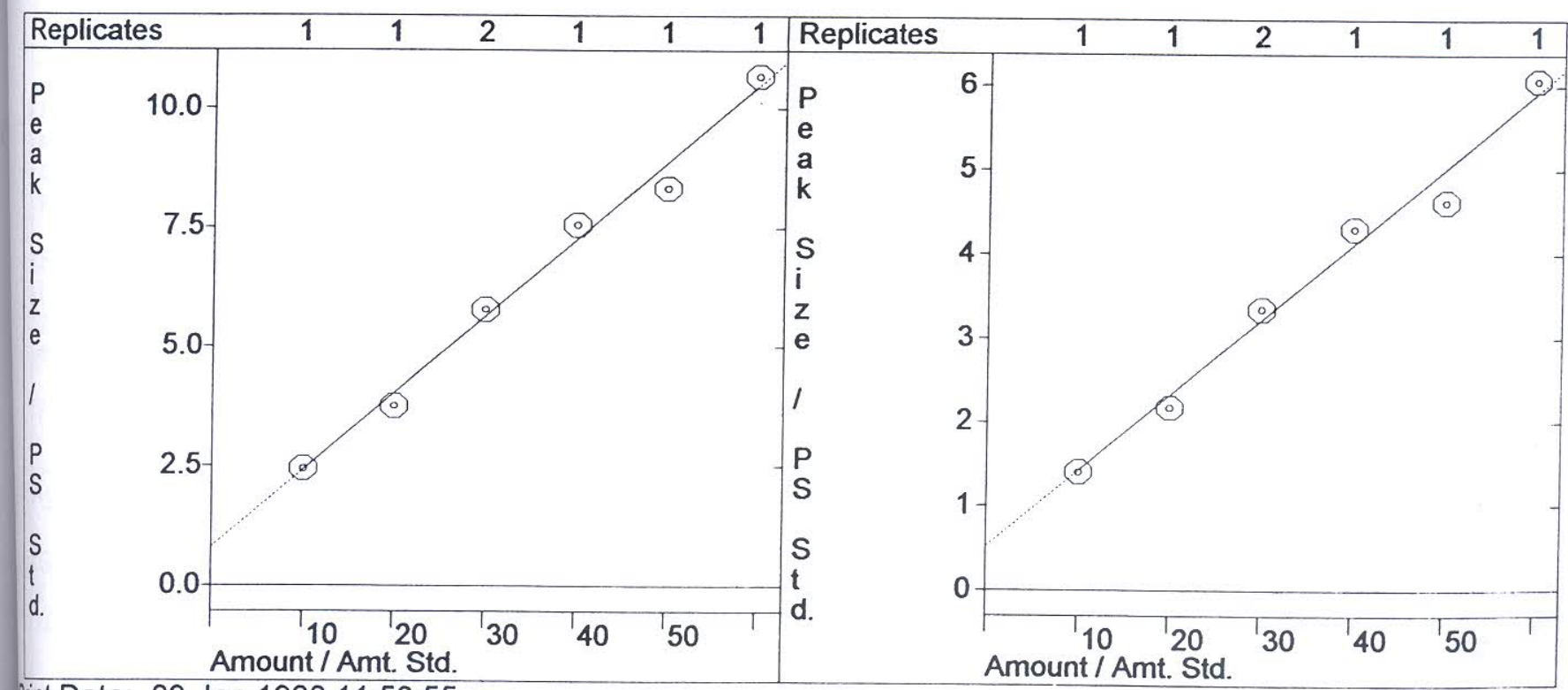

Pint Date: 03 Jan 1980 11:50:55 
Calibration Curves Report - Page 2

File: c:Istarlmodule16lthmacet2.mth

Detector: ADC Board, Address: 16, Channel ID: B

bromodiclorometano

Internal Standard Analysis

Resp. Fact. RSD: $18.09 \%$

Curve Type: Linear

Origin: Ignore (Edited)

Corr. Coef. $\left(\mathrm{R}^{2}\right): 0.985693$

$y=+8.8751 e-002 x+1.3582 e+000$ cloral hidrato

Internal Standard Analysis

Resp. Fact. RSD: $19.33 \%$

Curve Type: Linear

Origin: Ignore (Edited)

Corr. Coef. $\left(R^{2}\right): 0.960872$

$y=+6.6225 e-002 x+1.1236 e+000$

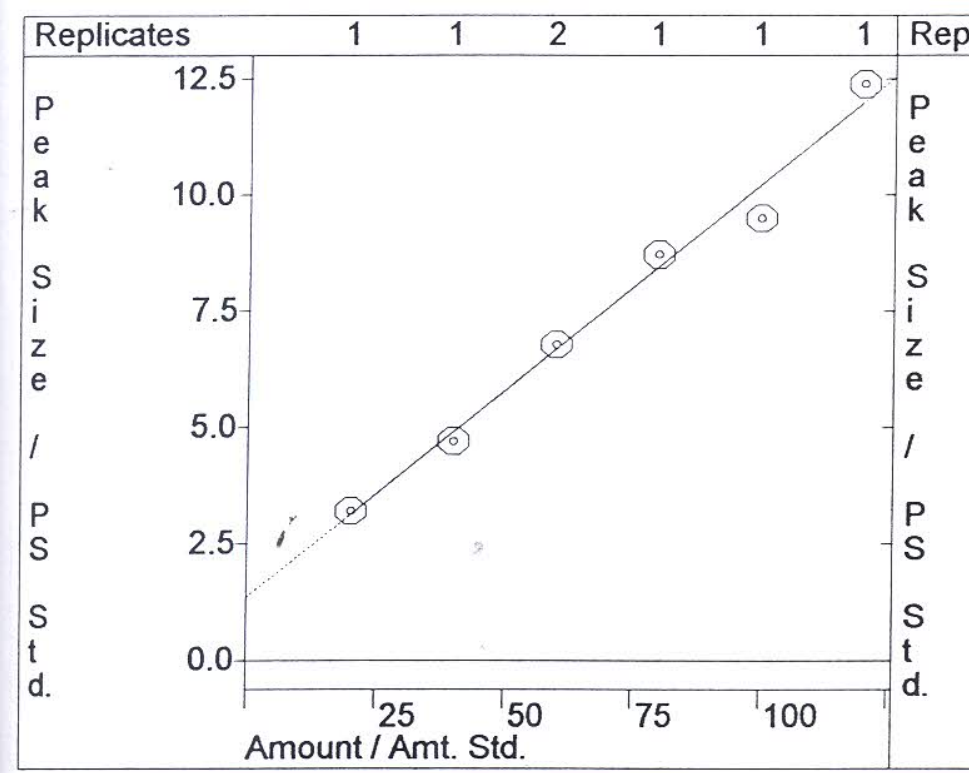

Replicates

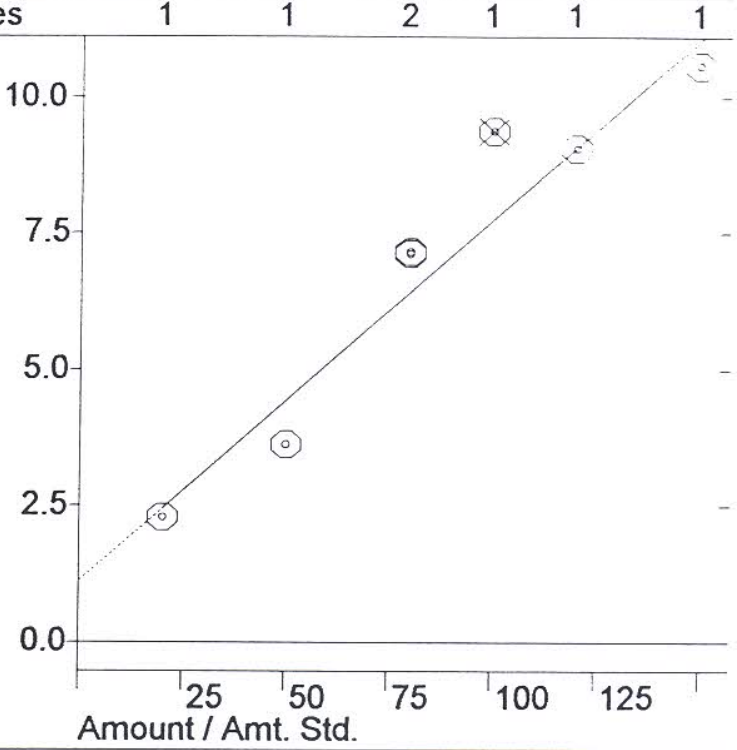

1,1-dicloropropanona

Internal Standard Analysis

Resp. Fact. RSD: $11.75 \%$

Curve Type: Linear

Origin: Ignore (Edited)

Corr. Coef. $\left(R^{2}\right): 0.981718$

$y=+5.8932 e-002 x+1.5571 e-001$

cloropicrina

Internal Standard Analysis

Resp. Fact. RSD: $11.91 \%$

Curve Type: Linear

Origin: Ignore (Edited)

Corr. Coef.(R $\left.{ }^{2}\right): 0.989995$

$y=+2.2546 e-001 x+7.3414 e-001$

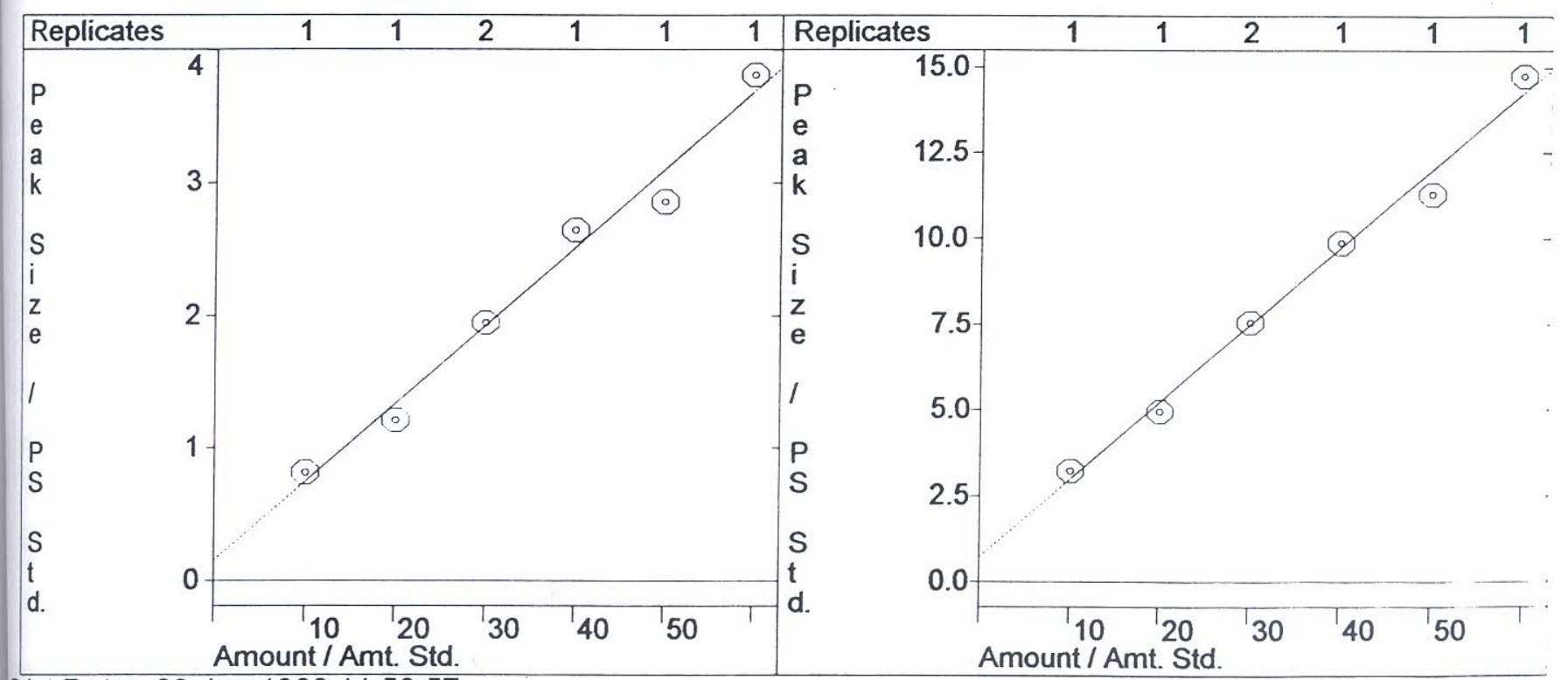

Print Date: 03 Jan 1980 11:50:57 
Calibration Curves Report - Page 4

File: c:Istarlmodule16lthmacet2.mth

Detector: ADC Board, Address: 16, Channel ID: B

\section{bromoformio}

Internal Standard Analysis

Resp. Fact. RSD: $19.94 \%$

Curve Type: Linear

Origin: Ignore (Edited)

Corr. Coef. $\left(R^{2}\right): 0.949273$

$y=+2.6058 e-002 x+2.5158 e+000$

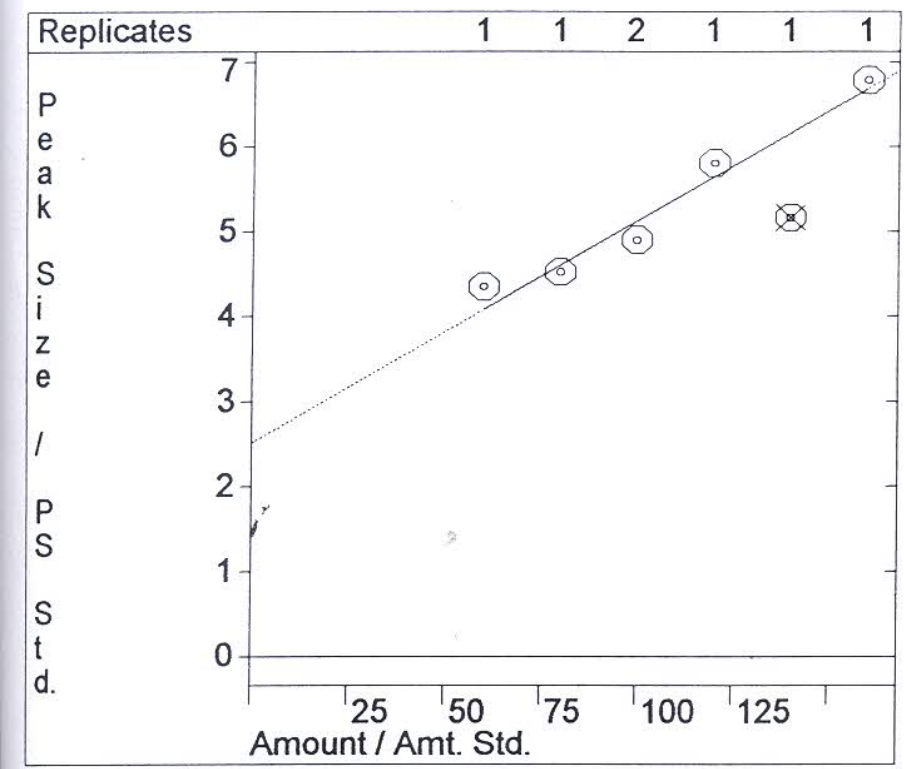

Pint Date: 03 Jan 1980 11:51:02 
Title

Run File

Method File

Sample ID
Subprodutos organo-halogenados metodo 551 EPA

C: \STAR \MODULE16\HAAOZ038.RUN

C: \STAR\MODULE16\THMACET2.MTH

ponto 1
Injection Date: 20-JUL-4 10:15 AM

Operator : PASCHOALATO, C

Workstation:

Instrument : star $3600 \mathrm{cx}$

Channel : $\mathrm{B}=\mathrm{ECD}$
Calculation Date: 20-JUL-4 10:42 AM

Detector Type: ADCB (10 Volts)

Bus Address : 16

Sample Rate : $10.00 \mathrm{~Hz}$

Run Time

: $20.002 \mathrm{~min}$

Star Chromatography Software

Run Mode

Peak Measurement: Peak Area

Calculation Type: Internal Standard

Level

\begin{tabular}{|c|c|}
\hline eak & Peak \\
\hline No. & Name \\
\hline- & ----------- \\
\hline 1 & PI \\
\hline 2 & cloroformio \\
\hline 3 & tricloroacet \\
\hline 4 & dicloroaceto \\
\hline 5 & bromodicloro \\
\hline 6 & cloral hidra \\
\hline 7 & 1,1-ditlorop \\
\hline 8 & cloropicrina \\
\hline 9 & dibromocloro \\
\hline 10 & $1,1,1$-triclo \\
\hline 11 & bromocloroac \\
\hline 12 & dibromoaceto \\
\hline 13 & bromoformio \\
\hline & --- \\
\hline
\end{tabular}

Totals :

\begin{tabular}{|c|c|c|}
\hline Ret. & Time & \\
\hline $\begin{array}{l}\text { Time } \\
\text { (min) }\end{array}$ & $\begin{array}{l}\text { Offset } \\
\text { (min) }\end{array}$ & $\begin{array}{c}\text { Area } \\
\text { (counts) }\end{array}$ \\
\hline$-\cdots--$ & $\ldots-\ldots$ & ------ \\
\hline 4.259 & 0.000 & 8701 \\
\hline 6.735 & -0.001 & 8202 \\
\hline 8.884 & -0.000 & 21737 \\
\hline 9.356 & -0.000 & 12500 \\
\hline 9.883 & 0.000 & 28498 \\
\hline 10.241 & -0.000 & 20341 \\
\hline 10.820 & -0.000 & 7236 \\
\hline 13.064 & -0.001 & 28642 \\
\hline 13.433 & -0.001 & 22848 \\
\hline 14.408 & -0.000 & 758 \\
\hline 15.468 & -0.001 & 10103 \\
\hline 16.948 & 0.108 & 9279 \\
\hline 17.113 & -0.069 & 40276 \\
\hline$-\ldots$ & $====$ & $===$ \\
\hline
\end{tabular}

\begin{tabular}{rrl}
\multicolumn{3}{c}{ Width } \\
Sep. & $1 / 2$ & Status \\
Code & $($ sec $)$ & Codes \\
--- & --- &.--- \\
BB & 5.7 & SR \\
BB & 6.0 & \\
BB & 7.4 & \\
BB & 5.8 & \\
BP & 6.9 & \\
PV & 7.7 & \\
VB & 7.4 & \\
BV & 7.2 & \\
VB & 7.0 & \\
BB & 7.2 & \\
BB & 7.6 & \\
BV & 7.2 & \\
VB & 7.4 & \\
--- &.--- &
\end{tabular}

Status Codes:

$\mathrm{R}$ - Reference peak

S - Internal standard peak

Total Unidentified Counts :

Detected Peaks: 20

29857 counts

Rejected Peaks: 1

Multiplier: 1.000000
Identified Peaks: 13

Divisor: 1.000000

Amount Standard: 1.000000

Baseline offset: -20 microvolts

Noise (used): 330 microvolts - monitored before this run

Manual injection

Print Date: Tue Jul 20 11:01:27 2004 
Title: Subprodutos organo-halogenados metodo 551 EPA

Run File : C: \STAR\MODULE16\HAAOZ038.RUN

Method File : C: \STAR\MODULE16\THMACET2.MTH

Sample ID: ponto 1

Injection Date: 20-JUL-4 10:15 AM

Operator : PASCHOALATO, C

Workstation:

Instrument : star $3600 \mathrm{Cx}$

Channel
Calculation Date: 20-JUL-4 10:42 AM

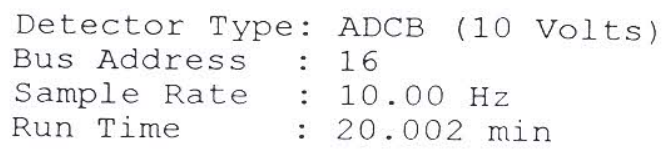

Run Time : $20.002 \mathrm{~min}$

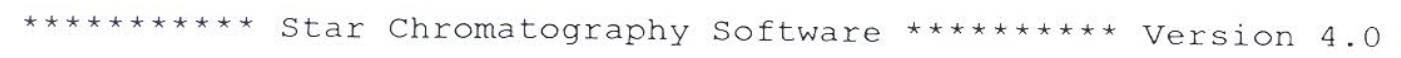


Title : Subprodutos organo-halogenados metodo 551 EPA

Run File : C:\STAR\MODULE16\HAAOZ039.RUN

Method File : C: \STAR \MODULE16\THMACET2.MTH

Sample ID : ponto 2

Injection Date: 20-JUL-4 10:44 AM

Calculation Date: 20-JUL-4 11:06 AM

Operator : PASCHOALATO, C

Workstation:

Instrument : star $3600 \mathrm{cx}$

Channel : $\mathrm{B}=\mathrm{ECD}$

Detector Type: ADCB (10 Volts)

Bus Address : 16

Sample Rate : $10.00 \mathrm{~Hz}$

Run Time

: $20.002 \mathrm{~min}$

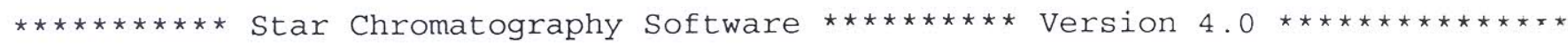

Run Mode : Calibration

Peak Measurement: Peak Area

Calculation Type: Internal Standard

Level

\begin{tabular}{|c|c|c|c|c|c|c|c|}
\hline & & Ret. & Time & & & Width & \\
\hline Peak & Peak & Time & Offset & Area & Sep. & $1 / 2$ & status \\
\hline No. & Name & $(\min )$ & (min) & (counts) & Code & $(\mathrm{sec})$ & Codes \\
\hline$\cdots$ & ---------- & $-\cdots---$ & ------ & ------- & --- & ----- & \\
\hline 1 & $\mathrm{PI}$ & 4.248 & -0.011 & 4771 & $\mathrm{BB}$ & 4.7 & SR \\
\hline 2 & cloroformio & 6.727 & 0.009 & 5306 & BB & 5.8 & \\
\hline 3 & tricloroacet & 8.884 & 0.025 & 17950 & $\mathrm{BB}$ & 7.4 & \\
\hline 4 & dicloroaceto & 9.362 & 0.031 & 10370 & $\mathrm{BB}$ & 6.0 & \\
\hline 5 & bromodicloro & 9.885 & 0.029 & 22480 & $\mathrm{BP}$ & 6.7 & \\
\hline 6 & cloral hidra & 10.242 & 0.029 & 17314 & PV & 7.6 & \\
\hline 7 & 1,1 -diclórop & 10.825 & 0.034 & 5762 & VB & 7.6 & \\
\hline 8 & cloropicrina & 13.078 & 0.049 & 23653 & BV & 7.2 & \\
\hline 9 & dibromocloro & 13.437 & 0.040 & 18517 & VB & 7.1 & \\
\hline 10 & $1,1,1$-triclo & 14.418 & 0.049 & 598 & $\mathrm{BB}$ & 7.7 & \\
\hline 11 & bromocloroac & 15.470 & 0.043 & 7870 & $\mathrm{BB}$ & 7.4 & \\
\hline 12 & dibromoaceto & 16.945 & 0.043 & 7888 & BV & 6.5 & \\
\hline 13 & bromoformio & 17.113 & 0.046 & 21560 & VB & 7.3 & \\
\hline-- & $\begin{array}{l}\text { Totals: } \\
\text { Totals }\end{array}$ & $\cdots-\cdots$ & $\begin{array}{r}===== \\
0.416\end{array}$ & $\begin{array}{r}====== \\
164039\end{array}$ & --- & ----- & \\
\hline
\end{tabular}

Status Codes:

$\mathrm{R}$ - Reference peak

S - Internal Standard peak

Total Unidentified Counts :

24682 counts

Detected Peaks: 22

Rejected Peaks: 1

Identified Peaks: 13

Amount Standard: 1.000000

Multiplier: 1.000000

Divisor: 1.000000

Baseline Offset: -13 microvolts

Noise (used): 240 microvolts - monitored before this run

Manual injection

Print Date: Tue Jul 20 11:35:14 2004

Page 1 of 1 
Title : Subprodutos organo-halogenados metodo 551 EPA

Run File : C: \STAR\MODULE16\HAAOZ039.RUN

Method File: C: \STAR\MODULE16\THMACET2.MTH

Sample ID: ponto 2

Injection Date: 20-JUL-4 10:44 AM

Calculation Date: 20-JUL-4 11:06 AM

Operator : PASCHOALATO, C

Workstation:

Instrument : star $3600 \mathrm{Cx}$

Channel : $\mathrm{B}=\mathrm{ECD}$

Detector Type: ADCB (10 Volts)

Bus Address : 16

Sample Rate: $10.00 \mathrm{~Hz}$

Run Time : $20.002 \mathrm{~min}$

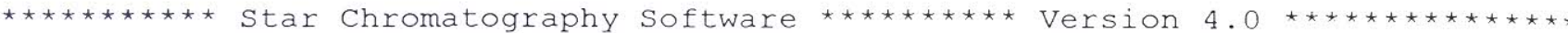

Chart Speed $=\quad 1.04 \mathrm{~cm} / \mathrm{min}$ Attenuation $=150$

start $\mathrm{Time}=0.000 \mathrm{~min}$ End Time $=20.002 \mathrm{~min} \mathrm{Min} / \mathrm{Tick}=1.00$

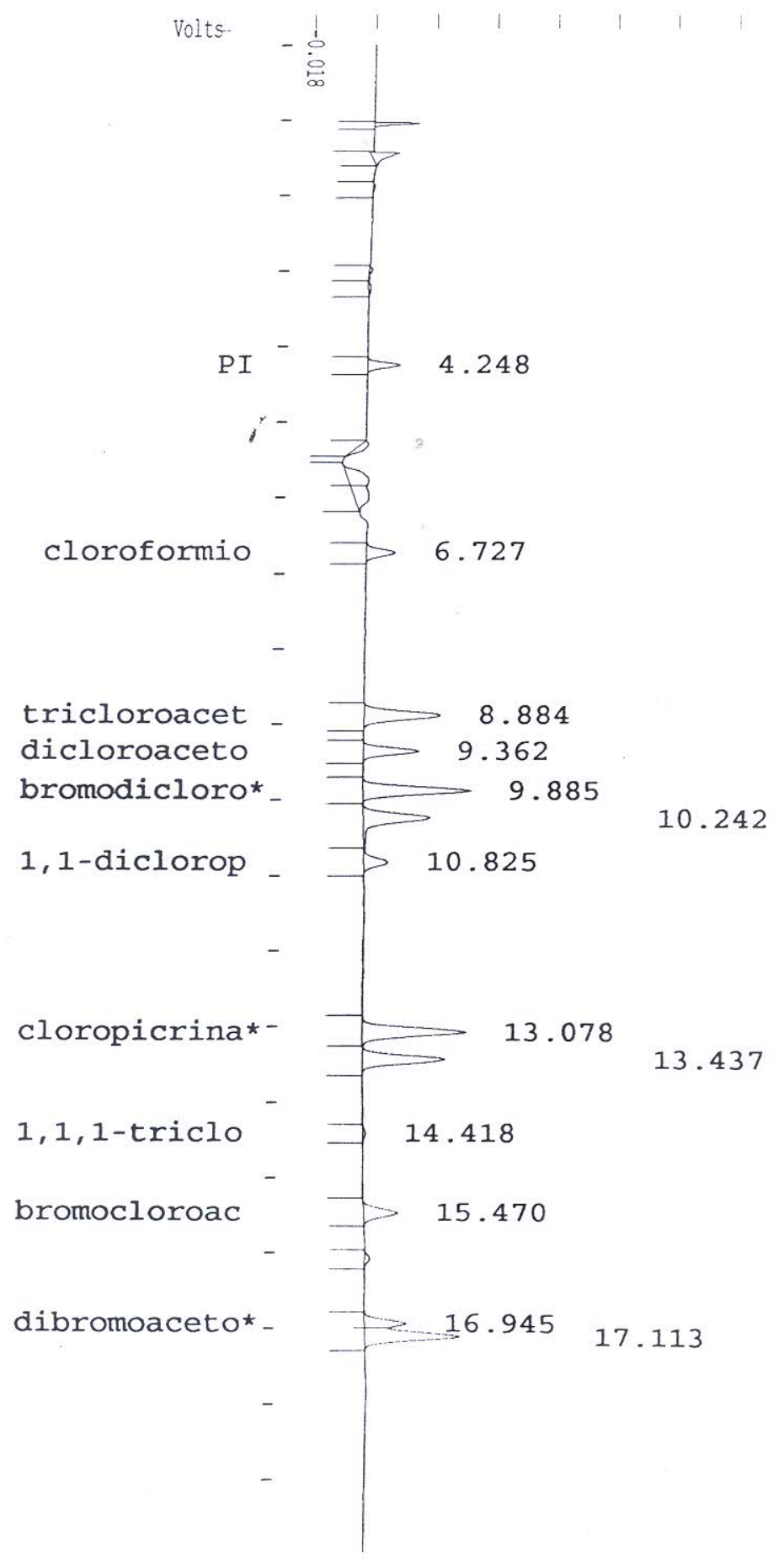

$<W I=2.0$

$<W I=4.0$

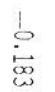

$<W I=8.0$

dicloroaceto 
Method File : C: \STAR \MODULE16\THMACET2.MTH

Sample ID: ponto 3

Injection Date: 20-JUL-4 11:20 AM

Calculation Date: 20-JUL-4 11:53 AM

Operator: PASCHOALATO, C
Workstation:
Instrument : star $3600 \mathrm{CX}$
Channel : $\mathrm{B}=\mathrm{ECD}$

Detector Type: ADCB (10 Volts)
Bus Address : 16
Sample Rate $: 10.00 \mathrm{~Hz}$
Run Time

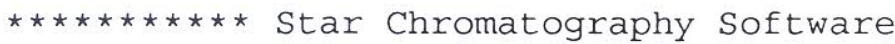

Run Mode

Peak Measurement: Peak Area

Calculation Type: Internal standard

Level

\begin{tabular}{|c|c|}
\hline eak & Peak \\
\hline No. & Name \\
\hline & ---- \\
\hline 1 & $\mathrm{PI}$ \\
\hline 2 & cloroformio \\
\hline 3 & tricloroacet \\
\hline 4 & dicloroaceto \\
\hline 5 & bromodicloro \\
\hline 6 & cloral hidra \\
\hline 7 & 1,1 -díclorop \\
\hline 8 & cloropicrina \\
\hline 9 & dibromocloro \\
\hline 10 & $1,1,1$-triclo \\
\hline 11 & bromocloroac \\
\hline & dibromoaceto \\
\hline 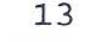 & bromoformio \\
\hline & - \\
\hline
\end{tabular}

Totals:

\begin{tabular}{|c|c|c|}
\hline Ret. & Time & \\
\hline $\begin{array}{l}\text { Time } \\
\text { (min) }\end{array}$ & $\begin{array}{l}\text { Offset } \\
\text { (min) }\end{array}$ & $\begin{array}{c}\text { Area } \\
\text { (counts) }\end{array}$ \\
\hline------ & $--\cdots--$ & $\cdots \cdots-\cdots$ \\
\hline 4.259 & 0.012 & 11613 \\
\hline 6.736 & -0.008 & 18082 \\
\hline 8.887 & -0.021 & 69114 \\
\hline 9.359 & -0.029 & 39320 \\
\hline 9.885 & -0.026 & 80400 \\
\hline 10.241 & -0.028 & 76203 \\
\hline 10.823 & -0.031 & 25373 \\
\hline 13.075 & -0.039 & 90816 \\
\hline 13.440 & -0.034 & 68697 \\
\hline 14.413 & -0.044 & 2900 \\
\hline 15.469 & -0.044 & 32275 \\
\hline 16.947 & -0.043 & 31725 \\
\hline 17.111 & -0.048 & 62407 \\
\hline$\cdots-$ & $\begin{aligned}= & ===== \\
& -0.383\end{aligned}$ & $\begin{array}{r}== \\
\\
608925\end{array}$ \\
\hline
\end{tabular}

Status Codes:

$R$ - Reference peak

S - Internal standard peak

Total Unidentified Counts :

38107 counts

Detected Peaks: 34

Rejected Peaks: 7

Identified Peaks: 13

Amount Standard: 1.000000

Multiplier: 1.000000

Divisor: 1.000000

Baseline offset: -27 microvolts

Noise (used): 200 microvolts - monitored before this run

Manual injection

Print Date: Tue Jul 20 11:58:12 2004

Page 1 of 1 
Method File : C: \STAR\MODULE16\THMACET2.MTH

Sample ID: ponto 3

Injection Date: 20-JUL-4 11:20 AM

Operator : PASCHOALATO, C

Workstation:

Instrument : star $3600 \mathrm{cx}$

Channel

: $\mathrm{B}=\mathrm{ECD}$
Calculation Date: 20-JUL-4 11:53 AM

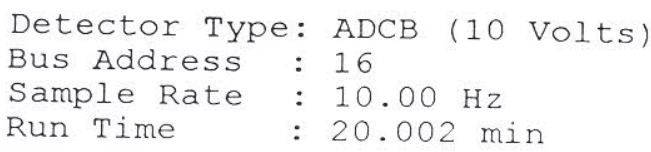

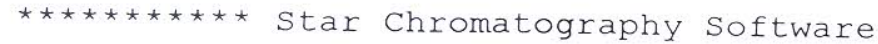

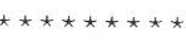

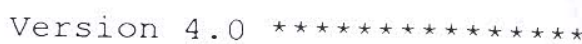

Chart Speed $=$

start Time $=$ $1.04 \mathrm{~cm} / \mathrm{min}$

Attenuation $=150$

End Time

$=20.002 \mathrm{~min}$

Zero Offset $=5 \%$

$\mathrm{Min} / \mathrm{TiCk}=1.00$

Volts

\section{cloroformio}

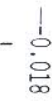

$\stackrel{\circ}{i}$

$<W I=2.0$

$<W I=4.0$

PI

4.259

tricloroacet dicloroaceto bromodicloro* 1,1-diclorop

\section{cloropicrina*-} 1,1,1-triclo bromocloroac dibromoaceto* 
: Subprodutos organo-halogenados metodo 551 EPA

ile : C: \STAR \MODULE16\THMOZ009.RUN

d File : C: \STAR \MODULE16\THMACET2.MTH

ID : ponto 4

tion Date: 20-JUL-4 11:49 AM Calculation Date: 20-JUL-4 12:15 PM

$\begin{array}{lll}\text { tor : PASCHOALATO, C } & \begin{array}{l}\text { Detector Type: ADCB (10 Volts) } \\ \text { Bus Address : }\end{array} \\ \text { ument : star } 3600 \mathrm{Cx} & \text { Sample Rate }: 10.00 \mathrm{~Hz} \\ \text { el } & \text { Run Time } & : 20.002 \mathrm{~min}\end{array}$

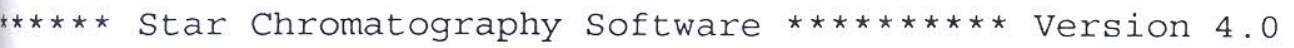

ode : Calibration

Measurement: Peak Area

lation Type: Internal standard

: 4

\begin{tabular}{|c|c|c|c|c|c|c|}
\hline & Ret. & Time & & \multicolumn{3}{|c|}{ Width } \\
\hline Peak & Time & Offset & Area & Sep. & $1 / 2$ & status \\
\hline Name & $(\min )$ & (min) & (counts) & Code & $(\mathrm{sec})$ & coqes \\
\hline------- & ------ & ------ & $-\cdots-\cdots-$ & ---- & ----- & $-\cdots--$ \\
\hline & 4.272 & 0.014 & 12685 & $\mathrm{BB}$ & 6.2 & SR \\
\hline roformio & 6.753 & -0.005 & 23574 & VB & 7.2 & \\
\hline cloroacet & 8.899 & -0.018 & 95898 & $\mathrm{BP}$ & 7.4 & \\
\hline oroaceto & 9.373 & -0.017 & 54652 & PP & 6.2 & \\
\hline odicloro & 9.895 & -0.023 & 110653 & PV & 6.7 & \\
\hline ral hidra & 10.252 & -0.023 & 117739 & VV & 7.7 & \\
\hline -diclorop & 10.833 & -0.026 & 33566 & VV & 7.9 & \\
\hline ropicrina & 13.081 & -0.037 & 125492 & BV & 7.1 & \\
\hline omocloro & 13.451 & -0.034 & 95622 & VB & 6.9 & \\
\hline 1 -triclo & 14.422 & -0.039 & 3962 & $\mathrm{BB}$ & 7.1 & \\
\hline nocloroac & 15.476 & -0.044 & 45781 & BV & 8.0 & \\
\hline omoaceto & 16.951 & -0.052 & 42477 & BV & 6.4 & \\
\hline loformio & 17.124 & -0.044 & 73686 & VB & 7.4 & \\
\hline $\begin{array}{l}--\cdots-\cdots \\
\text { ls. }\end{array}$ & ------ & $\begin{array}{r}===== \\
-0.348\end{array}$ & $\begin{array}{r}====== \\
835787\end{array}$ & -- & ----- & - \\
\hline
\end{tabular}

Codes :

ference peak

ternal standard peak

unidentified Counts :

35513 counts

ed Peaks: 34

Rejected Peaks: 7

Identified Peaks: 13

Standard: 1.000000

Multiplier: 1.000000.

Divisor: 1.000000

ne offset: -21 microvolts

(used): 210 microvolts - monitored before this run

injection

ate: Tue Jul $2012: 20: 472004$

Page 1 of 1 
Title : Subprodutos organo-halogenados metodo $551 \mathrm{EPA}$

Run File : C: \STAR\MODULE16\THMOZ009.RUN

Method File : C: \STAR\MODULE16\THMACET2.MTH

Sample ID: ponto 4

Injection Date: 20-JUL-4 11:49 AM Calculation Date: 20-JUL-4 12:15 PM

$\begin{array}{ll}\text { Operator : PASCHOALATO, C } & \text { Detector Type: ADCB (10 Volts) } \\ \text { Workstation: } & \text { Bus Address : } 16 \\ \text { Instrument : star } 3600 \mathrm{CX} & \text { Sample Rate }: 10.00 \mathrm{~Hz} \\ \text { Channel }: \mathrm{B}=\mathrm{ECD} & \text { Run Time }: 20.002 \mathrm{~min}\end{array}$

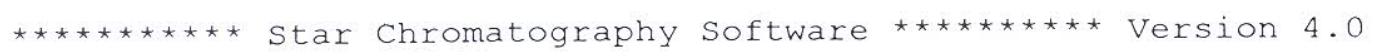

Chart speed $=\quad 1.04 \mathrm{~cm} / \mathrm{min} \quad$ Attenuation $=150$

start Time =

$0.000 \mathrm{~min}$

End Time

Zero Offset $=5 \%$

volts

$-$

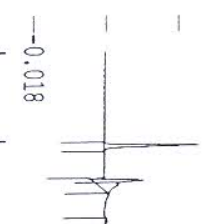

$\underset{\substack{\infty \\ \omega}}{b}$

$<W I=2.0$

$<\mathrm{WI}=4.0$

PI

$-$

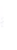

$\Longrightarrow$

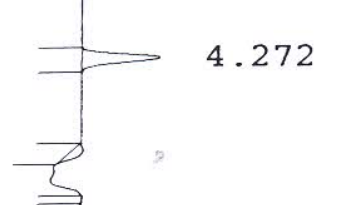

cloroformio

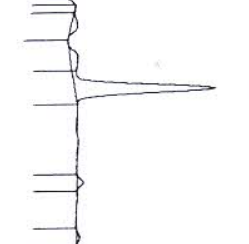

6.753

tricloroacet

dicloroaceto

bromodicloro*

1,1-diclorop

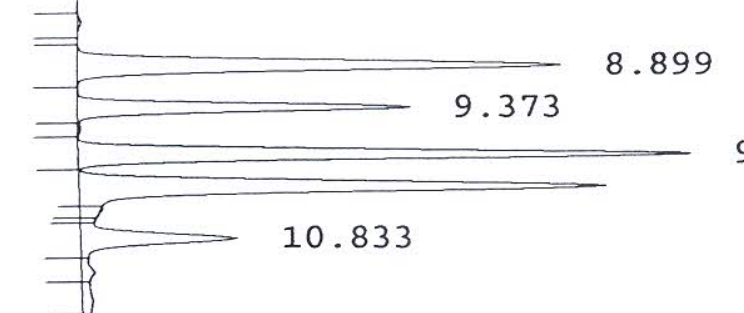

9.895

$<W I=8.0$

cloropicrina* -

$1,1,1-$ triclo

bromocloroac

dibromoaceto*

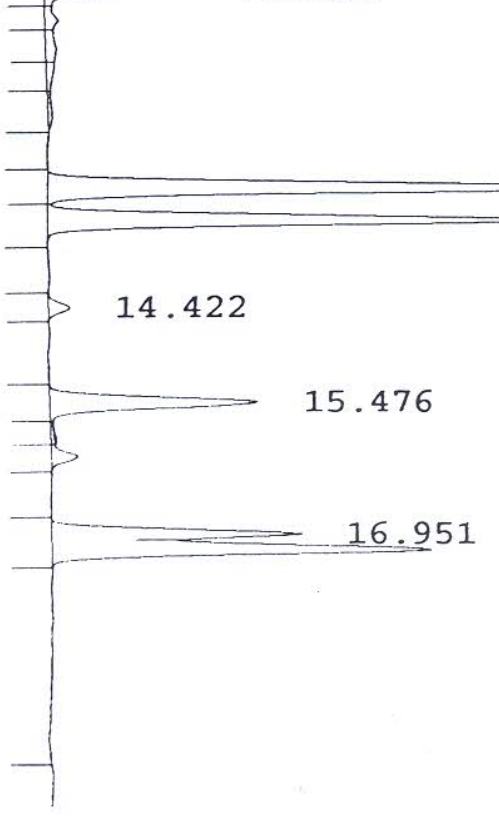

10.252

13.081

13.451 
Title Subprodutos organo-halogenados metodo 551 EPA

Run File : C: \STAR\MODULE16\THMOZ010.RUN

Method File : C: \STAR\MODULE16\THMACET2.MTH

Sample ID: ponto 5

Injection Date: 20-JUL-4 12:18 PM

Operator : PASCHOALATO, C

Workstation:

Instrument : star $3600 \mathrm{Cx}$

Channel : $\mathrm{B}=\mathrm{ECD}$
Calculation Date: 20-JUL-4 1:54 PM

Detector Type: ADCB (10 Volts)

Bus Address : 16

Sample Rate: $10.00 \mathrm{~Hz}$

Run Time : $20.002 \mathrm{~min}$

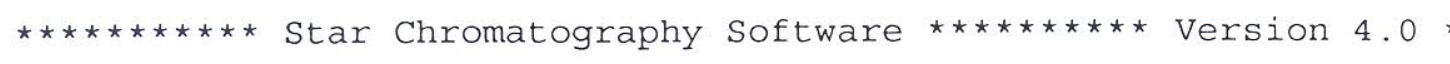

Run Mode

Peak Measurement:

Calculation Type: Internal Standard

Level

\begin{tabular}{rl} 
Peak & \multicolumn{1}{c}{ Peak } \\
No. & Name \\
-- &..$--\ldots$ \\
1 & PI \\
2 & Cloroformio \\
3 & tricloroacet \\
4 & dicloroaceto \\
5 & bromodicloro \\
6 & cloral hidra \\
7 & $1,1-$ diclorop \\
8 & cloropicrina \\
9 & dibromocloro \\
10 & $1,1,1-t r i c l o$ \\
11 & bromocloroac \\
12 & dibromoaceto \\
13 & bromoformio \\
--- & - - - - - - -
\end{tabular}

Totals:

\begin{tabular}{|c|c|c|}
\hline Ret. & Time & \\
\hline $\begin{array}{l}\text { Time } \\
\text { (min) }\end{array}$ & $\begin{array}{l}\text { Offset } \\
\text { (min) }\end{array}$ & $\begin{array}{c}\text { Area } \\
\text { (counts) }\end{array}$ \\
\hline$---\cdot-$ & $-\cdots-\cdots$ & $----\cdot-\cdot$ \\
\hline 4.268 & -0.003 & 16153 \\
\hline 6.747 & -0.000 & 29560 \\
\hline 8.894 & 0.004 & 136555 \\
\hline 9.363 & -0.002 & 75876 \\
\hline 9.885 & -0.001 & 155880 \\
\hline 10.243 & -0.000 & 148548 \\
\hline 10.823 & -0.001 & 46863 \\
\hline 13.072 & 0.002 & 185243 \\
\hline 13.437 & -0.003 & 136713 \\
\hline 14.410 & 0.000 & 5743 \\
\hline 15.468 & 0.006 & 63135 \\
\hline 16.942 & 0.005 & 61397 \\
\hline 17.111 & 0.001 & 93049 \\
\hline-- & $\begin{aligned} &=== \\
& 0.008\end{aligned}$ & $\begin{array}{r}===== \\
1154715\end{array}$ \\
\hline
\end{tabular}

\begin{tabular}{lrl}
\multicolumn{3}{c}{ Width } \\
Sep. & $1 / 2$ & Status \\
Code & $($ sec $)$ & Codes \\
--- &.-- &.--- \\
BV & 7.8 & SR \\
VB & 7.0 & \\
BP & 7.3 & \\
PP & 5.9 & \\
PV & 6.4 & \\
VV & 7.5 & \\
VV & 7.9 & \\
VV & 6.9 & \\
VP & 6.6 & \\
TF & 0.0 & \\
VV & 7.9 & \\
BV & 7.6 & \\
VB & 7.5 & \\
--- & ---- & $\ldots$ \\
&
\end{tabular}

55018 counts

Rejected Peaks: 18

Identified Peaks: 13

Divisor: 1.000000

Multiplier: 1.000000

Status Codes:

$R$ - Reference peak

S - Internal standard peak

Total Unidentified Counts :

Detected Peaks: 51

Amount Standard: 1.000000

Baseline offset: -8 microvolts

Noise (used): 170 microvolts - monitored before this run

Manual injection

Print Date: Tue Jul 20 14:10:26 2004

Page 1 of 1 
Title

Run File

Method File

Sample ID

: Subprodutos organo-halogenados metodo 551 EPA

: C: \STAR\MODULE16\THMOZ010.RUN

: C: \STAR\MODULE16\THMACET2.MTH

: ponto 5

Injection Date: 20-JUL-4 12:18 PM

Calculation Date: 20-JUL-4 1:54 PM
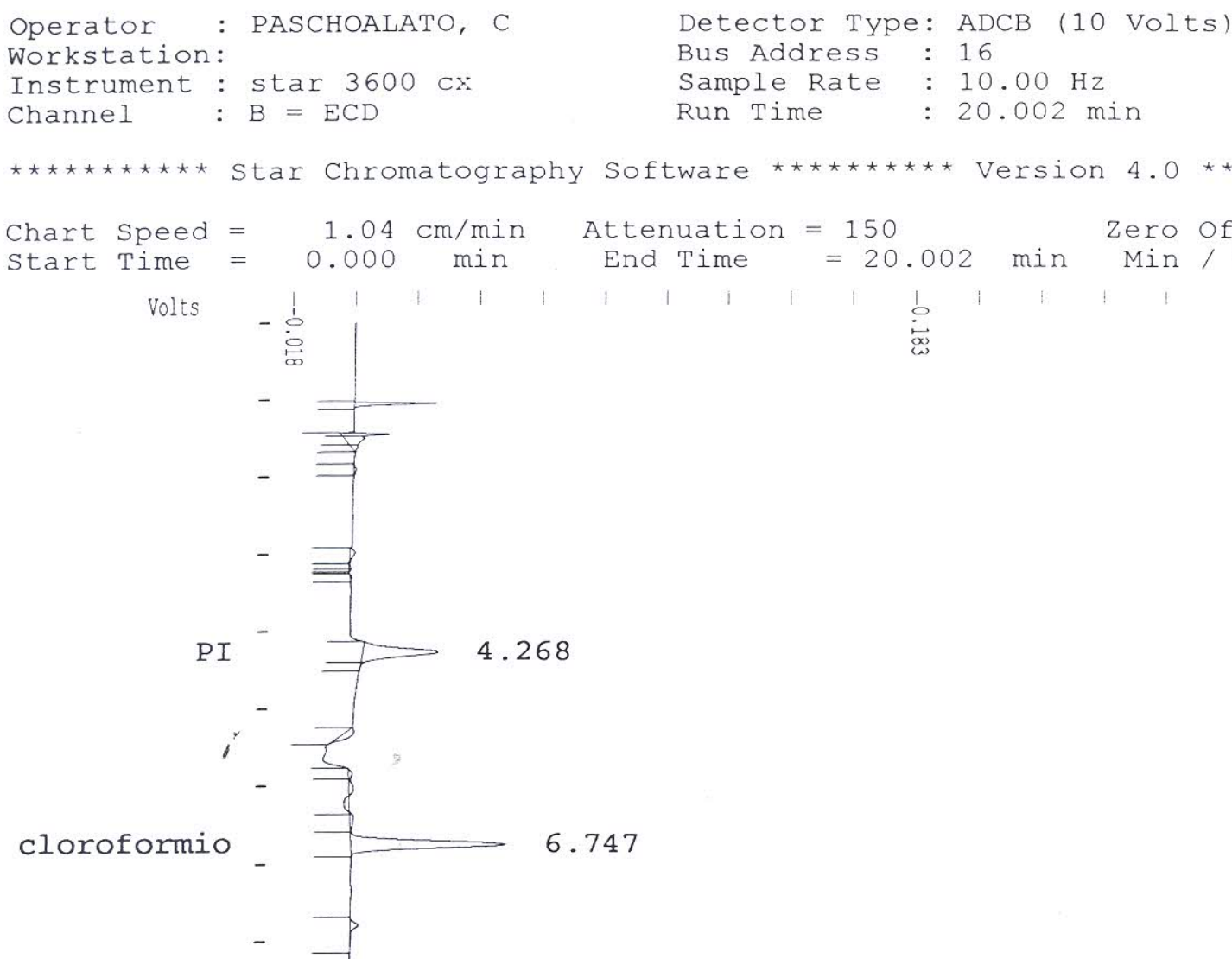

47

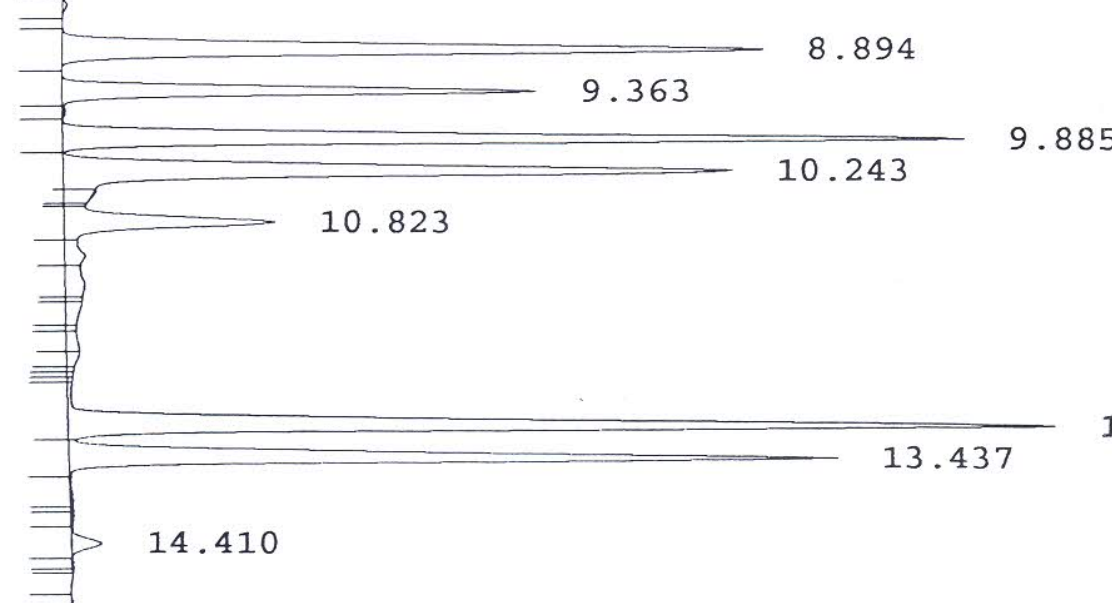

13.072

15.468 
Title : Subprodutos organo-halogenados metodo 551 EPA

Run File

C:\STAR \MODULE16\THMOZ011.RUN

Method File: C: \STAR\MODULE16\THMACET2.MTH

Sample ID: ponto 6

Injection Date: 20-JUL-4 1:35 PM

Calculation Date: 20-JUL-4 1:55 PM

Operator : PASCHOALATO, C

Workstation:

Instrument : star $3600 \mathrm{cx}$

Channel : $\mathrm{B}=\mathrm{ECD}$

Detector Type: ADCB (10 Volts)

Bus Address : 16

Sample Rate : $10.00 \mathrm{~Hz}$

Run Time : $20.002 \mathrm{~min}$

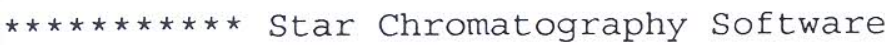

Run Mode

: Calibration

Peak Measurement: Peak Area

Calculation Type: Internal standard

Level

6

\begin{tabular}{|c|c|c|c|c|c|c|c|}
\hline & & Ret & Time & & & Width & \\
\hline eak & Peak & Time & Offset & Area & sep. & $1 / 2$ & Status \\
\hline No. & Name & $(\min )$ & $(\min )$ & (counts) & Code & (sec) & Codes \\
\hline-- & $\ldots \ldots \ldots \ldots$ & $-\cdots-\cdots$ & $\ldots-\ldots$ & $---\cdot---$ & ---- & ---- & --- \\
\hline 1 & PI & 4.252 & -0.016 & 13067 & $\mathrm{BB}$ & 5.9 & SR \\
\hline 2 & cloroformio & 6.726 & 0.005 & 30038 & $\mathrm{BB}$ & 6.1 & \\
\hline 3 & tricloroacet & 8.870 & 0.010 & 141104 & $\mathrm{BB}$ & 7.2 & \\
\hline 4 & dicloroaceto & 9.347 & 0.020 & 80260 & $\mathrm{BP}$ & 6.0 & \\
\hline 5 & bromodicloro & 9.868 & 0.021 & 163810 & PV & 6.5 & \\
\hline 6 & cloral hidra & 10.230 & 0.026 & 139927 & $\mathrm{VV}$ & 7.7 & \\
\hline 7 & 1,1 -diclorop & 10.807 & 0.026 & 50433 & VV & 8.3 & \\
\hline 8 & cloropicrina & 13.065 & 0.043 & 195026 & VV & 7.1 & \\
\hline 9 & dibromocloro & 13.428 & 0.042 & 146203 & VP & 7.0 & \\
\hline 10 & $1,1,1$-triclo & 14.401 & 0.046 & 6481 & $\mathrm{TF}$ & 0.0 & \\
\hline 11 & bromocloroac & 15.461 & 0.051 & 60559 & VV & 8.3 & \\
\hline 12 & dibromoaceto & 16.933 & 0.057 & 64334 & $\mathrm{BV}$ & 7.6 & \\
\hline 13 & bromoformio & 17.103 & 0.057 & 89722 & VB & 7.5 & \\
\hline & Totals: & $\ldots-\cdots$ & $\begin{aligned}== & === \\
& 0.388\end{aligned}$ & $\begin{array}{r}====== \\
1180964\end{array}$ & $\cdots$ & -- & - \\
\hline
\end{tabular}

Status Codes:

$R$ - Reference peak

S - Internal standard peak

Total Unidentified Counts :

82616 counts

Detected Peaks: 41

Rejected Peaks: 6

Identified Peaks: 13

Amount Standard: 1.000000

Multiplier: 1.000000

Divisor: 1.000000

Baseline offset: 14 microvolts

Noise (used): 200 microVolts - monitored before this run

Manual injection

Print Date: Tue Jul 20 14:12:39 2004

Page 1 of 1 
Title : Subprodutos organo-halogenados metodo 551 EPA

Run File : C:\STAR\MODULE16\THMOZ015.RUN

Method File: C: \STAR\MODULE16\THMACET2.MTH

Sample ID : ponto 3

Injection Date: 20-JUL-4 4:12 PM

Calculation Date: 3-JAN-80 11:35 AM

Operator : PASCHOALATO, C

Workstation:

Instrument : star $3600 \mathrm{cx}$

Channel: $\mathrm{B}=\mathrm{ECD}$

Detector Type: $\mathrm{ADCB}$ (10 Volts)
Bus Address $: 16$
Sample Rate $: 10.00 \mathrm{~Hz}$
Run Time

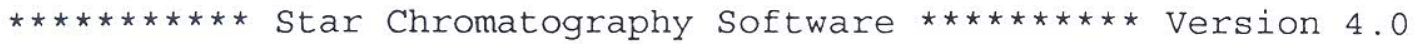

Run Mode : Verification

Peak Measurement: Peak Area

Calculation Type: Internal Standard

Level

Tolerance

$: 3$

$: 100.0 \%$

\begin{tabular}{|c|c|c|c|c|c|c|c|c|}
\hline $\begin{array}{l}\text { Peak } \\
\text { No. }\end{array}$ & $\begin{array}{l}\text { Peak } \\
\text { Name }\end{array}$ & $\begin{array}{l}\text { Expected } \\
\text { Result } \\
(u g / L)\end{array}$ & $\begin{array}{c}\text { Calculated } \\
\text { Result } \\
(u g / L)\end{array}$ & $\begin{array}{c}\text { Dev. } \\
\frac{\circ}{0}\end{array}$ & $\begin{array}{l}\text { Ret. } \\
\text { Time } \\
\text { (min) }\end{array}$ & $\begin{array}{l}\text { Time } \\
\text { Offset } \\
\text { (min) }\end{array}$ & $\begin{array}{c}\text { Area } \\
\text { (counts) }\end{array}$ & $\begin{array}{l}\text { Status } \\
\text { Codes }\end{array}$ \\
\hline-- & $-------\cdot-\cdot--$ & ---- & $-\cdots--$ & $\cdots--$ & ----- & $\cdots---$ &.-----1 & $\overline{R S}$ \\
\hline $\begin{array}{l}1 \\
2\end{array}$ & $\begin{array}{l}\text { PI } \\
\text { cloroforn }\end{array}$ & $\begin{array}{l}\text { N/A } \\
0.00\end{array}$ & INT STD & $\begin{array}{r}0.0 \\
10.9\end{array}$ & 4.265 & 0.000 & 13876 & RS \\
\hline 3 & tricloroacet & 30.00 & $\begin{array}{l}66.54 \\
32.05\end{array}$ & $\begin{array}{r}10.9 \\
6.8\end{array}$ & $\begin{array}{l}6.142 \\
8.889\end{array}$ & $\begin{array}{r}0.000 \\
-0.000\end{array}$ & $\begin{array}{l}19862 \\
80309\end{array}$ & \\
\hline 4 & diclorroaceto & 30.00 & 32.63 & 8.8 & 9.363 & 0.000 & 46469 & \\
\hline 5 & bromodicloro & 60.00 & 64.50 & 7.5 & 9.885 & 0.000 & 94012 & \\
\hline 6 & cloral hidra & 80.00 & 89.38 & 11.7 & 10.245 & -0.000 & 98723 & \\
\hline 7 & 1,1 -diclorop & 30.00 & 30.87 & 2.9 & 10.825 & -0.000 & 26842 & \\
\hline 8 & cloropicrina & 30.00 & 31.12 & 3.7 & 13.075 & -0.000 & 104954 & \\
\hline 9 & dibromocloro & 60.00 & 62.79 & 4.7 & 13.439 & 0.000 & 79723 & \\
\hline 10 & $1,1,1$-triclo & 30.00 & 29.73 & 0.9 & 14.413 & -0.000 & 3151 & \\
\hline 11 & bromocloroac & 30.00 & 32.68 & 8.9 & 15.473 & 0.000 & 37011 & \\
\hline 12 & dibromoaceto & 30.00 & 32.02 & 6.7 & 16.944 & 0.000 & 35644 & \\
\hline 13 & bromoformio & 100.00 & 101.31 & 1.3 & 17.110 & -0.000 & 67957 & \\
\hline-- & $\begin{array}{l}\text { Totals: } \\
\text { Tots }\end{array}$ & - & $\begin{array}{r}======== \\
605.62\end{array}$ & $\cdots$ & --- & $\begin{aligned}== & === \\
& 0.000\end{aligned}$ & $==\begin{array}{r}==== \\
708533\end{array}$ & \\
\hline
\end{tabular}

Status Codes:

$R$ - Reference peak

$S$ - Internal Standard peak

Total Unidentified Counts :

18036 counts

Detected Peaks: 36

Amount Standard: 1.000000

Baseline Offset: -12 microvolts

Noise (used): 180 microvolts - monitored before this run

Manual injection
Rejected Peaks: 17

Multiplier: 1.000000
Identified Peaks: 13

Divisor: 1.000000 
Method File : C: \STAR \MODULE16\THMACET2.MTH

Sample ID: ponto 3

Injection Date: 20-JUL-4 4:12 PM

Operator : PASCHOALATO, C

Workstation:

Instrument : star $3600 \mathrm{Cx}$

Channel : $\mathrm{B}=\mathrm{ECD}$
Calculation Date: 3-JAN-80 11:35 AM

Detector Type: ADCB (10 Volts)

Bus Address : 16

Sample Rate: $10.00 \mathrm{~Hz}$

Run Time : $20.002 \mathrm{~min}$

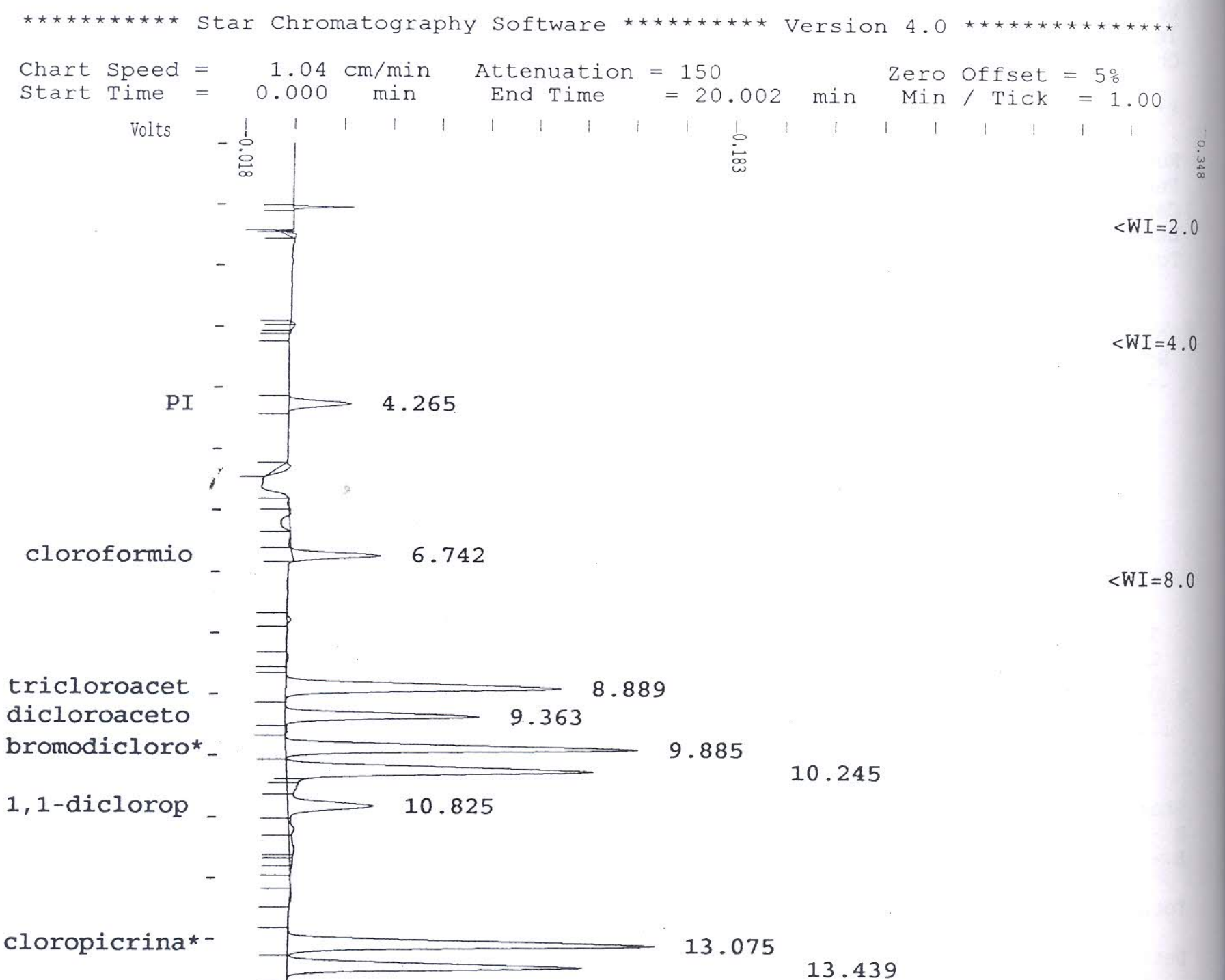




\title{
APÊNCICE B
}

\author{
B-01 Resumo da curva de calibração EPA 552 (HAAO3) \\ B-02 Cromatograma branco calibração \\ B-03 Cromatograma ponto 1 \\ B-04 Cromatograma ponto 2 \\ B-05 Cromatograma ponto 3 \\ B-06 Cromatograma ponto 4 \\ B-07 Cromatograma ponto 6 \\ B-08 Cromatograma ponto 7 \\ B-09 Cromatograma de verificação - ponto 2
}


on Curves Report - Page 3

starlmodule16lhaao3.mth

ADC Board, Address: 16, Channel ID: B

Standard Analysis

Fact. RSD: $33.03 \%$

Type: Linear

Force

loef. $\left(R^{2}\right): 0.972850$

$4986 \mathrm{e}-002 \mathrm{x}$
TBAA

Internal Standard Analysis

Resp. Fact. RSD: $4.321 \%$

Curve Type: Linear

Origin: Force

Corr. Coef.(R $\left.{ }^{2}\right): 0.997043$

$y=+5.3238 e-002 x$

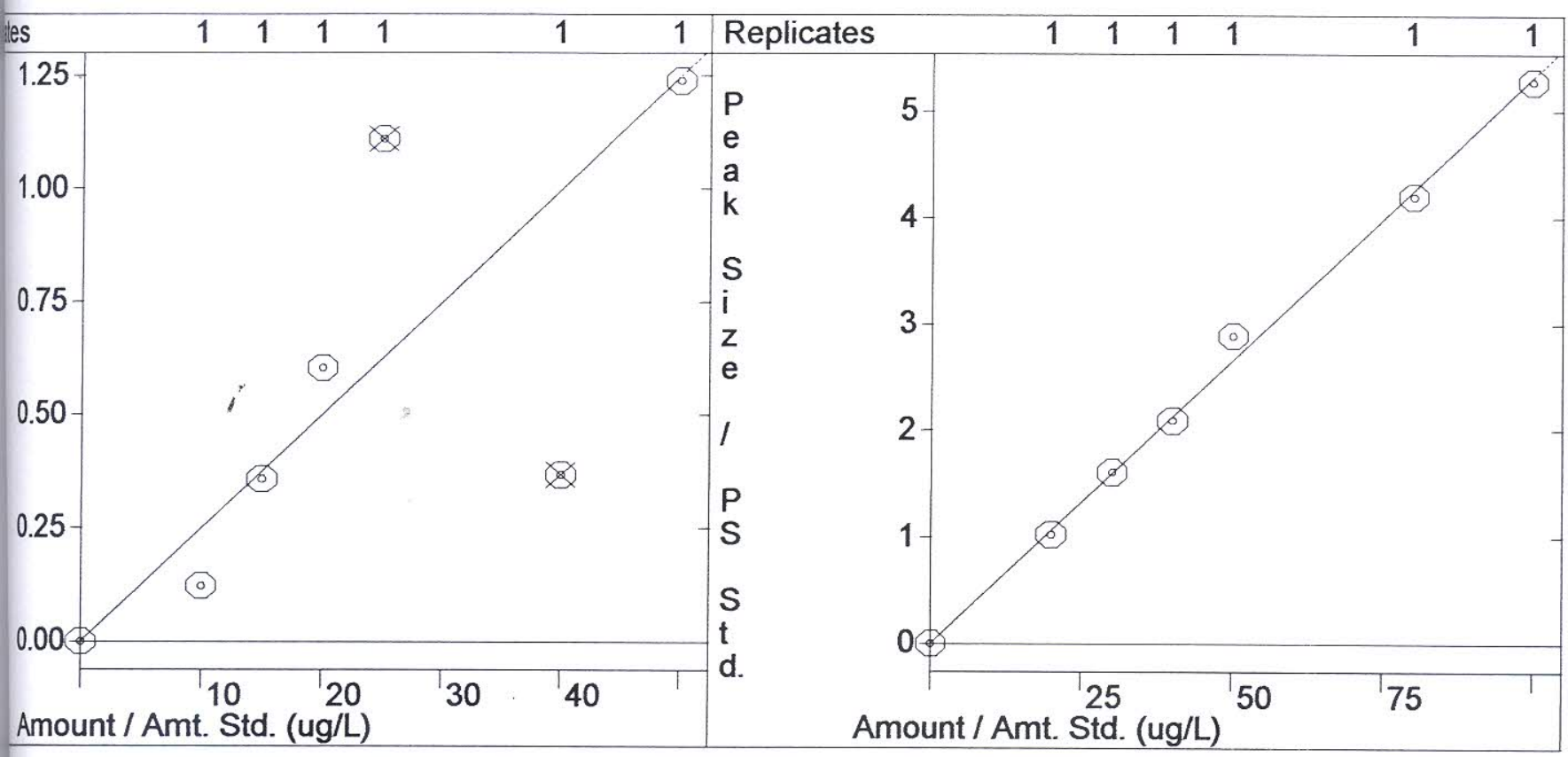

dfor Internal Standard Analysis

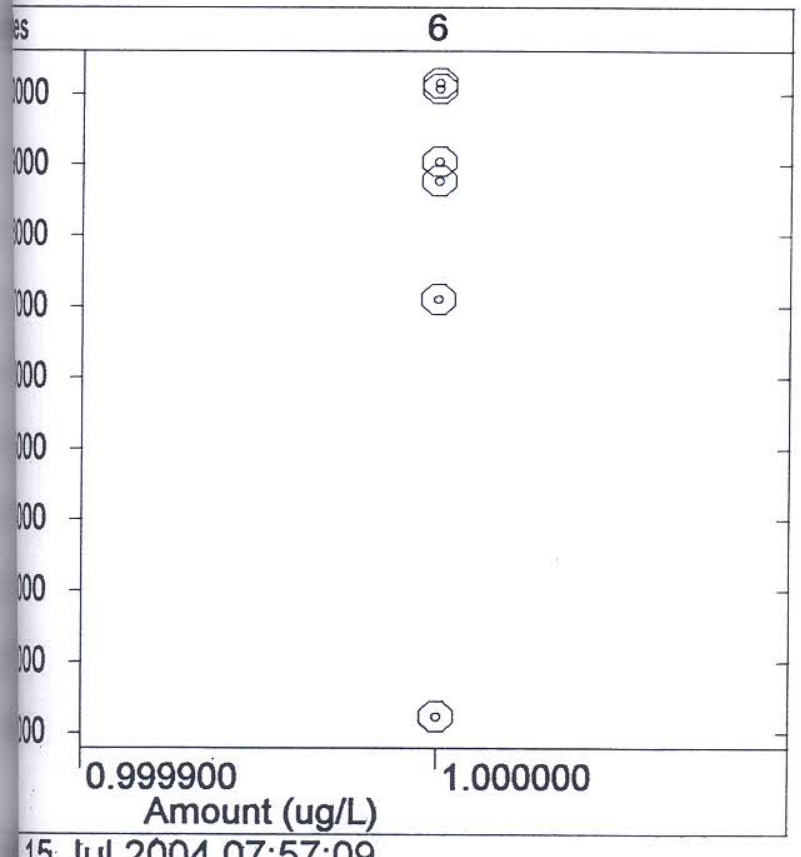

15. Jul 2004 07:57:09 


\section{MCAA}

Internal Standard Analysis

Resp. Fact. RSD: $16.69 \%$

Curve Type: Linear

Origin: Force

Corr. Coef. $\left(\mathrm{R}^{2}\right): 0.954806$

$y=+9.8747 e-002 x$
MBAA

Internal Standard Analysis

Resp. Fact. RSD: $12.68 \%$

Curve Type: Linear

Origin: Force

Corr. Coef. $\left(R^{2}\right): 0.979227$

$y=+9.1799 e-002 x$

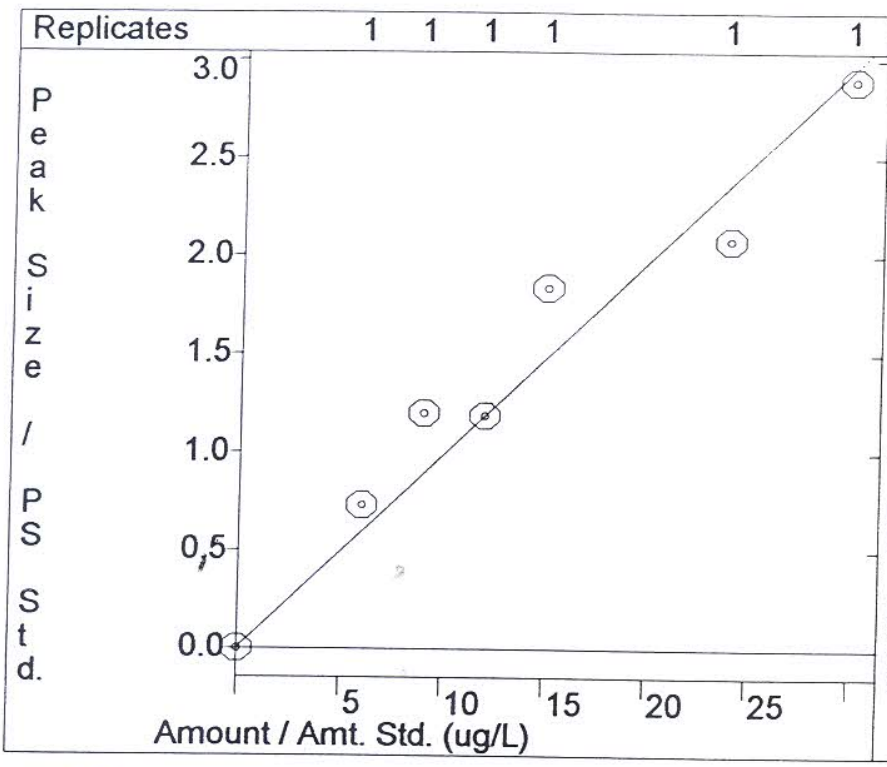

\section{DCAA}

Internal Standard Analysis

Resp. Fact. RSD: $8.818 \%$

Curve Type: Linear

Origin: Force

Corr. Coef.(R $\left.{ }^{2}\right)$ : 0.986474

$y=+9.1208 e-002 x$

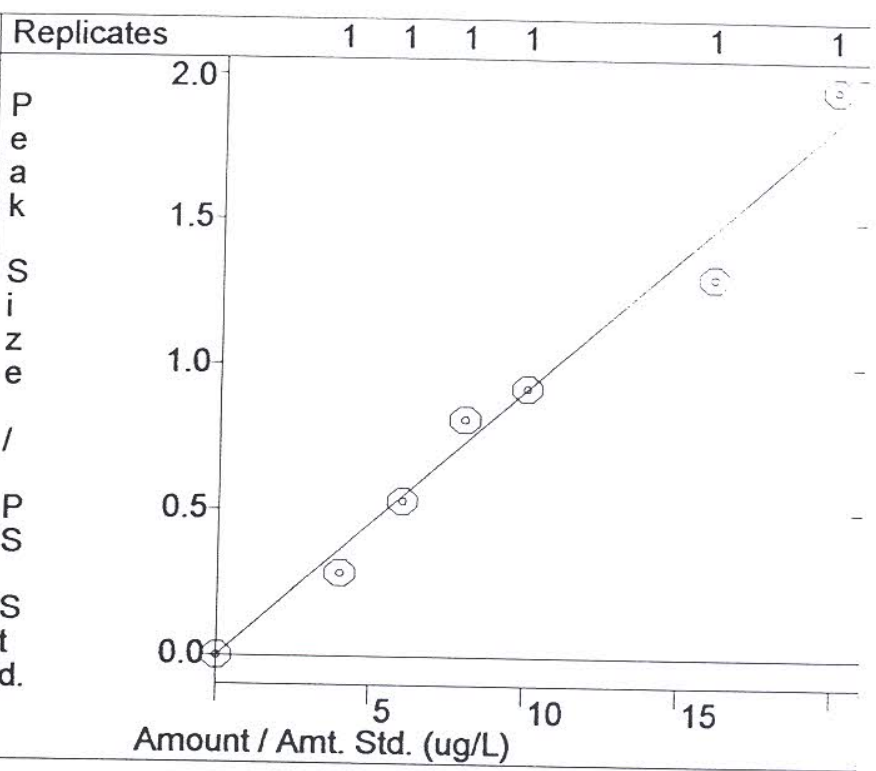

SURR

Internal Standard Analysis

Resp. Fact. RSD: $35.94 \%$

Curve Type: Linear

Origin: Force

Corr. Coef. $\left(R^{2}\right): 0.746244$

$y=+4.7765 e-001 x$

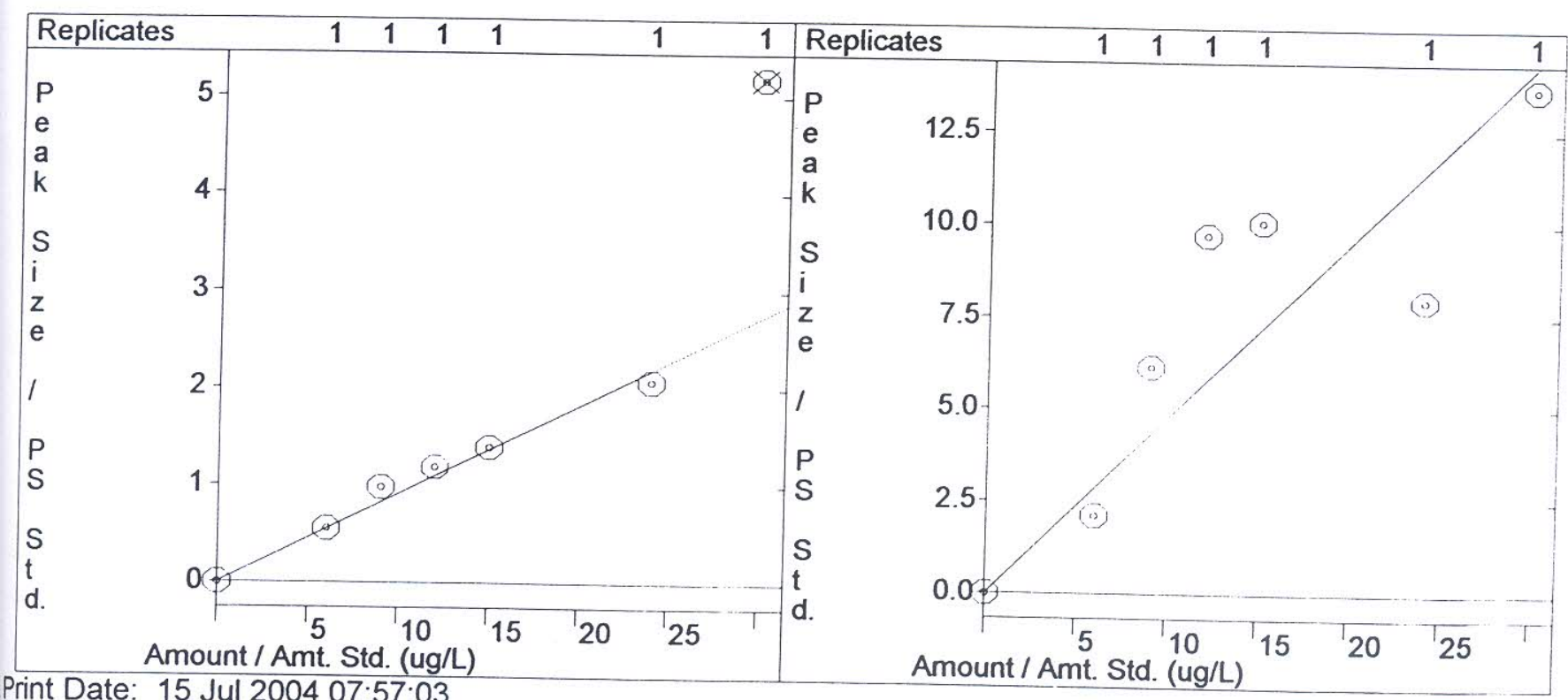


TCAA

Internal Standard Analysis

Resp. Fact. RSD: $22.84 \%$

Curve Type: Linear

Origin: Force

Corr. Coef. $\left(R^{2}\right): 0.954240$

$y=+2.8097 e-001 x$
BCAA

Internal Standard Analysis

Resp. Fact. RSD: $17.50 \%$

Curve Type: Linear

Origin: Force

Corr. Coef. $\left(R^{2}\right): 0.984304$

$y=+3.7770 e-001 x$

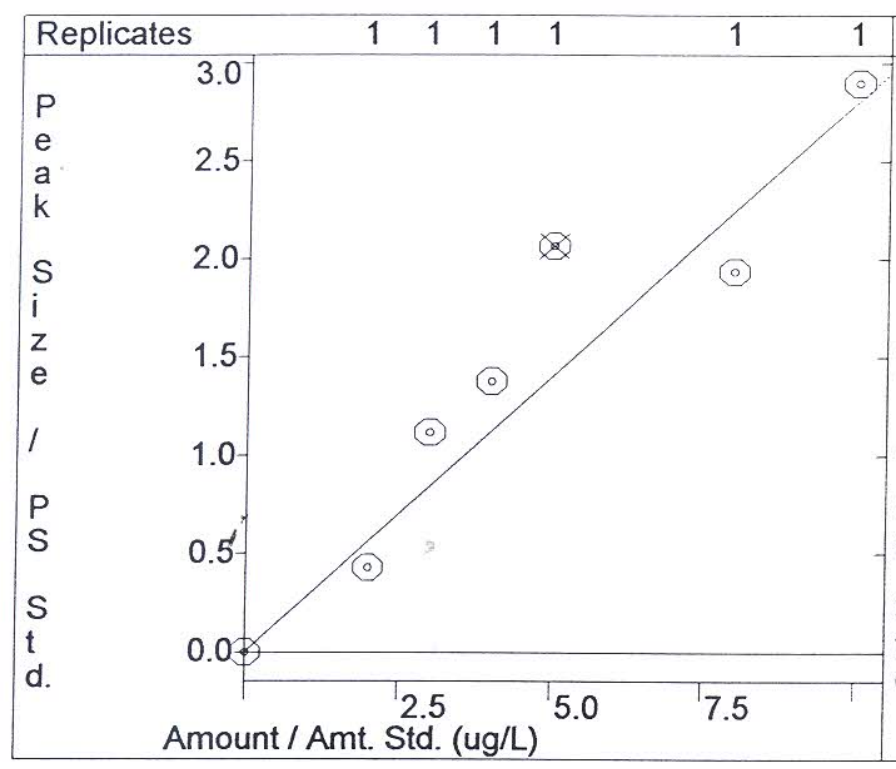

\section{BDCAA}

Internal Standard Analysis

Resp. Fact. RSD: $11.94 \%$

Curve Type: Linear

Origin: Force

Corr. Coef.( $\left.R^{2}\right): 0.973603$

$y=+2.2150 e-001 x$

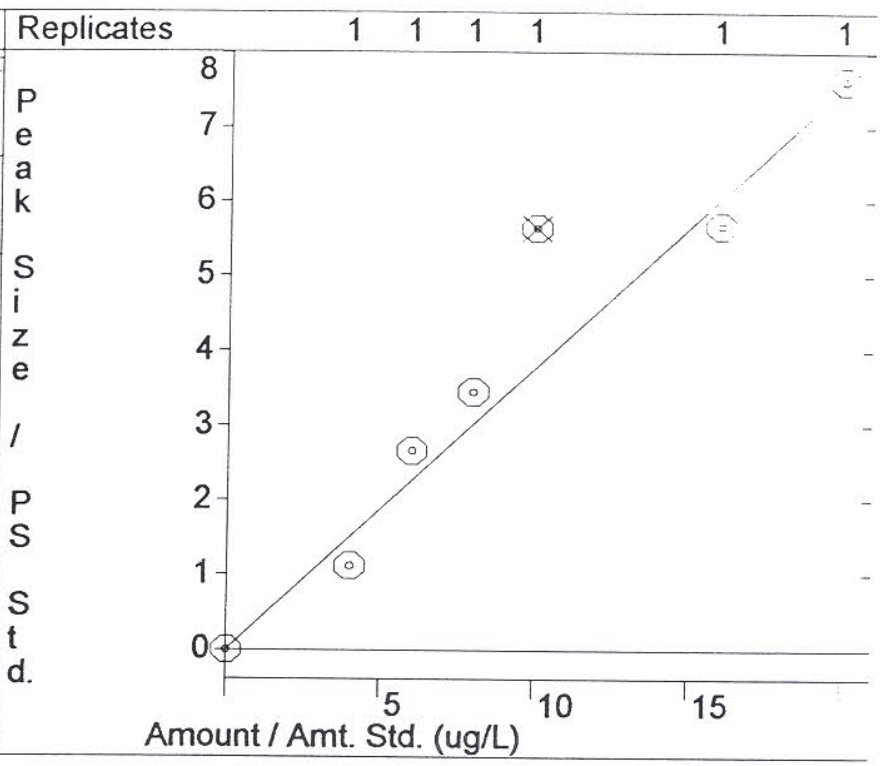

DBAA

Internal Standard Analysis

Resp. Fact. RSD: 9.366\%

Curve Type: Linear

Origin: Force

Corr. Coef. $\left(\mathrm{R}^{2}\right)$ : 0.987957

$y=+4.5720 e-001 x$

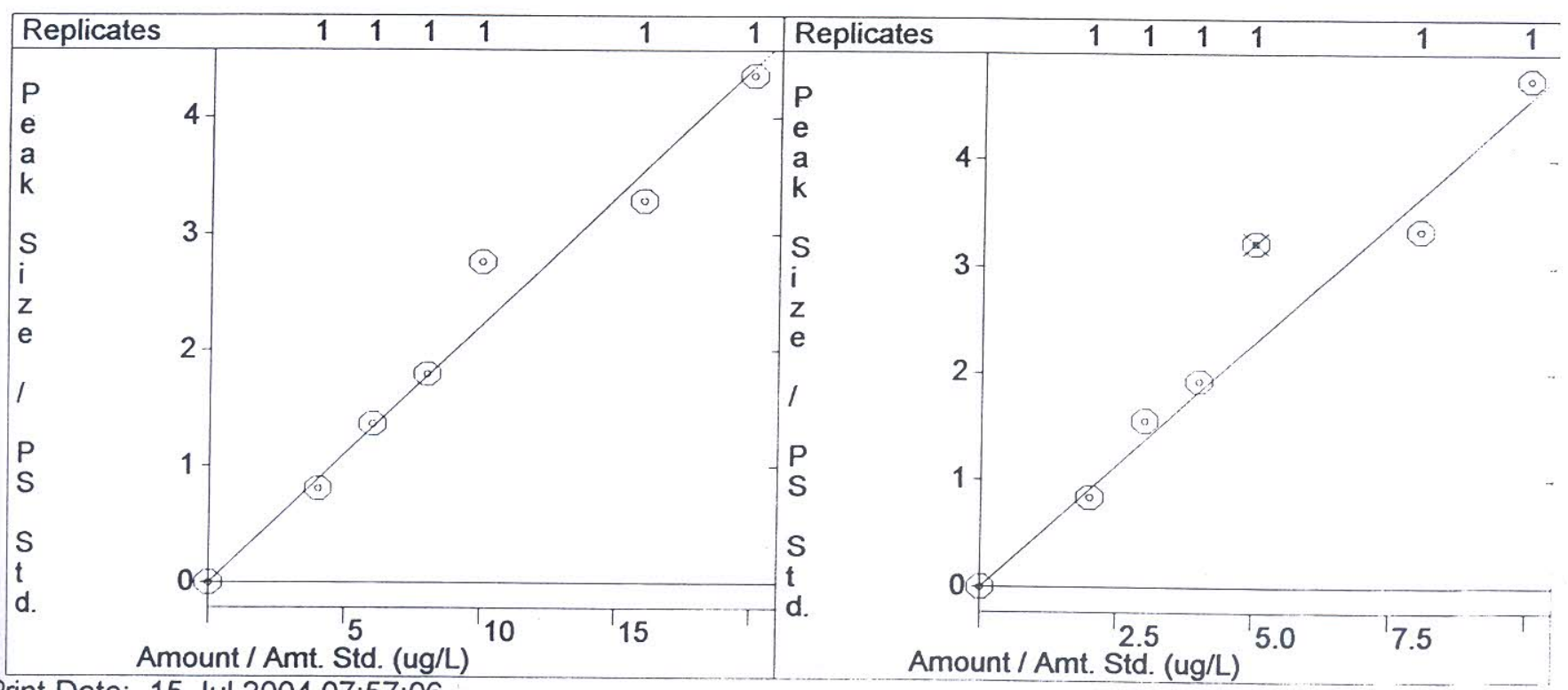

Print Date: 15 Jul 2004 07:57:06 
Calibration Curves Report - Page 3

File: c:Istarlmodule16lhaao3.mth

Detector: ADC Board, Address: 16, Channel ID: B

CDBAA

Internal Standard Analysis

Resp. Fact. RSD: $33.03 \%$

Curve Type: Linear

Origin: Force

Corr. Coef. $\left(\mathrm{R}^{2}\right): 0.972850$

$y=+2.4986 e-002 x$
TBAA

Internal Standard Analysis

Resp. Fact. RSD: $4.321 \%$

Curve Type: Linear

Origin: Force

Corr. Coef. $\left(R^{2}\right): 0.997043$

$y=+5.3238 e-002 x$

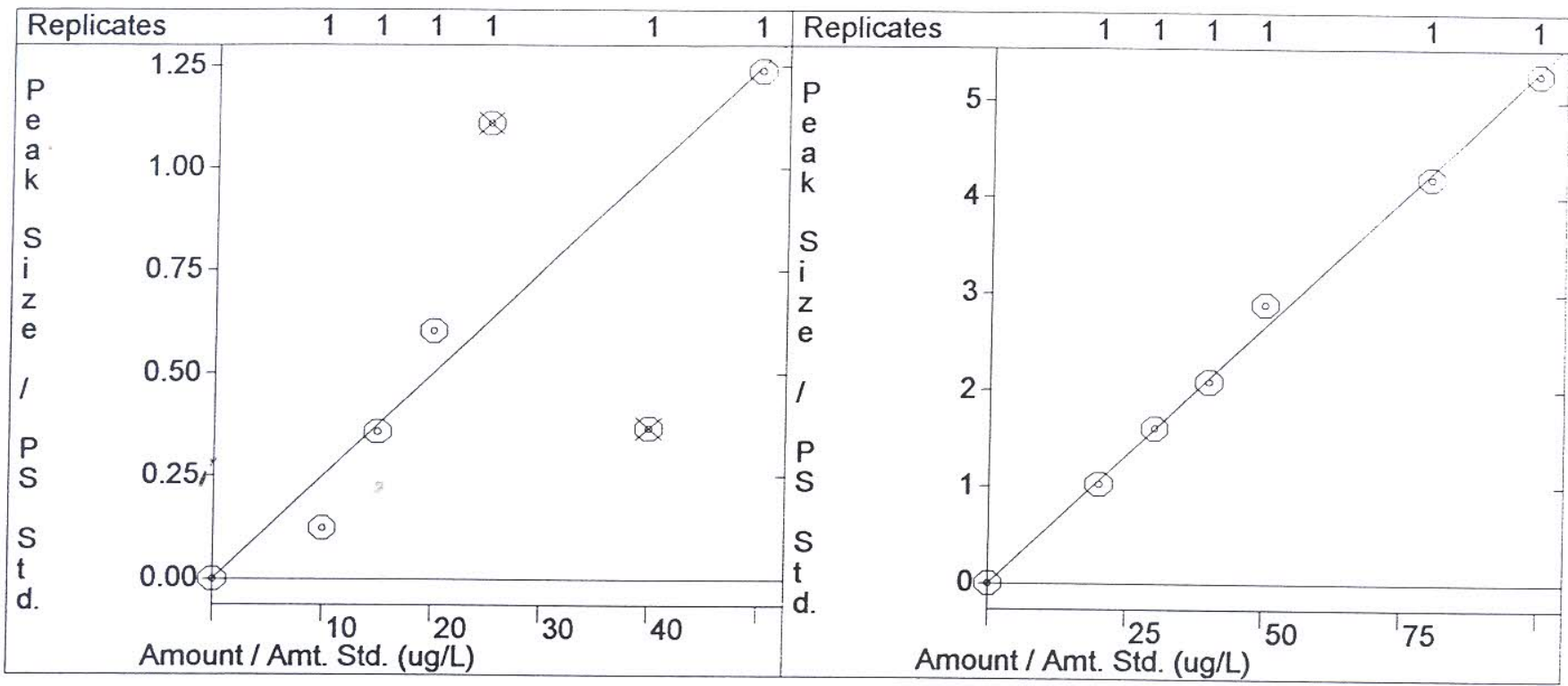

PI

Standard for Internal Standard Analysis

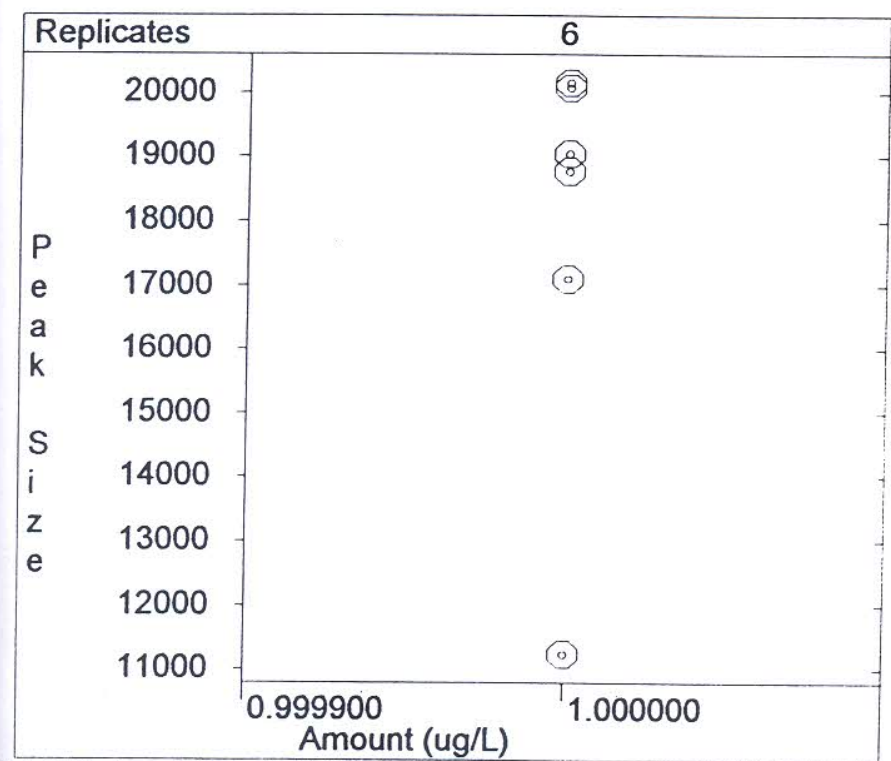

Print Date: 15 Jul 2004 07:57:09 
Title : Subprodutos organo-halogenados metodo 552 EPA

Run File : C: \STAR \MODULE16\HAAOZ027.RUN

Method File : C: \STAR \MODULE16\HAAO3.MTH

Sample ID : branco curva

Injection Date: 15-JUL-4 2:15 PM Calculation Date: 15-JUL-4 2:39 PM

Operator : PASCHOALATO, C Detector Type: ADCB (10 Volts)

Workstation:

Instrument : star $3600 \mathrm{cx}$

Channel : $\mathrm{B}=\mathrm{ECD}$

Bus Address : 16

Sample Rate : $10.00 \mathrm{~Hz}$

Run Time: $24.002 \mathrm{~min}$

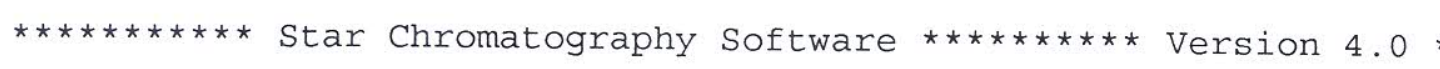

Run Mode : Analysis

Peak Measurement: Peak Area

Calculation Type: Internal Standard

\begin{tabular}{|c|c|c|c|c|c|c|c|c|}
\hline & & & Ret & Time & & \multicolumn{3}{|c|}{ Width } \\
\hline $\begin{array}{l}\text { Peak } \\
\text { No. }\end{array}$ & $\begin{array}{l}\text { Peak } \\
\text { Name }\end{array}$ & $\begin{array}{l}\text { Result } \\
(\mathrm{ug} / \mathrm{L})\end{array}$ & $\begin{array}{l}\text { Time } \\
\text { (min) }\end{array}$ & $\begin{array}{l}\text { Offset } \\
\text { (min) }\end{array}$ & $\begin{array}{c}\text { Area } \\
\text { (counts) }\end{array}$ & $\begin{array}{l}\text { Sep. } \\
\text { Code }\end{array}$ & $\begin{array}{c}1 / 2 \\
(\mathrm{~s} \in \mathrm{c})\end{array}$ & $\begin{array}{l}\text { Status } \\
\text { Codes }\end{array}$ \\
\hline--- & ---------- & --------- & ------ & ------- & $---\cdots--$ & --- & ---- & $\ldots \ldots$ \\
\hline 1 & PI & INT STD & 21.129 & -0.027 & 39743 & VV & 4.8 & SR \\
\hline--- & Totals: & $\begin{array}{r}======= \\
0.00\end{array}$ & ------ & $\begin{aligned}= & ==== \\
& -0.027\end{aligned}$ & $\begin{array}{r}====== \\
39743\end{array}$ & --- & $---\cdot$ & $-\ldots--$ \\
\hline
\end{tabular}

Status Codes:

R - Reference peak

S - Internal Standard peak

Total Unídentified Counts : 425686 counts

Detected Peaks: 158 Rejected Peaks: 146 Identified Peaks: 1

Amount Standard: 1.000000 Multiplier: 1.000000 Divisor: 1.000000

Baseline offset: 5 microvolts

Noise (used): 230 microVolts - monitored before this run

Manual injection

Print Date: Thu Jul 15 17:34:31 2004

Page 1 of 1 
Method File : C: $\backslash$ STAR $\backslash$ MODULE16 $\backslash$ HAAO3.MTH

Sample ID : branco curva

Injection Date: 15-JUL-4 2:15 PM

Operator : PASCHOALATO, C Workstation:

Instrument : star $3600 \mathrm{cx}$

Channel: $\mathrm{B}=\mathrm{ECD}$
Calculation Date: 15-JUL-4 2:39 PM

Detector Type: ADCB (10 Volts)

Bus Address : 16

Sample Rate: $10.00 \mathrm{~Hz}$

Run Time: $24.002 \mathrm{~min}$

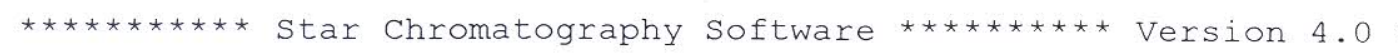

Chart speed $=$

$0.87 \mathrm{~cm} / \mathrm{min}$ Attenuation $=150$

Zero Offset $=5 \%$

start Time $=$

$0.000 \mathrm{~min}$

End Time

$=24.002$

$\min$

$\mathrm{Min} / \mathrm{Tick}=1.00$

Volts

$-\underset{\infty}{\stackrel{b}{\circ}}$

$\underset{\substack{\infty \\ \infty}}{\infty}$

$<W I=8.0$

PI

$<W I=4.0$

$<W I=2.0$

21.129 
Title : Subprodutos organo-halogenados metodo 552 EPA

Run File : C:\STAR \MODULE16\HAAOZ004.RUN

Method File: C: \STAR \MODULE16\HAAO3.MTH

Sample ID : PONTO 1

Injection Date: 13-JUL-4 2:09 PM Calculation Date: 13-JUL-4 2:33 PM

Operator : PASCHOALATO, C

Workstation:

Instrument : star $3600 \mathrm{cx}$

Detector Type: ADCB (10 Volts)

Channel : $\mathrm{B}=\mathrm{ECD}$

Bus Address : 16

Sample Rate: $10.00 \mathrm{~Hz}$

Run Time : $24.002 \mathrm{~min}$

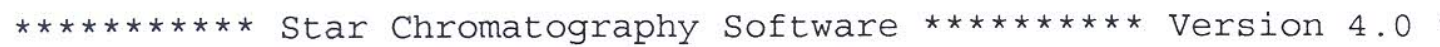

Run Mode : Calibration

Peak Measurement: Peak Area

Calculation Type: Internal standard

Level

1

\begin{aligned} Peak & \multicolumn{2}{c}{ Peak } \\ No. & \multicolumn{2}{c}{ Name } \\.-- &..$- \ldots \\ 1 &$ MCAA \\ 2 & MBAA \\ 3 & DCAA \\ 4 & SURR \\ 5 & TCAA \\ 6 & BCAA \\ 7 & BDCAA \\ 8 & DBAA \\ 9 & CDBAA \\ 10 & TBAA \\ 11 & PI \\ - & $-\ldots\end{aligned}$

Ret. Time

Time Offset

(min) (min) (cor

Area
(counts)

\begin{tabular}{rrl}
\multicolumn{3}{c}{ Width } \\
Sep. & $1 / 2$ & Status \\
Code & $($ sec $)$ & Codes \\
--- &.--- &..--- \\
BB & 5.1 & \\
BB & 4.7 & \\
BV & 4.7 & \\
BB & 4.8 & \\
BB & 4.8 & \\
BV & 4.4 & \\
BB & 4.0 & \\
BB & 4.5 & \\
BB & 4.0 & \\
BB & 3.5 & \\
BB & 3.8 & SR \\
--- &.--- & $\ldots$
\end{tabular}

Totals :

8.661

10.591

(min) . . . . . . - -

11.014

0.008

13904

0.022

5401

10509

.201

0.017

40021

12.982

0.004

8160

21293

16.866

0.010

15319

17.529

0.006

15972

17.965

0.005

2341

20.721

21.182

.000

19504

$-0.006 \quad 19044$

$\begin{array}{rl}== & ======== \\ 0.081 & 171468\end{array}$

Status Codes:

R - Reference peak

S - Internal standard peak

Total Unidentified Counts :

66682 counts

Detected Peaks: 29

Rejected Peaks: 2

Identified Peaks: 11

Amount Standard: 1.000000

Multiplier: 1.000000

Divisor: 1.000000

Baseline Offset: -23 microvolts

Noise (used): 800 microvolts - monitored before this run

Manual injection

Print Date: Tue Jul 13 16:31:06 2004

Page 1 of 1 
Method File: C: \STAR\MODULE16\HAAO3.MTH

Sample ID : PONTO 1

Injection Date: 13-JUL-4 2:09 PM

Calculation Date: 13-JUL-4 2:33 PM

Operator : PASCHOALATO, C

Workstation:

Instrument : star $3600 \mathrm{cx}$

Detector Type: ADCB (10 Volts)

Channel : $\mathrm{B}=\mathrm{ECD}$

Sample Rate: $10.00 \mathrm{~Hz}$

Run Time : $24.002 \mathrm{~min}$

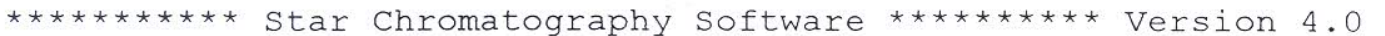

Chart Speed $=$

Start Time =

$0.87 \mathrm{~cm} / \mathrm{min}$ Attenuation $=150$

Zero Offset $=5 \%$

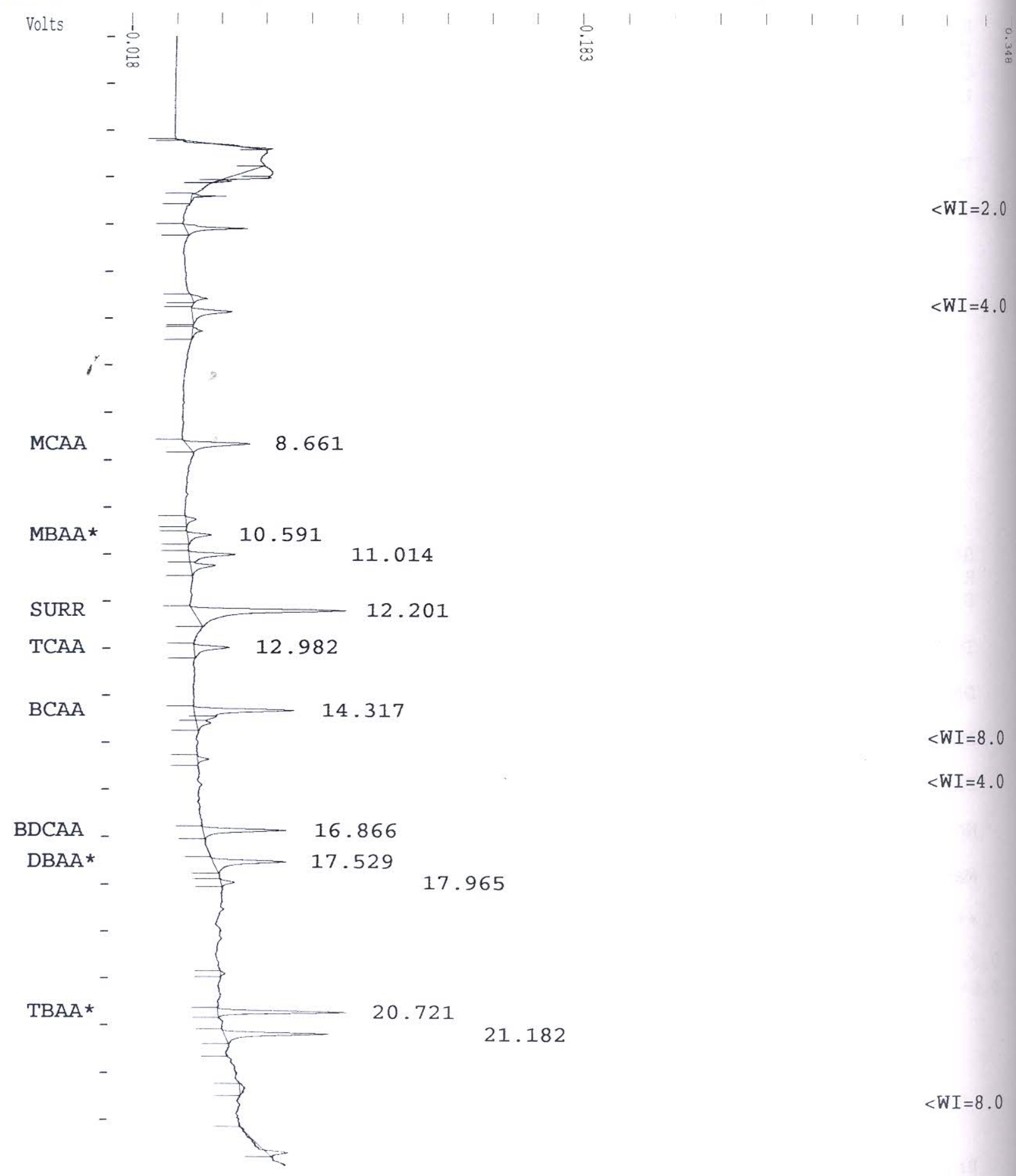


Title : Subprodutos organo-halogenados metodo 552 EPA

Run File : C: \STAR\MODULE16\HAAOZ016.RUN

Method File : C: \STAR \MODULE16\HAAO3.MTH

Sample ID : ponto 2

Injection Date: 14-JUL-4 12:29 PM

Operator : PASCHOALATO, C

Workstation:

Instrument : star $3600 \mathrm{CX}$

Channel : $\mathrm{B}=\mathrm{ECD}$
Calculation Date: 14-JUL-4 3:10 PM

Detector Type: ADCB (10 Volts)

Bus Address : 16

Sample Rate: $10.00 \mathrm{~Hz}$

Run Time : $24.002 \mathrm{~min}$

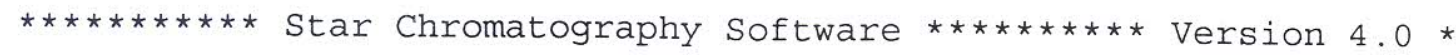

Run Mode : Calibration

Peak Measurement: Peak Area

Calculation Type: Internal Standard

Level 2

\begin{tabular}{|c|c|}
\hline Peak & Peak \\
\hline No. & Name \\
\hline-- & 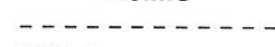 \\
\hline 1 & $\mathrm{MCAA}$ \\
\hline 2 & MBAA \\
\hline 3 & DCAA \\
\hline 4 & SURR \\
\hline 5 & TCAA \\
\hline 6 & $B C A A$ \\
\hline 7 & $B D C A A^{\circ}$ \\
\hline 8 & DBAA \\
\hline 9 & CDBAA \\
\hline 10 & TBAA \\
\hline 11 & PI \\
\hline
\end{tabular}

Totals :

\begin{tabular}{|c|c|c|}
\hline Ret. & Time & \\
\hline $\begin{array}{l}\text { Time } \\
\text { (min) }\end{array}$ & $\begin{array}{l}\text { Offset } \\
\text { (min) }\end{array}$ & $\begin{array}{c}\text { Area } \\
\text { (counts) }\end{array}$ \\
\hline------ & ------ & $-\cdots-\cdots$ \\
\hline 8.652 & -0.011 & 24173 \\
\hline 10.561 & -0.014 & 10743 \\
\hline 10.986 & -0.018 & 19682 \\
\hline 12.188 & -0.012 & 123615 \\
\hline 12.961 & -0.018 & 22555 \\
\hline 14.291 & -0.010 & 53720 \\
\hline 16.845 & -0.003 & 27441 \\
\hline 17.506 & -0.006 & 31330 \\
\hline 17.947 & -0.005 & 7216 \\
\hline 20.695 & -0.001 & 32419 \\
\hline 21.157 & -0.012 & 20154 \\
\hline-- & $\begin{aligned}= & ==== \\
& -0.110\end{aligned}$ & $\begin{array}{r}====== \\
373048\end{array}$ \\
\hline
\end{tabular}

Status Codes:

$R$ - Reference peak

S - Internal standard peak

Total Unidentified Counts :

35797 counts

Detected Peaks: 17

Rejected Peaks: 0

Identified Peaks: 11

Amount Standard: 1.000000

Multiplier: 1.000000

Divisor: 1.000000

Baseline Offset: -3 microvolts

Joise (used): 1590 microvolts - monitored before this run Manual injection

'rint Date: Wed Jun 02 10:57:31 2004 


\section{Title}

: Subprodutos organo-halogenados metodo 552 EPA

Run File : C: \STAR \MODULE16\HAAOZ016.RUN

Method File : C: \STAR \MODULE16\HAAO3.MTH

Sample ID : ponto 2

Injection Date: 14-JUL-4 12:29 PM

Calculation Date: 14-JUL-4 3:10 PM

Operator : PASCHOALATO, C Workstation:

Instrument : star $3600 \mathrm{cx}$

Channel : $\mathrm{B}=\mathrm{ECD}$

Detector Type: ADCB (10 Volts)

Bus Address : 16

Sample Rate : $10.00 \mathrm{~Hz}$

Run Time: $24.002 \mathrm{~min}$

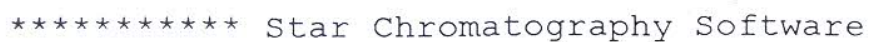

Chart speed $=$

start Time =

$0.87 \mathrm{~cm} / \mathrm{min}$ Attenuation $=150$

End Time

$=24.002 \mathrm{~min}$

Zero offset $=5 \%$

$0.000 \mathrm{~min}$

$\stackrel{\circ}{\stackrel{\infty}{\infty}}$ 
Title Subprodutos organo-halogenados metodo 552 EPA

Run File C: \STAR \MODULE16\HAAOZ003.RUN

Method File : C: \STAR \MODULE16\HAAO3.MTH

Sample ID : PONTO 3

Injection Date: 13-JUL-4 1:25 PM

Calculation Date: 14-JUL-4 11:39 AM

Operator : PASCHOALATO, C

Workstation:

Instrument : star $3600 \mathrm{cx}$

Channel : $\mathrm{B}=\mathrm{ECD}$

Detector Type: ADCB (10 Volts)

Bus Address : 16

Sample Rate : $10.00 \mathrm{~Hz}$

Run Time : $26.002 \mathrm{~min}$

$\star \star \star \star \star \star * \star \star \star * \star$ Star Chromatography Software

Version 4.0

Run Mode : Calibration

Peak Measurement: Peak Area

Calculation Type: Internal Standard

Level $: 3$

\begin{tabular}{|c|c|c|c|c|c|c|c|}
\hline & & Ret. & Time & & & Width & \\
\hline $\begin{array}{l}\text { Peak } \\
\text { No. }\end{array}$ & $\begin{array}{l}\text { Peak } \\
\text { Name }\end{array}$ & Time & $\begin{array}{c}\text { Offset } \\
\text { (min) }\end{array}$ & Area & Sep. & $1 / 2$ & Status \\
\hline - . & Natle & $(\min )$ & $\begin{array}{l}(\min ) \\
-\ldots \ldots\end{array}$ & $\begin{array}{l}\text { (counts) } \\
-\end{array}$ & code & $\begin{array}{l}\text { (sec) } \\
-\ldots-\ldots\end{array}$ & \\
\hline 1 & MCAA & 8.656 & 0.001 & 13330 & BV & 6.7 & \\
\hline 2 & MBAA & 10.573 & 0.001 & 9146 & VP & 6.5 & \\
\hline 3 & DCAA & 11.000 & -0.000 & 13304 & PV & 6.4 & \\
\hline 4 & SURR & 12.201 & 0.001 & 109104 & PV & 5.8 & \\
\hline 5 & TCAA & 12.979 & -0.002 & 15501 & VV & 6.9 & \\
\hline 6 & $B C A A$ & 14.312 & 0.000 & 38827 & $\mathrm{BP}$ & 5.2 & \\
\hline 7 & $B D C A=$ & 16.866 & -0.001 & 20139 & VB & 4.2 & \\
\hline 8 & DBAA & 17.530 & -0.001 & 21632 & PV & 5.4 & \\
\hline 9 & CDBAA & 17.971 & 0.000 & 6782 & VV & 5.7 & \\
\hline 10 & TBAA & 20.720 & -0.005 & 23500 & VP & 3.8 & \\
\hline 11 & PI & 21.188 & 0.007 & 11236 & VV & 4.7 & SR \\
\hline-- & Totals: &.- & $\begin{aligned} &===== \\
& 0.001\end{aligned}$ & $\begin{aligned}== & ===== \\
& 282501\end{aligned}$ & & & \\
\hline
\end{tabular}

Status Codes:

R - Reference peak

$S$ - Internal Standard peak

Total Unidentified Counts : 539675 counts

Detected Peaks: 102

Rejected Peaks: 23

Identified Peaks: 11

Amount Standard: 1.000000

Multiplier: 1.000000

Divisor: 1.000000

Baseline Offset: -13 microvolts

Noise (used): 280 microVolts - monitored before this run

Manual injection 
Run File : C: \STAR \MODULE16\HAAOZ003.RUN

Method File: C: \STAR\MODULE16\HAAO3.MTH

Sample ID : PONTO 3

Injection Date: 13-JUL-4 1:25 PM

Calculation Date: 14-JUL-4 11:39 AM

Operator : PASCHOALATO, C

Workstation:

Instrument : star $3600 \mathrm{cx}$

Channel: $\mathrm{B}=\mathrm{ECD}$

Detector Type: ADCB (10 Volts)

Bus Address : 16

Sample Rate: $10.00 \mathrm{~Hz}$

Run Time: $26.002 \mathrm{~min}$

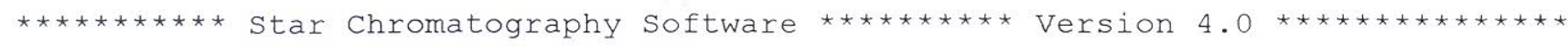

Chart Speed $=0.80 \mathrm{~cm} / \mathrm{min} \quad$ Attenuation $=150 \quad$ Zero Offset $=5 \%$

Start Time $=0.000 \mathrm{~min}$ End Time $=26.002 \mathrm{~min} \mathrm{Min} / \mathrm{Tick}=1.00$

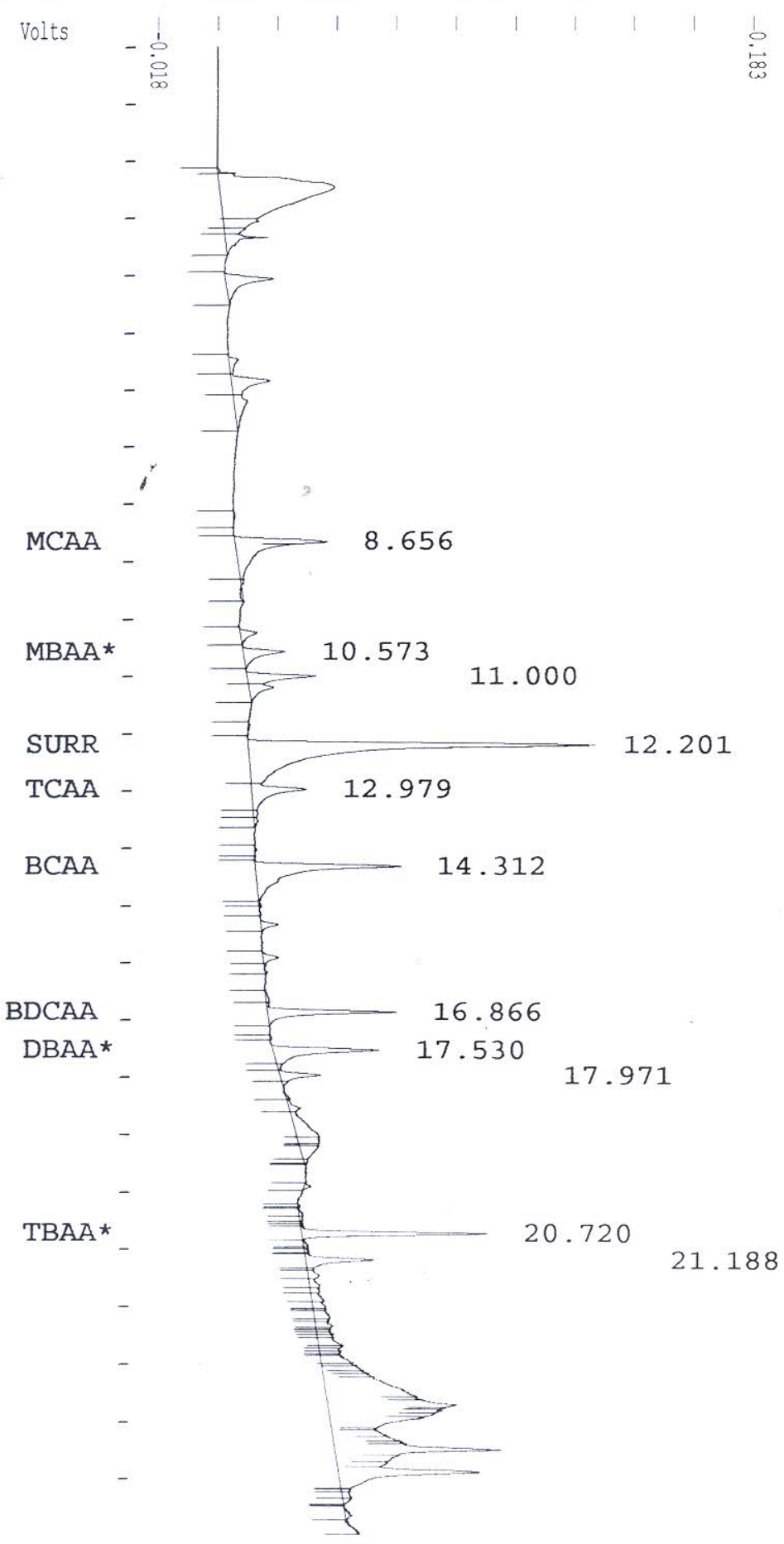

$<W I=8.0$

$<\mathrm{WI}=4.0$ 
Title : Subprodutos organo-halogenados metodo 552 EPA

Run File : C: \STAR \MODULE16\HAAOZ013.RUN

Method File : C: \STAR \MODULE16 \HAAO3.MTH

Sample ID : ponto 4

Injection Date: 14-JUL-4 10:10 AM Calculation Date: 14-JUL-4 3:09 PM

$\begin{array}{ll}\text { Operator : PASCHOALATO, C } & \text { Detector Type: ADCB (10 Volts) } \\ \text { Workstation: } & \text { Bus Address : } 16 \\ \text { Instrument : star } 3600 \mathrm{CX} & \text { Sample Rate : } 10.00 \mathrm{~Hz} \\ \text { Channel : } \mathrm{B}=\mathrm{ECD} & \text { Run Time }: 24.002 \mathrm{~min}\end{array}$

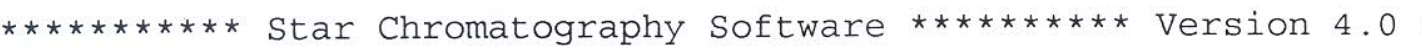

Run Mode : Calibration

Peak Measurement: Peak Area

Calculation Type: Internal Standard

Level : 4

\begin{tabular}{|c|c|c|c|c|c|c|c|}
\hline & & Ret. & Time & & \multicolumn{3}{|c|}{ width } \\
\hline Peak & Peak & Time & Offset & Area & Sep. & $1 / 2$ & status \\
\hline No. & Name & (min) & $(\min )$ & (counts) & code & $(\mathrm{sec})$ & Codes \\
\hline--- & ----------- & ------ & $-\cdots-\cdots$ & ------- & ---- & $-\cdots-$ & -- \\
\hline 1 & MCAA & 8.644 & 0.003 & 31407 & BV & 5.9 & \\
\hline 2 & MBAA & 10.550 & -0.003 & 15764 & VV & 5.7 & \\
\hline 3 & DCAA & 10.979 & -0.002 & 23767 & VV & 5.6 & \\
\hline 4 & SURR & 12.182 & 0.004 & 172130 & BV & 5.2 & \\
\hline 5 & TCAA & 12.955 & -0.000 & 35325 & VV & 5.7 & \\
\hline 6 & $\mathrm{BCAA}$ & 14.285 & -0.001 & 96518 & PV & 4.5 & \\
\hline 7 & $\mathrm{BDCAA}$ & 16.837 & 0.002 & 47218 & VV & 4.7 & \\
\hline 8 & DBAA & 17.497 & -0.002 & 55060 & VV & 5.3 & \\
\hline 9 & CDBAA & 17.941 & 0.003 & 18965 & VV & 6.9 & \\
\hline 10 & TBAA & 20.692 & 0.009 & 49410 & PP & 3.7 & \\
\hline 11 & $\mathrm{PI}$ & 21.150 & -0.038 & 17100 & VV & 5.1 & SR \\
\hline-- & Totals: & ------- & $\begin{aligned}= & ===== \\
& -0.025\end{aligned}$ & $\begin{array}{r}====== \\
562664\end{array}$ & ---- & ---- & - \\
\hline
\end{tabular}

Státus Codes:

$\mathrm{R}$ - Reference peak

$S$ - Internal standard peak

Toţal Unidentified Counts :

190972 counts

Detected Peaks: 80

Rejected Peaks: 24

Identified Peaks: 11

Amount Standafd: 1.000000

Multiplier: 1.000000

Divisor: 1.000000

Raselinte offset: -9 microvolts

Noise (ysed): 190 microvolts - monitored before this run

Manual injection

Print Date: Thu Jul 15 10:24:16 2004

Page 1 of 1 
Method File: C: STAR \MODULE16\HAAO3.MTH

Sample ID : ponto 4

Injection Date: 14-JUL-4 10:10 AM

Operator : PASCHOALATO, C

Workstation:

Instrument : star $3600 \mathrm{Cx}$

Channel: $\mathrm{B}=\mathrm{ECD}$
Calculation Date: 14-JUL-4 3:09 PM

Detector Type: ADCB (10 Volts)

Bus Address : 16

Sample Rate: $10.00 \mathrm{~Hz}$

Run Time : $24.002 \mathrm{~min}$

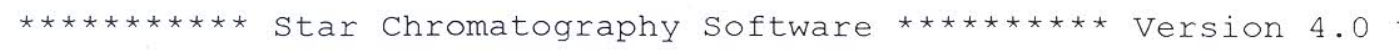

Chart speed $=0.87 \mathrm{~cm} / \mathrm{min} \quad$ Attenuation $=150 \quad$ Zero offset $=5 \%$

Start Time $=0.000 \mathrm{~min}$ End Time $=24.002 \mathrm{~min} \mathrm{Min} / \mathrm{TiCk}=1.00$

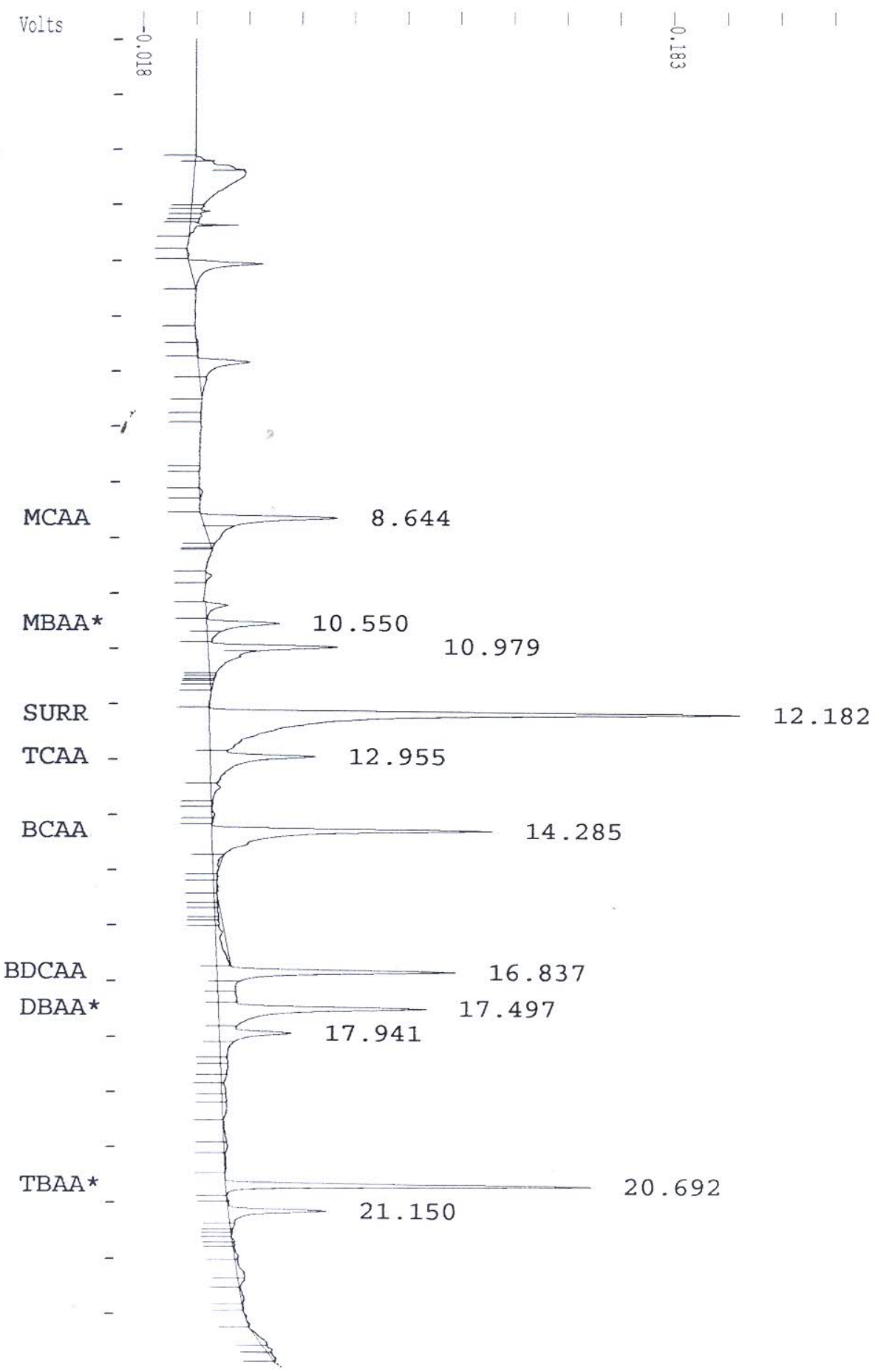

$<W I=8.0$

$<\mathrm{WI}=4.0$

$<W I=8.0$ 
Title

Run File

Method File

Sample ID
Subprodutos organo-halogenados metodo 552 EPA C: \STAR \MODULE16\HAAOZ008.RUN

C: \STAR \MODULE16\HAAO3. MTH

PONTO 6
Injection Date: 13-JUL-4 5:29 PM

Operator : PASCHOALATO, C

Workstation:

Instrument : star $3600 \mathrm{cx}$

Channel: $\mathrm{B}=\mathrm{ECD}$
Calculation Date: 14-JUL-4 3:10 PM

Detector Type: ADCB (10 Volts)

Bus Address : 16

Sample Rate: $10.00 \mathrm{~Hz}$

Run Time : $24.002 \mathrm{~min}$

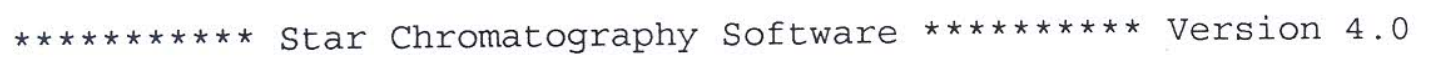

Run Mode : Calibration

Peak Measurement: Peak Area

calculation Type: Internal Standard

Level

\begin{tabular}{|c|c|c|c|c|c|c|c|}
\hline & & Ret. & Time & & & Width & \\
\hline eak & Peak & Time & Offset & Area & Sep. & $1 / 2$ & status \\
\hline No. & Name & $(\min )$ & $(\min )$ & (counts) & Code & $(\mathrm{sec})$ & Codes \\
\hline--- & ----------- & $---\cdots-$ & $-\cdots-\cdots$ & ------- & ---- & ----- & - \\
\hline 1 & MCAA & 8.661 & 0.012 & 41754 & $\mathrm{BB}$ & 4.5 & \\
\hline 2 & MBAA & 10.577 & 0.019 & 26178 & $\mathrm{BB}$ & 4.5 & \\
\hline 3 & DCAA & 11.000 & 0.014 & 41577 & BV & 4.4 & \\
\hline 4 & SURR & 12.200 & 0.009 & 159906 & $\mathrm{BB}$ & 4.4 & \\
\hline 5 & TCAA & 12.976 & 0.013 & 38896 & BB & 4.5 & \\
\hline 6 & BCAA & 14.304 & 0.008 & 113906 & $\mathrm{BB}$ & 3.9 & \\
\hline 7 & $\mathrm{BDCAA}$ & 16.854 & 0.005 & 66017 & $\mathrm{BB}$ & 3.9 & \\
\hline 8 & DBAA & 17.511 & 0.002 & 67039 & $\mathrm{BB}$ & 4.1 & \\
\hline 9 & CDBAA & 17.952 & -0.001 & 7387 & $\mathrm{BB}$ & 4.0 & \\
\hline 10 & TBAA & 20.704 & -0.002 & 84272 & $\mathrm{BB}$ & 3.4 & \\
\hline 11 & $\mathrm{PI}$ & 21.165 & 0.015 & 20075 & BV & 4.0 & SR \\
\hline$-\cdots$ & $\begin{array}{l}\text { Totals: } \\
\text { Tots }\end{array}$ & ------ & $\begin{aligned}== & === \\
& 0.094\end{aligned}$ & $\begin{array}{r}====== \\
667007\end{array}$ & -- & --- & - \\
\hline
\end{tabular}

Status Codes:

$\mathrm{R}$ - Reference peak

S - Internal standard peak

Total Unidentified Counts :

54076 counts

Detected Peaks: 17

Amount Standard: 1.000000

Rejected Peaks: 0

Multiplier: 1.000000
Identified Peaks: 11

Divisor: 1.000000

Baseline Offset: -26 microvolts

Noise (used): 1620 microvolts - monitored before this run

Manual injection 
Title

Run File

Subprodutos organo-halogenados metodo 552 EPA

Method C: SSTAR \MODULE16\HAAOZ008. RUN

Sample ID : PONTO 6

Injection Date: 13-JUL-4 5:29 PM

Operator : PASCHOALATO, C

Workstation:

Instrument : star $3600 \mathrm{Cx}$

Channel

: $\mathrm{B}=\mathrm{ECD}$
Calculation Date: 14-JUL-4 3:10 PM

Detector Type: ADCB (10 Volts)

Bus Address : 16

Sample Rate : $10.00 \mathrm{~Hz}$

Run Time : $24.002 \mathrm{~min}$
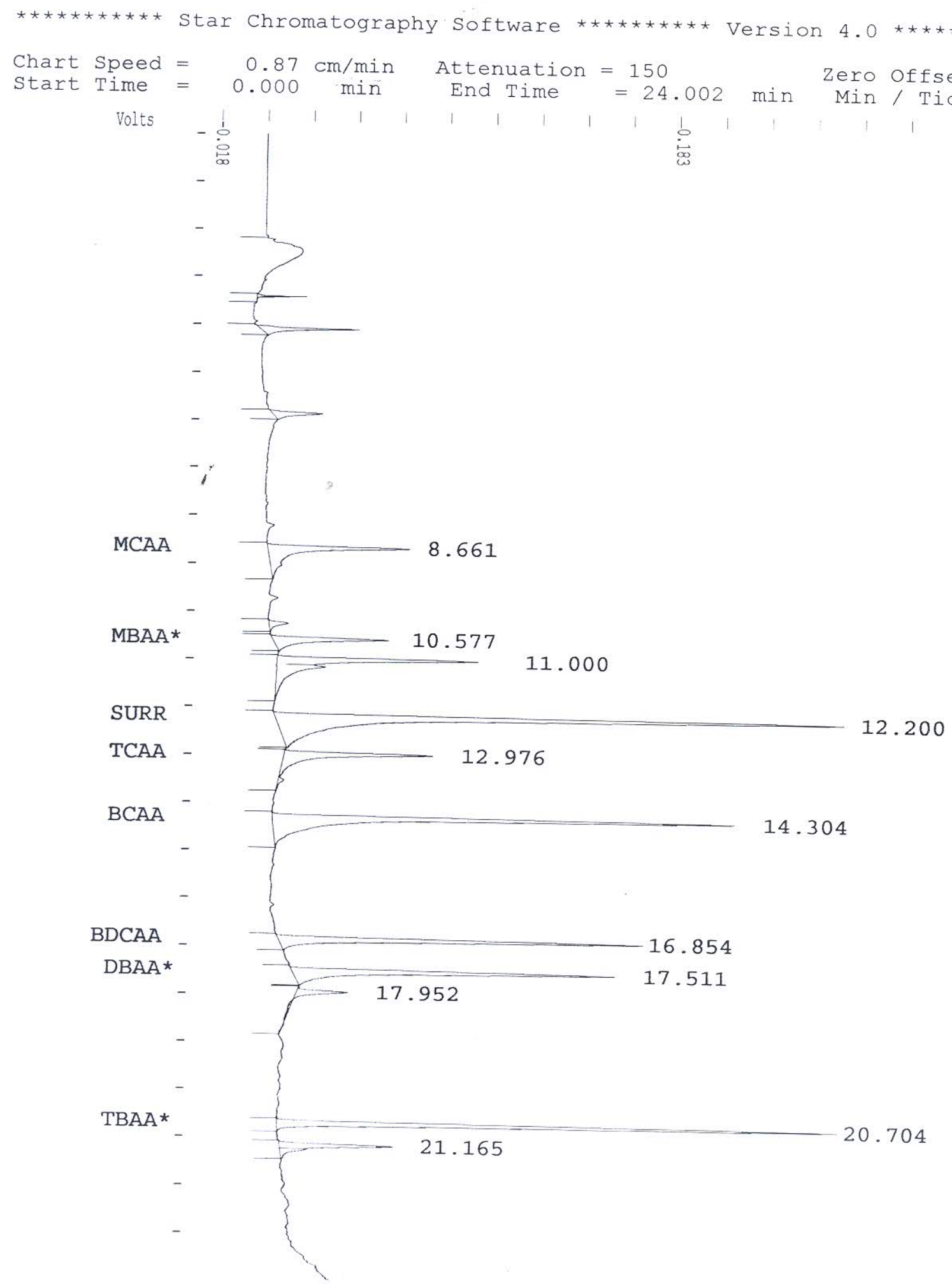
Title : Subprodutos organo-halogenados metodo 552 EPA

Run File : C: \STAR\MODULE16\HAAOZ009.RUN

Method File: C: \STAR \MODULE16\HAAO3.MTH

Sample ID : PONTO 7

Injection Date: 13-JUL-4 6:09 PM Calculation Date: 14-JUL-4 11:40 AM

Operator : PASCHOALATO, C

Workstation:

Instrument : star $3600 \mathrm{cx}$

Channel: $\mathrm{B}=\mathrm{ECD}$

Detector Type: ADCB (10 Volts)

Bus Address : 16

Sample Rate : $10.00 \mathrm{~Hz}$

Run Time : $24.002 \mathrm{~min}$

$\star \star \star \star \star \star \star * \star \star \star \star *$ Star Chromatography Software

Run Mode : Calibration

Peak Measurement: Peak Area

Calculation Type: Internal standard

Level

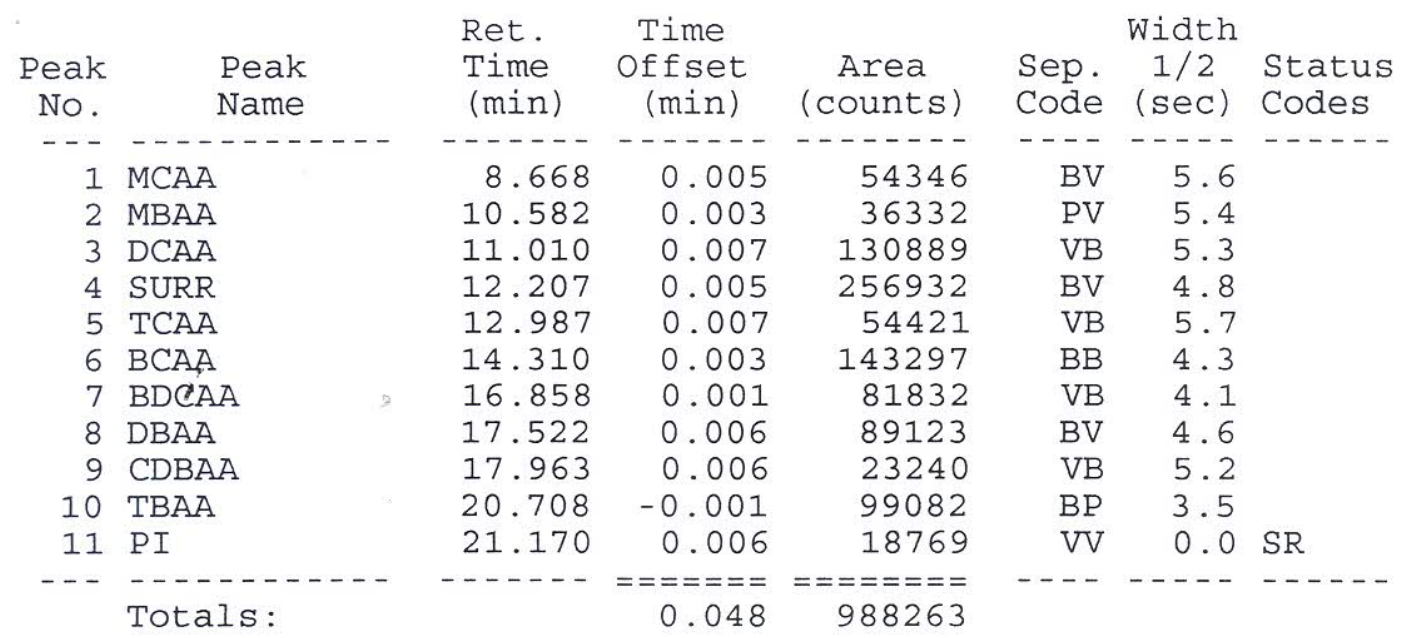

Status Codes:

$R$ - Reference peak

S - Internal standard peak

Total Unidentified Counts :

112090 counts

Detected Peaks: 56

Rejected Peaks: 21

Identified Peaks: 11

Amount Standard: 1.000000

Multiplier: 1.000000

Divisor: 1.000000

Baseline offset: 7 microvolts

Noise (used): 270 microvolts - monitored before this run

Manual injection

Print Date: Wed Jul 14 12:00:26 2004

Page 1 of 1 
Sample ID : PONTO 7

Injection Date: 13-JUL-4 6:09 PM

Calculation Date: 14-JUL-4 11:40 AM

Operator : PASCHOALATO, C

Workstation:

Instrument : star $3600 \mathrm{cx}$

Detector Type: ADCB (10 Volts)

Channel

$: \mathrm{B}=\mathrm{ECD}$

Bus Address: 16

Sample Rate : $10.00 \mathrm{~Hz}$

Run Time : $24.002 \mathrm{~min}$

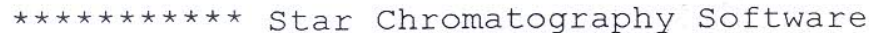

$<\mathrm{WI}=8.0$

Chart speed $=$

$\begin{aligned} 0.87 \mathrm{~cm} / \mathrm{min} \text { Attenuation } & =150 \\ 0.000 \mathrm{~min} & \text { End Time }\end{aligned}$

Zero Offset $=5 \%$

start Time =

$0.000 \mathrm{~min}$

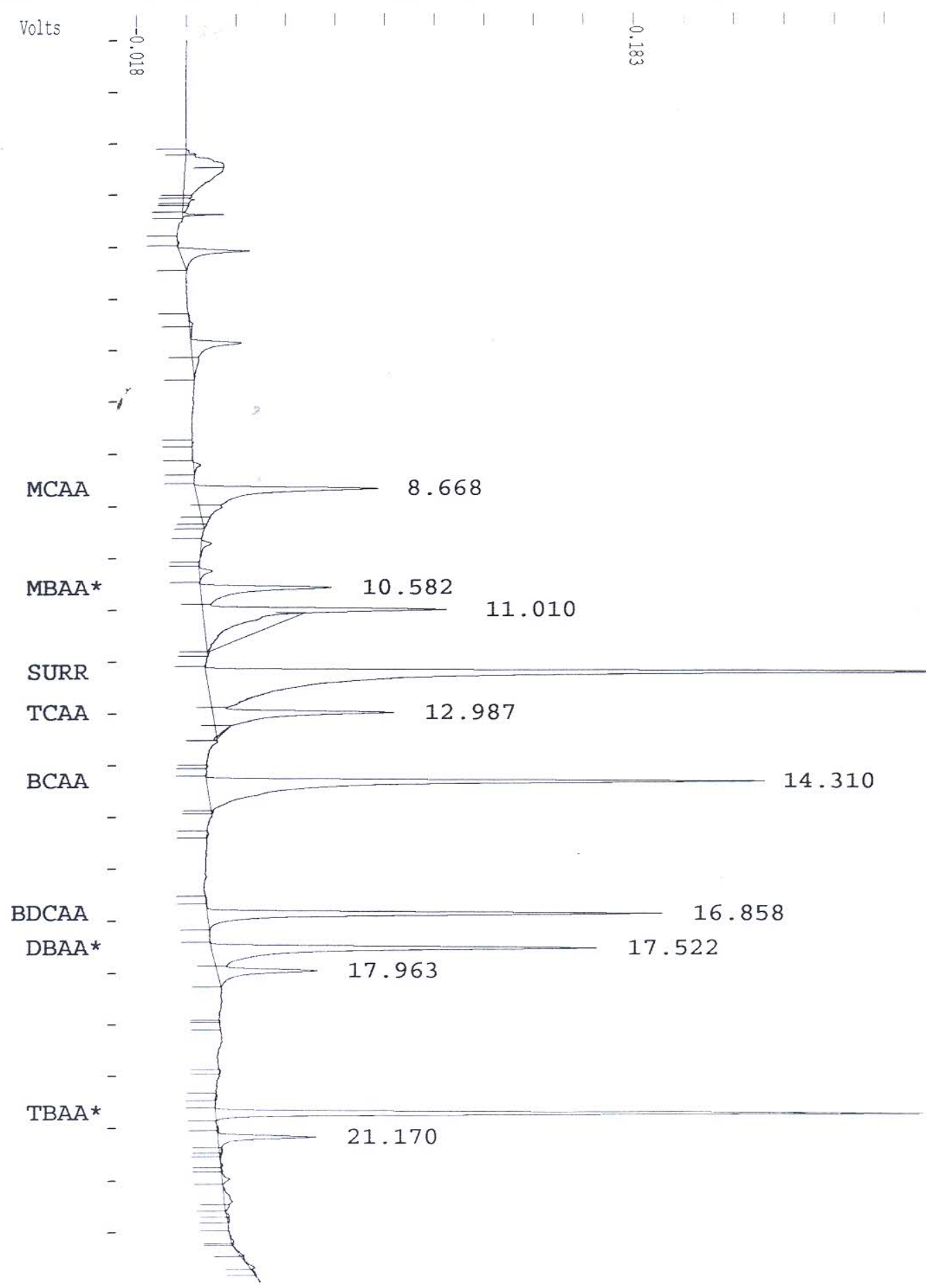

20.708

$<W I=8.0$

12.207

$<W I=4.0$ 
Title : Subprodutos organo-halogenados metodo 552 EPA

Run File: C: \STAR \MODULE16\HAAOZ016.RUN

Method File: C: \STAR\MODULE16\HAAO3.MTH

Sample ID : ponto 2

Injection Date: 14-JUL-4 12:29 PM

Calculation Date: 14-JUL-4 1:40 PM

Operator: PASCHOALATO, C

Workstation:

Instrument : star $3600 \mathrm{cx}$

Detector Type: ADCB (10 Volts)

Channel : $\mathrm{B}=\mathrm{ECD}$

Bus Address : 16

Sample Rate : $10.00 \mathrm{~Hz}$

Run Time : $24.002 \mathrm{~min}$

$\star \star \star \star \star * \star * \star \star \star \star *$ Star Chromatography Software

$\star \star \star \star \star \star \star \star \star \star *$ Version 4.0

Run Mode : Verification

Peak Measurement: Peak Area

Calculation Type: Internal Standard

Level : 2

Tolerance : $100.0 \%$

\begin{tabular}{|c|c|c|c|c|c|c|c|c|}
\hline & & Expected & Calculated & & Ret. & Time & & \\
\hline $\begin{array}{l}\text { Peak } \\
\text { No. }\end{array}$ & $\begin{array}{l}\text { Peak } \\
\text { Name }\end{array}$ & $\begin{array}{l}\text { Result } \\
(\mathrm{ug} / \mathrm{L})\end{array}$ & $\begin{array}{l}\text { Result } \\
(\mathrm{ug} / \mathrm{L})\end{array}$ & $\begin{array}{c}\text { Dev. } \\
\frac{\circ}{0}\end{array}$ & $\begin{array}{l}\text { Time } \\
(\text { min) }\end{array}$ & $\begin{array}{l}\text { Offset } \\
\text { (min) }\end{array}$ & $\begin{array}{c}\text { Area } \\
\text { (counts) }\end{array}$ & $\begin{array}{l}\text { Status } \\
\text { Codes }\end{array}$ \\
\hline--- & - - - - - - - - - - & ----- & ------ & ----- & $-\cdots-\cdots$ & $\ldots-\cdots$ & $\ldots \ldots$ & $-\cdots--$ \\
\hline 1 & MCAA & 9.00 & 9.27 & 3.0 & 8.652 & -0.011 & 18280 & \\
\hline 2 & MBAA & 6.00 & 6.38 & 6.4 & 10.561 & -0.014 & 11717 & \\
\hline 3 & DCAA & 9.00 & 8.76 & 2.6 & 10.986 & -0.018 & 22563 & \\
\hline 4 & SURR i & 9.00 & 12.74 & 41.6 & 12.188 & -0.012 & 120921 & \\
\hline 5 & TCAA & 3.00 & 3.06 & 2.1 & 12.961 & -0.018 & 18047 & \\
\hline 6 & BCAA & 6.00 & 6.77 & 12.9 & 14.291 & -0.010 & 53720 & \\
\hline 7 & $\mathrm{BDCAA}$ & 6.00 & 6.16 & 2.7 & 16.845 & -0.003 & 27441 & \\
\hline 8 & $\mathrm{DBAA}$ & 3.00 & 3.24 & 7.9 & 17.506 & -0.006 & 31330 & \\
\hline 9 & CDBAA & 15.00 & 14.11 & 5.9 & 17.947 & -0.005 & 7216 & \\
\hline 10 & TBAA & 30.00 & 30.32 & 1.1 & 20.695 & -0.001 & 32419 & \\
\hline 11 & PI & $\mathrm{N} / \mathrm{A}$ & INT STD & 0.0 & 21.157 & -0.012 & 20154 & RS \\
\hline- & Totals: & $\ldots$ & $\begin{aligned}== & ===== \\
& 100.81\end{aligned}$ & $\ldots-\cdots$ & $\ldots \ldots$ & $\begin{aligned}= & ===== \\
& -0.110\end{aligned}$ & $=======$ & \\
\hline
\end{tabular}

Status Codes:

R - Reference peak

S - Internal standard peak

Total Unidentified Counts :

36801 counts

Detected Peaks: 17

Rejected Peaks: 0

Multiplier: 1.000000

Amount Standard: 1.000000

Baseline Offset: -3 microvolts

Noise (used): 1590 microvolts - monitored before this run

Manual injection

Print Date: Wed Jul 14 13:40:59 2004

Page 1 of 1 
Method File : C: \STAR \MODULE16\HAAO3.MTH

Sample ID : ponto 2

Injection Date: 14-JUL-4 12:29 PM

Calculation Date: 14-JUL-4 1:40 PM

Operator : PASCHOALATO, C

Workstation:

Instrument : star $3600 \mathrm{cx}$

Channel: $\mathrm{B}=\mathrm{ECD}$

Detector Type: ADCB (10 Volts)

Bus Address : 16

Sample Rate: $10.00 \mathrm{~Hz}$

Run Time : $24.002 \mathrm{~min}$

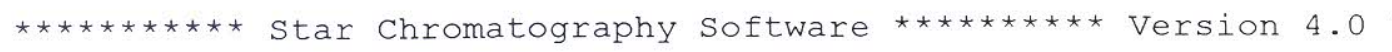

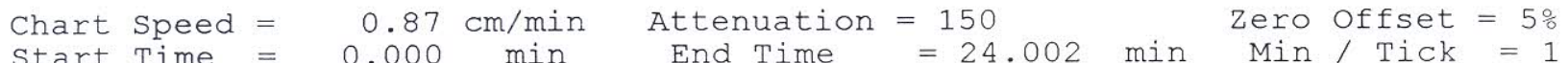

End Time

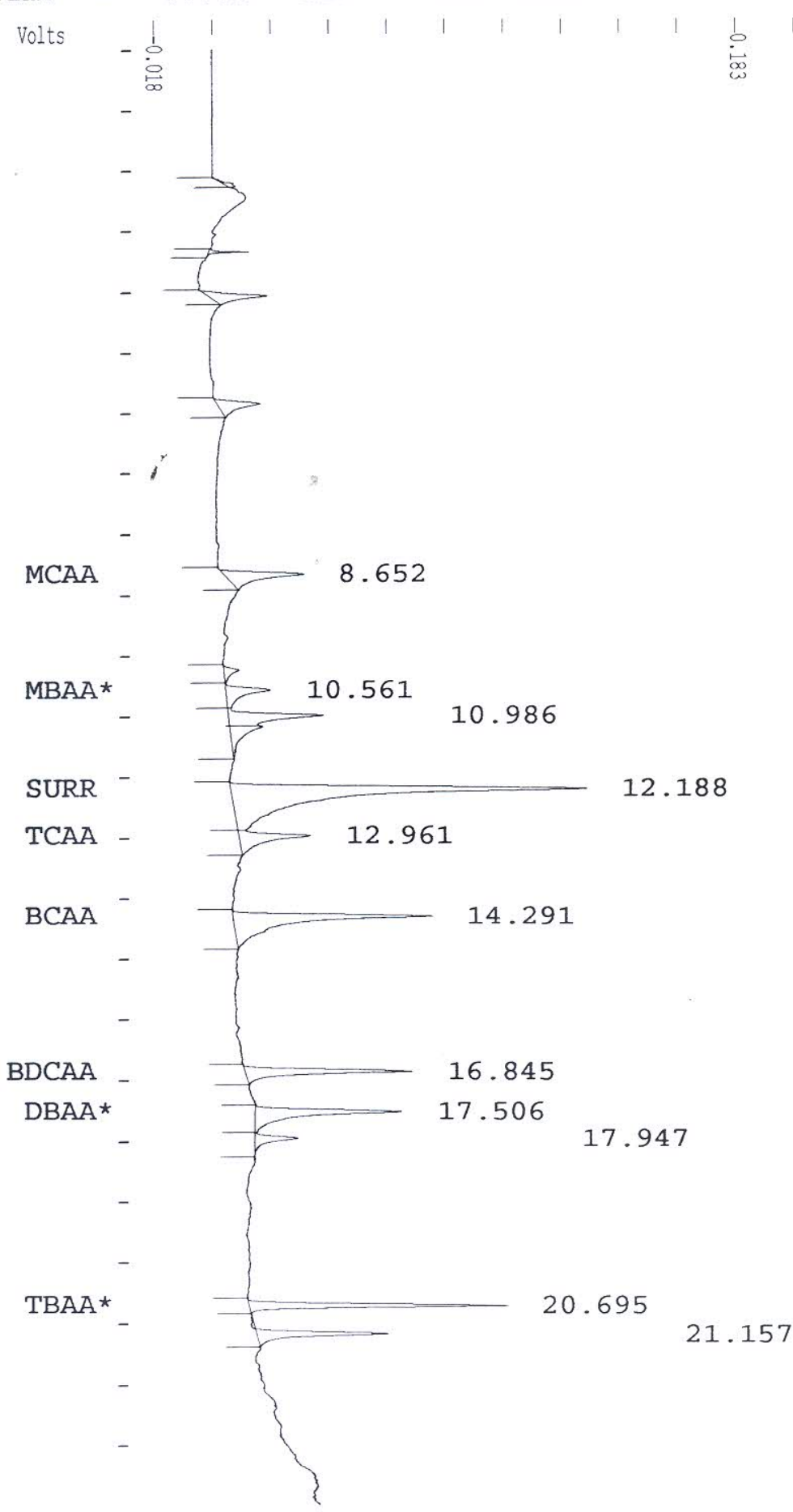

$<W I=2.0$

$<\mathrm{WI}=4.0$

$<W I=8.0$ 


\section{APÊNDICE C}

C-01 Cromatograma PF 7 dias branco 30min 551

C-02 Cromatograma PF 7 dias branco 168h 551

C-03 Cromatograma PF 7 dias 30 min 551

C-04 icromatograma PF 7 dias 168h 551

C-05 Cromatograma PF 7 dias Branco 30 min 552

C-06 Cromatograma PF 7 dias branco 168h 552

C-07 Cromatograma PF 7 dias 30 min 552

C-08 Cromatograma PF 7 dias 168h 552 
: Subprodutos organo-halogenados metodo 551.1 EPA

: C: \STAR \MODULE16\REPPE021.RUN

File : C: \STAR \MODULE16\551.MTH

ID : PF Branco 30min

Ion Date: 13-MAY-4 12:16 PM

: PASCHOALATO, C

ation:

nent : star $3600 \mathrm{Cx}$

: $\mathrm{B}=\mathrm{ECD}$
Calculation Date: 13-MAY-4 12:37 PM

Detector Type: ADCB (10 Volts)

Bus Address : 16

Sample Rate: $10.00 \mathrm{~Hz}$

Run Time

$: 20.002 \mathrm{~min}$

Star Chromatography Software $* \star \star \star \star \star \star * \star * \star *$ Version 4.0

peed $=1.04 \mathrm{~cm} / \mathrm{min} \quad$ Attenuation $=150 \quad$ Zero offset $=5 \%$

ime $=0.000 \mathrm{~min}$ End Time $=20.002 \mathrm{~min} \mathrm{Min} / \mathrm{Tick}=1.00$

Volts

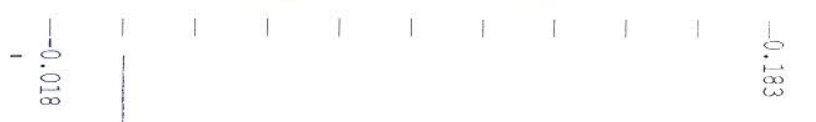

$<W I=2.0$

PI

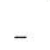

俩

$<W I=4.0$

ormic

6.740

acetc

9. 362

9. 894

4.258

(

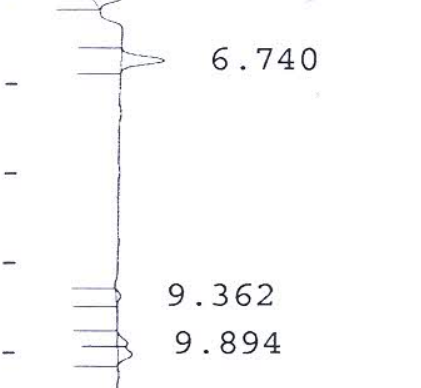

$<W I=8.0$ 
Title Subprodutos organo-halogenados metodo 551.1 EPA

Run File C: \STAR \MODULE16\REPPF021. RUN

Method File: C: \STAR\MODULE16\551.MTH

Sample ID: PF Branco 30min

Injection Date: 13-MAY-4 12:16 PM

Operator : PASCHOALATO, C
Workstation:
Instrument : star $3600 \mathrm{CX}$
Channel : $\mathrm{B}=\mathrm{ECD}$

Calculation Date: 13-MAY-4 12:37 PM Detector Type: ADCB (10 Volts) Bus Address : 16 Sample Rate: $10.00 \mathrm{~Hz}$ Run Time : $20.002 \mathrm{~min}$

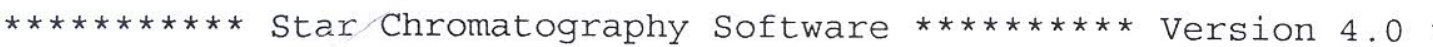

Run Mode : Analysis

Peak Measurement: Peak Area

Calculation Type: Internal Standard

\begin{tabular}{|c|c|c|c|c|c|c|c|c|}
\hline & & & Ret. & Time & & & Width & \\
\hline Peak & Peak & Result & Time & Offset & Area & Sep. & $1 / 2$ & Sta \\
\hline No. & Name & (ug/L) & (min) & $(\min )$ & (counts) & code & (sec) & $\mathrm{Cor}$ \\
\hline- & $--1---1----$ & 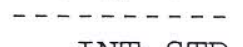 & ------ & ------ & ------- & ---- & ----- & $-\cdots$ \\
\hline 1 & PI & INT STD & 4.258 & -0.018 & 20292 & $\mathrm{~PB}$ & 5.8 & SR \\
\hline 2 & cloroformio & 17.77 & 6.740 & 0.008 & 6710 & $\mathrm{BB}$ & 5.8 & \\
\hline 3 & dicloroaceto & 0.35 & 9.362 & 0.015 & 700 & BB & 6.3 & \\
\hline 4 & bromodicloro & 0.71 & 9.894 & 0.025 & 1496 & BV & 6.8 & \\
\hline- & Totals: & $\begin{array}{r}======== \\
18.83\end{array}$ & ------ & $\begin{aligned}== & ==== \\
& 0.030\end{aligned}$ & $\begin{array}{r}====== \\
29198\end{array}$ & ---- & ----- & \\
\hline
\end{tabular}

Statusi Codes:

$R$ - Reference peak

$S$ - Internal Standard peak

Total Unidentified Counts : 49514 counts

Detected Peaks: 14

Rejected Peaks: 1

Identified Peaks: 4

Amount Standard: 1.000000

Multiplier: 1.000000

Divisor: 1.000000

Baseline Offset: 24 microvolts

Noise (used): 250 microvolts - monitored before this run

Manual injection 
Title : Subprodutos organo-halogenados metodo $551.1 \mathrm{EPA}$

Run File : C: \STAR\MODULE16\REPPF020.RUN

Method File : C: \STAR \MODULE16\551.MTH

Sample ID : PF Branco 168h

Injection Date: 13-MAY-4 10:38 AM

Operator : PASCHOALATO, C

Workstation:

Instrument : star $3600 \mathrm{cx}$

Channel : $\mathrm{B}=\mathrm{ECD}$
Calculation Date: 2-JUN-4 3:55 AM Detector Type: ADCB (10 Volts)

Bus Address : 16

Sample Rate: $10.00 \mathrm{~Hz}$

Run Time : $20.002 \mathrm{~min}$

$\star \star \star \star \star \star \star * \star * \star \star$ Star Chromatography Software

Version 4.0

Run Mode : Analysis

Peak Measurement: Peak Area

Calculation Type: Internal Standard

\begin{tabular}{|c|c|c|c|c|c|c|c|c|}
\hline & & & Ret & Time & & & width & \\
\hline Peak & Peak & Result & Time & Offset & Area & Sep. & $1 / 2$ & St \\
\hline No. & Name & $(u g / L)$ & (min) & (min) & (counts) & Code & $(\mathrm{sec})$ & $\mathrm{Co}$ \\
\hline--- & $-----\cdots---$ & $\ldots-\cdots-\cdots$ & $-\cdots---$ & ------ & $-\cdots-\cdots$ & --- & $\ldots--$ & -- \\
\hline 1 & PI & INT STD & 4.275 & -0.018 & 21431 & VB & 5.7 & $S R$ \\
\hline 2 & cloroformio & 20.60 & 6.760 & 0.005 & 8217 & $\mathrm{BB}$ & 5.9 & \\
\hline 3 & bromodicloro & 0.70 & 9.913 & 0.019 & 1602 & $\mathrm{BV}$ & 6.8 & \\
\hline 4 & cloral hidra & 9.45 & 10.270 & 0.019 & 9546 & VB & 7.4 & \\
\hline 5 & dibromocloro & 1.06 & 13.711 & 0.246 & 2033 & BV & 6.8 & \\
\hline-- & ----------- & $========$ & ------- & $======$ & $======$ & --- & ----- & \\
\hline & Totals: & 31.81 & & 0.271 & 42829 & & & \\
\hline & ' & & & & & & & \\
\hline 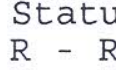 & is Codes: & & & & & & & \\
\hline & lefere & & & & & & & \\
\hline & 1 Stand & cd peak & & & & & & \\
\hline
\end{tabular}

Total Unidentified Counts :

47631 counts

Detected Peaks: 17

Rejected Peaks: 4

Identified Peaks: 5

Amount Standard: 1.000000

Multiplier: 1.000000

Divisor: 1.000000

Baseline offset: -13 microvolts

Noise (used): 270 microvolts - monitored before this run

Manual injection 
: Subprodutos organo-halogenados metodo 551.1 EPA

: C: \STAR\MODULE16\REPPF010.RUN

File: C: \STAR\MODULE16\551.MTH

ID : PF 7 dias 30min

tion Date: 13-MAY-4 5:41 AM

tor : PASCHOALATO, C

tation:

ument : star $3600 \mathrm{cx}$

el: $\mathrm{B}=\mathrm{ECD}$

Calculation Date: 2-JUN-4 3:43 AM

Detector Type: ADCB (10 Volts)

Bus Address : 16

Sample Rate: $10.00 \mathrm{~Hz}$

Run Time : $20.002 \mathrm{~min}$

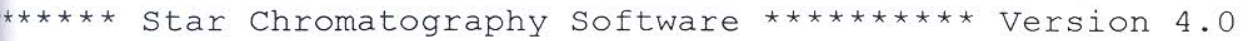

$1.04 \mathrm{~cm} / \mathrm{min}$ Attenuation $=100$

Zero Offset $=5 \%$

Time $=$ $0.000 \mathrm{~min}$ End Time

$=20.002 \mathrm{~min}$

Min/ Tick = 1.00

Volts

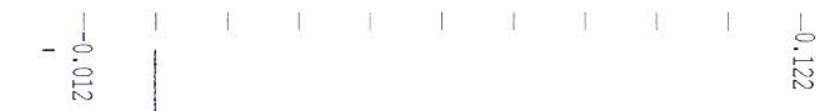

!

$-$

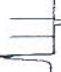

PI

4.264

$<W I=4.0$

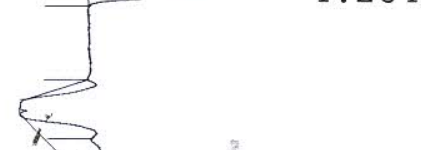

6.741

$<W I=2.0 *$

oformio

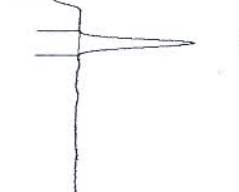

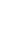

9.359

9.891

10.243

$<W I=8.0$

13.686

15.498 
Title

Run File

Method File

Sample ID
Subprodutos organo-halogenados metodo 551.1 EPA

C: \STAR \MODULE16\REPPFO10.RUN

C: \STAR \MODULE16\551.MTH

PF 7 dias $30 \mathrm{~min}$
Injection Date: 13-MAY-4 5:41 AM

Operator : PASCHOALATO, C

Workstation:

Instrument : star $3600 \mathrm{cx}$

Channel : $\mathrm{B}=\mathrm{ECD}$
Calculation Date: 2-JUN-4 3:43 AM

Detector Type: ADCB (10 Volts)

Bus Address : 16

Sample Rate: $10.00 \mathrm{~Hz}$

Run Time : $20.002 \mathrm{~min}$

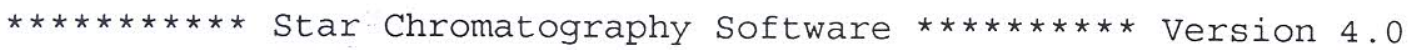

Run Mode : Analysis

Peak Measurement: Peak Area

Calculation Type: Internal Standard

\begin{tabular}{|c|c|c|c|c|c|c|c|c|}
\hline & & & Ret. & Time & & \multicolumn{3}{|c|}{ width } \\
\hline Peak & Peak & Result & Time & Offset & Area & Sep. & $1 / 2$ & \\
\hline No. & Name & (ug/L) & (min) & $(\min )$ & (counts) & Code & $(\mathrm{sec})$ & \\
\hline-- & ------ & ------- & ------ & ------ & ------ & --- & ---- & \\
\hline 1 & PI & INT STD & 4.264 & -0.030 & 18840 & BB & 5.9 & $S R$ \\
\hline 2 & cloroformio & 34.63 & 6.741 & 0.003 & 12143 & $\mathrm{BB}$ & 5.9 & \\
\hline 3 & dicloroaceto & 2.18 & 9.359 & 0.013 & 4121 & $\mathrm{BB}$ & 5.9 & \\
\hline 4 & bromodicloro & 0.80 & 9.891 & 0.022 & 1604 & BV & 6.8 & \\
\hline 5 & cloral hidra & 2.48 & 10.243 & 0.020 & 2204 & $\mathrm{VB}$ & 7.2 & \\
\hline 6 & dibromocloro & 0.73 & 13.686 & 0.257 & 1228 & $\mathrm{BB}$ & 6.7 & \\
\hline 7 & $1,1,1$-triclo & 2.72 & 15.498 & 0.075 & 3494 & $\mathrm{BP}$ & 7.5 & \\
\hline & Totals: & $\begin{array}{r}======= \\
43.54\end{array}$ & ------- & $\begin{aligned}= & === \\
& 0.360\end{aligned}$ & $\begin{array}{r}====== \\
43634\end{array}$ & --- & & \\
\hline
\end{tabular}

Status Codes:

$\mathrm{R}$ - Reference peak

$S$ - Internal standard peak

Total Unidentified Counts : 50944 counts

Detected Peaks: 19 Rejected Peaks: 3

Identified Peaks: 7

Amount Standard: 1.000000

Multiplier: 1.000000

Divisor: 1.000000

Baseline Offset: 21 microvolts

Noise (used): 260 microvolts - monitored before this run

Manual injection 
Title : Subprodutos organo-halogenados metodo 551.1 EPA

Run File : C: \STAR \MODULE16\REPPF019.RUN

Method File : C: \STAR \MODULE16\551.MTH

Sample ID : PF 7 dias168h

Injection Date: 13-MAY-4 10:09 AM

Operator : PASCHOALATO, C

Workstation:

Instrument : star $3600 \mathrm{cx}$

Channel : $\mathrm{B}=\mathrm{ECD}$
Calculation Date: 2-JUN-4 3:52 AM

Detector Type: ADCB (10 Volts)

Bus Address : 16

Sample Rate: $10.00 \mathrm{~Hz}$

Run Time : $20.002 \mathrm{~min}$

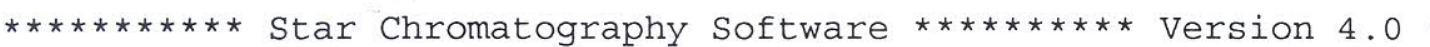

Run Mode : Analysis

Peak Measurement: Peak Area

Calculation Type: Internal standard

\begin{tabular}{|c|c|c|c|c|c|c|c|c|}
\hline & & & Ret & Time & & & Width & \\
\hline eak & Peak & Result & Time & Offset & Area & Sep. & $1 / 2$ & Status \\
\hline No. & Name & (ug/L) & $(\min )$ & (min) & (counts) & Code & (sec) & Code \\
\hline - - & -------1 & --------- & $---\ldots$ & ------ & $\ldots-\ldots$ & $\ldots--$ & $--\cdots$ & \\
\hline 1 & PI & INT STD & 4.282 & -0.011 & 24764 & $\mathrm{BB}$ & 6.6 & SR \\
\hline 2 & cloroformio & 117.82 & 6.761 & -0.006 & 54303 & $\mathrm{BB}$ & 6.0 & \\
\hline 3 & dicloroaceto & 5.68 & 9.378 & -0.009 & 14099 & $\mathrm{BB}$ & 5.9 & \\
\hline 4 & bromodicloro & 1.38 & 9.904 & -0.008 & 3651 & BV & 7.6 & \\
\hline 5 & cloral hidra & 28.82 & 10.264 & -0.004 & 33628 & VB & 7.7 & \\
\hline 6 & cloropicrina & 0.21 & 13.106 & -0.010 & 1248 & $\mathrm{BB}$ & 6.9 & \\
\hline 7 & dibromocloro & 0.60 & 13.705 & 0.217 & 1327 & $\mathrm{BB}$ & 6.7 & \\
\hline 8 & $1,1,1$-triclo & 1.01 & 15.514 & 0.023 & 1702 & $\mathrm{BB}$ & 7.3 & \\
\hline & $\begin{array}{l}\text { Totals: } \\
\text { Totals }\end{array}$ & $\begin{array}{r}======= \\
155.52\end{array}$ & ------ & $\begin{aligned}== & === \\
& 0.192\end{aligned}$ & $\begin{array}{r}====== \\
134722\end{array}$ & & & \\
\hline
\end{tabular}

Status Codes:

$\mathrm{R}$ - Reference peak

S - Internal standard peak

Total Unidentified Counts :

39691 counts

Detected Peaks: 17

Rejected Peaks: 2

Identified Peaks: 8

Amount Standard: 1.000000

Multiplier: 1.000000

Divisor: 1.000000

Baseline Offset: -6 microvolts

Noise (used): 270 microvolts - monitored before this run

Manual injection 
Method File : C: \STAR \MODULE16\552.MTH

Sample ID : PFHaa Branco 30min

Injection Date: 18-MAY-4 6:25 AM

Calculation Date: 18-MAY-4 6:52 AM

Operator : PASCHOALATO, C

Workstation:

Instrument : star $3600 \mathrm{cx}$

Channel: $\mathrm{B}=\mathrm{ECD}$

Detector Type: ADCB (10 Volts)

Bus Address : 16

Sample Rate : $10.00 \mathrm{~Hz}$

Run Time : $27.002 \mathrm{~min}$

$\star \star \star \star \star \star \star \star * \star * \star$ Star Chromatography Software

Version 4.0

Run Mode : Analysis

Peak Measurement: Peak Area

Calculation Type: Internal Standard

\begin{tabular}{|c|c|c|c|c|c|c|c|c|}
\hline & & & Ret & Time & & & Width & \\
\hline $\begin{array}{l}\text { Peak } \\
\text { No. }\end{array}$ & $\begin{array}{l}\text { Peak } \\
\text { Name }\end{array}$ & $\begin{array}{l}\text { Result } \\
(\mathrm{ug} / \mathrm{L})\end{array}$ & $\begin{array}{l}\text { Time } \\
\text { (min) }\end{array}$ & $\begin{array}{l}\text { Offset } \\
\text { (min) }\end{array}$ & $\begin{array}{c}\text { Area } \\
\text { (counts) }\end{array}$ & $\begin{array}{l}\text { Sep. } \\
\text { Code }\end{array}$ & $\begin{array}{c}1 / 2 \\
(\mathrm{sec})\end{array}$ & $\begin{array}{l}\text { Status } \\
\text { Codes }\end{array}$ \\
\hline--- & ---------- & --------- & ------- & ------ & $-----\cdots$ & --- & ----- & \\
\hline 1 & MCAA & 0.26 & 8.629 & -0.167 & 7194 & BB & 5.2 & \\
\hline 2 & DCAA & 0.32 & 11.121 & -0.014 & 1424 & BV & 4.8 & \\
\hline 3 & TCAA & 0.22 & 13.109 & -0.010 & 2301 & BB & 5.1 & \\
\hline 4 & BDCAA & 0.23 & 17.181 & 0.182 & 1347 & BV & 10.8 & \\
\hline 5 & DBAA & 0.39 & 17.670 & 0.015 & 5070 & VV & 38.1 & \\
\hline 6 & CDBAA & 12.04 & 18.012 & -0.099 & 6087 & VV & 0.0 & \\
\hline 7 & TBAA & 6.70 & 20.837 & -0.024 & 1815 & VV & 0.0 & \\
\hline 8 & $\mathrm{PI}$, & INT STD & 21.319 & -0.012 & 50250 & VV & 6.4 & SR \\
\hline--- & Totals: & $====\begin{array}{r}== \\
20.16\end{array}$ & ------ & $\begin{aligned}= & ==== \\
& -0.129\end{aligned}$ & $\begin{array}{r}===== \\
75488\end{array}$ & --- & ---- & \\
\hline
\end{tabular}

Status Codes:

$R$ - Reference peak

$S$ - Internal Standard peak

Total Unidentified Counts :

791254 counts

Detected Peaks: 68

Rejected Peaks: 13

Identified Peaks: 8

Amount Standard: 1.000000 Multiplier: 1.000000

Divisor: 1.000000

Baseline offset: -9 microvolts

Noise (used): 260 microvolts - monitored before this run

Manual injection

Print Date: Tue May 18 07:13:43 2004

Page 1 of 1 


\begin{tabular}{|c|c|}
\hline Title & : Determinacao de \\
\hline Run File & : C $: \backslash S T A R \backslash M O D U L E 16 \backslash N P F H A 012 . R U N$ \\
\hline hod File & : C $: \backslash S T A R \backslash M O D U L E 16 \backslash 552 . \mathrm{MTH}$ \\
\hline mple ID & : PF Haa Branco 168h \\
\hline
\end{tabular}

Injection Date: 18-MAY-4 7:16 AM Calculation Date: 18-MAY-4 8:26 AM

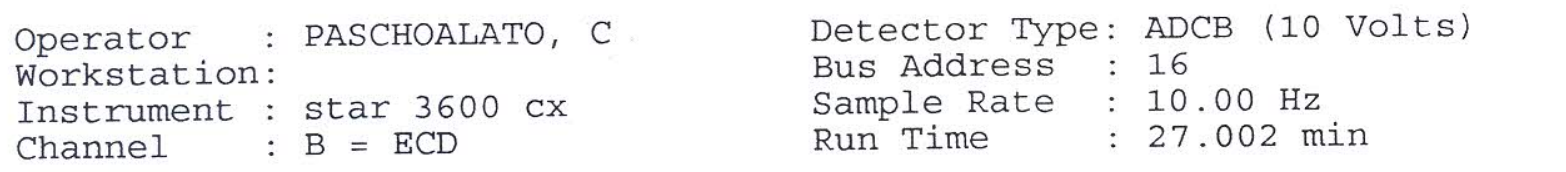

\begin{tabular}{|c|c|c|c|c|c|c|c|c|}
\hline & & & Ret. & Time & & & width & \\
\hline Peak & Peak & Result & Time & Offset & Area & Sep. & $1 / 2$ & Status \\
\hline No. & Name & $(u g / L)$ & $(\min )$ & $(\min )$ & (counts) & Code & $(\mathrm{sec})$ & Codes \\
\hline--- & $\cdots---\cdots-\cdots$ & --------- & ------ & ------- & ------- & ---- & ----- & \\
\hline 1 & MCAA & 0.92 & 8.787 & -0.012 & 10864 & VV & 0.0 & \\
\hline 2 & DCAA & 27.91 & 11.128 & -0.011 & 61031 & VV & 13.8 & \\
\hline 3 & surr & 0.95 & 12.199 & -0.150 & 10765 & VV & 6.0 & \\
\hline 4 & TCAA & 4.05 & 13.116 & -0.008 & 18859 & VV & 8.0 & \\
\hline 5 & $B C A A$ & 0.49 & 14.430 & -0.015 & 2612 & VV & 0.0 & \\
\hline 6 & BDCAA & 0.91 & 17.004 & -0.002 & 2602 & VV & 0.0 & \\
\hline 7 & DBAA & 0.41 & 17.650 & -0.012 & 2622 & VV & 0.0 & \\
\hline 8 & CDBAA & 11.84 & 18.192 & 0.073 & 2458 & VV & 0.0 & \\
\hline 9 & TBAA & $\times 154.89$ & 21.028 & 0.159 & 19655 & VV & 0.0 & $\mathrm{C}$ \\
\hline 10 & $\mathrm{PI}$ & INT STD & 21.327 & -0.004 & 24469 & VV & 6.5 & SR \\
\hline-- & $\begin{array}{l}\text { Totals: } \\
\text { Tots }\end{array}$ & $\begin{array}{r}======== \\
202.37\end{array}$ & ------- & $\begin{aligned}== & === \\
& 0.018\end{aligned}$ & $\begin{array}{r}====== \\
155937\end{array}$ & -- & -- & \\
\hline
\end{tabular}

Status Codes:

$R$ - Reference peak

$C$ - out of calibration range

S - Internal standard peak

Total Unidentified Counts : 1076342 counts

Detected Peaks: 113

Amount Standard: 1.000000

Rejected Peaks: 16

Multiplier: 1.000000
Identified Peaks: 10

Divisor: 1.000000

Baseline offset: 31 microvolts

Noise (used): 210 microvolts - monitored before this run

Manual injection

Data Handling: Result Out of Range 
Title : Determinacao de acidos haloaceticos

zun File : C: \STAR\MODULE16\6FEV013.RUN

Method File: C: \STAR\MODULE16\HAA5.MTH

Sample ID : PF Cl $30 \mathrm{~min}$

Injection Date: 9-JAN-4 9:34 AM Calculation Date: 9-JAN-4 10:15 AM

Jperator : PASCHOALATO, C Detector Type: ADCB (10 Volts)

Norkstation:

Instrument : star $3600 \mathrm{Cx}$

Bus Address : 16

Sample Rate : $10.00 \mathrm{~Hz}$

shannel: $\mathrm{B}=\mathrm{ECD}$

Run Time

$: 26.002 \mathrm{~min}$

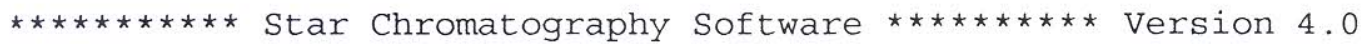

Run Mode : Analysis

Peak Measurement: Peak Area

Calculation Type: Internal standard

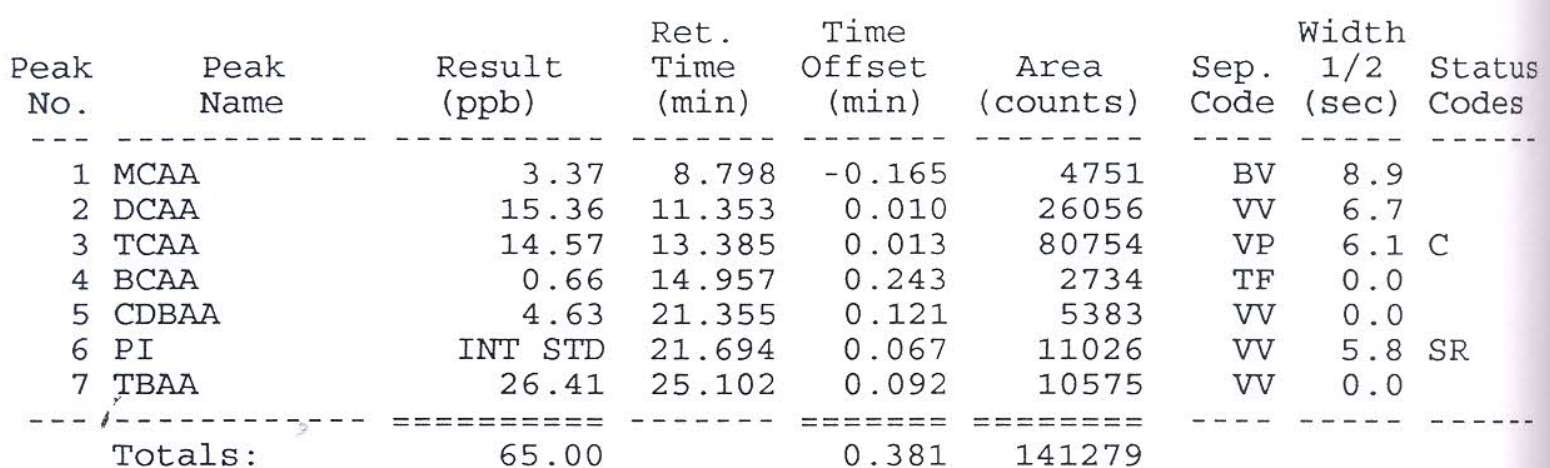

Status Codes:

R - Reference peak

$\therefore$ - Out of calibration range

S - Internal Standard peak

Total Unidentified Counts :

303390 counts

Detected Peaks: 77

Rejected Peaks: 41

Identified Peaks: 7

Amount Standard: 1.000000 Multiplier: 1.000000

Divisor: 1.000000

Baseline offset: -23 microvolts

Noise (used): 100 microvolts - monitored before this run

Manual injection

Jata Handling: Result Out of Range

Print Date: Fri Jan 09 10:17:09 2004

Page 1 of 1 
Title : Determinacao de acidos haloaceticos

Run File : C: \STAR\MODULE16\6FEV019.RUN

Method File : C: \STAR \MODULE16\HAA5.MTH

Sample ID : PF Cloro $168 \mathrm{~h}$

Injection Date: 9-JAN-4 2:21 PM Calculation Date: 9-JAN-4 2:48 PM

Operator : PASCHOALATO, C Detector Type: ADCB (10 Volts)

Workstation:

Instrument : star $3600 \mathrm{cx}$

Bus Address : 16

Sample Rate: $10.00 \mathrm{~Hz}$

Channel: $\mathrm{B}=\mathrm{ECD}$

Run Time : $26.002 \mathrm{~min}$

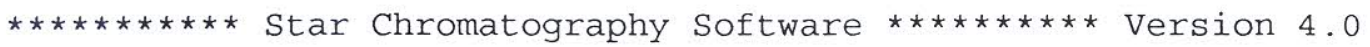

Run Mode : Analysis

Peak Measurement: Peak Area

Calculation Type: Internal standard

\begin{tabular}{|c|c|c|c|c|c|c|c|c|}
\hline & & & Ret. & Time & & \multicolumn{3}{|c|}{ width } \\
\hline Peak & Peak & Result & Time & Offset & Area & Sep. & $1 / 2$ & status \\
\hline No. & Name & (ppb) & (min) & (min) & (counts) & Code & (sec) & $\mathrm{Co}$ \\
\hline--- & $---\cdots-\cdots$ & 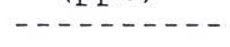 & $-\ldots-\cdots$ & $-\ldots-\cdots$ & $---\cdots--$ & $\ldots$ & $\ldots-$. & \\
\hline 1 & MCAA & 8.17 & 8.792 & -0.158 & 18544 & VV & 0.0 & \\
\hline 2 & DCAA & 87.40 & 11.336 & 0.009 & 238983 & $\mathrm{~PB}$ & 5.7 & $\mathrm{C}$ \\
\hline 3 & TCAA & 101.48 & 13.359 & 0.006 & 906353 & $\mathrm{BB}$ & 4.3 & C \\
\hline 4 & DBAA & 0.27 & 18.003 & 0.036 & 2118 & $\mathrm{BV}$ & 5.1 & \\
\hline 5 & PI & INT STD & 21.665 & 0.038 & 17771 & VB & 3.6 & SR \\
\hline 6 & TBAA & 3.37 & 24.988 & 0.012 & 2173 & $\mathrm{VV}$ & 0.0 & \\
\hline- & $\begin{array}{l}\text { Totals: } \\
\text { Total }\end{array}$ & $\begin{array}{r}======== \\
200.69\end{array}$ & $-\ldots . .-$ & $\begin{aligned}= & ===== \\
& -0.057\end{aligned}$ & $\begin{array}{l}====== \\
1185942\end{array}$ & --- & $-\ldots$ & \\
\hline
\end{tabular}

Status Codes:

R - Reference peak

C - Out of calibration range

S - Internal Standard peak

Total Unidentified Counts : 1474896 counts

Detected Peaks: 126

Rejected Peaks: 91

Identified Peaks: 6

Amount Standard: 1.000000 Multiplier: 1.000000

Divisor: 1.000000

Baseline offset: -8 microvolts

Noise (used): 150 microvolts - monitored before this run

Manual injection

Data Handing: Result Out of Range 


\section{APÊNDICE D}

D-01 Cromatograma do ensaio com pré-oxidação com cloro, filtração em papel, pós-cloração e incubação a $25^{\circ} \mathrm{C}$ com tempo de contato de $24 h-551$.

D-02 Eromatograma do ensaio com pré-oxidação com cloro, filtração em papel, pós-cloração e incubação a $25^{\circ} \mathrm{C}$ com tempo de contato de $24 h-552$.

D-03 Cromatograma do ensaio com pré-oxidação com cloro, coagulação filtração em papel, pós-cloração e incubação a $25^{\circ} \mathrm{C}$ com tempo de contato de $24 \mathrm{~h}-551$.

D-04 Cromatograma do ensaio com pré-oxidação com cloro, coagulação filtração em papel, pós-cloração e incubação a $25^{\circ} \mathrm{C}$ com tempo de contato de $24 h-552$. 
Title

Run File

Method File

Sample ID
Subprodutos organo-halogenados metodo 551.1 EPA C: \STAR\MODULE16\RCLCL026.RUN

C: \STAR \MODULE16\551.MTH

rCl-Cl s/C $24 \mathrm{~h}$
Injection Date: 25-MAY-4 9:46 PM

Operator : PASCHOALATO, C Workstation:

Instrument : star $3600 \mathrm{cx}$

Channel: $\mathrm{B}=\mathrm{ECD}$
Calculation Date: 25-MAY-4 10:06 PM Detector Type: ADCB (10 Volts) Bus Address : 16

Sample Rate: $10.00 \mathrm{~Hz}$

Run Time

$: 20.002 \mathrm{~min}$

$\star \star \star \star \star \star \star \star \star \star \star \star *$ Star Chromatography Software

Run Mode

: Analysis

Peak Measurement: Peak Area

Calculation Type: Internal Standard

$\begin{array}{rrrrrrr}\begin{array}{r}\text { Peak } \\ \text { No. }\end{array} & \begin{array}{c}\text { Peak } \\ \text { Name }\end{array} & \begin{array}{c}\text { Result } \\ \text { (ug/L) }\end{array} & \begin{array}{l}\text { Ret. } \\ \text { Time } \\ \text { (min) }\end{array} & \begin{array}{r}\text { Time } \\ \text { Offset } \\ \text { (min) }\end{array} & \begin{array}{c}\text { Area } \\ \text { (counts) }\end{array} & \begin{array}{r}\text { Sep. } \\ \text { Code }\end{array} \begin{array}{c}\text { Width } \\ \text { (sec) }\end{array} \text { Status } \\ \text { Codes }\end{array}$

Status Codes:

$R$ - Reference peak

$S$ - Internal Standard peak

Total Unidentified Counts :

48217 counts

Detected Peaks: 20

Rejected Peaks: 0

Identified Peaks: 6

Amount Standard: 1.000000

Multiplier: 1.000000

Divisor: 1.000000

Baseline offset: -22 microvolts

Noise (used) : 220 microvolts - monitored before this run

Manual injection 
Title

Run File

Method File

Sample ID

Determinacao de acidos haloaceticos

C: \STAR\MODULE16\RCLCL010.RUN

C: \STAR\MODULE16\552.MTH

$\mathrm{rCl}-\mathrm{Cl}$ s/c $24 \mathrm{~h}$

Injection Date: 21-MAY-4 12:14 PM

Operator : PASCHOALATO, C

Workstation:

Instrument : star $3600 \mathrm{cx}$

Channel

$\mathrm{B}=\mathrm{ECD}$

\section{Star Chromatography software}

Calculation Date: 21-MAY-4 12:41 PM

Chart Speed $=$
Start Time $=$

$0.77 \mathrm{~cm} / \mathrm{min}$

$0.000 \mathrm{~min}$

$\begin{aligned} \text { Attenuation } & =200 \\ \text { End Time } & =27\end{aligned}$

$=27.002 \mathrm{~min}$

Zero Offset $=5$ \%

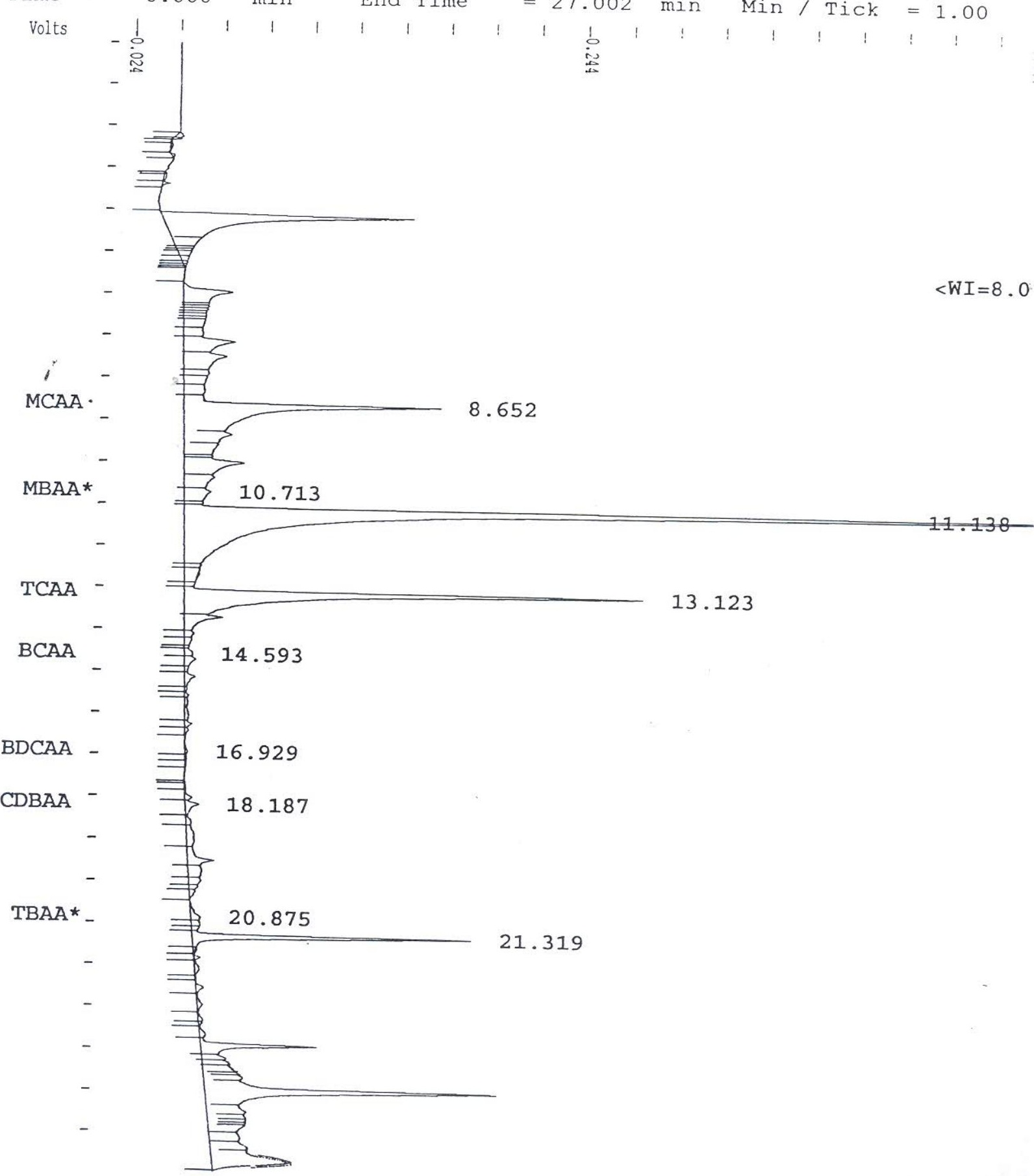

Detector Type: ADCB (10 Volts)

$: 10.00 \mathrm{~Hz}$ $27.002 \mathrm{~min}$

mple Rate

4.0 
Method File: C: \STAR\MODULE16\552.MTH

Sample ID : $\mathrm{rCl}-\mathrm{Cl}$ s/c $24 \mathrm{~h}$

Injection Date: 21-MAY-4 12:14 PM

Operator : PASCHOALATO, C Workstation:

Instrument : star $3600 \mathrm{Cx}$ Channel : $\mathrm{B}=\mathrm{ECD}$
Calculation Date: 21-MAY-4 12:41 PM Detector Type: ADCB (10 Volts) Bus Address : 16 Sample Rate : $10.00 \mathrm{~Hz}$ Run Time : $27.002 \mathrm{~min}$

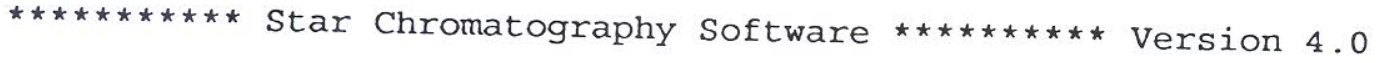

Run Mode : Analysis

Peak Measurement: Peak Area

Calculation Type: Internal Standard

\begin{tabular}{|c|c|c|c|c|c|c|c|c|}
\hline & & & Ret. & Time & & \multicolumn{3}{|c|}{ width } \\
\hline $\begin{array}{l}\text { Peak } \\
\text { No. }\end{array}$ & $\begin{array}{l}\text { Peak } \\
\text { Name }\end{array}$ & $\begin{array}{l}\text { Result } \\
(\mathrm{ug} / \mathrm{L})\end{array}$ & $\begin{array}{l}\text { Time } \\
\text { (min) }\end{array}$ & $\begin{array}{l}\text { Offset } \\
\text { (min) }\end{array}$ & Area & Sep. & $1 / 2$ & Stat \\
\hline--- & ----- & $\ldots \ldots$ & $\ldots \ldots$ &.--1 & $\begin{array}{l}\text { (counts) } \\
-------\end{array}$ & Code & (sec) & Code \\
\hline 1 & MCAA & 4.64 & 8.652 & -0.145 & 194315 & VV & 6. & \\
\hline 2 & MBAA & 4.50 & 10.713 & 0.009 & 22564 & VV & 0.0 & \\
\hline 3 & DCAA & 92.60 & 11.138 & 0.003 & 629679 & vV & 5.2 & C \\
\hline 4 & TCAA & 14.96 & 13.123 & 0.003 & 232660 & vV & 5.9 & C \\
\hline 5 & BCAA & 0.24 & 14.593 & 0.154 & 4024 & vV & 0.0 & \\
\hline 6 & $B D C A A$ & 0.13 & 16.929 & -0.071 & 1118 & VV & 0.0 & \\
\hline 7 & $\mathrm{CDBAA}$ & 8.51 & 18.187 & 0.074 & 6517 & VV & 7.8 & \\
\hline 8 & TBAA & 15.26 & 20.875 & 0.013 & 6259 & PV & 35.1 & \\
\hline 9 & PI & INT STD & 21.319 & -0.011 & 76094 & $\mathrm{VP}$ & 4.2 & \\
\hline - & $----1--$ & $======$ & ------ & $=======$ & $=======$ & -- & $\begin{array}{r}4.2 \\
----.\end{array}$ & SR \\
\hline & Totals: & 140.84 & & 0.029 & 1173230 & & & \\
\hline
\end{tabular}

Status Codes:

$R$ - Reference peak

C - Out of calibration range

$S$ - Internal standard peak

Total Unidentified Counts : 1151068 counts

Detected Peaks: 98

Amount Standard: 1.000000

Rejected Peaks: 17

Multiplier: 1.000000

Baseline Offset: 6 microvolts

Noise (used): 280 microvolts - monitored before this run

Manual injection

Data Handling: Result out of Range
Identified Peaks: 9

Divisor: 1.000000 
Method File: C: STAR\MODULE16\RCLCL030.RUN

Sample ID: :Cl-Cl AE 24h

Injection Date: 27-MAY-4 10:29 AM

Operator : PASCHOALATO, C Workstation:

Instrument : star $3600 \mathrm{cx}$

Channel : $\mathrm{B}=\mathrm{ECD}$

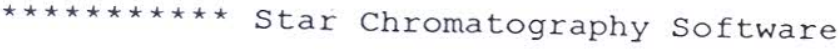

Calculation Date: 27-MAY-4 11:21 AM

Chart speed $=$

start Time

$$
1.04 \mathrm{~cm} / \mathrm{min}
$$

$0.000 \mathrm{~min}$

Attenuation $=150$

End Time

$=20$

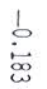

Detector Type: ADCB (10 Volts)

Bus Address : 16

ample Rate: $10.00 \mathrm{~Hz}$

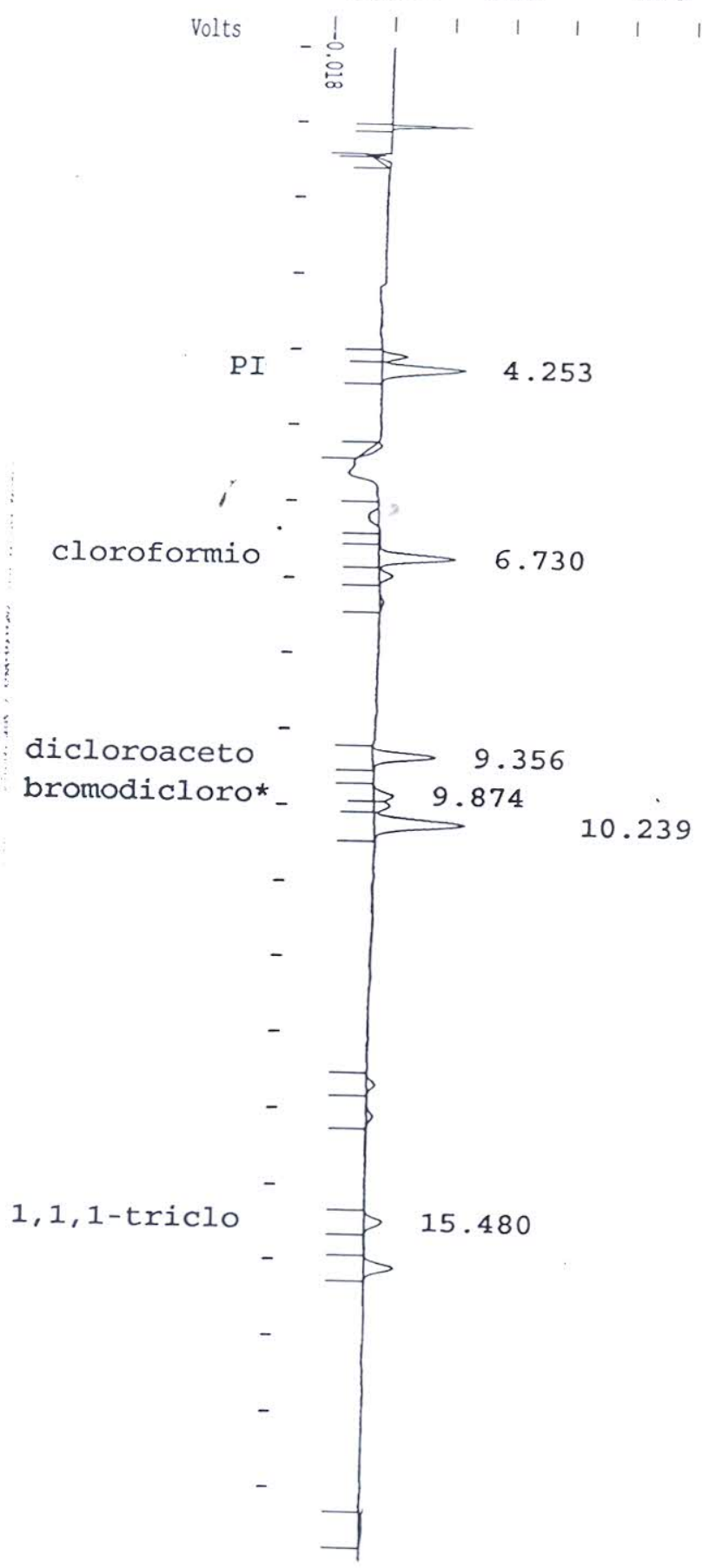

$<W I=2.0$

$<W I=4.0$

$<W I=8.0$ 
Injection Date: 27-MAY-4 10:29 AM

Operator : PASCHOALATO, C Workstation:

Instrument : star $3600 \mathrm{cx}$

Channel: $\mathrm{B}=\mathrm{ECD}$
Calculation Date: 27-MAY-4 11:21 AM

Detector Type: ADCB (10 Volts)

Bus Address : 16

Sample Rate : $10.00 \mathrm{~Hz}$

Run Time

Run Mode

Star Chromatography Software

: Analysis

Calcueasurement: Peak Area

Calculation Type: Internal Standard

\begin{tabular}{|c|c|c|c|c|c|c|c|c|}
\hline Peak & Peak & Result & Ret. & Time & & \multicolumn{3}{|c|}{ Width } \\
\hline No. & Name & $\begin{array}{l}\text { Result } \\
(\mathrm{ug} / \mathrm{L})\end{array}$ & $\begin{array}{l}\text { Time } \\
\text { (min) }\end{array}$ & $\begin{array}{l}\text { Offset } \\
\text { (min) }\end{array}$ & $\begin{array}{c}\text { Area } \\
\text { (counts) }\end{array}$ & Sep. & $1 / 2$ & Status \\
\hline 1 & PI & ----- & $--\cdots-$. & ------ & $-\ldots-.--$ & $\begin{array}{l}\text { code } \\
\ldots . . .-\end{array}$ & $\begin{array}{l}(\text { sec) } \\
-----\end{array}$ & Codes \\
\hline$\frac{1}{2}$ & Cloroformio & INT STD & 4.253 & -0.023 & 16961 & VB & 6.5 & $S R$ \\
\hline 3 & $\begin{array}{l}\text { clorotormio } \\
\text { dicloroaceto }\end{array}$ & 45.97 & 6.730 & 0.006 & 14513 & VV & 8.2 & \\
\hline 4 & $\begin{array}{l}\text { dicloroaceto } \\
\text { bromodicloro }\end{array}$ & 7.21 & 9.356 & 0.020 & 11897 & $\mathrm{BB}$ & 6.1 & \\
\hline 5 & $\begin{array}{l}\text { cromodicloro } \\
\text { cloral hidra }\end{array}$ & 2.35 & 9.874 & 0.018 & 4128 & $\mathrm{BV}$ & 6.8 & \\
\hline 6 & $\begin{array}{l}\text { cloral hidra } \\
1,1,1 \text {-triclo }\end{array}$ & $27 \cdot 32$ & 10.239 & 0.025 & 21630 & VB & 7.8 & \\
\hline & $\begin{array}{l}1, \perp, 1-\operatorname{CrIC\perp O} \\
-\cdots-\cdots\end{array}$ & $=====\begin{array}{r}3.38 \\
====\end{array}$ & 15.480 & 0.041 & 4008 & $\mathrm{BB}$ & 7.4 & \\
\hline & Totals: & $\begin{array}{r}=== \\
86.23\end{array}$ & & $\begin{array}{r}===== \\
0.087\end{array}$ & $\begin{array}{r}====== \\
73137\end{array}$ & -- & & \\
\hline
\end{tabular}

Status Códes:

R - Reference peak

$S$ - Internal standard peak

Total Unidentified Counts :

betected Peaks: 20

29442 counts

Amount Standard: 1.000000

Rejected Peaks : 2

Identified Peaks: 6

Multiplier: 1.000000

Divisor: 1.000000

Baseline Offset: -8 microvolts

Noise (used): 190 microvolts - monitored before this run

Manual injection 
Title : Determinacao de acidos haloaceticos

Run File : C:\STAR\MODULE16\RCLCL005.RUN

Method File : C: \STAR\MODULE16\552.MTH

Sample ID : rCl-Cl AE $24 \mathrm{~h}$

Injection Date: 19-MAY-4 3:57 AM

Calculation Date: 19-MAY-4 4:20 AM

Operator : PASCHOALATO, C

Workstation:

Instrument : star $3600 \mathrm{cr}$

Detector Type: ADCB (10 Volts)

Channel : $\mathrm{B}=\mathrm{ECD}$

Bus Address : 16

Sample Rate: $10.00 \mathrm{~Hz}$

Run Time : $23.002 \mathrm{~min}$

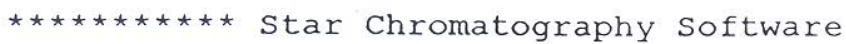

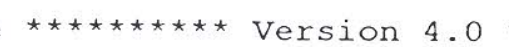

Chart Speed $=0.90 \mathrm{~cm} / \mathrm{min}$ Attenuation $=200$

start Time

$0.000 \mathrm{~min}$

End Time

Zero Offset $=5$ \%

Volts

$-\frac{1}{0}$

$\begin{array}{llll}1 & 1 & 1 \\ 0 & 1 & 1 & 1 \\ 0 & 1 & & -1\end{array}$

$=23.002 \mathrm{~min}$

Min / Tick

MCAA

$-$

立

$<W I=8.0$

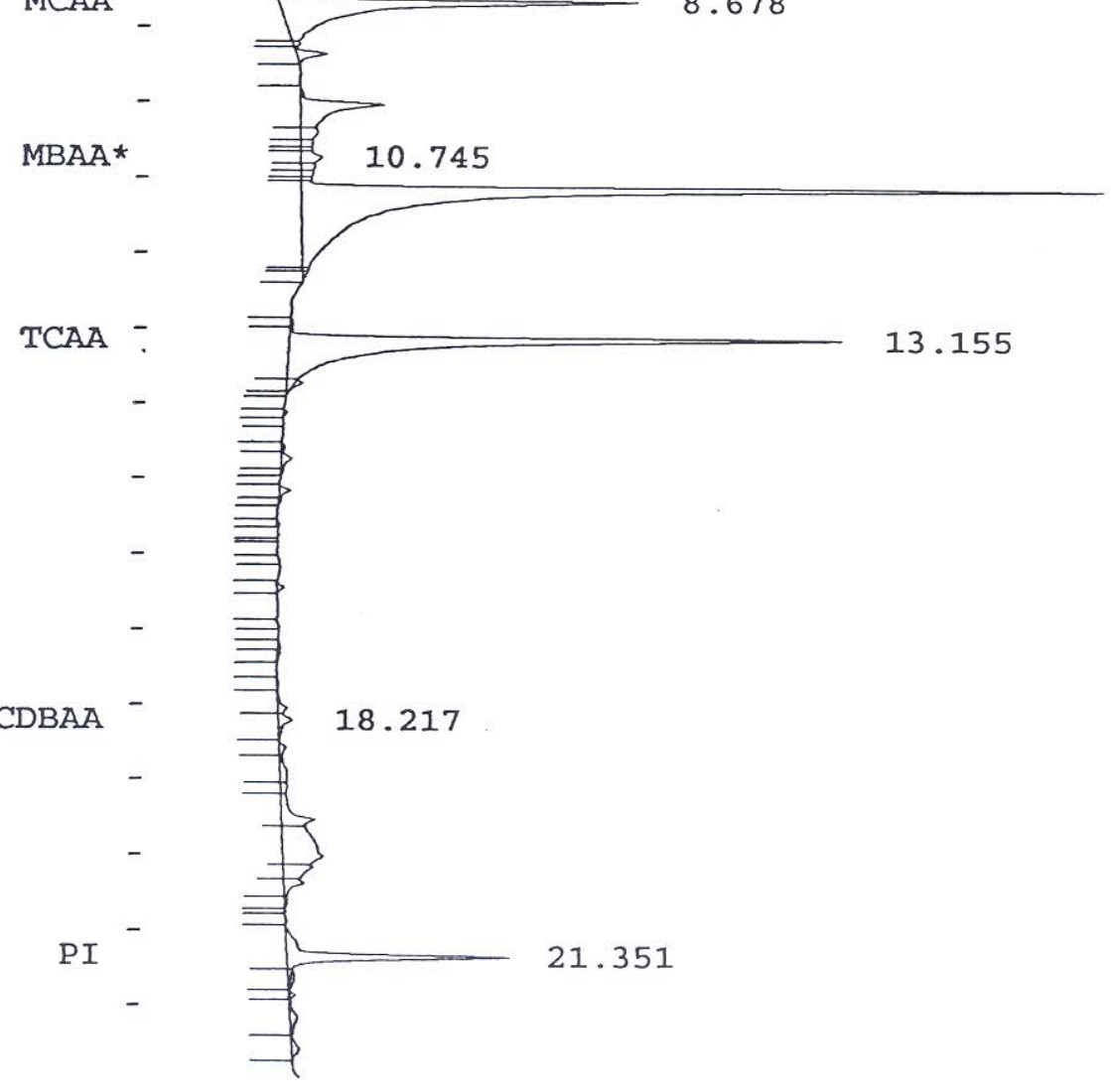

11.170

$<W I=4.0$

$<W I=8.0$ 
Method File: C: \STAR \MODULE16\RCLCL005.RUN

Sample ID : C: \STAR \MODULE16\552.MTH

: $\mathrm{rCl}-\mathrm{Cl} \mathrm{AE} \mathrm{24h}$

Injection Date: 19-MAY-4 3:57 AM

Calculation Date: 19-MAY-4 4:20 AM

Operator : PASCHOALATO, C

Workstation:

Instrument : star $3600 \mathrm{cx}$

Channel : $\mathrm{B}=\mathrm{ECD}$

Detector Type: ADCB (10 Volts)

Bus Address : 16

Sample Rate : $10.00 \mathrm{~Hz}$

Run Time

$: 23.002 \mathrm{~min}$

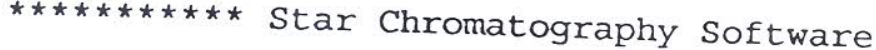

Run Mode

: Analysis

Peak Measurement: Peak Area

Calculation Type: Internal Standard

\begin{tabular}{|c|c|c|c|c|c|c|c|c|}
\hline Peak & Peak & Result & Ret. & Time & & \multicolumn{3}{|c|}{ Width } \\
\hline No. & Name & $(u g / L)$ & $\begin{array}{l}\text { Time } \\
\text { (min) }\end{array}$ & $\begin{array}{l}\text { Offset } \\
\text { (min) }\end{array}$ & $\begin{array}{c}\text { Area } \\
\text { (counts }\end{array}$ & Sep. & $1 / 2$ & Statu \\
\hline & & ------ & ------ & $-\cdots-\cdots$ & 1 & code & $\begin{array}{l}(\mathrm{sec}) \\
-\end{array}$ & $\mathrm{Cc}$ \\
\hline $\begin{array}{l}1 \\
2\end{array}$ & MCAA & 4.12 & 8.678 & -0.131 & 99029 & PV & 5.3 & \\
\hline $\begin{array}{l}2 \\
3\end{array}$ & MBAA & 1.86 & 10.745 & 0.025 & 5334 & VV & 0.0 & \\
\hline 4 & DCAA & 63.71 & 11.170 & 0.019 & 248621 & VB & 4.5 & C \\
\hline $\begin{array}{l}4 \\
5\end{array}$ & TCAA & 16.90 & 13.155 & 0.016 & 150892 & VB & 4.7 & $\mathrm{C}$ \\
\hline 6 & $\begin{array}{l}\text { CDBAA } \\
\text { PI }\end{array}$ & 8.40 & 18.217 & 0.078 & 3692 & VV & 7.3 & \\
\hline & $\begin{array}{l}P \perp \\
----\end{array}$ & $\begin{array}{l}\text { INT STD } \\
===ニ=ニ=~\end{array}$ & 21.351 & 0.020 & 43670 & PV & 4.1 & $S R$ \\
\hline & Totals: & 94.99 & -- & $\begin{array}{c}==== \\
0.027\end{array}$ & 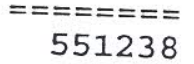 & - & -- & \\
\hline
\end{tabular}

Status dodes:

$R$ - Reference peak

C - Out of calibration range

S - Internal standard peak

Total Unidentified Counts

Detected Peaks: 65

Amount Standard: 1.000000

Rejected Peaks: 24

Identified Peaks: 6

Baseline offset: -10 microvolts

Divisor: 1.000000

Noise (used) : 290 microvolts - monitored before this run

Manual injection

Data Handling: Result Out of Range 


\section{APÊNDICE E}

E-01 Cromatograma do ensaio com pré-oxidação com permanganato de potássio, filtração em papel, pós-cloração e incubação a $25^{\circ} \mathrm{C}$ com tempo de contato de $24 \mathrm{~h}-551$.

E-02 Gromatograma do ensaio com pré-oxidação com permanganato de potássio, filtração em papel, pós-cloração e incubação a $25^{\circ} \mathrm{C}$ com tempo de contato de $24 \mathrm{~h}-552$.

E-03 Cromatograma do ensaio com pré-oxidação com permanganato de potássio, coagulação filtração em papel, pós-cloração e incubação a $25^{\circ} \mathrm{C}$ com tempo de contato de $24 \mathrm{~h}-551$.

E-04 Cromatograma do ensaio com pré-oxidação com permanganato de potássio, coagulação filtração em papel, pós-cloração e incubação a $25^{\circ} \mathrm{C}$ com tempo de contato de $24 \mathrm{~h}-552$. 
Title

: Determinacao de acidos haloaceticos

Run File

C: \STAR\MODULE16\KMNCL010.RUN

Method File : C: \STAR\MODULE16\552.MTH

Sample ID : KMn $\mathrm{Cl} 12 \mathrm{~h}$

Injection Date: 21-MAY-4 11:48 PM

Calculation Date: 22-MAY-4 0:15 AM

operator : PASCHOALATO, C

Workstation:

Instrument : star $3600 \mathrm{cx}$

Channel

: $\mathrm{B}=\mathrm{ECD}$

Detector Type: ADCB (10 Volts)

Bus Address : 16

Sample Rate : $10.00 \mathrm{~Hz}$

Run Time

: $27.002 \mathrm{~min}$

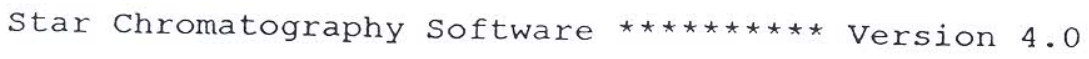

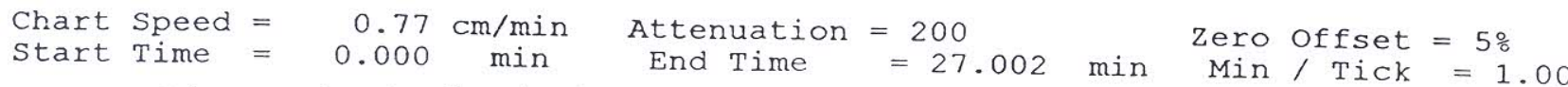

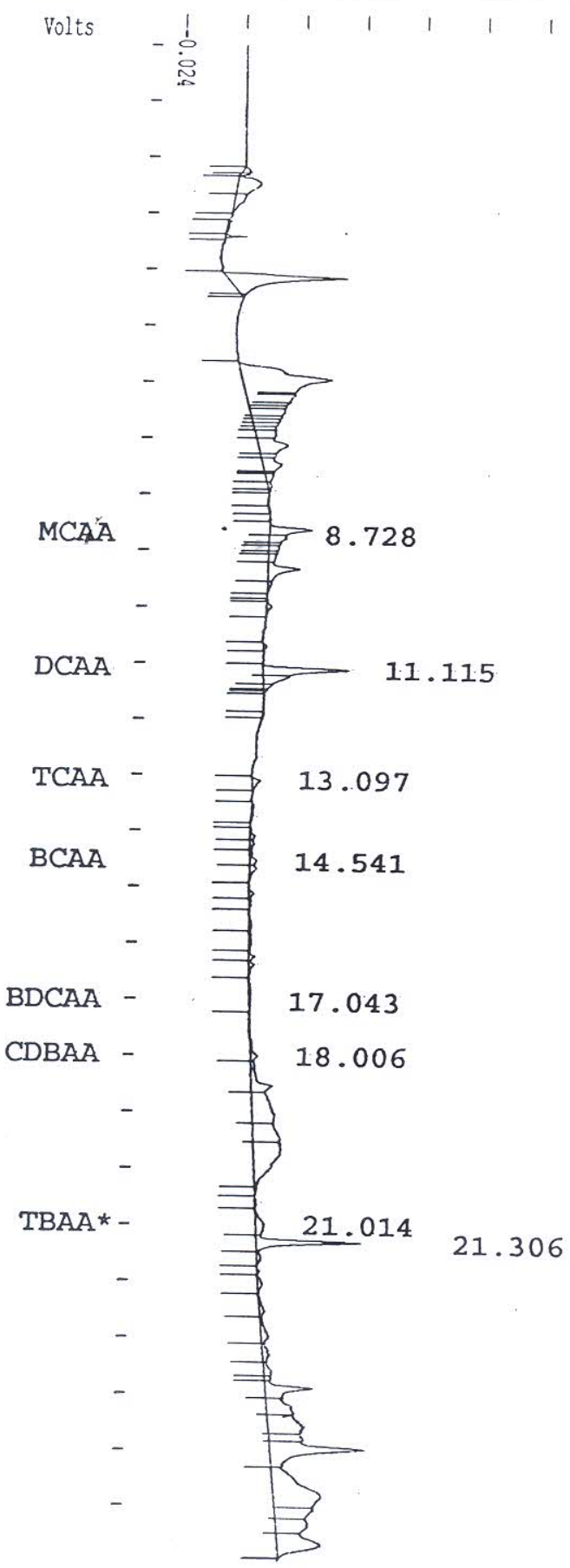

$<W I=2.0$

$<W I=4.0$

$<W I=8.0$

$<W I=16.0$ 
Title : Determinacao de acidos haloaceticos

Run File : C: \STAR\MODULE16 \kmnCl010.RUN

Method File : C: \STAR\MODULEI6\552.MTH

Sample ID : KMn Cl $12 \mathrm{~h}$ AIE

Injection Date: 21-MAY-4 11:48 PM

Calculation Date: 22-MAY-4 0:15 A

Operator : PASCHOALATO, C

Workstation:

Instrument : star $3600 \mathrm{cx}$

Detector Type: ADCB (10 Volts)

Channel : $\mathrm{B}=\mathrm{ECD}$

Bus Address : 16

Sample Rate : $10.00 \mathrm{~Hz}$

Run Time

: $27.002 \mathrm{~min}$

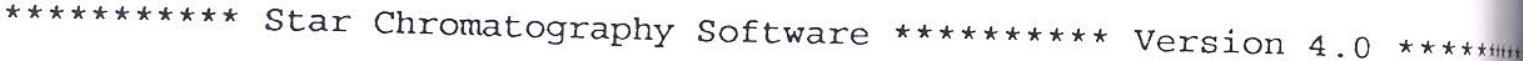

Run Mode

: Analysis

Peak Measurement: Peak Area

Calculation Type: Internal Standard

\begin{tabular}{|c|c|c|c|c|c|c|c|c|}
\hline $\begin{array}{l}\text { Peak } \\
\text { No. } \\
-\ldots-\end{array}$ & $\begin{array}{c}\text { Peak } \\
\text { Name }\end{array}$ & $\begin{array}{l}\text { Result } \\
(\mathrm{ug} / \mathrm{L})\end{array}$ & $\begin{array}{l}\text { Ret. } \\
\text { Time } \\
\text { (min) }\end{array}$ & $\begin{array}{l}\text { Time } \\
\text { Offset } \\
\text { (min) }\end{array}$ & $\begin{array}{c}\text { Area } \\
\text { (counts) }\end{array}$ & $\begin{array}{l}\text { Sep. } \\
\text { Code }\end{array}$ & $\begin{array}{c}\text { Width } \\
1 / 2 \\
\text { (sec) }\end{array}$ & $\begin{array}{l}\mathrm{St} \\
\mathrm{Co}\end{array}$ \\
\hline 1 & $\mathrm{MCAA}$ & 042 & ------ & ------ & $----\cdots--$ & $\cdots$ & $-\cdots-$ & \\
\hline 2 & DCAA & 0.42 & 8.728 & -0.063 & 4834 & VV & 4.7 & \\
\hline 3 & TCAA & 11.01 & 11.115 & -0.013 & 20371 & BV & 5.3 & \\
\hline 4 & $B C A A$ & $\begin{array}{l}0.51 \\
0.57\end{array}$ & 13.097 & -0.015 & 2175 & $\mathrm{BB}$ & 7.1 & \\
\hline 5 & BDCAA & $\begin{array}{l}0.57 \\
0.53 x\end{array}$ & 14.541 & 0.111 & 2588 & VV & 7.6 & \\
\hline 6 & CDBAA & $\begin{array}{r}0.53 x \\
12.27\end{array}$ & 17.043 & 0.054 & 1284 & PP & 50.5 & \\
\hline 7 & TBAA & $\begin{array}{l}12.27 \\
50.92\end{array}$ & 18.006 & -0.095 & 2558 & PV & 34.4 & \\
\hline 8 & BI & $\begin{array}{r}50.92 \\
\text { INT STD }\end{array}$ & 21.014 & 0.166 & 5682 & PV & 0.0 & \\
\hline- & $--\cdots-$. & $\begin{array}{l}\text { INT STD } \\
======\end{array}$ & 21.306 & -0.025 & 20705 & VV & 4.8 & $S R$ \\
\hline & Totals: & $\begin{aligned}= & == \\
& == \\
& 76.23\end{aligned}$ & ------ & $\begin{array}{r}===== \\
0.120\end{array}$ & $\begin{array}{r}====== \\
60197\end{array}$ & -- & $\ldots$ & \\
\hline
\end{tabular}

Status Codes:

$R$ - Reference peak

$S$ - Internal standard peak

Total Unidentified Counts : 592243 counts

Detected Peaks: 83

Rejected Peaks: 17

Identified Peaks: 8

Amount Standard: 1.000000 Multiplier: 1.000000

Divisor: 1.000000

Baseline offset: 16 microvolts

Noise (used): 290 microvolts - monitored before this run

Manual injection 
Title : Subprodutos organo-halogenados metodo 551.1 EPA

Run File : C:\STAR\MODULE16\KMNCL018.RUN

Method File : C: \STAR\MODULE16\551.MTH

Sample ID : KMn Cl AE $12 \mathrm{~h}$

Injection Date: 26-MAY-4 1:14 AM

Calculation Date: 26-MAY-4 1:34 AM

Operator : PASCHOALATO, C

Workstation:

Instrument : star $3600 \mathrm{cx}$

Detector Type: ADCB (10 Volts)

Bus Address : 16

Sample Rate : $10.00 \mathrm{~Hz}$

Run Time : $20.002 \mathrm{~min}$

Channel: $\mathrm{B}=\mathrm{ECD}$

Version 4.0

Chart Speed $=$

start Time

$1.04 \mathrm{~cm} / \mathrm{min}$ $0.000 \mathrm{~min}$

Volts

$$
\text { - }
$$

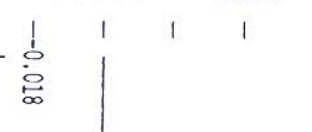

$\begin{aligned} \text { Attenuation } & =150 \\ \text { End Time } & =20 .\end{aligned}$

$=20.002 \mathrm{~min}$

$\begin{aligned} \text { Zero Offset } & =5 \% \\ \text { Min / Tick } & =1.00\end{aligned}$

Min / Tick $=1.00$
Minset

cloroformito

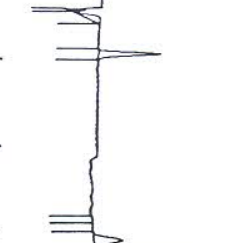

4.255

$<W I=4.0$

dicloroaceto

bromodicloro* -
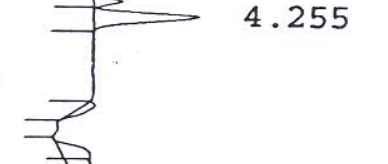

6.735

$<W I=8.0$

$1,1,1-$ triclo

15.500 
Title : Subprodutos organo-halogenados metodo 551.1 EPA

Run File C: \STAR\MODULE16\KMNCL018.RUN

Method File : C: \STAR\MODULE16\551.MTH

Sample ID

: KMn Cl AE $12 \mathrm{~h}$

Injection Date: 26-MAY-4 1:14 AM

Operator : PASCHOALATO, C

Workstation:

Instrument : star $3600 \mathrm{cx}$

Channel : $\mathrm{B}=\mathrm{ECD}$

Calculation Date: 26-MAY-4 1:34 AM

Detector Type: ADCB (10 Volts)

Bus Address : 16

Sample Rate: $10.00 \mathrm{~Hz}$

Run Time : $20.002 \mathrm{~min}$

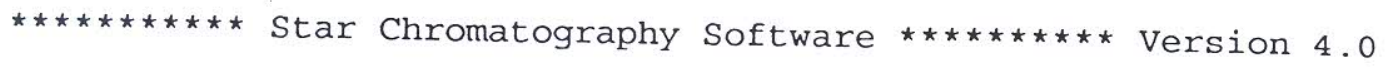

Run Mode : Analysis

Peak Measurement: Peak Area

Calculation Type: Internal Standard

\begin{tabular}{|c|c|c|c|c|c|c|c|c|}
\hline $\begin{array}{l}\text { Peak } \\
\text { No. }\end{array}$ & $\begin{array}{c}\text { Peak } \\
\text { Name }\end{array}$ & $\begin{array}{l}\text { Result } \\
\text { (ug/L) }\end{array}$ & $\begin{array}{l}\text { Ret. } \\
\text { Time } \\
\text { (min) }\end{array}$ & $\begin{array}{l}\text { Time } \\
\text { Offset } \\
\text { (min) }\end{array}$ & $\begin{array}{c}\text { Area } \\
\text { (counts) }\end{array}$ & $\begin{array}{l}\text { Sep. } \\
\text { Code }\end{array}$ & $\begin{array}{c}\text { width } \\
1 / 2 \\
\text { (sec) }\end{array}$ & $\begin{array}{l}\text { Status } \\
\text { Codes }\end{array}$ \\
\hline 1 & PI & INT STD & $--2-2-1$ & 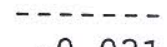 & ----- & ---- & ---- & \\
\hline 2 & cloroformio & $\begin{array}{r}1 N T S T D \\
25.41\end{array}$ & 4.255 & -0.021 & 18945 & VB & 6.7 & SR \\
\hline 3 & dicloroaceto & $\begin{array}{r}25.41 \\
3.12\end{array}$ & 6.735 & 0.007 & 8958 & $\mathrm{BB}$ & 5.9 & \\
\hline 4 & bromodicloro & $\begin{array}{l}3.12 \\
4.98\end{array}$ & 9.362 & 0.020 & 5759 & $\mathrm{BB}$ & 6.0 & \\
\hline 5 & cloral hidra & $\begin{array}{r}4.98 \\
19.88\end{array}$ & 10.012 & 0.149 & 9776 & BV & 7.3 & \\
\hline 6 & cloropicrina & $\begin{array}{r}19.88 \\
0.14\end{array}$ & 10.241 & 0.020 & 17581 & VB & 7.6 & \\
\hline 7 & $1,1,1$-triclo & $\begin{array}{l}0.14 \\
1.88\end{array}$ & 13.088 & 0.035 & 633 & $\mathrm{BB}$ & 7.2 & \\
\hline - & tr------ - - & $=====$ & $\begin{array}{r}15.500 \\
--.--.\end{array}$ & $\begin{array}{r}0.050 \\
======\end{array}$ & $\begin{array}{r}2488 \\
======ニ=\end{array}$ & $\begin{array}{r}\mathrm{BB} \\
---\end{array}$ & $\begin{array}{r}7.3 \\
-----\end{array}$ & \\
\hline & Totals: & 55.41 & & 0.260 & 64140 & & & \\
\hline
\end{tabular}

Status Codes:

$R$ - Reference peak

$S$ - Internal standard peak

Total Unidentified Counts :

57779 counts

Detected Peaks: 24

Rejected Peaks: 2

Identified Peaks: 7

Amount Standard: 1.000000 Multiplier: 1.000000

Divisor: 1.000000

Baseline offset: 18 microvolts

Noise (used): 200 microvolts - monitored before this run

Manual injection

Print Date: Wed May 26 04:11:47 2004

Page 1 of 1 
Title : Subprodutos organo-halogenados metodo 551.1 EPA

Run File : C: \STAR\MODULE16\KMNCL023.RUN

Method File : C: \STAR\MODULE16\551.MTH

Sample ID : : $\mathrm{KMn}-\mathrm{Cl}$ s/c $24 \mathrm{~h}$

Injection Date: 26-MAY-4 4:21 AM

operator : PASCHOALATO, C

Workstation:

Instrument : star $3600 \mathrm{cx}$

Channel: $\mathrm{B}=\mathrm{ECD}$
Calculation Date: 26-MAY-4 4:41 AM

Detector Type: ADCB (10 Volts)

Bus Address : 16

Sample Rate $: 10.00 \mathrm{~Hz}$

Run Time : $20.002 \mathrm{~min}$

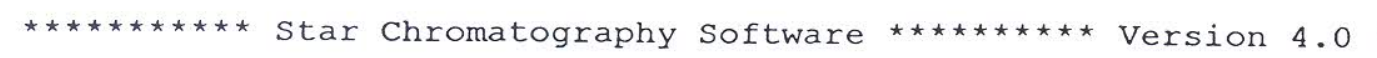

Chart Speed $=1.04 \mathrm{~cm} / \mathrm{min} \quad$ Attenuation $=150 \quad$ Zero offset $=5 \%$

Start $\mathrm{Time}=0.000 \mathrm{~min}$ End Time $=20.002 \mathrm{~min} \mathrm{Min} / \mathrm{Tick}=1.0$

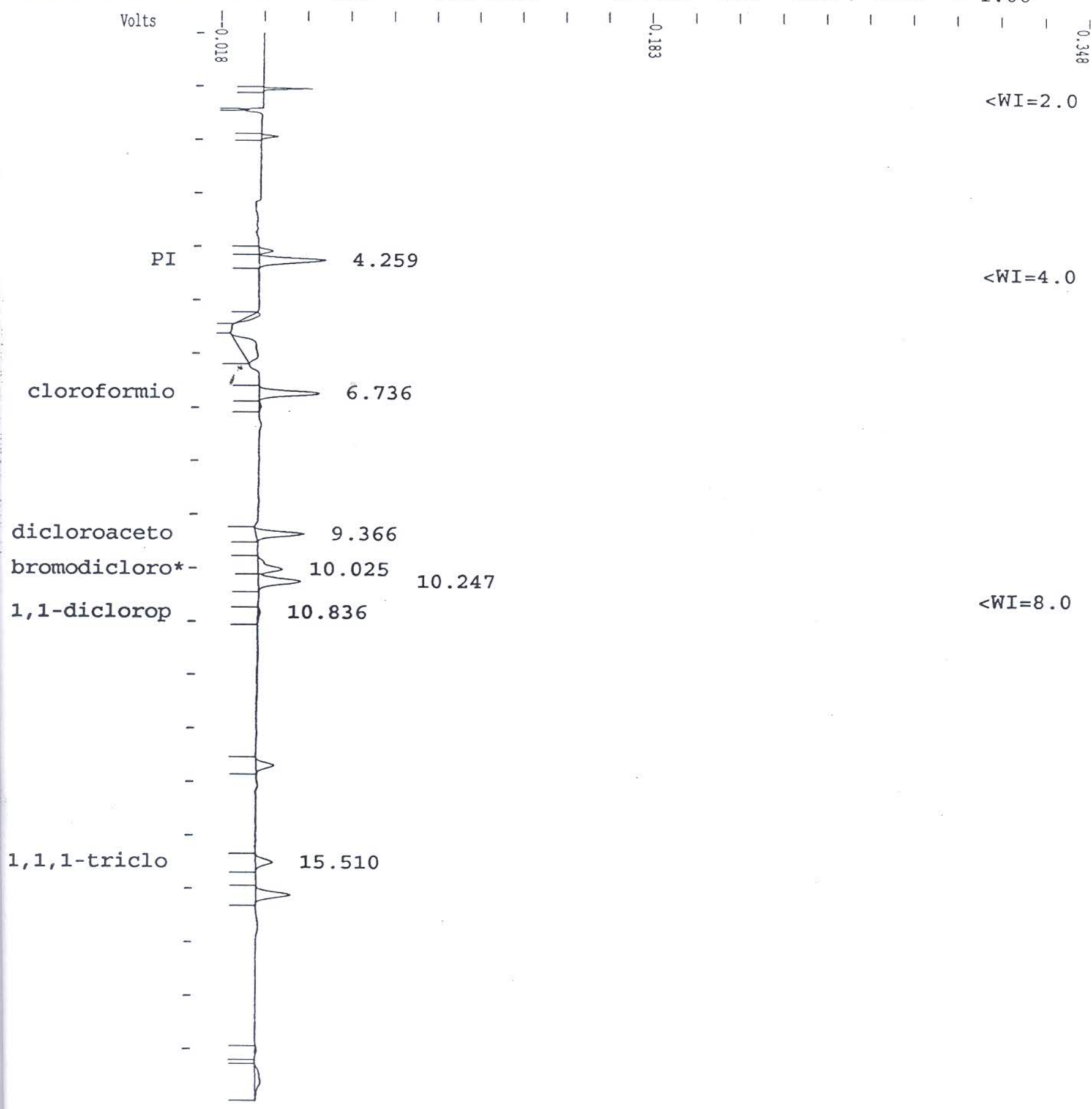




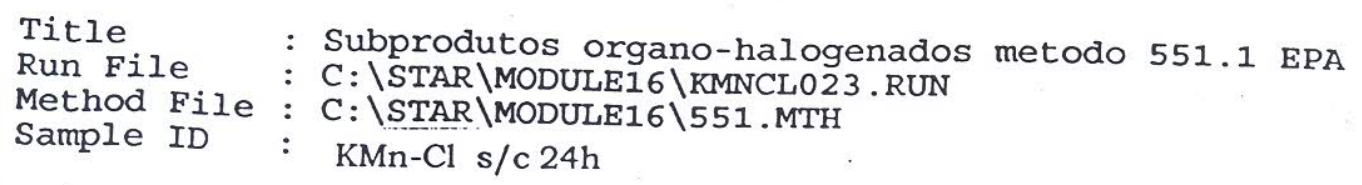

Injection Date: 26-MAY-4 4:21 AM Operator : PASCHOALATO, C Workstation:

Instrument : star $3600 \mathrm{Cx}$

Channel : $\mathrm{B}=\mathrm{ECD}$

Calculation Date: 26-MAY-4 4:41 AM Detector Type: ADCB (10 Volts)

Bus Address : 16

Sample Rate : $10.00 \mathrm{~Hz}$

Run Time : $20.002 \mathrm{~min}$

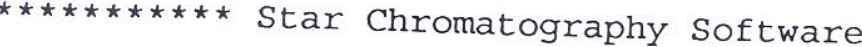

Run Mode

: Analysis

Peak Measurement: Peak Area

Calculation Type: Internal Standard

\begin{tabular}{|c|c|c|c|c|c|c|c|c|}
\hline $\begin{array}{c}\text { Peak } \\
\text { No. } \\
---\end{array}$ & $\begin{array}{c}\text { Peak } \\
\text { Name } \\
\end{array}$ & $\begin{array}{l}\text { Result } \\
\text { (ug/L) }\end{array}$ & $\begin{array}{l}\text { Ret. } \\
\text { Time } \\
\text { (min) }\end{array}$ & $\begin{array}{l}\text { Time } \\
\text { Offset } \\
\text { (min) }\end{array}$ & $\begin{array}{c}\text { Area } \\
\text { (counts) }\end{array}$ & $\begin{array}{l}\text { Sep. } \\
\text { Code }\end{array}$ & $\begin{array}{l}\text { Width } \\
1 / 2 \\
(\text { sec })\end{array}$ & $\begin{array}{l}\text { Status } \\
\text { Codes }\end{array}$ \\
\hline 1 & PI & INT STD & 4.259 & -0.017 & $\overline{7524}$ & ---- & ----- & \\
\hline 2 & cloroformio & 50.74 & 6.736 & 0.003 & 17524 & VB & 6.0 & SR \\
\hline 3 & dicloroaceto & 7.31 & 9.366 & 0.017 & 16548 & BB & 6.1 & \\
\hline 4 & bromodicloro & 4.76 & 10.025 & $0 \quad 154$ & 12461 & BB & 6.0 & \\
\hline 5 & cloral hidra & 17.21 & 10.247 & 0.154 & 8637 & BV & 7.1 & \\
\hline 6 & 1,1-diclorop & 0.73 & 10.836 & 0.018 & 14076 & VB & 7.6 & \\
\hline 7 & 1,1,1-triclo & 4.34 & 15.510 & 0.029 & 720 & $\mathrm{BB}$ & 6.5 & \\
\hline & $-1--------1$ & $====$ & $-1-1-1$ & $\begin{array}{r}0.049 \\
=======\end{array}$ & 5312 & $\mathrm{BB}$ & 7.1 & \\
\hline & Is: & 85.09 & & $\begin{array}{r}===== \\
0.253\end{array}$ & $\begin{array}{r}======= \\
75278\end{array}$ & - & & \\
\hline
\end{tabular}

Status Codes:

$R$ - Reference peak

$S$ - Internal Standard peak

Total Unidentified Counts :

Detected Peaks: 18

48958 counts

Amount Standard: 1.000000

Rejected Peaks: 3

Identified Peaks: 7

Baseline Offset: 4 microvolts

Multiplier: 1.000000

Divisor: 1.000000

Noise (used): 250 microvolts - monitored before this run

Manual injection 
ITitle : Determinacao de acidos haloaceticos

Run File : C: \STAR\MODULE16\KMNCL005.RUN

Method File : C: \STAR\MODULE16\552.MTH

Sample ID : KMn-Cl s/c 24h

Injection Date: 21-MAY-4 6:21 PM Calculation Date: 21-MAY-4 6:48 PM

Operator : PASCHOALATO, C

Workstation:

Instrument : star $3600 \mathrm{cx}$

Channel : $\mathrm{B}=\mathrm{ECD}$

Detector Type: $\mathrm{ADCB}$ (10 Volts)

Bus Address : 16

Sample Rate : $10.00 \mathrm{~Hz}$

Run Time : $27.002 \mathrm{~min}$

$\star \star \star \star \star \star \star \star * \star * *$ Star Chromatography Software

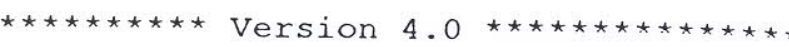

Chart speed $=$

start Time $=$

$0.77 \mathrm{~cm} / \mathrm{min}$

Attenuation $=200$

Zero offset $=5$ 응

$0.000 \mathrm{~min}$

End Time

$=27.002 \mathrm{~min}$

Min / Tick

$=1.00$

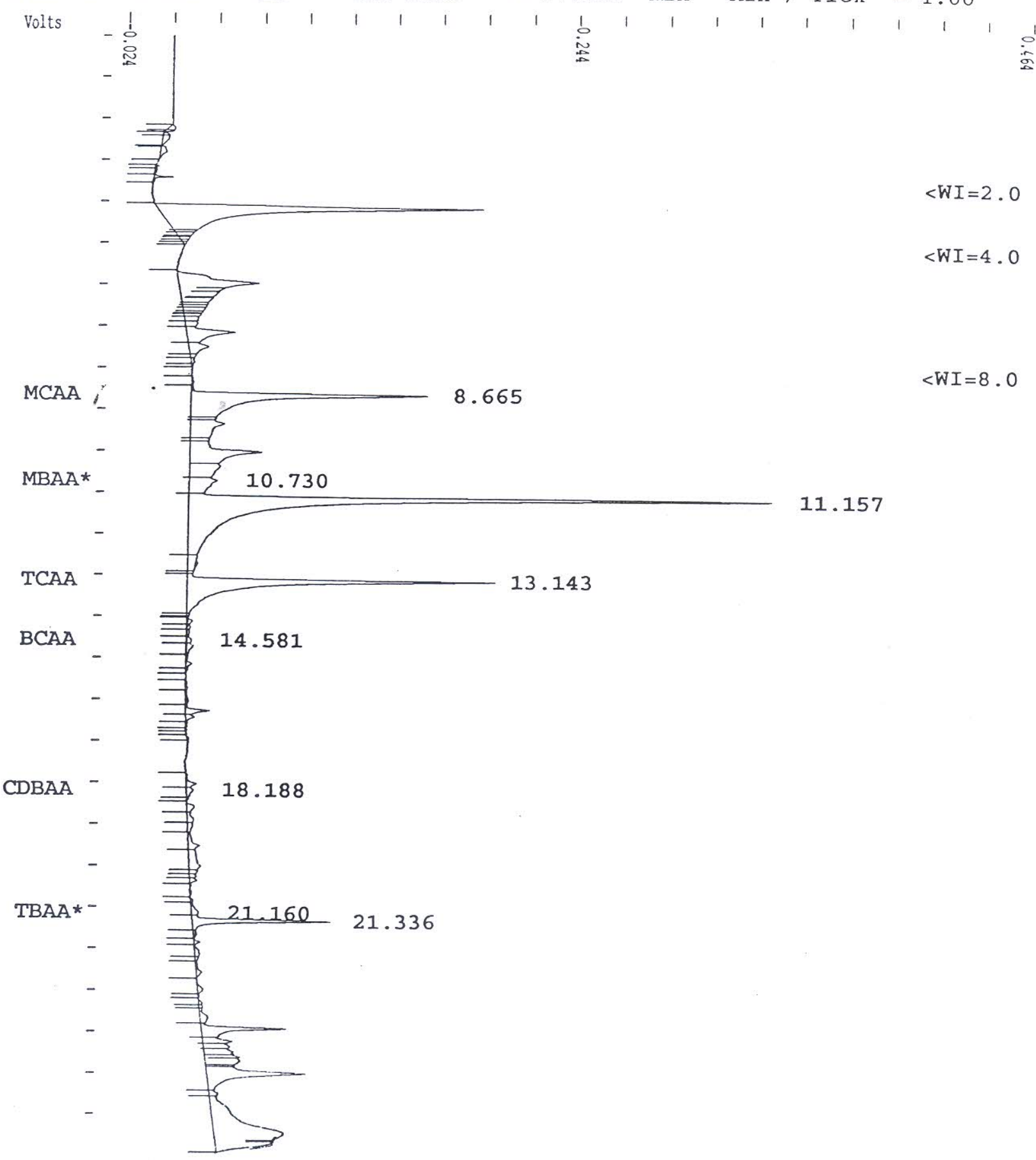




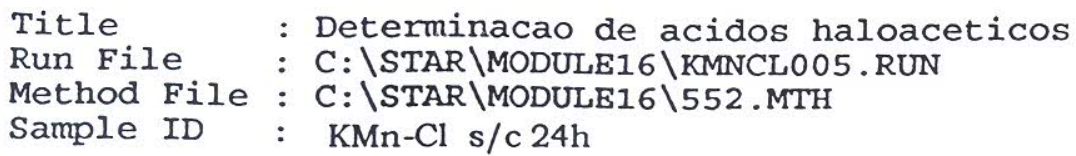

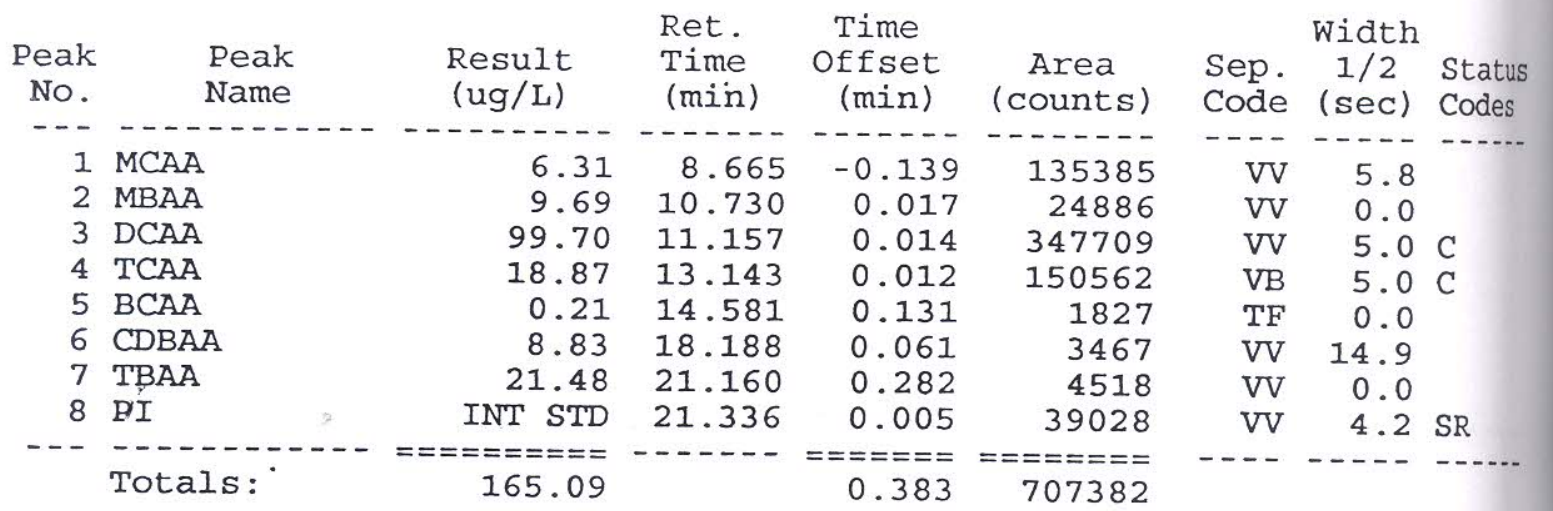

Status Codes:

$\mathrm{R}$ - Reference peak

$C$ - Out of calibration range

$S$ - Internal standard peak

Total Unidentified Counts :

896878 counts

Detected Peaks: 97

Rejected Peaks: 24

Identified Peaks: 8

Amount Standard: 1.000000 Multiplier: 1.000000

Divisor: 1.000000

Baseline offset: -6 microvolts

Noise (used) : 310 microvolts - monitored before this run

Manual injection

Data Handling: Result Out of Range 


\section{APÊNDICE F}

F-01 Cromatograma do ensaio da pré-oxidação com dióxido de cloro, filtração em papel, pós-cloração, incubação a $25^{\circ} \mathrm{C}$ com tempo de contato de $12 \mathrm{~h}$, método 551.

F-02 Cromatograma do ensaio da pré-oxidação com dióxido de cloro, filtração em papel, pós-cloração, incubação a $25^{\circ} \mathrm{C} \mathrm{com}$ tempo de contato de $12 \mathrm{~h}$, método 552.

F-03 Cromatograma do ensaio da pré-oxidação com dióxido de cloro, coagulação, filtração em papel, pós-cloração, incubação a $25^{\circ} \mathrm{C}$ com tempo de contato de $12 \mathrm{~h}$, método 551.

F-04 Cromatograma do ensaio da pré-oxidação com dióxido de cloro, coagulação, filtração em papel, pós-cloração, incubação a $25^{\circ} \mathrm{C}$ com tempo de contato de $12 \mathrm{~h}$, método 552. 
Title : Subprodutos organo-halogenados metodo 551.1 EPA

Run File : C:\STAR\MODULE16\DIOCLO10.RUN

Method File : C: \STAR \MODULE16\551.MTH

Sample ID : Diox-Cl s/c $12 \mathrm{~h}$

Injection Date: 2-JUN-4 4:29 PM Calculation Date: 2-JUN-4 4:50 PM

Operator : PASCHOALATO, C Detector Type: ADCB (10 Volts)

Workstation:

Instrument : star $3600 \mathrm{cx}$

Bus Address : 16

Channel : $\mathrm{B}=\mathrm{ECD}$

Sample Rate: $10.00 \mathrm{~Hz}$

Run Time : $20.002 \mathrm{~min}$

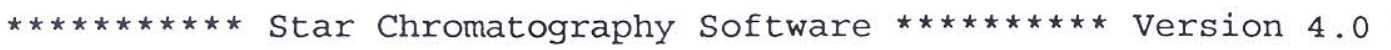

Run Mode : Analysis

Peak Measurement: Peak Area

Calculation Type: Internal standard

\begin{tabular}{|c|c|c|c|c|c|c|c|c|}
\hline & & & Ret & Time & & \multicolumn{3}{|c|}{ Width } \\
\hline eak & Peak & Result & Time & Offset & Area & Sep. & $1 / 2$ & status \\
\hline No. & Name & $(u g / L)$ & (min) & (min) & (counts) & Code & (sec) & $\mathrm{Cc}$ \\
\hline - - & $-\cdots---1-1$ & $\ldots-\cdots$ & $\ldots-\cdots$ & $\ldots \ldots$ & $\ldots \ldots$ & $\ldots$ & $-\ldots-$ & $\ldots$ \\
\hline 1 & $\mathrm{PI}$ & INT STD & 4.275 & -0.018 & 16007 & VB & 6.3 & SR \\
\hline 2 & cloroformio & 74.72 & 6.760 & 0.004 & 22903 & $\mathrm{BB}$ & 6.1 & \\
\hline 3 & dicloroaceto & 5.96 & 9.387 & 0.015 & 9562 & $\mathrm{BB}$ & 6.0 & \\
\hline 4 & bromodicl & 2.15 & 9.914 & 0.018 & 3675 & BV & 6.9 & \\
\hline 5 & cloral hidra & 19.83 & 10.271 & 0.020 & 15504 & VB & 7.6 & \\
\hline 6 & cloropicrina & 0.22 & 13.117 & 0.023 & 840 & $\mathrm{BB}$ & 6.0 & \\
\hline 7 & $1,1,1$-triclo & 3.60 & 15.528 & 0.035 & 3954 & $\mathrm{BB}$ & 7.8 & \\
\hline- & $y-\cdots$ & $====$ = $=$ = $=$ = & $-\cdots$ & $=======$ & $=======$ & ---- & $\ldots-$. & -- \\
\hline
\end{tabular}

Status Codes:

R - Reference peak

$S$ - Internal standard peak

Total Unidentified Counts :

43165 counts

Detected Peaks: $23 \quad$ Rejected Peaks: 2

Identified Peaks: 7

Amount Standard: 1.000000 Multiplier: 1.000000

Divisor: 1.000000

Baseline Offset: -5 microvolts

Noise (used): 200 microvolts - monitored before this run

Manual injection

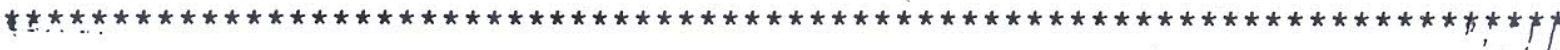

Print Date: Wed Jun 02 16:52:22 2004

Page 1 of 1 
Method File : C: \STAR\MODULE16\551.MTH

Sample ID : Diox-Cl s/c $12 \mathrm{~h}$

Injection Date: 2-JUN-4 4:29 PM

Calculation Date: 2-juN-4 4:50 PM

Operator : PASCHOALATO, C

Workstation:

Instrument : star $3600 \mathrm{cx}$

Detector Type: ADCB (10 Volts)

Channel

$: \mathrm{B}=\mathrm{ECD}$

Bus Address : 16

Sample Rate : $10.00 \mathrm{~Hz}$

Run Time: $20.002 \mathrm{~min}$

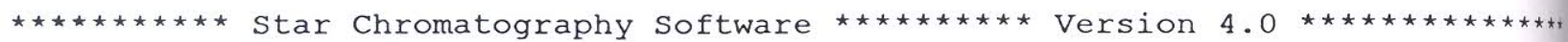

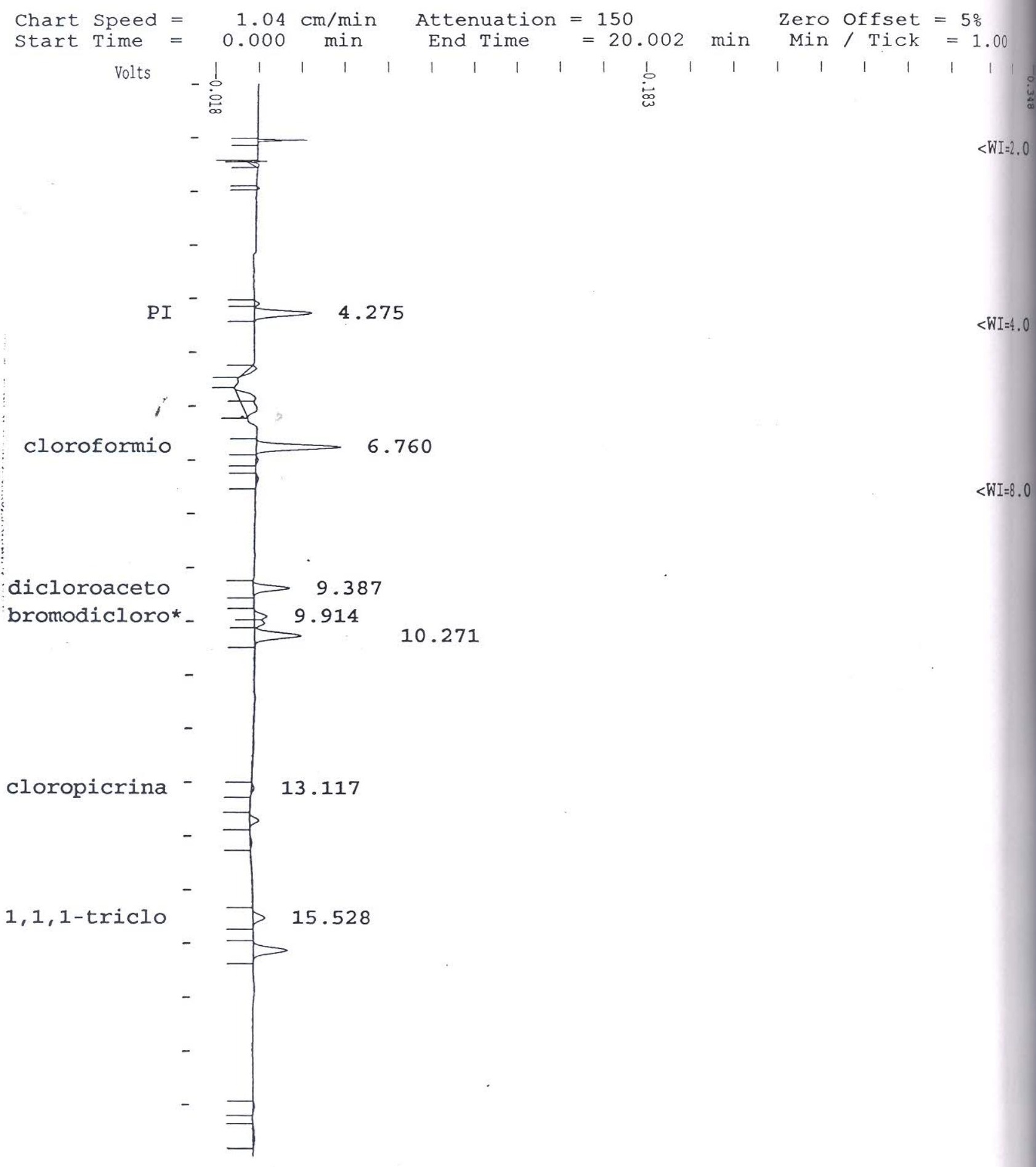




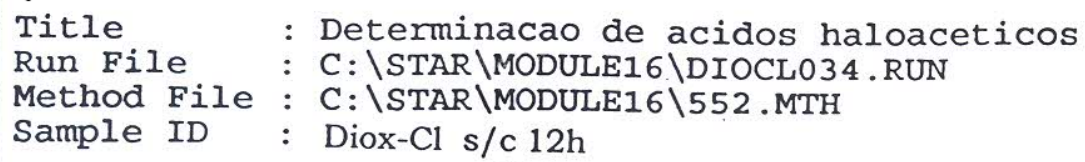

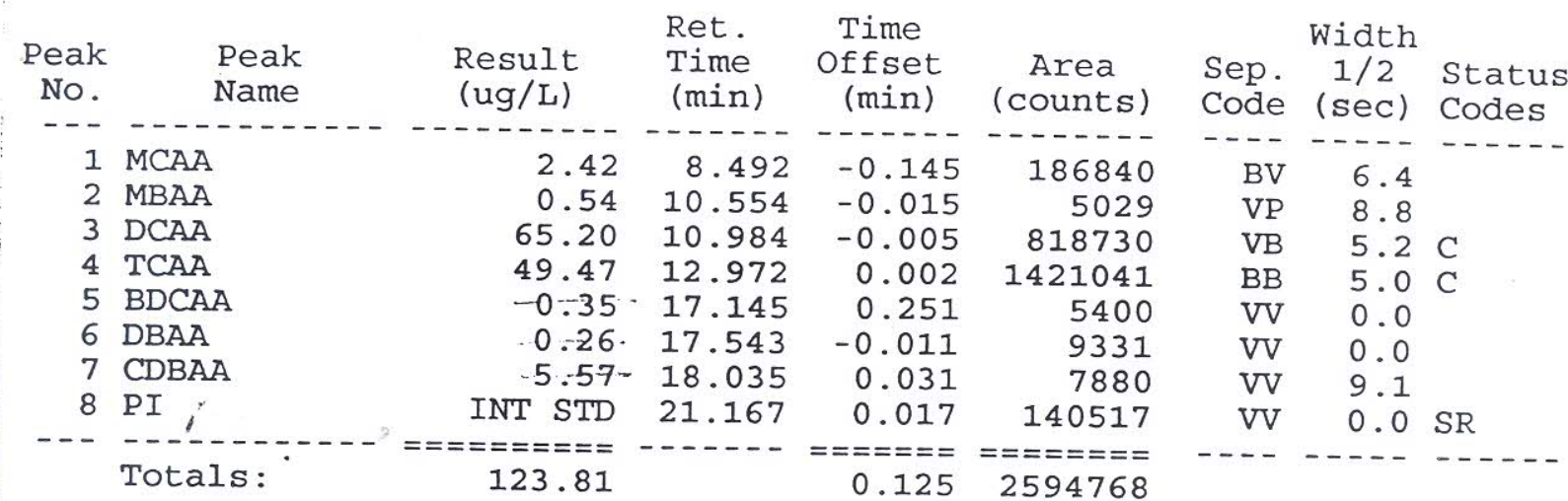

Status Codes:

$\mathrm{R}$ - Reference peak

$C$ - Out of calibration range

$S$ - Internal standard peak

Total Unidentified Counts : 1257800 counts

Detected Peaks: 85

Rejected Peaks: 53

Identified Peaks: 8

Amount Standard: 1.000000 Multiplier: 1.000000

Divisor: 1.000000

Baseline Offset: -27 microvolts

Noise (used): 270 microvolts - monitored before this run

Manual injection

Data Handling: Result Out of Range 
Title : Determinacao de acidos haloaceticos

Run File : C: \STAR\MODULEI6\DIOCL034.RUN

Method File : C: \STAR\MODULE16\552.MTH

Sample ID : Diox-Cl s/c $12 \mathrm{~h}$

Injection Date: 8-JUN-4 4:52 PM Calculation Date: 8-JUN-4 5:19 PM

Operator : PASCHOALATO, C

Workstation:

Instrument : star $3600 \mathrm{cx}$

Detector Type: ADCB (10 Volts)

Channel

$$
\text { : } \mathrm{B}=\mathrm{ECD}
$$

Bus Address : 16

Sample Rate : $10.00 \mathrm{~Hz}$

Run Time : $27.002 \mathrm{~min}$

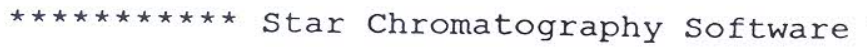

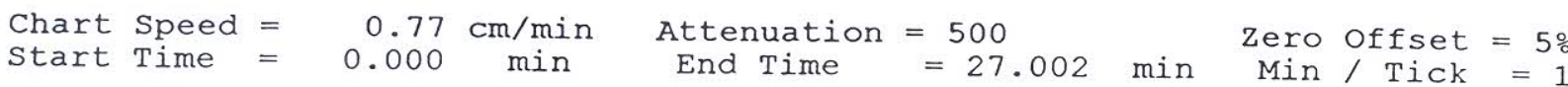

웅

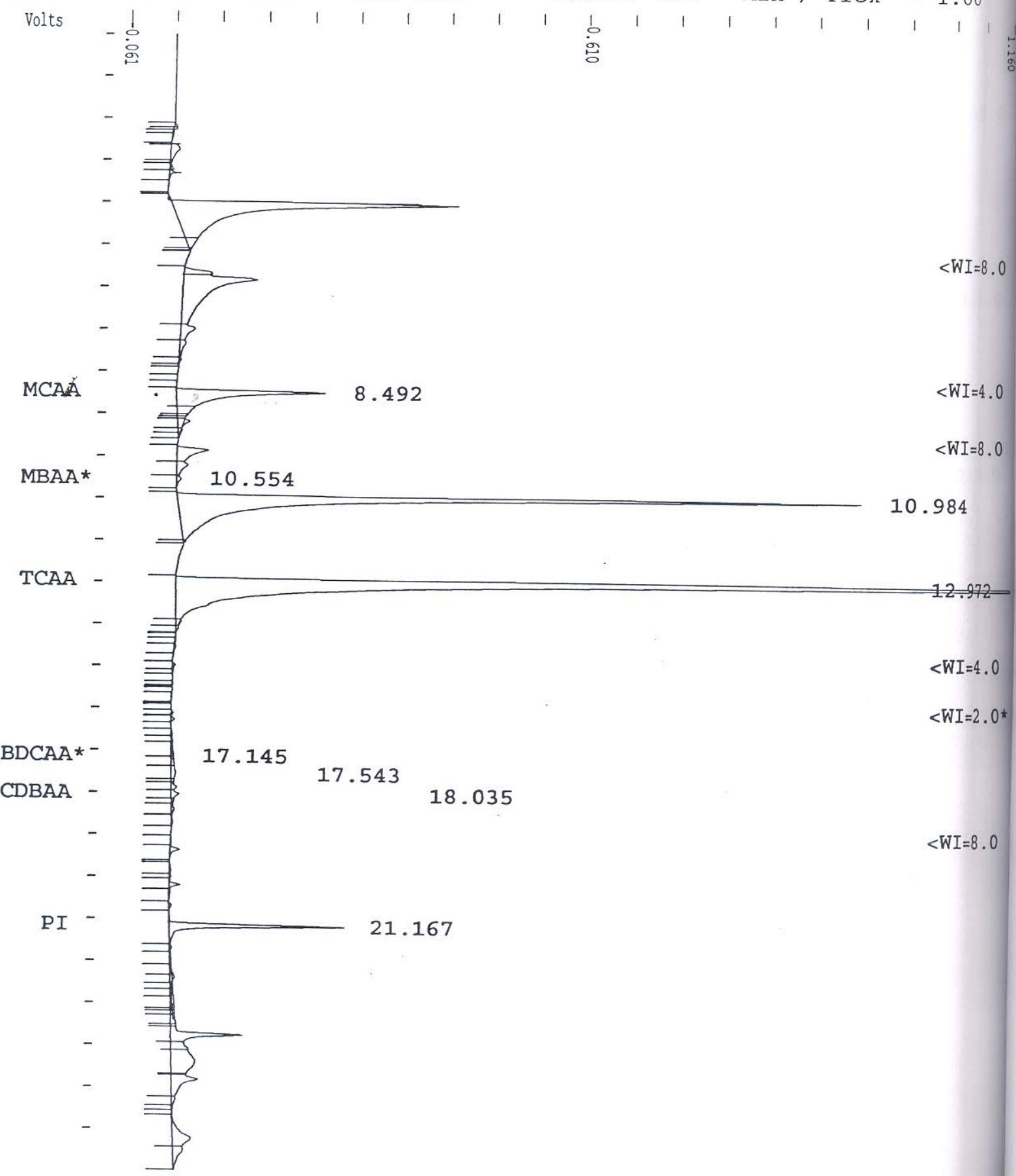




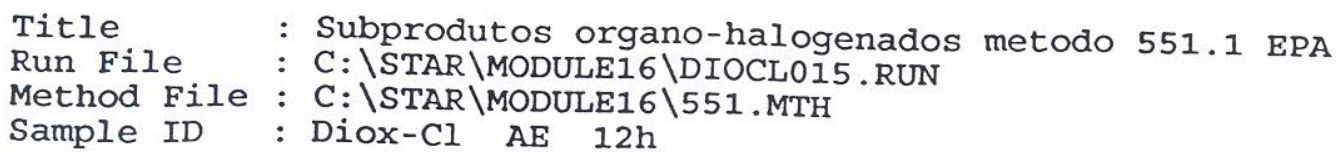

Injection Date: 3-JUN-4 10:20 AM

Calculation Date: 3-JUN-4 10:40 AM

Operator : PASCHOALATO, C

Workstation:

Instrument : star $3600 \mathrm{Cx}$

Channel

: $\mathrm{B}=\mathrm{ECD}$

Detector Type: ADCB (10 Volts)

Bus Address : 16

Sample Rate : $10.00 \mathrm{~Hz}$

Run Time

\section{$\star \star \star \star \star \star \star \star \star \star \star * *$ Star Chromatography Software}

Run Mode

Peak Measurement: Peak Area

Calculation Type: Internal Standard

\begin{tabular}{|c|c|c|c|c|c|c|c|c|}
\hline & & & Ret. & Time & & \multicolumn{3}{|c|}{ Width } \\
\hline $\begin{array}{l}\text { Peak } \\
\text { No. }\end{array}$ & $\begin{array}{l}\text { Peak } \\
\text { Name }\end{array}$ & $\begin{array}{l}\text { Result } \\
(\mathrm{ug} / \mathrm{L})\end{array}$ & $\begin{array}{l}\text { Time } \\
\text { (min) }\end{array}$ & $\begin{array}{l}\text { Offset } \\
\text { (min) }\end{array}$ & $\begin{array}{c}\text { Area } \\
\text { (counts) }\end{array}$ & $\begin{array}{l}\text { Sep. } \\
\text { Code }\end{array}$ & $\begin{array}{c}1 / 2 \\
(\text { sec })\end{array}$ & $\begin{array}{l}\text { Status } \\
\text { Codes }\end{array}$ \\
\hline-- & 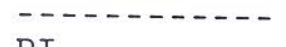 & - - - - - & ------ & $----\cdots$ & $-----\cdot-$ & --- & ---- & $---\cdots$ \\
\hline 1 & PI & INT STD & 4.267 & -0.026 & 12669 & VB & 5.4 & $S R$ \\
\hline 2 & cloroformio & 30.18 & 6.751 & 0.007 & 7117 & $\mathrm{BB}$ & 5.9 & \\
\hline 3 & dicloroaceto & 3.08 & 9.383 & 0.028 & 3905 & $\mathrm{BB}$ & 5.9 & \\
\hline 4 & bromodicloro & 2.91 & 9.908 & 0.031 & 3935 & BV & 6.6 & \\
\hline 5 & cloral hidra & 12.83 & 10.264 & 0.032 & 7661 & VB & 7.5 & \\
\hline 6 & cloropicrina & 0.19 & 13.117 & 0.046 & 558 & $\mathrm{BB}$ & 6.7 & \\
\hline 7 & $1,1,1$-triclo & 2.18 & 15.530 & 0.065 & 1883 & $\mathrm{BB}$ & 7.1 & \\
\hline . & Totals: & $\begin{array}{r}===== \\
51.37\end{array}$ & & $\begin{array}{r}== \\
0.183\end{array}$ & $\begin{array}{r}====== \\
37728\end{array}$ & - & -- & \\
\hline
\end{tabular}

Status Codes:

$R$ - Reference peak

$S$ - Internal Standard peak

Total Unidentified Counts : 35998 counts

Detected Peaks: 27

Rejected Peaks: 6

Identified Peaks: 7

Amount Standard: 1.000000

Multiplier: 1.000000

Divisor: 1.000000

Baseline offset: -5 microvolts

Noise (used) : 130 microvolts - monitored before this run

Manual injection 
Title : Subprodutos organo-halogenados metodo $551.1 \mathrm{EPA}$

Run File : C: \STAR\MODULE16\DIOCLO15.RUN

Method File : C: \STAR\MODULE16\551.MTH

Sample ID : Diox-Cl AE $12 \mathrm{~h}$

Injection Date: $3-J U N-4$ 10:20 AM

Calculation Date: 3-JUN-4 10:40 AM

Operator : PASCHOALATO, C

Workstation:

Instrument : star $3600 \mathrm{cx}$

Detector Type: $\mathrm{ADCB}$ (10 Volts)

Bus Address : 16

Sample Rate : $10.00 \mathrm{~Hz}$

Channel

: $\mathrm{B}=\mathrm{ECD}$

Run Time: $20.002 \mathrm{~min}$

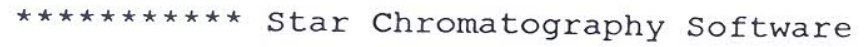

$\star \star \star \star \star \star \star \star \star$ Version 4.0

Chart speed $=$

start Time

$1.04 \mathrm{~cm} / \mathrm{min}$

0.000

$\min$

Attenuation $=150$

End Time $=20.002 \mathrm{~min}$

Zero Offset $=5 \%$

Volts

1
-0
0
0
0 品

Min / Tick $=1.00$

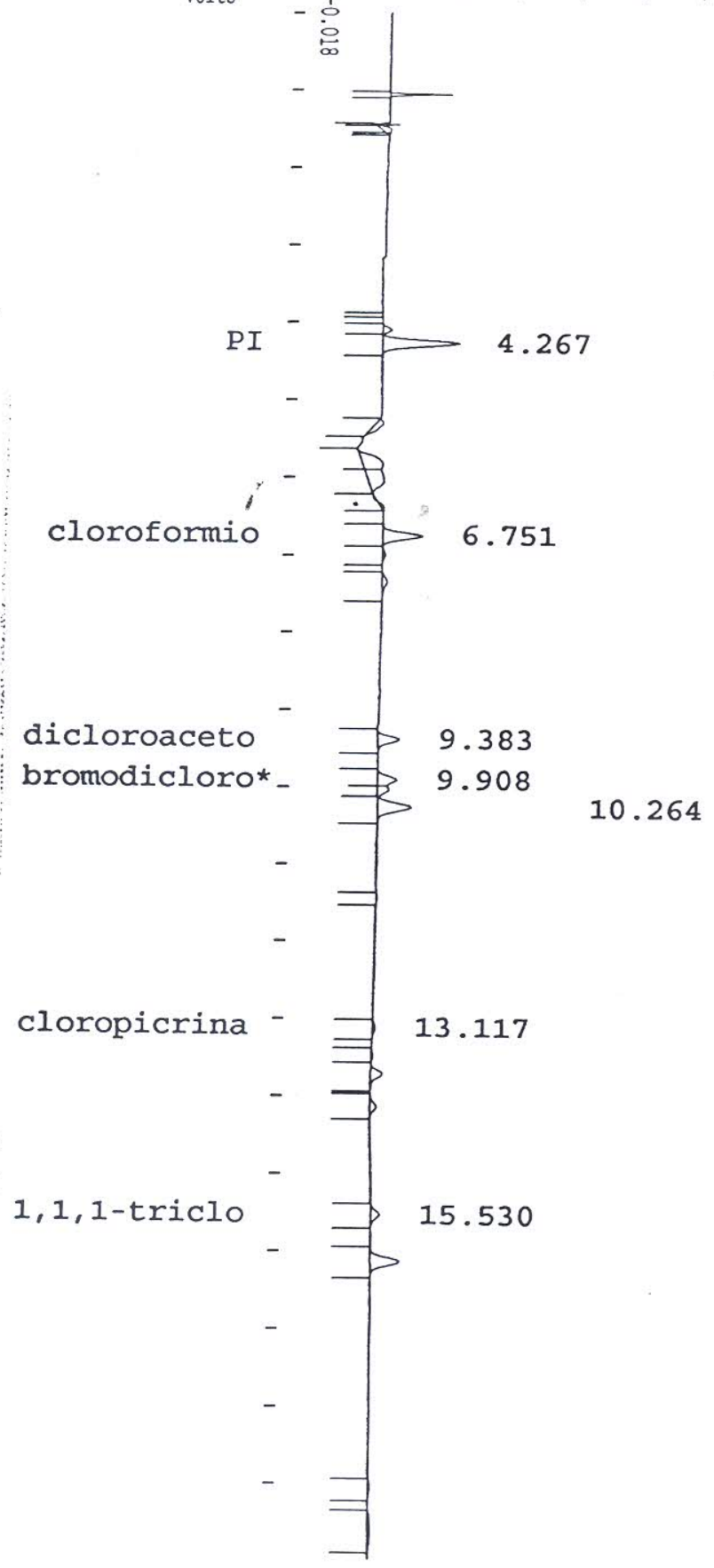

$<W I=8.0$ 


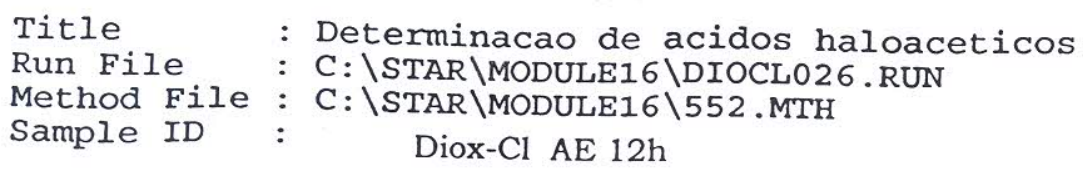

Injection Date: 8-JUN-4 9:18 AM

Calculation Date: 6-AUG-4 11:47 PM

Operator: PASCHOALATO, C

Workstation:

Instrument : star $3600 \mathrm{cx}$

Channel

Detector Type: $\mathrm{ADCB}$ (10 Volts)

Bus Address : 16

Sample Rate : $10.00 \mathrm{~Hz}$

Run Time : $27.002 \mathrm{~min}$

$\star \star \star \star \star * \star * * * \star$ Star Chromatography Software

Run Mode

: Analysis

Peak Measurement: Peak Area

Calculation Type: Internal Standard

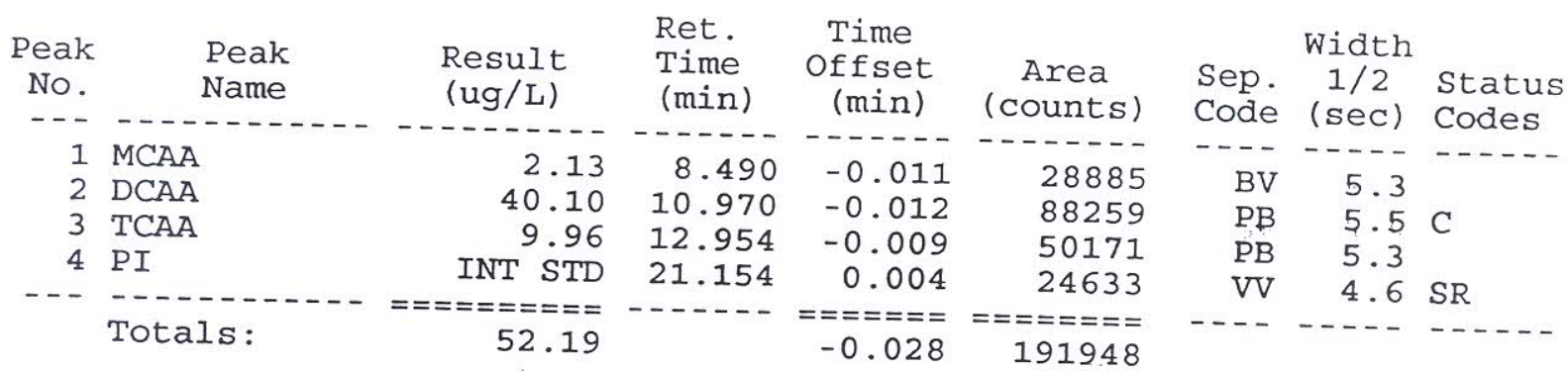

Status Codes:

R - Reference peak

C - Out of calibration range

S - Internal Standard peak

Total Unidentified Counts :

783708 counts

Detected Peaks: 127

Rejected Peaks: 86

Identified Peaks: 4

Amount Standard: 1.000000

Multiplier: 1.000000

Divisor: 1.000000

Baseline offset: -3 microvolts

Noise (used) : 200 microvolts - monitored before this run

Manual injection

Data Handling: Result out of Range 
Title : Determinacao de acidos haloaceticos

Run File: C: \STAR\MODULE16\DIOCL026.RUN

Method File : C: \STAR\MODULE16\552.MTH

Sample ID : Diox-Cl AE $12 \mathrm{~h}$

Injection Date: 8-JUN-4 9:18 AM

Calculation Date: 6-AUG-4 11:47 PM

Operator : PASCHOALATO, C

Workstation:

Instrument : star $3600 \mathrm{cx}$

Channel: $\mathrm{B}=\mathrm{ECD}$

Detector Type: ADCB (10 Volts)

Bus Address : 16

Sample Rate : $10.00 \mathrm{~Hz}$

Run Time : $27.002 \mathrm{~min}$

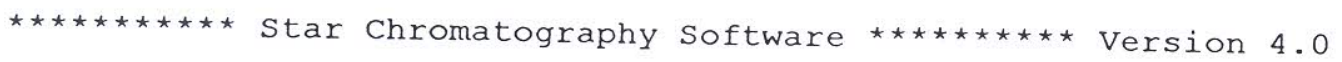

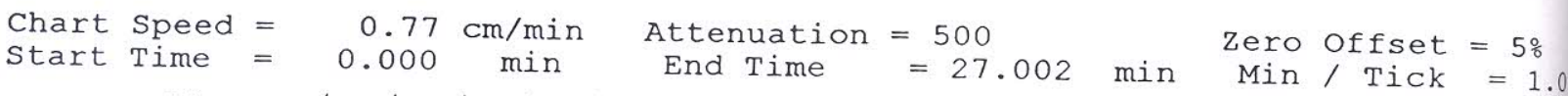

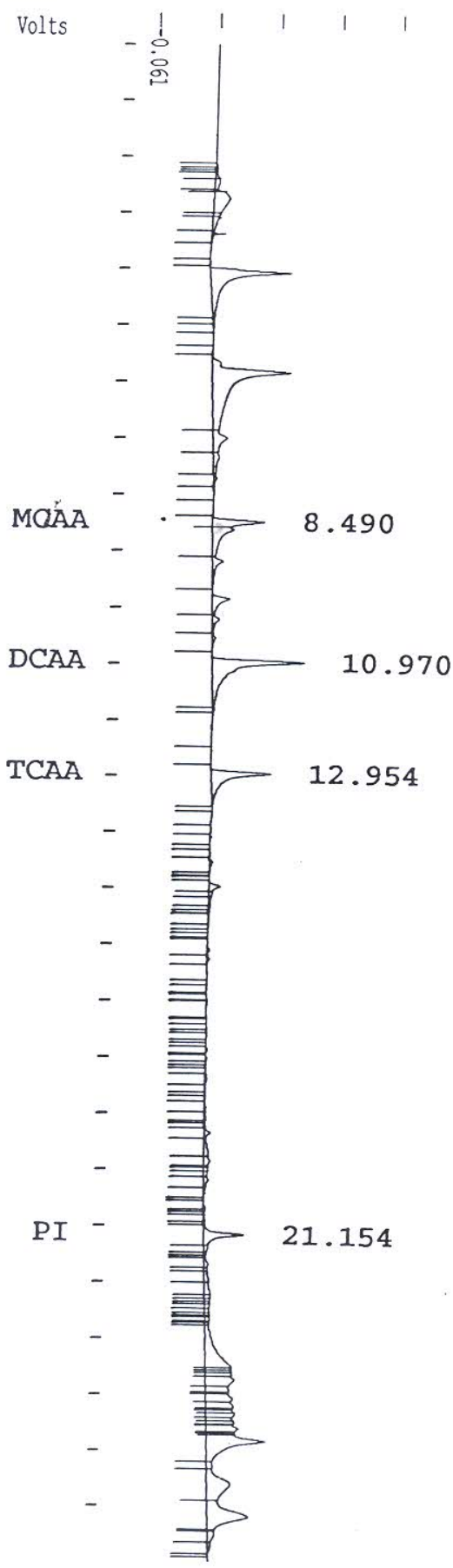




\section{APÊNDICE G}

G-01 Cromatograma do ensaio com pré-oxidação com peróxido de hidrogênio, filtração em papel, pós-cloração e incubação a $25^{\circ} \mathrm{C}$ com tempo de contato de $24 \mathrm{~h}-551$.

G-02 Cromatograma do ensaio com pré-oxidação com peróxido de Kidrogênio, filtração em papel, pós-cloração e incubação a $25^{\circ} \mathrm{C}$ com tempo de contato de $24 \mathrm{~h}-552$.

G -03 Cromatograma do ensaio com pré-oxidação com peróxido de hidrogênio, coagulação filtração em papel, pós-cloração e incubação a $25^{\circ} \mathrm{C}$ com tempo de contato de $24 \mathrm{~h}-551$.

G-04 Cromatograma do ensaio com pré-oxidação com peróxido de hidrogênio, coagulação filtração em papel, pós-cloração e incubação a $25^{\circ} \mathrm{C}$ com tempo de contato de $24 \mathrm{~h}-552$. 
Title : Subprodutos organo-halogenados metodo 551.1 EPA

Run File: C: \STAR\MODULE16\PEROX013.RUN

Method File : C:\STAR\MODULE16\551.MTH

Sample ID : Perox $-\mathrm{Cl}$ s/c $24 \mathrm{~h}$

Injection Date: 4-JUN-4 11:22 AM Calculation Date: 4-JUN-4 11:42 AM

Operator : PASCHOALATO, C Detector Type: ADCB (10 Volts)

Workstation: Bus Address: 16

Instrument : star $3600 \mathrm{cx} \quad$ Sample Rate : $10.00 \mathrm{~Hz}$

Channel : $\mathrm{B}=\mathrm{ECD} \quad$ Run Time $: 20.002 \mathrm{~min}$

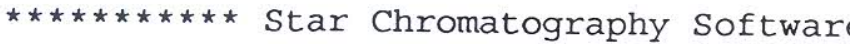

Run Mode : Analysis

Peak Measurement: Peak Area

Calculation Type: Internal Standard

\begin{tabular}{|c|c|c|c|c|c|c|c|c|}
\hline & & & Ret. & Time & & \multicolumn{3}{|c|}{ width } \\
\hline $\begin{array}{l}\text { Peak } \\
\text { No. }\end{array}$ & $\begin{array}{l}\text { Peak } \\
\text { Name }\end{array}$ & $\begin{array}{l}\text { Result } \\
\text { (ug/L) }\end{array}$ & $\begin{array}{l}\text { Time } \\
\text { (min) }\end{array}$ & $\begin{array}{l}\text { Offset } \\
\text { (min) }\end{array}$ & $\begin{array}{c}\text { Area } \\
\text { (counts) }\end{array}$ & $\begin{array}{l}\text { Sep. } \\
\text { Code }\end{array}$ & $\begin{array}{c}1 / 2 \\
\text { (sec) }\end{array}$ & $\begin{array}{l}\text { Status } \\
\text { Codes }\end{array}$ \\
\hline-- & ------ & -------- & ------ & ------ & ------- & ---- & $-\cdots$ & \\
\hline 1 & PI & INT STD & 4.245 & -0.048 & 9039 & VB & 4.9 & SR \\
\hline 2 & cloroformio & 19.27 & 6.727 & 0.019 & 3242 & $\mathrm{BB}$ & 5.8 & \\
\hline 3 & cloral hidra & 5.56 & 10.010 & -0.168 & 2370 & $\mathrm{BB}$ & 7.2 & \\
\hline 4 & dibromocloro & 1.58 & 13.693 & 0.324 & 1270 & $\mathrm{BB}$ & 7.2 & \\
\hline- & Totals: & $\begin{array}{r}======== \\
26.41\end{array}$ & ------ & $\begin{aligned}== & ==== \\
& 0.127\end{aligned}$ & $\begin{array}{r}====== \\
15921\end{array}$ & ---- & ---- & -- \\
\hline
\end{tabular}

Status Codes:

$\mathrm{R}$ - Reference peak

S - Internal standard peak

Total Unidentified Counts :

Detected Peaks: 11

27941 counts

Rejected Peaks: 1

Multiplier: 1.000000

Identified Peaks: 4

Amount Standard: 1.000000

Baseline offset: 1 microvolts

Noise (used): 260 microvolts - monitored before this run

Manual injection 
Title : Subprodutos organo-halogenados metodo $551.1 \mathrm{EPA}$

Run File : C: \STAR\MODULE16\PEROX013.RUN

Method File : C: \STAR \MODULE16\551.MTH

Sample ID : Perox-Cl s/c $24 \mathrm{~h}$

Injection Date: 4-JUN-4 11:22 AM

Calculation Daté: 4-JUN-4 11:42 AM

Operator : PASCHOALATO, C

Workstation:

Instrument : star $3600 \mathrm{cx}$

Detector Type: ADCB (10 Volts)

Bus Address : 16

Sample Rate: $10.00 \mathrm{~Hz}$

Channel

: $\mathrm{B}=\mathrm{ECD}$

Run Time

: $20.002 \mathrm{~min}$

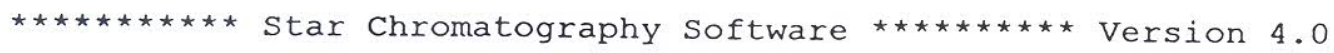

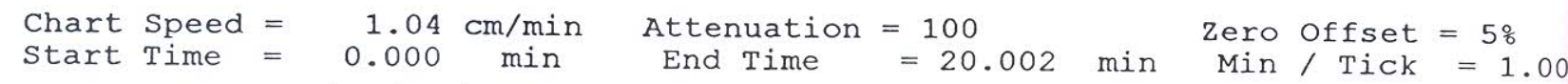

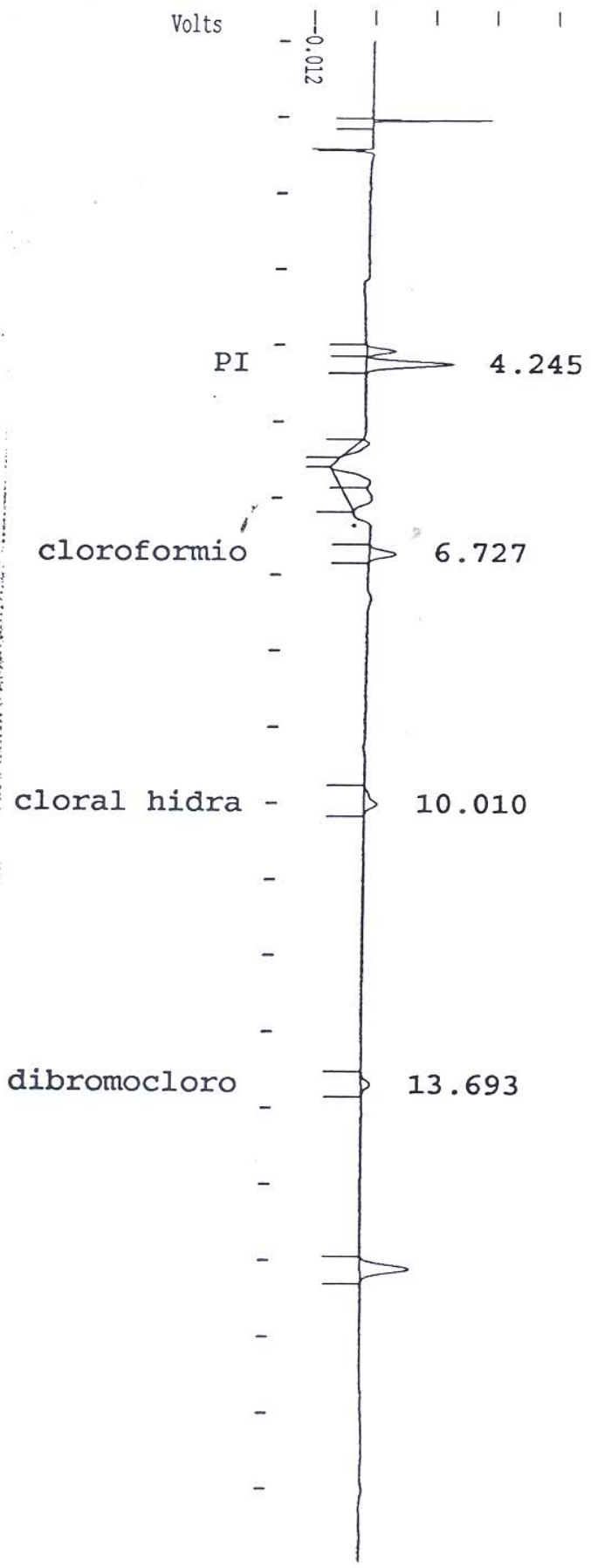

$<W I=4.0$

$<W I=8.0$ 
Title : Determinacao de acidos haloaceticos

Run File : C: \STAR\MODULE16 \PEROX032.RUN

Method File : C: \STAR\MODULE16\552.MTH

Sample ID: Perox-Cl s/c $24 \mathrm{~h}$

Injection Date: 9-JUN-4 3:42 PM

Calculation Date: 9-JUN-4 4:09 PM

Operator : PASCHOALATO, C

Workstation:

Instrument : star $3600 \mathrm{cx}$

Channel : $\mathrm{B}=\mathrm{ECD}$

Detector Type: ADCB (10 Volts)

Bus Address : 16

Sample Rate : $10.00 \mathrm{~Hz}$

Run Time : $27.002 \mathrm{~min}$

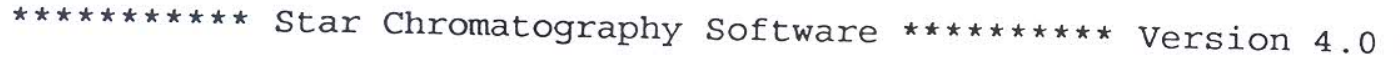

Run Mode : Analysis

Peak Measurement: Peak Area

Calculation Type: Internal standard

\begin{tabular}{|c|c|c|c|c|c|c|c|c|}
\hline $\begin{array}{c}\text { Peak } \\
\text { No. }\end{array}$ & $\begin{array}{c}\text { Peak } \\
\text { Name }\end{array}$ & $\begin{array}{l}\text { Result } \\
\text { (ug/L) }\end{array}$ & $\begin{array}{l}\text { Ret. } \\
\text { Time } \\
\text { (min) }\end{array}$ & $\begin{array}{l}\text { Time } \\
\text { Offset } \\
\text { (min) }\end{array}$ & $\begin{array}{c}\text { Area } \\
\text { (counts) }\end{array}$ & $\begin{array}{l}\text { Sep. } \\
\text { Code }\end{array}$ & $\begin{array}{c}\text { Width } \\
1 / 2 \\
\text { (sec) }\end{array}$ & $\begin{array}{l}\text { Status } \\
\text { Codes }\end{array}$ \\
\hline 1 & $\mathrm{BCAA}$ & 0.94 & 14.556 & $\begin{array}{c}-\cdot-\cdot-\overline{1} \\
0.239\end{array}$ & -------- & -- & ---- & - \\
\hline 2 & $\mathrm{BDCAA}$ & 2.30 & & $\begin{array}{r}0.239 \\
-0.154\end{array}$ & 4299 & VV & 8.2 & \\
\hline 3 & DBAA & 0.76 & $\begin{array}{l}10.146 \\
17.724\end{array}$ & $\begin{array}{r}-0.154 \\
0.163\end{array}$ & 5274 & VV & 0.0 & \\
\hline 4 & $\mathrm{PI}$ & INT STD & 21.174 & 0.163 & $\begin{array}{r}4136 \\
20806\end{array}$ & $\begin{array}{l}\text { VV } \\
\text { VV }\end{array}$ & 0.0 & \\
\hline- & Totals: & $\begin{array}{r}========= \\
4.00\end{array}$ & $-\cdots-\cdots$ & $\begin{array}{r}====== \\
0.272\end{array}$ & $=======$ & ---- & $\begin{array}{r}5.6 \\
----.\end{array}$ & $\begin{array}{l}S R \\
--\cdots\end{array}$ \\
\hline
\end{tabular}

\section{Status Codes:}

R - Referénce peak

$S$ - Internal standard peak

Total Unidentified Counts :

Detected Peaks: 98

616076 counts

Amount Standard: 1.000000

Rejected Peaks: 77

Identified Peaks: 4

Multiplier: 1.000000

Divisor: 1.000000

Baseline offset: -34 microvolts

Noise (used): 250 microvolts - monitored before this run

Manual injection 
Run File: C: \STAR\MODULE16\PEROX032.RUN

Method File: C: \STAR\MODULE16\552.MTH

Sample ID : Perox-Cl s/C $24 \mathrm{~h}$

Injection Date: 9-JUN-4 3:42 PM Calculation Date: 9-JUN-4 4:09 PM

Operator : PASCHOALATO, C

Workstation:

Instrument : star $3600 \mathrm{cx}$

Channel

$\mathrm{B}=\mathrm{ECD}$

Detector Type: ADCB (10 Volts)

Bus Address : 16

Sample Rate : $10.00 \mathrm{~Hz}$

Run Time

$: 27.002 \mathrm{~min}$

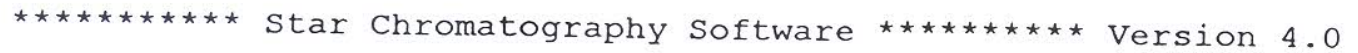

Chart speed $=$

$0.77 \mathrm{~cm} / \mathrm{min}$ Attenuation $=500$

start Time

$0.000 \mathrm{~min}$

End Time

$=27.002$

$\min$

Zero offset $=5 \%$

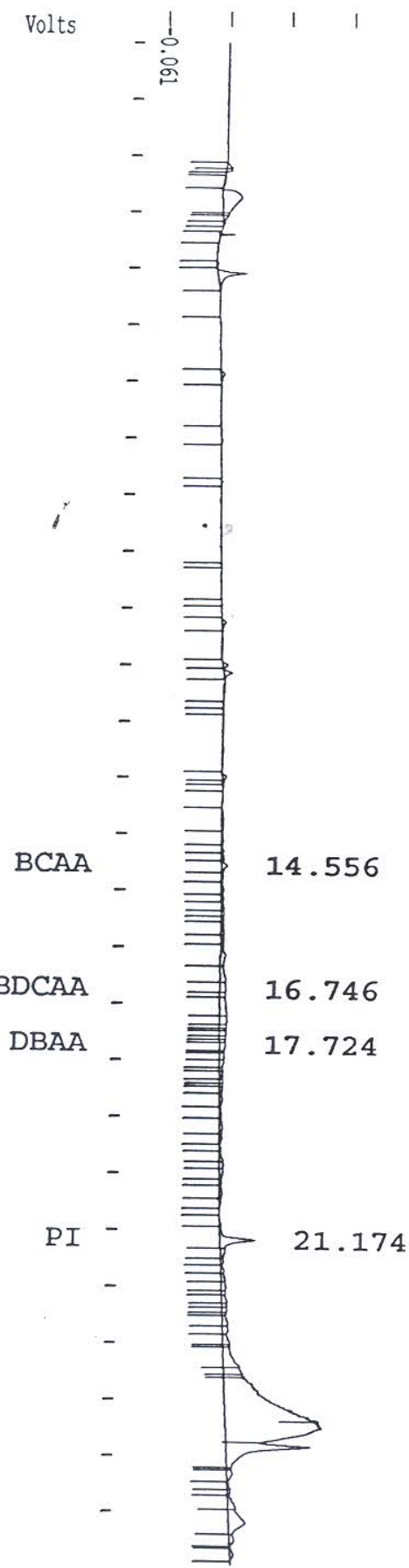

$<W I=8.0 *$

$<W I=8.0$ 


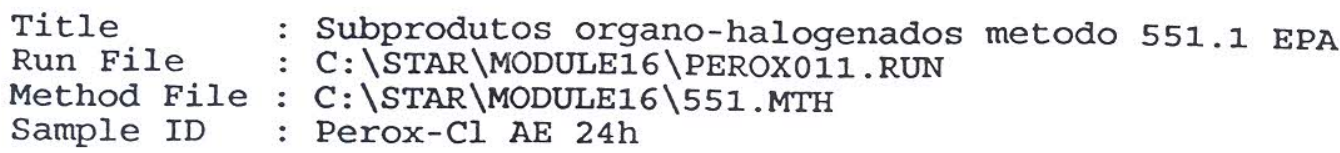

Injection Date: 4-JUN-4 9:54 AM Calculation Date: 4-JUN-4 10:15 AM Operator : PASCHOALATO, C Workstation: Instrument : star $3600 \mathrm{cx}$ Channel : $\mathrm{B}=\mathrm{ECD}$ Detector Type: ADCB (10 Volts) Bus Address : 16 Sample Rate : $10.00 \mathrm{~Hz}$ Run Time : $20.002 \mathrm{~min}$

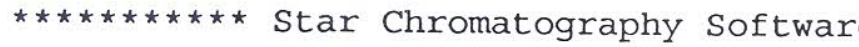

Run Mode : Analysis

Peak Measurement: Peak Area

Calculation Type: Internal Standard

\begin{tabular}{|c|c|c|c|c|c|c|c|c|}
\hline & & & Ret & Time & & & Width & \\
\hline $\begin{array}{l}\text { Peak } \\
\text { No. }\end{array}$ & $\begin{array}{l}\text { Peak } \\
\text { Name }\end{array}$ & $\begin{array}{l}\text { Result } \\
\text { (ug/L) }\end{array}$ & $\begin{array}{l}\text { Time } \\
\text { (min) }\end{array}$ & $\begin{array}{l}\text { Offset } \\
\text { (min) }\end{array}$ & $\begin{array}{c}\text { Area } \\
\text { (counts) }\end{array}$ & $\begin{array}{l}\text { Sep. } \\
\text { Code }\end{array}$ & $\begin{array}{c}1 / 2 \\
(\text { sec })\end{array}$ & $\begin{array}{l}\text { Status } \\
\text { Codes }\end{array}$ \\
\hline- & - & - & ------ & ------ & ------- & ---- & ----- & \\
\hline 1 & PI & INT STD & 4.252 & -0.041 & 7232 & VB & 4.8 & SR \\
\hline 2 & Cloroformio & 20.52 & 6.733 & 0 . & 2761 & $\mathrm{BB}$ & 5.7 & \\
\hline 3 & cloral hidra & 10.69 & 10.021 & -0.175 & 3645 & BB & 6.7 & \\
\hline 4 & dibromocloro & 6.05 & 13.698 & 0.304 & 3901 & $\mathrm{BB}$ & 7.1 & \\
\hline & $\begin{array}{l}---- \\
\text { Tota }\end{array}$ & $\begin{array}{l}==== \\
37.26\end{array}$ & ------ & $======$ & $===$ & -- & ---- & - \\
\hline
\end{tabular}

Status Codes:

$R$ - Reference peak

S - Internal standard peak

Total Unidentified Counts : 38105 counts

Detected Peaks: 15

Rejected Peaks: 2

Identified Peaks: 4

Amount standard: 1.000000 Multiplier: 1.000000

Divisor: 1.000000

Baseline Offset: -4 microvolts

Noise (used): 230 microvolts - monitored before this run Manual injection 
Sample ID: Perox-CI AE $24 \mathrm{~h}$

Injection Date: 4-JUN-4 9:54 AM

Operator : PASCHOALATO, C

Workstation:

Instrument : star $3600 \mathrm{cx}$

Channel

$\mathrm{B}=\mathrm{ECD}$

Calculation Date: 4-JUN-4 10:15 AM

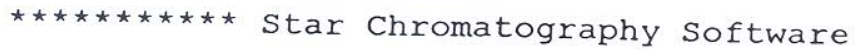

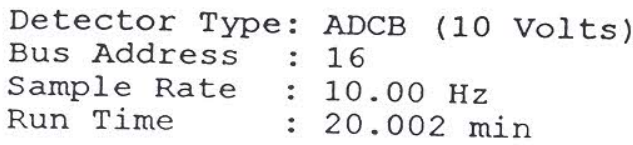

Chart Speed $=\quad 1.04 \mathrm{~cm} / \mathrm{min} \quad$ Attenuation $=100$

start Time

Attenuation
End Time

$=20.002 \mathrm{~min}$

Zero Offset $=5$ \%

Volts

- !

। ।

完

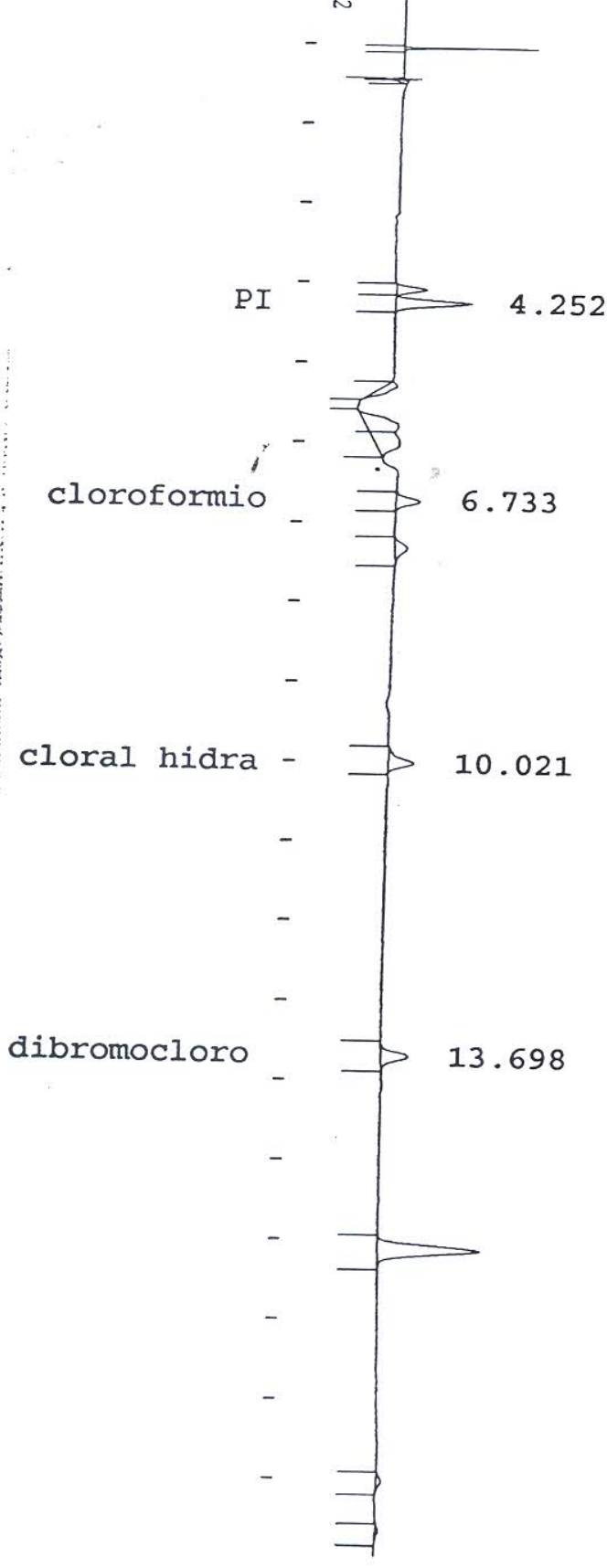

$<W I=8.0$ 
Title : Determinacao de acidos haloaceticos

Run File : C:\STAR\MODULE16\PEROX027.RUN

Method File: C:\STAR\MODULE16\552.MTH

Sample ID : Perox-Cl AE $24 \mathrm{~h}$

Injection Date: 9-JUN-4 10:54 AM

Calculation Date: 9-JUN-4 11:22 AM

Operator : PASCHOALATO, C

Workstation:

Instrument : star $3600 \mathrm{Cx}$

Channel

$\mathrm{B}=\mathrm{ECD}$

Detector Type: ADCB (10 Volts)

Bus Address : 16

Sample Rate : $10.00 \mathrm{~Hz}$

Run Time : $27.002 \mathrm{~min}$

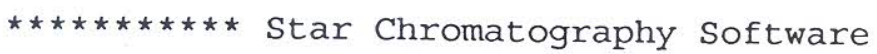

Run Mode

: Analysis

Peak Measurement: Peak Area

Calculation Type: Internal Standard

\begin{tabular}{|c|c|c|c|c|c|c|c|c|}
\hline & & & Ret. & Time & & \multicolumn{3}{|c|}{ Width } \\
\hline Peak & Peak & Result & Time & Offset & Area & Sep. & $1 / 2$ & statu \\
\hline No. & Name & (ug/L) & (min) & (min) & (counts) & Code & (sec) & Codes \\
\hline & DCAA & 0.83 & ------ & $\cdots-\cdots$ & $\cdots \cdots$ & --- & ---- & \\
\hline 1 & DCAA & $\begin{array}{l}0.83 \\
0.46\end{array}$ & 11.087 & 0.100 & 4882 & VV & 6.1 & \\
\hline 2 & DBAA & 0.46 & 17.499 & -0.052 & 7874 & VV & 0.0 & \\
\hline 3 & TBAA & -11.29 & 21.027 & 0.264 & 4002 & VV & 0.0 & \\
\hline 4 & PI & INT STD & 21.163 & 0.013 & 65801 & VV & 5.2 & $S R$ \\
\hline- & Totals: & $\begin{array}{r}======== \\
12.58\end{array}$ & ------ & $\begin{aligned}== & ==== \\
& 0.325\end{aligned}$ & $\begin{array}{r}=== \\
82559\end{array}$ & $\ldots$ &.-- & $\ldots$ \\
\hline
\end{tabular}

Status Codes:

$R$ - Refetence peak

$S$ - InternaI standard peak

Total Unidentified Counts : 856687 counts

Detected Peaks: 108

Rejected Peaks: 76

Identified Peaks: 4

Amount Standard: 1.000000

Multiplier: 1.000000

Divisor: 1.000000

Baseline offset: 18 microvolts

Noise (used): 280 microvolts - monitored before this run

Manual injection 
Title : Determinacao de acidos haloaceticos

Run File : C: \STAR\MODULE16\PEROX027.RUN

Method File : C: \STAR\MODULE16\552.MTH

Sample ID : Perox-Cl AE $24 \mathrm{~h}$

Injection Date: 9-JUN-4 10:54 AM

Operator : PASCHOALATO, C Workstation:

Instrument : star $3600 \mathrm{cx}$

Channel : $\mathrm{B}=\mathrm{ECD}$
Calculation Date: 9-JUN-4 11:22 AM

Detector Type: ADCB (10 Volts)

Bus Address : 16

Sample Rate: $10.00 \mathrm{~Hz}$

Run Time: $27.002 \mathrm{~min}$

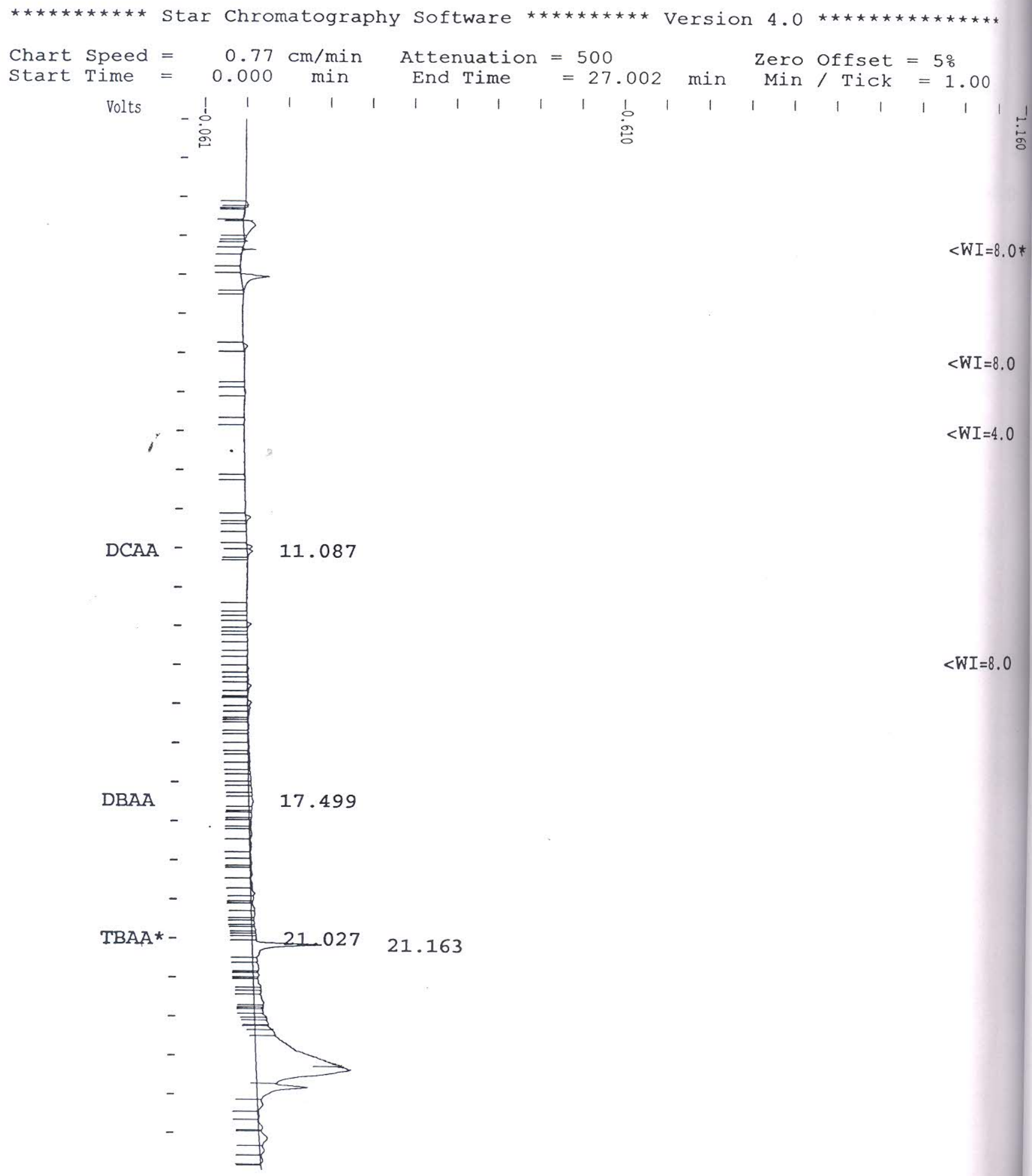




\section{APÊNDICE H}

H-01 Cromatograma do ensaio com pré-oxidação com ozônio, filtração em papel, pós-cloração e incubação a $25^{\circ} \mathrm{C}$ com tempo de contato de $24 h-551$.

H-02 Cromatograma do ensaio com pré-oxidação com ozônio, filtração ém papel, pós-cloração e incubação a $25^{\circ} \mathrm{C}$ com tempo de contato de $24 h-552$.

H-03 Cromatograma do ensaio com pré-oxidação com ozônio, coagulação filtração em papel, pós-cloração e incubação a $25^{\circ} \mathrm{C}$ com tempo de contato de $24 \mathrm{~h}-551$.

H-04 Cromatograma do ensaio com pré-oxidação com ozônio, coagulação filtração em papel, pós-cloração e incubação a $25^{\circ} \mathrm{C}$ com tempo de contato de $24 h-552$. 
Method File : C:\STAR\MODULE16 THMOZ023. RUN

Sample ID : Ozonio s/c $24 \mathrm{~h}$

Injection Date: 21-JUL-4 10:58 AM

Calculation Date: 21-JUL-4 11:18 AM

Operator : PASCHOALATO, C

Workstation:

Instrument : star $3600 \mathrm{cx}$

Channel: $\mathrm{B}=\mathrm{ECD}$

Detector Type: ADCB (10 Volts)

Bus Address : 16

Sample Rate : $10.00 \mathrm{~Hz}$

Run Time : $20.002 \mathrm{~min}$

$\star \star \star \star \star \star \star \star \star \star \star * \star$ Star Chromatography Software

Run Mode

Peak Measurement: Analysis

Peak Area

Ine: Internal Standard

\begin{tabular}{|c|c|c|c|c|c|c|c|c|}
\hline $\begin{array}{l}\text { Peak } \\
\text { No. } \\
-\end{array}$ & $\begin{array}{c}\text { Peak } \\
\text { Name }\end{array}$ & $\begin{array}{l}\text { Result } \\
\text { (ug/L) }\end{array}$ & $\begin{array}{l}\text { Ret. } \\
\text { Time } \\
\text { (min) }\end{array}$ & $\begin{array}{l}\text { Time } \\
\text { Offset } \\
\text { (min) }\end{array}$ & $\begin{array}{c}\text { Area } \\
\text { (counts) }\end{array}$ & $\begin{array}{l}\text { Sep. } \\
\text { Code }\end{array}$ & $\begin{array}{c}\text { Width } \\
1 / 2 \\
\text { (sec) }\end{array}$ & $\begin{array}{l}\text { Status } \\
\text { Codes }\end{array}$ \\
\hline 1 & PI & INT STD & 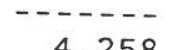 & - - - - - - & -- & ---- & ---- & ----- \\
\hline 2 & cloroformio & 55.10 & $\begin{array}{l}4.258 \\
6.730\end{array}$ & $\begin{array}{r}0.007 \\
-0.007\end{array}$ & 12228 & VB & 6.0 & SR \\
\hline 3 & dicloroaceto & 5.90 & 9.351 & $\begin{array}{l}-0.007 \\
-0.010\end{array}$ & 14160 & BV & 6,0 & \\
\hline 4 & bromodicloro & 4.69 & 9.872 & $\begin{array}{l}-0.010 \\
-0.012\end{array}$ & 7339 & $\mathrm{BB}$ & 6.1 & \\
\hline 5 & cloral hidra & 30.42 & 10.234 & $\begin{array}{l}-0.012 \\
-0.013\end{array}$ & 5980 & $\mathrm{BP}$ & 6.8 & \\
\hline 6 & 1,1-diclorop & 1.00 & 10.927 & $\begin{array}{r}-0.013 \\
0.102\end{array}$ & 29208 & $\mathrm{~PB}$ & 7.8 & \\
\hline 7 & cloropicrina & 0.25 & 13.073 & $\begin{array}{r}0.102 \\
-0.014\end{array}$ & 761 & $\mathrm{BB}$ & 5.2 & \\
\hline 8 & $1,1,1$-triclo & 5.43 & 14.081 & $\begin{array}{l}-0.014 \\
-0.342\end{array}$ & 745 & $\mathrm{BB}$ & 7.0 & \\
\hline 9 & bromocloroac & 5.74 & 15.467 & $\begin{array}{l}-0.342 \\
-0.019\end{array}$ & 508 & BB & 7.2 & \\
\hline & $----1-\cdots--$ & 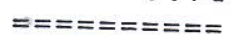 & $\ldots \ldots$ & $\begin{aligned} & -0.019 \\
== & ====\end{aligned}$ & 5675 & $\mathrm{BB}$ & 7.7 & \\
\hline & Totals: & 108.53 & & $\begin{aligned}== & ==== \\
& =0.308\end{aligned}$ & $\begin{array}{r}==x==== \\
76604\end{array}$ & -- & --- & \\
\hline
\end{tabular}

Status Codes:

$R$ - Reference peak

$S$ - Internal standard peak

Total Unidentified Counts :

Detected Peaks: 20

30746 counts

Amount Standard: 1.000000

Rejected Peaks: 2

Identified Peaks: 9

Multiplier: 1.000000

Divisor: 1.000000

Baseline Offset: -20 microvolts

Noise (used): 250 microvolts - monitored before this run

Manual injection 
Title : Subprodutos organo-halogenados metodo 551 EPA

Run File: C: \STAR\MODULE16\THMOZ023.RUN

Method File : C: \STAR\MODULE16 $\backslash$ THMACET2.MTH

Sample ID : Ozonio s/c $24 \mathrm{~h}$

Injection Date: 21-JUL-4 10:58 AM

Operator : PASCHOALATO, C
Workstation:

Instrument : star $3600 \mathrm{cx}$

Channel: $\mathrm{B}=\mathrm{ECD}$

Calculation Date: 21-JUL-4 11:18 AM

Detector Type: ADCB (10 Volts)

Bus Address : 16

Sample Rate: $10.00 \mathrm{~Hz}$

Run Time : $20.002 \mathrm{~min}$

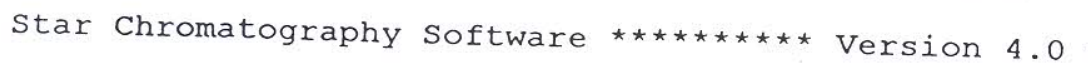

Chart speed $=$

Start Time

$1.04 \mathrm{~cm} / \mathrm{min}$

Attenuation $=150$

Zero offset $=5$ 응

Volts $0.000 \mathrm{~min}$ End Time

$=20.002 \mathrm{~min}$

$\operatorname{Min} / \mathrm{Tick}=1.00$

品

$<W I=4.0$

$<W I=2.0$

dicloroaceto

$<W I=8.0$ 


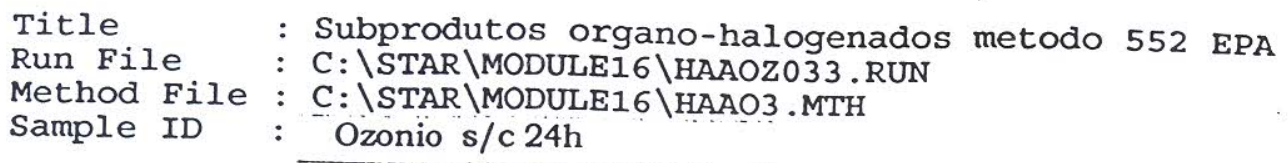

\begin{tabular}{|c|c|c|c|c|c|c|c|c|}
\hline & & & Ret. & Time & & \multicolumn{3}{|c|}{ Width } \\
\hline Peak & Peak & Result & Time & Offset & Area & $\mathrm{Se}$ & $1 / 2$ & status \\
\hline No. & $\begin{array}{c}\text { Name } \\
\end{array}$ & (ug/L) & $(\min )$ & $(\min )$ & (counts) & Code & $($ sec) & Codes \\
\hline 1 & MCAA & 3393 & $-\cdots--$ & กา & -- & $\cdots-$ & $-\cdots$ & ----- \\
\hline 2 & MBAA & $\begin{array}{r}33.93 \\
2.13\end{array}$ & 8.520 & -0.128 & 109675 & $\mathrm{BB}$ & 4.9 & C \\
\hline 3 & $D C A A$ & 2.13 & 10.566 & 0.010 & 6393 & $\mathrm{BB}$ & 4.8 & \\
\hline 4 & TCAA & 71.77 & 10.991 & 0.010 & 214285 & $\mathrm{BB}$ & 4.7 & C \\
\hline 5 & $B C A A$ & 17.43 & 12.963 & 0.007 & 160283 & $\mathrm{BB}$ & 4.7 & C \\
\hline 6 & PI & 2.03 & 14.100 & -0.185 & 25147 & $\mathrm{BB}$ & 4.6 & \\
\hline- & $\ldots$ & $\begin{array}{l}\text { INT STD } \\
======\end{array}$ & 21.149 & -0.007 & 32736 & $\mathrm{BB}$ & 4.3 & SR \\
\hline & Totals: & $\begin{array}{r}===x== \\
127.29\end{array}$ & 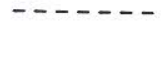 & $\begin{array}{r}==x=== \\
-0.293\end{array}$ & $\begin{array}{r}======= \\
548519\end{array}$ & --- & $\cdots$ & - \\
\hline
\end{tabular}

Status Codes:

R - Reference peak

$C$ - Out of calibration range

$S$ - Internal Standard peak

Total Unidentified Counts : 1595700 counts

Detected Peaks: 20

Rejected Peaks: 2

Identified Peaks: 6

Amount Standard: 1.000000

Multiplier: 1.000000

Divisor: 1.000000

Baseline Offset: -14 microvolts

Noise (used) : 4050 microvolts - monitored before this run

Manual injection

Data Handling: Result Out of Range 
Method File : C: \STAR\MODULE16\HAAO3.MTH

Sample ID : Ozonio s/c $24 \mathrm{~h}$

Injection Date: 15-JUL-4 7:09 PM

Operator : PASCHOALATO, C

Workstation:

Instrument : star $3600 \mathrm{cx}$

Channel : $\mathrm{B}=\mathrm{ECD}$
Calculation Date: 15-JUL-4 7:33 PM

Detector Type: $\mathrm{ADCB}$ (10 Volts)

Bus Address : 16

Sample Rate: $10.00 \mathrm{~Hz}$

Run Time : $24.002 \mathrm{~min}$

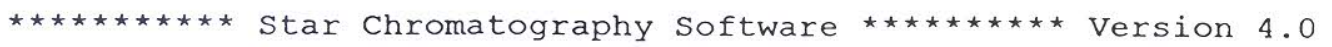

Chart speed $=0.87 \mathrm{~cm} / \mathrm{min} \quad$ Attenuation $=300 \quad$ Zero Offset $=5 \%$

Start $\mathrm{Time}=0.000 \mathrm{~min}$ End Time $=24.002 \mathrm{~min} \mathrm{Min} / \mathrm{Tick}=1.00$

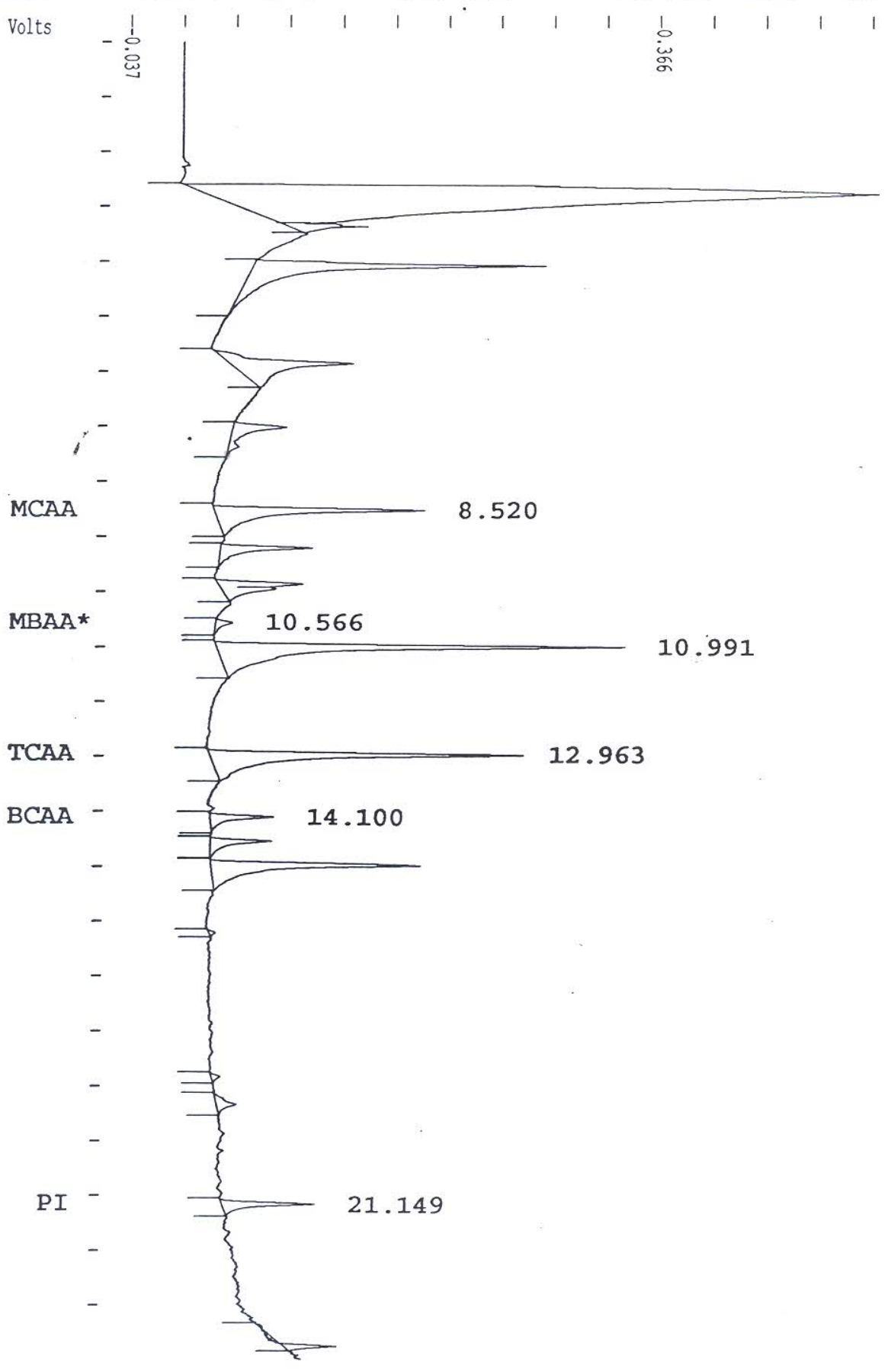


Title Subprodutos organo-halogenados metodo 551 EPA

Run File : C: \STAR\MODULE16\THMOZ030.RUN

Method File : C: \STAR\MODULE16\THMACET2.MTH

Sample ID : Ozonio AE $24 \mathrm{~h}$

Injection Date: $21-J U L-4 \quad 3: 28$ PM

Operator : PASCHOALATO, C

Workstation:

Instrument : star $3600 \mathrm{cx}$

Channel: $\mathrm{B}=\mathrm{ECD}$
Calculation Dațe: 21-JUL-4 3:48 PM

Detector Type: ADCB (10 Volts)

Bus Address : 16

Sample Rate: $10.00 \mathrm{~Hz}$

Run Time : $20.002 \mathrm{~min}$

$\star \star \star \star \star \star \star \star \star \star \star *$ Star Chromatography Software

Run Mode

: Analysis

Peak Measurement: Peak Area

Calculation Type: Internal Standard

\begin{tabular}{|c|c|c|c|c|c|c|c|c|}
\hline & & & Ret & Time & & \multicolumn{3}{|c|}{ Width } \\
\hline Peak & Peak & Result & Time & Offset & Area & Sep. & $1 / 2$ & st \\
\hline No. & Name & $(\mathrm{ug} / \mathrm{L})$ & $(\min )$ & $(\min )$ & (counts) & Code & $(\mathrm{sec})$ & Codes \\
\hline$-\overline{1}$ & 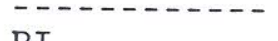 & - & $\cdots \cdots$ & $\cdots \cdots$ & $-\cdots--$ & --- & & \\
\hline 1 & PI & INT STD & 4.259 & 0.008 & 12048 & VB & 5.6 & SR \\
\hline 2 & cloroformio & 47.84 & 6.734 & -0.004 & 12112 & BV & 5.9 & \\
\hline 3 & dicloroaceto & 9.55 & 9.360 & -0.002 & 11707 & $\mathrm{BB}$ & 6.0 & \\
\hline 4 & bromodicloro & 6.92 & 9.886 & 0.001 & 8689 & BV & 6.7 & \\
\hline 5 & cloral hidra & 25.82 & 10.241 & -0.007 & 24423 & VB & 7.7 & \\
\hline 6 & 1,1-diclorop & 1.17 & 10.939 & 0.112 & 880 & $\mathrm{BB}$ & 5.5 & \\
\hline 7 & dibromocloro & 1.17 & 13.669 & 0.217 & 1288 & BV & 6.7 & \\
\hline 8 & 1,1,1-triclo & 11.96 & 14.085 & -0.340 & 1102 & VP & 8.5 & \\
\hline 9 & bromoclọroac & 5.78 & 15.470 & -0.017 & 5629 & BV & 7.5 & \\
\hline & Totals: & $\begin{array}{r}======= \\
110.21\end{array}$ & ------ & $\begin{aligned}== & === \\
& =0.032\end{aligned}$ & $\begin{aligned}== & ==== \\
& 77878\end{aligned}$ & $\ldots$ & $\ldots$ & \\
\hline
\end{tabular}

Status Codes:

$R$ - Reference peak

$S$ - Internal standard peak

Total Unidentified Counts : 39229 counts

Detected Peaks: 21

Rejected Peaks: 2

Identified Peaks: 9

Amount Standard: 1.000000

Multiplier: 1.000000

Divisor: 1.000000

Baseline Offset: -4 microvolts

Noise (used) : 240 microvolts - monitored before this run

Manual injection 
Title : Subprodutos organo-halogenados metodo 551 EPA

Method File: C: ISTAR\MODULE16\THMOZ030.RUN

Sample ID : C: ISTAR\MODULE16\THMACET2.MTH

Injection Date: $21-J U L-4 \quad 3: 28$ PM

Operator: PASCHOALATO, C

Workstation:

Instrument : star $3600 \mathrm{Cx}$

Channel : $\mathrm{B}=\mathrm{ECD}$

Calculation Date: 21-JUL-4 3:48 PM

Detector Type: ADCB (10 Volts)

Bus Address : 16

Sample Rate: $10.00 \mathrm{~Hz}$

Run Time

$: 20.002 \mathrm{~min}$

Star Chromatography Software

Chart speed =

Start Time $=$

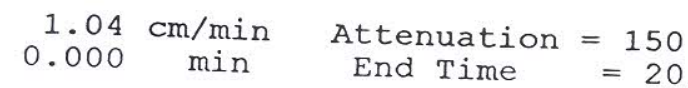

$=20.002 \mathrm{~min}$

Zero Offset $=5$ \%

Volts

$-\underset{1}{1}$

$\underset{\substack{b \\ \stackrel{\infty}{\infty} \\ \omega}}{\infty}$

Min / Tick $=1.00$

$\begin{array}{llcc} & 1 & 1 & \text { Tick } \\ & & & 1\end{array}$

$<\mathrm{WI}=2$

$<\mathrm{WI}=4$. (

10.241

$<W I=8.0$

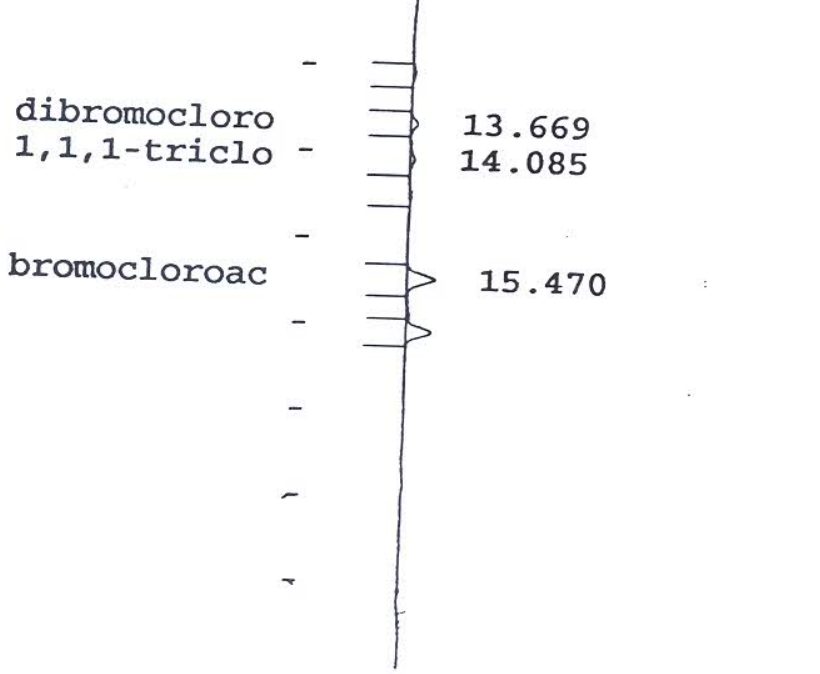


Method File: C: \STAR \MODULE16\HAAO3.MTH

Sample ID: Ozonio AE $24 \mathrm{~h}$

Injection Date: 15-JUL-4 4:51 PM Operator : PASCHOALATO, C Workstation:

Instrument : star $3600 \mathrm{cx}$

Channel: $\mathrm{B}=\mathrm{ECD}$
Calculation Date: 15-JUL-4 5:15 PM Detector Type: $\mathrm{ADCB}$ (10 Volts) Bus Address : 16 Sample Rate : $10.00 \mathrm{~Hz}$ Run Time : $24.002 \mathrm{~min}$

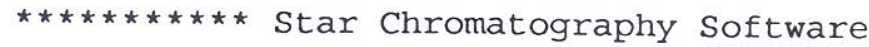

Run Mode : Analysis

Peak Measurement: Peak Area

Calculation Type: Internal Standard

\begin{tabular}{|c|c|c|c|c|c|c|c|c|}
\hline & & & Ret. & Time & & \multicolumn{3}{|c|}{ Width } \\
\hline Peak & Peak & Result & Time & Offset & Area & Sep. & $1 / 2$ & statu \\
\hline No. & Name & (ug/L) & (min) & (min) & (counts) & Code & (sec) & Codes \\
\hline--- & 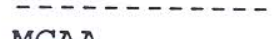 & 102.50 & - - - & $\cdots--\cdots$ & $\cdots \cdots-\cdots$ & $-\cdots$ & $-\cdots-$ & - \\
\hline 1 & MCAA & & 8.502 & -0.147 & 160521 & VV & 4.7 & $\mathrm{C}$ \\
\hline 2 & MBAA & 5.24 & 10.550 & -0.007 & 7626 & VV & 0.0 & \\
\hline 3 & DCAA & 68.61 & 10.975 & -0.008 & 99240 & VV & 5.3 & C \\
\hline 4 & TCAA & 9.74 & 12.951 & -0.006 & 43418 & $\mathrm{BB}$ & 4.8 & \\
\hline 5 & $B C A A$ & 14.21 & 14.091 & -0.196 & 85085 & VV & 4.7 & \\
\hline 6 & PI & INT STD & 21.151 & -0.005 & 15859 & VV & 5.0 & SR \\
\hline-- & Totals: & $========$ & ------ & $======$ & $======$ & -- & --- & \\
\hline
\end{tabular}

Status Codes:

R - Reference peak

C - Out of calibration range

$S$ - Internal Standard peak

Total Unidentified Counts : 3064835 counts

Detected Peaks: 151

Rejected Peaks: 86

Identified Peaks: 6

Amount Standard: 1.000000

Multiplier: 1.000000

Divisor: 1.000000

Baseline Offset: 8 microvolts

Noise (used): 210 microvolts - monitored before this run

Manual injection

Data Handling: Result Out of Range

Print Date: Thu Jul 15 17:50:27 2004 
Title

: Subprodutos organo-halogenados metodo 552 EPA

Run File

: C: \STAR\MODULE16\HAAOZ030.RUN

Method File : C: \STAR\MODULE16\HAAO3.MTH

Sample ID : Ozonio AE $24 \mathrm{~h}$

Injection Date: 15-JUL-4 4:51 PM

Operator: PASCHOALATO, C

Workstation:

Instrument : star $3600 \mathrm{cx}$

Channel

: $\mathrm{B}=\mathrm{ECD}$

Calculation Date: 15-JUL-4 5:15 PM

Detector Type: ADCB (10 Volts)

Bus Address : 16

Sample Rate : $10.00 \mathrm{~Hz}$

Run Time : $24.002 \mathrm{~min}$

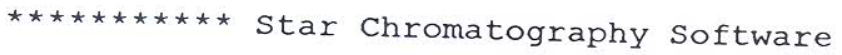

Version 4.0

Chart speed $=$

Start Time $=$

$0.87 \mathrm{~cm} / \mathrm{min}$

Attenuation $=150$

End Time

$=24.002$

$02 \mathrm{~min}$

Zero Offset $=5 \%$

Volts

111

$\begin{array}{lll}1 & 1\end{array}$

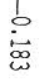

$\mathrm{Min} / \mathrm{TiCk}=1.00$

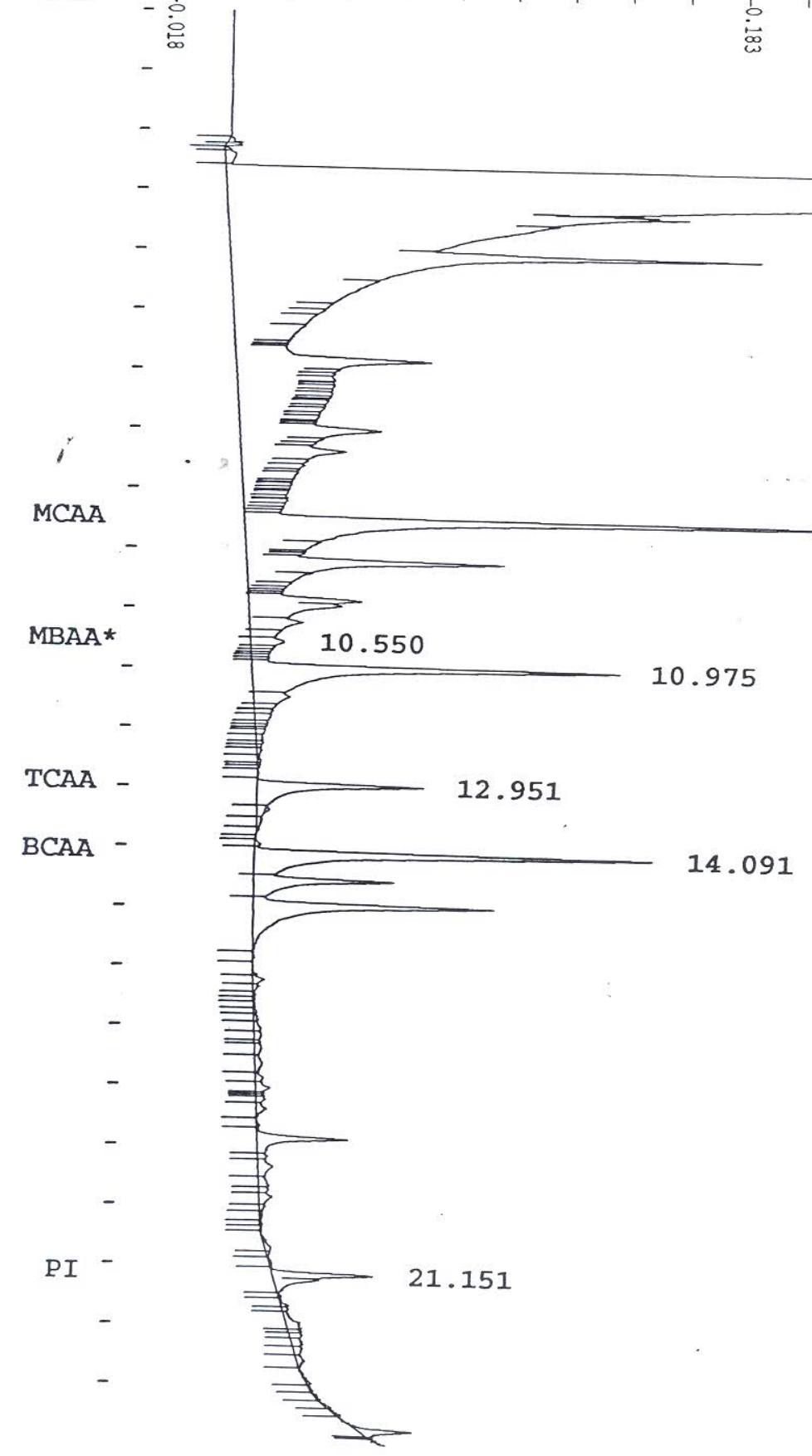

8.502

$<W I=8.0$ 


\section{APÊNDICE I}

I-01 Cromatograma do ensaio com pré-oxidação com peroxônio, filtração em papel, pós-cloração e incubação a $25^{\circ} \mathrm{C}$ com tempo de contato de $24 \mathrm{~h}-551$.

I-02 Cromatograma do ensaio com pré-oxidação com peroxônio, filtração em papel, pós-cloração e incubação a $25^{\circ} \mathrm{C}$ com tempo de contato de $24 \mathrm{~h}-552$.

I-03 Cromatograma do ensaio com pré-oxidação com peroxônio, coagulação filtração em papel, pós-cloração e incubação a $25^{\circ} \mathrm{C}$ com tempo de contato de $24 \mathrm{~h}-551$.

I-04 Cromatograma do ensaio com pré-oxidação com peroxônio, coagulação filtração em papel, pós-cloração e incubação a $25^{\circ} \mathrm{C}$ com tempo de contato de $24 \mathrm{~h}-552$. 
Method File: C: \STAR\MODULE16\THMACET2.MTH

Sample ID: Perox/ozonio sc $24 \mathrm{~h}$

Injection Date: 4-AUG-4 9:53 PM

Calculation Date: 4-AUG-4 10:13 PM

Operator : PASCHOALATO, C

Workstation:

Instrument : star $3600 \mathrm{cx}$

Detector Type: ADCB (10 Volts)

Channel

: $\mathrm{B}=\mathrm{ECD}$

$\begin{array}{ll}\text { Bus Address } & 16 \\ \text { Sample Rate } & 10.00 \mathrm{~Hz} \\ \text { Run Time } & : 20.002 \mathrm{~min}\end{array}$

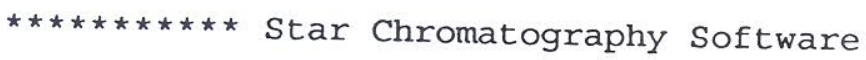

Run Mode

: Analysis

Peak Measurement: Peak Area

Calculation Type: Internal Standard

$\begin{array}{rrrrrrr}\begin{array}{r}\text { Peak } \\ \text { No. }\end{array} & \begin{array}{c}\text { Peak } \\ \text { Name }\end{array} & \begin{array}{c}\text { Result } \\ \text { (ug/L) }\end{array} & \begin{array}{l}\text { Ret. } \\ \text { Time } \\ \text { (min) }\end{array} & \begin{array}{r}\text { Time } \\ \text { Offset } \\ \text { (min) }\end{array} & \begin{array}{c}\text { Area } \\ \text { (counts) }\end{array} & \begin{array}{r}\text { Sep. } \\ \text { Code }\end{array} \begin{array}{c}\text { Width } \\ \text { (sec) }\end{array} \text { Status } \\ \text { Codes }\end{array}$

Status Codes:

R - Reference peak

$S$ - Internal standard peak

Total Unidentified Counts :

25616 counts

Detected Peaks: 19

Rejected Peaks: 5

Identified Peaks: 7

Amount Standard: 1.000000

Multiplier: 1.000000

Divisor: 1.000000

Baseline Offset: -27 microvolts

Noise (used) : 210 microvolts - monitored before this run

Manual injection 
Method File : C: \STAR\MODULE16\THMACET2.MTH

Sample ID : Perox/ozonio sC $24 \mathrm{~h}$

Injection Date: 4-AUG-4 9:53 PM Calculation Date: 4-AUG-4 10:13 PM

Operator : PASCHOALATO, C Workstation:

Instrument : star $3600 \mathrm{cx}$

Detector Type: ADCB (10 Volts)

Bus Address : 16

Channel : $\mathrm{B}=\mathrm{ECD}$

Sample Rate: $10.00 \mathrm{~Hz}$

Run Time : $20.002 \mathrm{~min}$

$\star \star \star \star \star \star \star \star \star \star \star$ Star Chromatography Software

$\star \star \star \star \star \star \star \star \star \star$ Version 4.0

Chart speed =

start $\mathrm{Time}=$

$1.04 \mathrm{~cm} / \mathrm{min}$

$0.000 \mathrm{~min}$

$\begin{aligned} \text { Attenuation } & =150 \\ \text { End Time } & =20\end{aligned}$

$=20.002 \mathrm{~min}$

Zero Offset $=5$ 응

Min / Tick $=1.00$

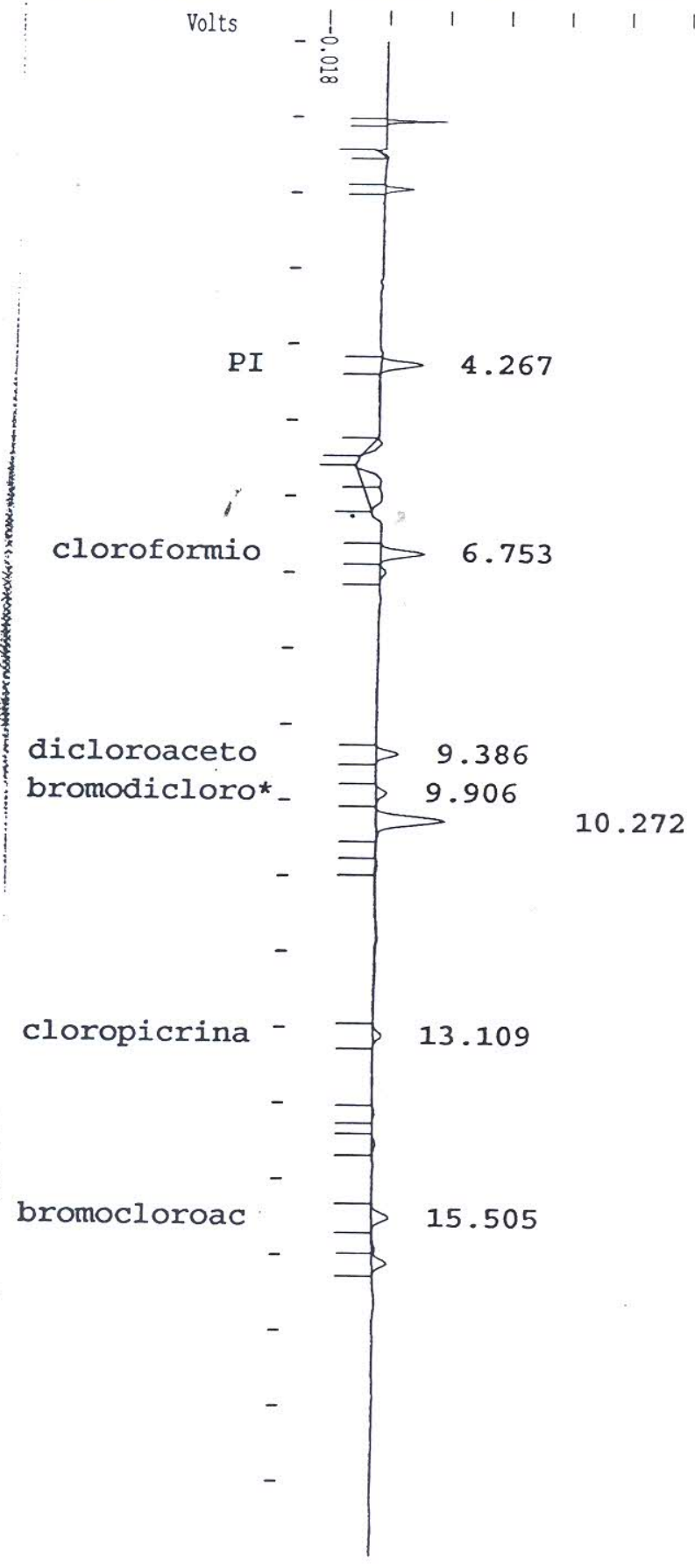


Method File: C:\STAR\MODULE16\HAAO3.MTH

Sample ID : Perox/ ozônio s/c $24 \mathrm{~h}$

Injection Date: 6-AUG-4 5:32 PM Calculation Date: 6-AUG-4 6:37 PM

$\begin{array}{ll}\text { Operator : PASCHOALATO, C } & \text { Detector Type: ADCB (10 Volts) } \\ \text { Workstation: } & \text { Bus Address : } 16 \\ \text { Instrument : star } 3600 \mathrm{cx} & \text { Sample Rate : } 10.00 \mathrm{~Hz} \\ \text { Channel }: \mathrm{B}=\mathrm{ECD} & \text { Run Time }\end{array}$

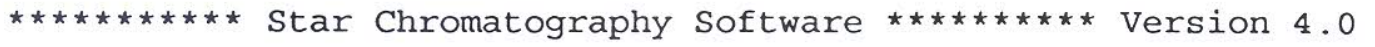

Run Mode : Analysis

Peak Measurement: Peak Area

Calculation Type: Internal Standard

\begin{tabular}{|c|c|c|c|c|c|c|c|c|}
\hline & & & Ret. & Time & & & Width & \\
\hline Peak & Peak & Result & Time & Offset & Area & Sep. & $1 / 2$ & status \\
\hline No. & Name & (ug/L) & $(\min )$ & $(\min )$ & (counts) & Code & (sec) & Codes \\
\hline--- & ------------ & ------ & $-----\cdot$ & $\ldots \ldots$ & $-\cdots--\cdots$ & --- & $\ldots-\cdots$ & $\ldots$ \\
\hline 1 & MCAA & 21.65 & 9.005 & -0.142 & 210841 & VV & 5.6 & \\
\hline 2 & MBAA & 3.35 & 11.089 & -0.020 & 30371 & VV & 0.0 & \\
\hline 3 & DCAA & 21.12 & 11.513 & -0.019 & 190013 & VV & 5.6 & \\
\hline 4 & TCAA & 9.39 & 13.512 & -0.005 & 260184 & PV & 4.9 & \\
\hline 5 & DBAA & 0.90 & 14.665 & -0.196 & 40772 & VV & 4.5 & \\
\hline 6 & $B D C A A$ & 3.46 & 17.524 & 0.067 & 75495 & VV & 29.1 & \\
\hline 7 & CDBAA & $28 \div 44$ & 17.959 & -0.139 & 70094 & vV & 0.0 & \\
\hline 8 & TBAA & $7-57$ & 18.621 & 0.061 & 39771 & vV & 0.0 & \\
\hline 9 & $\mathrm{BCAA}$, & 0.18 & 21.320 & 0.011 & 6759 & $\mathrm{PP}$ & 10.3 & \\
\hline 10 & $\mathrm{PI}$ & INT STD & 21.781 & -0.028 & 98630 & $\mathrm{PP}$ & 4.5 & SR \\
\hline - - & Totals: & $\begin{array}{r}======== \\
96.06\end{array}$ & ------ & $\begin{aligned}= & ==== \\
& -0.410\end{aligned}$ & $\begin{array}{r}====== \\
1022930\end{array}$ & --- & ---- & -- \\
\hline
\end{tabular}

Status Codes:

$R$ - Reference peak

S - Internal standard peak

Total Unidentified Counts : 3737847 counts

Detected Peaks: 136

Rejected Peaks: 48

Identified Peaks: 10

Amount Standard: 1.000000

Multiplier: 1.000000

Divisor: 1.000000

Baseline Offset: -30 microvolts

Noise (used): 360 microvolts - monitored before this run

Manual injection 
Title

Run File

Subprodutos organo-halogenados metodo 552 EPA

Method File:

Injection Date: 6-AUG-4 5:32 PM

Operator: PASCHOALATO, C

Workstation:

Instrument : star $3600 \mathrm{cx}$

Channel

$: \mathrm{B}=\mathrm{ECD}$

Calculation Date: 6-AUG-4 6:37 PM

Detector Type: ADCB (10 Volts)

Bus Address : 16

Sample Rate : $10.00 \mathrm{~Hz}$

Run Time : $24.002 \mathrm{~min}$

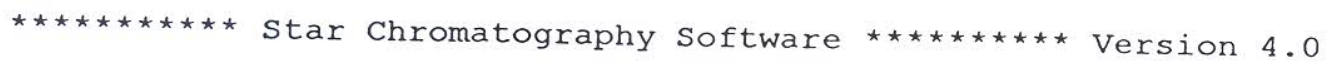

Chart Speed $=0.87 \mathrm{~cm} / \mathrm{min}$ Attenuation $=500$

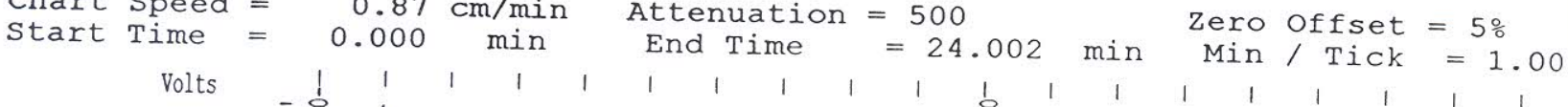

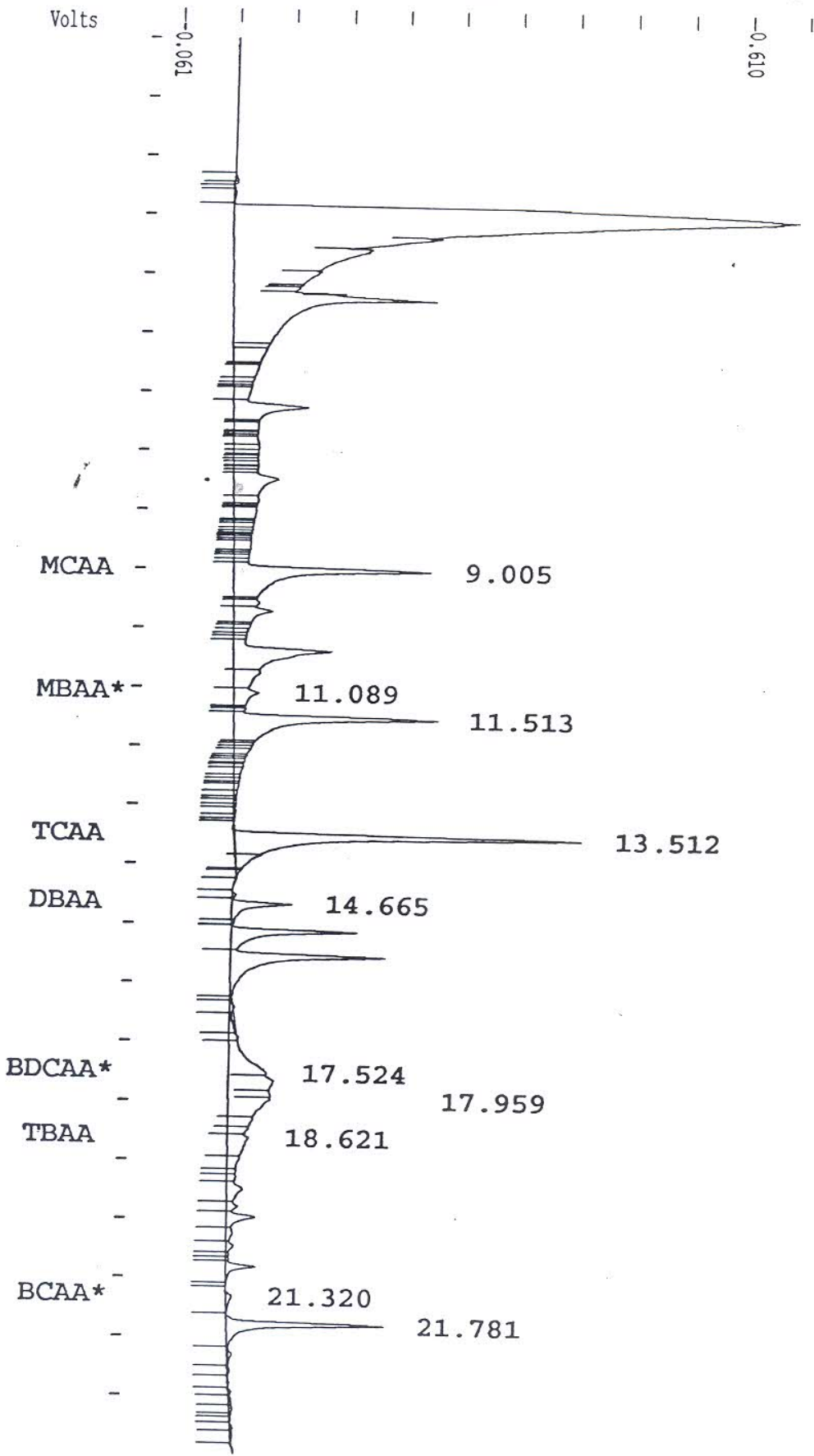

$<W I=8.0$ 
Method File : C: \STAR\MODULE16\THMACET2.MTH

Sample ID : perox/ozonio AE $24 \mathrm{~h}$

Injection Date: 3-AUG-4 4:56 PM

Calculation Date: 3-AUG-4 5:16 PM

Operator : PASCHOALATO, C

Workstation:

Instrument : star $3600 \mathrm{cx}$

Channel: $\mathrm{B}=\mathrm{ECD}$

Detector Type: ADCB (10 Volts)

Bus Address: 16

Sample Rate : $10.00 \mathrm{~Hz}$

Run Time : $20.002 \mathrm{~min}$

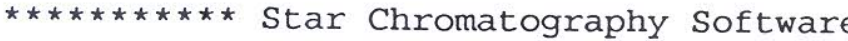

Run Mode : Analysis

Peak Measurement: Peak Area

Calculation Type: Internal Standard

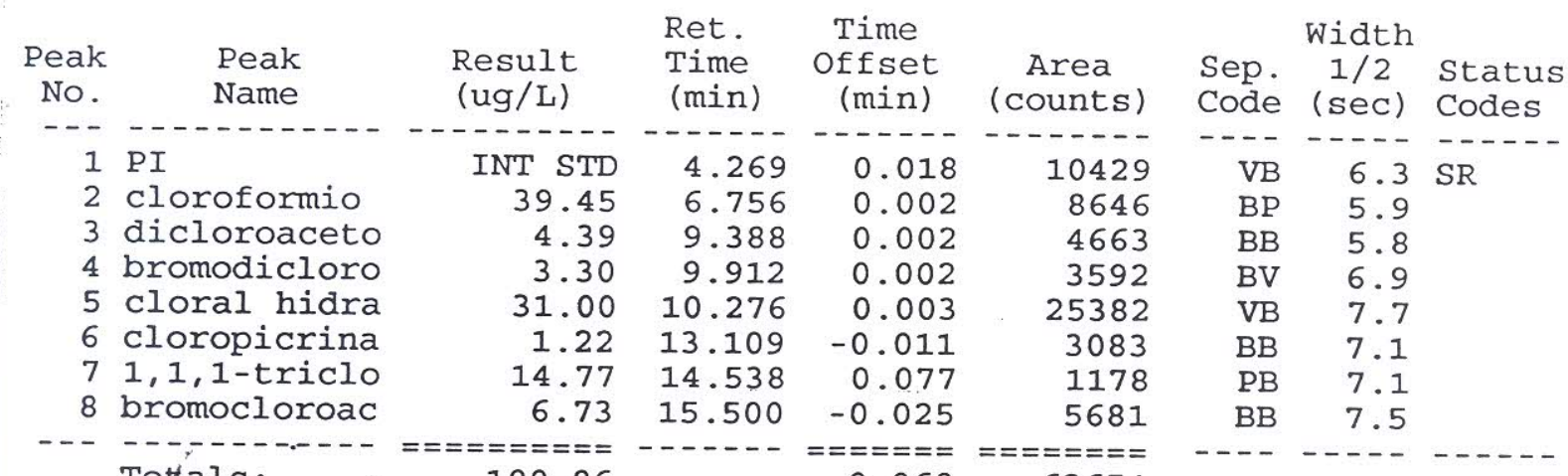

Status Codes:

$R$ - Reference peak

S - Internal standard peak

Total Unidentified Counts :

35821 counts

Detected Peaks: 26

Rejected Peaks: 7

Identified Peaks: 8

Amount Standard: 1.000000

Multiplier: 1.000000

Divisor: 1.000000

Baseline offset: -28 microvolts

Noise (used): 210 microvolts - monitored before this run

Manual injection 
Method File: C: \STAR\MODULE16\THMACET2.MTH

Sample ID: perox/ozonio AE $24 \mathrm{~h}$

Injection Date: 3-AUG-4 4:56 PM Calculation Date: 3-AUG-4 5:16 PM

Operator: PASCHOALATO, C

Workstation:

Instrument : star $3600 \mathrm{cx}$

Channel : $\mathrm{B}=\mathrm{ECD}$

Detector Type: $\mathrm{ADCB}$ (10 Volts)

Bus Address : 16

Sample Rate: $10.00 \mathrm{~Hz}$

Run Time

: $20.002 \mathrm{~min}$

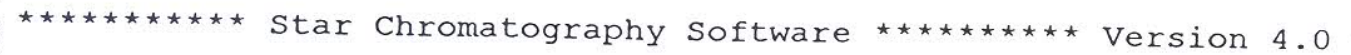

Chart Speed $=\quad 1.04 \mathrm{~cm} / \mathrm{min}$ Attenuation $=150$

Zero Offset $=5 \%$

start Time=

$0.000 \mathrm{~min}$

End Time

$=20.002 \mathrm{~min}$

Min / Tick

Volts

!

$\underset{\substack{0 \\ \dot{c}}}{\stackrel{1}{0}}$

$<\mathrm{WI}=2.0$

$\longrightarrow$

$<W I=4.0$

10.276

$<W I=8.0$

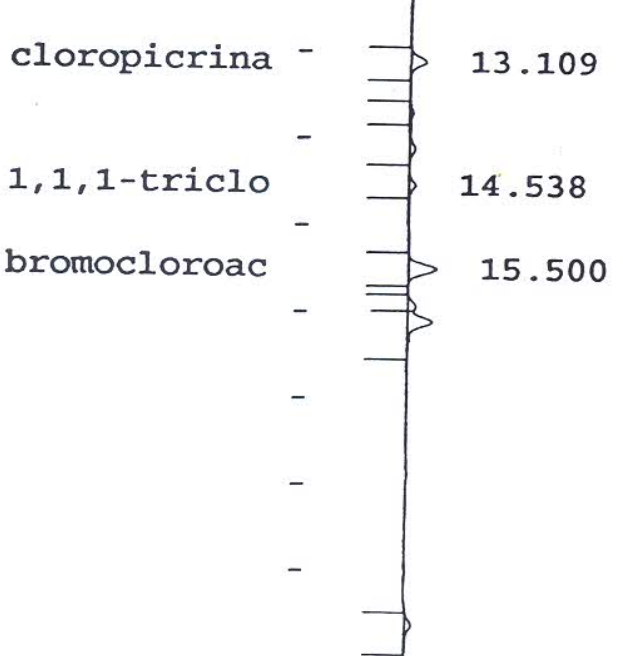


Method File: C:\STAR\MODULE16\HAAO3.MTH

Sample ID : Perox/ozonio AE $24 \mathrm{~h}$

Injection Date: 6-AUG-4 3:21 PM Calculation Date: 6-AUG-4 6:22 PM

Operator : PASCHOALATO, C

Workstation:

Instrument : star $3600 \mathrm{cx}$

Channel : $\mathrm{B}=\mathrm{ECD}$

Detector Type: ADCB (10 Volts)

Bus Address : 16

Sample Rate : $10.00 \mathrm{~Hz}$

Run Time : $24.002 \mathrm{~min}$

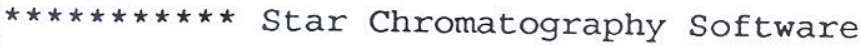

Run Mode : Analysis

Peak Measurement: Peak Area

Calculation Type: Internal Standard

\begin{tabular}{|c|c|c|c|c|c|c|c|c|}
\hline $\begin{array}{l}\text { Peak } \\
\text { No. }\end{array}$ & $\begin{array}{l}\text { Peak } \\
\text { Name }\end{array}$ & $\begin{array}{l}\text { Result } \\
\text { (ug/L) }\end{array}$ & $\begin{array}{l}\text { Ret. } \\
\text { Time } \\
\text { (min) }\end{array}$ & $\begin{array}{l}\text { Time } \\
\text { Offset } \\
\text { (min) }\end{array}$ & $\begin{array}{c}\text { Area } \\
\text { (counts) }\end{array}$ & $\begin{array}{l}\text { Sep. } \\
\text { Code }\end{array}$ & $\begin{array}{c}\text { Width } \\
1 / 2 \\
\text { (sec) }\end{array}$ & $\begin{array}{l}\text { Status } \\
\text { Codes }\end{array}$ \\
\hline--- & ------ & $-\cdots---$ & $\ldots \ldots$ & $\ldots \ldots$ & $-\cdots----$ & --- & $-\cdots$ & \\
\hline 1 & MCAA & 24.76 & 8.989 & -0.158 & 210886 & VV & 6.2 & \\
\hline 2 & MBAA & 1.53 & 11.073 & -0.036 & 12094 & VV & 0.0 & \\
\hline 3 & DCAA & 13.16 & 11.501 & -0.031 & 103544 & VV & 7.4 & \\
\hline 4 & TCAA & 9.56 & 13.503 & -0.015 & 231599 & VV & 5.5 & \\
\hline 5 & DBAA & 0.48 & 14.837 & -0.024 & 19041 & VV & 0.0 & \\
\hline 6 & $\mathrm{BDCAA}$ & 1.40 & 17.381 & -0.076 & 26674 & vV & 0.0 & \\
\hline 7 & CDBAA & $16 \div-43$ & 18.167 & 0.068 & 35413 & VV & 0.0 & \\
\hline 8 & TBAA & 1.42 & 18.517 & -0.043 & 6528 & VV & 0.0 & \\
\hline 9 & $\mathrm{PI}$ & INT STD & 21.781 & -0.028 & 86259 & PV & 5.6 & SR \\
\hline & Totals: & $\begin{array}{r}====== \\
68.74\end{array}$ & ------ & $\begin{array}{c}====== \\
-0.343\end{array}$ & $\begin{array}{r}====== \\
732038\end{array}$ & -. & $\ldots$ & $\ldots$ \\
\hline
\end{tabular}

Status Codes:

$R$ - Reference peak

$S$ - Internal standard peak

Total Unidentified Counts : 2519786 counts

Detected Peaks: 186

Rejected Peaks: 87

Identified Peaks: 9

Amount Standard: 1.000000 Multiplier: 1.000000

Divisor: 1.000000

Baseline Offset: 20 microvolts

Noise (used): 230 microvolts - monitored before this run

Manual injection 
: Subprodutos organo-halogenados metodo 552 EPA

Run File

C: CSTAR\MODULE16\HAAPZ014.RUN

1e : C: \STAR\MODULE16\HAAO3.MTH

Sample ID: Perox/ozonio $\mathrm{AE} 24 \mathrm{~h}$

Injection Date: 6-AUG-4 3:21 PM

Calculation Date: 6-AUG-4 6:22 PM

Operator: PASCHOALATO, C

Workstation:

Instrument : star $3600 \mathrm{cx}$

Detector Type: $\mathrm{ADCB}$ (10 Volts)

Channel : $\mathrm{B}=\mathrm{ECD}$

Bus Address : 16

Sample Rate : $10.00 \mathrm{~Hz}$

Run Time : $24.002 \mathrm{~min}$

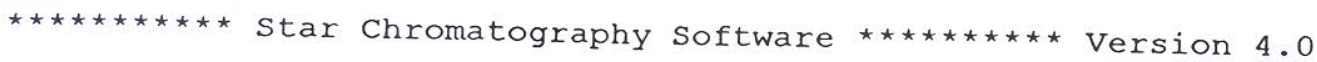

Chart Speed $=0.87 \mathrm{~cm} / \mathrm{min} \quad$ Attenuation $=500$

start Time

$0.000 \mathrm{~min}$

End Time

$=24.002 \mathrm{~min}$

Zero Offset $=5$ \%

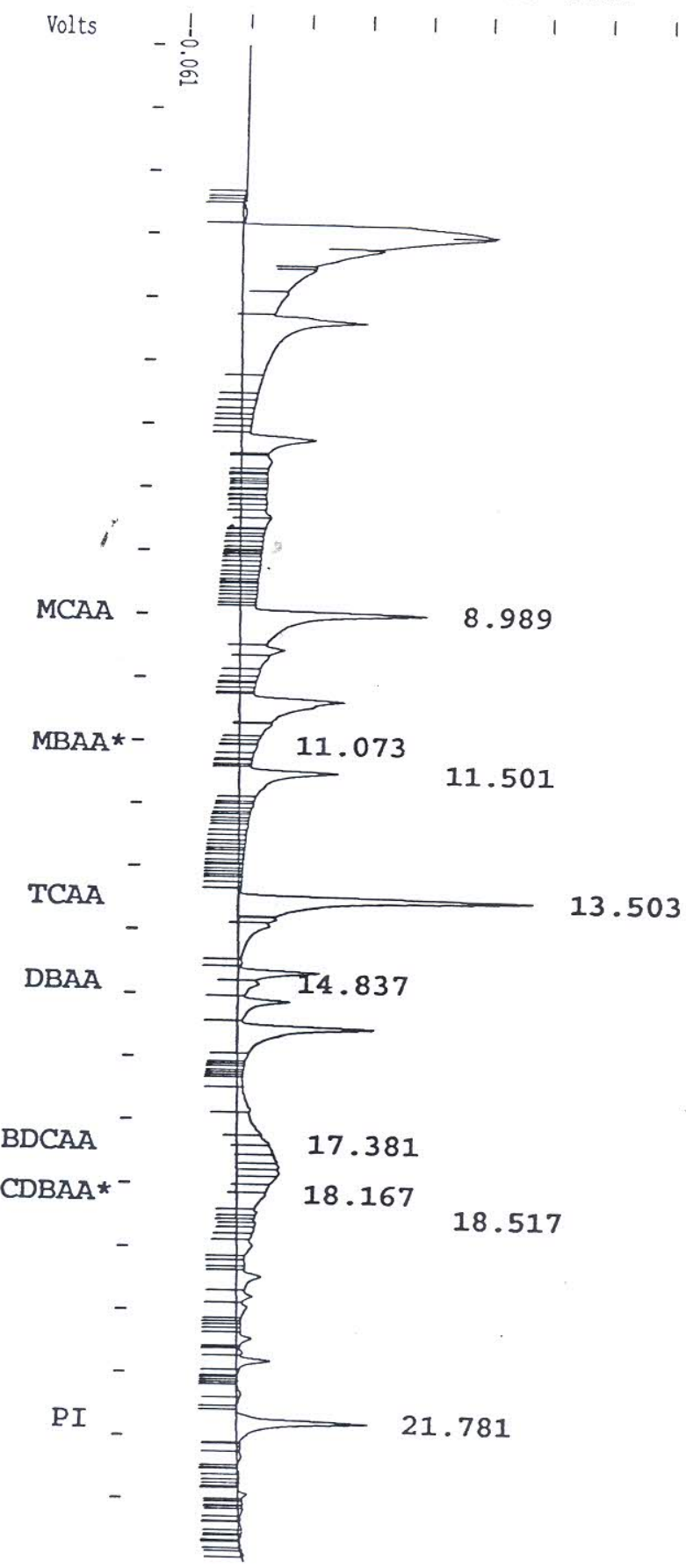
응

Min / Tick $=1.00$ 